\author{
UNIVERSIDADE DE SÃO PAULO \\ PROGRAMA DE PÓS-GRADUAÇÃO INTERUNIDADES EM MUSEOLOGIA
}

Erica Andreza Coelho Bowersox

\title{
A Museologia e o Sagrado: \\ Um estudo sobre o Museu Nossa Senhora Aparecida
}

São Paulo 


\title{
UNIVERSIDADE DE SÃO PAULO \\ PROGRAMA DE PÓS-GRADUAÇÃO INTERUNIDADES EM MUSEOLOGIA
}

Erica Andreza Coelho Bowersox

\section{A Museologia e o Sagrado: \\ Um estudo sobre o Museu Nossa Senhora Aparecida}

\author{
Dissertação apresentada ao Programa de Pós- \\ Graduação Interunidades em Museologia da \\ Universidade de São Paulo para obtenção do título \\ de Mestre em Museologia. \\ Área de Concentração: Museologia \\ Orientadora: Profa. Dra. Marília Xavier Cury \\ Linha de Pesquisa: Teoria e Método da Gestão \\ Patrimonial e dos Processos Museológicos \\ Versão corrigida $\left({ }^{*}\right)$ \\ ${ }^{*}$ ) A versão original encontra-se disponível no \\ MAE/USP.
}

São Paulo 
Autorizo a reprodução e divulgação integral ou parcial deste trabalho, por qualquer meio convencional ou eletrônico, para fins de estudo e pesquisa, desde que citada a fonte.

Ficha catalográfica elaborada pelo Serviço de Biblioteca e Documentação, MAE/USP, com os dados fornecidos pelo(a) autor(a)

Bowersox, Erica Andreza Coelho

A Museologia e o Sagrado: Um estudo sobre o

Museu Nossa Senhora Aparecida / Erica Andreza

Coelho Bowersox; orientador Marília Xavier Cury . - -

São Paulo, 2019 .

$390 \mathrm{p}$.

Dissertação (Mestrado - Programa de Pós-Graduação em Interunidades em Museologia) -- Museu de Arqueologia e Etnologia, Universidade de São Paulo, 2019 .

1. Cultura material e religiosa. 2. Santuário Nacional de Aparecida. 3. Museu Nossa Senhora Aparecida. 4. Museologia e o Sagrado. 5. Processo de musealização. I. Cury, Marília Xavier, orient. I. Título. 
BOWERSOX, E. A. C. A Museologia e o Sagrado: Um estudo sobre o Museu Nossa Senhora Aparecida. 2019. 390 f. Dissertação (Mestrado em Museologia). Programa de Pós-Graduação Interunidades em Museologia, Universidade de São Paulo, São Paulo, 2019.

Aprovado em: 27/08/2019

\section{Banca Examinadora}

Profa. Dra.: Marília Xavier Cury (Orientadora)

Instituição: Museu de Arqueologia e Etnologia - Universidade de São Paulo Julgamento:

Assinatura:

Profa. Dra.: Maria Isabel Rocha Roque

Instituição: Universidade Europeia - Portugal

Julgamento:

Assinatura:

Prof. Dr.: Adilson José de Almeida

Instituição: Museu Paulista - Universidade de São Paulo

Julgamento:

Assinatura: 
Dedico este trabalho aos meus pais Geraldo e Evanir e ao meu esposo William, com amor, gratidão pela compreensão e incansável apoio durante a realização da dissertação. 


\section{Agradecimentos}

"Aqueles que passam por nós, não vão sós, não nos deixam sós.

Deixam um pouco de si, levam um pouco de nós" Antoine de Saint-Exupery.

Primeiramente, agradeço a Deus pelo dom da vida, por me permitir trilhar novos caminhos e pela oportunidade de continuar a aprender a cada dia.

Agradeço a todos os professores do Programa de Pós-Graduação Interunidades em Museologia da Universidade de São Paulo (PPGMus-USP), em especial àqueles que contribuíram mais diretamente nas pesquisas e orientação: às Professoras Dra. Heloisa Maria Silveira Barbuy, orientadora até o exame de qualificação, e a Dra. Marília Xavier Cury, orientadora após o exame de qualificação. Ao Dr. Adilson José de Almeida, do Serviço de Objetos do Museu Paulista da USP, pelas sugestões valiosas apresentadas em minha banca de qualificação.

Ao longo da pesquisa foram muitos os que ajudaram de alguma forma na realização desta dissertação, manisfesto aqui minha gratidão aos colegas da $6^{a}$ turma do PPGMus-USP, Aliene, Denyse, Juliana, Letícia, Otávio, Pércila e Thaís; e aos funcionários da Biblioteca do MAE-USP.

Aos amigos do Centro de Documentação e Memória do Santuário Nacional de Aparecida e Instituto de Estudos Valeparaibanos, que colaboraram com as pesquisas e digitalização de documentos. E à Academia Marial de Aparecida, que disponibilizou espaço para realização das entrevistas semiestruturadas.

Aos entrevistados Dom Darci José Nicioli, Guido Machado Braga, Tereza Galvão Pasin, Padre Víctor Hugo Lapenta da Silveira, C.Ss.R., Zenilda Cristina da Cunha, que contribuíram com informações valiosas de convivência com a Professora Conceição Borges Ribeiro Camargo, fundadora do Museu Nossa Senhora Aparecida. Em especial às grandes amigas e colegas de profissão Giselle Peixe e Silvia Bigareli, responsáveis pela revitalização institucional do Museu e fontes de inspiração profissional.

Ao Santuário Nacional de Aparecida, que me abriu as portas para a carreira profissional na área de museologia, proporcionando grandes realizações, e aos colegas do Museu Nossa Senhora Aparecida, pela parceria.

Agradecimento especial aos meus pais e ao meu esposo, que tiveram bastante paciência e solidariedade ao longo do tempo de estudo. E agradeço sinceramente a todos que, direta ou indiretamente, colaboraram e ofereceram-me seus incentivos durante a realização deste trabalho. 


\section{Resumo}

BOWERSOX, E. A. C. A Museologia e o Sagrado: Um estudo sobre o Museu Nossa Senhora Aparecida. 2019. 390 f. Dissertação (Mestrado em Museologia). Programa de Pós-Graduação Interunidades em Museologia, Universidade de São Paulo, São Paulo, 2019.

A musealização de objetos ligados ao culto católico e à devoção constitui uma categoria própria da cultura material do Homem e da sua relação com o Sagrado, caracterizada por temas e simbologias diversas. Atendendo à importância do legado histórico do Museu Nossa Senhora Aparecida, o presente estudo analisa as práticas museológicas em torno dos bens culturais ligados ao culto católico e, em especial, à devoção a Nossa Senhora Aparecida, acrescidos de acervos diversos ofertados pelos devotos em visita à Basílica. Em termos estruturais, os objetivos da pesquisa se complementam, compreendendo a criação do Museu Nossa Senhora Aparecida, em 1956, que a princípio não possuía a característica de uma instituição estritamente religiosa. Buscando uma reflexão entre museologia e sacralidade, a pesquisa centrou-se na análise de aquisições e políticas de formação do acervo, práticas institucionais para a qualificação profissional e realização de processos museológicos, as ações necessárias para salvaguarda dos bens culturais e as propostas comunicacionais com temática religiosa - marcadas pela recente inauguração da cúpula central da Basílica e do circuito de visitação, entre os anos de 2017 e 2018. Por meio da bibliografia e fontes documentais pesquisadas, buscou-se estabelecer relações entre o Santuário Nacional de Aparecida e o processo de musealização de acervos, a partir da alocação do Museu e da formação das coleções, com base nos documentos de doação, listas de inventário e fichas catalográficas. Para maior compreensão, foi imprescindível a realização de entrevistas semiestruturadas e análise de depoimentos em formato audiovisual existentes no Museu. Num âmbito histórico, traçou-se a evolução do Museu, com análise delimitada pelas exposições de longa duração, que determinaram novas temáticas a partir da instalação do Museu na Torre da Basílica. Dentro de um plano mais teórico, analisou-se o objeto museológico como documento, portador de informação, contribuindo nas reflexões sobre o processo de musealização de objetos religiosos, levando em consideração que a entidade responsável pela musealização dos acervos é a própria Basílica de Aparecida.

Palavras-chaves: 1 - Cultura material e religiosa, 2 - Santuário Nacional de Aparecida, 3 - Museu Nossa Senhora Aparecida, 4 - Museologia e o Sagrado, 5 Processo de musealização. 


\begin{abstract}
BOWERSOX, E. A. C. The Museology and the Sacred: A study about the Our Lady Aparecida Museum. 2019. 390 f. Dissertation (Master in Museology). Postgraduate Program in Museology, University of São Paulo, São Paulo, 2019.

The musealization of objects linked to Catholic worship and devotion constitutes a proper category of mankind's material culture and its relation to the Sacred, characterized by diverse themes and symbologies. Considering the important historical legacy of the Our Lady Aparecida Museum, this study analyzes the museological practices around the cultural assets linked to the Catholic mass and, in particular, to the devotion of Our Lady Aparecida, plus various collections offered by devotees visiting the Basilica. In structural terms, the objectives of this research paper complement each other, including the creation of the Our Lady Aparecida Museum, in 1956, which at first did not have the characteristic of a purely religious institution. Seeking a reflection between museology and sacredness, this research paper focused on the analysis of acquisitions and formation policies of the collection, institutional practices for the professional qualification and realization of museological processes, the actions needed to safeguard the cultural assets and the communication initiatives with religious themes - marked by the recent inauguration of the central dome of the Basilica and the circuit of visitation, between the years of 2017 and 2018. Through the bibliography and documentary sources, a historical thread was sought, linking the National Shrine of Aparecida, the musealization of collections, from the relocation of the Museum and the formation of collections, based on donated documents, inventory lists and catalogs. For greater understanding, it was essential to conduct semi-structured interviews and analysis of audiovisual testimonials in the Museum. This allowed the evolution of the Museum to be traced in a historical context, with the analysis delimited by the long-term exhibitions, and by the relocation of the Museum to the Tower of the Basilica. Within a more theoretical plan, a museological object was analyzed as a document, a bearer of information, thereby contributing to the reflections on the process of musealization of religious objects, while taking into account that the entity responsible for the musealization of the collections is the Basilica of Aparecida itself.
\end{abstract}

Keywords: 1 - Material and religious culture, 2 - National Shrine of Aparecida, 3 - Our Lady of Aparecida Museum, 4 - Museology and the Sacred, 5 - Process of musealization. 


\section{Lista de Figuras}

Figura 1: Convento das Irmãs Canisianas, Aparecida (SP).

Figura 2: Inauguração do Museu Nossa Senhora Aparecida nas Oficinas Gráficas de Arte Sacra - Convento das Irmãs Canisianas, 1956.

Figura 3: Aspecto externo das Oficinas Gráficas de Arte Sacra, onde o Museu foi instalado.

Figura 4: Aspectos internos da primeira Exposição do Museu Nossa Senhora Aparecida, em duas salas nas Oficinas Gráficas de Arte Sacra. 39

Figura 5: Aspectos internos da primeira Exposição do Museu Nossa Senhora Aparecida, em duas salas nas Oficinas Gráficas de Arte Sacra. 39

Figura 6: Museu Nossa Senhora Aparecida localizado na Galeria do Hotel Recreio.

Figura 7: Aspecto externo da Sala dos Milagres, à esquerda da Basílica Velha......43

Figura 8: Aspecto interno da Sala dos Milagres. ..................................................44

Figura 9: Abertura do Museu Nossa Senhora Aparecida no $2^{-}$andar da Torre Brasília - Santuário Nacional de Aparecida, 1967..............................................49

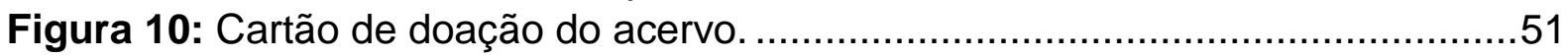

Figura 11: Antiga etiqueta da exposição. ......................................................51

Figura 12: Aspecto interno do Museu instalado no $2^{\circ}$ andar da Torre Brasília..........53

Figura 13: Sala dos Milagres na Torre Brasília. ................................................54

Figura 14: Objetos atribuídos aos milagres de Nossa Senhora Aparecida. .............55

Figura 15: Relato sobre o Museu e a Sala dos Milagres .....................................56

Figura 16: Escavações arqueológicas em Aparecida (SP). ................................58

Figura 17: Relação das peças da Antiga Basílica. .................................................61

Figura 18: Relação das peças da Antiga Basílica. ..............................................62

Figura 19: Exemplo de anotação contendo informação sobre uma doação..............69

Figura 20: Livro Tombo № 1, com termo de abertura no dia 8 de setembro de 1991, contém 200 páginas numeradas. O Termo de encerramento deste Livro Tombo, assinado pelo diretor da Arquidiocese, está datado 9 de março de 1993, e contém

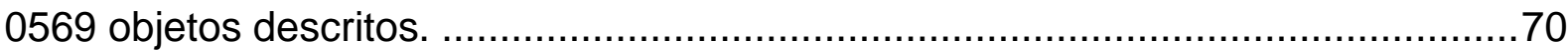

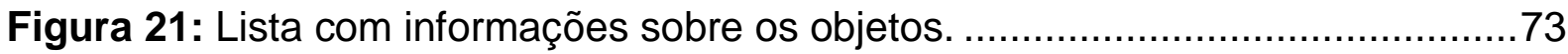

Figura 22: Lista com informações sobre os objetos. ......................................... 74

Figura 23: Termo de Doação de Bens Móveis. ................................................75

Figura 24: Aspecto interno do Museu instalado no $2^{\circ}$ andar da Torre Brasília..........85

Figura 25: Aspecto interno do Museu instalado no $2^{\circ}$ andar da Torre Brasília..........86

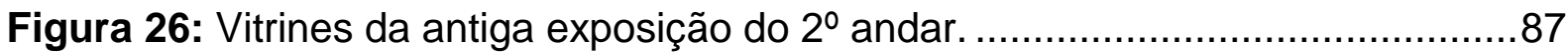

Figura 27: Acervo da coleção de louças e porcelanas. ........................................8

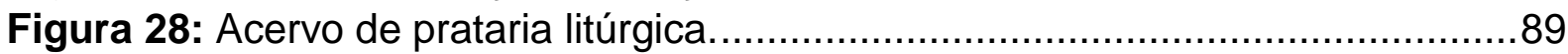

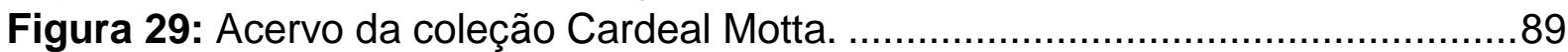

Figura 30: Acervo da coleção de objetos religiosos. .............................................

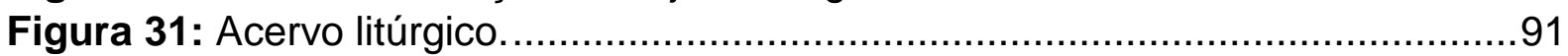

Figura 32: Acervo da coleção de objetos religiosos. ........................................92

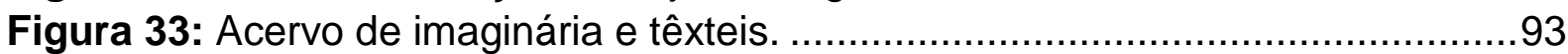

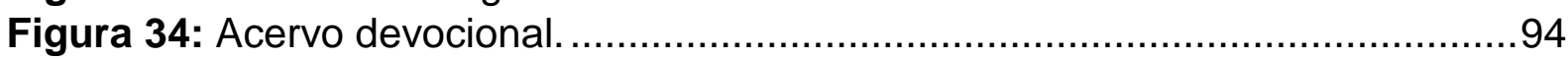

Figura 35: Acervo de pinturas com temática religiosa..........................................94

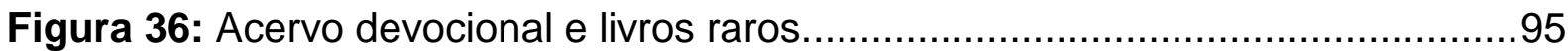


Figura 37: Vitrines da antiga exposição do $2^{\circ}$ andar. .........................................96

Figura 38: Acervo da coleção de instrumentos musicais e relógios. .......................97

Figura 39: Acervo da coleção de objetos de comunicação. .................................98

Figura 40: Acervo da coleção de arte popular...................................................98

Figura 41: Acervo de arte popular, esculturas e instrumentos musicais. ................99

Figura 42: Acervo de bonecos artesanais e numismática. ..................................100

Figura 43: Acervo da coleção de tropeirismo. .................................................101

Figura 44: Acervo da Revolução Constitucionalista de 1932. ..............................102

Figura 45: Acervo da Segunda Guerra Mundial. ................................................103

Figura 46: Vitrines da antiga exposição do $2^{0}$ andar. ......................................... 104

Figura 47: Acervo da coleção de etnologia. .................................................105

Figura 48: Acervo da coleção de etnologia. ................................................... 106

Figura 49: Acervo da coleção de etnologia. .....................................................106

Figura 50: Coleção de animais, não mais existentes no acervo...........................107

Figura 51: Etiqueta da antiga exposição. ....................................................110

Figura 52: Inauguração do Museu dos Ciclos Socioeconômicos do Vale do Paraíba,

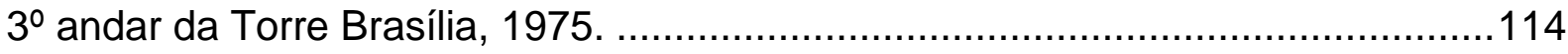

Figura 53: Livro de assinaturas da inauguração do Museu...............................115

Figura 54: Texto de abertura da exposição. ...................................................118

Figura 55: Aspecto interno da exposição - Ciclo da Subsistência. .........................120

Figura 56: Aspecto interno da exposição - Ciclo da Subsistência.........................120

Figura 57: Aspecto interno da exposição - Ciclo da Subsistência.........................121

Figura 58: Aspecto interno da exposição - Ciclo Bandeirista. .................................122

Figura 59: Aspecto interno da exposição - Ciclo Bandeirista. ...............................123

Figura 60: Aspecto interno da exposição - Ciclo Bandeirista. ...............................124

Figura 61: Aspecto interno da exposição - Ciclo da Cana-de-Açúcar. ....................125

Figura 62: Aspecto interno da exposição - Ciclo da Cana-de-Açúcar. ....................126

Figura 63: Aspecto interno da exposição - Ciclo da Cana-de-Açúcar. ....................126

Figura 64: Aspecto interno da exposição - Ciclo do Café......................................129

Figura 65: Aspecto interno da exposição - Ciclo do Café....................................130

Figura 66: Aspecto interno da exposição - Ciclo do Café.......................................131

Figura 67: Aspecto interno da exposição - Ciclo da Economia Mista.....................132

Figura 68: Aspecto interno da exposição - Ciclo da Economia Mista.....................133

Figura 69: Aspecto interno da exposição - Ciclo da Economia Mista.....................133

Figura 70: Aspecto interno da exposição - Ciclo Industrial...................................135

Figura 71: Aspecto interno da exposição - Ciclo Industrial...................................135

Figura 72: Croqui para elaboração da exposição........................................137

Figura 73: Croqui para elaboração da exposição............................................137

Figura 74: Croqui para elaboração da exposição............................................138

Figura 75: Revisão nos textos para correções. ................................................139

Figura 76: Anotações para finalização da exposição. .......................................140

Figura 77: Diretora Zilda Augusta Ribeiro, à direita, durante celebração em preparação ao Natal, realizada no corredor de entrada da antiga exposição do $2^{\circ}$ andar da Torre Brasília.

Figura 78: Diretor Guido Machado Braga organizando a vitrine de relógios na antiga exposição do $2^{\circ}$ andar da Torre Brasília. .......................................................... 169

Figura 79: Área de trabalho $-8^{0}$ andar. .................................................... 171 


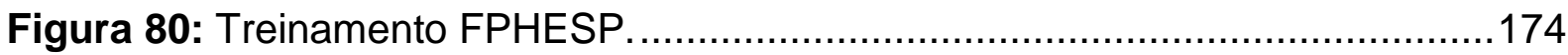

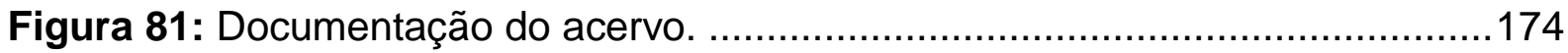

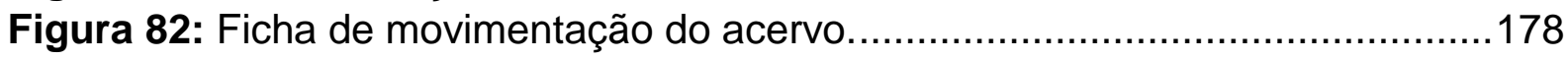

Figura 83: Fluxo de entrada de objetos.......................................................181

Figura 84: Fluxo de entrada de objetos identificado pela FPHESP......................182

Figura 85: Área de trabalho - 5o andar........................................................186

Figura 86: Reserva Técnica - 5o andar......................................................186

Figura 87: Oficina sobre a coleção de numismática..........................................195

Figura 88: Visita técnica ao Museu Paulista da USP. ......................................195

Figura 89: Oficina sobre a coleção de arqueologia. ..........................................198

Figura 90: Oficina sobre a coleção de armaria................................................199

Figura 91: Visita técnica ao Museu de Polícia Militar do Estado de São Paulo......200

Figura 92: Área Técnica - 3o andar da Torre...................................................201

Figura 93: Planta - Área Técnica do Museu. ....................................................202

Figura 94: Reserva Técnica - 3o andar.......................................................203

Figura 95: Mirante da Torre Brasília antes da reforma.....................................207

Figura 96: Mirante da Torre Brasília após a revitalização. ...................................208

Figura 97: Domus Aurea (Casa de Ouro).....................................................210

Figura 98: Organograma do Museu Nossa Senhora Aparecida ..........................213

Figura 99: Sistema de Catalogação "Pergamum". .............................................226

Figura 100: Inauguração exposição Rainha do Céu, Mãe dos Homens: Aparecida do

Brasil - 1ำ andar da Torre Brasília, Santuário Nacional de Aparecida. ....................235

Figura 101: Planta - Exposição 10 andar............................................................2.236

Figura 102: Núcleo sobre Maria - Exposição "Rainha do Céu, Mãe dos Homens: Aparecida do Brasil." ................................................................................239

Figura 103: Núcleo sobre as invocações de Maria - Exposição "Rainha do Céu, Mãe dos Homens: Aparecida do Brasil." .............................................................241

Figura 104: Núcleo sobre Nossa Senhora da Conceição - Exposição "Rainha do Céu, Mãe dos Homens: Aparecida do Brasil."....................................................242

Figura 105: Núcleo sobre as representações de Nossa Senhora Aparecida Exposição "Rainha do Céu, Mãe dos Homens: Aparecida do Brasil"......................244

Figura 106: Núcleo sobre a devoção - Exposição "Rainha do Céu, Mãe dos Homens: Aparecida do Brasil."...

Figura 107: Núcleo que retrata a Coroação de Nossa Senhora Aparecida Exposição "Rainha do Céu, Mãe dos Homens: Aparecida do Brasil.".....................247

Figura 108: Núcleo histórico - Exposição "Rainha do Céu, Mãe dos Homens:

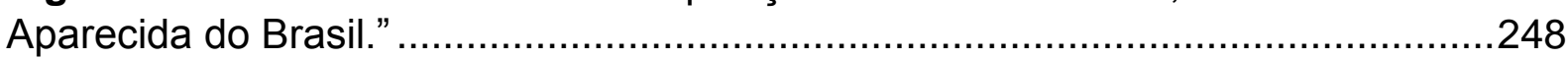

Figura 109: Planta - Exposição 2o andar.......................................................254

Figura 110: Núcleo histórico - Exposição "O Museu e suas Histórias"....................255

Figura 111: Núcleo o homem e o sagrado - Exposição "O Museu e suas Histórias". 257

Figura 112: Núcleo o homem e o sagrado - Exposição "O Museu e suas Histórias". 258

Figura 113: Núcleo o homem e o sagrado - Exposição "O Museu e suas Histórias". 258

Figura 114: Núcleo o homem e expressão - Exposição "O Museu e suas Histórias". 
Figura 115: Núcleo o homem e expressão - Exposição "O Museu e suas Histórias". 260

Figura 116: Núcleo o homem e cotidiano - Exposição "O Museu e suas Histórias". 261

Figura 117: Núcleo o homem e a natureza - Exposição "O Museu e suas Histórias". 262

Figura 118: Exposição Coleção Santa Gertrudes de Imagens Paulistas do século XVII. 264

Figura 119: Núcleo Frei Agostinho de Jesus - Exposição "Coleção Santa Gertrudes de Imagens Paulistas do século XVII". .266

Figura 120: Núcleo Mestre do "Cabelinho Xadrez" - Exposição "Coleção Santa Gertrudes de Imagens Paulistas do século XVII". 266 Figura 121: Núcleo Mestre de Angra - Exposição "Coleção Santa Gertrudes de Imagens Paulistas do século XVII" 267 Figura 122: Núcleo Mestre de Sorocaba - Exposição "Coleção Santa Gertrudes de Imagens Paulistas do século XVII". 267

Figura 123: Núcleo Mestre de Pirapora de Bom Jesus e do Mestre do "Bolo-denoiva" - Exposição "Coleção Santa Gertrudes de Imagens Paulistas do século XVII". 268

Figura 124: Núcleo de artistas não identificados - Exposição "Coleção Santa Gertrudes de Imagens Paulistas do século XVII". 268

Figura 125: Núcleo Frei Agostinho de Jesus - Exposição "Coleção Santa Gertrudes de Imagens Paulistas do século XVII". 270

Figura 126: Planta - Circuito de Visitação à Cúpula..........................................276

Figura 127: Inauguração do Circuito de Visitação à Cúpula. 277

Figura 128: Primeiro módulo expositivo do circuito de visitação à cúpula, "Basílica Nacional: A construção de um sonho". .278

Figura 129: Primeiro núcleo - "Basílica Nacional: A construção de um sonho"......279 Figura 130: Segundo núcleo - "Basílica Nacional: A construção de um sonho".....280 Figura 131: Terceiro núcleo - "Basílica Nacional: A construção de um sonho"......282 Figura 132: Quarto núcleo - "Basílica Nacional: A construção de um sonho". ........283 Figura 133: Segundo módulo expositivo do circuito de visitação à cúpula, "Corações aos Céus: Criação, Beleza e Redenção". 284

Figura 134: Segundo módulo expositivo do circuito de visitação à cúpula, "Corações aos Céus: Criação, Beleza e Redenção". 285 Figura 135: Segundo módulo expositivo do circuito de visitação à cúpula, "Corações aos Céus: Criação, Beleza e Redenção". 286 Figura 136: Segundo módulo expositivo do circuito de visitação à cúpula, "Corações aos Céus: Criação, Beleza e Redenção". 286 Figura 137: Terceiro módulo do circuito de visitação à cúpula, "300 Anos de Bênçãos e de Graças"..........................................................................287

Figura 138: Primeiro núcleo - Exposição "300 Anos de Bênçãos e de Graças".....287 Figura 139: Segundo núcleo - Exposição "300 Anos de Bênçãos e de Graças"....289 Figura 140: Terceiro núcleo - Exposição "300 Anos de Bênçãos e de Graças". ....290 Figura 141: Quarto núcleo - Exposição "300 Anos de Bênçãos e de Graças". ......291 Figura 142: Contrato de Doação e outros encargos que entre si fazem Vicente Camargo e sua esposa Conceição Borges Ribeiro Camargo com a Sociedade 
Santuário Nacional de Nossa Senhora Aparecida. Inclui a Lista de inventário das peças e objetos constantes do Museu doado na data 30 de janeiro de 1967. Páginas 1 e 2 . 354

Figura 143: Contrato de Doação e outros encargos que entre si fazem Vicente Camargo e sua esposa Conceição Borges Ribeiro Camargo com a Sociedade Santuário Nacional de Nossa Senhora Aparecida. Inclui a Lista de inventário das peças e objetos constantes do Museu doado na data 30 de janeiro de 1967. Páginas 3 e 4 . 355

Figura 144: Contrato de Doação e outros encargos que entre si fazem Vicente Camargo e sua esposa Conceição Borges Ribeiro Camargo com a Sociedade Santuário Nacional de Nossa Senhora Aparecida. Inclui a Lista de inventário das peças e objetos constantes do Museu doado na data 30 de janeiro de 1967. Páginas 5 e 6 .

Figura 145: Termo de Oferecimento de Bem. 389

Figura 146: Termo de Oferecimento de Bem ao Museu - Descrição do Bem. 390 


\section{Lista de Quadros}

Quadro 1: Lista de entrada de objetos (1993) ……............................................76

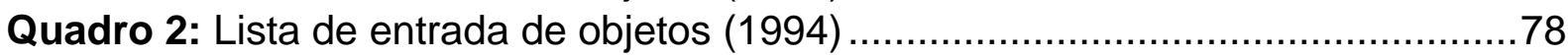

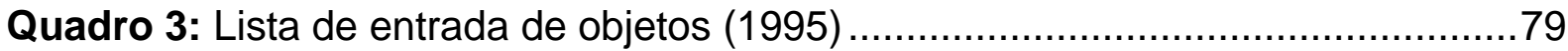

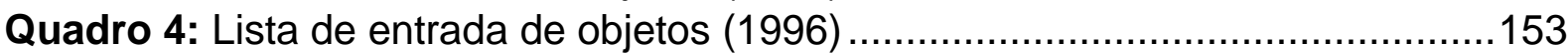

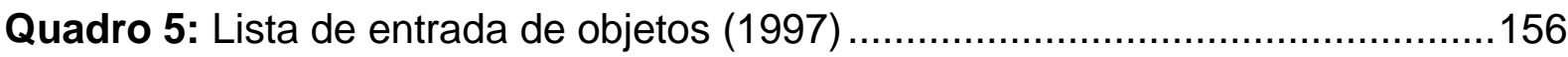

Quadro 6: Lista de entrada de objetos (1998) ...............................................157

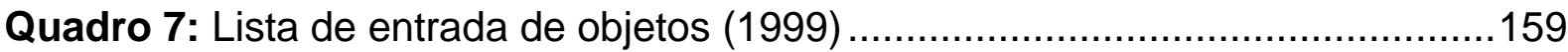

Quadro 8: Lista de entrada de objetos (2000) ……........................................160

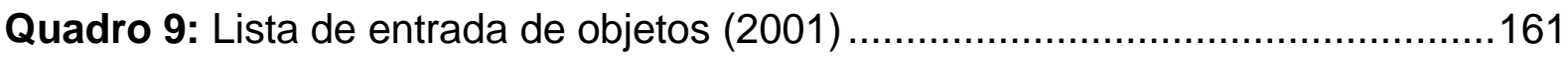

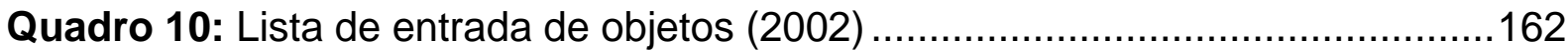

Quadro 11: Quantificação dos objetos em exposição. ......................................175

Quadro 12: Linha do tempo no Mirante da Torre …….....................................205

Quadro 13: Linha do tempo no Mirante da Torre .............................................206

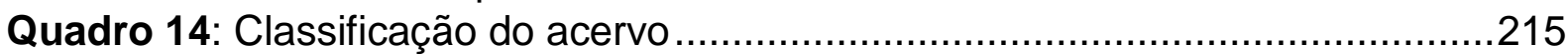

Quadro 15: Classe 1 - Estruturas/construção...............................................216

Quadro 16: Classe 2 - Interiores ...............................................................216

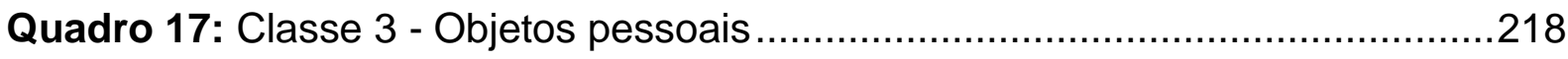

Quadro 18: Classe 4 - Comunicação ………………....................................219

Quadro 19: Classe 5 - Lazer, recreação, entretenimento, desporto ......................221

Quadro 20: Classe 6 - Transporte e distribuição ...............................................221

Quadro 21: Classe 7 - Ferramenta e equipamento de trabalho, comunicação, ciência e tecnologia .....................................................................................222

Quadro 22: Classe 8 - Armaria, equipamentos de defesa, munições e acessórios223

Quadro 23: Classe 9 - Embalagem e recipiente; Classe 10 - Penitência e castigo; Classe 11 - Objetos não classificáveis ..............................................................223

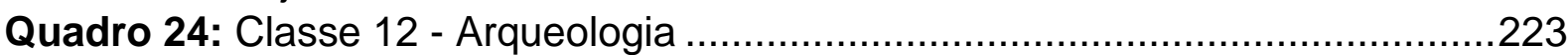

Quadro 25: Classe 13 - Amostras/Fragmentos/Remanescentes..........................224

Quadro 26: Elementos que compõem a exposição............................................337

Quadro 27: Elementos que compõem a exposição............................................339

Quadro 28: Elementos que compõem a exposição .............................................347

Quadro 29: Elementos que compõem a exposição.............................................348

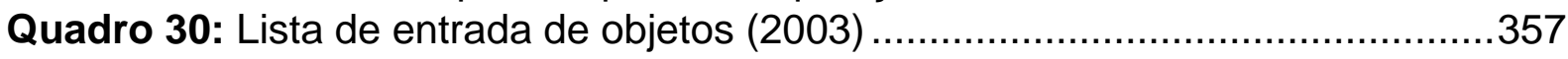

Quadro 31: Lista de entrada de objetos (2004) ...............................................360

Quadro 32: Lista de entrada de objetos (2005) …….......................................363

Quadro 33: Lista de entrada de objetos (2006) ..............................................365

Quadro 34: Lista de entrada de objetos (2007) ..............................................368

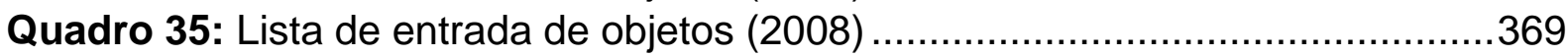

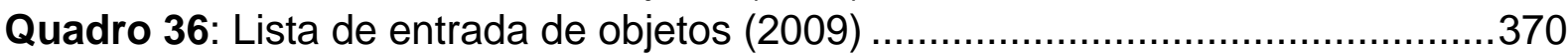

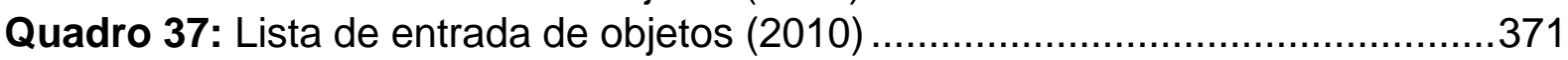

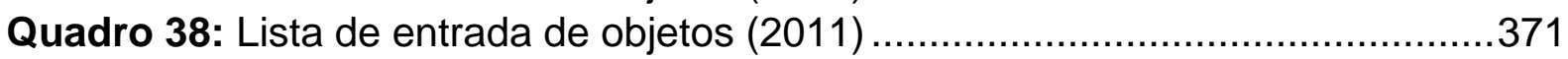

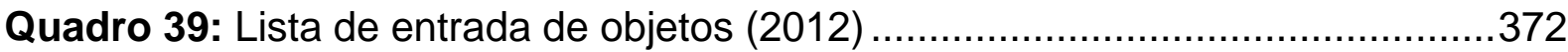

Quadro 40: Lista de entrada de objetos (2013) …...........................................372

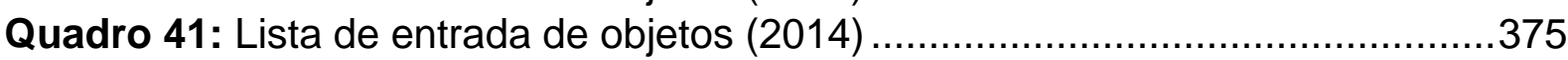

Quadro 42: Lista de entrada de objetos (2015) …….......................................377

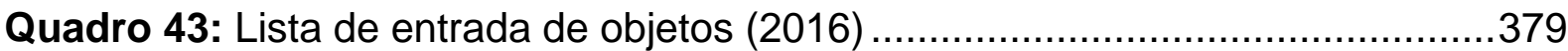




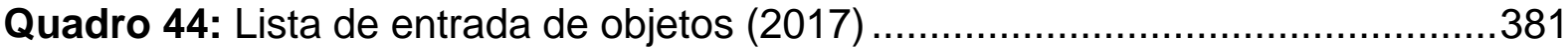

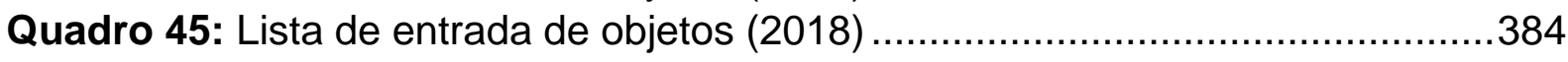

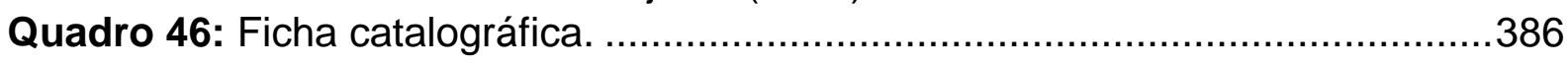




\section{Lista de abreviaturas e siglas}

ASN - Acervo Santuário Nacional

CDM - Centro de Documentação e Memória

C.Ss.R. - Congregação do Santíssimo Redentor

DAC - Departamento de Assuntos Culturais

FAAP - Fundação Armando Alvarez Penteado

FPHESP - Fundação Patrimônio Histórico da Energia de São Paulo

GED - Gerenciamento Eletrônico de Documentos

IBGE - Instituto Brasileiro de Geografia e Estatística

ICOFOM - International Committee for Museology, traduzido do inglês, Comitê Internacional de Museologia

ICOM - International Council of Museums, traduzido do inglês, Conselho Internacional de Museus

IEV - Instituto de Estudos Valeparaibanos

IHGSP - Instituto Histórico e Geográfico de São Paulo

IPHAN - Instituto do Patrimônio Histórico e Artístico Nacional

MAE-USP - Museu de Arqueologia e Etnologia da Universidade de São Paulo

MBA - Master of Business Administration

MEC - Ministério da Educação e Cultura

MNSA - Museu Nossa Senhora Aparecida

SEEC - Serviço de Estatística da Educação e Cultura

SENAC - Serviço Nacional de Aprendizagem Comercial

UNISAL - Centro Universitário Salesiano de São Paulo

USP - Universidade de São Paulo 
Introdução

Capítulo 1 - O Museu Nossa Senhora Aparecida - Período de 1956 a 1996 ........32

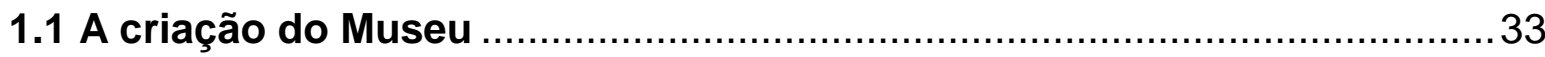

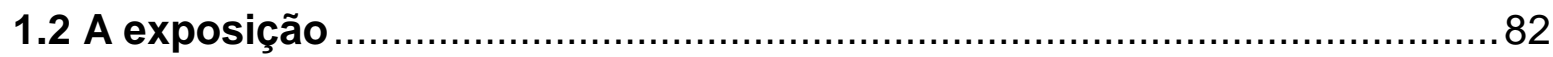

1.3 Museu dos Ciclos Socioeconômicos do Vale do Paraíba ........................114

Capítulo 2 - As trajetórias do Museu: mudanças na gestão e reestruturação. 146

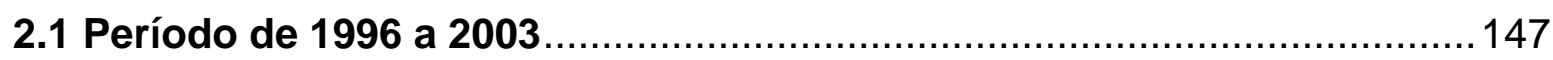

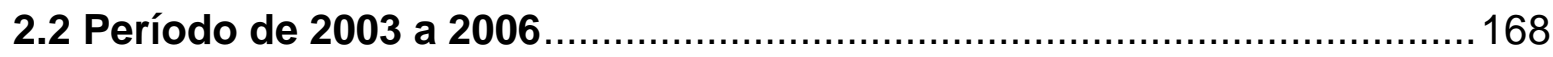

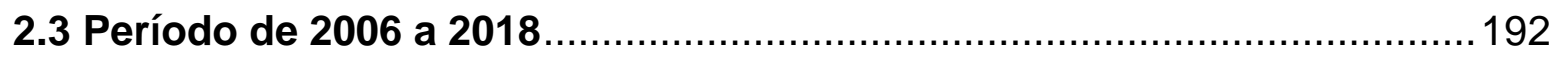

2.3.1 Gestão compartilhada e qualificação técnica ....................................192

2.3.2 Sistema de classificação e documentação do acervo........................215

Capítulo 3 - Propostas de comunicação: o sagrado no museu .........................233

3.1 Exposição Rainha do Céu, Mãe dos Homens: Aparecida do Brasil........234

3.2 Exposições 0 Museu e suas Histórias e Coleção Santa Gertrudes de

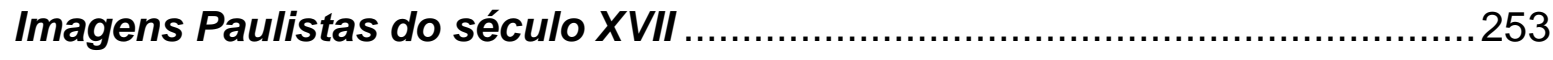

3.3 Exposição Circuito de Visitação à Cúpula.............................................275

3.4 Síntese sobre as exposições do Museu Nossa Senhora Aparecida .......295

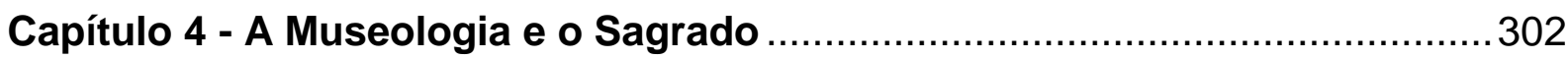

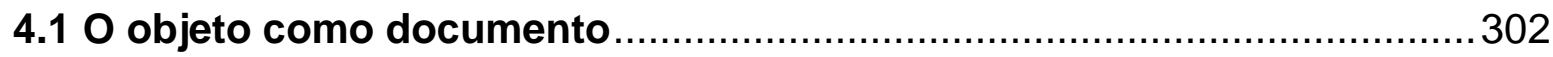

4.2 Reflexões sobre a musealização de objetos ligados ao culto católico e à

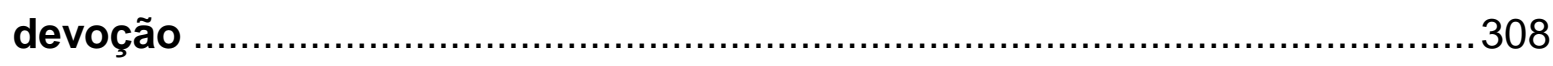

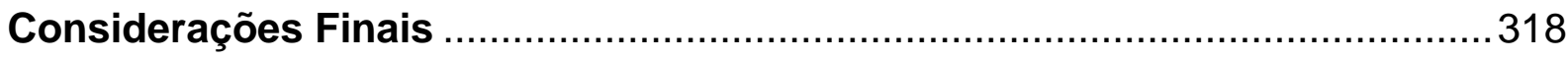

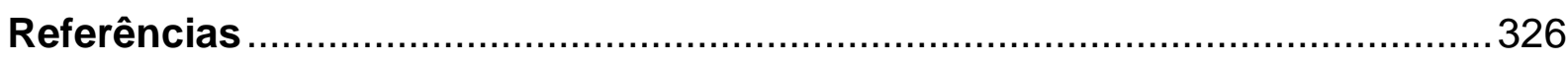

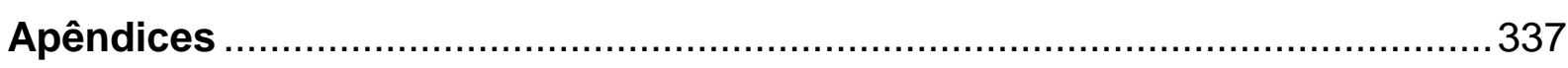

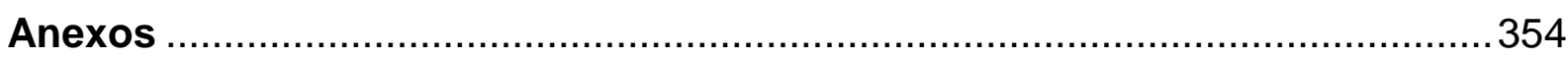




\section{Introdução}

O município de Aparecida (SP) compõe um circuito turístico-religioso no Vale do Paraíba, que inclui as cidades de Guaratinguetá, Lorena, Canas e Cachoeira Paulista. Nesse contexto, o Santuário Nacional de Aparecida é um dos maiores santuários católicos do mundo, recebendo a cada ano cerca de 12 milhões de visitantes, de acordo com o website oficial do Santuário, A12 (2019).

Essa devoção crescente deve-se ao milagroso encontro da Imagem de Nossa Senhora da Conceição, por pescadores da região, que atribuíram Aparecida ao seu nome, por ter aparecido nas águas do rio Paraíba do Sul. Entre os pescadores destacaram-se Domingos Garcia, João Alves e Filipe Pedroso.

Os trabalhos de pescaria iniciaram em meados do mês de outubro de 1717 no porto de José Correa Leite e foram descendo pelo rio Paraíba do Sul. Porém, com o insucesso na pesca, percorreram aproximadamente $6 \mathrm{~km}$ do rio, se aproximando do porto de Itaguaçu. Em certo ponto, ao lançar a rede, João Alves sentiu um peso ao puxa-la e viu que ao tirar a rede do rio havia uma imagem de Nossa Senhora sem a cabeça. Ele mostrou a imagem aos colegas, comovido com o fato, e a colocou no fundo da canoa para lançar a rede novamente e continuar a sua pesca. Foi nesse momento, após outra tentativa de pesca, que observaram que a cabeça da imagem também veio à superfície e ao unir cabeça e corpo, depararam-se com uma enegrecida imagem de Nossa Senhora da Conceição ${ }^{1}$. Foi então que perceberam que Nossa Senhora apareceu das águas do rio, por intermédio de suas orações, para abençoá-los nesta tarefa árdua de pescaria, em virtude da passagem do novo governador da Capitania, o Conde de Assumar.

De maneira geral, considera-se a pesca milagrosa que ocorreu após o encontro da imagem de Nossa Senhora da Conceição Aparecida, o primeiro milagre. Outros milagres começaram a se destacar ao longo dos anos e as notícias se espalharam por meio dos viajantes que paravam para rezar.

\footnotetext{
1 Imagem de Nossa Senhora da Conceição, feita em barro cozido, provavelmente do período seiscentista, procedente do estado de São Paulo. Mede $36 \mathrm{~cm}$ de altura e pesa 2,2550 kg, sem a base em prata que the foi acrescida posteriormente. Não se sabe ao certo a sua autoria, mas há estudos que atribuem sua autoria a um dos discípulos de Frei Agostinho da Piedade, possivelmente o Frei Agostinho de Jesus, que trabalhou em São Paulo por volta de 1650, bem como no Mosteiro de Parnaíba, local onde foi encontrada várias obras de sua autoria. Frei Agostinho de Jesus faleceu em 11 de agosto de 1661, cerca de 56 anos antes do encontro da Imagem de Nossa Senhora da Conceição Aparecida. Fonte: BRUSTOLONI, Júlio. A Senhora da Conceição Aparecida - História da Imagem, da Capela, das Romarias. Aparecida: Editora Santuário, 1982, p.15.
} 
Os peregrinos, devotos de Nossa Senhora Aparecida, ainda hoje percorrem os mais diversos caminhos, desde uma trilha até viagens em grupos familiares, romarias paroquiais, entre outros, feitas por meio de carro, de ônibus, a cavalo ou a pé, em busca de conforto espiritual ou turismo religioso.

Com base nesse contexto, questionamos de que forma o Museu Nossa Senhora Aparecida se inseriu nessa circunstância, considerando que, atualmente, o Museu ocupa no Santuário Nacional de Aparecida três andares da Torre Brasília, bem como o Mirante da Torre, com uma ampla vista panorâmica da cidade e região, por onde se inicia a visita ao Museu. Desse espaço, dois andares são ocupados por exposições de longa duração e um andar para reserva técnica. Além disso, há uma pinacoteca e uma sala de armazenamento provisório, em outros dois andares da Torre, tendo em vista uma possível expansão dessa reserva técnica, que se torna necessária, devido ao crescente aumento dos acervos e coleções.

A estrutura do Museu contempla também, desde outubro de 2017, o Circuito de Visitação à Cúpula, com três módulos expositivos, acessíveis pelos elevadores da Nave Norte, que levam aos corredores superiores da Basílica e à vista interna da Cúpula Central.

Ainda assim surgem as questões: quais são as relações do Santuário Nacional de Aparecida com a atuação do Museu? Qual o perfil das aquisições e doações realizadas? Como ocorre a inserção de objetos, em especial objetos religiosos, no espaço museológico? Como são realizados os processos museológicos, que garantam a preservação dos acervos? Quais são os públicos do Museu e como se relacionam com os objetos expostos? Qual o objetivo do Museu Nossa Senhora Aparecida e sua função social, a partir de diversas demandas que precisam ser atendidas? Enfim, como o Museu pode contribuir com o conhecimento dos temas que ele aborda?

A partir dessas indagações e dos conhecimentos sobre o objeto de estudo adquiridos pela minha experiência profissional no Museu Nossa Senhora Aparecida, complementada por uma trajetória acadêmica que teve o Museu como objeto de pesquisa², lancei-me ao Programa de Pós-Graduação Interunidades em Museologia

\footnotetext{
2 Produções acadêmicas desenvolvidas pela pesquisadora Erica Andreza Coelho relacionadas ao Museu Nossa Senhora Aparecida:

COELHO, E. A. A relação entre museu e escola. 2009. 61 f. Relatório Final (Licenciatura em História). UNISAL, Centro Universitário Salesiano de São Paulo, 2009.
} 
da Universidade de São Paulo (PPGMus - USP), com o intuito de refletir sobre a criação do Museu, as políticas de aquisição e formação de acervo, assim como as práticas institucionais para qualificação profissional e realização dos processos museológicos e projetos de expografia com temática religiosa.

Com o início dos trabalhos, comecei a analisar, por meio do estudo de casos semelhantes, como podem ocorrer as múltiplas relações entre uma instituição religiosa e um museu? E quais as influências dessa gestão no que se refere à formação de acervos, espaços expositivos e a relação com o público?

Ainda assim me perguntava qual seria a contribuição desta pesquisa para 0 campo da Museologia. E esse foi o ponto norteador que permeou o desenvolvimento do trabalho, que veio ao encontro do tema do $41^{\circ}$ Simpósio Anual do Comitê Internacional de Museologia (ICOFOM - International Committee for Museology, traduzido do inglês), que ocorreu entre os dias 15 e 19 de outubro de 2018, no Irã, com o intuito de analisar as relações entre a Museologia e o Sagrado. Este trabalho em especial propõe, através dessa perspectiva, um estudo sobre a história e formação das coleções e exposições do Museu Nossa Senhora Aparecida.

De maneira geral, buscou-se compreender como se construíram os processos comunicacionais com análise delimitada pelas exposições de longa duração. E foram quatro exposições que mais recentemente marcaram as transformações no Museu, a partir do processo de revitalização institucional: na primeira, inaugurada em 2005, buscou-se a criação de um espaço que contextualizasse a presença de Maria e a história do encontro da Imagem de Nossa Senhora Aparecida nas águas do Rio Paraíba do Sul e os inúmeros milagres ocorridos após esse fato. A segunda exposição, inaugurada em 2012, apresenta as relações do homem com o sagrado, com seu cotidiano, com sua expressão e com a natureza ao seu redor. A terceira exposição, inaugurada em 2016 no mesmo local da exposição anterior, apresenta

COELHO, E. A.; GONÇALVES, C. H.; LIMA, J. H.; PEREIRA, E. W.; SOUZA, T. M. Tour: Uma Solução tecnológica para o Museu Nossa Senhora Aparecida. 2016. 65 f. Relatório Técnico-científico - 5o Semestre, apresentado no VIII Simpósio de Desenvolvimento Tecnológico da FATEC Guaratinguetá. (Curso Superior de Tecnologia em Gestão da Tecnologia da Informação). FATEC, Faculdade de Tecnologia de Guaratinguetá, 2016.

COELHO, E. A.; GONÇALVES, C. H.; LIMA, J. H.; OLIVEIRA, A. C. M.; PEREIRA, E. W.; SOUZA, T. M. Tour System: solução tecnológica para instituições culturais. 2016. 199 f. Relatório Técnicocientífico - 60 Semestre (Curso Superior de Tecnologia em Gestão da Tecnologia da Informação). FATEC, Faculdade de Tecnologia de Guaratinguetá, 2016.

COELHO, E. A. Museu Nossa Senhora Aparecida: 60 anos de cultura e devoção. 2017, 62 f. Monografia (Especialização em Gestão Cultural). SENAC, 2017. 
imagens paulistas do século XVII. E, por fim, a quarta exposição trata-se de um circuito composto por três módulos expositivos, inaugurados entre 2017 e 2018. Este Circuito de Visitação à Cúpula Central da Basílica de Aparecida foi concebido durante as celebrações dos 300 anos do encontro da Imagem de Nossa Senhora Aparecida, compreendendo a finalização das obras do artista sacro Cláudio Pastro, responsável pelo revestimento artístico dos pisos, paredes internas e cúpula da Basílica de Nossa Senhora Aparecida.

Em suma, o objetivo deste trabalho é estudar o Museu Nossa Senhora Aparecida, suas coleções, acervos e exposições, com o intuito de analisar os processos museológicos, bem como a atuação do Museu Nossa Senhora Aparecida para preservação dos bens culturais e da memória religiosa, buscando com isso uma reflexão entre a museologia e o sagrado.

Por meio da bibliografia e fontes de pesquisa, buscou-se estabelecer relações entre o Santuário Nacional de Aparecida e o processo de musealização de acervos religiosos, por meio das atividades do Museu, como também analisar o processo de revitalização institucional do Museu e suas propostas expositivas.

Foram consultados documentos produzidos pela Profa. Conceição Borges Ribeiro Camargo, fundadora do Museu, com o intuito de identificar sua atuação no município de Aparecida (SP). Para isso, foi fundamental a leitura dos manuscritos e correspondências localizados no Museu, bem como artigos de jornais, além do estudo dos Almanaques de Nossa Senhora Aparecida - Ecos Marianos, produzidos anualmente pela Editora Santuário desde o final da década de 1920 até os dias atuais.

A pesquisa compreendeu também a alocação do Museu, o estudo de formação do acervo, com base nos documentos de entrada e doação, listas de inventário e fichas catalográficas dos objetos e por meio da constituição de seu lugar-sede e de formação das coleções, de acordo com os locais em que o Museu foi sendo instalado com o passar do tempo.

É necessário levar em consideração que o acervo foi originado a partir de coletas e aquisições feitas pela professora Conceição Borges Ribeiro Camargo, concomitantemente às doações feitas pelos romeiros peregrinos em visita à Basílica de Nossa Senhora Aparecida, os quais passavam pela chamada Sala dos Milagres, atualmente conhecida como Sala das Promessas, na qual ofertavam ex-votos e, com o decorrer do tempo, passaram a ofertar objetos antigos ao Museu. 
De maneira geral, o estudo das coleções está atrelado aos agrupamentos por tipologias que a professora Conceição Borges Ribeiro Camargo realizou e que foram reorganizados posteriormente pelos novos diretores do Museu.

Para maior compreensão das informações, relacionando com as fontes documentais, foi imprescindível a realização de entrevistas semiestruturadas e a análise de depoimentos já realizados anteriormente, em formato audiovisual existentes no Museu, com o intuito de coletar informações com antigos diretores do Museu e administradores do Santuário, bem como demais responsáveis pela revitalização institucional do Museu. Nesse contexto, os entrevistados foram: Zilda Augusta Ribeiro (depoimento existente no Museu, realizado em 2003), Guido Machado Braga (entrevista realizada em agosto de 2017), Tereza Galvão Pasin (entrevista realizada em dezembro de 2017), Zenilda da Cunha (entrevista realizada em janeiro de 2018), Giselle Peixe e Silvia Bigareli (entrevista realizada em janeiro de 2018), Dom Darci José Nicioli (entrevista realizada em maio de 2018) e Padre Víctor Hugo Silveira Lapenta (entrevista realizada em agosto de 2018).

Optou-se pela transcriação de trechos das entrevistas, bem como de materiais audiovisuais pertencentes à Instituição, conforme metodologia aplicada por José Carlos Meihy (2005), em seu Manual de História Oral, com o intuito de apresentar as fontes analisadas, evidenciando ao leitor os caminhos percorridos na pesquisa. $^{3}$

\section{A cultura material como elemento de análise}

De maneira geral, diversas questões se fazem cada vez mais presentes num mundo em que a preservação se torna uma questão de identidade cultural. Nesse contexto, ao expandir o conceito de museu, preservar o patrimônio cultural significa preservar a identidade cultural; porquanto, o setor de museus vem evoluindo e acompanhando o desenvolvimento da sociedade.

Segundo Ulpiano Toledo Bezerra de Meneses, em sua apresentação sobre a pesquisa no Museu como produção de conhecimento, apresentado no IV Seminário sobre Museus-Casas, no Rio de Janeiro, aborda que "a cultura é uma dimensão que pode qualificar qualquer lugar, momento ou instância da vida humana" (MENESES, 2002, p. 21). Nessa perspectiva, a cultura é fruto da miscigenação de diferentes

\footnotetext{
${ }^{3}$ As gravações na íntegra encontram-se na Área Técnica do Museu Nossa Senhora Aparecida.
} 
povos que introduziram seus hábitos e costumes, o compartilhamento de patrimônios comuns como a língua, a religião, as artes, a música, o trabalho, os esportes, as festas, entre outros, em um processo dinâmico de construção contínua.

Diante disso, a identidade cultural é, pois, uma forma de caracterização das pessoas, através de seu modo de agir, sendo possível a identificação a partir dos modos específicos de sua cultura. De acordo com Stuart Hall, em seu livro $A$ identidade cultural na pós-modernidade, "[...] nessas identidades culturais, ao mesmo tempo que internalizamos seus significados e valores, tornando-os 'parte de nós', contribui para alinhar nossos sentimentos subjetivos com os lugares objetivos que ocupamos no mundo social e cultural" (HALL, 2001, p. 12).

Gonçalves (2005), em seu texto Os museus e a representação do Brasil, publicado na Revista do Instituto do Patrimônio Histórico e Artístico Nacional (IPHAN), aborda que os museus têm sido associados, nas modernas sociedades ocidentais, aos espaços da cultura, sendo considerados como espaços materiais de representação social. Para o autor, o espaço material dos museus é constituído, social e simbolicamente, pelo tenso entrecruzamento de diversas relações entre os variados grupos sociais.

Heloisa Barbuy, em sua tese de doutorado intitulada $A$ Cidade-Exposição: comércio e cosmopolitismo em São Paulo, 1860-1914 (estudo de história urbana e cultura material), argumenta que "[...] a expressão "Cultura Material" é normalmente mais associada ao universo dos objetos (ou coisas) que povoam o quotidiano urbano ou rural [...]" (BARBUY, 2001, p. 24). Desta maneira, a evidência da cultura material é um elemento importante para análise, e os museus estão entre as principais instituições que guardam os indicadores da dimensão cultural das sociedades.

Nesse contexto, de acordo com a autora "[...] a cultura material é uma expressão que se tornou necessária para designar certo tipo de estudo em torno de objetos, mas também todo estudo que se debruça sobre aspectos materiais da cultura" (BARBUY, 2001, p. 24).

De acordo com Poulot, em seu livro Museu e Museologia,

A análise dos objetos de museu, dos musealia, é também a das condições sob as quais uma cultural material específica é elaborada, formatada, comunicada e interpretada. Com efeito, a materialidade do museu manifesta-se tanto nos objetos que ele possui quanto nos dispositivos de seu tratamento - catálogos, fichários, arquivos, diversas publicações. A esse respeito, o museu, mesmo que tenha a ver com um projeto específico, 
participa de procedimentos e convenções que não the são exclusivos relativamente ao tratamento, à identificação e à exposição dos artefatos: esses dispositivos podem remeter à especulação comercial, ao trabalho acadêmico e ao espetáculo urbano. (POULOT, 2013, p. 32).

Para Ulpiano Toledo Bezerra de Meneses (2000, p. 94) "identidade e memória são assim ingredientes fundamentais da interação social, [...] e, por isso, não poderiam em hipótese alguma estar ausentes dos museus que pretendam dar conta dos aspectos fundamentais de uma sociedade [...]". Para o autor, se a memória se constrói filtrando e selecionando, ela pode também ser induzida, provocada, garantindo assim a produção e reprodução da vida social. Ainda segundo o autor:

O conhecimento não mais se produz especulativamente a partir de pressupostos teológicos, teóricos ou filosóficos, mas do sensível é que se chega ao inteligível: daí a consolidação das coisas materiais como documentos, fontes de informação. Desta postura surgem traços que marcam o museu ainda hoje. Antes de mais nada, a própria noção de coleção, não como um conjunto disparatado de objetos, mas como uma série sistematicamente organizada de "fontes". (MENESES, 2002, p. 29).

Heloisa Barbuy, em seu artigo Documentação museológica e pesquisa em museus, argumenta que, "de fato, se tratados do ponto de vista histórico, os artefatos são, sem dúvida alguma, poderosos portadores de informações, mesmo individualmente, mas, sobretudo, enquanto integrantes de sistemas culturais configurados materialmente" (BARBUY, 2008, p.34). Por isso, o museu deve levar em consideração a sociedade na qual está imerso, pois cabe a ele relacionar passado e presente por meio da preservação dos artefatos, possibilitando sua leitura. De acordo com a autora,

Não se trata, no entanto, de abordar qualquer problemática histórica a partir
de fontes materiais. Embora isto também possa ser feito, a questão
essencial é que o exame de universos materiais trazem problemáticas
novas, muitas vezes relacionadas a dimensões não percebidas quando se
examinam fontes relacionadas apenas a ideias abstratas e não a
expressões materiais da cultura. (BARBUY, 2001, p. 25). Para Gonçalves (2005, p. 256) "esse processo de circulação da cultura está submetido a divisões e hierarquias, a estruturas nacionais e locais de natureza social e simbólica, cuja lógica de funcionamento precisa ser decifrada para que se possam perceber os limites reais e avaliar lucidamente os seus efeitos sociais".

Diante dessas perspectivas, o museu é, portanto, uma base institucional necessária, uma condição dentro da qual o fato museológico ${ }^{4}$ se realiza. Conforme

\footnotetext{
4 Principal conceito abordado por Waldisa Rússio, compreendido como a profunda relação entre o homem, sujeito que conhece, e o objeto, documento e testemunho de uma realidade sobre a qual o homem igualmente atua. Essa profunda relação entre o homem e o objeto se estabelece no espaço
} 
abordado por Waldisa Rússio, o objetivo da museologia é o conhecimento claro e intenso do fato museológico e do espaço institucionalizado do museu dentro de um contexto.

De acordo com Poulot (2013), essa temática implica três desafios:

O da construção do "museal" no seio da vida social dos objetos, ou seja, de uma história da cultura material e de seus valores; em seguida, o da política da instituição na esfera pública enquanto lugar específico de representação de um patrimônio ou de disciplinas; enfim, o da utilização do estabelecimento enquanto ele materializa, tradicionalmente, um espaço de práticas, para não dizer, de rituais (POULOT, 2013, p. 130-131).

Ainda segundo o autor, os museus representam depósitos de valores que acabam servindo de referências, considerando os debates que podem surgir por meio das coleções e apresentação ao público. Nesse contexto, para o autor, a musealização contemporânea se exerce sobre o artefato.

Para Ulpiano Toledo Bezerra de Meneses (2002, p. 23),

O museu é por excelência o espaço da representação do mundo, dos seres, das coisas, das relações. Não é o único espaço, pois a ciência é também um espaço de representação do mundo, assim como a arte. Qual, então, sua especificidade? É que esta representação se faz com segmentos do mundo físico, se faz com elementos que integram a nossa própria natureza enquanto seres humanos, natureza que está marcada pela nossa corporalidade.

É necessário, pois, a implantação de processos museais que identifiquem e reconheçam as diferentes comunidades a que se destinam, procurando adequar estratégias de ação, procedimentos metodológicos e técnicas, buscando aplicá-los às especificidades de cada comunidade.

\section{A Museologia e o Sagrado}

A partir desta fundamentação sobre o método de pesquisa e a atuação da museologia, que considera a cultura material como importante fonte de informação, propomos estudar o processo de musealização do sagrado no Santuário Nacional de Aparecida, a partir da perspectiva do Museu Nossa Senhora Aparecida, a formação de suas coleções, acervos e exposições.

Nesse aspecto, de acordo com Poulot (2013, p. 127),

A museologia é, com toda a evidência, uma construção recente, a própria palavra tem a ver com uma antiga tradição. A Museographia do marchand Caspar Friedrich Neickel, publicada em Hamburgo, em 1727, reflete sobre a escolha dos lugares mais adequados para receber a coleção, sobre a

institucionalizado do museu, constituindo um cenário onde se apresentam os resultados de sua ação transformadora. 
melhor maneira de conservar tanto os produtos da natureza quanto os artificialia e, finalmente, sobre sua classificação.

François Mairesse (2018, tradução nossa), em sua apresentação $A$

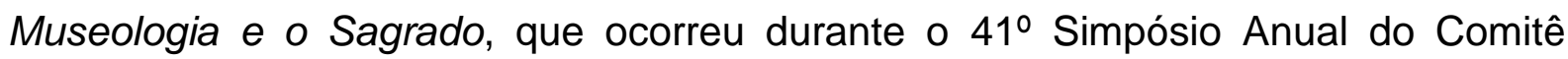
Internacional de Museologia (ICOFOM - International Committee for Museology, traduzido do inglês), argumenta que a noção de sagrado não aparece diretamente na museologia, embora muitos museus dedicam-se às manifestações do sagrado, levando em consideração suas coleções originárias, de fato oriunda de espaços sagrados ou até mesmo relacionadas ao culto, por exemplo, pinturas, objetos de culto, etc. Com isso, o museu passa a produzir algumas qualidades sagradas.

Em relação à percepção do sagrado na Igreja, Rita Capurro (2018), em seu texto Reinterpretando um lugar sagrado. Quando uma igreja se torna um museu do ponto de vista eclesiástico, também apresentado no 41ํㅗำósio Anual do Comitê Internacional de Museologia, analisa que,

Na Igreja Cristã Romana, o uso da palavra sagrado está ligado a lugares ou coisas que conectam a vida na terra com a dimensão de Deus; santos, relíquias e coisas consagradas são sagradas. Em particular, para o último, a condição de sagrado é ligada ao seu uso: das igrejas aos vasos sagrados, todos esses elementos são criados com características e significados específicos e cumprem sua condição de santidade quando são usados na liturgia (CAPURRO, 2018, p. 49-50, tradução nossa).

De acordo com François Mairesse (2018), a partir de uma perspectiva integrativa da museologia, é possível considerar o sagrado como uma das categorias da musealidade. Como, por exemplo, a relação museu-templo-religião em nível institucional.

No que tange à relação patrimônio-musealidade-sagrado, o autor questiona como a musealização é influenciada pela sacralidade do objeto e como ocorre a construção da noção de sagrado no museu. No que se refere à epistemologia na relação entre museologia-sagrado-teologia, o autor questiona se a definição do sagrado, na museologia, é semelhante à da filosofia, antropologia ou teologia. Como constituir o sagrado no contexto museológico, considerando a premissa da relação homem-realidade à qual a museologia se baseia.

Segundo Rita Capurro (2018, tradução nossa), em geral há dois elementos na museologia que reúnem as ideias do museu e do sagrado, são eles: a arquitetura e o processo de musealização. Mas, do ponto de vista religioso, há ações diferentes e específicas, no que se refere ao sagrado e ao profano, considerando que o senso secular de religiosidade nos museus está presente nos principais museus nacionais. 
Para a autora, a questão da arquitetura é visível no elo entre o templo grego e, em particular, a fachada dos primeiros museus nacionais, levando em consideração a conexão original entre a palavra Museu e as Musas do Olimpo. Já o segundo elemento, que trata do processo de musealização, considera a entrada do objeto ao Museu, semelhante ao processo de "sacralização", ou seja, a criação de um objeto sagrado. Desta forma, analisando de maneira antropológica, a autora afirma que a categoria do sagrado pode ser aplicada aos museus, embora apenas por semelhanças.

Em linhas gerais, para discorrer sobre esse tipo de processo de musealização, é necessário, primeiramente, verificar se o sagrado pode ser e como deve ser musealizado. Para isso, de acordo com Maria Isabel Roque (2011), em seu livro O Sagrado no Museu, é preciso estudar a preservação e exposição de objetos referentes às práticas religiosas, partindo-se da premissa de que o sentido do sagrado é musealizável, conhecer como esse tipo de musealização tem sido feito e refletir sobre esse tipo de processo.

Marília Xavier Cury (2018), em seu trabalho com os indígenas Kaingang, apresentado no $41^{\circ}$ Simpósio Anual do Comitê Internacional de Museologia, faz uma reflexão sobre o sagrado no museu, pois a ideia de patrimônio continua a se apropriar de objetos sagrados no ambiente museológico. Segundo a autora, "no caso do sagrado no museu, os indígenas nos ensinam o conhecimento da espiritualidade. $\mathrm{O}$ conhecimento e as práticas espirituais desses povos indígenas são mantidos pela tradição, as culturas fortalecidas e refeitas" (CURY, 2018, p. 61, tradução nossa).

De acordo com a autora, a discussão sobre sagrado no museu a partir da perspectiva indígena nos fornece argumentos importantes para a análise, considerando, primeiramente, que os indígenas vivem o sagrado. Como exemplo, Marília Xavier Cury (2018) cita a participação dos indígenas no Museu de Arqueologia e Etnologia da Universidade de São Paulo (MAE-USP), em 2017, para a requalificação das coleções Kaingang. A autora conta que, durante os trabalhos, os indígenas:

Alertaram-nos que os objetos que evocam os ancestrais não poderiam ser manipulados. Advertidos de que as peças não poderiam ser medidas, dissemos que teríamos que manipulá-las. Eles responderam que podíamos, porque nos importamos - curamos -, é por isso que o diálogo com os indígenas é um caminho inevitável para boas práticas e reposicionamento profissional. (CURY, 2018, p. 62, tradução nossa). 
Para Marília Xavier Cury (2018), a Museologia precisa trabalhar mais com o intuito de construir o respeito pelos povos indígenas, considerando que a espiritualidade faz parte do cotidiano indígena, além de ser um sistema de comunicação no qual o Pajé desempenha um papel muito importante. Por isso os profissionais de museus e pesquisadores precisam buscar orientação adequada para manipulação de artefatos indígenas sagrados e remanescentes humanos. Nesse ponto, os indígenas Kaingang, de forma colaborativa, auxiliaram em termos de exposições e ações educativas. Para a autora, uma pedagogia museológica não pode esquecer essas lições.

Marília Xavier Cury (2018, p. 63, tradução nossa) ainda argumenta que "não são os museus que tornam o objeto sagrado, mas são objetos sagrados para as culturas indígenas que fazem do museu um lugar para novos aprendizados". Para isso, os profissionais de museus precisam estar preparados com profundo respeito pelo conhecimento indígena.

De acordo com a autora, a Museologia pode contribuir com processos colaborativos como a curadoria museológica, considerando que, ao colocar a espiritualidade indígena como eixo, é possível nos afastar de certas concepções, com o intuito de quebrar paradigmas, nos quais os museus tratam o sagrado, assim como a ideia de patrimônio quando se apropria de objetos sagrados. Pois, as concepções de artes sacras podem ser limitadas, assim como outras categorias patrimoniais de lugares, objetos e práticas.

A autora argumenta que hoje vivenciamos grandes mudanças, e, com os processos colaborativos na Museologia, é possível conhecer outras perspectivas de vida que devem ser respeitadas pelos museus.

Nesse sentido, porém, em referência à Igreja Católica, Maria Isabel Roque, em sua tese, analisa a maneira como o museu refere o sagrado, a forma como exprime o pensamento imaterial, os sentimentos religiosos, e como referenciar os objetos litúrgicos e devocionais numa apresentação museológica. Segundo a autora, "a musealização do objecto religioso é atualmente encarada como uma das soluções mais eficazes para a preservação [...]" (ROQUE, 2011, p. 11).

A autora considera que a museologia do patrimônio católico, veiculando os aspectos da sua ligação ao sagrado, não ultrapassou ainda o perímetro eclesiástico. Com isso, podemos observar a influência do clero na formação de Museus de Arte 
Sacra e tesouros eclesiásticos, normalmente instalados em igrejas, mosteiros, conventos ou demais ambientes administrados pelo clero.

Entretanto, para Rita Capurro (2018), a reutilização de igrejas como museus, assim como o ato de hospedar um museu em uma igreja, é uma das questões mais difíceis a serem abordadas.

A conversão em museus de muitos edifícios religiosos que perderam sua função original cria um possível equívoco sobre a santidade do lugar, ainda mais quando o processo de musealização é feito por uma instituição religiosa, e quando o propósito do edifício é um museu de objetos religiosos. (CAPURRO, 2018, p. 50, tradução nossa).

Para a autora, "há uma responsabilidade específica de manter a separação entre a dimensão do sagrado e a do profano, e isso é mais difícil, pois a linguagem formal do prédio e a natureza das coleções lembram um contexto completamente sagrado" (CAPURRO, 2018, p. 51, tradução nossa).

De acordo com Roque (2011, p. 15), "a questão central da museologia é, neste contexto, identificar a forma como o museu recontextualiza os conteúdos funcionais, semânticos e simbólicos deste patrimônio ligado ao sagrado", para a correta musealização dos acervos.

Manuel del Carpio (2000), em sua pesquisa sobre a musealização da arte sacra no Brasil e as diferentes influências culturais, apresentada ao Programa de Especialização em Museologia, do Museu de Arqueologia e Etnologia - MAE-USP, aborda que é importante analisar o processo de ressignificação dos objetos, no qual os objetos religiosos, ao entrarem no museu, passam a ser classificados como artefatos culturais. De acordo com o autor,

No museu os objetos não têm "poder" individual ou "mistério" - qualidades um dia possuídas pelo seu caráter religioso. Parece, no entanto, que estes objetos de culto retirados de seu contexto de sacralidade e submetidos à reclassificação segundo critérios da museologia, conservam e readquirem novos "mistérios" na sua comunicação com o público para certos setores da população. Existem relatos de que muitos dos Museus Sacros, principalmente os ocupados por edificações com funcionalidade religiosa anterior, testemunham comportamentos místicos de parte dos visitantes ao estarem frente ao objeto museal. (CARPIO, 2000, p. 33).

O autor argumenta que "museu sacro e o objeto musealizado na sua apresentação ao público, retirados de seu contexto de sacralidade, conservam ou readquirem a devoção popular" (CARPIO, 2000, p. 34). Desta forma, segundo o autor, quando estes objetos são apreciados principalmente pela comunidade mais simples ou do interior, essa apreciação é feita de forma religiosa, muitas vezes seguidas da invocação. 
Considerando que na maioria dos casos os prédios ocupados pelos museus podem ter tido alguma origem religiosa anterior, como é o caso do Museu Nossa Senhora Aparecida desde a sua fundação, instalado inicialmente no Convento das Irmãs Canisianas, posteriormente transferido para uma sala da Galeria do Hotel Recreio, pertencente à Congregação Redentorista, e nos dias atuais o Museu ocupando diversos ambientes na Basílica de Nossa Senhora Aparecida, também denominada Santuário Nacional de Aparecida.

A partir dessa análise, é possível retomar algumas questões apontadas por Rita Capurro, no que se refere à inserção de museus em espaços religiosos, que irão permear esta dissertação,

\begin{abstract}
Quais são as especificidades dos museus colocados nas igrejas? Quais são os instrumentos para a interpretação desses lugares? Quais são as ferramentas para sublinhar a diferença entre o sagrado representado e o sagrado vivido em um contexto religioso? Essas questões abrem diferentes campos de pesquisa do ponto de vista religioso e eclesiástico, e do ponto de vista museológico. (CAPURRO, 2018, p. 51, tradução nossa).
\end{abstract}

\title{
Estrutura da dissertação
}

No sentido de colaborar para melhor compreensão entre a Museologia e o Sagrado, por meio das coleções, acervos e exposições do Museu Nossa Senhora Aparecida, esta pesquisa estrutura-se em quatro capítulos, subdivididos conforme as temáticas abordadas.

Para cumprir o seu propósito, essa pesquisa abordará alguns eixos interligados: a formação de acervos e coleções; a relação da Sala dos Milagres ou Sala das Promessas com o Museu Nossa Senhora Aparecida; e os processos museológicos para qualificação profissional e a musealização dos objetos ligados ao culto católico e a devoção.

No capítulo 1 - O Museu Nossa Senhora Aparecida - 1956 a 1996, será apresentada a fase inicial de formação do Museu, que abrange o período de 1956 a 1996, com administração da fundadora Profa. Conceição Borges Ribeiro Camargo e seu esposo Vicente Camargo. Será apresentado o ambiente expositivo, com a antiga configuração da exposição do $2^{\circ}$ andar da Torre Brasília, administrado pela fundadora do Museu. No contexto geral, uma formação material interessa-nos particularmente, pois acreditamos que a chamada Sala das Promessas, também conhecida como Sala dos Milagres ou Quarto dos Milagres, possa a ser identificada como uma característica de coleção de acervo religioso e devocional, por meio da 
oferta de objetos que remetem a uma promessa ou graça alcançada. Acreditamos também que a Sala dos Milagres possa ter sido um estímulo para a criação do Museu Nossa Senhora Aparecida, pela proximidade de localização e algumas similaridades na formação de coleções, além das transferências de objetos ao Museu. Atualmente, a Sala das Promessas é uma fonte de aquisição de acervos, pois alguns objetos são transferidos para incorporação ao acervo do Museu, após a seleção e análise por uma comissão técnica e aprovação dos missionários redentoristas.

No capítulo 2 - As trajetórias do Museu: mudanças na gestão e reestruturação, será abordada a segunda fase do Museu, quando passou a ser administrado diretamente pelo Santuário Nacional de Aparecida. Essa fase será dividida em duas: a primeira, que abrange o período de 1996 a 2003, após o falecimento da fundadora e a necessidade de uma nova direção; posteriormente, serão analisadas as etapas de revitalização institucional do Museu, iniciadas em 2003 até os dias atuais, que compreendem a criação do Plano Museológico, implantação de reserva técnica climatizada, a organização das coleções e os processos de identificação e classificação do acervo, profissionalização das equipes de trabalho, bem como o uso de Sistemas de Gerenciamento de Documentos, para catalogação dos objetos em software específico.

No capítulo 3 - Propostas de comunicação: o sagrado no museu, serão analisadas as exposições de longa duração, sendo elas: Rainha do Céu, Mãe dos Homens: Aparecida do Brasil, localizada no $1^{\circ}$ andar, O Museu e suas Histórias, localizada no $2^{\circ}$ andar, Coleção Santa Gertrudes de Imagens Paulistas do século XVII, localizada no $2^{\circ}$ andar, e, por fim, o Circuito de Visitação à Cúpula, com três módulos expositivos localizados no corredor superior da Nave Norte e na Cúpula Central do Santuário Nacional de Aparecida.

No capítulo 4 - A museologia e o sagrado, dentro de um plano mais teórico, o objeto museológico será analisado como documento, contribuindo nas reflexões sobre o processo de musealização de objetos sagrados, ao considerar a cultura material como importante fonte de informação. De maneira geral, ao analisarmos a produção internacional e brasileira sobre a relação entre ciência e documento, observamos que a estabilização da informação em publicações e trabalhos científicos, permite validar os estudos realizados. Nesse sentido, é importante considerar os espaços de criação do conhecimento científico, entre eles o Museu, 
visto como um Laboratório e espaço de difusão do conhecimento produzido. Nesse contexto, a musealização de objetos ligados ao culto católico e à devoção constitui uma categoria própria da cultura material do Homem e da sua relação com o Sagrado, caracterizada por temas e simbologias diversas.

Esta pesquisa, conceitualmente vinculada à Museologia, terá interfaces com a História (área de formação da autora), com o intuito de justificar e valorizar o acervo abrigado no Museu Nossa Senhora Aparecida e os processos museológicos para preservação da memória religiosa. 


\section{Capítulo 1 - O Museu Nossa Senhora Aparecida - Período de 1956 a 1996}

Neste capítulo será abordada a fase inicial do Museu, que abrange o período de 1956 a 1996, com administração da fundadora Profa. Conceição Borges Ribeiro Camargo e seu esposo Vicente Camargo, com o intuito de contribuir para a melhor compreensão sobre a formação do Museu Nossa Senhora Aparecida.

O método de pesquisa será a partir da sua alocação, do estudo de formação do acervo, com base em antigas fotografias e nos documentos de entrada e doação de objetos, listas de inventário e fichas catalográficas, e por meio da constituição de seu lugar-sede e de formação das coleções, de acordo com os locais em que o Museu foi sendo instalado com o passar do tempo.

Serão analisadas também as antigas exposições instaladas no $2^{\circ}$ e $3^{\circ}$ andares da Torre Brasília, no Santuário Nacional de Aparecida, sendo possível observar as tipologias das coleções e a forma em que os objetos foram agrupados nas vitrines.

No contexto geral, uma formação material interessa-nos particularmente, pois acreditamos que a chamada Sala das Promessas, também conhecida como Sala dos Milagres ou Quarto dos Milagres, possa a ser identificada como uma característica de coleção de acervo religioso e devocional, por meio da oferta de objetos que remetem a uma promessa ou graça alcançada.

A partir dessa perspectiva, acreditamos que a Sala dos Milagres possa ter sido um estímulo para a criação do Museu Nossa Senhora Aparecida, pela proximidade de localização e algumas similaridades na formação de coleções. Atualmente, a Sala das Promessas, no subsolo do Santuário Nacional de Aparecida, é uma fonte de aquisição de acervos, considerando que alguns objetos são transferidos para incorporação ao acervo do Museu, após seleção e análise por uma comissão técnica e aprovação dos Missionários Redentoristas.

Em relação às fontes de pesquisa e bibliografia, as principais referências consultadas foram os documentos localizados no Museu Nossa Senhora Aparecida e no Instituto de Estudos Valeparaibanos (IEV), do qual a Profa. Conceição Borges Ribeiro Camargo era membro. Assim como artigos de jornais e artigos do Almanaque de Nossa Senhora Aparecida - Ecos Marianos, preservados no Centro de Documentação e Memória (CDM) do Santuário Nacional de Aparecida. 
Também foi imprescindível a análise do Contrato de Doação do Museu entre os fundadores e a Sociedade Santuário Nacional de Nossa Senhora Aparecida, firmado em 1967, no qual os doadores fazem livre e espontaneamente a doação, a título gratuito, das peças constantes no inventário e também de todas as demais peças que venham a ser ofertadas ao Museu.

A partir desse contrato, é possível verificar o acervo inicial do Museu, pois há uma relação de inventário das peças, no período em que o Museu foi instalado na Basílica de Nossa Senhora Aparecida.

As listas de entrada de objetos, com documentos de doação a partir de 1993, foram fundamentais para compreender o perfil de doação dos visitantes do Museu, embora vários manuscritos com data anterior também tenham sido convertidos em Termos de Doação de Bens Móveis.

Com base no estudo dessas listas de entrada e pesquisa nas fichas catalográficas, foi possível identificar que alguns objetos foram de fato incorporados ao acervo do Museu e hoje estão documentados e armazenados na Reserva Técnica. Entretanto, para a grande maioria dos objetos que constam nas listas, não foi possível fazer essa associação e encontrar a sua localização, embora se acredite que alguns desses objetos estejam armazenados na Reserva Técnica do Museu, apesar de não ser possível afirmar sua procedência, devido à perda de informações sobre as aquisições.

\subsection{A criação do Museu}

O Museu Nossa Senhora Aparecida foi fundado pela professora e historiadora Conceição Borges Ribeiro Camargo ${ }^{5}$ em 08 de setembro de 1956. Na ocasião da inauguração, o acervo inicial foi abrigado em duas salas nas Oficinas Gráficas de Arte Sacra (Figura 1), no Convento das Irmãs Canisianas, que vieram da Suíça em 1951 para criar o primeiro Convento da Congregação das Irmãs de São Pedro Canísio, em Aparecida (SP), e cooperar com o apostolado da Boa Imprensa, a pedido dos Missionários Redentoristas (ECOS MARIANOS, 1957).

\footnotetext{
${ }^{5}$ Conceição Borges Ribeiro Camargo, professora e pesquisadora, filha do português Jaime Ribeiro e da aparecidense Julieta Borges Ribeiro, nasceu em 05 de setembro de 1914, em Aparecida (SP). Casou-se com Vicente Camargo, após a fundação do Museu Nossa Senhora Aparecida. Fez parte de vários movimentos culturais e cívicos na região do Vale do Paraíba e foi uma personagem muito ativa no resgate e salvaguarda dos objetos arqueológicos encontrados durante escavações no município de Aparecida (SP).
} 
$\mathrm{Na}$ inauguração do Museu Nossa Senhora Aparecida (Figura 2) esteve presente Dom Carlos Carmelo de Vasconcellos Motta, Cardeal Arcebispo de São Paulo, que veio especialmente para a solenidade. Também estiveram presentes 0 Dr. Luís Silveira, representante da Fundação Casper Líbero, Sr. Manoel Alves Nunes, vice-prefeito de Aparecida, Dr. Manoel Eduardo Pereira, Juiz de Direito, o Padre José Ferreira da Rosa, Vigário da Basílica, o Prof. André Alckmin Filho, Prefeito de Guaratinguetá, o Sargento Aristeu de Oliveira, que dirigiu a fanfarra do Ginásio Municipal com vibrante marcha, acompanhados por diversos sacerdotes, Missionários Redentoristas do município de Aparecida (SP).

Ao descerrar a fita simbólica, o Cardeal Motta deu sua bênção ao salão da exposição e "percorreu com atenção e interesse as duas salas, ouvindo as explicações da organizadora, ressaltando o valor dos documentos históricos e das peças de cerâmica indígena local" (ECOS MARIANOS, 1957, p. 40).

Figura 1: Convento das Irmãs Canisianas, Aparecida (SP).

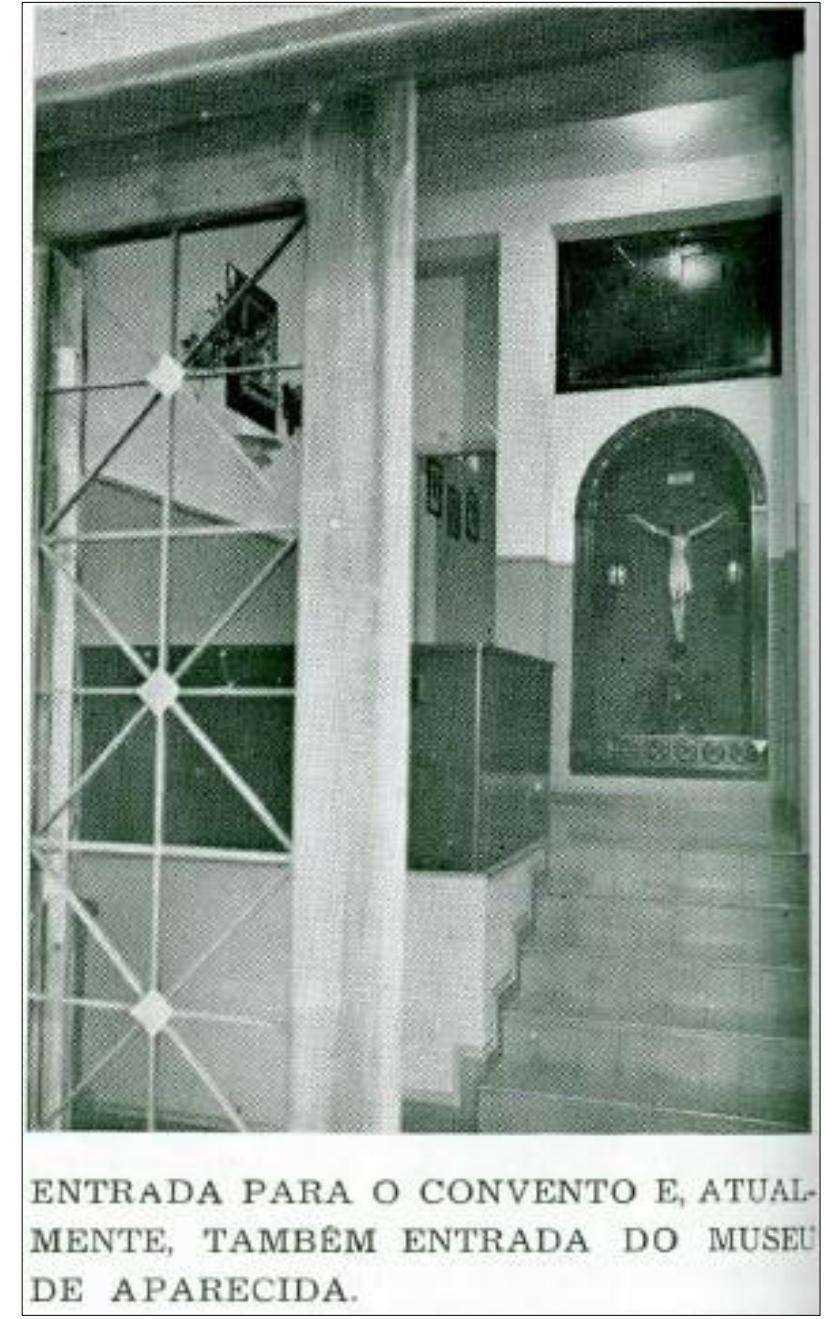

Fonte: ECOS MARIANOS, 1957, p. 244. CDM/Santuário Nacional. 
O Jornal A Gazeta, de 25 de setembro de 1956, também fez uma publicação referente à inauguração do Museu Nossa Senhora Aparecida.

Em duas salas gentilmente cedidas pelas Irmãs Canisianas foi inaugurado, em Aparecida, pelo Cardeal Motta, arcebispo de São Paulo, o Museu Nossa Senhora Aparecida.

Depois de longa preparação a fundadora do Museu, d. Conceição Borges Ribeiro viu realizado o seu sonho de muitos anos. Nas duas salas habilmente montadas - estão reunidas peças de raro valor histórico-profano e religioso e que foram recolhidas em Aparecida e nos arredores. Ali está o primeiro oratório de Nossa Senhora Aparecida - talvez a peça mais preciosa. Vêm-se imagens de santos, moldadas pela arte popular do Vale do Paraíba do qual é representante o célebre "Chico Santeiro". Também estão expostos candelabros e objetos da antiga capela, quadros e fotocópias de documentos antiquíssimos etc.

A parte profana é representada por machadinhas, igaçabas e objetos de cerâmica indígena, encontrados no Vale do Paraíba. Utensílios diversos de uso doméstico tais como rocas, lampiões antigos, vasilhames, etc. e também uma pesada algema de atar o pulso dos escravos estão expostos no Museu. (A GAZETA, 1956)

Figura 2: Inauguração do Museu Nossa Senhora Aparecida nas Oficinas Gráficas de Arte Sacra Convento das Irmãs Canisianas, 1956.

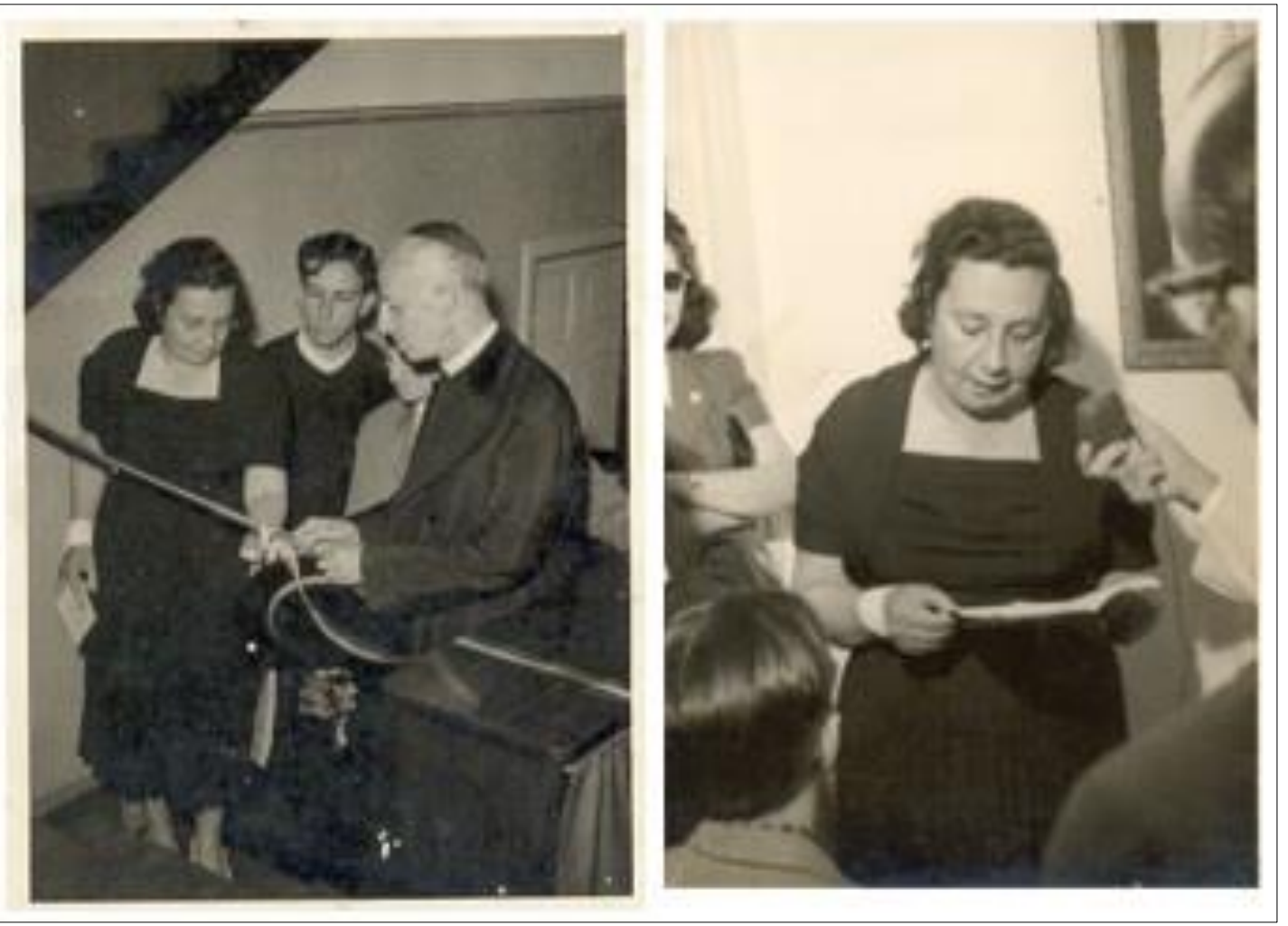

Fonte: MNSA/Santuário Nacional.

Após a leitura da ata, seguindo-se vários oradores, entre eles o Professor José Luiz Pasin, Presidente do Centro Cultural de Estudos e Debates "Eduardo Prado", Doutor José Mauro da Silveira e o Padre Doutor José Vicente Cesar, Diretor da Anthropos do Brasil, o Cardeal Motta, acompanhado de seu secretário, padre 
José Alves Motta Filho e do Prof. Luiz Silveira, diretor da escola de jornalismo Casper Líbero, proferiu um discurso exaltando o valor do Museu por sua finalidade cultural, ao dizer que:

Cultivar as tradições de um povo é como alimentar as raízes de uma árvore; quando queremos cuidar de uma planta, não são os galhos, as flores e as folhas que merecem a nossa atenção e sim as raízes; as tradições são como as raízes da árvore nacional, quer as religiosas quer as cívicas. (ECOS MARIANOS, 1957, p. 40)

Em relação ao acervo indígena, o Cardeal Motta fez referência à nossa formação étnica, relacionando as origens portuguesas e americana indígena, que contribuíram para a formação do sangue brasileiro. Em seu discurso, Cardeal Motta complementa que "os índios não têm tido quem lhes advogue as tradições e é uma gloriosa nota de brasilidade e de tradição indígena do Vale do Paraíba a que o Museu imprime em sua organização" (A GAZETA, 1956).

Ao concluir seu pronunciamento, o Cardeal Motta "pediu bênção a Nossa Senhora para que mais tarde o museu atinja plenamente o seu objetivo, alargandose em todas as suas seções, para a glória do futuro desta pequena grande cidade de Aparecida do Norte" (ECOS MARIANOS, 1957, p. 40; PASIN, 2016. p. 2).

A partir desse discurso do Cardeal Motta, conforme reproduzido pela Profa. Tereza Pasin no evento em comemoração aos 60 anos do Museu Nossa Senhora Aparecida, podemos relacionar os conceitos de tradição, povo, enraizamento e civismo, que são evidentes no pronunciamento, reforçando a ideia de que o museu é um local para se estudar as tradições da sociedade por meio de seus artefatos.

Nesse contexto, de acordo com Rússio6 (s.d. apud BRUNO, 2010. p. 76),

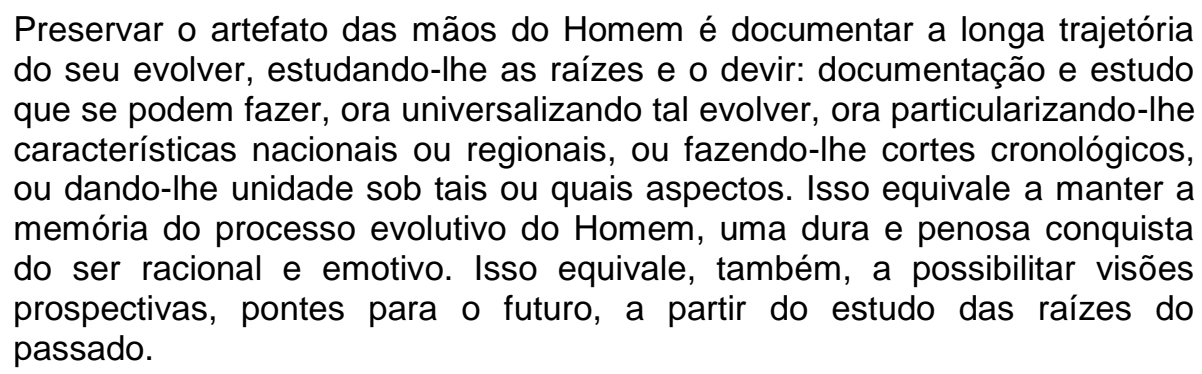

Ainda segundo a autora, a principal tarefa do museu é registrar, portanto, os aspectos da trajetória do homem, podendo ser variáveis os recursos de comunicação adaptados à época. Desta forma, o museu irá variar de acordo com a sociedade, quanto à forma e aos seus meios.

${ }^{6}$ RÚSSIO, Waldisa. Museu, para quê? (A necessidade da arte). s.d. Acervo: Instituto de Estudos Brasileiros da Universidade de São Paulo (IEB-USP). 
Para Hugues de Varine (2012, p. 40), "o patrimônio sempre foi um elemento essencial da identidade local, regional, nacional”. Já Mário de Andrade (1993, p. 7) argumenta que "a religião está na gênese de todas as civilizações e culturas, das mais antigas às mais recentes. Somos tão recentes, que sequer ultrapassamos a infância cultural; mesmo assim, agimos como se desfigurados pela herança das tradições, usos e costumes [...], a fim de encontrarmos a própria identidade".

Outro fator importante para análise é a função social do museu, a qual Hugues de Varine (2008, p. 12) questiona a visão do museu sobre seu papel e se a sociedade os considera como meios de desenvolvimento ou apenas um local de consumo cultural.

Deste modo, para Gonçalves (2005, p. 271), "não basta dizer que os museus representam identidades nacionais, identidades étnicas, religiosas, etc. É preciso responder por que essas representações feitas por meio de objetos materiais continuam a exercer sua magia e a despertar fascínio nas pessoas".

Em relação aos locais de funcionamento do Museu Nossa Senhora Aparecida, ao longo dos anos, as coleções foram abrigadas em diversos locais na cidade de Aparecida (SP). A primeira localização e local de inauguração, conforme mencionado anteriormente, foi no prédio das Oficinas Gráficas de Arte Sacra, na rua Dr. Oliveira Braga n‥ 80, em Aparecida (SP).

O aspecto externo das Oficinas Gráficas de Arte Sacra (Figura 3), no Convento das Irmãs Canisianas, revela as fases de contrução realizadas em momentos diferentes: a parte central foi construída em 1920; o edifício à esquerda, em 1926, e o edifício à direita, em 1937. 
Figura 3: Aspecto externo das Oficinas Gráficas de Arte Sacra, onde o Museu foi instalado.

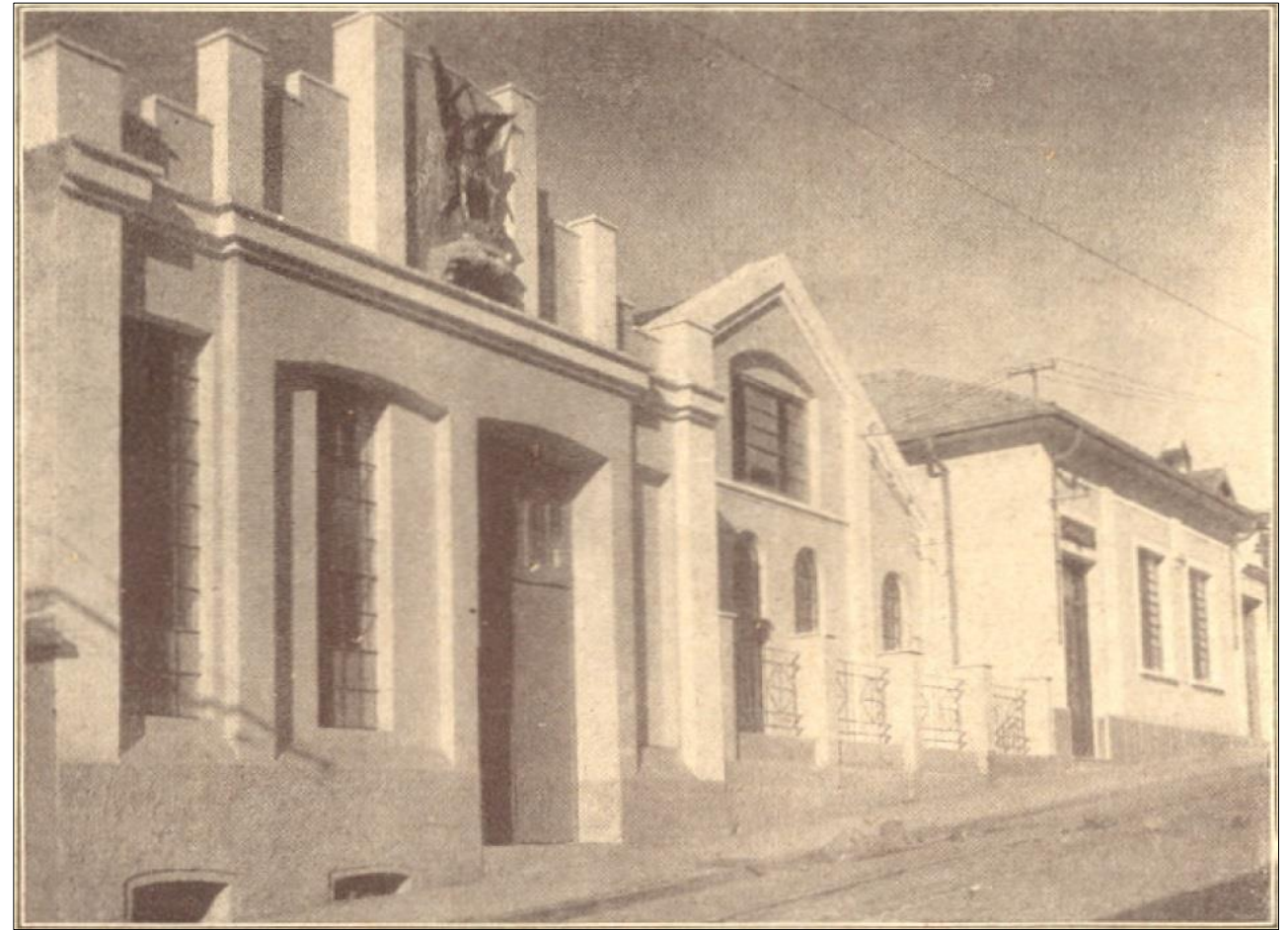

Fonte: Ecos Marianos, 1938, p. 9. CDM/ Santuário Nacional.

Após um ano da inauguração (Figuras 4 e 5), verificamos que o Museu já necessitava de um novo local para instalação, conforme publicação do Jornal Santuário de Aparecida de 08 de dezembro de 1957, ao referenciar:

Alguns dos muitos objetos e peças de museu que a professora Conceição Borges Ribeiro vem colecionando há muitos anos. [...] Seria ótimo se tais e tantos objetos fossem dispostos num museu definitivo. Seria mais um ponto de atração para nossos romeiros e visitantes. É uma sugestão que fazemos às nossas autoridades. (SANTUÁRIO DE APARECIDA, 1957, p. 8). 
Figura 4: Aspectos internos da primeira Exposição do Museu Nossa Senhora Aparecida, em duas salas nas Oficinas Gráficas de Arte Sacra.

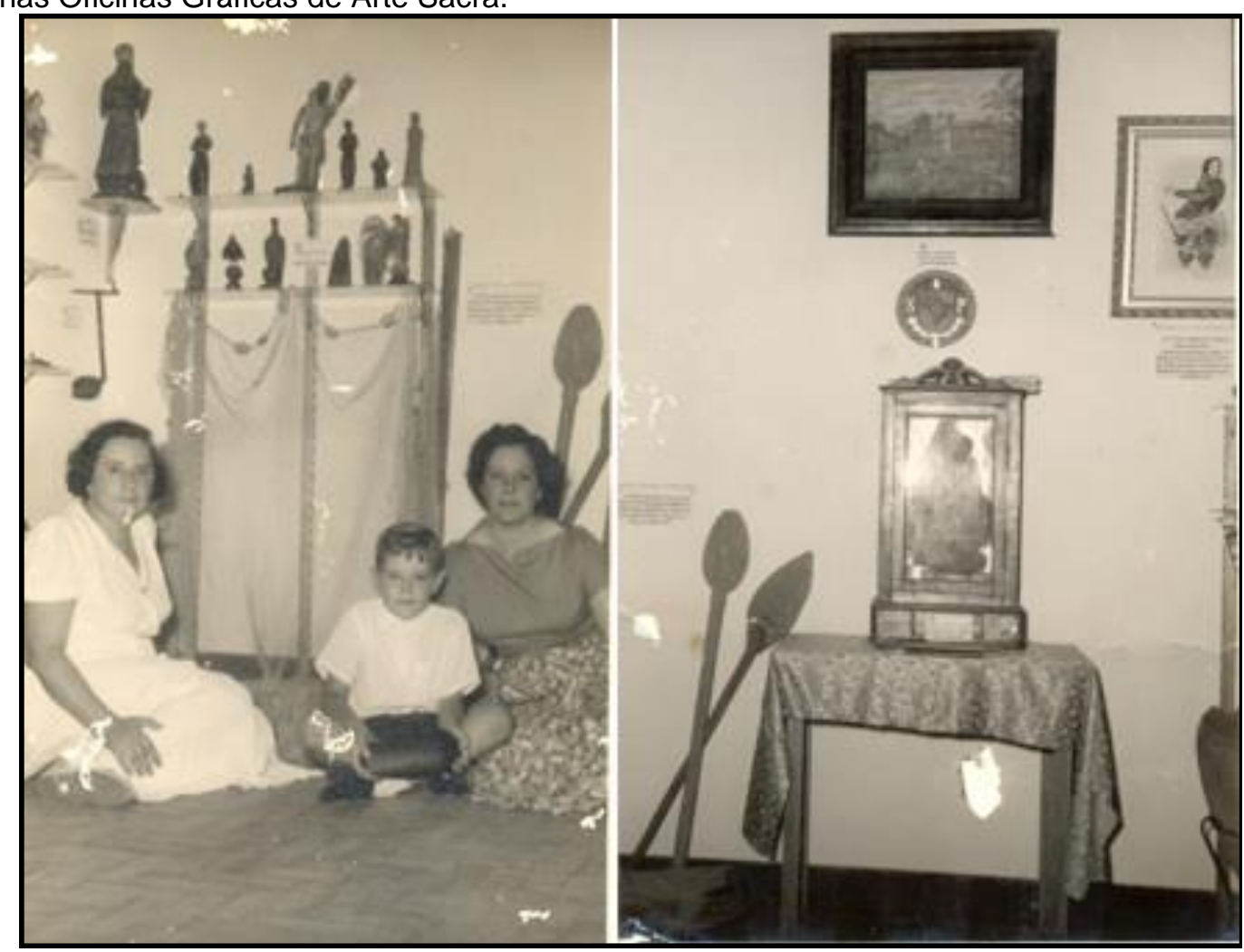

Fonte: MNSA/ Santuário Nacional.

Figura 5: Aspectos internos da primeira Exposição do Museu Nossa Senhora Aparecida, em duas salas nas Oficinas Gráficas de Arte Sacra.

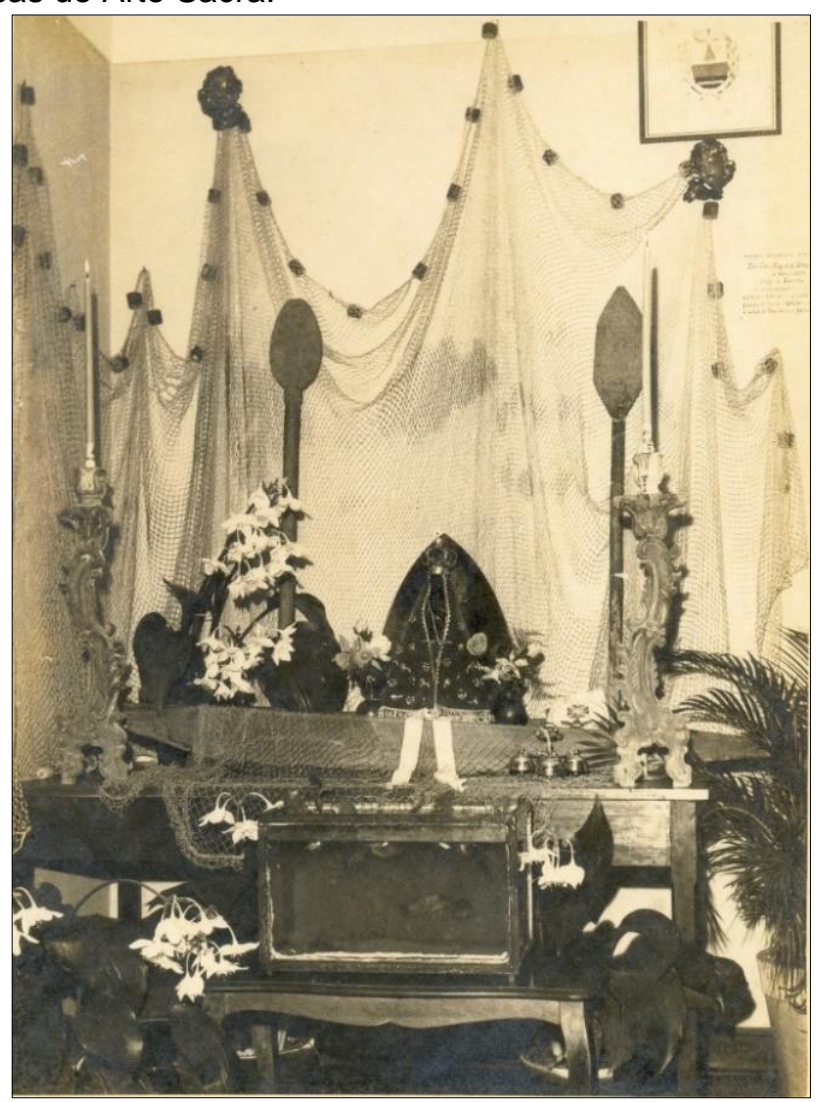

Fonte: MNSA/ Santuário Nacional. 
Dois anos depois, em 1958, o Museu incorpora-se ao Centro Social Redentorista, pertencente à Congregação do Santíssimo Redentor, de acordo com a informação publicada no Jornal Santuário de Aparecida, de 09 de novembro de 1958, "o museu, incorporado ultimamente ao 'Centro Social Redentorista', contém peças de alto valor artístico: santos de madeira, pinturas, objetos antigos. Além de outras coisas dignas de nota, apresenta ao visitante uma reconstituição do milagre do encontro da virgem milagrosa" (SANTUÁRIO DE APARECIDA, 1958, p. 1).

Posteriormente, em 1961, por meio de uma parceria citando a doação do acervo, os organizadores do Museu, com apoio da Congregação do Santíssimo Redentor, constroem um salão na Galeria do Hotel Recreio, pertencente também à Congregação, para instalação do Museu.

O Hotel Recreio era localizado na Praça Nossa Senhora Aparecida, ao lado da Basílica Velha (Figura 6), sendo possível identificar a entrada do Museu à esquerda do prédio, assim como um grande letreiro na parte superior, indicando a Sala dos Milagres.

Figura 6: Museu Nossa Senhora Aparecida localizado na Galeria do Hotel Recreio.

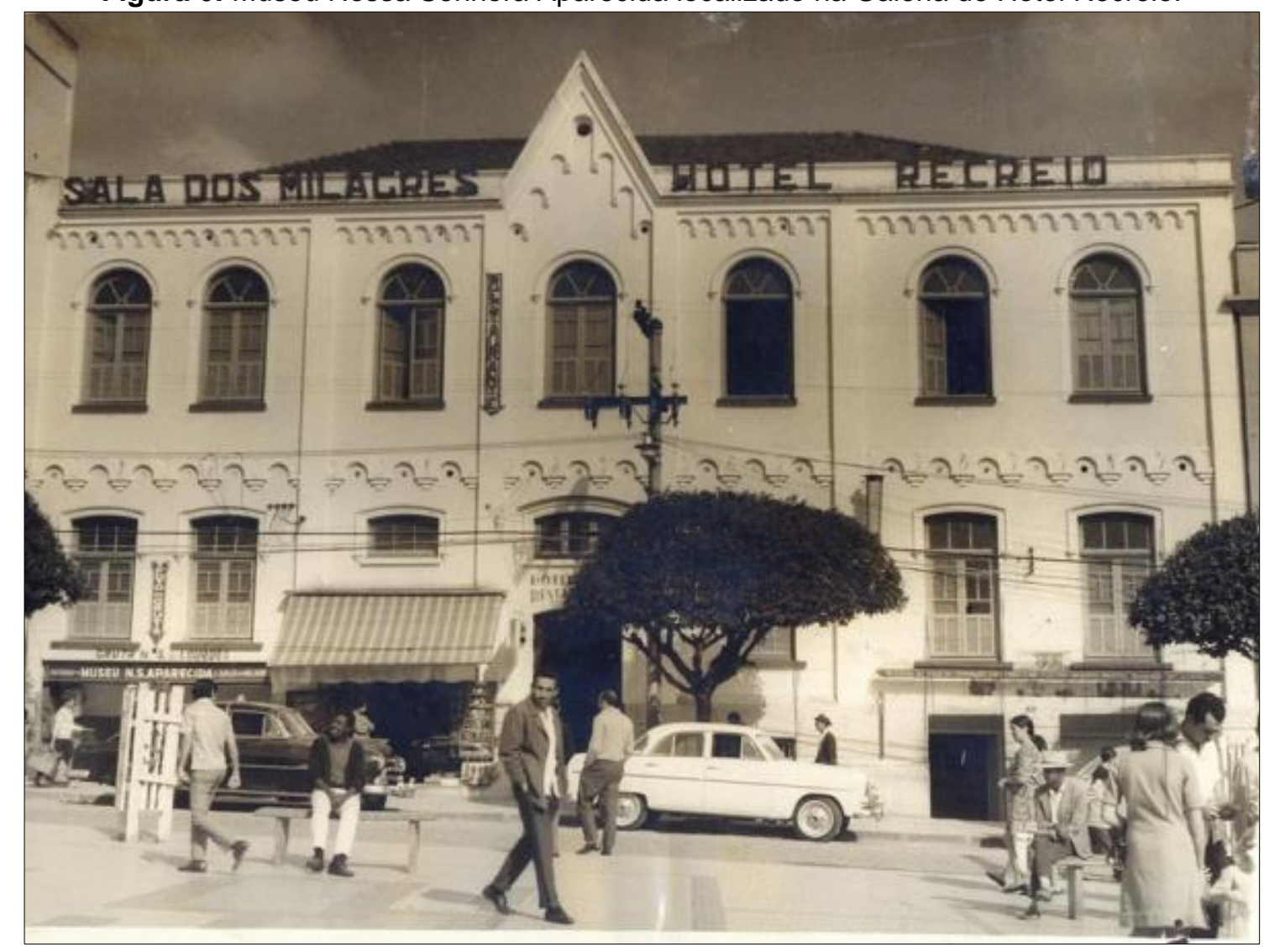

Fonte: Leilão de Arte Brasileira. Disponível em:

$<h t t p: / / w w w . l e i l a o d e a r t e b r a s i l e i r a . c o m \cdot b r / p e c a \cdot a s p ? \mid D=110800 \& c t d=89 \&$ tot=\&tipo=20\&artista=>. Acesso em: 18 nov. 2018. 
Nessa época, além de o Museu estar localizado na Galeria do Hotel Recreio, também havia outros agrupamentos de objetos materiais, entre eles um Museu de Cera, ao qual a Profa. Conceição Borges demonstra não ser muito favorável, de acordo com as correspondências entre ela e membros do clero ${ }^{7}$.

Guido Machado Braga ${ }^{8}$, acrescenta que na Galeria do Hotel Recreio havia também na época um Museu de Egiptologia.

[...] era particular. As pessoas, os dois artistas eram irmãos, eles alugaram o espaço e montaram com réplicas perfeitíssimas de peças egípcias, inclusive sarcófagos, múmia, eles que fizeram, eram artistas, uma pena que foi embora, acabou. (BRAGA, 2017, informação verbal).

Próximo ao Museu havia também a Sala dos Milagres, que inicialmente surgiu no interior da Basílica Velha, depois foi instalada em prédio próprio ao lado esquerdo da Basílica (Figura 7), conforme podemos observar no texto a seguir, publicado em 1927, na primeira edição do Almanaque de Nossa Senhora Aparecida - Ecos Marianos:

Ao lado da Basilica, em predio proprio, acha-se uma vasta sala a que quasi todos os romeiros fazem demorada visita e que é chamada "Sala dos Milagres".

As paredes desta sala estão, até o tecto, cobertas de photographias.

São muitas centenas de photographias que ahi se vêm, de pessoas de todas as idades e condições e de familias inteiras. Entretanto, a sala não é uma exposição de retratos, é antes uma galeria de devotos de N. Senhora Apparecida.

Muitos devotos de N. Senhora que della alcançaram algum favor extraordinario, offerecem-lhe seo retrato com uma dedicatoria cheia de agradecimentos e muitas vezes realmente commovedora. Outras pessoas que desejariam permanecer sempre aos pés de tão boa Mãe, deixam-lhe seo retrato, para continuarem a estar ahi ao menos em effigie e para se mostrarem publicamente servos e devotos da Virgem Maria.

Porém, não são apenas photographias que se veem na Sala dos Milagres;

Ha ahi um grande quadro que representa a solemne Coroação da Imagem milagrosa de N. Senhora, ha ex-votos de cera, ha a corrente que cahiu do pescoço do escravo, ha numerosas muletas offerecidas em acção de graças.

Destacam-se entre os quadros as reproducções de factos extraordinarios em que claramente se viu a intervenção misericordiosa da Virgem Apparecida.

7 CAMARGO, C. B. R.; CAMARGO, V. [Carta] 16 set. 1967, Aparecida [para] ROSA, J. F., Aparecida. 1f. Apresentação de propostas para o problema de instalação de um Museu de Cera ao lado do Museu Nossa Senhora Aparecida.

8 BRAGA, Guido Machado. Entrevista concedida a Victor Hugo Barros e a Erica Andreza Coelho. Aparecida, 20 set. 2017, 33 min 08 s. Som, Formato MP3. 
Alguns destes quadros são obra tosca de pintores improvisados que não se distinguem pela arte, mas simplesmente pelo desejo commovente de se mostrarem gratos e tornarem conhecida a bondade de N. Senhora. Embora o pincel não tenha sabido reproduzir os sentimentos da alma, estes adivinham-se e comprehendem-se.

Outros quadros são feitos por mão de mestre ou são photographias de uma reconstituição do facto no lugar e nas circumstancias em que se deu. (ECOS MARIANOS, 1927, p. 59-60).

Em 1958, a Sala dos Milagres foi transferida para a Galeria do Hotel Recreio, pois, com a criação da Arquidiocese de Aparecida, a sala ao lado da Basílica foi ocupada pela Cúria Metropolitana. Foi apenas em 1966 que a Sala dos Milagres se instalou no $1^{\circ}$ andar da Torre da Basílica Nova de Nossa Senhora Aparecida, sendo transferida, definitivamente, ao subsolo da Basílica em 1974, conforme relato do padre Júlio Brustoloni sobre os percursos dos ex-votos, em seu livro História de Nossa Senhora da Conceição Aparecida. A Imagem, o Santuário e as Romarias.

Como consta dos documentos, os ex-votos já eram depositados no altar da primitiva Capelinha do Itaguaçu. A maioria deles tinha relação com o milagre das velas e, por isso, se ofertavam velas e lâmpadas ou o óleo necessário para mantê-las acesas.

Poucos e bem simples eram os ex-votos de início, tornando-se mais numerosos com o crescer da devoção. Construída a primeira igreja em louvor de Nossa Senhora Aparecida, inaugurada pelo Pe. José Alves Vilella, em 1745, a Sala dos Milagres, Quarto dos Milagres no dizer dos documentos, e seu conteúdo foram transferidos para uma sala contígua do lado direito do presbitério. O número dos ex-votos cresceu tanto que, em 1810, eles se estendiam até nos cubículos das naves laterais da igreja. Em 1860, por testemunho do jornalista Augusto Emílio Zaluar, sabendo que os ex-votos invadiam a nave central e o coro da igreja. O mesmo afirmava mais tarde o Cel. Rodrigo Pires do Rio.

Em 1884, um repórter do jornal paulista 'Correio Paulistano' refere-se aos ex-votos que estavam pendurados nas paredes de toda a igreja em desordenada desordem. Na época, da antiga igreja só restava a nave central sobre a qual Monte Carmelo estava construindo a nova igreja, a atual Basílica Velha. Ao demoli-la, em 1886, os ex-votos foram transferidos para as tribunas esquerdas do presbitério da igreja em construção. Ali ficou a Sala dos Milagres até 1904.

Em 1904, quando os novos capelães, por motivo da festa da Coroação, fizeram nova pintura da igreja, transferiram-na para a tribuna da nave lateral esquerda, da qual possuímos foto. $\mathrm{O}$ acesso era pela porta da torre direita. No período entre 1886 a 1888, quando a Imagem Milagrosa ficou exposta na tribuna do presbitério, enquanto se concluía o corpo da igreja, os exvotos ficavam quase que no mesmo recinto. Assim quem ia visitar a Imagem passava necessariamente pelas paredes cobertas de 'milagres'.

Em 1913, houve nova transferência: a Sala passou para o grande salão, ao lado da sacristia da Basílica Velha, num antigo prédio que se situava onde está hoje a Sala de Reuniões, ao lado da atual Livraria Santuário.

Com as diversas mudanças, muitos ex-votos sugestivos e valiosos se perderam, mas era imensamente grande, ainda em 1925, quando o acima citado jornal 'Correio Paulistano' publicou uma página inteira sobre a Sala 
dos Milagres. "A Sala está, diz o jornal, de alguns anos para cá, funcionando numa casa muito antiga, localizada ao lado da Basílica".

Após a instalação da Arquidiocese de Aparecida, em 1958, o local foi ocupado pela Cúria Metropolitana, e a Sala começou novamente sua peregrinação, agora já a caminho da Basílica Nova. Naquele ano, foi instalada, provisoriamente, num dos salões da Galeria do Hotel Recreio. Em 1966, parte dos ex-votos foi instalada no primeiro andar da Torre, permanecendo a outra na Galeria. Somente em 1974 é que toda a Sala dos Milagres desceu para o subsolo da Basílica Nova, onde, embora bem instalada, aguarda um lugar definitivo. (BRUSTOLONI, 1998, p. 131-133).

Esses agrupamentos de objetos materiais podem ser entendidos como museus ou embriões de museus e podem ter influenciado de certa maneira a própria formação de acervos e coleções do Museu Nossa Senhora Aparecida, pois alguns objetos encontrados em antigas fotografias da Sala dos Milagres atualmente estão incorporados ao acervo do Museu, como é o caso de uma grande pintura de Rosalbino Santoro, um pintor italiano, que reproduziu a cena da Coroação da Imagem de Nossa Senhora Aparecida ocorrida em 1904, a partir de uma fotografia da época, (observada na Figura 8).

Figura 7: Aspecto externo da Sala dos Milagres, à esquerda da Basílica Velha.

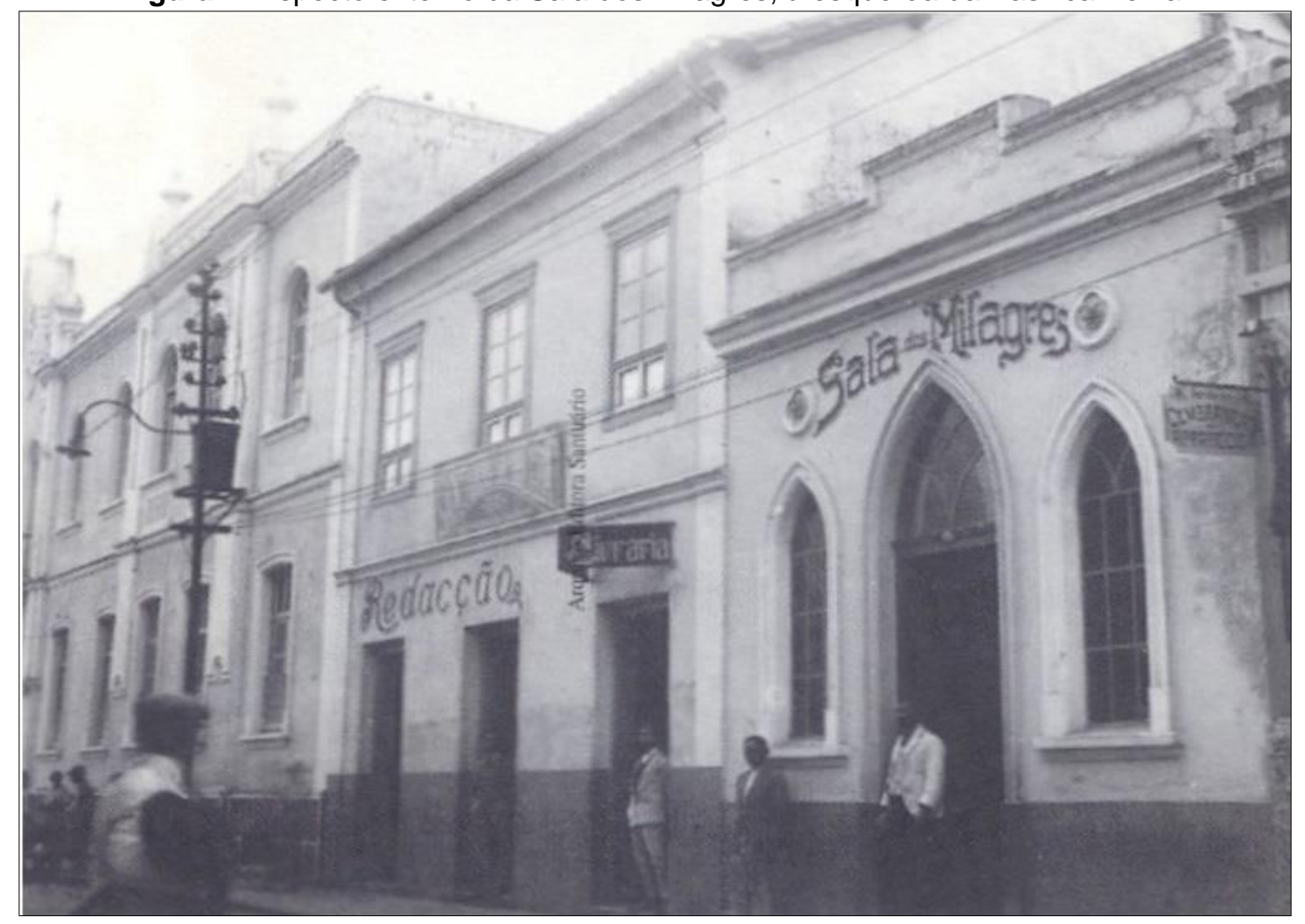

Fonte: CDM/ Santuário Nacional. 
Figura 8: Aspecto interno da Sala dos Milagres.

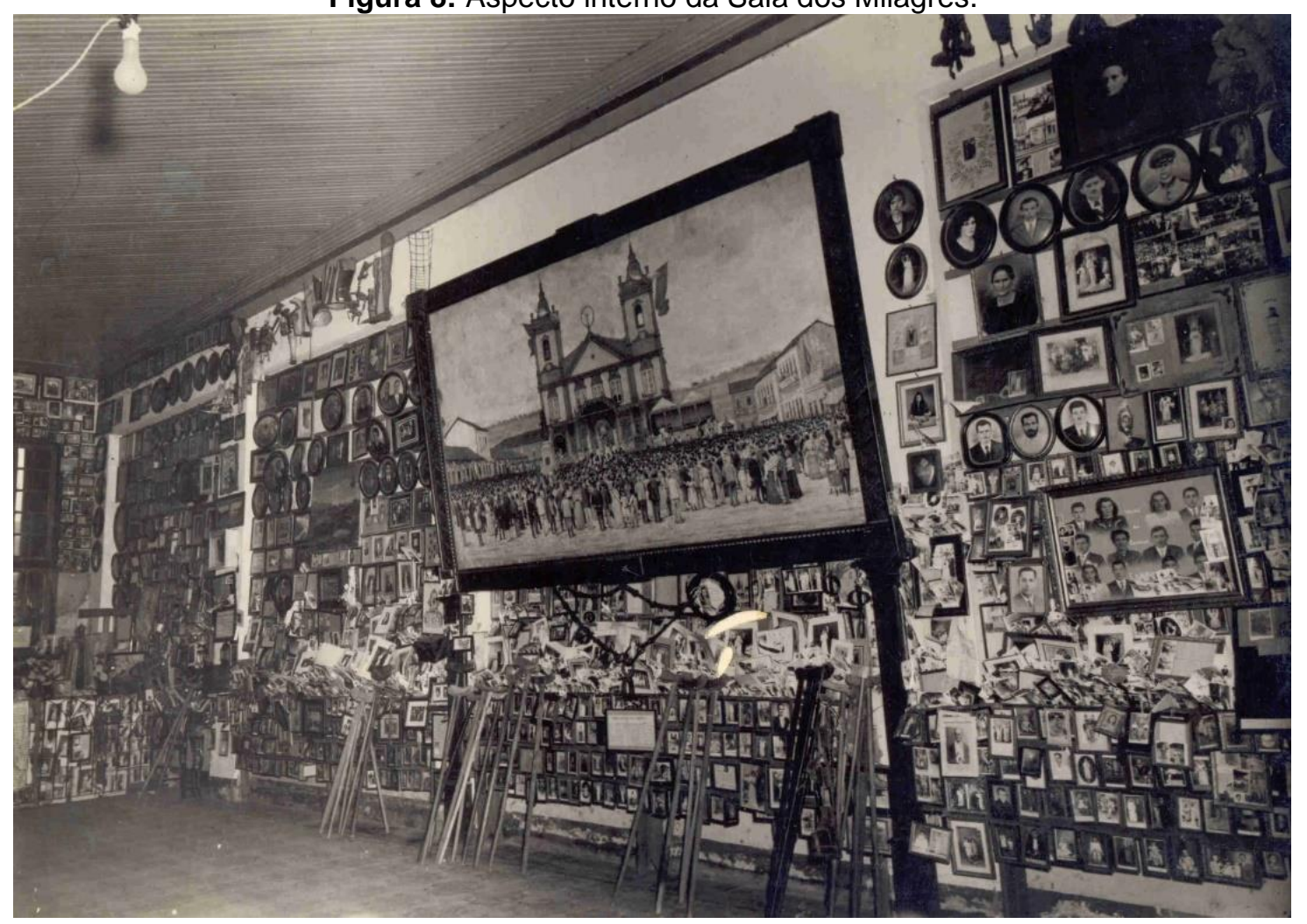

Fonte: Ecos Marianos, 1927. CDM/ Santuário Nacional.

Segundo o artigo de Vittorio Cappelli (2014a, p. 13),

Mais tarde, em 1907, ele realizou uma pintura de grande formato, que representa a manifestação religiosa popular da Coroação de Nossa Senhora Aparecida, a coroação da Virgem, patrona do Brasil, ocorreu perto de Taubaté. Ainda hoje, a nova Basílica de Nossa Senhora Aparecida e o anexo Museu, dentro do qual é preservada a grande tela de Santoro, são um destino para uma incessante peregrinação de todo o Brasil (tradução nossa).

Ainda segundo o autor, em outro artigo para a revista Calabrese di Storia del '900, "na cerimônia de entrega da rica coroa, doada pela Princesa Isabel, o núncio apostólico participou com toda a igreja brasileira e o presidente da república Rodrigues Alves. Dois anos após a execução, em 1909, a grande pintura é colocada no Santuário" (CAPPELLI, 2014b, p. 47. Tradução nossa).

A obra de Rosalbino Santoro é datada de 1907, período em que o pintor vivia no município de Taubaté (SP). Atualmente, a pintura encontra-se em exposição no $1^{\circ}$ andar da Torre Brasília e foi restaurada por Renato Rinaldi em 2004.

De acordo com Rússio9 (1981 apud BRUNO, 2010. p. 125),

A musealização não acarreta apenas a comunicação museológica. Ela acarreta uma valorização, uma ênfase sobre certos objetos. A musealização

9 RÚSSIO, Waldisa. A interdisciplinaridade em Museologia. Texto publicado em MuWoP Museological Working Papers, n. 2, p. 58-59 (versão original em francês e inglês), 1981. 
repousa em pesquisas prévias, na seleção dos objetos, na documentação, na direção, na administração, conservação e, eventualmente, na restauração. Essa musealização recobre, portanto, ações muito diferentes que dependem de domínios científicos muito diversos.

A partir desse argumento de Waldisa Rússio e do exemplo apresentado acima, é possível refletir sobre o processo de musealização ao se fazer uma análise sobre o modo como um objeto material - a Imagem de Nossa Senhora Aparecida -, acrescido de outro objeto, neste caso a coroa ofertada pela Princesa Isabel ${ }^{10}$, passou de um ex-voto a acervo, considerando que a coroa foi ofertada como pagamento de uma promessa devido a uma graça alcançada.

É interessante notar que esse acervo se tornou uma iconografia, numa operação que incluiu um registro fotográfico do momento da Coroação da Imagem de Nossa Senhora Aparecida e, posteriormente, a criação de uma cena em pintura reproduzindo a fotografia, com conotações imateriais, que passou por um processo de musealização.

Posteriormente, em 1967, considerando o bom relacionamento entre os organizadores do Museu com a Arquidiocese de Aparecida, e mediante um convênio com o Santuário Nacional de Aparecida, o Museu Nossa Senhora Aparecida é transferido para o $2^{\circ}$ andar da Torre Brasília, localizada no Santuário Nacional de Aparecida, Av. Dr. Júlio Prestes, s/nº, Ponte Alta, Aparecida (SP).

Conceição Borges Ribeiro Camargo e seu esposo Vicente Camargo assinam, portanto, em 30 de janeiro de 1967, um "Contrato de Doação"11 de todo o conjunto que compõe o Museu, tendo como outorgada donatária a Sociedade Santuário Nacional de Nossa Senhora Aparecida.

10 De acordo com o artigo de Conceição Borges Ribeiro Camargo, que relata a visita da Princesa Isabel à Capela de Nossa Senhora Aparecida, em 6 de novembro de 1884, consta que "a Princesa Isabel cumpriu nessa ocasião piedosa promessa a Nossa Senhora Aparecida - a promessa de varrer a igreja de Nossa Senhora, conforme crônica do "Santuário de Aparecida", no dia 19 de novembro de 1921. E doou uma corôa de ouro, a mesma que serviu na coroação da Virgem Aparecida, no ano de 1904". Ver: Revista do Instituto Histórico e Geográfico de São Paulo. Vol. 67. São Paulo: IHGSP, 1970. p. 294.

Ainda nesse volume da revista do IHGSP, na ata da assembleia ordinária de 3 de maio, consta que "seguiu-se com a palavra Da Conceição Borges Ribeiro, que leu interessante comunicação intitulada <<Passagem da Princesa Isabel por Aparecida e Guaratinguetá>> - viagem que a ilustre Regente do Império realizou em 1868 em companhia de seu espôso, o Conde d'Eu. Incidentemente, Dá Conceição tratou de fatos da história de Aparecida do Norte e de figuras ligadas à Capela da Santa, como Leão XIII". Ver: Revista do Instituto Histórico e Geográfico de São Paulo. Vol. 67. São Paulo: IHGSP, 1970. p. 418.

${ }^{11}$ CONTRATO de doação e outros encargos que entre si fazem Vicente Camargo e sua esposa Conceição Borges Ribeiro Camargo com a Sociedade Santuário Nacional de Nossa Senhora Aparecida, 1967. Fonte: Museu Nossa Senhora Aparecida. 
De acordo com a Cláusula Primeira do Contrato de Doação, os doadores são legítimos senhores e proprietários de um "Museu de arte sacra, cerâmica indígena e outras peças antigas", tudo de acordo com a relação discriminativa de inventário ${ }^{12}$.

A partir desta definição do Museu que consta no Contrato de Doação, é possível remeter a Dominique Poulot (2013, p. 16), quando diz que "nossos museus contemporâneos estão associados certamente a arquétipos antigos. Assim, o túmulo ou o templo, a um só tempo, lugar de acúmulo de riquezas intelectuais e lugar de sacralização, representariam as raízes de uma antropologia da musealidade".

Na Cláusula Segunda, os doadores fazem livre e espontaneamente a doação, a título gratuito, das peças constantes no inventário e também de todas as demais peças que venham a ser ofertadas ao Museu.

$\mathrm{Na}$ Cláusula Terceira, a donatária se obriga a fornecer um local adequado no segundo andar da torre da Nova Basílica Nacional de Nossa Senhora Aparecida, para o funcionamento do Museu.

Na Cláusula Quarta, estipula-se que os serviços de expediente do Museu ficam sob o encargo e responsabilidade plena dos doadores até o falecimento de ambos, no qual a donatária poderá indicar outra pessoa para tal cargo de administração.

$\mathrm{Na}$ Cláusula Quinta, referente aos proventos ou rendimentos do ingresso, define que os doadores entregarão a parcela de $50 \%$ que reverterá em benefício das obras materiais ou assistenciais empreendidas pela donatária, sendo que a outra parcela restante os doadores utilizarão para cobertura das despesas e manutenção do Museu (exceto encargos relativos à energia elétrica, água, impostos e taxas que incidam sobre o local, pertencentes à donatária).

E, por fim, na Cláusula Sexta, estipulam-se alguns critérios e regulamentos internos para o funcionamento do Museu.

Apesar do Contrato de Doação ter sido validado a partir do dia 30 janeiro de 1967, os armários com as peças começaram a ser instalados no $2^{0}$ andar da Nova Basílica a partir do dia 12 de junho de 1966, conforme a lista de inventário do acervo anexa ao Contrato, descrita abaixo.

INVENTÁRIO DAS PEÇAS E OBJETOS CONSTANTES DO MUSEU DOADO NESTA DATA Å SOCIEDADE SANTUÁRIO NACIONAL DE N. S. APARECIDA

${ }^{12} \mathrm{O}$ Contrato de Doação, incluindo a relação discriminativa de inventário, na época do contrato, está disponível no ANEXO A. 
- 2 fósseis de Laranjal Paulista - Fósseis do Putim.

- 14 cachimbos, indígenas, africanos, caboclos.

- Sambaquis - ostras, conchas, caramujos do litoral do Est. de S. Paulo; Mar Casado, Guarujá, Maratuá, Cananeia, Boguaçu.

- Fragmentos de cerâmica indígena com desenhos, arqueologia de Aparecida.

- 4 peças de cerâmica indígena (2 com desenho), 1 com ossos, arqueologia de Aparecida.

- 30 machadinhos indígenas (1 verde), entre os machadinhos, mãos de pilão e 3 pedras ovais.

- Baú - fotocópia do manuscrito do Pe. José Alves Villela, narrando o encontro da imagem de Nossa Senhora Aparecida.

- 3 fotografias de Nossa Senhora Aparecida, sem manto.

- Almanaque da Coroação - ano de 1904 - Polyanthea, ano de 1929.

- Programas das primeiras romarias organizadas vindas de São Paulo: anos de 1904 - 1905 - 1906 - 1907 - 1908 - 1909 - 1910.

- Hinos a Nossa Senhora Aparecida - anos de 1905, 1907, 1909, 1912, 1917, 1930, 1931, 1935, 1936, 1939, 1943.

- 21 imagens de madeira e de barro, entre tamanho de 18 a 37 centímetros, todas do início do século e do século passado.

- Bom Jesus (imagem de madeira) - pertenceu ao Barão de Tremembé, com 35 centímetros.

- 19 imagens - 6 do século 18 - de barro e de madeira, de 12 a 20 centímetros.

- 1 canoa pequena, cabeça e corpo de Nossa Senhora Aparecida (fac-símile da verdadeira).

- 2 crucifixos antigos - 1 com pedras imitando rubis.

- 3 imagens de louça.

- Cabeça do Profeta Daniel - cópia do original, trabalho do Aleijadinho Congonhas do Campo.

- 2 Divinos de madeira.

- Brasão de Armas de Aparecida - em um quadro, agradecimento do

Prefeito Municipal Sr. Américo Alves Pereira Filho.

- Algumas notas (dinheiro) antigas do Brasil e do exterior.

- 3 peças de cerâmica popular - Bahia.

- 6 peças de cerâmica popular - Congonhas do Campo.

- 5 peças "arte popular" - Bahia.

- 2 peças "arte popular" - Caxambu.

- 1 estojo com 32 pedras semi-preciosas com etiquetas - Ouro Preto-MG.

- 19 pedras semi-preciosas (pequenas)

- 6 peças (4 cachimbos) pedra-sabão - Ouro Preto

- 10 maçanetas (de porta), 2 com desenho.

- Figuras de cerâmica popular de Pindamonhangaba e Taubaté.

- 2 fechaduras antigas.

- 4 chaves.

- 3 candeias.

- 2 lampeões, 1 lamparina.

- 1 par de tulipas - 1 par de castiçais (metal).

- 1 espevitadeira.

- 1 pedaço de caibo do antigo Colégio dos Jesuítas (S. Paulo).

- 1 pedra de moinho de fubá.

- 17 ladrilhos da antiga Basílica (Reforma Monte Carmelo).

- 4 almofarizes, 1 sem a mãozinha.

- 3 garruchas.

- 1 lampeão de rua (Aparecida). 
- 1 fragmento (forma quadrada) de pedra da antiga Ladeira Monte Carmelo.

- 1 máquina de costura.

- 2 (dois) ferros de passar roupa.

- 3 chocolateiras (cobre).

- 1 faca com bainha de prata.

- 1 peça de fazer hóstia.

- 1 janela de rótula.

- 1 carda - peça que pertence à roca.

- 8 caçambas.

- 3 pares de estribos (diferentes).

-1 cincerro (de tropa).

- 1 panela, rancho do tropeiro.

- 5 garfos de romaria de tropa.

- Quartzo hiolino cristal.

- Ametista - cristal com pirita de cobre.

- 1 prato antigo (azul e branco).

- 1 caneta de prata.

- 1 copo com estampa de N. Sra. Aparecida.

- 1 copo com fotografia de Marechal Deodoro da Fonseca.

- 1 copo e 1 prato com a Igreja de Tremembé.

- 1 confessionário - século 19.

- Fotografia da Comissão de Honra que levou N. S. Aparecida para o Rio de Janeiro.

- Fotografia da chegada de Nossa Senhora Aparecida, quando da sua romaria ao Rio de Janeiro em maio de 1931.

- Dois quadros do artista CHICO SANTEIRO representando a "PESCA MILAGROSA" da Imagem de Nossa Senhora Aparecida e "O MILAGRE DAS VELAS". Estão em andamento ainda outros três, sendo que outros dois já estão prontos, aguardando transporte para o local do Museu, perfazendo $O$ total de sete quadros, representando o conjunto de "OS PRIMEIROS MILAGRES DE NOSSA SENHORA APARECIDA", doação também de Vicente Camargo e sua esposa Conceição Borges Ribeiro Camargo.

- 29 armários de vidro com prateleiras de vidro, 21 são grandes e 8 são menores. (CONTRATO, 1967).

A nova exposição do Museu foi inaugurada oficialmente no $2^{0}$ andar da Torre em 12 de outubro de 1967, conforme a Figura 9, referente à abertura do Museu na Basílica de Nossa Senhora Aparecida, contendo a relação discriminativa de objetos citados, que foram acrescidos de novas doações dos devotos.

O Jornal Oficial do Legislativo, de 24 de novembro de 1967, publicou um artigo referente à instalação do Museu na Basílica, que fez parte dos festejos do Ano Jubilar, em 12 de outubro de 1967, contando com a presença de autoridades eclesiásticas, civis e militares de Aparecida, Guaratinguetá, cidades vizinhas e da Capital de São Paulo. De acordo com o artigo do jornal,

$O$ ato inaugural foi presidido por Sua Eminência Dom Carlos Carmelo de Vasconcelos Motta, Cardeal Arcebispo da Arquidiocese de Aparecida e ao seu lado estavam Dom Antônio Ferreira de Macedo, Arcebispo Coadjutor, Dom Antônio Maria Alves de Siqueira, Arcebispo Coadjutor de Campinas, Monsenhor José Alves Motta Filho, Secretário do Senhor Cardeal Motta, 
Doutor José Mauro da Silveira, Juiz de Direito da Comarca de Aparecida, Doutor Paulo Heber de Moraes, Promotor Público, Monsenhor Oswaldo de Barros Bindão, Vigário da Matriz de Santo Antônio de Guaratinguetá e os organizadores e conservadores do Museu, Vicente Camargo e sua esposa Professora Conceição Borges Ribeiro Camargo. (OFICIAL DO LEGISLATIVO, 1967).

Figura 9: Abertura do Museu Nossa Senhora Aparecida no $2^{\circ}$ andar da Torre Brasília - Santuário Nacional de Aparecida, 1967.

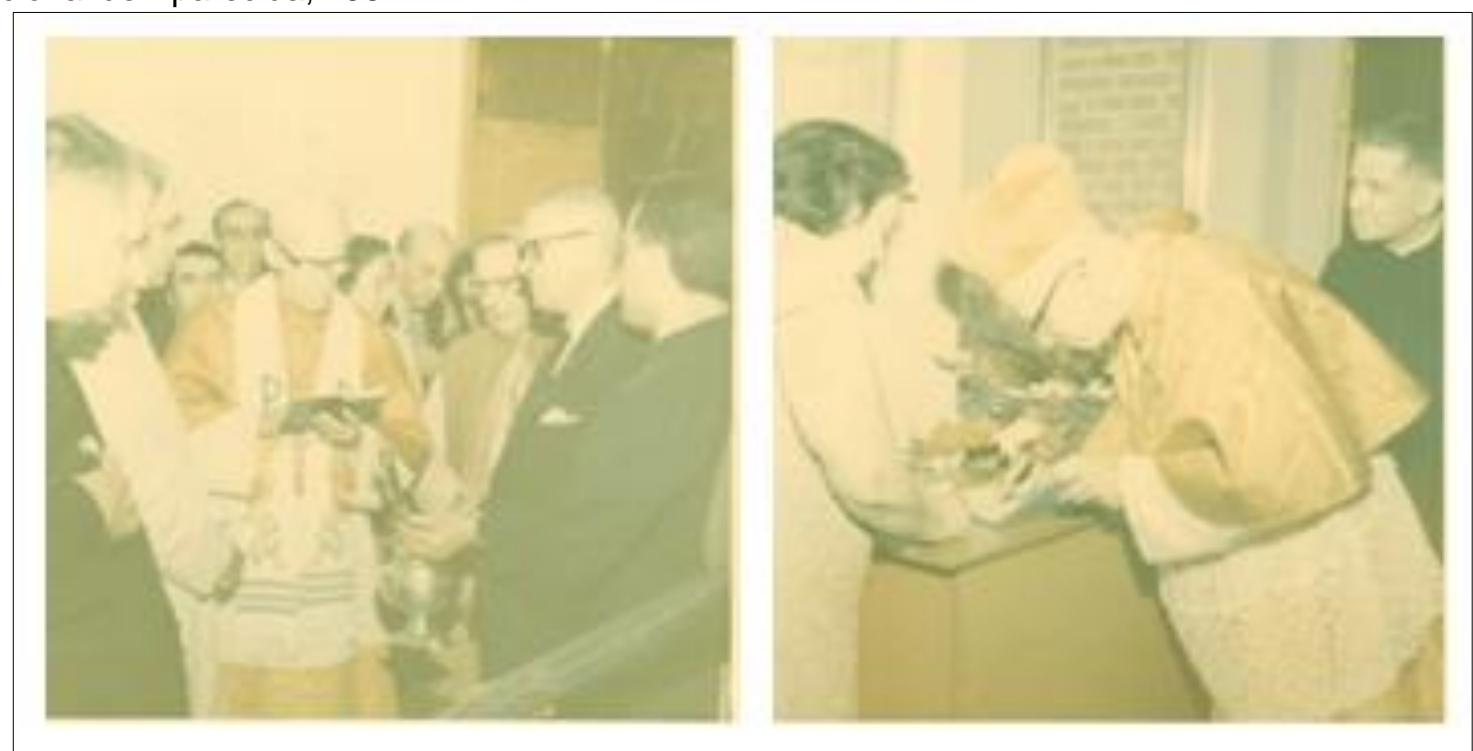

Fonte: MNSA/Santuário Nacional.

Ainda segundo o artigo do jornal, após descerrar a fita simbólica e a bênção realizada pelo Cardeal Motta, a Profa. Conceição Borges apresentou o Museu, oferecendo aos visitantes elementos da Pré-História, da História, material para estudos e peças que revelam arte, beleza e religião, conforme a publicação a seguir.

No Museu há secções de mineralogia, numismática, filatelia religiosa, arte popular, paramentos e alfaias, peças que pertenceram à Titulares do Império, autógrafos da Princesa Isabel e rica coleção de arte sacra com imagens dos séculos XVII e XVIII. Na parte referente às alfaias, castiçais e relicário que pertenceram à antiga Basílica, assim como ex-votos em bandejas de prata. $\mathrm{Na}$ secção de História, sob o quadro do milagre da corrente do escravo, a legislação sobre os escravos: passaporte, mudanças, matrículas, impostos de meia siza, compra, venda, etc. Os quadros dos "Primeiros Milagres de Nossa Senhora Aparecida, em alto relevo, do artista Chico Santeiro, constituem uma atração aos senhores romeiros.

Existem armários com arte popular e peças típicas das cidades do Vale do Paraíba e dos Estados do Brasil - com a Imprensa de Aparecida, destacando-se os <<Ecos Marianos>> - armários com estribos, cincerros e caçambas que recordam as primeiras romarias que de tropas vinham visitar Nossa Senhora Aparecida e também uma vitrine <<Epopeia de 1932>> com capacetes, granadas e documentos lembrando a Revolução Constitucionalista.

O Cardeal Dom Carlos Carmelo contribuiu para que o Museu ofereça a História de Aparecida e a História religiosa [...]. 
Aos conservadores do Museu, Vicente Camargo e Conceição Borges Ribeiro Camargo, os nossos cumprimentos pela pesquisa e pela grandiosa oferta que fazem à cidade de Aparecida, com votos de felicidade. (OFICIAL DO LEGISLATIVO, 1967).

Nesse período de transferência para a Basílica, parte do acervo permaneceu ainda na Galeria do Hotel Recreio, sob a responsabilidade da Sala dos Milagres, que realizou alterações nas etiquetas e não manteve os mesmos cuidados com a conservação das peças, conforme podemos observar por meio do manuscrito de Conceição Borges ${ }^{13}$ :

Material que veio do Museu "Nossa Senhora Aparecida" da Galeria do Hotel Recreio, nos dias 20 e 21 de dezembro de 1971 - para o $3^{\circ}$ andar da Tôrre da Nova Basílica.

O Material - as peças - não vieram conservadas como deixamos no dia 21 de setembro de 1966 - vieram quebradas em péssimo estado de conservação, faltando algumas. Vieram quebradas na impossibilidade de uma restauração. 60\% do conjunto "Os Primeiros Milagres de Nossa Senhora Aparecida", feito pelo artista Chico Santeiro - Francisco Ferreira aqui de Aparecida, a pedido do Senhor José Hélio Galvão Nunes foram as peças deixadas na Sala dos Milagres da Galeria do Hotel Recreio são 7 (sete), lindos quadros.

Do conjunto "Os Primeiros [Milagres] de Nossa Senhora Aparecida", em arte moderna - feita pela escultora e artista Dona Teresa D'Amico e cujos quadros estiveram em exposição na Galeria Prestes Maia em São Paulo, das 16 (dezesseis) figuras que deixamos, 14 (quatorze) estavam quebradas em fragmentos.

Após quase 5 mêses de estudo e classificação das peças que vieram da Galeria, agora é que foi possível fazermos uma classificação, pois os cartões que deixamos foram substituídos por estes - (colados ao lado).

Em nossos cartões havia o seguinte: nome da peça - ano ou século procedência - Estado e ofertante. Foram todos substituídos por "Museu Nossa Senhora Aparecida" - Doações dos Devotos - só nome da peça alguns cartões com nomes errados e datas erradas. Poucos com o nome do ofertante - pois os mesmos cartões estão em nosso arquivo.

De maio de 1972, só agora, com a graça de Deus, é possível identificar peças do Museu da Galeria com as do Museu da Basílica - 2o andar da Tôrre - ampliando as seções e surgindo outras. (CAMARGO, s.d.).

A Figura 10 demonstra como foram realizadas as novas etiquetas para substituição das etiquetas dos objetos que permaneceram na antiga exposição na Galeria do Hotel Recreio, conforme mencionado pela Profa. Conceição Borges.

${ }^{13}$ Manuscrito de Conceição Borges Ribeiro Camargo, sem data, pertencente ao acervo documental do Museu Nossa Senhora Aparecida, intitulado "Material que veio do Museu "Nossa Senhora Aparecida" da Galeria do Hotel Recreio, nos dias 20 e 21 de dezembro de 1971 - para o 3ํandar da Tôrre da Nova Basílica". 
Figura 10: Cartão de doação do acervo.

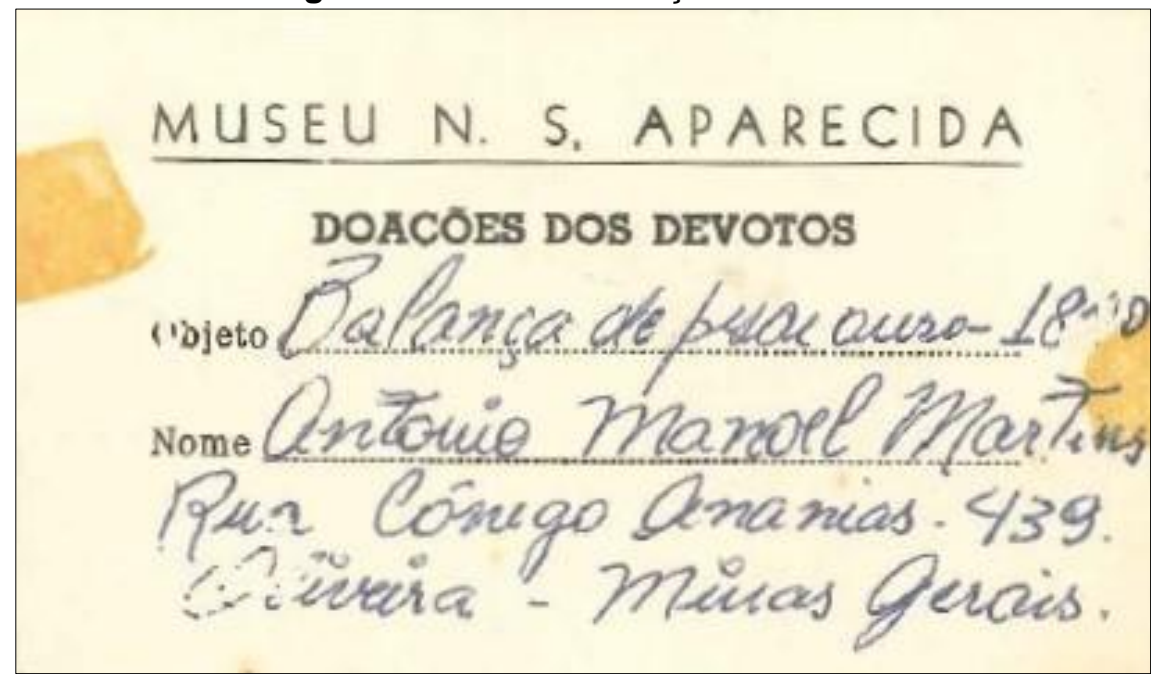

Fonte: MNSA/Santuário Nacional.

Com a instalação do Museu na Nova Basílica de Nossa Senhora Aparecida, o fluxo de visitação passa a aumentar constantemente, devido às grandes romarias e a busca por entretenimento.

Desta forma, ampliaram-se o número de doações de acervo ao Museu, que passam a ser inseridas nas vitrines no ato da doação acrescidos de cartões de identificação e alguns com informações de procedência e doador (Figura 11).

Figura 11: Antiga etiqueta da exposição.

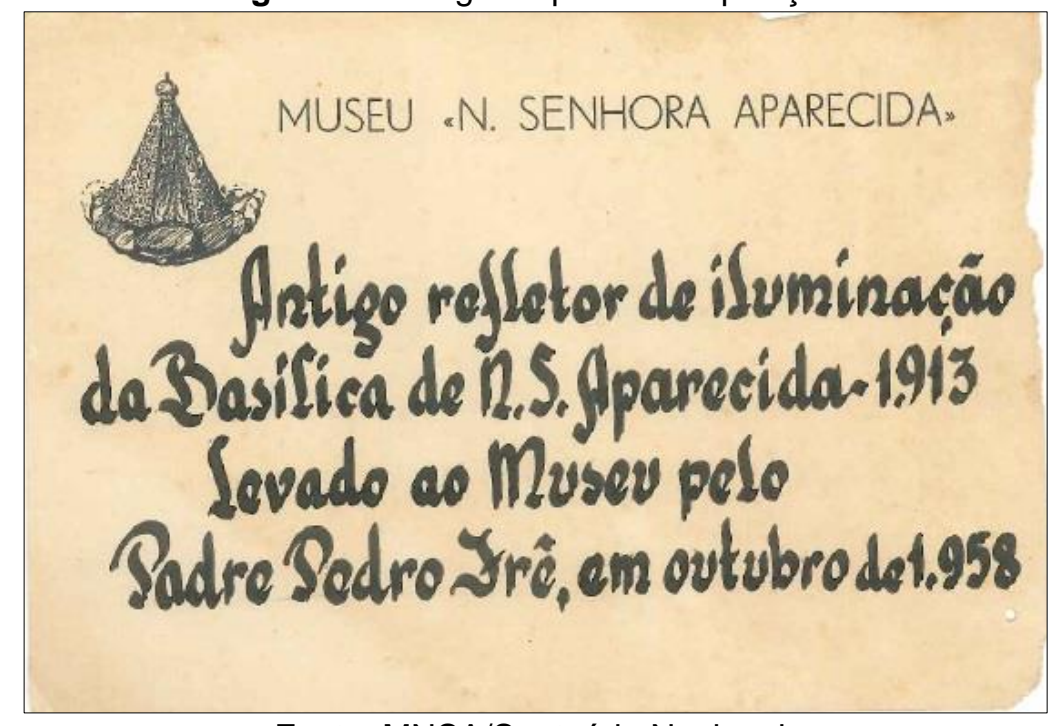

Fonte: MNSA/Santuário Nacional.

Além disso, conforme observado em alguns manuscritos da Profa. Conceição Borges, que compõem o acervo documental do Museu, alguns objetos pertencentes 
à Sala dos Milagres foram transferidos, posteriormente, para a nova exposição do Museu na Torre da Basílica Nova. ${ }^{14}$

Imagens de Nossa Senhora Aparecida, retiradas da "Sala dos Milagres", da Galeria do Hotel Recreio - e com a devida licença do senhor José Idélio Galvão Nunes - Gerente do Hotel Recreio - e com a presença da senhorita "Biluca", que trabalha no escritório do mesmo Hotel.

São imagens deixadas entre os retratos de promessa e até sobre o ladrilho da Sala - imagens que irão para completar uma coleção de diferentes imagens de Nossa Senhora Aparecida, para uma secção que será feita no Museu da Basílica Nacional - na Torre.

Fevereiro de 1972.

Foram retiradas 7 (sete) imagens, porém uma de loja comercial chegou quebrada.

1 - imagem de madeira - feita pelo artista aparecidense Chico Santeiro e queimada - altura 41 centímetros.

2 - imagem de madeira - arte popular, envernizada - altura 38 centímetros

3 - imagem de gesso - colorida - de loja comercial - altura 37 centímetros

4 - imagem de gesso - colorida - de loja comercial - altura 34 centímetros

5 - imagem de gesso - colorida - de loja comercial - altura 24 centímetros

6 - imagem de metal branco (chumbo?) - de loja comercial - altura 9 centímetros e meio

7 - uma imagem de gesso - colorida - de loja comercial - altura 23 centímetros-chegou quebrada não ficará na coleção do Museu. (CAMARGO, 1972.).

A Figura 12 demonstra o aspecto interno de uma das vitrines do Museu.

${ }^{14}$ Manuscrito de Conceição Borges Ribeiro Camargo, pertencente ao acervo documental do Museu Nossa Senhora Aparecida, identificado como uma relação de Imagens de Nossa Senhora Aparecida retiradas da "Sala dos Milagres", da Galeria do Hotel Recreio. 
Figura 12: Aspecto interno do Museu instalado no $2^{\circ}$ andar da Torre Brasília.

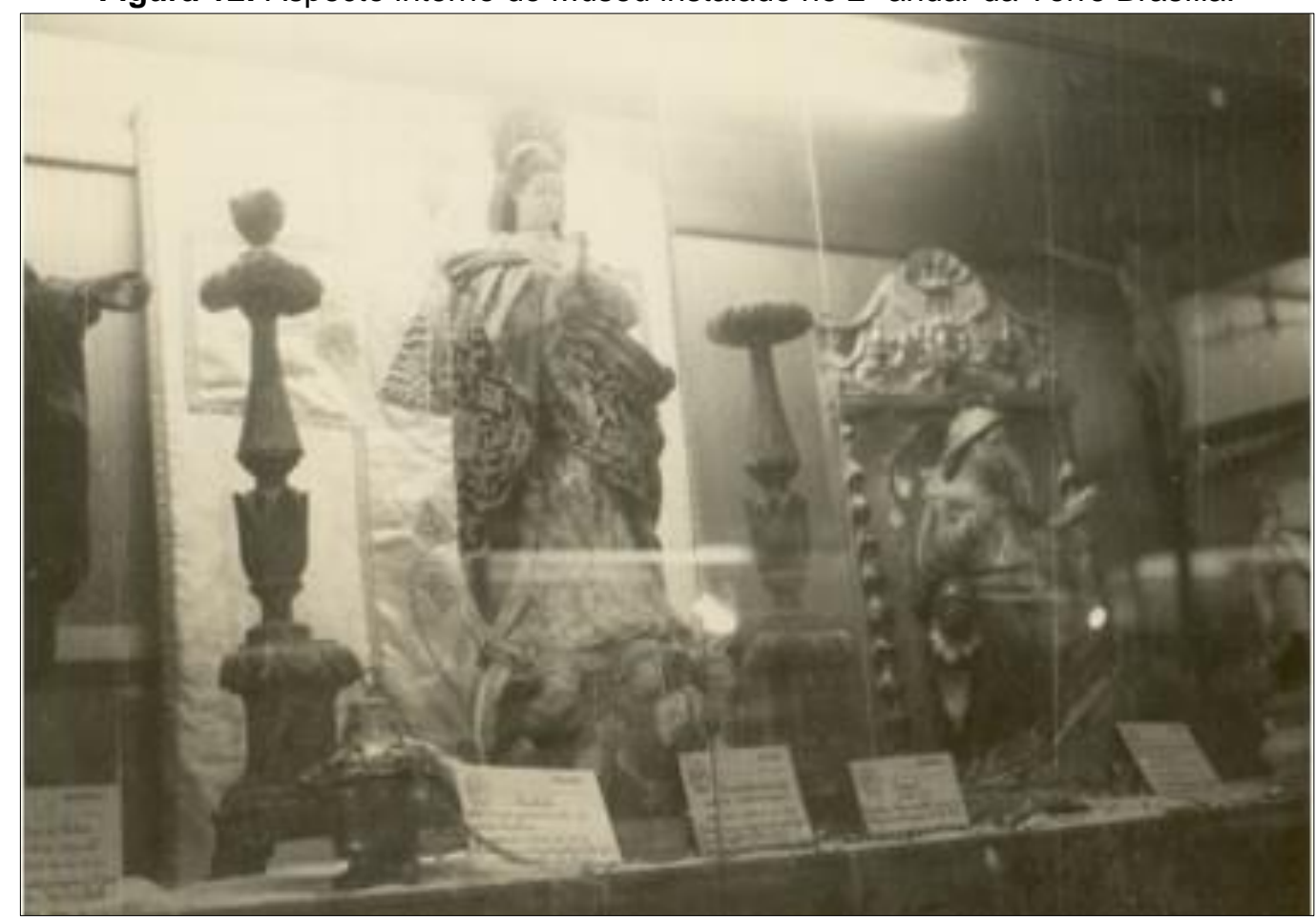

Fonte: MNSA/ Santuário Nacional.

Outro fator importante para análise é a instalação da Sala dos Milagres na Torre da Basílica Nova, em 1966, o que faz com que os visitantes também ofertassem mais objetos ao Museu, tanto ex-votos quanto demais objetos antigos para complementar as coleções do Museu. Pois haviam cartazes na exposição solicitando para que os visitantes fizessem doações de objetos antigos ao Museu.

A Figura 13, publicada no Almanaque de Nossa Sehora Aparecida - Ecos Marianos, do ano de 1967, retrata a Sala dos Milagres localizada no $1^{\circ}$ andar da Torre; no andar acima, estava instalada a nova exposição do Museu Nossa Senhora Aparecida. 
Figura 13: Sala dos Milagres na Torre Brasília.

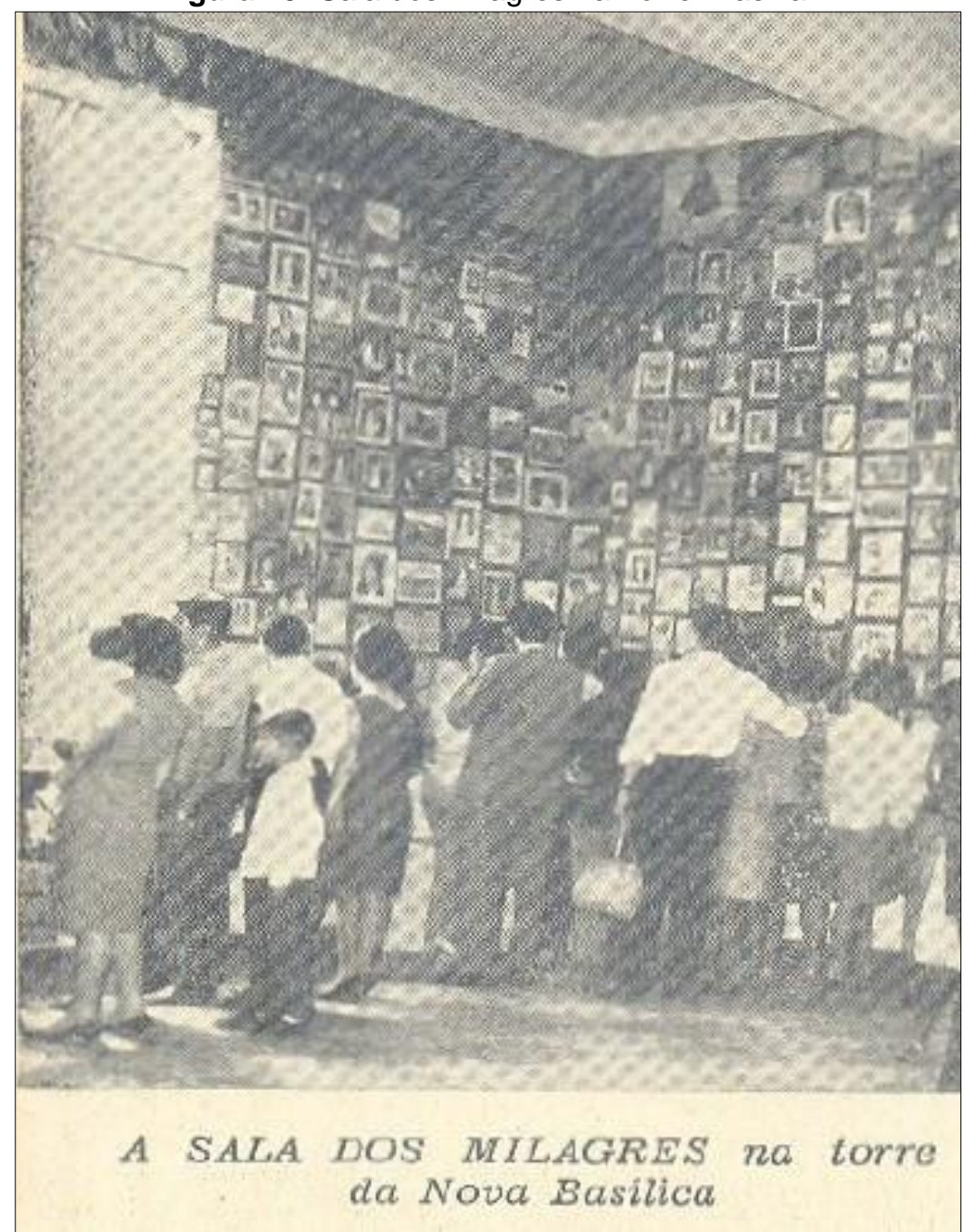

Fonte: Ecos Marianos, 1967, p. 230. CDM/ Santuário Nacional.

A Figura 14 demonstra objetos significativos, que são atribuídos aos milagres de Nossa Senhora Aparecida, referentes à libertação do escravo e à conversão do cavaleiro ateu, que incialmente estavam expostos na Sala dos Milagres e atualmente encontram-se em exposição no Museu Nossa Senhora Aparecida. 
Figura 14: Objetos atribuídos aos milagres de Nossa Senhora Aparecida.

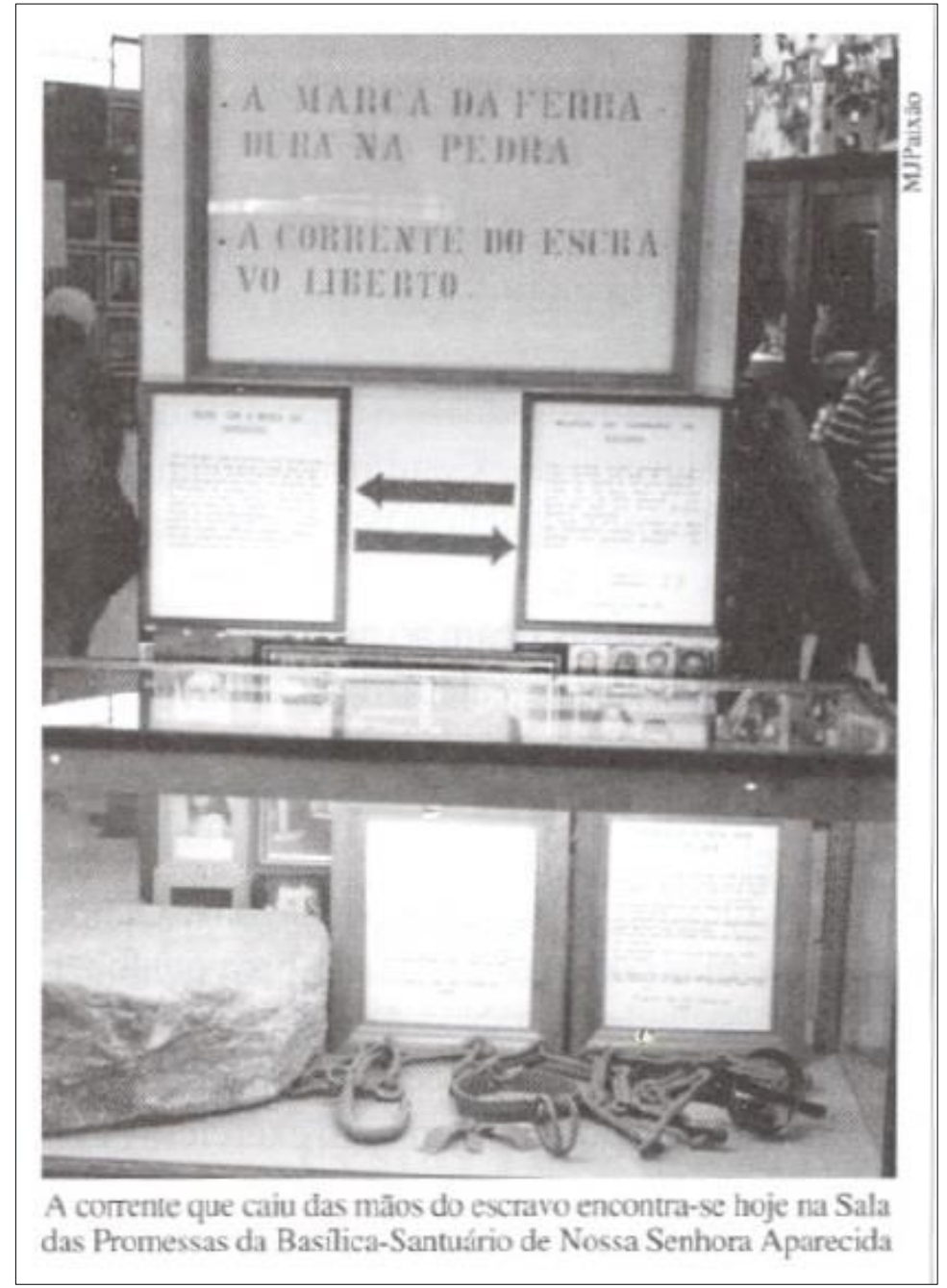

Fonte: Ecos Marianos, 1998. CDM/ Santuário Nacional.

A partir dessa perspectiva, observamos que o Museu Nossa Senhora Aparecida reúne um vasto acervo coletado pela Profa. Conceição Borges Ribeiro Camargo, com auxílio de seu esposo Vicente Camargo. Esse acervo passa a ser agregado por novas doações dos devotos de Nossa Senhora Aparecida, sejam elas relacionadas a objetos de promessa ou graça alcançada ofertados na Sala dos Milagres ou diretamente no Museu, assim como demais objetos antigos que apresentavam alguma afinidade com os objetos em exposição, para engrandecimento das coleções.

É importante levar em consideração que, para os organizadores, todas as seções estavam incompletas, o que abriu margem para a incorporação de objetos de todos os gêneros que eram doados ao Museu, não sendo consideradas na época como acervos duplicados, visando sempre o aumento das coleções. Com isso, observamos que a concepção de Museu para a Profa. Conceição Borges, 
correspondia ao conceito de Museu Histórico da época, com amplo interesse em expor todas as coleções, não havendo demanda para criação de reserva técnica.

Mesmo após a transferência definitiva da Sala dos Milagres para o subsolo da Nova Basílica de Nossa Senhora Aparecida, observamos que os visitantes ainda faziam confusões entre o Museu e a Sala dos Milagres, conforme podemos observar por meio do relato escrito no dia 01 de outubro de 1977 (Figura 15), na galeria de Confissões da Basílica Nova, quando perguntaram ao Padre Morgado, C.Ss.R., sobre a localização da Sala dos Milagres, tendo sido orientada a sua correta localização. Entretanto, a pessoa referia-se a outra sala que se pagava para ver coisas antigas, ou seja, o Museu Nossa Senhora Aparecida.

Figura 15: Relato sobre o Museu e a Sala dos Milagres

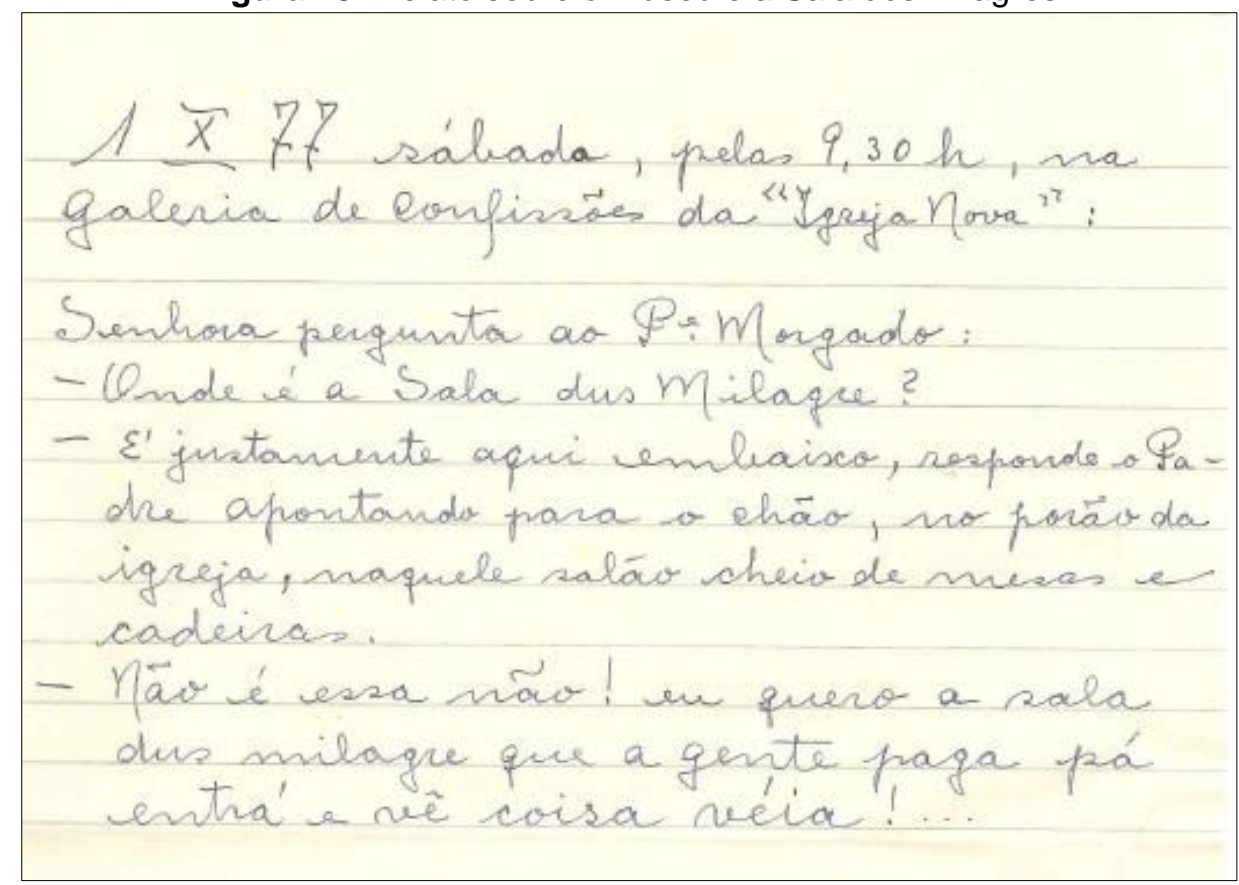

Fonte: MNSA/Santuário Nacional.

Nesse sentido, de acordo com Poulot (2013, p. 64), "qualquer que seja a natureza de sua coleção, o museu é guiado, em sua disposição, seu crescimento e a orientação de sua pesquisa, por uma missão de instrução pública que the confere toda a sua legitimidade". Para o autor, cada objeto contribui para a significação do conjunto de memórias, a qual a história no presente pretende apreender, em nome da história de uma memória coletiva.

Diante dessa perspectiva, o Museu Nossa Senhora Aparecida, em sua fundação, foi caracterizado com um conceito de museu abrangente e eclético, devido ao recolhimento e exposição de objetos de diversas áreas do conhecimento. 
Segundo Rússio ${ }^{15}$ (1974 apud BRUNO, 2010. p. 52), "[...] o museu eclético tende a se confundir com o regional, abarcando vários campos do conhecimento humano em função de uma paisagem específica: a região e sua realidade geográfica, econômica, antropocultural, ecológica, etc."

Para Dom Darci José Nicioli16 (2018, informação verbal), que conheceu o Museu ainda quando criança, a Profa. Conceição Borges era uma mulher magnífica, porque ela conseguiu reunir muitos objetos ofertados no Santuário Nacional. Acrescenta que "ela como uma pesquisadora, muito interessada pela cultura e amante da museologia, ela foi muito importante para o que é hoje o Museu Nossa Senhora Aparecida". Embora, sua visão inicial sobre o Museu era que se tratava de "um ajuntamento de coisas, na verdade um depósito. E era assim que se pensava antigamente" (NICIOLI, 2018, informação verbal).

Além das aquisições pessoais realizadas pelos organizadores do Museu e das doações dos romeiros, coletaram-se também, no decorrer do tempo, alguns exemplares de arqueologia, entre eles fragmentos e objetos cerâmicos retirados de sítios arqueológicos do município de Aparecida (SP) (Figura 16), reunidos por iniciativa da Profa. Conceição Borges.

15 RÚSSIO, Waldisa. Museu: uma organização em face das expectativas do mundo atual. Texto publicado em Seminários do Museu da Casa Brasileira (Solar Fábio Prado), Boletim n. 1, fev. 1974, p. 57-67.

${ }^{16} \mathrm{NICIOLI}$, Darci José (Arcebispo de Diamantina). Entrevista concedida a Erica Andreza Coelho. Aparecida, 19 abr. 2018, 6 min 14 s. Som, Formato M4A. 
Figura 16: Escavações arqueológicas em Aparecida (SP).

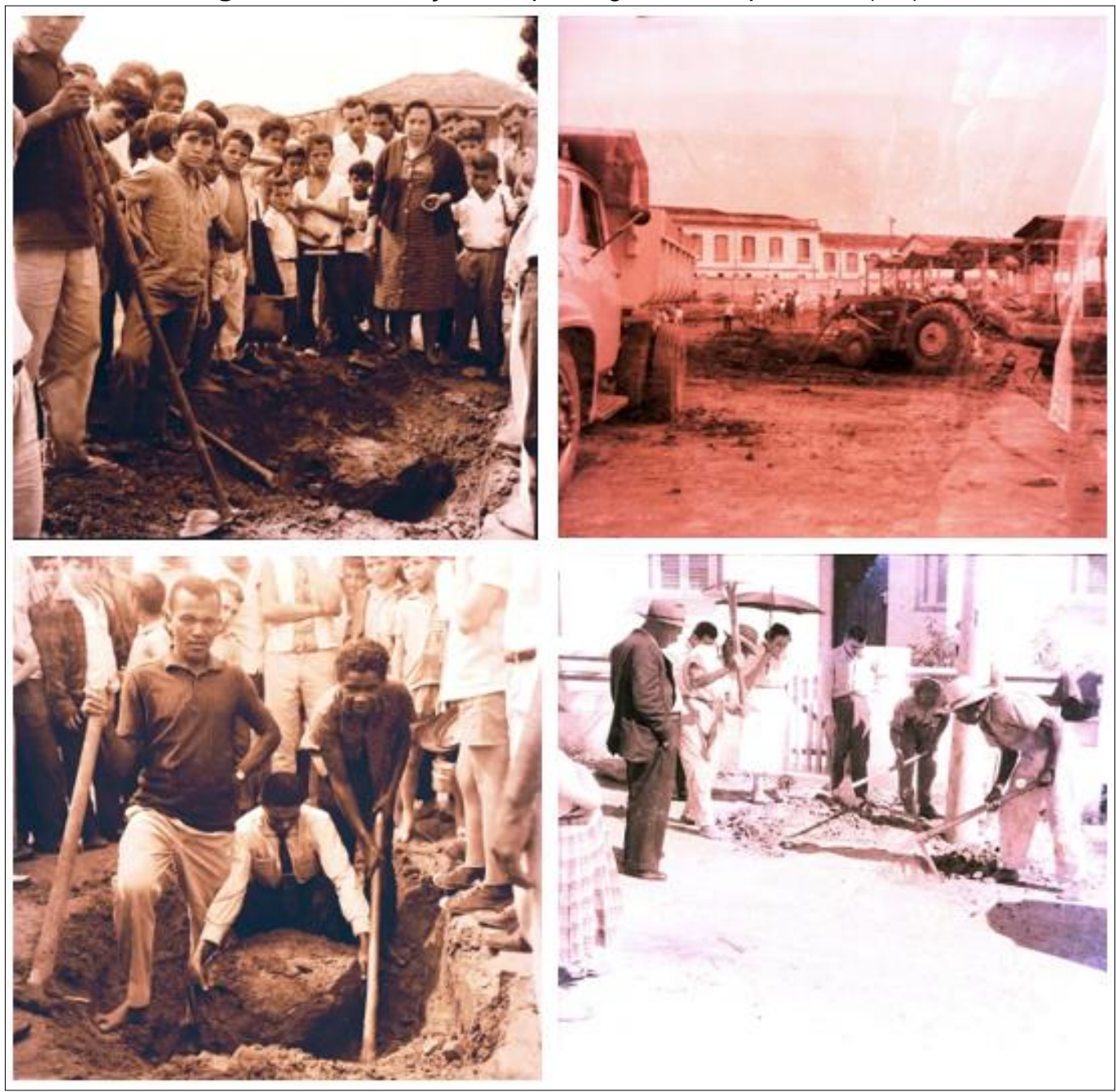

Fonte: MNSA/Santuário Nacional.

De acordo com Pasin (2016, p. 5), "as pesquisas de campo deixadas por Dona Conceição no quesito arqueologia de Aparecida são incontáveis". Conceição Borges foi uma personagem muito importante para o resgate e salvaguarda dos objetos arqueológicos encontrados durante escavações em Aparecida (SP).

Em suas pesquisas sobre arqueologia local, classificou os tipos de cerâmica encontrados, organizando por zonas geográficas, sendo elas: Primeira Zona - Largo da Feira e Estação Ferroviária; Segunda Zona - Rua João Andrade Costa e Convento das Carmelitas; Terceira Zona - Porto Itaguaçu.

De acordo com Braga (2017, informação verbal) ${ }^{17}$,

Ela, como especialista em arqueologia indígena, o pessoal de fora sabia que ela lidava com isso. Aqui em Aparecida mesmo, foi uma extensão, vários sítios arqueológicos, cemitério indígena, extraordinário, porque eu não sei se vocês sabem, os índios já habitavam essa região uns dois mil

17 BRAGA, Guido Machado. Entrevista concedida a Victor Hugo Barros e a Erica Andreza Coelho. Aparecida, 20 set. 2017, 33 min 08 s. Som, Formato MP3. 
anos antes de Cristo, muito antes. E, principalmente, uma tribo que transitou por aqui, que eram os Aratus. Ela achou depois, primeiro por sorte, na construção da estação rodoviária, os camaradas fazendo os alicerces viram aquelas pedras redondas e não mexeram, porque o engenheiro mais ou menos sabia, chamou a Dona Conceição e lá estavam as urnas funerárias. $[\ldots]$

$\mathrm{Na}$ rodoviária ela fez os próprios pedreiros, camaradas que trabalhavam para empresa, foram escavando, ajudaram a tirar as coisas, ela fotografou, documentou tudo. As escolas foram participar da retirada da primeira urna, foi muito bonito. E ela, então, era chamada em vários lugares. Jacareí, por exemplo, quando abriram a estrada Carvalho Pinto, estavam abrindo, passando os tratores, e os tratores começaram a quebrar, arrancar a calota de várias urnas que tinham lá, quando o engenheiro percebeu, falou "Para!". Pararam tudo. Como sabiam da existência da Dona Conceição, chamaram ela. Foi quando ela me chamou e a professora Glória para podermos acompanhar e fomos lá. Já havia uma turma da USP, da sessão de arqueologia da USP, fazendo a prospecção, um trabalho meticuloso e paciente, com pincel. E ela ia a vários lugares. Aparecida foi um grande sítio arqueológico.

Segundo Barbosa (2007, p. 17), "índios guaianazes, tapuias, tupis, guaranis, maromomis, puris e coroados devem ter passado ou fixado residência em Aparecida". O fato pode ser comprovado pela evidência arqueológica que surgiu durante escavações para construção de edificações no município. Segundo o autor, "os achados arqueológicos aconteceram nas imediações da Estação Ferroviária de Aparecida, na Rua Monte Carmelo, no Morro das Pitas, no local onde hoje se encontra a Estação Rodoviária e nas proximidades de onde está o Convento Carmelita" (BARBOSA, 2007, p. 17).

Grande parte desse acervo arqueológico, que foi resgatado durante as escavações, estão preservados no Museu Nossa Senhora Aparecida, e alguns exemplares que foram enviados ao Museu Paulista atualmente encontram-se no Museu de Arqueologia e Etnologia da Universidade de São Paulo (MAE-USP), enviados para salvaguarda e pesquisa.

Na época, de acordo com o Padre Machado (1978), o Padre Doutor José Vicente César, Diretor do Anthropos do Brasil, analisou o acervo arqueológico e apresentou um trabalho no 38 Congresso Internacional de Americanistas, realizado na Alemanha em agosto de 1968, trabalho no qual foi mencionado um machadinho de pedra verde, que também foi apresentado pela Profa. Conceição Borges no $X$ Simpósio do Vale do Paraíba, que ocorreu em Roseira (SP), entre os dias 19 e 21 de julho de 1990, e em demais publicações, como por exemplo, nos Cadernos Culturais do Vale do Paraíba, produzidos pelo Centro Educacional Objetivo, em 1990, que dedicou um caderno específico com o título Arqueologia no Vale do 
Paraíba - Escavações Arqueológicas em Aparecida, com texto produzido por Conceição Borges Ribeiro Camargo e Vicente Camargo.

De maneira geral, entende-se que a região também era considerada um local sagrado para os indígenas, pois foram encontradas urnas funerárias de cerâmica com remanescentes ósseos, portanto, um solo sagrado para sepultamento.

Em relação às demais coleções do Museu Nossa Senhora Aparecida, o Prof. Guido Braga diz que grande parte do acervo "foi coleta dela, não só objetos domésticos, como de arqueologia, peças. Mas, muita gente doou muita coisa, por isso que ela teve um acervo tão grande desse Museu" (BRAGA, 2017, informação verbal).

Além dos objetos arqueológicos, reuniram-se também objetos litúrgicos, relíquias, joias, paramentos religiosos, imaginária, arte popular, ex-votos, louças e porcelanas, prataria litúrgica e doméstica, pinturas, esculturas, objetos de uso doméstico cotidiano, instrumentos musicais, coleções de etnologia, mineralogia, numismática, filatelia, materiais da Revolução Constitucionalista de 1932 e Segunda Guerra Mundial, objetos da cultura tropeira, artesanatos, etc. Em especial, peças procedentes da Basílica Velha e da Sala das Promessas, ligadas à história do Santuário Nacional e a devoção a Nossa Senhora Aparecida, compondo, portanto, um acervo expressivo e diversificado.

Nesse contexto, Cesar Augusto Maia, ao organizar o acervo no início da década de 1990, para documentação no Livro de Tombo, relaciona os seguintes objetos como procedentes da Basílica Velha de Nossa Senhora Aparecida, que foram incorporados ao acervo do Museu (conforme Figuras 17 e 18). 
Figura 17: Relação das peças da Antiga Basílica.

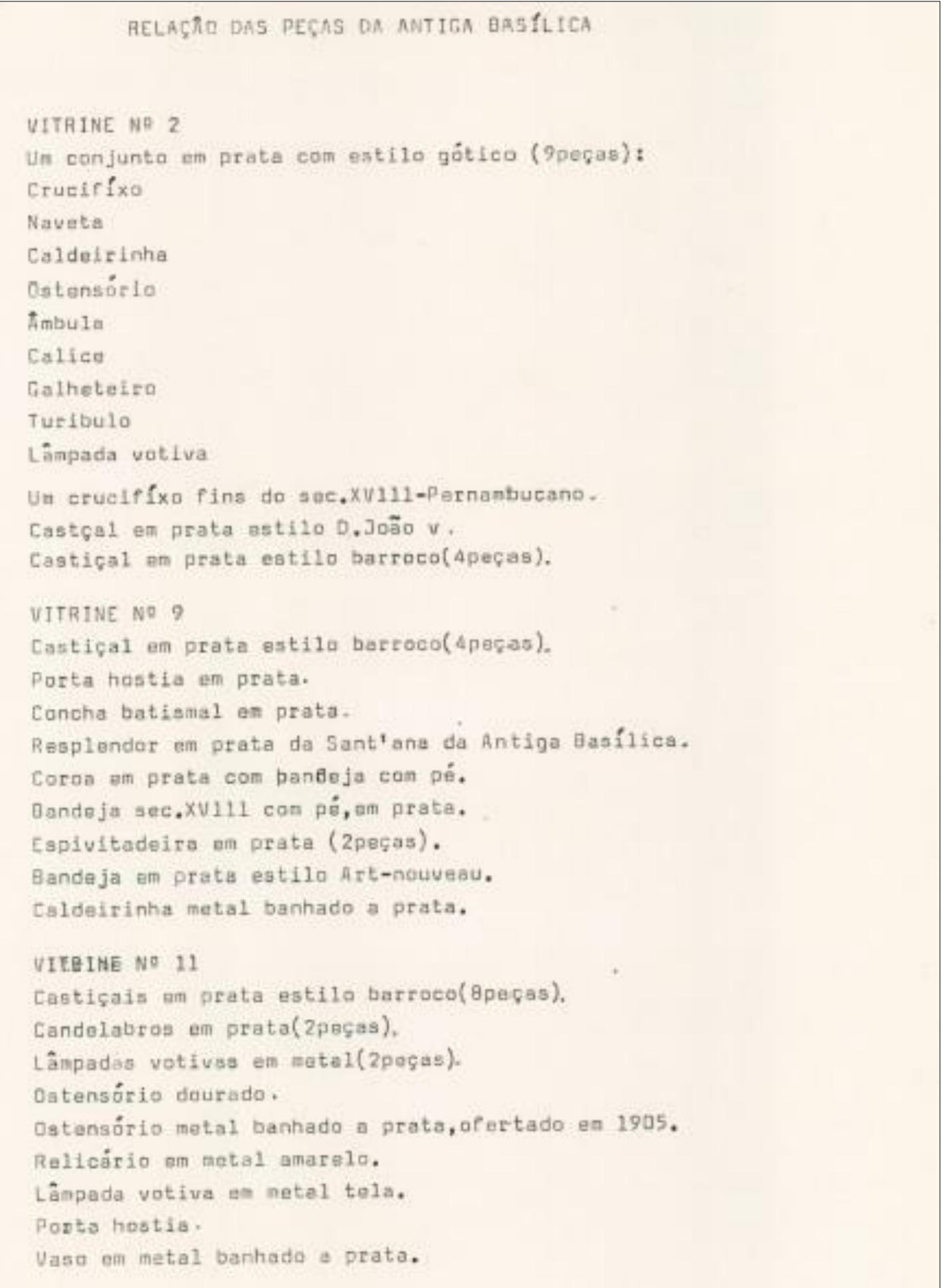

Fonte: MNSA/Santuário Nacional. 
Figura 18: Relação das peças da Antiga Basílica.

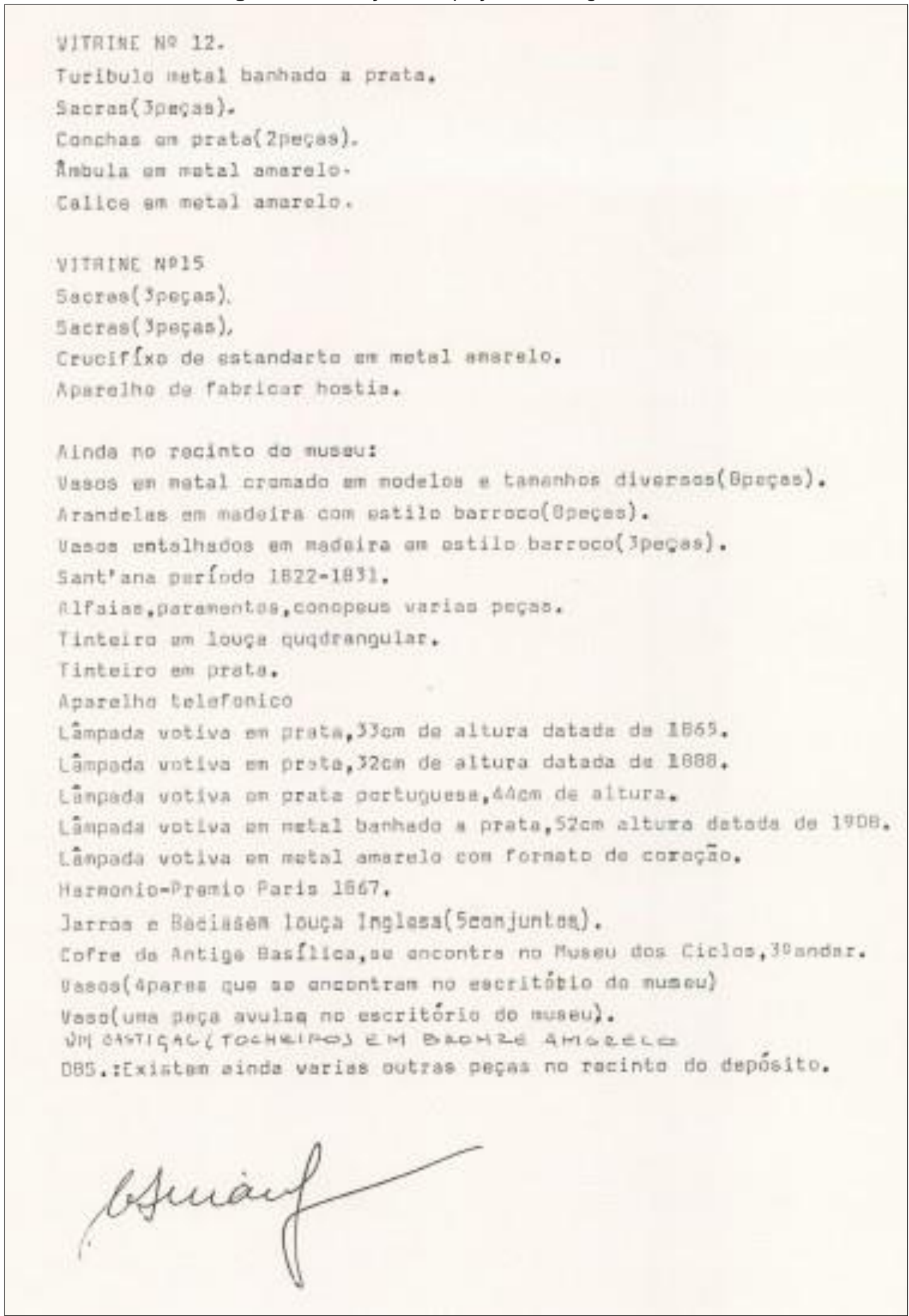

Fonte: MNSA/Santuário Nacional.

Ao verificar essa relação de acervos, analisando demais registros e fichas catalográficas, identificamos os números de inventário de alguns dos objetos listados, que mencionavam a Basílica Velha como procedência. 
De acordo com a relação de Cesar Maia, ao mencionar nove peças de um conjunto de estilo gótico, ele acabou não mencionando uma patena que estava junto ao cálice, assim como uma lâmpada votiva, que recebeu inicialmente o número de inventário MNSA 2.461 e um galheteiro documentado inicialmente com o número de inventário MNSA 0689, composto por três peças.

Com essa verificação, os números de inventário do conjunto foram atualizados, conforme descrito a seguir: MNSA 0969/01 - Ostensório, MNSA 0969/02 - Naveta, MNSA 0969/03 - Turíbulo, MNSA 0969/04 - Caldeirinha, MNSA 0969/05 - Cálice, MNSA 0969/06 - Patena, MNSA 0969/07 - Âmbula, MNSA 0969/08 - Crucifixo, MNSA 0969/09 - Lâmpada votiva (número inicial MNSA 2.461), MNSA 0969/10A - Bandeja (número inicial MNSA 0689/01), MNSA 0969/10B - Galheta (número inicial MNSA 0689/02) e MNSA 0969/10C - Galheta (número inicial MNSA 0689/03).

Em relação às bandejas e espevitadeiras, identificados com os números de inventário MNSA 0029 - Espevitadeira e MNSA 0747 - Bandeja, trata-se de um conjunto, pois possuem o mesmo número de registro no Livro de Tombo. Já as bandejas de número MNSA 0030 e MNSA 0747 estão com a mesma informação no campo Dados Patrimoniais da ficha catalográfica, por serem objetos semelhantes. No entanto, o objeto MNSA 0030 possui a marcação de tombo 00009 e o objeto MNSA 0747 possui a marcação de tombo 00479.

Após estudos, seguem os demais números de inventários em que foi possível a identificação, relacionando a listagem de Cesar Maia com as fichas catalográficas dos objetos em que constava a informação de procedência: MNSA 0722 - Custódia, MNSA 0694 - Concha batismal, MNSA 0701/01 - Caldeirinha, MNSA 1.612 Custódia, MNSA 0732 - Custódia, MNSA 0699 - Turíbulo, MNSA 1613 - Sacras (3 peças), MNSA 0938/01 - Concha de galheteiro, MNSA 0938/02 - Concha, MNSA 1.591 - Sacras (3 peças), MNSA 1.592 - Sacras (3 peças), MNSA 0966/01 - Ânfora, MNSA 0966/02 - Ânfora, MNSA 0966/03 - Ânfora, MNSA 2.458/01 - Lâmpada votiva, MNSA 2458/02 - Corrente, MNSA 2.460 - Lâmpada votiva, MNSA 2.459 - Lâmpada votiva, MNSA 2462 - Lâmpada votiva, MNSA 0984/01 - Jarra, MNSA 0984/02 Bacia, MNSA 0985/01 - Jarra, MNSA 0985/02 - Bacia, MNSA 0986/01 - Jarra, MNSA 0986/02 - Bacia, MNSA 0987/01 - Jarra, MNSA 0987/02 - Bacia, MNSA 0988/01 Jarra, MNSA 0988/02 - Bacia, MNSA 0282 - Cofre. Os demais objetos foram atribuídos, conforme associação descritiva nas Fichas Catalográficas, tendo sido 
identificados os números: MNSA 0701/02 - Aspersório, MNSA 1.587 - Ostensório, MNSA 0718 - Cálice, MNSA 0714 - Cortador de hóstia, MNSA 2.406 - Tocheiro, MNSA 0730 - Conjunto de castiçais, MNSA 11.390 - Conjunto de arandelas.

Infelizmente, em vários objetos não foi possível fazer a identificação do número de inventário ou definir sua localização entre o acervo do Museu, por meio da descrição física nas fichas catalográficas.

De maneira geral, com essas características da formação de acervos e coleções do Museu Nossa Senhora Aparecida, podemos observar algumas similaridades e, também, estabelecer relações com os Museus Históricos Pedagógicos do Estado de São Paulo, pelo período de criação, pois foram implantados a partir de 1956, assim como o tipo de mobiliário utilizado nas exposições e a forma de expor os objetos.

Com base no artigo de Simona Misan (2008), outro fator que leva a pensar na similaridade entre o Museu Nossa Senhora Aparecida e a rede de Museus Históricos e Pedagógicos do Estado de São Paulo é a prática estabelecida por Vinício Stein Campos ao assumir a direção do Serviço de Museus Históricos, que contou com o apoio do Instituto Histórico e Geográfico de São Paulo (IHGSP), para indicação do nome de um patrono a ser rememorado, assim como a participação de sócios correspondentes do IHGSP, para proferir aulas de história da cidade que sediava o museu.

É possível estabelecer essa conexão, pois a Profa. Conceição Borges foi sócia do IHGSP, e acreditamos na possibilidade de sintonia com os Museus Históricos e Pedagógicos do Estado de São Paulo na formação do Museu Nossa Senhora Aparecida, considerando o contexto histórico-cultural do período em que foram criados, além de ser possível estabelecer algumas diferenças entre as políticas culturais do Estado de São Paulo e iniciativas privadas, como é o caso do Museu Nossa Senhora Aparecida.

A partir de consultas nas revistas do IHGSP, é possível associar o contato entre a Profa. Conceição Borges e Vinício Stein Campos, considerando que ele era o $2^{\circ}$ secretário da mesa que presidiu os trabalhos na data da posse de Conceição Borges Ribeiro Camargo no IHGSP.

De acordo com ata da sessão ordinária de 05 de fevereiro de 1966, os novos sócios, Conceição Borges Ribeiro Camargo e Henrique Orciuoli, foram apresentados com as formalidades do estilo. 
Recebidos sob palmas do plenário, leram o respectivo têrmo de compromisso e posse, na forma usual. A seguir, o sr. Presidente deu-lhes as boas-vindas em rápido discurso, dizendo da satisfação de todos e da esperança do sodalício em que venham com assiduidade emprestar o seu valioso concurso ao desenvolvimento das atividades do Instituto. Registrou o sr. Presidente, em sua oração, com emoção, a presença na sessão de Sua Eminência o Senhor Arcebispo de Aparecida D. Carlos Carmelo de Vanconcelos Mota [Vasconcellos Motta], dirigindo-Ihe carinhosa saudação. Para saudar os novos consócios, foi dada a palavra ao sr. Agostinho Ramos, que em palavras fluentes e entusiásticas proferiu o elogio de ambos, alongando-se na enumeração dos títulos e serviços de dona Conceição Borges Ribeiro Camargo, heroína de 32 e pesquisadora de arqueologia. (IHGSP, 1968. p. 439-440) ${ }^{18}$.

Segundo Pasin (2016, p. 7), que se apresenta como discípula da Profa. Conceição Borges, em seu discurso em comemoração aos 60 anos do Museu Nossa Senhora Aparecida, disse que "não poderia ficar sem registro, os dias que passamos, Dona Conceição, o Sr. Vicente "garimpando" imagens do século passado, nos bairros Pedrinhas e Pilões".

A partir desse relato e com informações sobre a procedência dos objetos, constante em algumas fichas catalográficas, observamos que era costume de Profa. Conceição ir até as residências em busca de peças para a coleção de imaginárias, que foram adquiridas ou coletadas em capelas e hoje compõem um riquíssimo acervo de obras do século XIX.

Esse aspecto no discurso da Profa. Tereza Pasin foi destacado, pois é possível verificar o interesse da Profa. Conceição Borges na seleção de acervos para incorporação ao Museu, como um procedimento de curadoria. Os bairros citados em sua fala são bairros rurais do munícipio de Guaratinguetá (SP), cidade vizinha de Aparecida (SP).

A partir de análises dos documentos que compõem o acervo documental do Museu Nossa Senhora Aparecida, observamos que Conceição Borges contribuía com informações estatísticas para o Instituto Brasileiro de Geografia e Estatística

18 Revista do Instituto Histórico e Geográfico de São Paulo. Vol. 65. São Paulo: IHGSP, 1968. p. 439440. Consultando outros volumes da revista do IHGSP, observamos que a Profa. Conceição Borges produziu artigos para a revista e participava das assembleias por meio de leitura de suas pesquisas, tendo recebido condecorações, como é o caso relatado na ata da sessão do dia 7 de outubro de 1972, na qual consta que "neste ato ingressa no auditório o sr. Roberto Costa de Abreu Sodré, exgovernador do Estado, que se fazia acompanhar de sua exma. esposa. O sr. Presidente convida-o a participar da mesa a seu lado e outorga-lhe o Colar D. Pedro I, venera que é igualmente entregue a d. Conceição Borges Ribeiro Camargo, D. Carmelo Vasconcelos Mota, [...] respondeu pelos homenageados o sr. Abreu Sodré, que acentuou o sentido de firme defesa das tradições culturais e históricas paulistas, que imprimiu à sua administração de 1968 a 1971. [...]

A consócia d. Conceição Borges Ribeiro Camargo leu o seu interessante estudo sobre $<<$ Aparecida, a Casa de Bragança e D. Pedro I >>, trabalho de pesquisa histórica sobre a história de Aparecida e a controvertida questão da visita do Príncipe à Capela em 1822". Ver: Revista do Instituto Histórico e Geográfico de São Paulo. Vol. 72. São Paulo: IHGSP, 1974. p. 443-444. 
(IBGE), o Departamento de Assuntos Culturais do Ministério da Educação e Cultura (DAC-MEC), assim como o Comitê Brasileiro do Conselho Internacional de Museus (ICOM - International Council of Museums, traduzido do inglês), no Rio de Janeiro.

Conceição Borges se correspondia com a Sra. Fernanda de Camargo e Almeida Moro ${ }^{19}$, Presidente do Comitê Brasileiro do ICOM, Rio de Janeiro, de quem recebia circulares e memorandos para o preenchimento de formulários para o Cadastro de Museus. Em duas correspondências ela cita Waldisa Rússio, para quem também enviou o mesmo formulário preenchido para a Delegacia Regional em São Paulo, da Associação de Membros do ICOM-Brasil.

De acordo com o manuscrito de Conceição Borges para preenchimento do formulário "DAC-MEC 4"20 (Departamento de Assuntos Culturais - Ministério da Educação e Cultura), que aborda a situação museológica e museográfica, nesse período foram quantificados aproximadamente 3.000 objetos no Museu Nossa Senhora Aparecida, entre peças em exposição e armazenadas no depósito. Em relação à estatística de visitação, em 1974 foi registrada uma média anual de 284.000 visitantes, 303.300 visitantes em 1975 e 293.300 visitantes em 1976.

Esse formulário enviado pelo Sr. Manuel Diégues Júnior, Diretor-Geral do Departamento de Assuntos Culturais, conforme recomendação do Ministério da Educação e Cultura, tinha por objetivo o levantamento das condições físicas, administrativas, técnicas e financeiras dos museus brasileiros, com o intuito de reunir elementos para formulação de uma política permanente de amparo ao setor, com a criação, inclusive, de um Sistema Nacional de Museus. De acordo com a Circular no 04, datada 10/05/1977 e assinada pelo Sr. Manuel Diégues Júnior,

\begin{abstract}
Entre os objetivos visados está o de propiciar aos museus um intercâmbio permanente de informações, com a criação de um 'Banco de Dados Museológicos', bem como a identificação de suas necessidades mais prementes, com vistas ao fornecimento de auxílio técnico e, eventualmente, financeiro, e a possibilidade de estabelecer uma ação integrada entre as instituições culturais de todo o país.

Diante das inúmeras críticas e indagações que se acumulam na atualidade sobre o problema dos museus brasileiros e seu papel na comunidade nacional, acreditamos ser a análise dos dados e das condições reais dessas instituições o único caminho para encontro de soluções viáveis, práticas e de longo alcance para sua melhoria, aperfeiçoamento e integração.
\end{abstract}

\footnotetext{
${ }^{19}$ CAMARGO, C. B. R. 17 set. 1978, Aparecida [para] MORO, F. C. A. Aparecida. 2 f. Preenchimento de formulários para o Cadastro de Museus ao Comitê Brasileiro do ICOM, Rio de Janeiro.

20 DIÉGUES JUNIOR, Manuel. [Circular no 04] 10 maio 1977, Rio de Janeiro. [para] CAMARGO, C. B. R. Levantamento das condições físicas, administrativas, técnicas e financeiras dos museus brasileiros - Departamento de Assuntos Culturais.
} 
Em relação ao número de peças das coleções, classificadas por assunto, no ano de 1975, havia as seguintes tipologias e quantidade de objetos: alfaia - 55 peças; armaria - 30 peças, arqueologia - 115 peças, botânica - 1 peça, cerâmica - 80 peças, condecorações - 25 peças, cristais - 1 peça, desenho e artes gráficas - 49 peças, escultura - 3 peças, etnologia - 61 peças, filatelia - 120 peças, geologia - 12 peças, indumentária - 2 peças, joalheria - 35 peças, mobiliário - 3 peças, numismática - 1.650 peças, objeto de uso - 280 peças, pintura - 14 peças, prataria 74 peças, e outros objetos diversos - 626 peças. A classificação, segundo a natureza das coleções, foi identificada como "Misto" e "Outros Museus", não se enquadrando nas demais classificações indicadas pela Secretaria de Estatísticas.

No levantamento documental do Museu também foram localizados alguns formulários "EC-5 - Museus"21, com informações de alguns anos da década de 1970 e 1980, que foram enviados para o Serviço de Estatística da Educação e Cultura (SEEC), registrando cerca de 400 mil visitantes em 1984.

Em um dos manuscritos de Conceição Borges analisados durante 0 levantamento documental, para preenchimento do formulário EC-5 - Museus ${ }^{22}$, observamos que a exposição do $2^{\circ}$ andar passou a ser insuficiente para expor todos os objetos recebidos em doação. Com isso, algumas coleções foram transferidas ao $3^{\circ}$ andar, conforme descrição a seguir constante no rascunho para preenchimento do formulário EC-5 - Museus:

Por falta de espaço, em comum a este Museu, no andar acima, $3^{\circ}$ andar, está a "Secção de História". É o Museu dos "Ciclos Sócio-Econômicos do Vale do Paraíba", com 154 peças mais ou menos.

Anexa à "Secção de História", nas paredes, "Brasões Municipais", com 409 Brasões. A "Secção de História" e especialmente para estudos e pesquisas de professores e alunos. A entrada é grátis, porque o ingresso ao Museu do $2^{\circ}$ andar é válido para o $3^{\circ}$ andar. (CAMARGO, s. d.).

O Museu dos Ciclos Sócio-Econômicos do Vale do Paraíba foi inaugurado em 1975, no $3^{\circ}$ andar, durante as comemorações do Sesquicentenário da Independência do Brasil. A criação deste Museu será abordada no item 1.3 desta dissertação.

${ }^{21}$ BARBOSA, Leila. [Memorando no 496/84] 21 dez. 1984, Guaratinguetá [para] CAMARGO, C. B. R. Guaratinguetá. 1 f. Formulário para preenchimento do questionário EC-5 - Museus, para a Secretaria de Planejamento da Presidência da República, Fundação Instituto Brasileiro de Geografia e Estatística - IBGE.

22 Manuscrito de Conceição Borges Ribeiro Camargo, sem data, pertencente ao acervo documental do Museu Nossa Senhora Aparecida, identificado e analisado como rascunho para preenchimento do "Quadro 3 - quesito 8" do formulário EC-5 - Museus. 
De acordo com o manuscrito da Profa. Conceição Borges $^{23}$ referente ao pronunciamento no aniversário de 20 anos do Museu, a Galeria Heráldica dos Brasões Municipais foi instalada nos corredores do $3^{\circ}$ andar tendo sido organizada pelo heraldista Arcinóe Antonio Peixoto de Faria, composta por 250 Brasões de Armas.

Ambos os locais expositivos eram incentivados pelo Cardeal Motta, Arcebispo de Aparecida, conforme consta em artigo publicado pelo Jornal O Estado de São Paulo, de 05 de setembro de 1976, em virtude dos 20 anos da criação do Museu.

Fundado por iniciativa da professora Conceição Borges Ribeiro Camargo, reúne valioso acervo iconográfico e documentário relativo ao culto de Nossa Senhora Aparecida e a história da basílica nacional ao longo de mais de 200 anos. Tem em anexo no $3^{\circ}$ andar da torre o Museu dos Ciclos Sócio Econômicos do Vale do Paraíba dirigido por Vicente Camargo. O cardeal d. Carlos Carmelo de Vasconcelos Motta, arcebispo de Aparecida, tem dado todo o seu apoio à iniciativa. (O ESTADO DE SÃO PAULO, 1976).

O Jornal Santuário de Aparecida, de 12 de setembro de 1976, também fez uma publicação sobre as comemorações dos 20 anos do Museu Nossa Senhora Aparecida, o qual consta que,

No último dia 8 completou 20 anos de uma existência toda ela dedicada à Aparecida e aos romeiros que visitam a Terra da Padroeira, o Museu "Nossa Senhora Aparecida".

[...] Todo o seu acervo foi transferido para o segundo andar da torre da Igreja nova onde até hoje se encontra e onde também, em consequência de haver mais espaço, pode ser ampliado.

Diariamente centenas de peregrinos visitam as dependências do Museu, onde há objetos relacionados com a história de Aparecida e com a história do Vale do Paraíba.

O Museu está entregue à guarda do Sr. Vicente Camargo e da Professora Conceição Borges Ribeiro Camargo, que muito têm feito para aumentar ainda mais o seu acervo. (SANTUÁRIO DE APARECIDA, 1976, p. 8).

Com base nessas informações sobre a ampliação do espaço expositivo do Museu, podemos observar um grande esforço dos organizadores para receber novas doações, considerando que no início não havia uma política definida para aquisição de acervos, nem mesmo havia um termo para recebimento de doações.

Com isso, acreditamos que o conceito de Museu dos organizadores definiu as características das doações, bem como a dinâmica para incorporações e baixas, considerando que se tratava de uma instituição de caráter particular.

${ }^{23}$ Manuscrito de Conceição Borges Ribeiro Camargo, sem data, pertencente ao acervo documental do Museu Nossa Senhora Aparecida, identificado como rascunho para o pronunciamento de 20 anos do Museu. 
De maneira geral, os documentos mais antigos referentes à entrada de objetos dizem respeito a manuscritos com informações em pedaços de papel, que serviam de base para o desenvolvimento de etiquetas para exposição.

Essas etiquetas antigas que foram reunidas e preservadas serviram de referência para posterior documentação do acervo, principalmente para registro no Livro de Tombo no início da década de 1990 (Figura 19).

Figura 19: Exemplo de anotação contendo informação sobre uma doação.

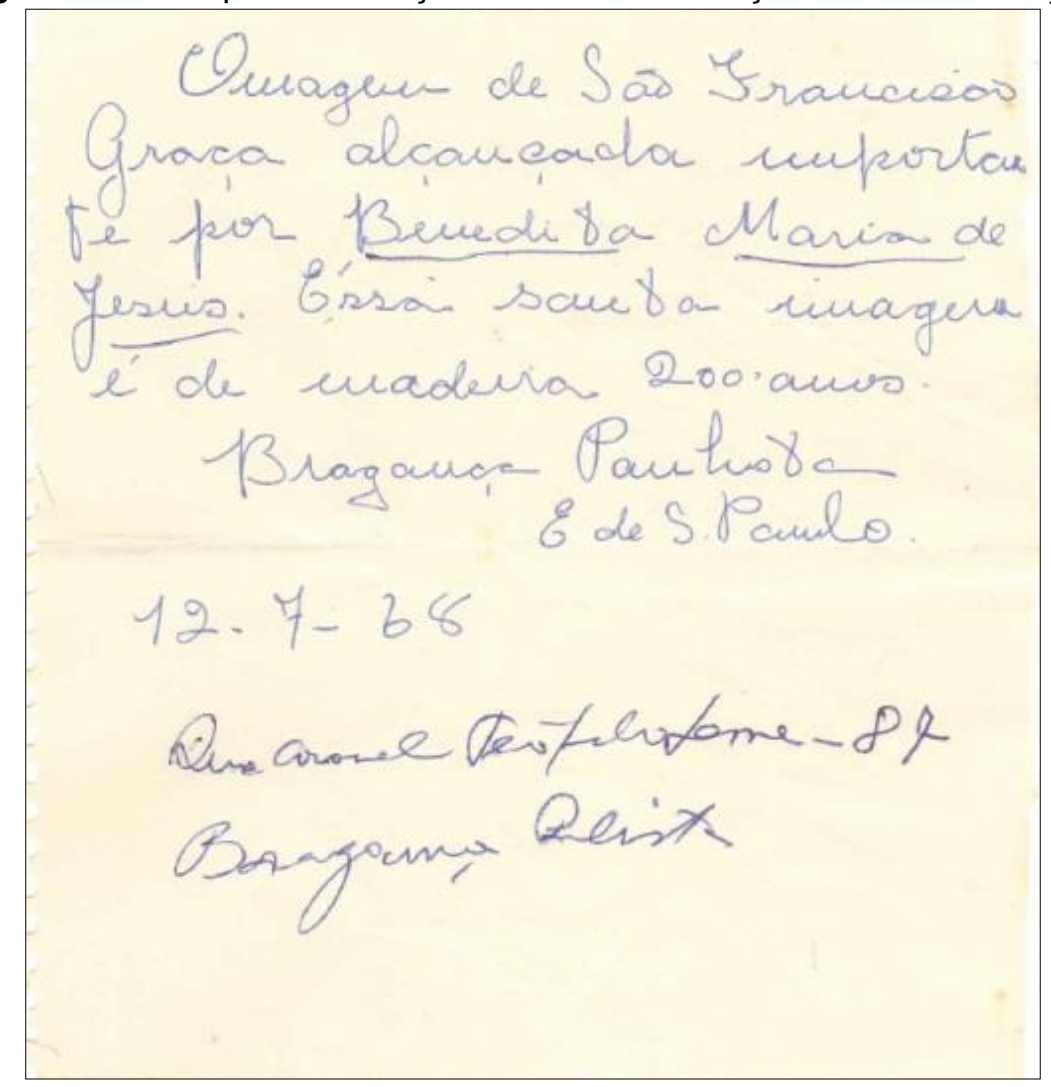

Fonte: MNSA/ Santuário Nacional.

De acordo com o Relatório Final de Prestação de Serviços Especializados, realizado pela equipe executora do projeto da Fundação Patrimônio Histórico da Energia de São Paulo (FPHESP), composta por Giselle Marques Leite (supervisão), Renato Rinaldi (conservação), Maria Sílvia Bigareli (coordenação local) e Ana Lúcia Gomes Gonçalves e Michel Henrique de Oliveira (estagiários), apresentado em outubro de 2003 por Claudinéli Moreira Ramos, Gestora de Documentação da FPHESP.

O Museu tem em seus arquivos cópias eletrostáticas do Livro Tombo, agrupadas em 4 pastas plastificadas, com numeração de objetos 00001 a 01240, assim distribuídos: 
- Pasta "Livro de Tombo N. 1", com Termo de Abertura de 08/09/1991, assinado por Conceição Borges Ribeiro Camargo - registros de 00001 00259;

- Pasta "Continuação N. 1" - registros de 00260 a 00569, com Termo de Encerramento de 09/03/1993;

- Pasta "Livro Tom N. 2", com Termo de Abertura de 25/03/1993, assinado pela "Comendadora Conceição Borges Ribeiro Camargo, Diretora/Fundadora do Museu Nossa Senhora Aparecida, em 8-setembro1956" - registros de 00570 a 00888;

- Pasta "P. 101 a 200" - Com Termo de Encerramento em 28/12/1994 registros de 00889 a 1240 (RAMOS, 2003, p. 42).

Há também outro volume do Livro de Tombo, sendo este original, no modelo Livro/Ata com 200 páginas numeradas. Porém, não há Termo de Abertura e contém os registros de 1.241 a 1.293, entre os anos de 1993 a 1996.

Este volume do Livro de Tombo apresenta a mesma estrutura dos livros anteriores (Figura 20). De maneira geral, as páginas do Livro de Tombo eram organizadas em colunas com os seguintes campos: № Tombo, data, descrição do objeto, categoria, № Tombo (repete-se por estar na outra página), aquisição e observação.

Figura 20: Livro Tombo № 1, com termo de abertura no dia 8 de setembro de 1991, contém 200 páginas numeradas. O Termo de encerramento deste Livro Tombo, assinado pelo diretor da Arquidiocese, está datado 9 de março de 1993, e contém 0569 objetos descritos.

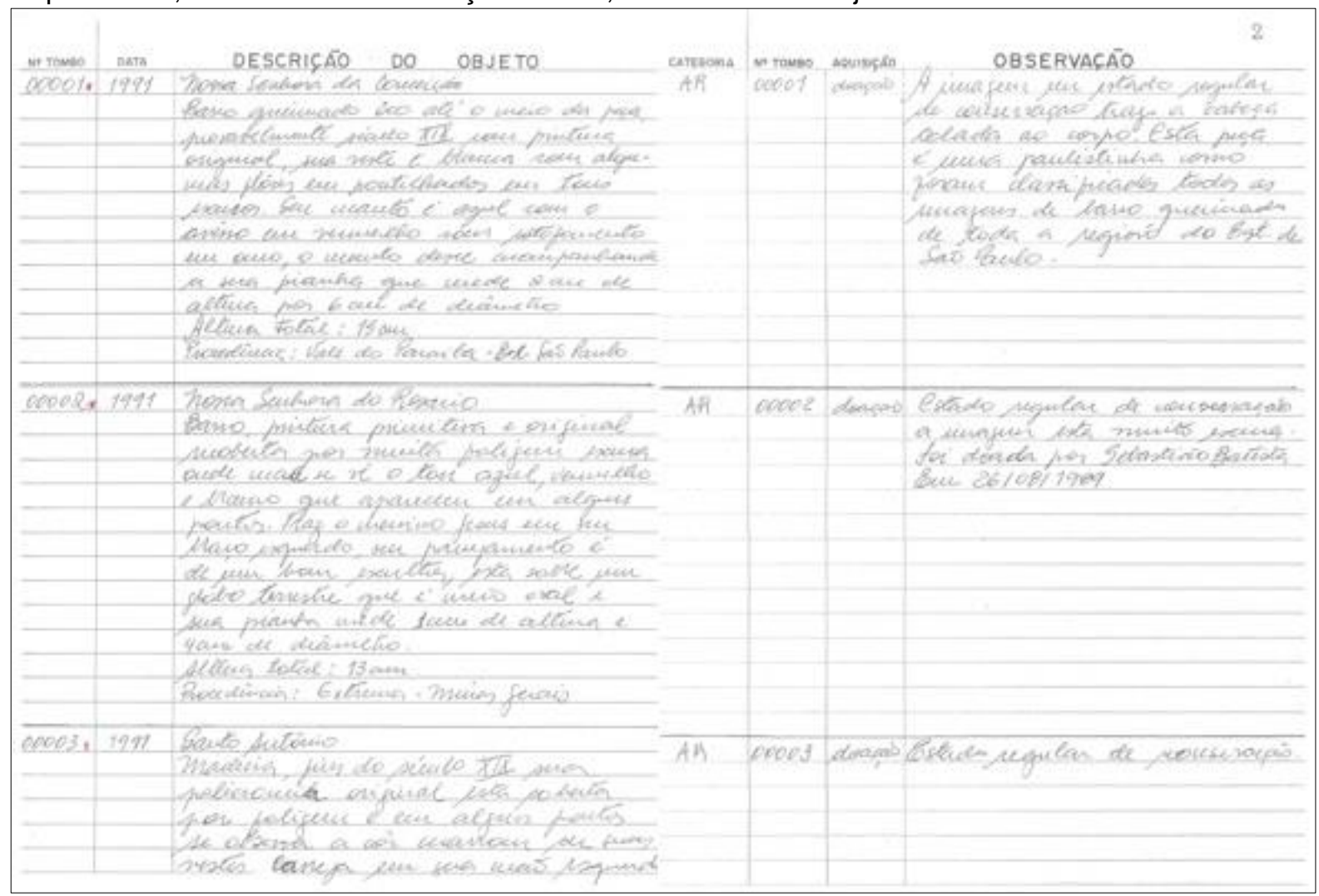

Fonte: MNSA/ Santuário Nacional. 
Também serviram de referência as etiquetas de identificação dos objetos em exposição, manuscritas ou datilografadas, pois, a partir das informações contidas nas etiquetas, foi possível atribuir os dados patrimoniais relativos ao acervo, bem como informações sobre sua origem, procedência, época, identificação, data da doação e demais dados fornecidos pelos doadores, que serviram de base para preenchimento do Livro de Tombo.

Entretanto, devido às diversas movimentações ao longo do tempo, muitas dessas etiquetas não foram mantidas juntas aos seus respectivos objetos, o que torna inviável sua atribuição atualmente, pois não é possível comprovar a qual objeto a etiqueta pertenceu devido às similaridades de objetos no acervo. Mas, sem dúvida, essas etiquetas continuam sendo riquíssimas fontes de análise.

Após o registro no Livro de Tombo, a marcação dos objetos em geral era feita com tinta nanquim preta ou branca, selada com esmalte incolor. Porém, registros anteriores realizados, provavelmente, pela Profa. Conceição Borges Ribeiro Camargo, eram feitos em esparadrapo, sem nenhuma referência à numeração realizada para o Livro de Tombo.

Segundo Ramos (2003, p. 51),

Percebe-se, no preenchimento das colunas do Livro de Tombo, não ter
havido rigor quanto ao tipo de informação inserido em cada uma; o mesmo
gênero de informação (por exemplo, estado de conservação) pode ser
encontrado na coluna Descrição do Objeto ou na coluna Observações,
indistintamente. Quanto ao quinto volume de registro, a coluna Observações
foi sempre empregada para pôr o nome do doador, uma vez que não foi
prevista coluna específica para isso; o estado de conservação está descrito
na coluna Descrição do Objeto.

De acordo com o Relatório Final de Prestação de Serviços Especializados, as discrepâncias entre a marcação e a numeração de tombo podem ser resumidas da seguinte maneira:

- Objetos cuja marcação não corresponde ao Livro de Tombo, sem possibilidade de estabelecer relação marca/registro (provavelmente algum registro anteriormente havido);

- Objetos cujo número não corresponde ao Livro de Tombo, mas nota-se que houve lapso na sequência de numeração, com número marcado no objeto antecedendo ou sucedendo a numeração de tombo;

- Objetos sem marcação e sem tombamento. (RAMOS, 2003, p. 46).

Com isso, verificamos que esse sistema de atribuição de números aos objetos apresenta incoerências, principalmente pela não localização de vários objetos no 
acervo do Museu, quantificados em aproximadamente oitenta objetos do total de registros.

Esse sistema de atribuição de números também não permite expressar relações entre objetos de um mesmo conjunto, pois foram atribuídos números de tombo diferentes para cada peça. A inconsistência de informação reflete-se também na própria numeração, no momento da marcação do número no objeto, considerando que aproximadamente quarenta objetos foram identificados com número de tombo duplicado, porém com descrições divergentes.

De maneira geral, consideramos que o tombamento do acervo se iniciou tardiamente na história do Museu, tendo em vista que ele foi inaugurado em 1956 e o primeiro Livro de Tombo foi criado em 1991. É importante mencionar que o Livro de Tombo, considerado como documento básico para registro do acervo, não reflete atualmente a situação real do acervo, pois o seu preenchimento foi interrompido em 1993, não tendo sido atualizado posteriormente, mesmo tendo sido identificadas algumas divergências nas informações. Entretanto, embora seja um registro tardio e com algumas divergências de informações, o cadastramento do acervo em Livro de Tombo permite ainda hoje a checagem de parte das coleções.

No acervo documental do Museu Nossa Senhora Aparecida, também foram identificados bilhetes com informações de doações, alguns indicando apenas o nome do doador e o objeto, outros já citando também a data de doação e procedência.

Há listagens mais completas de objetos com informações de doador, procedência e data da doação e em algumas das listas há também um histórico sobre o objeto.

A Figura 21 demonstra uma das listas para confecção de etiquetas, que foram feitas pelo letrista Sr. Olavo Couto, em junho de 1985. 
Figura 21: Lista com informações sobre os objetos.

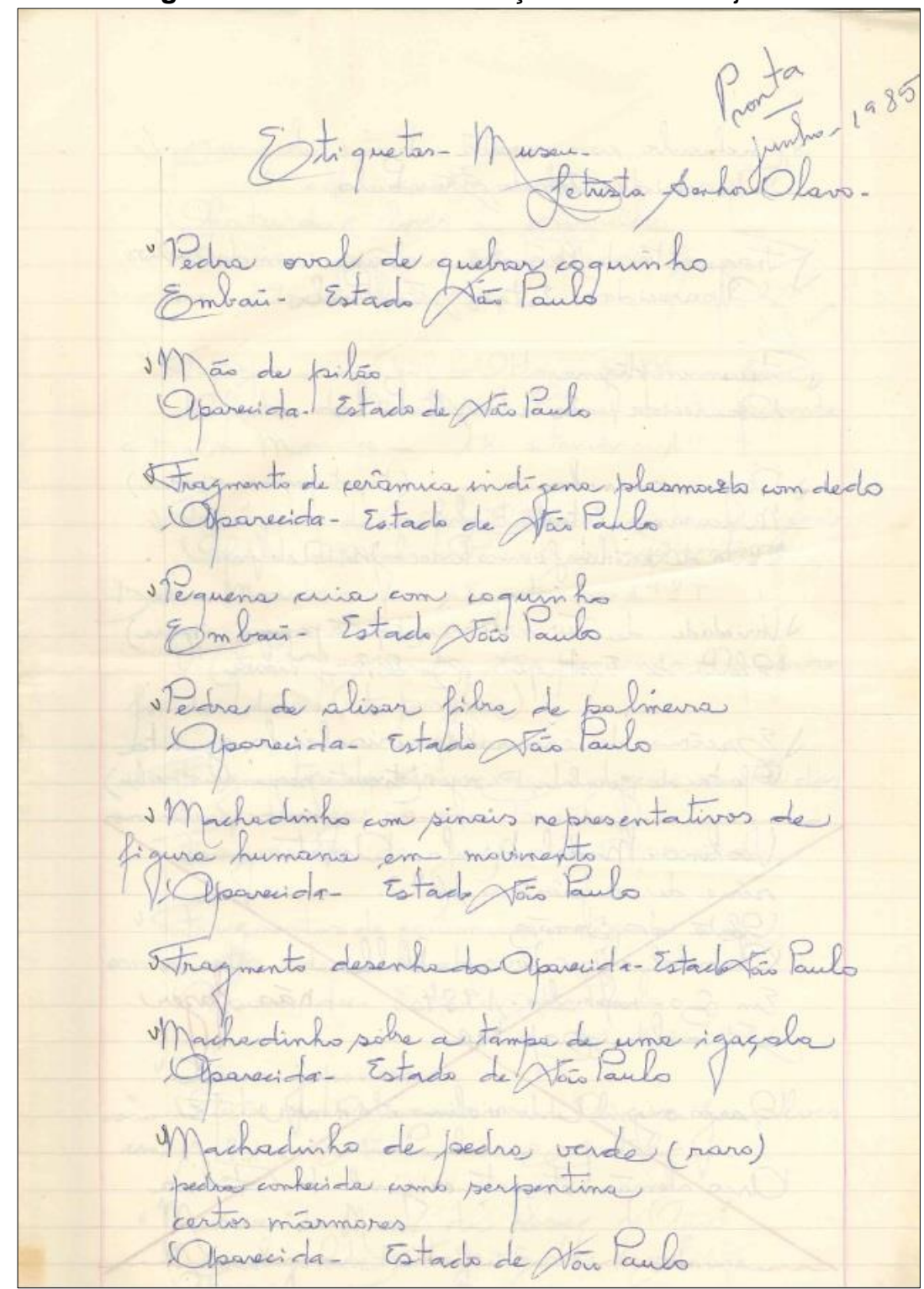

Fonte: MNSA/ Santuário Nacional.

Em alguns manuscritos há indicações de dimensões de largura e comprimento, bem como indicação com o que e como se deve escrever, por exemplo, "à pincel", "faixa larga, feita à pincel", "tira", "tirinha", "tiras pequenas e estreitas", "desta largura", com indicação do tamanho de três linhas de uma folha pautada e uma outra com indicação de cinco linhas de uma folha pautada, "cartão maior", "cartão pequeno". Em um dos manuscritos há um desenho de um retângulo, indicando o tamanho em que as etiquetas deveriam ser confeccionadas.

Outra hipótese, ao analisar as listas com a relação de objetos, é que também poderiam servir como um guia para colocação de etiquetas nos objetos posteriormente, como um controle para verificação do objeto que já estava com a devida identificação, pois em um dos manuscritos há a inscrição "sim" próxima ao 
texto da etiqueta, ou um "v", possivelmente de "visto" e em outros manuscritos há a inscrição "falta", "fazer outro", compreendido como uma pendência.

Outra hipótese, em relação aos diversos tipos de listas encontradas, é que também poderiam ter servido como lista de inventário de objetos, pois em alguns dos manuscritos há uma numeração crescente. Já em outro há indicação de características para identificação do objeto para o momento de instalação da nova etiqueta na exposição, por exemplo, "o médio", "o menor", "o maior", com alguns sinais de já terem sidos verificados anteriormente, como, por exemplo, com um " $x$ " assinalado no início.

A Figura 22 é um exemplo da lista encontrada no acervo documental do Museu Nossa Senhora Aparecida.

Figura 22: Lista com informações sobre os objetos.

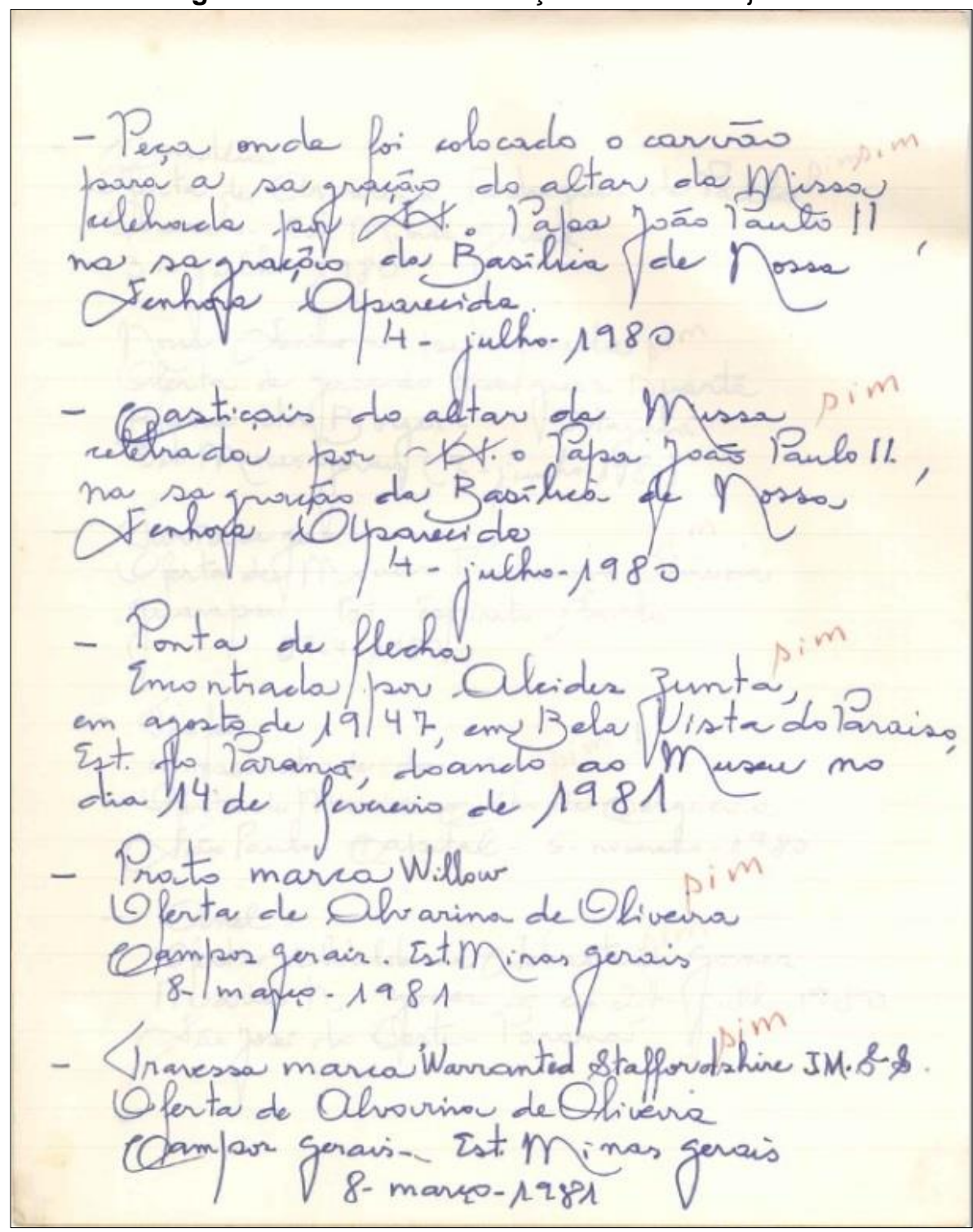

Fonte: MNSA/ Santuário Nacional. 
No início da década de 1990, foi instituído o Termo de Doação de Bens Móveis (Figura 23) para preenchimento no ato da doação com assinatura do ofertante. Posteriormente, algumas informações sobre doações que estavam manuscritas em recortes de papel foram transcritas no Termo de Doação, mantendo a anotação original anexada ao documento, em alguns dos casos.

A partir do ano de 1993, observamos que os Termos de Doação de Bens Móveis passaram a ser utilizados com mais frequência. Esse documento em papel timbrado era identificado como "Arquidiocese de Aparecida", contendo o endereço do Museu, localizado no $2^{\circ}$ andar da Torre.

Figura 23: Termo de Doação de Bens Móveis.

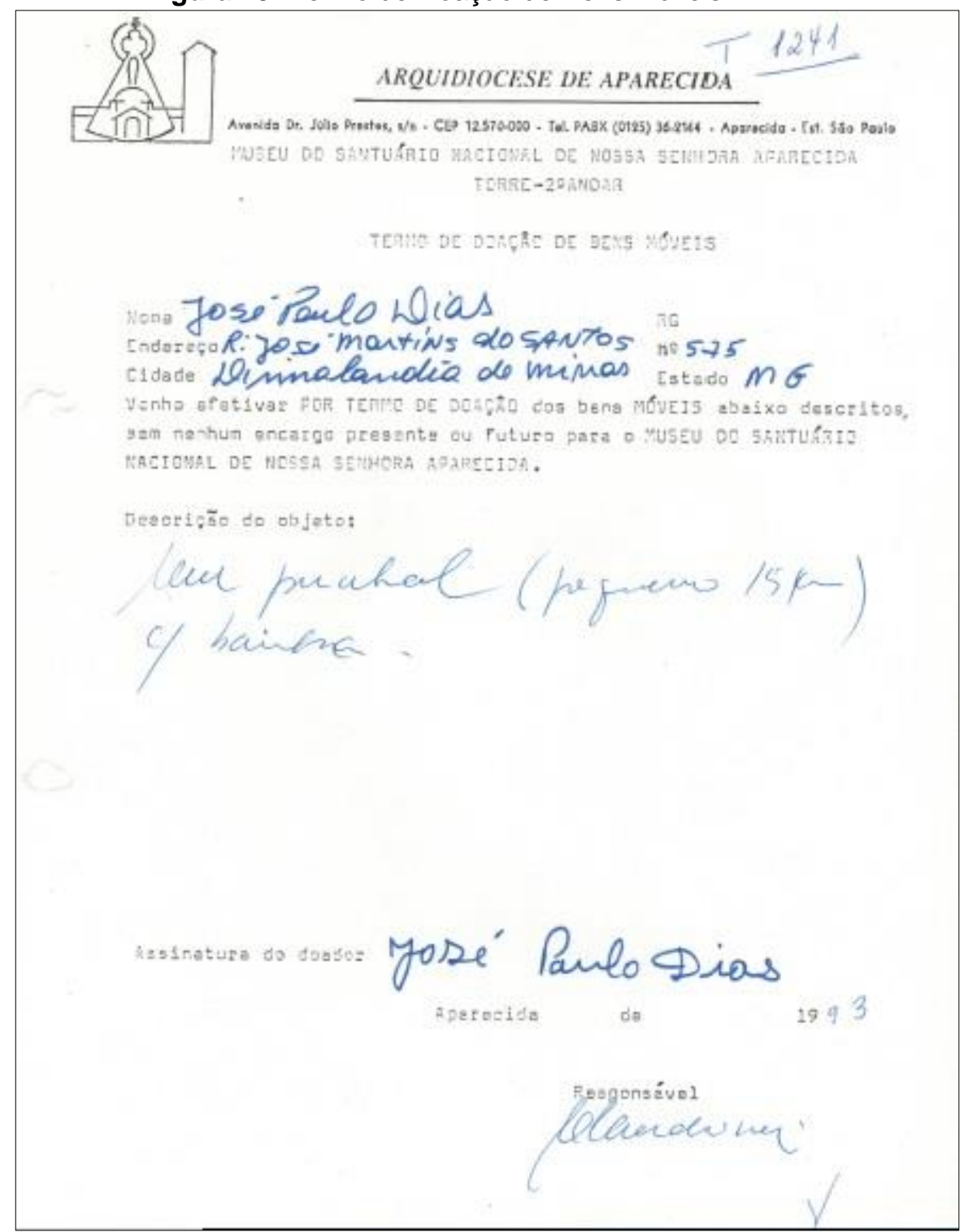

Fonte: MNSA/ Santuário Nacional. 
O Termo de Doação de Bens Móveis era impresso e complementado por preenchimento manual no ato da doação, realizado pelo doador ou funcionário do Museu (conforme observado na Figura 23).

As informações que constam no documento são: Nome; RG; Endereço / №; Cidade / Estado; o texto "Venho efetivar POR TERMO DE DOAÇÃO de bens móveis abaixo descritos, sem nenhum encargo presente ou futuro para o Museu do Santuário Nacional de Nossa Senhora Aparecida"; Descrição do objeto; Assinatura do doador; Local e data; e o Responsável.

Tais documentos, localizados nos arquivos do Museu Nossa Senhora Aparecida, estão organizados por ano, em pastas do tipo fichário, armazenadas em envelopes plásticos para organização sequencial. Os documentos receberam posteriormente uma etiqueta adesiva no canto superior direito, para numeração em ordem crescente, com base na cronologia das datas de doação.

De acordo com Ramos (2003, p. 52),

\begin{abstract}
O conjunto de termos de doação possibilita ter ideia do acervo colecionado até os dias atuais, ainda que de forma assistemática e insegura, já que este tipo de documento não informa a destinação das peças no museu, sua localização, seu estado; por vezes nem há descrição do objeto doado. As peças também não estão sendo marcadas, o que dificulta estabelecer correlações entre peça e registro.
\end{abstract}

A seguir será apresentada uma série de listas, organizadas por ano e data de doação, a partir da análise dos Termos de Doação de Bens Móveis, nos quais consta a entrada de objetos no Museu Nossa Senhora Aparecida. Desta forma, é possível analisar o perfil das doações ofertadas na década de 1990.

Quadro 1: Lista de entrada de objetos (1993)

\begin{tabular}{|c|c|c|c|c|}
\hline $\begin{array}{c}\text { No de } \\
\text { entrada }\end{array}$ & Descrição do Objeto & Data & Doador & $\begin{array}{c}\text { Responsável } \\
\text { Recebimento }\end{array}$ \\
\hline E-01/1993 & Punhal com bainha & 1993 & José Paulo Dias & Claudinei Silva \\
\hline E-02/1993 & Notas & Sem data & Marlene & - \\
\hline E-03/1993 & 3 Colheres de prata & Sem data & Antônio Rigo & - \\
\hline E-04/1993 & 01 Cascalho e 01 cristal & 1993 & Pedro Guarreto & $\begin{array}{c}\text { Danival } \\
\text { Mascarini }\end{array}$ \\
\hline E-05/1993 & Anel de prata & 1993 & Valdomiro Martins & - \\
\hline E-06/1993 & Máquina de costura de mão & $01 / 05 / 1993$ & Julieta Garcia & Claudinei Silva \\
\hline E-07/1993 & \multicolumn{2}{|c|}{ Gasômetro } & Luiza Baseo Catanio & $\begin{array}{c}\text { Conceição } \\
\text { Borges }\end{array}$ \\
\hline E-08/1993 & Reichsbanfnote (NR6288333d) & $13 / 06 / 1993$ & Aluisio de Queiroz & Claudinei Silva \\
\hline E-09/1993 & $\begin{array}{c}\text { Relógio de bolso - Ômega (№ } \\
\text { série: } 5134717)\end{array}$ & $26 / 06 / 1933$ & Luiz Tomaz da Silva & $\begin{array}{c}\text { Conceição } \\
\text { Borges }\end{array}$ \\
\hline
\end{tabular}




\begin{tabular}{|c|c|c|c|c|}
\hline $\begin{array}{c}\text { № de } \\
\text { entrada }\end{array}$ & Descrição do Objeto & Data & Doador & $\begin{array}{l}\text { Responsável } \\
\text { Recebimento }\end{array}$ \\
\hline E-10/1993 & Sem informação do objeto & 04/07/1993 & José Benedito da Silva & $\begin{array}{c}\text { Conceição } \\
\text { Borges }\end{array}$ \\
\hline E-11/1993 & Garrucha 320 (№ série: E-99303 & 06/07/1993 & José Roberto da Silva & Cesar Maia \\
\hline E-12/1993 & $\begin{array}{c}1 \text { Cédula da Rússia (1D-1º- } \\
\text { 75911131961) }\end{array}$ & $18 / 07 / 1993$ & $\begin{array}{c}\text { Marcelo Viana } \\
\text { Patemaque } \\
\end{array}$ & $\begin{array}{l}\text { Conceição } \\
\text { Borges }\end{array}$ \\
\hline E-13/1993 & Bule de prata (1920) & $18 / 07 / 1993$ & Eunice Moreira & Claudinei Silva \\
\hline E-14/1993 & 1 Moeda 2.000 réis - 1912 & 18/07/1993 & Daniel Moreira Sotero & Claudinei Silva \\
\hline E-15/1993 & $\begin{array}{c}1 \text { Moeda } 400 \text { réis - Oswaldo Cruz } \\
-1936\end{array}$ & 01/08/1993 & Cláudio Manoel da Silva & $\begin{array}{c}\text { Conceição } \\
\text { Borges }\end{array}$ \\
\hline E-16/1993 & Relógio de bolso - Cortebert & 01/08/1993 & Geraldo José Costa & $\begin{array}{c}\text { Conceição } \\
\text { Borges }\end{array}$ \\
\hline E-17/1993 & $\begin{array}{c}4 \text { Estampas - São José/Bom } \\
\text { Jesus/N. Sr }{ }^{\mathrm{a}} \text { Amamentando/ N. } \\
\text { Sr. decendo da cruz }\end{array}$ & 01/08/1993 & José Pereira de Andrade & $\begin{array}{l}\text { Conceição } \\
\text { Borges }\end{array}$ \\
\hline E-18/1993 & $\begin{array}{c}2 \text { Imagens de Cerâmica Folclore } \\
\text { Espanhol }\end{array}$ & 13/08/1993 & Padres Redentoristas & Cesar Maia \\
\hline E-19/1993 & $\begin{array}{c}\text { Abridor de correspondência - } \\
\text { punhal }\end{array}$ & $15 / 08 / 1993$ & $\begin{array}{c}\text { Bernardino dos Santos } \\
\text { Filho }\end{array}$ & Cesar Maia \\
\hline E-20/1993 & Bloco em cristal & 21/08/1993 & $\begin{array}{c}\text { Geraldo Rodrigues de } \\
\text { Miranda }\end{array}$ & Claudinei Silva \\
\hline E-21/1993 & 2 Moedas 1.500 - italiana & 22/08/1993 & Giuseppe Carlomagno & Claudinei Silva \\
\hline E-22/1993 & Relógio? & $28 / 08 / 1993$ & Maria Zuleica da Rocha & Claudinei Silva \\
\hline E-23/1993 & 4 colheres e 3 grafos de prata & 19/09/1993 & $\begin{array}{l}\text { Maria Helena dos Santos } \\
\text { Moreira }\end{array}$ & Claudinei Silva \\
\hline E-24/1993 & 1 moeda 40 reis - 1824 & $25 / 09 / 1993$ & Rosemary Maiolini & Claudinei Silva \\
\hline E-25/1993 & $\begin{array}{l}1 \text { cristal preso no suporte de } \\
\text { madeira }\end{array}$ & $12 / 10 / 1993$ & Aristóteles Barbosa & Claudinei Silva \\
\hline E-26/1993 & Coroa de N. S de prata & $17 / 10 / 1993$ & Ida Lúcia da Silva & Claudinei Silva \\
\hline E-27/1993 & 1 Cachimbo de 1945 & $17 / 10 / 1993$ & Alcino Ribeiro da Silva & Claudinei Silva \\
\hline E-28/1993 & 1 Sanfona - Odeschin & 24/10/1993 & $\begin{array}{c}\text { Celci Teodoro de } \\
\text { Almeida } \\
\end{array}$ & Claudinei Silva \\
\hline E-29/1993 & Relógio - Studio & $31 / 10 / 1993$ & José Leite Machado & Claudinei Silva \\
\hline E-30/1993 & 1 Corrente de prata & $14 / 11 / 1993$ & Rita Airta de Souza & Claudinei Silva \\
\hline E-31/1993 & 1 Pulseira & $14 / 11 / 1993$ & $\begin{array}{c}\text { Maria Adalgiza Fenelon } \\
\text { de Souza }\end{array}$ & Claudinei Silva \\
\hline E-32/1993 & Relógio (Jean Phillip - quartz) & 08/12/1993 & $\begin{array}{l}\text { Francisco Luiz de } \\
\text { Carvalho } \\
\end{array}$ & Cesar Maia \\
\hline E-33/1993 & Sem informação & $10 / 12 / 1993$ & Agenor Costa A. Neto & $\begin{array}{l}\text { Luiz Carlos } \\
\text { Soares }\end{array}$ \\
\hline
\end{tabular}

Fonte: MNSA/Santuário Nacional.

O Quadro 1 releva que em 1993 os objetos registrados se mostram bem diversos, notando-se uma recorrência na doação de relógios de bolso e de pulso, assim como cédulas e moedas.

Ao verificar as fichas catalográficas de documentação do acervo, dos trinta e três números de entrada de objetos que foram registrados no ano de 1993, oito objetos foram identificados pela documentação do acervo, sendo estes: punhal com bainha ( $\left.n^{\circ} 01\right)$, três colheres de prata $\left(n^{\circ} 03\right)$, cédula de $\left(n^{\circ} 08\right)$, relógio de bolso ( $n^{\circ}$ 
16), abridor de correspondência (no 19), cristal em suporte de madeira (no 25), cachimbo ( $n^{\circ}$ 27) e a sanfona ( $n$ - 28). Tendo recebido, respectivamente, os seguintes números de inventário: 1466, 2576, 7779, 2059, 2591, 0912, 2675 e 3262.

Os demais objetos não foram encontrados.

Quadro 2: Lista de entrada de objetos (1994)

\begin{tabular}{|c|c|c|c|c|}
\hline $\begin{array}{c}\text { № de } \\
\text { entrada }\end{array}$ & Descrição do Objeto & Data & Doador & $\begin{array}{l}\text { Responsável } \\
\text { Recebimento } \\
\end{array}$ \\
\hline E-01/1994 & 3 Moedas & 16/06/1905 & Janete Cristiana Mukim & $\begin{array}{l}\text { Luiz Carlos } \\
\text { Soares }\end{array}$ \\
\hline E-02/1994 & $\begin{array}{c}1 \text { Moeda/ } 1 \text { cédula } 5 \text { dólares/ } 1 \\
\text { cédula } 2 \text { dólares - Canadá }\end{array}$ & 06/01/1994 & Irmã Eliana & Claudinei Silva \\
\hline E-03/1994 & 13 cédulas - Brasil & 25/01/1994 & Maria Pires Rego & Claudinei Silva \\
\hline E-04/1994 & Sem informações & 05/02/1994 & José Maria Pires & - \\
\hline E-05/1994 & Máquina de moer café (miniatura) & 06/02/1994 & José Benedito Pereira & $\begin{array}{l}\text { Conceição } \\
\text { Borges }\end{array}$ \\
\hline E-06/1994 & Moedas & $16 / 02 / 1994$ & Izolina Maria Ferreira & - \\
\hline E-07/1994 & Maxilar de porco & 26/02/1994 & $\begin{array}{l}\text { Francisco Manoel da } \\
\text { Prima Silva }\end{array}$ & $\begin{array}{l}\text { Rogélio } \\
\text { Eugenio }\end{array}$ \\
\hline E-08/1994 & 3 garrafas com artesanato dentro & 13/03/1994 & Elmiro Ferreira da Silva & - \\
\hline E-09/1994 & Relógio & 02/04/1994 & Dalva Enlor de Oliveira & Claudinei Silva \\
\hline E-10/1994 & Sem informações & 02/04/1994 & Marcelo de Souza & Claudinei Silva \\
\hline E-11/1994 & $\begin{array}{c}1 \text { Moeda (Papa João Paulo II/ NS. } \\
\text { Aparecida) }\end{array}$ & $19 / 04 / 1994$ & Ricardo Cesar Dias & - \\
\hline E-12/1994 & Mata Borrão & $12 / 05 / 1994$ & Hélio Ramos & Claudinei Silva \\
\hline$E-13 / 1994$ & Máquina de costura & 21/05/1994 & Avelino José de Freitas & Claudinei Silva \\
\hline E-14/1994 & Relógio de parede & 05/06/1994 & Eliza Mendes Ribeiro & Claudinei Silva \\
\hline E-15/1994 & 5 moedas japonesas & $12 / 06 / 1994$ & Clarice Luz Weda & Claudinei Silva \\
\hline E-16/1994 & Pedras semipreciosas & 09/07/1994 & Ana Rocha Dias & - \\
\hline$E-17 / 1994$ & Rédea & $10 / 07 / 1994$ & José Luiz Cabral & Claudinei Silva \\
\hline E-18/1994 & 3 pedaços de rocha & $10 / 07 / 1994$ & $\begin{array}{c}\text { Virginia Francisca } \\
\text { Rodrigues }\end{array}$ & Claudinei Silva \\
\hline E-19/1994 & Quadro (?) & $15 / 07 / 1994$ & Pedro Alves dos Santos & - \\
\hline E-20/1994 & Placa de São Domingos & 21/08/1994 & Ir. Mônica & - \\
\hline E-21/1994 & 1 mortuária & 04/09/1994 & $\begin{array}{c}\text { Jorge Soares de } \\
\text { Moraes }\end{array}$ & $\begin{array}{l}\text { Luiz Carlos } \\
\text { Soares }\end{array}$ \\
\hline E-22/1994 & Sem informações & $11 / 09 / 1994$ & Maria Leuides da Costa & $\begin{array}{l}\text { Claudinei da } \\
\text { Silva }\end{array}$ \\
\hline E-23/1994 & Relógio & $17 / 09 / 1994$ & Luiz Francisco Moreira & $\begin{array}{l}\text { Luiz Carlos } \\
\text { Soares } \\
\end{array}$ \\
\hline E-04/1994 & Pulseira de prata & 24/09/1994 & $\begin{array}{c}\text { Nivaldo Supertino de } \\
\text { Macedo }\end{array}$ & $\begin{array}{l}\text { Luiz Carlos } \\
\text { Soares }\end{array}$ \\
\hline E-05/1994 & $\begin{array}{c}1 \text { Medalha/ } 1 \text { anel/ } 1 \text { pedra } \\
\text { ametista }\end{array}$ & $25 / 09 / 1994$ & $\begin{array}{c}\text { Maria José de Freitas } \\
\text { Almeida }\end{array}$ & $\begin{array}{l}\text { Luiz Carlos } \\
\text { Soares }\end{array}$ \\
\hline E-06/1994 & Garrucha 320 & 02/10/1994 & $\begin{array}{c}\text { Manoel Coelho de } \\
\text { Oliveira } \\
\end{array}$ & $\begin{array}{l}\text { Luiz Carlos } \\
\text { Soares }\end{array}$ \\
\hline E-07/1994 & $\begin{array}{c}1 \text { Chaveiro - Imagem São Pedro e } \\
\text { Paulo VI }\end{array}$ & 22/10/1994 & Honorato Alves Ferreira & $\begin{array}{l}\text { Luiz Carlos } \\
\text { Soares }\end{array}$ \\
\hline E-28/1994 & 25 moedas & 27/10/1994 & $\begin{array}{c}\text { José Roberto Abide da } \\
\text { Silva }\end{array}$ & - \\
\hline
\end{tabular}




\begin{tabular}{|c|c|c|c|c|}
\hline $\begin{array}{c}\text { No de } \\
\text { entrada }\end{array}$ & Descrição do Objeto & Data & "conclusão" \\
\hline E-29/1994 & Medalha & $29 / 10 / 1994$ & Antônio Pereira Prado & $\begin{array}{c}\text { Responsável } \\
\text { Recebimento }\end{array}$ \\
\hline E-30/1994 & $\begin{array}{c}\text { Relógio de bolso - Grosskopf } \\
\text { Patente }\end{array}$ & $30 / 10 / 1994$ & $\begin{array}{c}\text { Ataíde Barbosa dos } \\
\text { Santos }\end{array}$ & $\begin{array}{c}\text { Luiz Carlos } \\
\text { Soares }\end{array}$ \\
\hline E-31/1994 & Rédia & $08 / 12 / 1994$ & José de Souza Andrade & - \\
\hline E-32/1994 & Relógio de bolso - Ômega & $18 / 12 / 1994$ & $\begin{array}{c}\text { Armando Alves de } \\
\text { Carvalho }\end{array}$ & $\begin{array}{c}\text { Rogélio } \\
\text { Eugenio }\end{array}$ \\
\hline E-33/1994 & Peça indígena (?) & $18 / 12 / 1994$ & $\begin{array}{c}\text { Zilda de Anhaia de } \\
\text { Melo }\end{array}$ & - \\
\hline
\end{tabular}

Fonte: MNSA/Santuário Nacional.

Em 1994, ao analisarmos os Termos de Doação de Bens Móveis, observamos que a partir deste ano a Profa. Conceição Borges passa a não assinar o recebimento de objetos. Portanto, acreditamos que poss a ser indício de que não frequentava mais assiduamente o Museu.

Com base nas informações do Quadro 2, notamos que a média de doações era de três a cinco objetos ao mês. Desta lista, apenas três objetos foram possíveis localizar por meio da documentação, sendo estes: mata borrão ( $n=12$ ), relógio de parede $\left(n^{\circ} 14\right)$ e o relógio de bolso ( $\left.n^{\circ} 30\right)$. Tendo recebido, respectivamente, os seguintes números de inventário: $2.791,2.416$ e 2.181.

Quadro 3: Lista de entrada de objetos (1995)

\begin{tabular}{|c|c|c|c|c|}
\hline $\begin{array}{c}\text { № de } \\
\text { entrada }\end{array}$ & Descrição do Objeto & Data & Doador & $\begin{array}{l}\text { Responsável } \\
\text { Recebimento } \\
\end{array}$ \\
\hline E-01/1995 & $\begin{array}{c}1 \text { Moeda } 400 \text { reis - Oswaldo Cruz } \\
(1936)\end{array}$ & $17 / 06 / 1995$ & Valdirei Ouvidio & 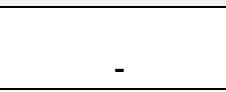 \\
\hline E-02/1995 & - & 1995 & Odila Zambour Ulidua & - \\
\hline E-03/1995 & $\begin{array}{c}\text { Cédula } 100 \text { Guaranis - Paraguai } \\
(1952)\end{array}$ & 26/01/1995 & $\begin{array}{c}\text { Jeorge Correia da Silva } \\
\text { Passarinho }\end{array}$ & $\begin{array}{l}\text { Rogélio } \\
\text { Eugênio }\end{array}$ \\
\hline E-04/1995 & $\begin{array}{l}1 \text { Cédula } 5 \text { cruzeiros (1962) / } \\
1 \text { cédula } 50 \text { cruzeiros (1967) }\end{array}$ & 09/03/1995 & João Luis Torres & $\begin{array}{l}\text { Rogélio } \\
\text { Eugênio }\end{array}$ \\
\hline E-05/1995 & $\begin{array}{c}\text { Baleira de cristal trabalhada com } \\
\text { traços }\end{array}$ & 07/04/1995 & Abadia Alnerinda Silva & - \\
\hline E-06/1995 & Imagem de Nossa Senhora & $18 / 05 / 1995$ & Luiz Carlos Martins & $\begin{array}{l}\text { Rogélio } \\
\text { Eugênio }\end{array}$ \\
\hline E-07/1995 & 1 Cédula Grega - Crings (1930) & 22/06/1995 & Juviano Gomes de Sá & Heloísa Reis \\
\hline E-08/1995 & Cédula 100 Guaranis - Paraguai & $14 / 07 / 1995$ & Lucio E.M. Gonçalves & - \\
\hline E-09/1995 & $\begin{array}{c}\text { Cruz de madeira com a face de } \\
\text { Cristo }\end{array}$ & $17 / 07 / 1995$ & Divina pereira de Melo & $\begin{array}{c}\text { Danival } \\
\text { Mascarini }\end{array}$ \\
\hline$E-10 / 1995$ & $\begin{array}{c}\text { Tapete artesanal (Esculpida em } \\
\text { 1993) }\end{array}$ & $17 / 07 / 1995$ & Matilde Caetano Faria & Sônia Cristina \\
\hline$E-11 / 1995$ & Pedra Ametista - grande & 23/07/1995 & $\begin{array}{c}\text { Rodrigo Batista } \\
\text { Carneiro }\end{array}$ & Sônia Cristina \\
\hline$E-12 / 1995$ & 2 Pedras pequenas - formato "C" & 23/07/1995 & $\begin{array}{c}\text { Salique Rodrigo } \\
\text { Carneiro } \\
\end{array}$ & Sônia Cristina \\
\hline E-13/1995 & Luneta & 27/07/1995 & $\begin{array}{c}\text { Maria Isaura Tavares } \\
\text { Lessa } \\
\end{array}$ & 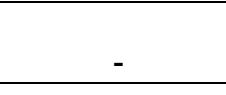 \\
\hline
\end{tabular}




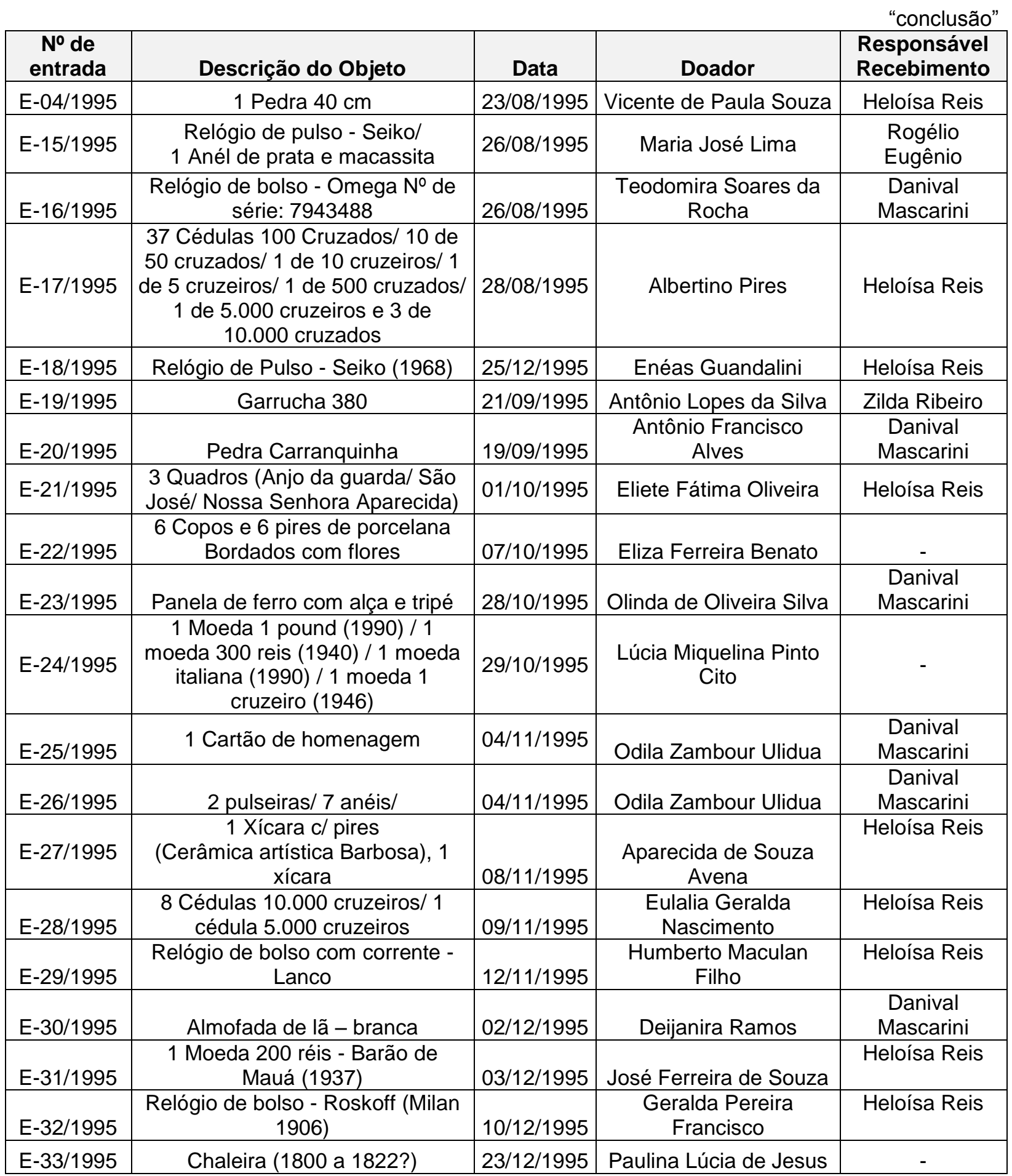

Fonte: MNSA/Santuário Nacional.

No Quadro 3, observamos que houve grande recorrência de doações de cédulas e moedas, além de outros objetos diversos. Dos trinta e três números de entrada de objetos que foram registrados no ano de 1995, seis objetos foram identificados pela documentação do acervo, sendo estes: luneta ( $n^{\circ}$ 13), relógio de pulso ( $n^{\circ}$ 15), relógio de bolso ( $n^{\circ}$ 16), xícara com pires ( $n^{\circ}$ 27), relógio de bolso com 
corrente ( $n$ ㄴ 29) e o relógio de bolso ( $n$ - 32). Tendo recebido, respectivamente, os seguintes números de inventário: 2.671, 2.104, 2.183, 1.022, 2.056 e 2.177.

Ao observarmos as listas de doação dos objetos nos anos de 1993, 1994 e 1995, por meio do Termo de Doação de Bens Móveis, notamos que coincidentemente foram registradas trinta e três doações ao ano, ou seja, aproximadamente cem registros de entrada de acervos, com superior número de objetos ofertados. Entretanto, desse montante, apenas dezessete foram identificados após análises no Livro de Tombo, etiquetas antigas e fichas catalográficas de documentação do acervo, conforme detalhado anteriormente.

A partir de 1996, com uma nova gestão no Museu, os registros das novas doações foram realizados com maior frequência. As demais listas com a relação dos objetos ofertados a partir de 1996 serão apresentadas no Capítulo 2, que irá abordar o processo de revitalização institucional do Museu Nossa Senhora Aparecida, a partir dos serviços realizados pela Fundação Patrimônio Histórico da Energia de São Paulo. 


\subsection{A exposição}

O Museu Nossa Senhora Aparecida, inaugurado em 12 de outubro de 1967, no $2^{\circ}$ andar da Torre Brasília - Santuário Nacional de Aparecida, apresentava uma grande diversidade de tipologias de acervos e coleções em exposição, constituindose, além do projeto pedagógico de seus organizadores, as representações sociais de forma interativa com seus visitantes. De acordo com Braga (2017, informação verbal), "os romeiros ficaram extasiados diante de tanta diversidade". ${ }^{24}$

Deste modo, pretendemos analisar alguns aspectos dessa exposição, essencialmente por meio das fontes documentais e iconográficas, conforme estudo realizado por Heloísa Barbuy, ao argumentar que "para alcançarmos conteúdos mais profundos - as ideias-forças que se difundem em âmbito coletivo -, torna-se necessária a utilização de fontes que permitam uma abertura para o sistema simbólico da sociedade em questão. Essas fontes são prioritariamente as iconográficas" (BARBUY, 1995, p. 6).

A partir dessa perspectiva, as fontes primárias trazem muito material para discussão e para obtenção de informações empíricas, com interação entre imagens e textos.

Inicialmente, será feita uma abordagem por meio do Roteiro de observação para visitas a museus e exposições ${ }^{25}$, que servirá como metodologia de análise dessa antiga exposição do Museu Nossa Senhora Aparecida.

De acordo com Cury (2018, p. 1), "o objetivo específico do roteiro é apoiar a análise das formas como o museu, objeto de nossa observação, apresenta-se para o público e, sobretudo, como ele considera o visitante. O nosso foco principal é a exposição".

Em relação à infraestrutura, a exposição era localizada no $2^{\circ}$ andar da Torre Brasília, e o acesso era realizado por dois elevadores. Na sala da exposição havia janelas amplas, que ficavam abertas para auxiliar na ventilação. Porém, o acervo ficava exposto à luz solar ou em clima úmido, em dias chuvosos. Havia ventiladores nos tetos, portas de entrada e saída separadas, com acesso às escadas, além dos dois elevadores.

\footnotetext{
${ }^{24}$ BRAGA, Guido Machado. Entrevista concedida a Victor Hugo Barros e a Erica Andreza Coelho. Aparecida, 20 set. 2017,33 min 08 s. Som, Formato MP3.

${ }^{25}$ Roteiro de observação para visita a museus e exposições. Desenvolvido e disponibilizado pela Profa. Dra. Marília Xavier Cury, utilizado na disciplina: MEA 16 - Exposições Antropológicas - 1ํㅡㄴ semestre de 2018, no Museu de Arqueologia e Etnologia da USP.
} 
De maneira geral, o acesso dos visitantes ao Museu ocorria após a visitação ao Mirante, com aproximadamente cem metros de altura. Durante a descida, o ascensorista parava no $2^{\circ}$ andar da Torre, para que os visitantes pudessem visitar a exposição.

Em relação à identificação do Museu, havia poucas placas de sinalização, algumas indicações observadas em fotografias eram relacionadas ao fluxo de entrada e saída, para conduzir os grupos de visitantes, contando com a presença de guardinhas mirins ${ }^{26}$.

Além dos organizadores do Museu Nossa Senhora Aparecida, Profa. Conceição Borges e Vicente Camargo, os guardinhas mirins, entre quatro e seis adolescentes, eram os responsáveis pela recepção, cobrança de ingressos e orientação do público no Museu, conforme constam nos Formulários EC-5- Museus, destinados ao Plano Geral de Informações Estatísticas e Geográficas, com base na Lei oㅜ 5.534, de 14/11/1968, modificada pela Lei no 5.878, de 11/05/1973, solicitados periodicamente pelo Instituto Brasileiro de Geografia e Estatística (IBGE).

Havia também algumas placas metálicas com informações específicas sobre alguma efeméride ou personalidade homenageada em um núcleo expositivo, não chegando a ser considerada uma exposição temporária, pois o núcleo expositivo era acrescentado à exposição de longa duração, como, por exemplo, o núcleo temático sobre o Cardeal Motta, composto por algumas vitrines específicas sobre o Arcebispo da Arquidiocese de Aparecida, com objetos de uso pessoal ou ofertados pelo Cardeal, os quais estavam localizados dentro da mesma sala da exposição.

Nesse período, a bilheteria estava localizada na própria recepção da exposição, no $2^{\circ}$ andar da Torre. E, por meio das fotografias, notamos que a Profa. Conceição Borges realizava o acompanhamento de grupos, com monitoramento, embora não tenha sido localizado registro sobre agendamento de visitas;

\footnotetext{
${ }^{26}$ A Guarda Mirim de Aparecida (SP) foi fundada pela Professora Conceição Borges Ribeiro Camargo em 10 de março de 1955, com apoio do sargento Aristeu de Oliveira e do Prof. Murillo do Amaral, que reuniram os meninos que circulavam pela Praça Nossa Senhora Aparecida. Conceição Borges foi a diretora da Guarda Mirim durante nove anos, ministrando aulas de civismo e de economia, além de história da cidade. Contava com o apoio dos missionários redentoristas de Aparecida (SP), que ministravam as aulas de catecismo. Entre eles destacam-se os padres Rubem Leme Galvão, Silvério Negri, Clóvis Bovo e Antônio Silva. Uma das atribuições dos meninos da Guarda Mirim foi o trabalho de engraxate, que teve início em 31 de maio de 1956. Com um total de 250 meninos, os materiais de trabalho foram abençoados pelo padre José Ferreira Rosa, considerado o padrinho dos meninos engraxates. Atualmente a Guarda Mirim está presente em outros municípios do Vale do Paraíba.
} 
acreditamos que eram realizadas abordagens espontâneas por parte da Profa. Conceição Borges.

De acordo com Zenilda Cristina da Cunha27, sobre sua percepção em relação ao atendimento do Museu nesse período, Zenilda Cunha (2018) considera que a Profa. Conceição Borges era uma professora boa, embora muito brava. Mas ela tinha uma afeição, ela gostava. Zenilda Cunha complementa que:

Ela formava os grupos, ela chamava, ela conversava. E era bonito ver, ela
falava das escavações, ela falava da história de Aparecida. [...] A Conceição
Borges, ela era brava, porque ela tinha uns guardinhas que trabalhavam
com ela. Mas, ela ficava falando das coisas, da história de Aparecida, do
Vale do Paraíba e isso que era legal. [...]
Era bastante devota. Então você via o jeito dela, mesmo ela sendo assim,
mas ela transmitia no olhar. Era bacana ela contando toda a vivência dela e
tudo colocado ali no Museu, que o sonho dela era deixar lindo, colocar
Nossa Senhora, explicar a devoção a Nossa Senhora a partir de toda a
região de Aparecida, como Aparecida cresceu. Era muito interessante isso,
a vida dela. (CUNHA, 2018, informação verbal).

Embora não seja possível fazer uma visita exploratória à exposição, pois ela foi desativada no ano de 2005, iremos seguir a metodologia de análise conforme consta no Roteiro de observação para visitas a museus e exposições ${ }^{28}$.

A seguir, será apresentada uma série de fotografias das vitrines em exposição, com o intuito de analisar, a partir das imagens, os acervos e coleções que foram reunidos com o passar dos anos e como foram organizados no ambiente expositivo.

Desta forma, será possível verificar o perfil das doações e aquisições que constituíram o Museu Nossa Senhora Aparecida, que em sua maioria remetem aos objetos do cotidiano, além de objetos litúrgicos e devocionais, redefinindo a maneira de fazer a oralidade dos objetos, conforme mencionado por Poulot (2013), ao dizer que as coleções começaram por abrir-se à história recente e, em seguida, à história presente. Segundo o autor,

Com a antropologia e a etnologia, os objetos do cotidiano, objetos de família marcados por destinos individuais, podem integrar uma museografia de histórias de vidas. (Re)encontrar seus bens, os de sua família, no museu já não é, a partir daí, uma experiência reservada aos ricos e às pessoas influentes, alimentando - além das visitas de natureza militante, ou daquelas, enraizadas, dos habitantes do próprio local convocados implicitamente a se tornarem doadores - uma experiência contrastada do valor e do uso. No momento em que a museografia da história social triunfante privilegiava as apresentações didáticas de aventuras coletivas, a

27 CUNHA, Zenilda Cristina da. Entrevista concedida a Erica Andreza Coelho. Aparecida, 10 jan. 2018, $1 \mathrm{~h} 33$ min 17 s. Som, Formato M4A.

${ }^{28}$ Roteiro desenvolvido pela Profa. Dra. Marília Xavier Cury. 
da década de 1980 e das subsequentes coloca, no primeiro plano, indivíduos que se tornaram mediadores das coleções (POULOT, 2013, p. 109-110).

Ao observarmos fotografias da organização dessa exposição, notamos que não havia texto de curadoria ou textos complementares com o conceito da exposição e demais textos de apoio para compreensão dos diferentes núcleos expositivos, que aparentemente não apresentavam uma ligação direta entre si.

Considerando a época em que o Museu foi instalado na Basílica de Aparecida, é possível fazer uma reflexão ao relacionar o Museu Nossa Senhora Aparecida com demais Museus Históricos, pela semelhança na formação de acervos e características da expografia, com grandes aglomerados de objetos de diversas áreas do conhecimento.

Observamos que as vitrines com acervo eram separadas conforme a tipologia dos materiais e coleções. O próprio mobiliário remete ao que era utilizado no período, grandes armários de madeira e vidro com prateiras de vidro, que também podem ser observados em outros Museus Históricos.

Além dessa organização do acervo, observamos objetos de grande porte sobre os armários e fixados nas paredes e nos corredores externos da exposição e, em alguns casos, suspensos do teto (conforme observado nas Figuras 24 e 25).

Figura 24: Aspecto interno do Museu instalado no $2^{\circ}$ andar da Torre Brasília.

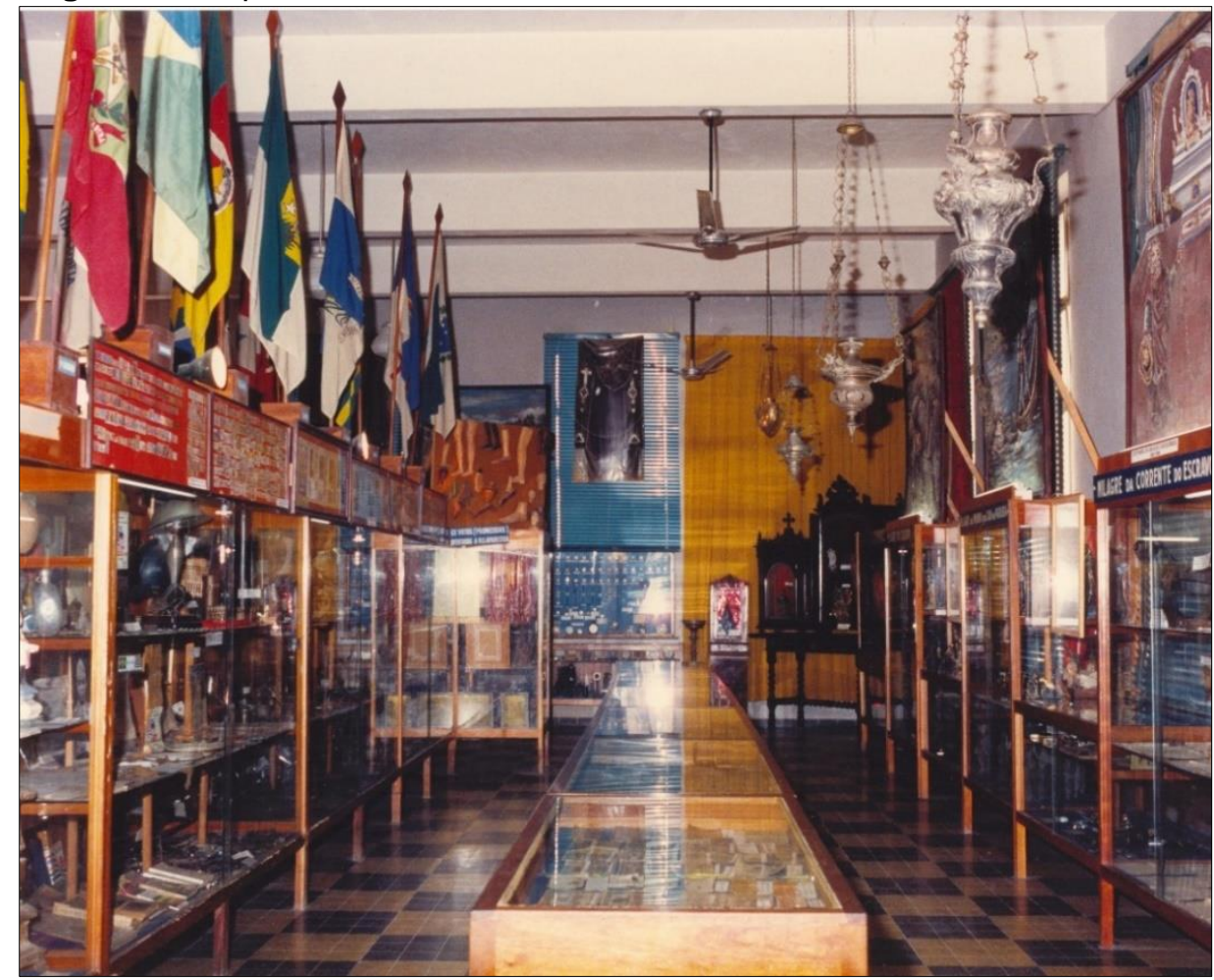

Fonte: MNSA/ Santuário Nacional. 
Figura 25: Aspecto interno do Museu instalado no $2^{\circ}$ andar da Torre Brasília.

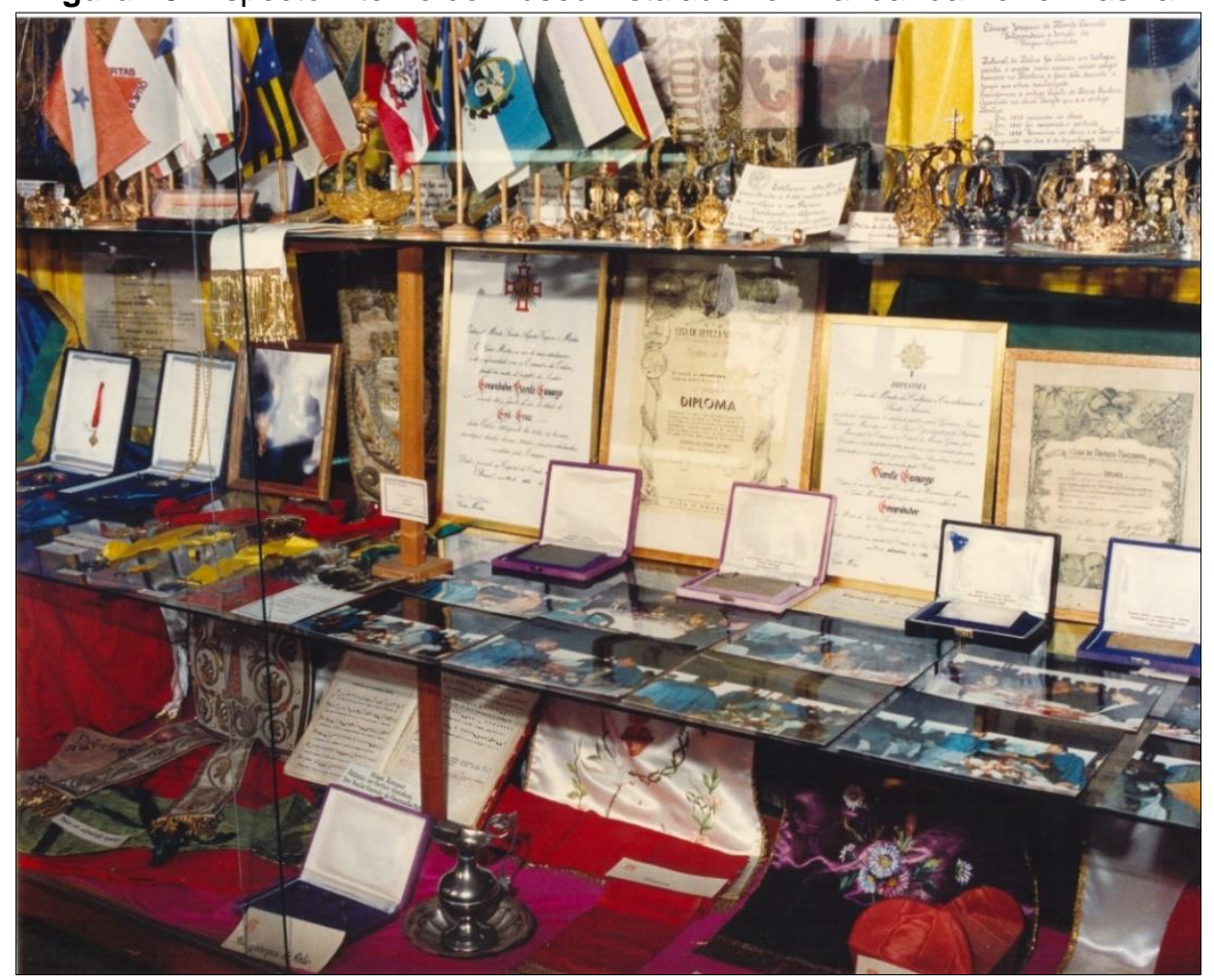

Fonte: MNSA/ Santuário Nacional.

Nesse período de transição de locais, não há informação da existência de uma Reserva Técnica, embora houvesse uma pequena sala para depósito. Acreditamos que grande parte do acervo estava em exposição, embora algumas coleções permaneceram na Galeria do Hotel Recreio, tendo sido transferidas posteriormente para a Torre da Basílica, no início da década de 1970.

$\mathrm{Na}$ Figura 26, constam algumas imagens das vitrines da exposição com as coleções de imaginária, prataria litúrgica e doméstica, objetos litúrgicos e louças. Algumas tipologias de objetos se repetiam em outras vitrines, devido ao pouco espaço interno e aumento constante das coleções. 
Figura 26: Vitrines da antiga exposição do $2^{\circ}$ andar.

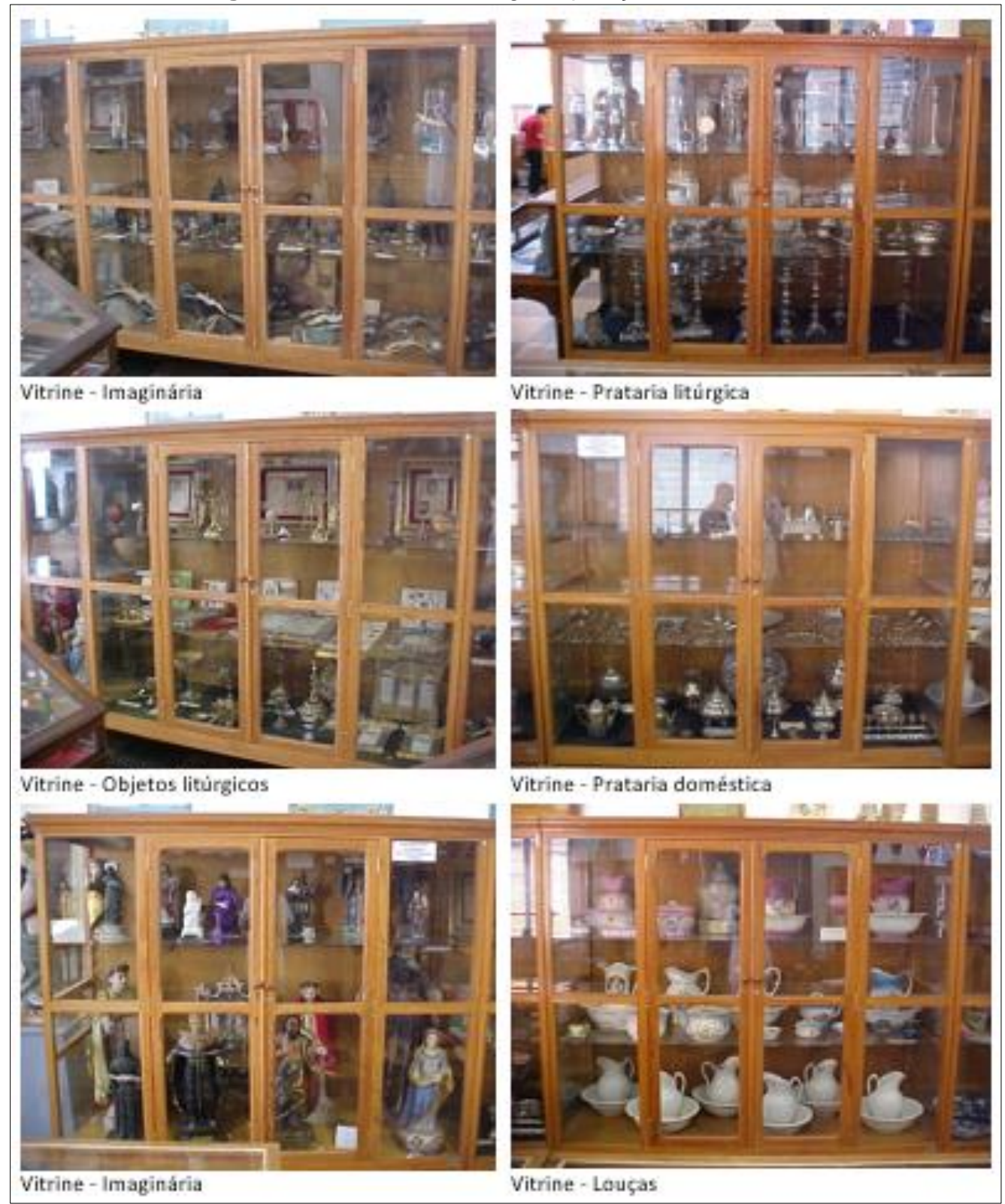

Fonte: MNSA/Santuário Nacional. Foto: Michel H. Oliveira.

Na Figura 27, podemos verificar parte da coleção de louças e porcelanas, classificadas como utensílios domésticos, que podem ser decorativos, para higiene ou objetos e recipientes para conservação, preparação, serviço e consumo de alimentos e bebidas. Nesta coleção há conjuntos de lavabos, saboneteiras e urinóis, além de vasos, travessas, conjuntos de chá e café, entre outros. 
Figura 27: Acervo da coleção de louças e porcelanas.

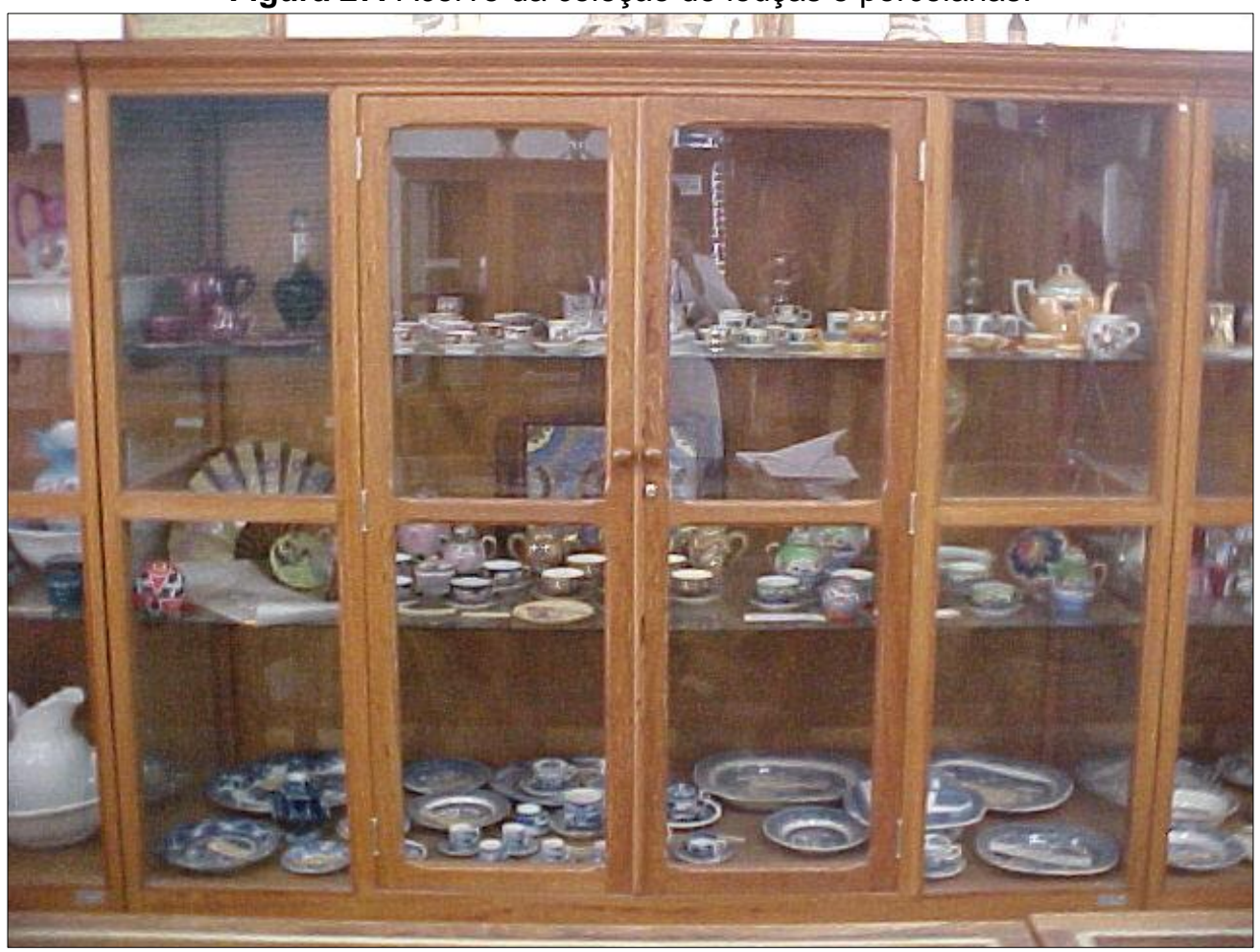

Fonte: MNSA/Santuário Nacional. Foto: Michel H. Oliveira.

Grande parte do acervo de prataria litúrgica é procedente da Antiga Basílica de Nossa Senhora Aparecida, com diversos conjuntos de tocheiros, castiçais, candelabros, vasos de altar, lâmpadas votivas, ânforas, custódias, cortadores de hóstia, aspersório, turíbulo, concha batismal, resplendores de imagens, entre outras peças. Já a coleção de prataria doméstica é composta por talheres, bandejas, conjuntos de café e demais objetos de uso doméstico cotidiano.

Alguns objetos da coleção de prataria litúrgica podem ser observados na Figura 28. 
Figura 28: Acervo de prataria litúrgica.

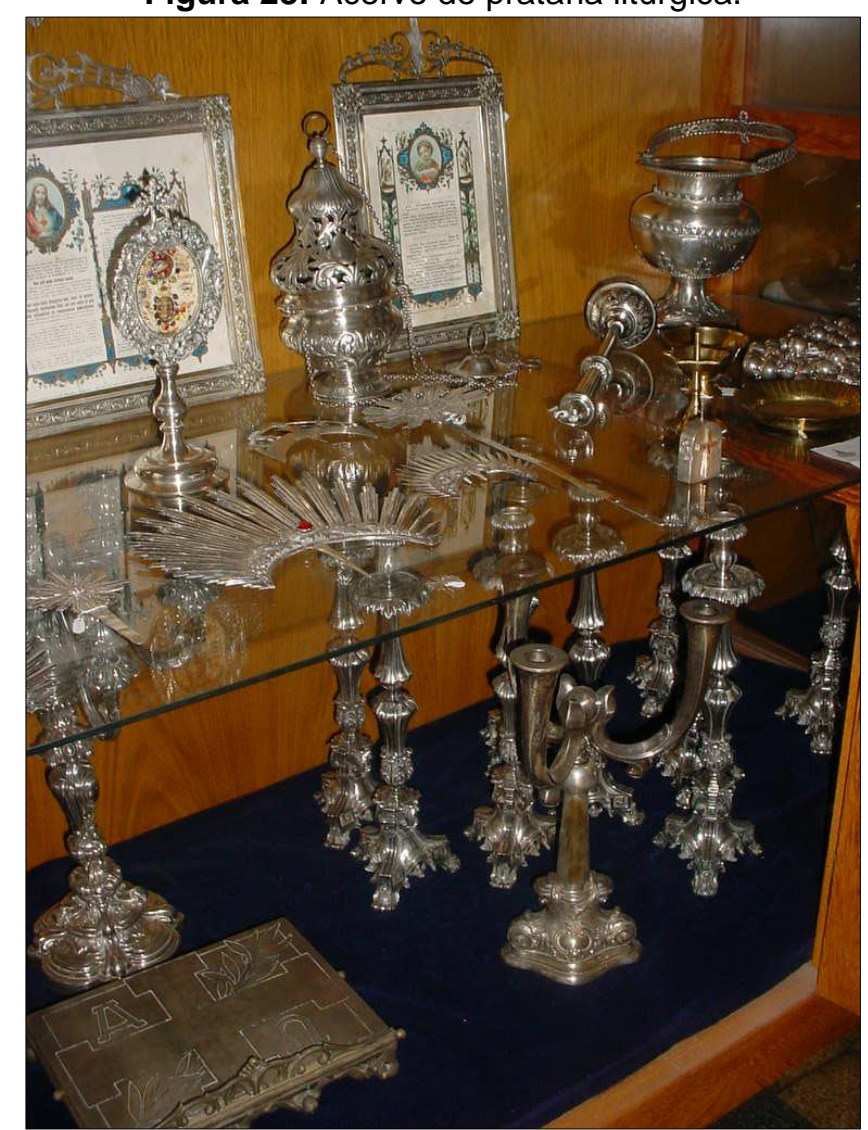

Fonte: MNSA/Santuário Nacional. Foto: Michel H. Oliveira.

Figura 29: Acervo da coleção Cardeal Motta.

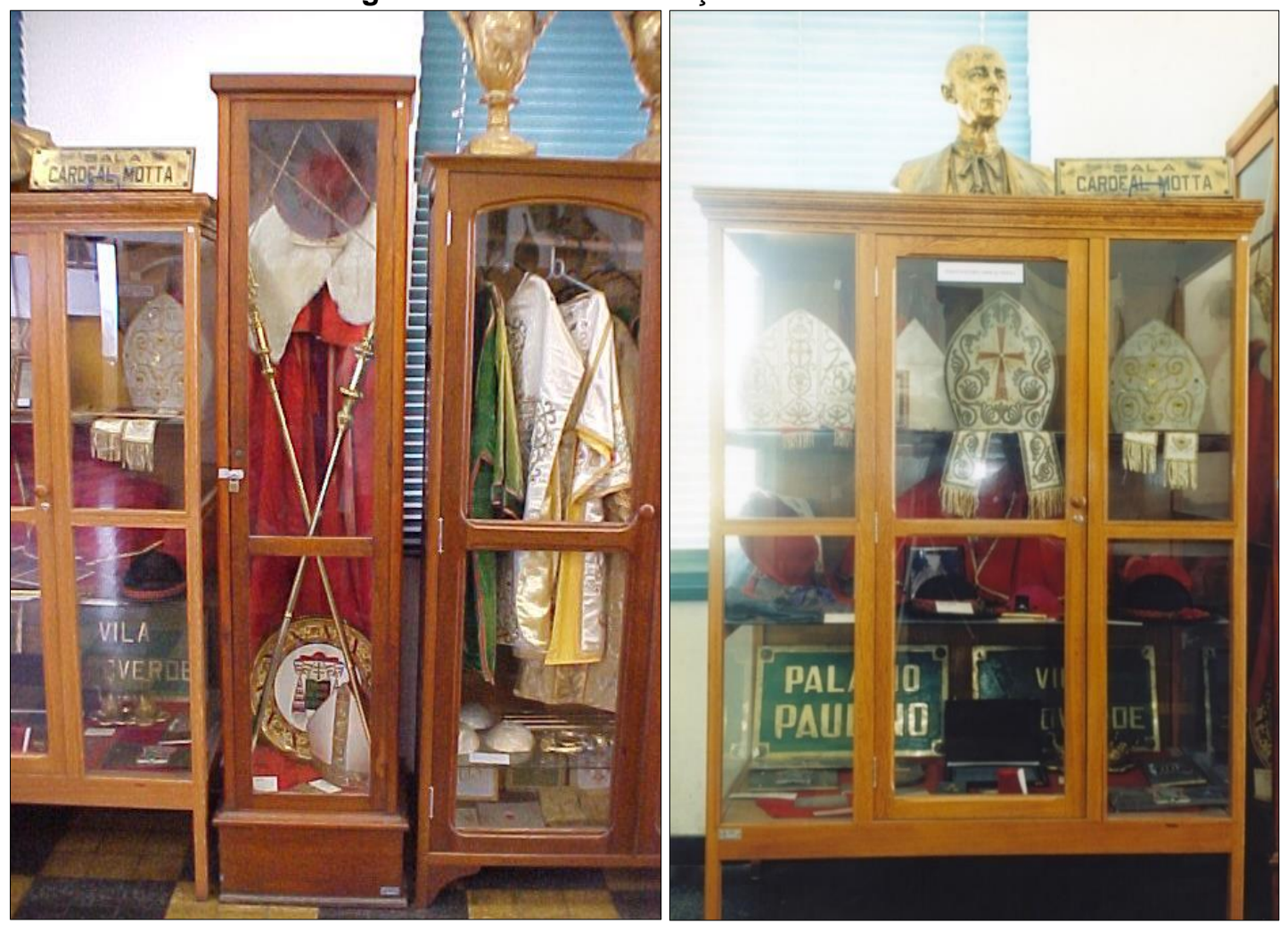

Fonte: MNSA/Santuário Nacional.

Foto (esquerda): Michel H. Oliveira. / Foto (direita): Vera de Souza. 
A Figura 29 compõe um núcleo referente ao Cardeal Dom Carlos Carmelo de Vasconcellos Motta, que esteve presente em vários eventos no Museu organizados pela Profa. Conceição Borges, desde sua inauguração, tendo contribuído com importantes aquisições de acervos.

Esse núcleo composto por objetos de uso pessoal do Cardeal Motta contém indumentária religiosa, mitra, solidéu, barrete, chapéu cardinalício, sapato, além de condecorações, placas de sua residência episcopal, de sua sala e placas de automóveis oficiais identificadas com o brasão cardinalício, assim como um prato decorativo e báculo. Há ainda, sobre a vitrine, um busto feito em metal pelo escultor Francisco Bussaco.

Recentemente, em 12 de outubro de 2012, familiares do Cardeal Motta fizeram a doação de uma coleção de bens pertencentes ao Cardeal Motta, que envolvem objetos e utensílios pessoais, fotos, documentos, livros, relíquias de santos, alguns com certificado de autenticidade, bem como diversas condecorações e placas de agradecimento. ${ }^{29}$

Figura 30: Acervo da coleção de objetos religiosos.

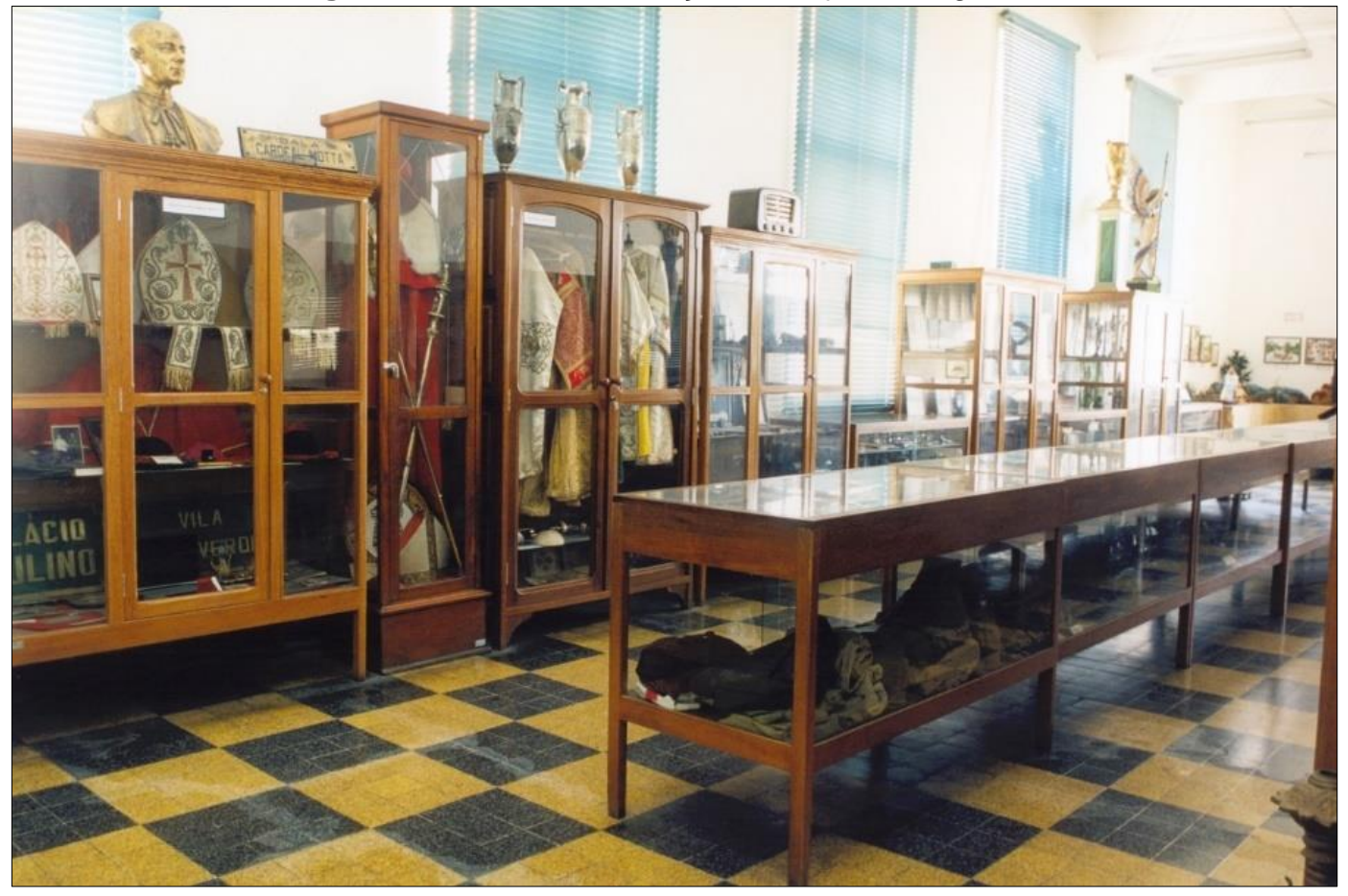

Fonte: MNSA/Santuário Nacional. Foto: Vera de Souza.

29 Ver o Contrato Particular de Doação, 12 de outubro de 2012, tendo como doadoras: Rita Maria de Vasconcelos Motta e Maria José de Vasconcelos Motta; e, do outro lado, como donatário, o Santuário Nacional de Nossa Senhora da Conceição Aparecida. 
Ao lado do núcleo do Cardeal Motta (Figura 30) estão demais objetos religiosos, como casulas, dalmáticas, véu umeral, capa pluvial, cíngulo, amito, túnica, estola, solideis papais, báculos, bolsas de corporal, entre outros paramentos.

$\mathrm{Na}$ Figura 31, ainda referente à coleção de objetos religiosos, podemos observar conjuntos de sacras, custódias, cálices, patenas, âmbulas, tecas, candelabros, castiçais e tocheiros em metal, além de peças têxteis, como estola e conjunto de bolsas de corporal.

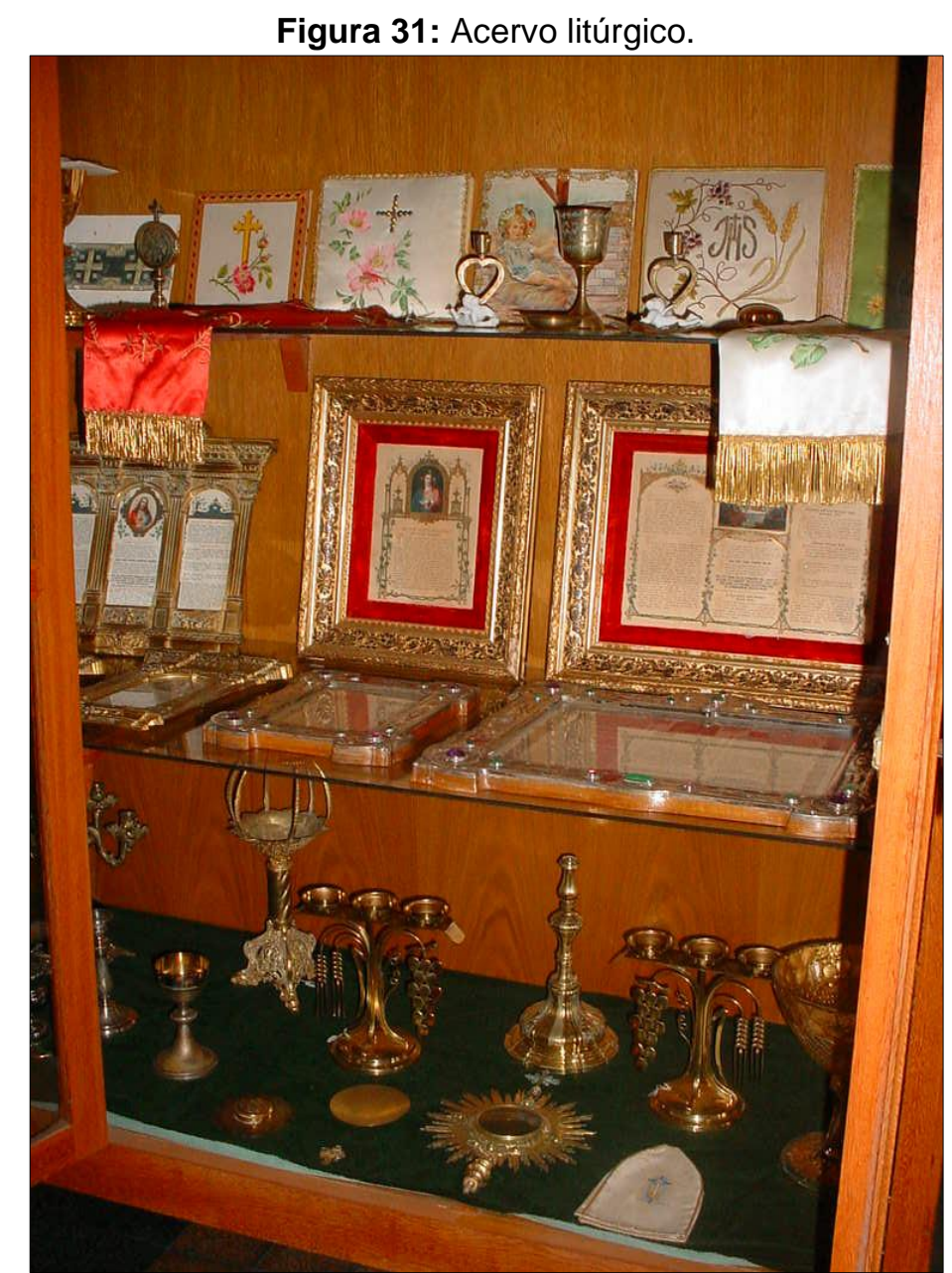

Fonte: MNSA/Santuário Nacional. Foto: Michel H. Oliveira.

Em relação à classificação do acervo, os objetos de culto estão classificados como objetos para aspersão e incensamento, consagração das igrejas, objetos relacionados à Eucaristia, procissão, oferendas e coleta, ritos, além de outros sacramentos. Há também tecidos e guarnição litúrgicos.

Outra tipologia é composta por vários objetos de devoção pessoal, contendo terços, medalhas e pingentes, crucifixos, pequenos oratórios, estampas com figuras 
de Nossa Senhora Aparecida. Algumas estampas possuem parcelas do manto de Nossa Senhora.

As Figuras 32 e 33 apresentam detalhes do mesmo armário, porém as fotografias são de períodos diferentes, sendo possível observar alterações do acervo exposto. Na Figura 32, há crucifixos de diversos tamanhos e materiais contendo véus de sacrário ao fundo, sendo possível visualizar apenas a parte superior do armário, que segue a mesma disposição do acervo na parte superior e inferior. Já na Figura 33, os crucifixos foram substituídos por imaginárias de madeira e de barro.

Figura 32: Acervo da coleção de objetos religiosos.

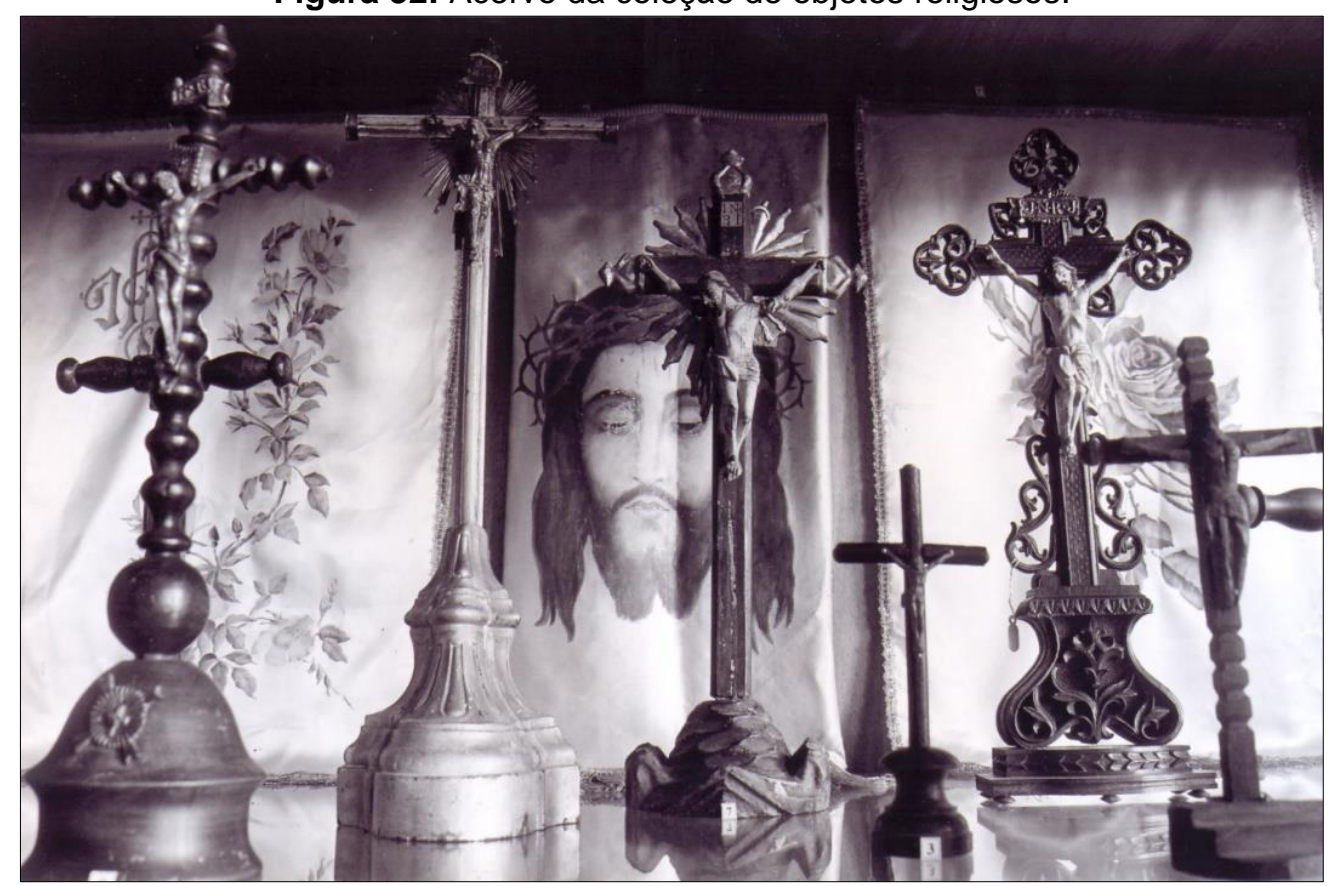

Fonte: MNSA/Santuário Nacional. Foto: Vera de Souza. 
Figura 33: Acervo de imaginária e têxteis.

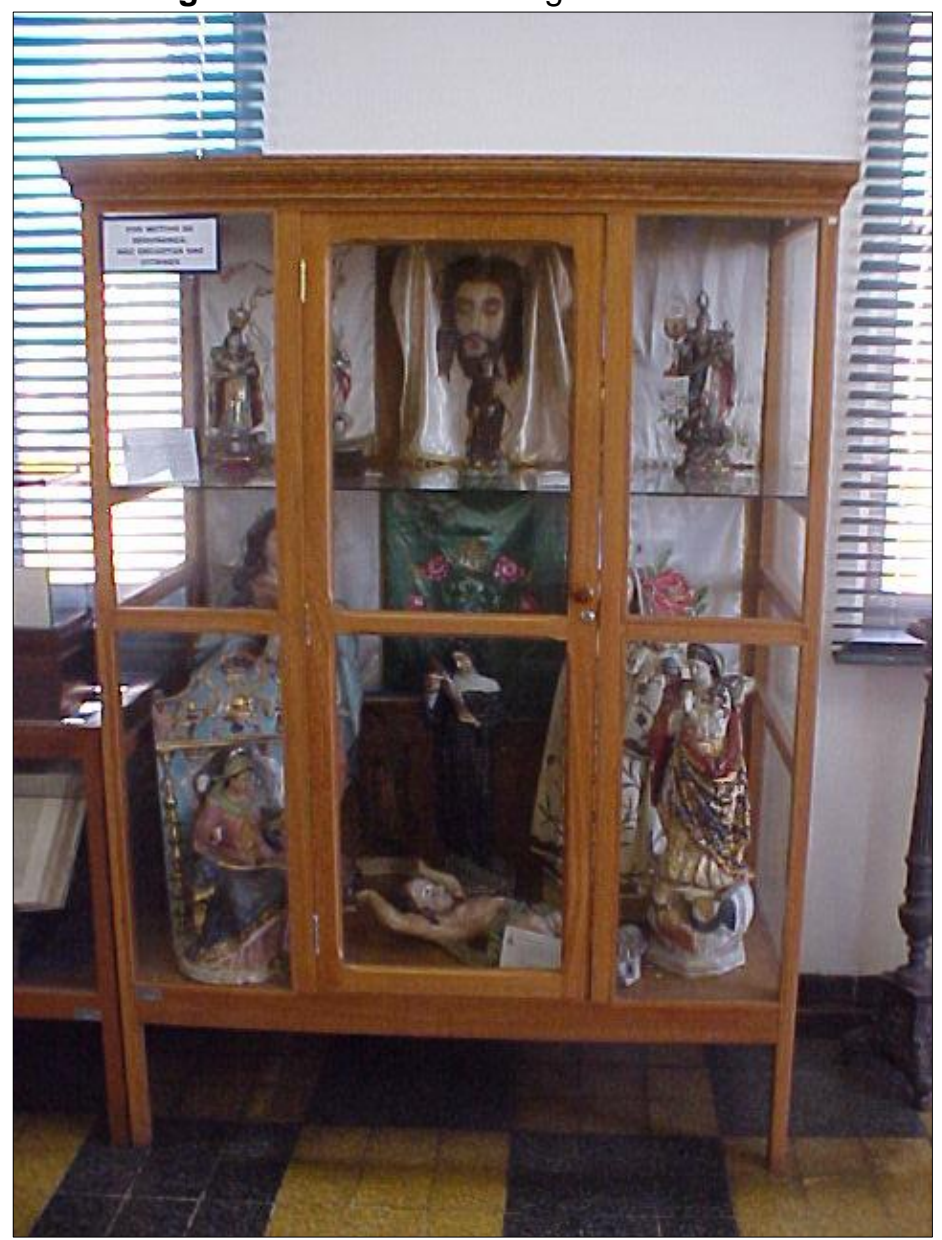

Fonte: MNSA/Santuário Nacional. Foto: Michel H. Oliveira.

O conjunto de esculturas religiosas compõe uma das maiores coleções do Museu Nossa Senhora Aparecida. As esculturas de vulto desse conjunto podem ser classificadas como: busto, cabeça, estátua, estatueta e grupo escultórico.

Especificamente, as figuras religiosas são classificadas como: crucifixos, divino, imagens de Nossa Senhora, imagens de Santas e de Santos, Mártires, Imagens de Jesus, Presépios, esculturas religiosas não identificadas e demais atributos de esculturas religiosas, como coroas, resplendores, mantos, etc.

Dando sequência aos armários com temática religiosa, na Figura 34 observamos os mantos utilizados pela Imagem de Nossa Senhora Aparecida, assim como coroas de diversos formatos e tamanhos. Neste armário há também livros de oração, crucifixos, chaves, rosas de prata, além de alguns objetos decorativos. Ao lado há um dos cofres procedentes da Antiga Basílica de Nossa Senhora Aparecida. 
Figura 34: Acervo devocional.

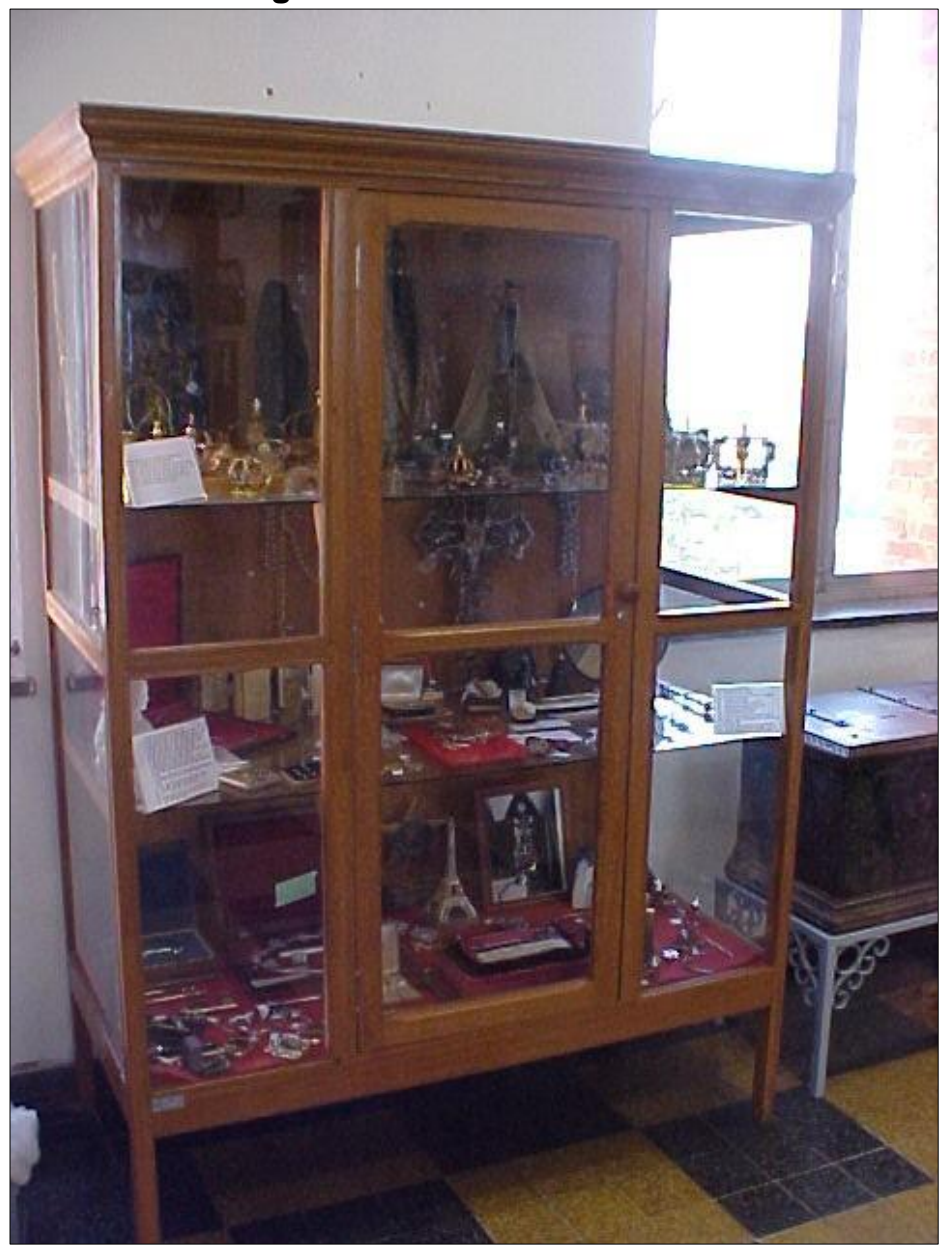

Fonte: MNSA/Santuário Nacional. Foto: Michel H. Oliveira.

Figura 35: Acervo de pinturas com temática religiosa.

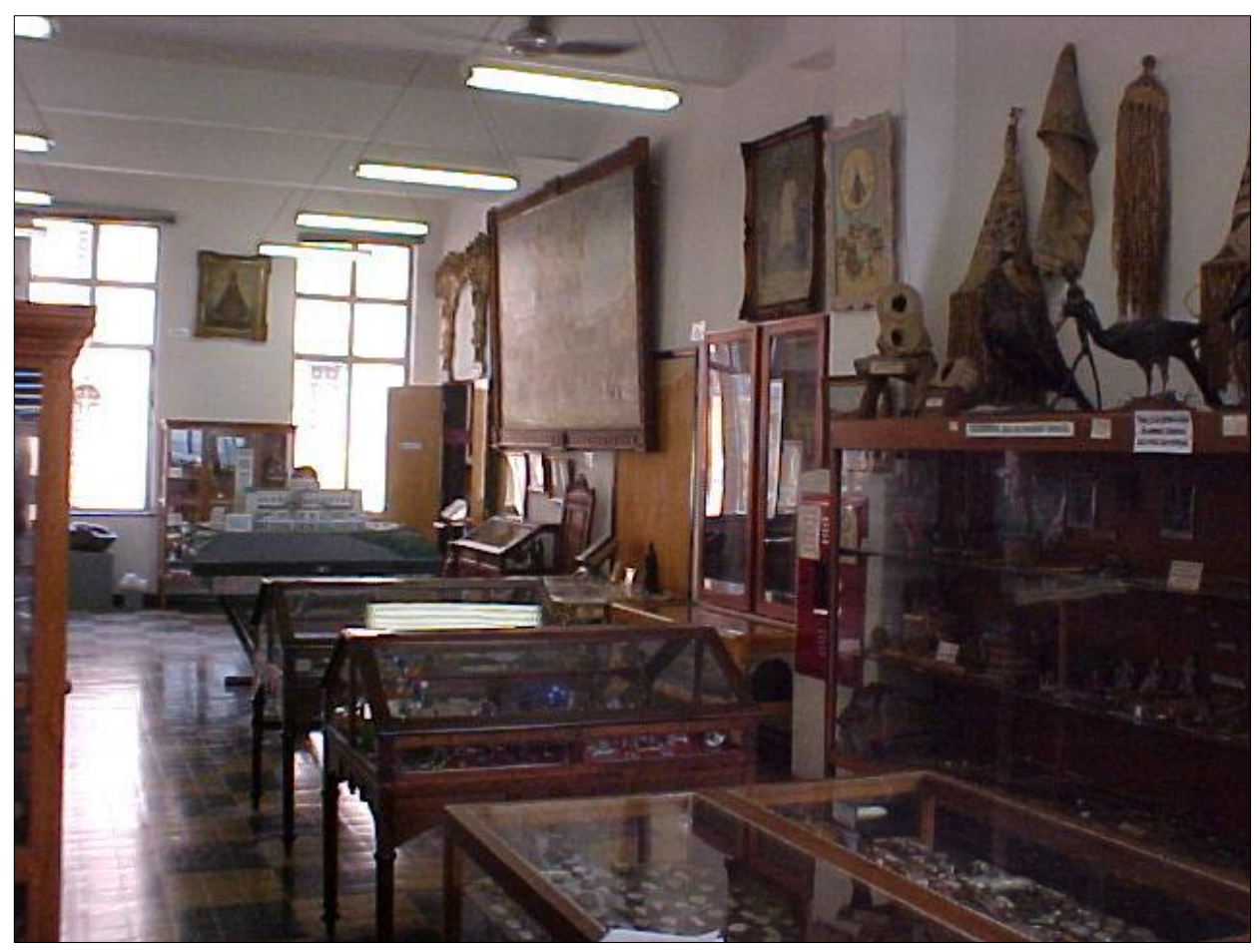

Fonte: MNSA/Santuário Nacional. Foto: Michel H. Oliveira. 
É importante considerar, também, as pinturas com temáticas religiosas, tais como a grande tela da Coroação de Nossa Senhora Aparecida, citada anteriormente, além de representações da Imagem de Nossa Senhora Aparecida, reproduções da praça com a Antiga Basílica, bem como o local escolhido para construção da Nova Basílica, entre outras pinturas (Figura 35).

$\mathrm{Na}$ Figura 35 é possível observar a existência de mobiliários diferenciados que ocupavam os espaços na parte central do salão e nas paredes, sob as janelas. Alguns desses mobiliários eram procedentes do antigo Museu da Cúria Metropolitana de São Paulo e foram doados pelo Arcebispo D. Paulo Evaristo Arns. De acordo com a correspondência entre a Profa. Conceição Borges e o Padre Galvão ${ }^{30}$ :

Os móveis pertencentes ao antigo museu da Cúria Metropolitana de São Paulo foram doados por Dom Paulo Evaristo Arns, em abril de 1971, para o Museu Nossa Senhora Aparecida. Na ocasião da doação todos foram usados no "Museu Documentação", localizado no $3^{\circ}$ andar da Torre. Porém, não despertou interesse aos visitantes. Posteriormente, alguns móveis foram utilizados no Museu Histórico, Didático e Pedagógico, denominado "Museu dos Ciclos Sócio-Econômicos do Vale do Paraíba". Com o encerramento do Museu, os móveis foram cedidos para iniciar o Museu do Seminário de Santa Therezinha, em Tietê (SP).

Figura 36: Acervo devocional e livros raros.

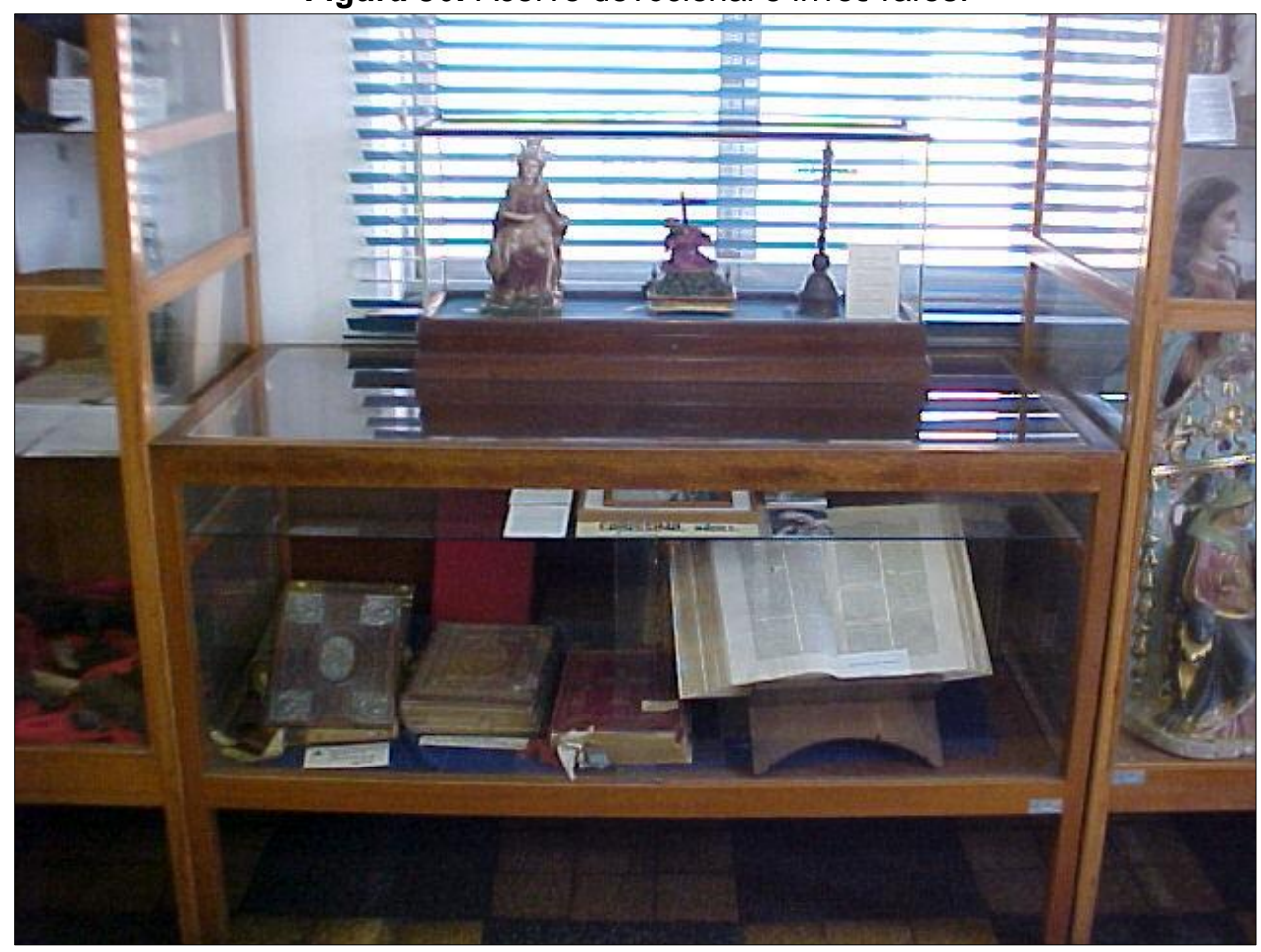

Fonte: MNSA/Santuário Nacional. Foto: Michel H. Oliveira.

30 CAMARGO, C. B. R. [Carta] 28 nov. 1980, Aparecida [para] GALVÃO. Aparecida. 1 f. Doação dos móveis do antigo museu da Cúria Metropolitana de São Paulo para o Museu Nossa Senhora Aparecida. 
Em relação ao acervo de livros raros, havia missais em exposição no $2^{\circ}$ andar, conforme observado na Figura 36. A grande parte da coleção de livros ficava exposta no $3^{\circ}$ andar, no Museu dos Ciclos Socioeconômicos do Vale do Paraíba, que foi inaugurado no ano de 1975. O referido Museu, também organizado pela Profa. Conceição Borges, será abordado no próximo item desta dissertação.

Em relação ao acervo de mobiliários e demais peças em madeira entalhada, há um fragmento de porta de um confessionário da Antiga Basílica de Nossa Senhora Aparecida, assim como genuflexórios, mesas e cadeiras, tocheiros, além de relógios do modelo carrilhão.

Os oratórios residenciais compõem uma coleção de nove peças, sendo a maioria em madeira entalhada, dos séculos XVIII e XIX, e alguns em policromia e folheados a ouro.

Figura 37: Vitrines da antiga exposição do $2^{\circ}$ andar.

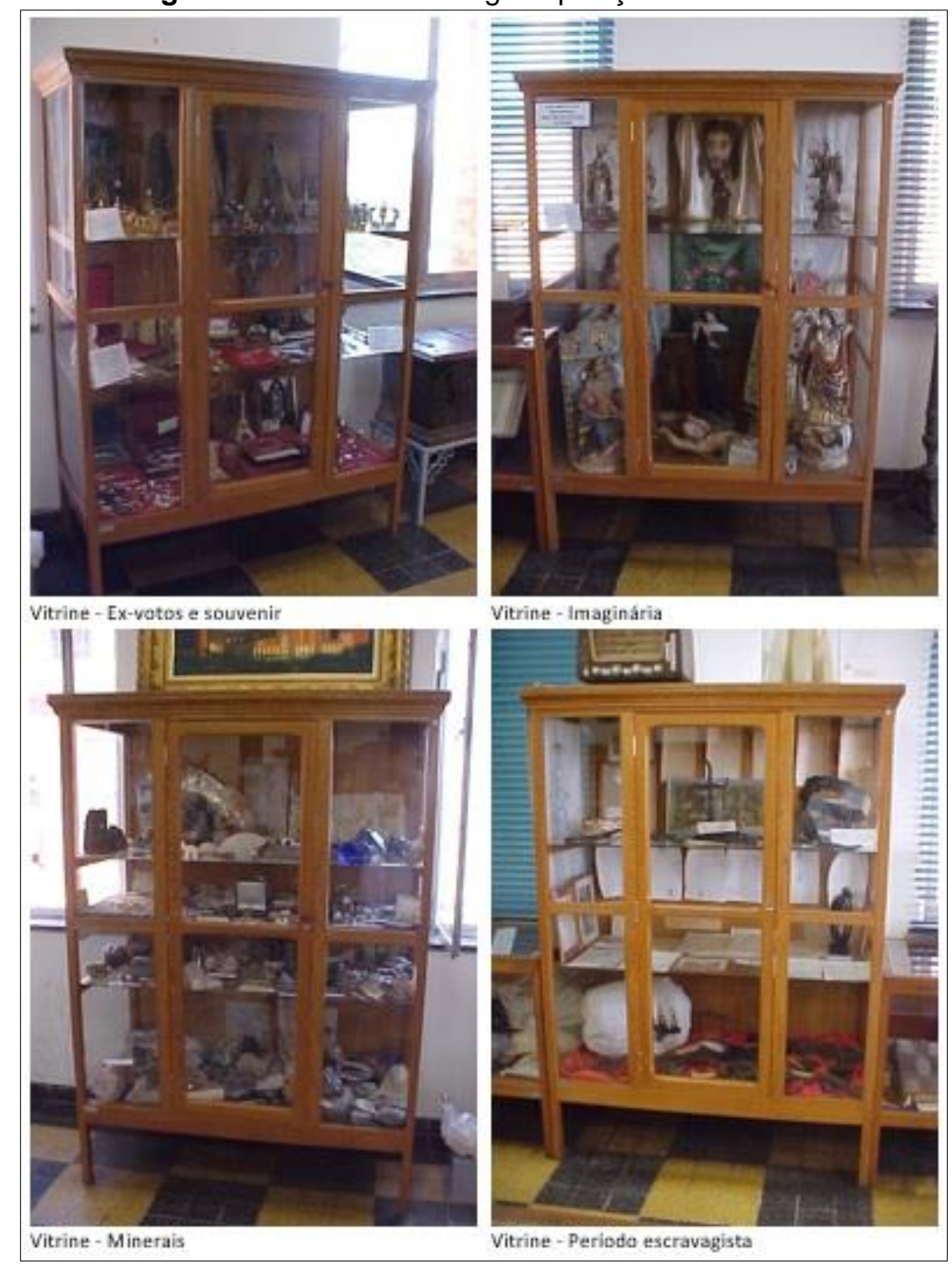

Fonte: MNSA/Santuário Nacional. Foto: Michel H. Oliveira. 
Na Figura 37 notamos a presença de ex-votos no Museu, talvez fosse interesse da Profa. Conceição Borges em formar uma coleção de ex-votos, mas não podemos descartar a hipótese da proximidade do Museu com a Sala dos Milagres ou a própria falta de conhecimento do doador em localizar o local correto para fazer a oferta do seu ex-voto, conforme ainda pode ser observado atualmente.

Em relação à organização do acervo, Zenilda Cunha ${ }^{31}$, em sua percepção sobre os ex-votos do Museu, diz que,

"[...] eu achava que o Museu era uma Sala das Promessas, porque eram coisas muito juntas, às vezes ela ganhava coisa, eu falo porque eu vi. Então, às vezes ela ganhava umas peças de porcelana no dia em que ela estava explicando para escola, e nem bem colocava nenhum dado, ela colocava uma coisa embaixo do prato e já colocava na prateleira. Então, ela ia recolhendo praticamente e colocando. Tudo exposto, ficava tudo junto. (CUNHA, 2018, p. 5, informação verbal).

Além dos ex-votos, observamos na Figura 37 outra vitrine com imaginárias e têxteis, minerais, bem como documentos e objetos de tortura do período escravagista.

Figura 38: Acervo da coleção de instrumentos musicais e relógios.

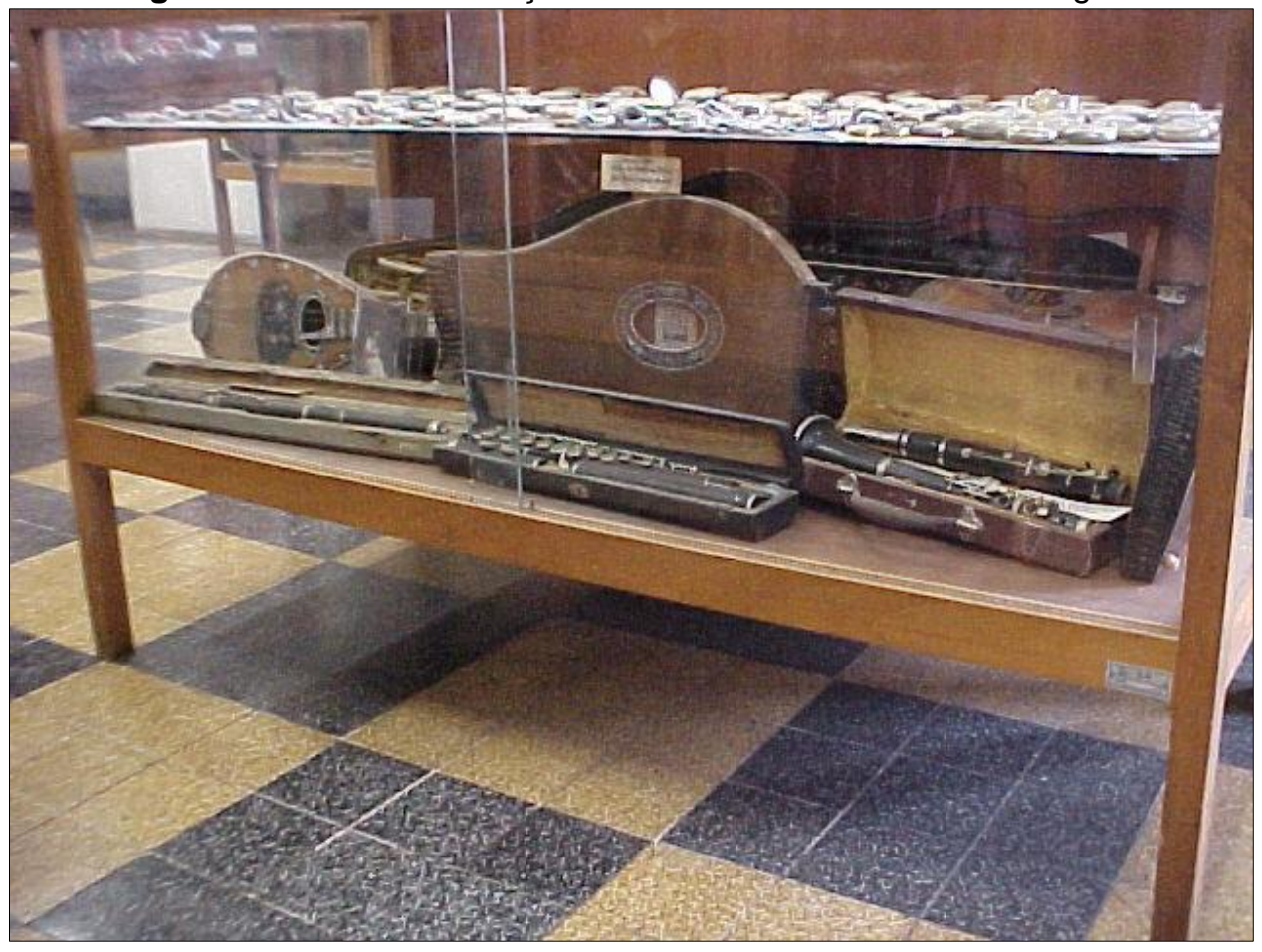

Fonte: MNSA/Santuário Nacional. Foto: Michel H. Oliveira.

A Figura 38 apresenta uma das vitrines baixas entre os corredores dos armários, expondo alguns instrumentos musicais e relógios, objetos recorrentes em

${ }^{31}$ CUNHA, Zenilda Cristina da. Entrevista concedida a Erica Andreza Coelho. Aparecida, 10 jan. 2018, 1 h 33 min 17 s. Som, Formato M4A. 
várias vitrines, devido à alta frequência de doações e o formato pequeno das vitrines, impossibilitando a exposição de toda a coleção em um mesmo local, até mesmo pela diversidade de tipologias, materiais e tamanhos dos objetos.

Em vitrines baixas, também eram expostas as máquinas de costura, máquinas de escrever, tinteiros, canetas e bicos de pena e demais objetos de comunicação escrita. Além de objetos de uso cotidiano feminino como leques, luvas, acessórios para cabelo. Alguns desses objetos podem ser visualizados na Figura 39.

Figura 39: Acervo da coleção de objetos de comunicação.

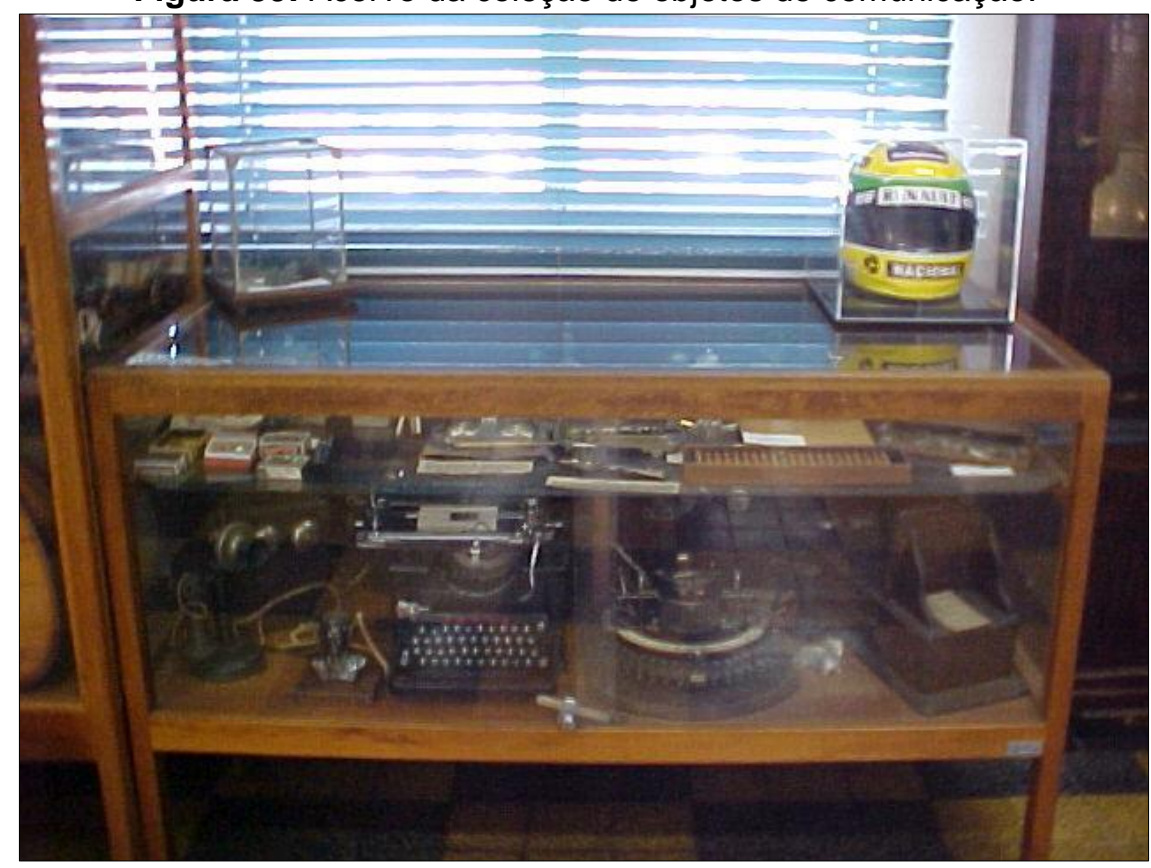

Fonte: MNSA/Santuário Nacional. Foto: Michel H. Oliveira.

Figura 40: Acervo da coleção de arte popular.

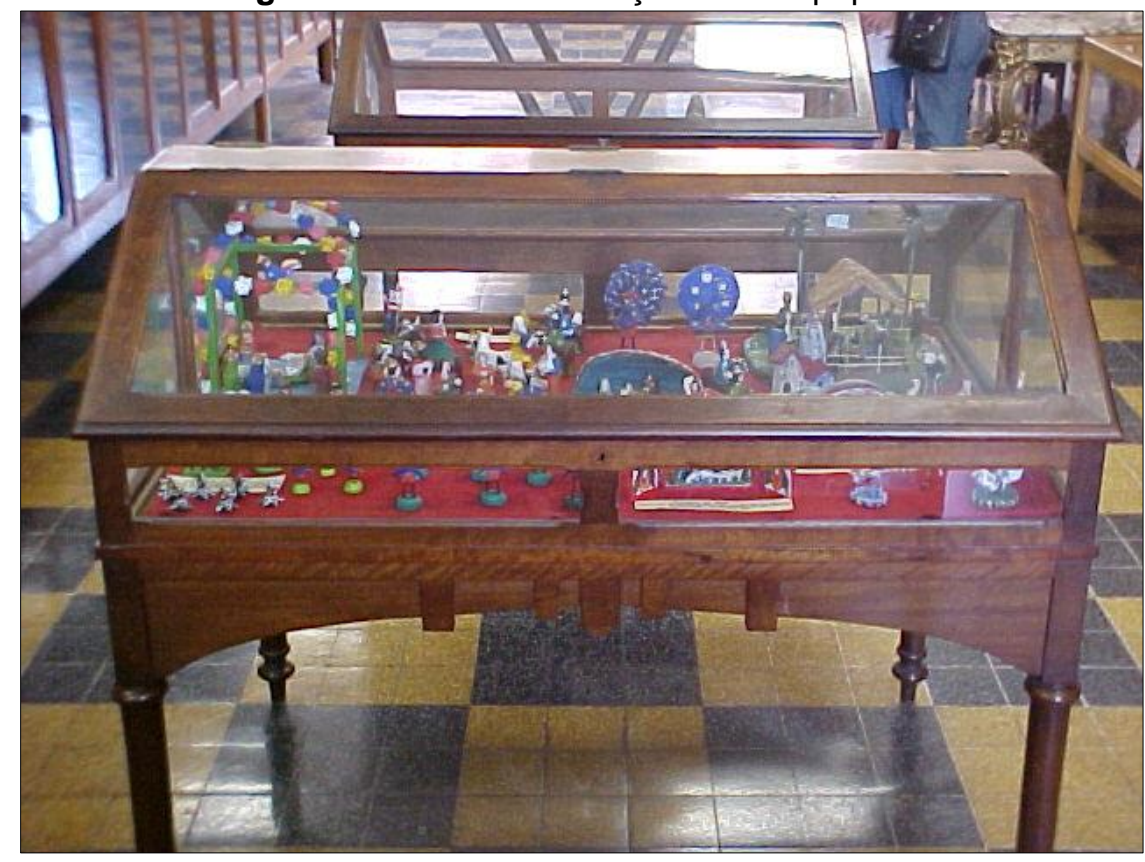

Fonte: MNSA/Santuário Nacional. Foto: Michel H. Oliveira. 
$\mathrm{Na}$ Figura 40 estão figuras de presépios que compõem a coleção de artesanatos, com várias peças produzidas pelas "Figureiras" de Taubaté (SP) e também de artesãos de São José dos Campos (SP).

Em outros armários há demais figuras de presépio em gesso, compondo expressivos conjuntos com figuras humanas e figuras de animais, quantificados em mais de cento e cinquenta peças de presépios.

Em relação ao acervo produzido pelas "Figureiras", há outros conjuntos não religiosos, como uma cena de casamento, uma banda de músicos, além dos pavões com predominância da cor azul, com tamanhos e ornamentações diferentes.

Figura 41: Acervo de arte popular, esculturas e instrumentos musicais.

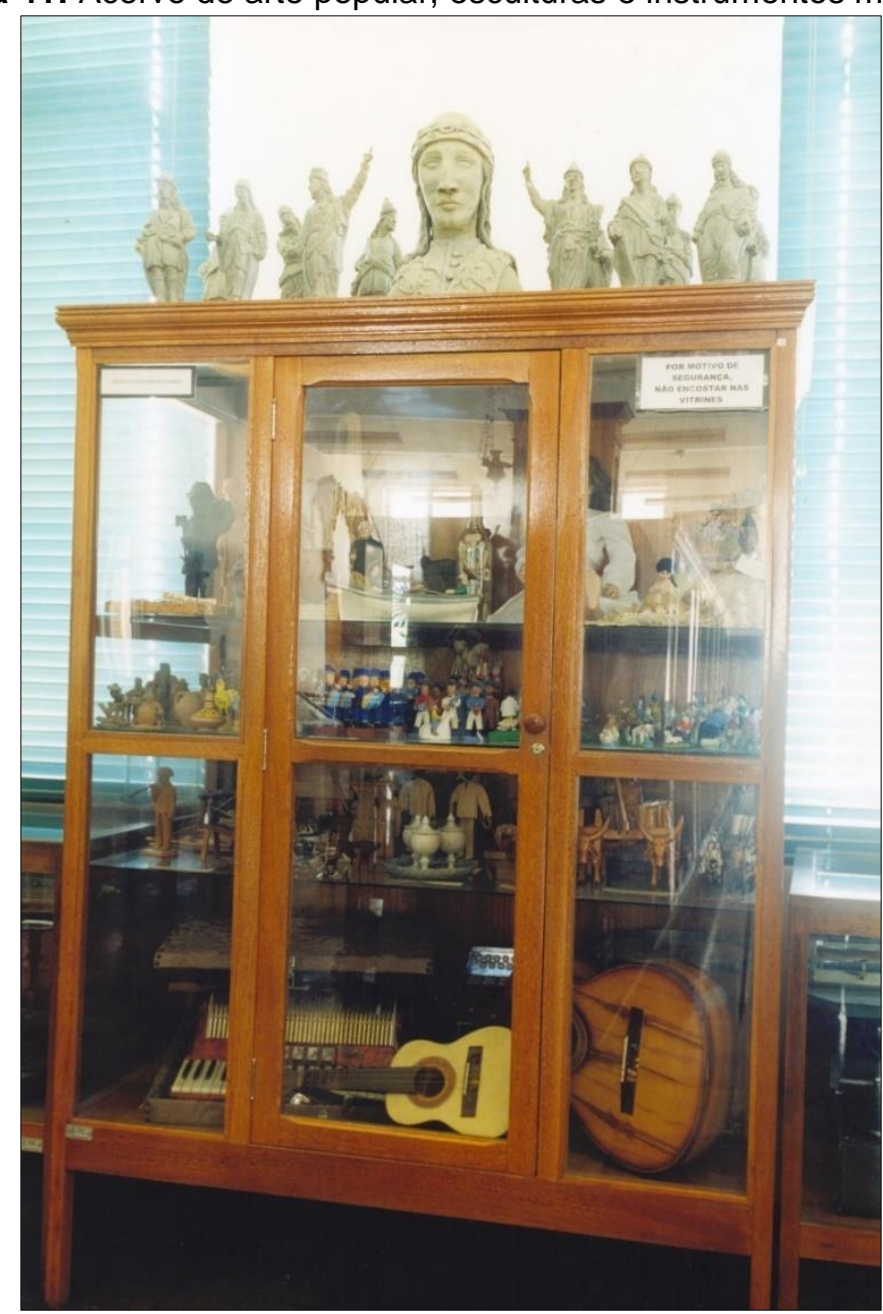

Fonte: MNSA/Santuário Nacional. Foto: Vera de Souza.

Na Figura 41, sobre o armário, há um conjunto de esculturas em pedra sabão procedente de Congonhas do Campo (MG), reprodução dos Profetas de Aleijadinho (Antônio Francisco de Lisboa, 1738 - 1814), adquiridos por Vicente Camargo, em 24 de maio de 1973. 
Por meio da análise da Figura 41, verificamos também que no interior do armário está parte da coleção de bonecas, artesanatos, além de um conjunto de esculturas produzido pelo Mestre Vitalino Filho, bem como parte da coleção de instrumentos musicais.

Figura 42: Acervo de bonecos artesanais e numismática.

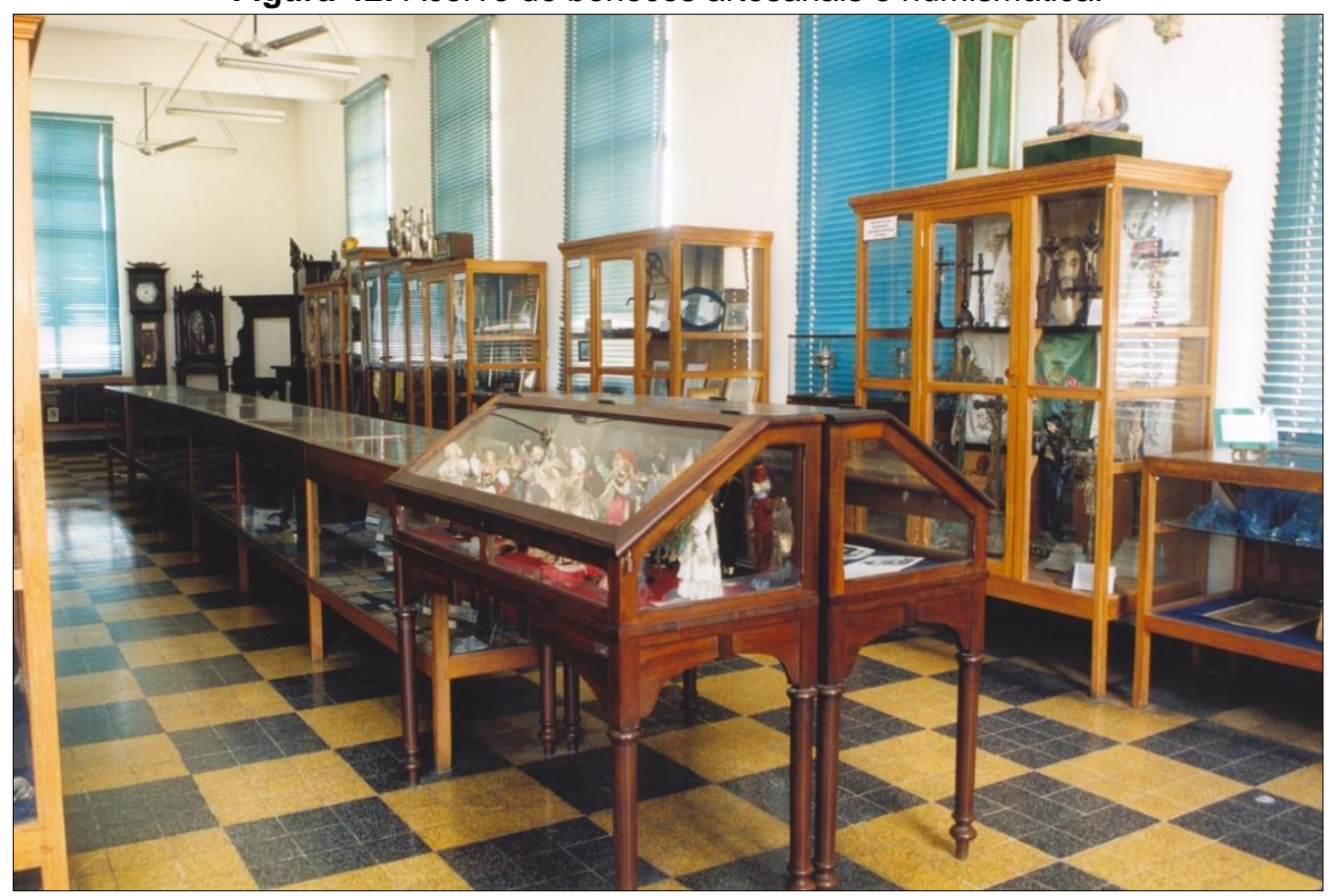

Fonte: MNSA/Santuário Nacional. Foto: Vera de Souza.

Na Figura 42 é possível verificar em primeiro plano a coleção de bonecos artesanais, composta por vinte e quatro bonecos trajando vestes com temáticas das nacionalidades, como, por exemplo, traje holandês, espanhol, indiano, italiano, japonês, trajes de época, de bailarina, odalisca, camponesa, além de diversos outros temas.

Seguindo a mesma sequência de vitrines baixas, está exposta a coleção de numismática, que é considerada a maior coleção do Museu Nossa Senhora Aparecida, contendo aproximadamente oito mil itens entre cédulas e moedas, nacionais e internacionais.

Inicialmente a coleção de numismática foi quantificada em aproximadamente vinte e seis mil moedas e mais de sete mil cédulas, entre nacionais e internacionais. Após o processo de triagem, seleção e documentação do acervo, iniciado em 2007, um recorte da coleção foi realmente incorporado ao acervo do Museu e os demais 
itens encaminhados para a unidade do Banco Central do Brasil localizada em São Paulo 32 .

Figura 43: Acervo da coleção de tropeirismo.

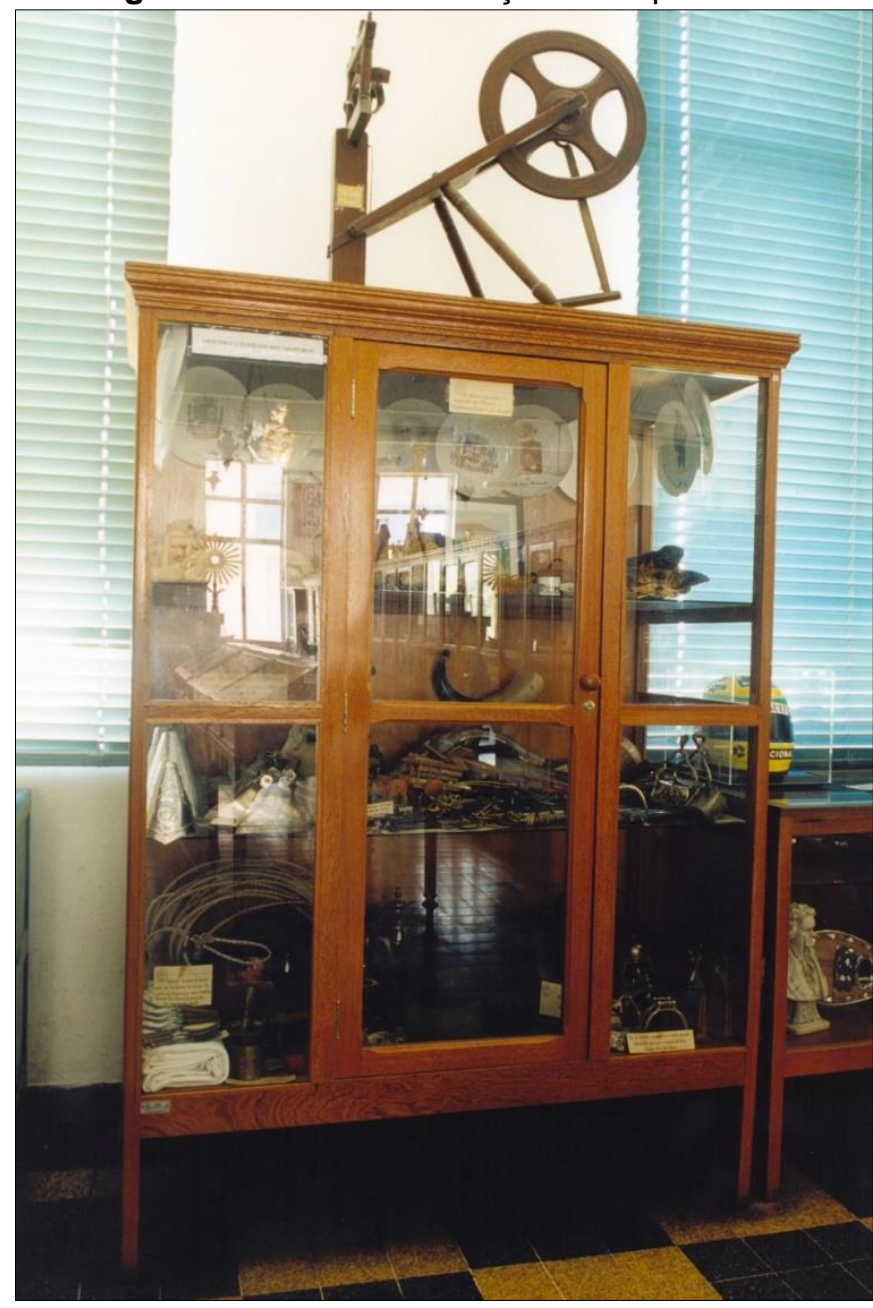

Fonte: MNSA/Santuário Nacional. Foto: Vera de Souza.

$\mathrm{Na}$ Figura 43 podemos verificar a coleção de objetos do Tropeirismo, composta por caçambas, estribos, esporas, cordas, guampas e demais materiais de uso cotidiano dos tropeiros como talheres, almofarizes, chaleiras, panelas, tachos, chocolateira, etc. Há também, na parte superior, a coleção de pratos brasonados de Paraty (RJ), assim como algumas esculturas e objetos diversos de pequeno porte, como também uma roca sobre o armário.

Ainda na Figura 43, ao lado direito, observamos uma réplica do capacete de Ayrton Senna, muito procurada pelos visitantes. Atualmente esta peça encontra-se

32 Conforme o Relatório Geral de Numismática, documento eletrônico, disponível na Área Técnica do Museu. Foram consultados também: Relatório de cédulas catalogadas; Relatório de cédulas excedentes; Relatório de moedas excedentes, que foram desenvolvidas pela equipe técnica do Museu, após a documentação do acervo. 
em exposição na Sala das Promessas, no subsolo da Nova Basílica de Nossa Senhora Aparecida.

Desta forma, verificamos que, devido à limitação de espaço, as temáticas e tipologias diversificadas eram agrupadas no mesmo armário ou vitrine, o que tornava o ambiente mais curioso e interessante aos visitantes.

Figura 44: Acervo da Revolução Constitucionalista de 1932.

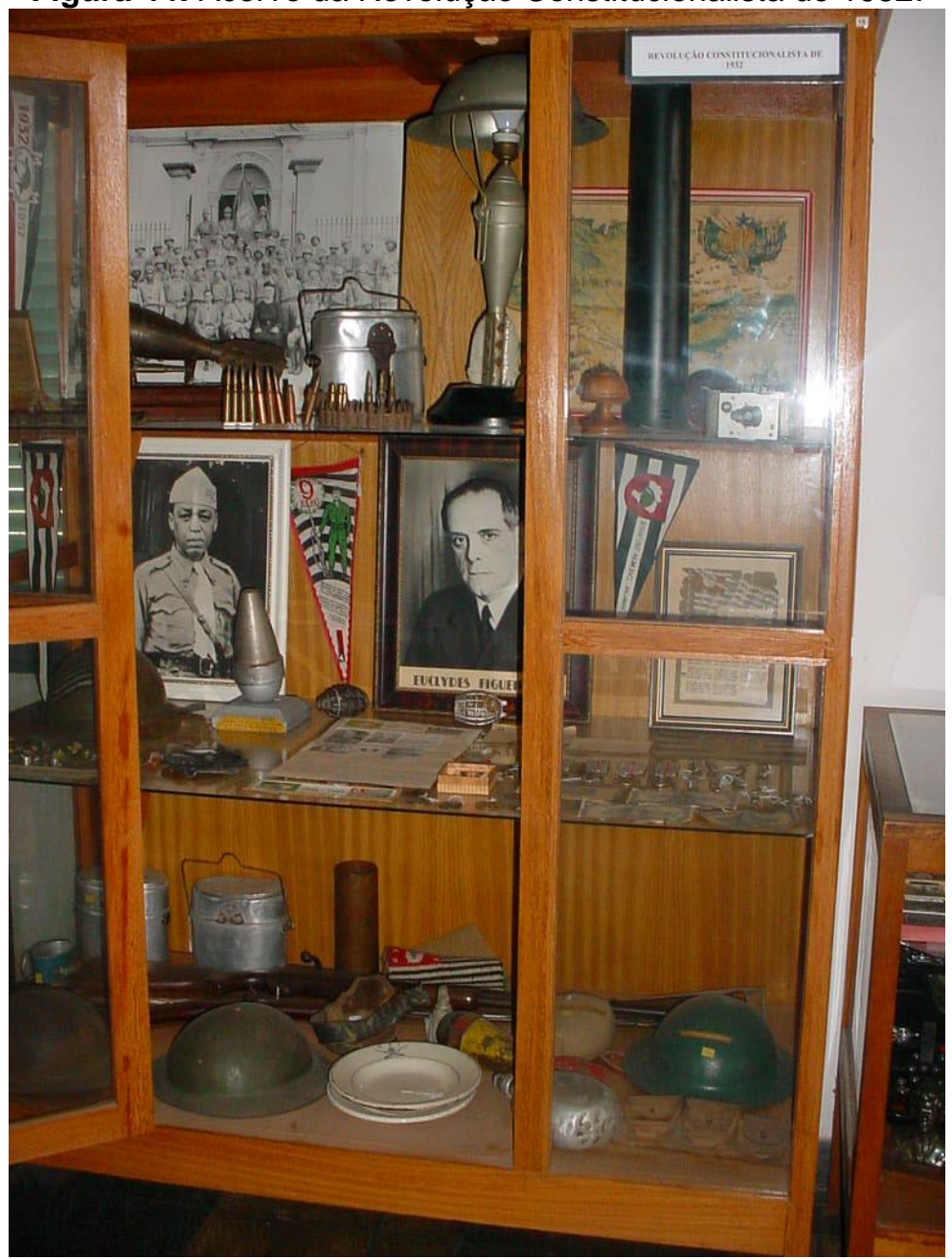

Fonte: MNSA/Santuário Nacional. Foto: Michel H. Oliveira.

Em relação ao acervo relacionado à Revolução Constitucionalista de 1932, por meio da Figura 44, podemos observar objetos alusivos a essa temática, como tinteiros em formato de capacete, flâmulas e condecorações, bem como souvenir desenvolvido com os materiais originais, como, por exemplo, luminária composta por um capacete e um morteiro, e demais morteiros sobre base de madeira, para dar um caráter decorativo ao objeto.

Este núcleo é composto por capacetes, cantis, marmitas, pratos, granadas, armas e munições, além de fotografias, documentos, objetos decorativos, conforme mencionado anteriormente, entre outras peças. 
Figura 45: Acervo da Segunda Guerra Mundial.

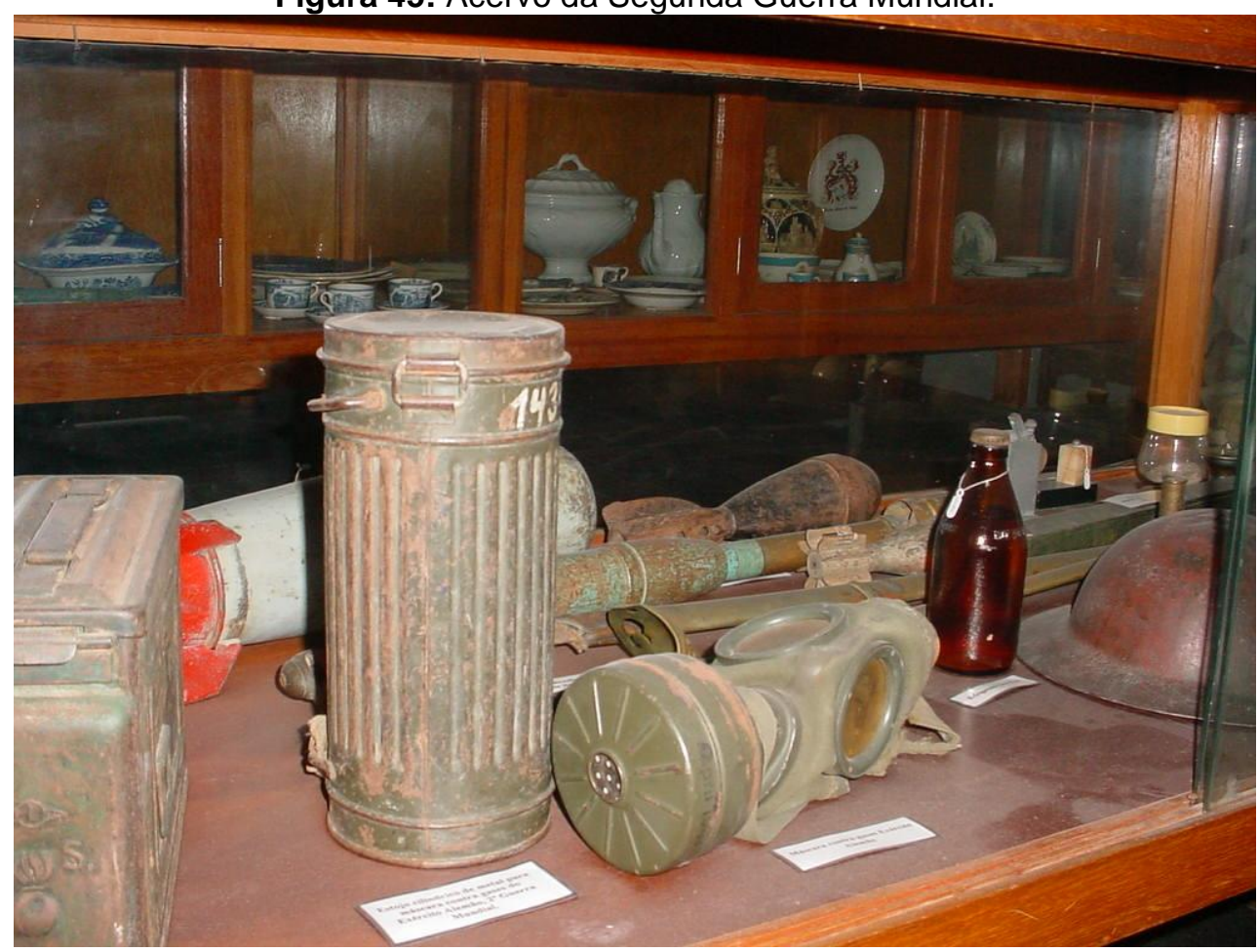

Fonte: MNSA/Santuário Nacional. Foto: Michel H. Oliveira.

Em outros núcleos, nas vitrines baixas, havia objetos relativos à Segunda Guerra Mundial, como, por exemplo, máscara de gás, estojos, morteiros, capacetes, fardas militares, cantis, canecas, entre outros objetos. Parte das peças pode ser observada na Figura 45.

De acordo com um recorte do Jornal O Aparecida, de 08 de maio de 1993,

O Museu Nossa Senhora Aparecida, localizado na Torre Brasília, da Basílica Nacional de Aparecida, acaba de ganhar um acervo de 140 peças da campanha da Força Expedicionária Brasileira que galhardamente defendeu as cores da Liberdade e da Democracia, contra o Nazi-Fascismo, no conflito mundial de 1939/1945.

A doação das peças da II Guerra foi procedida pelo Capitão Alarico José de Castro, ex-pracinha, do $3^{\circ}$ Batalhão do $6^{\circ}$ R. I., sediado em Caçapava e comandado, à época, pelo general Silvino Santos da Nóbrega. Dia 8 de Maio, comemora-se o DIA DA VITÓRIA das Forças Aliadas e assim trata-se de oportuna e histórica doação ao Museu, dirigido pela Professora Conceição Borges Ribeiro Camargo. (O APARECIDA, 1993).

Nesse núcleo havia também armas de fogo, que compõem uma grande coleção de garruchas, espingardas, bacamartes, assim como armas brancas, entre elas espadas, sabres e punhais de diversos tamanhos e formatos, vários deles compostos por bainhas. 
Figura 46: Vitrines da antiga exposição do $2^{\circ}$ andar.

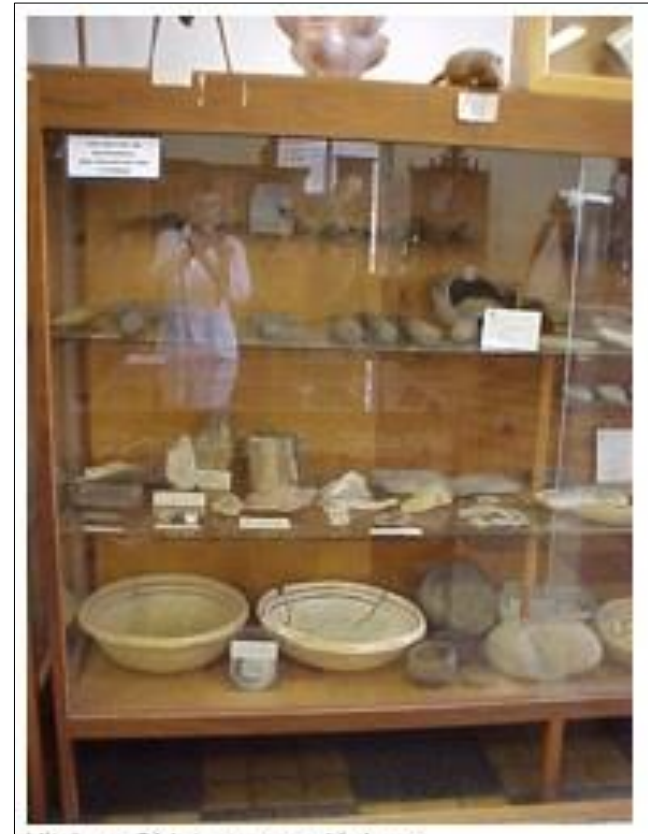

Vitrine - Objetos arqueald́gicos

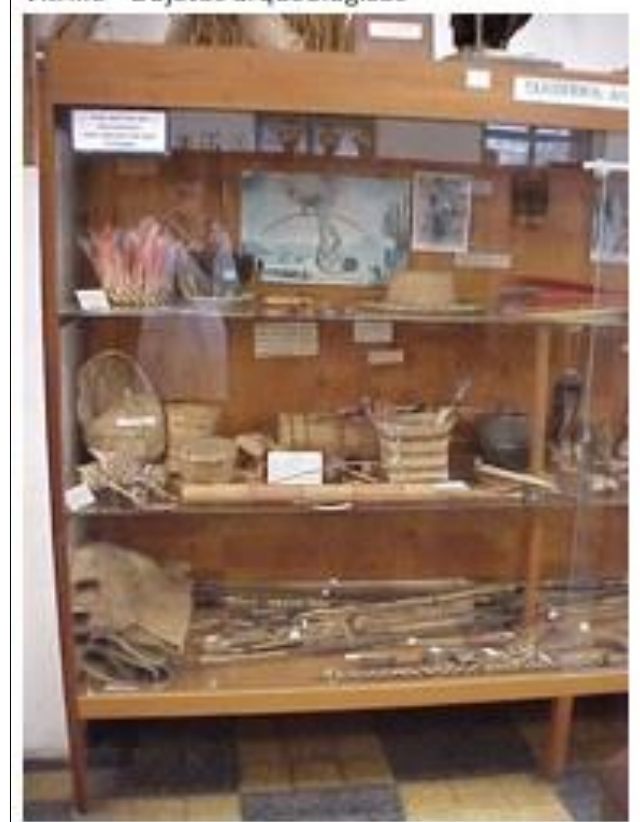

Vitrine - Objetos etnológicos

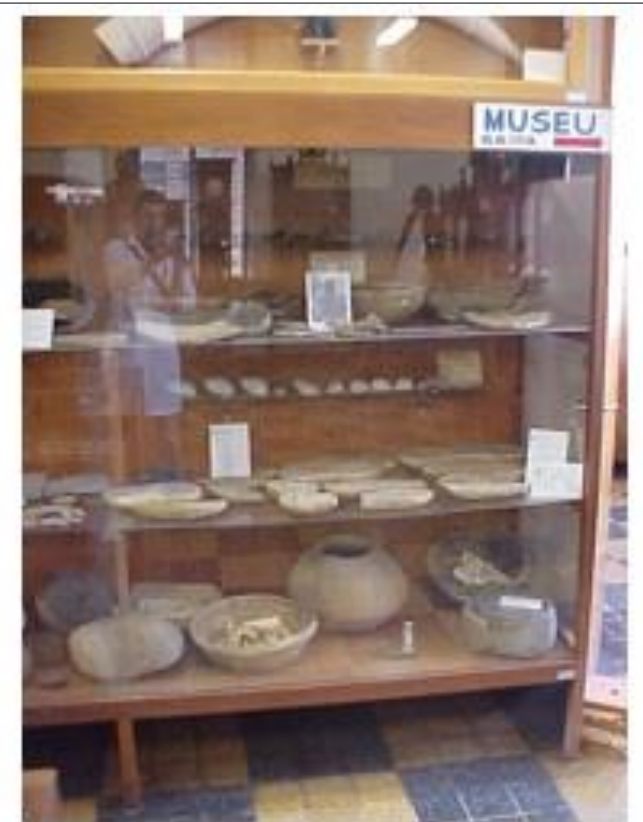

Vitrine - Objetos arquealágicos

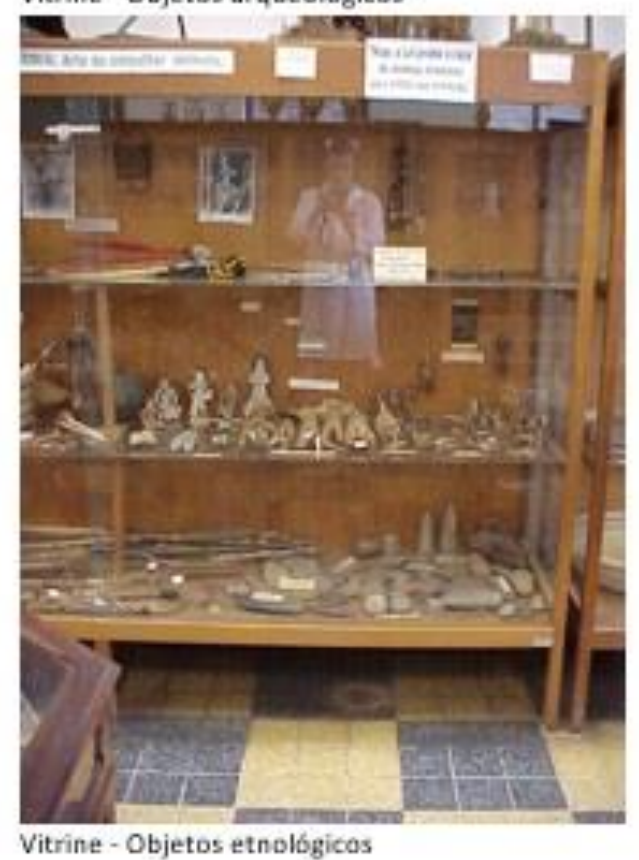

Fonte: MNSA/Santuário Nacional. Foto: Michel H. Oliveira.

$\mathrm{Na}$ Figura 46 observamos as coleções de paleontologia, arqueologia e etnologia. $O$ acervo de paleontologia possui diversos fósseis de peixes, alguns fósseis de mesossaurídeos, além de vegetais.

A coleção de arqueologia é composta por objetos líticos, entre eles, lâminas de machado com formatos diferentes, mão de pilão, pontas de projéteis e seixos. Já o acervo de cerâmica é composto por urnas funerárias, vasilhas, cachimbos e diversos fragmentos de cerâmica indígena. 
A maioria dos objetos cerâmicos presentes no acervo do Museu Nossa Senhora Aparecida são provenientes das escavações arqueológicas que ocorreram principalmente entre as décadas de 50 e 70, no munícipio de Aparecida (SP), nas quais a Profa. Conceição Borges foi uma personagem importante para salvaguarda desses materiais.

A partir do estudo dessas coleções, a Profa. Conceição Borges produziu artigos e participou de seminários, classificando os tipos de cerâmica encontrados, organizando-os por zonas geográficas, sendo elas: Primeira Zona: Largo da Feira e Estação Ferroviária; Segunda Zona: Rua João Andrade Costa e Convento das Carmelitas; e Terceira Zona: Porto Itaguaçu.

Figura 47: Acervo da coleção de etnologia.

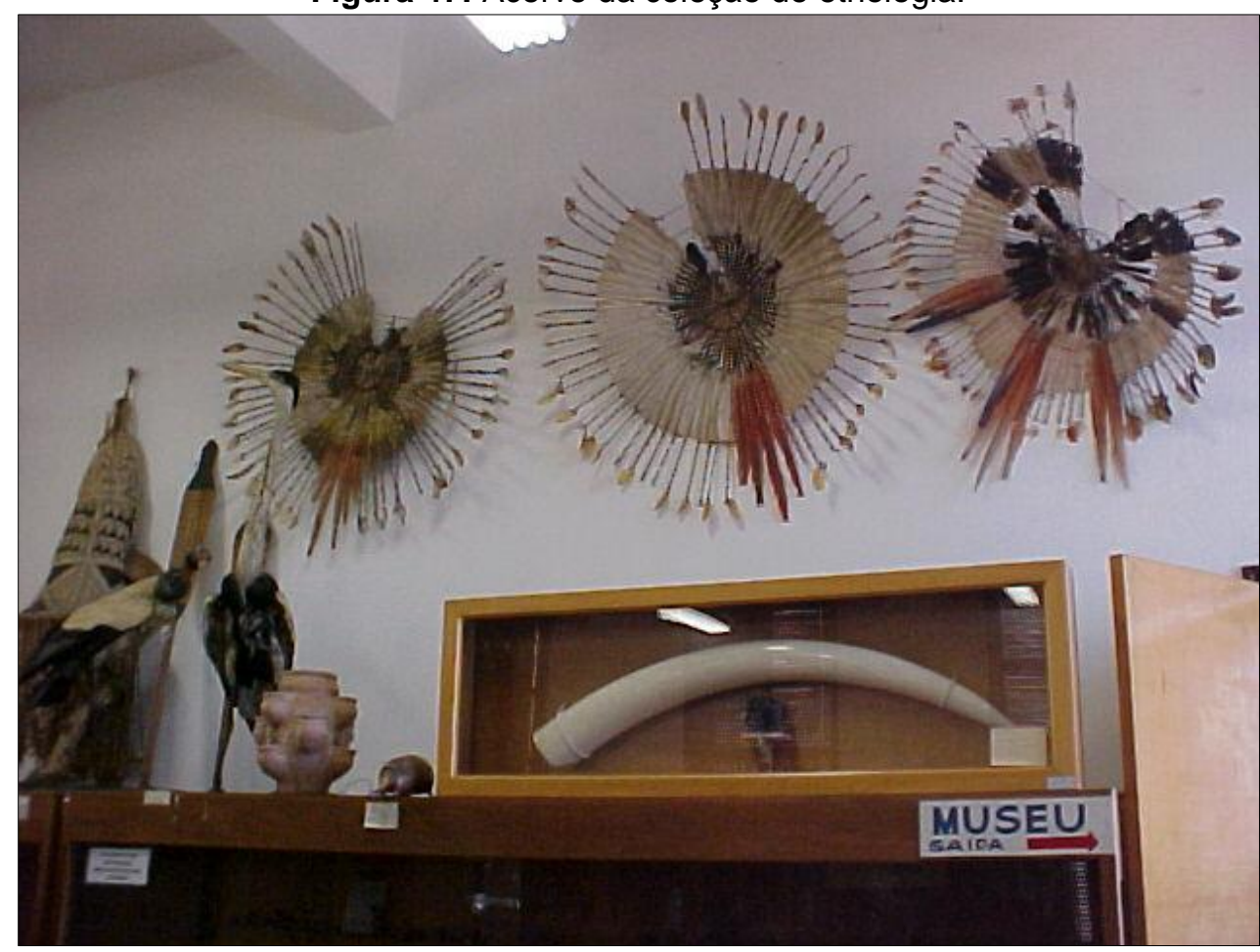

Fonte: MNSA/Santuário Nacional. Foto: Michel H. Oliveira.

Sobre os armários, conforme a Figura 47, havia elementos da coleção etnográfica ainda não documentada pela equipe técnica do Museu. É possível visualizar também o dente de marfim, atualmente em exposição no novo núcleo referente às relações do homem com o ambiente, que compõe a nova expografia no $2^{\circ}$ andar da Torre.

Ainda em relação à coleção etnográfica, nas Figuras 48 e 49 observamos parte do acervo composto por cestarias, colares, cocares, bonecas indígenas de barro e de madeira, entre outros, além de elementos de caça e combate, como arco e flecha e bordunas. 
Figura 48: Acervo da coleção de etnologia.

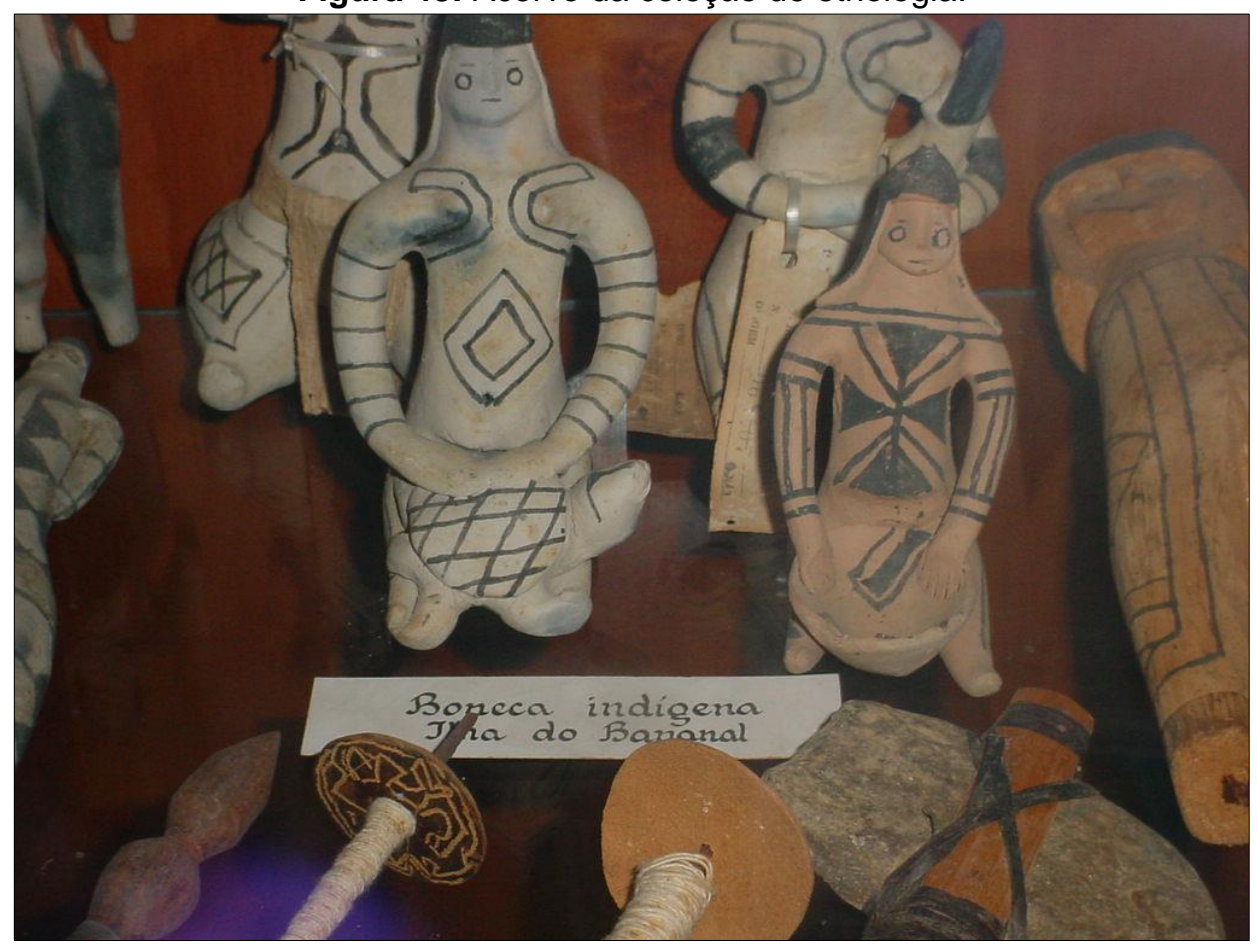

Fonte: MNSA/Santuário Nacional. Foto: Michel H. Oliveira.

Figura 49: Acervo da coleção de etnologia.

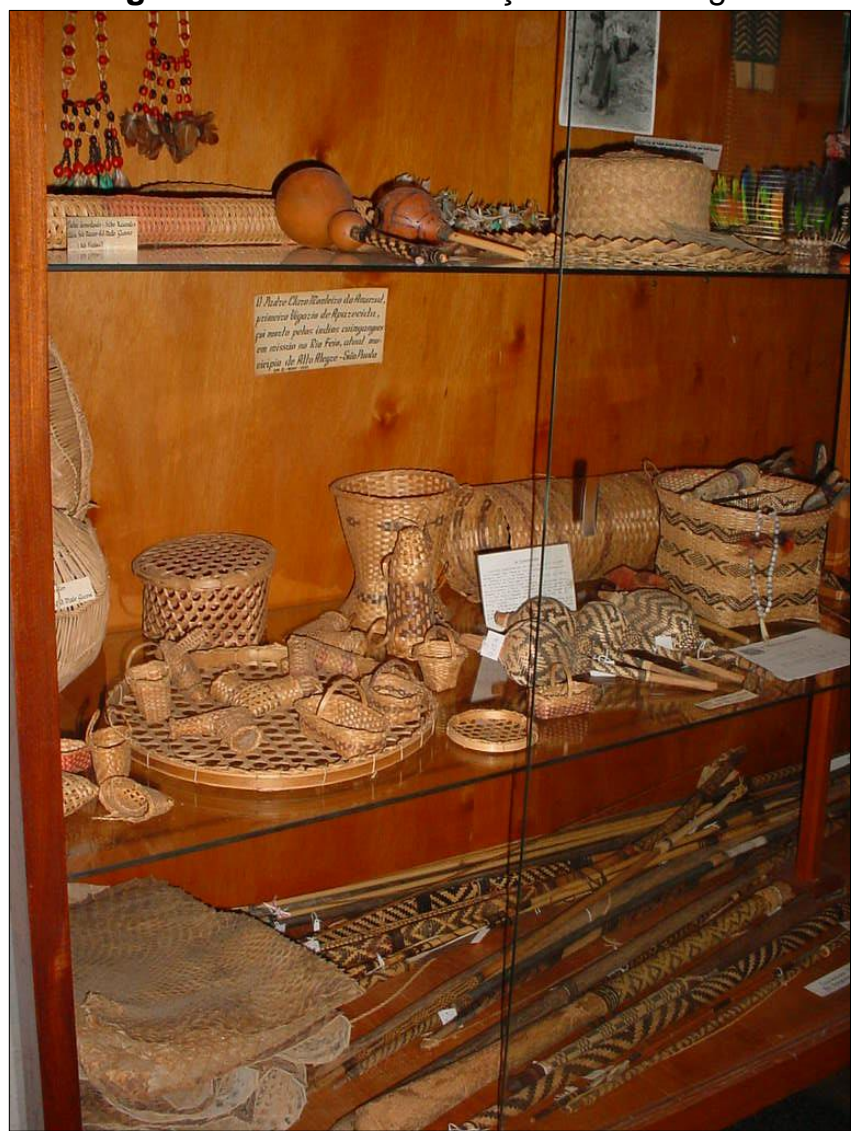

Fonte: MNSA/Santuário Nacional. Foto: Michel H. Oliveira. 
Figura 50: Coleção de animais, não mais existentes no acervo.

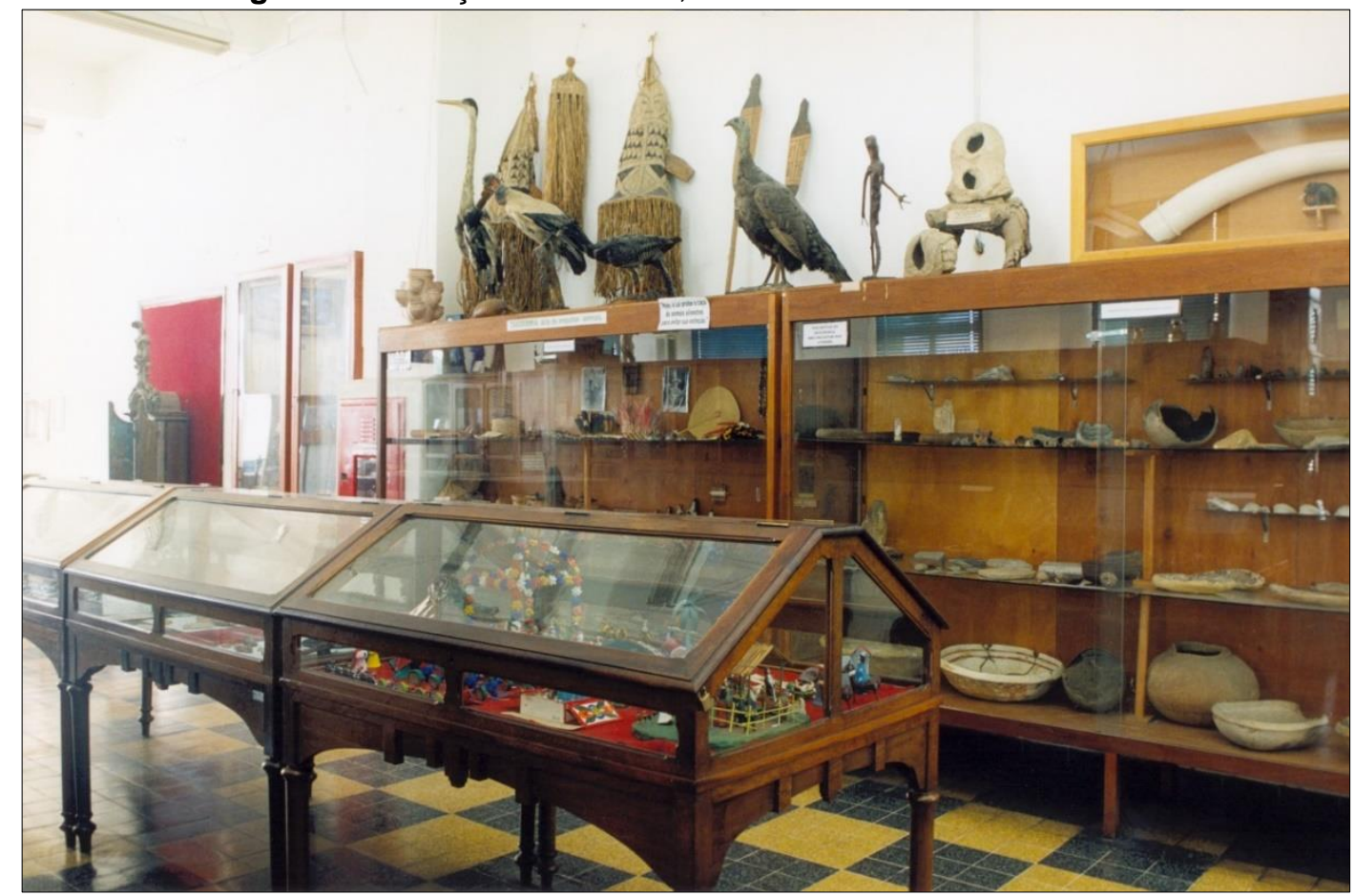

Fonte: MNSA/Santuário Nacional. Foto: Vera de Souza.

Na Figura 50 é possível observar parte da coleção de zoologia, composta por aves, não mais existente no acervo do Museu Nossa Senhora Aparecida. Pois, com o passar dos anos, as aves ficaram comprometidas por fungos e se deterioraram em um depósito, onde ficaram armazenados após a desativação dessa antiga exposição no $2^{\circ}$ andar.

Além das temáticas abordadas em cada conjunto de vitrines, as exposições temporárias eram feitas no próprio ambiente expositivo, conforme as comemorações fixadas no calendário, como por exemplo, o Dia do Índio, a Libertação dos Escravos, o Sesquicentenário do nascimento de D. Pedro II, bem como atividades educativas em estabelecimentos de ensino, como, por exemplo, a realização de palestras, em especial sobre a arqueologia de Aparecida (SP).

Retomando o Roteiro de observação para visita a museus e exposições ${ }^{33}$, quanto à eficácia e qualidade da exposição, consideramos que essa antiga exposição do Museu Nossa Senhora Aparecida, desenvolvida pela Profa. Conceição Borges, apresentava como tema geral a devoção a Nossa Senhora Aparecida, com o intuito de narrar o histórico do aparecimento da imagem e os inúmeros milagres retratados por meio dos ex-votos.

\footnotetext{
${ }^{33}$ Roteiro desenvolvido pela Profa. Dra. Marília Xavier Cury.
} 
Entretanto, não havia um título específico com essa temática e a exposição apresentava recortes conceituais organizados por núcleos de vitrines e armários temáticos, com outros temas e assuntos específicos não relacionados com o tema principal da exposição.

Apesar de não ter sido localizado textos de apoio e de curadoria em painéis ou nas paredes, alguns objetos eram expostos com etiquetas informativas sobre a procedência e com informações dos doadores, bem como havia etiquetas contextualizando parte dos objetos na vitrine.

Em relação ao espaço físico, a exposição ficava em um amplo salão no $2^{\circ}$ andar da Torre Brasília, organizada com corredores de armários e vitrines; não havia salas com assuntos específicos, porém algumas temáticas eram organizadas em determinados espaços da exposição, por exemplo, a Galeria de Personalidades llustres, que ficava nos corredores de entrada, na parte externa da sala da exposição, assim como a Galeria de Brasões Municipais.

Em relação à organização do acervo, havia um grande acúmulo de objetos em exposição, inclusive sobre os armários, fixados nas paredes ou suspensos do teto, ou seja, a exposição ocupava todo o espaço disponível, embora de forma organizada, conforme o conceito adotado pela Profa. Conceição Borges. Entretanto, considerando a maneira em que eram tratados e expostos, alguns objetos ficavam destituídos de seu valor de informação e testemunho.

De acordo com Guido Machado Braga ${ }^{34}$, diretor do Museu Nossa Senhora Aparecida no período de 2003 a 2006, ao assumir a direção no período de reestruturação com consultoria de Giselle Peixe,

\begin{abstract}
Nós desenvolvemos uma série de trabalhos, apesar de ser aquele Museu ainda conhecido da Dona Conceição Borges, as pessoas que conheciam mais a Museologia, achavam que aquilo era um amontado de mostras, de trabalhos, de obras, e os romeiros gostavam demais, enchiam os olhos deles todas aquelas coleções que tinha. Depois houve a necessidade de se transformar. (BRAGA, 2017, informação verbal).
\end{abstract}

Apesar das modificações propostas por Guido Braga posteriormente, em relação à disposição do mobiliário, no início ainda permaneceram com o mesmo trajeto de visitação proposto pela Profa. Conceição Borges, com corredores formados por vitrines e armários, com certas modificações na expografia e redução do acervo em exposição.

34 BRAGA, Guido Machado. Entrevista concedida a Victor Hugo Barros e a Erica Andreza Coelho. Aparecida, 20 set. 2017, 33 min 08 s. Som, Formato MP3. 
Em relação à distribuição do conceito expositivo no espaço, alguns núcleos eram sequenciais, devido à grande quantidade de objetos da mesma tipologia, o que não era possível organizar dentro de um mesmo armário ou vitrine.

Entretanto, os núcleos não eram sequenciais entre si, representando diversos temas de forma episódica. Mas, sem dúvida, identificamos a importância dada aos objetos museológicos, devido à relevância deles no contexto temático de cada núcleo; alguns eram organizados com mais evidência a determinados objetos, como por exemplo, uma instalação que narrava o encontro da Imagem de Nossa Senhora Aparecida.

Nesse período foram utilizados como recursos expográficos apenas etiquetas informativas sobre alguns objetos em exposição e pequenos cartões com textos no interior das vitrines e armários. Foram identificadas também algumas faixas informativas nas bordas superiores dos armários. Mas não foi localizado um painel com ficha técnica da exposição.

Em relação à qualidade dessa comunicação visual, não havia um padrão de tamanho, pois variava de acordo com o tamanho do texto que era manuscrito, ou conforme o espaço disponível na vitrine, seguindo o mesmo estilo de caligrafia, com tinta preta ou azul, em cartões de diversos tamanhos. Algumas etiquetas de acervos eram datilografadas.

Inicialmente as informações eram manuscritas pela própria Profa. Conceição Borges, em cartões com identificação do Museu, contendo informações escritas com caneta esferográfica, conforme observado na Figura 51, até serem produzidas as etiquetas definitivas.

Em relação aos demais textos externos, observamos algumas variações de cor, tamanho e estilo da caligrafia, produzidos de forma manuscrita. 
Figura 51: Etiqueta da antiga exposição.

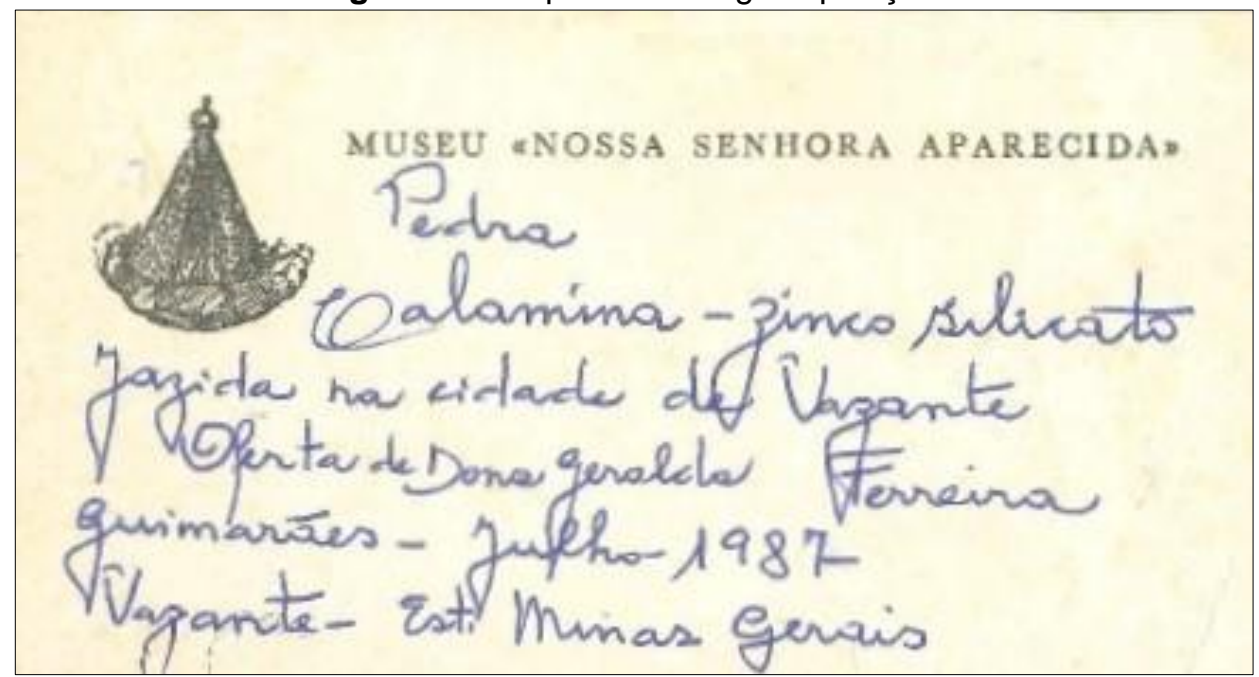

Fonte: MNSA/Santuário Nacional.

Não havia uma sonorização específica e a iluminação, em maior parte, era por luz solar, além da iluminação geral da sala da exposição e corredores externos. Também não havia um equilíbrio entre o mobiliário, comunicação visual e recursos expográficos, apesar da organização temática realizada pela Profa. Conceição Borges. Nesse aspecto, Guido Braga ${ }^{35}$ complementa que, antes de assumir a direção, "havia muita coisa dentro do Museu, era muito diversificado tudo, dando a impressão até de uma desordem visual" (BRAGA, 2017, informação verbal).

Em relação à acessibilidade, podemos considerar a acessibilidade aos cadeirantes, devido ao acesso à exposição por meio dos elevadores, apesar dos corredores entre os armários serem estreitos, devido ao grande fluxo de visitação. Não foram encontrados registros sobre demais recursos para acessibilidade de deficientes auditivos, visuais e de outras naturezas.

Durante a gestão da Profa. Conceição Borges, conforme rascunhos manuscritos dos formulários que compõem o acervo documental do Museu, que foram enviados para o Departamento de Assuntos Culturais no Rio de Janeiro, eram os próprios guardinhas mirins, orientados por ela, que faziam a segurança do espaço e do acervo em exposição fora do mobiliário. Eles eram uniformizados com fardas de guarda e colaboravam também com a orientação do público e esclarecimentos.

Em relação ao financiamento do Museu, inicialmente as coleções foram coletadas e adquiridas pela própria Profa. Conceição Borges, conforme relato de

35 BRAGA, Guido Machado. Entrevista concedida a Victor Hugo Barros e a Erica Andreza Coelho. Aparecida, 20 set. 2017, 33 min 08 s. Som, Formato MP3. 
Tereza Pasin, quando a acompanhava em visitas aos bairros rurais do município de Guaratinguetá (SP), para suas aquisições de imaginárias. Tereza Pasin ${ }^{36}$ argumenta que "Ela comprava. Naquela época era dinheiro vivo, eu lembro que ela levava esse dinheiro guardadinho, juntava bastante, e as pessoas ficavam satisfeitas". (PASIN, 2017, informação verbal). Tereza Pasin acrescenta que,

Nós fomos em casas. Interessante é que uma casa avisava outra casa e, às
vezes, ainda não dava muito bom negócio, voltávamos depois. Eram
passeios bons e eu gostava, eu achava tudo muito bonito, acho que tinha
coisa ali que eu não entendia muito, então eu tinha total apoio da minha
mãe. Eu penso que a Dona Conceição foi muito feliz, porque ela soube
valorizar coisas simples. (PASIN, 2017, informação verbal).

É importante considerar que a renda da bilheteria do Museu era dividida em $50 \%$ para os fundadores e conservadores do Museu e 50\% para o Santuário Nacional de Aparecida. E parte desta renda da Profa. Conceição Borges era destinada para manutenção do Museu e aquisição de novos objetos, que com o tempo foram acrescidos pela doação dos próprios visitantes.

De maneira geral, ao analisar esse conjunto de elementos que foram observados por meio do acervo documental e fotográfico, além dos relatos das entrevistas de pessoas que conviveram com a Profa. Conceição Borges, ou que colaboraram de certa forma com a organização e montagem da exposição, até mesmo administrando o Museu, após o falecimento de Conceição Borges, acreditamos que, apesar da quantidade de objetos em exposição nesse período, o espaço era condizente com a proposta da Profa. Conceição Borges, que era evidenciar a devoção a Nossa Senhora Aparecida, bem como apresentar diversas áreas do conhecimento, organizados por núcleos temáticos, embora não relacionados entre si.

Identificamos, também, que os recursos expográficos e a comunicação visual não eram equilibrados, porém essa deficiência de informações era complementada por abordagens que a Profa. Conceição Borges fazia aos grupos de visitantes, oferecendo monitoramentos espontâneos.

Nesse aspecto, os guardinhas mirins, orientados pela Profa. Conceição Borges, ficavam à disposição para esclarecimento de dúvidas, atuando principalmente na recepção, bilheteria e segurança da exposição.

\footnotetext{
${ }^{36}$ PASIN, Tereza Galvão. Entrevista concedida a Erica Andreza Coelho. Aparecida, 27 dez. 2017, 42 min $05 \mathrm{~s}$. Som, Formato M4A.
} 
Em suma, observamos que a exposição valorizava o patrimônio em sua diversidade, mas, especialmente, o patrimônio com a temática religiosa, conforme relatado por Zenilda Cunha ${ }^{37}$ sobre sua percepção em relação ao trabalho da Profa. Conceição Borges.

Era bastante devota. Então você via o jeito dela, [...] ela transmitia no olhar. Era bacana ela contando toda a vivência dela e tudo colocado ali no Museu, que o sonho dela era deixar lindo, colocar Nossa Senhora, explicar a devoção a Nossa Senhora a partir de toda a região de Aparecida, como Aparecida cresceu. Era muito interessante isso, a vida dela. (CUNHA, 2018, informação verbal).

Acreditamos que o conjunto de elementos era suficiente para o público compreender a proposta da exposição, que inclusive demonstrava bastante interesse em colaborar com doações, conforme informado por Zilda Ribeiro, que assumiu a direção do Museu Nossa Senhora Aparecida, no período de 1996 a 2002 , após falecimento de Conceição Borges Ribeiro Camargo.

De acordo com Zilda Ribeiro ${ }^{38}$, em depoimento concedido a Giselle Peixe e Silvia Bigareli em 2003, "o romeiro que vem que doa, ele faz questão que ponha o nome, porque ele quer falar, '- Olha, procura lá no Museu que lá tem o nome, lá tem o nome de meu pai, que doou isso, doou aquilo"' (RIBEIRO, 2003, informação verbal).

Zilda Ribeiro, ao ser questionada por Giselle Peixe sobre o conhecimento do visitante em relação à existência do Museu, para realizar doações, complementa que normalmente o visitante já conhece o Museu e promete realizar doações em sua próxima visita ao Santuário. Com isso, identificamos um sentimento de pertencimento por parte dos visitantes e doadores que queriam ser reconhecidos.

Entretanto, é preciso considerar a relação do Museu com a chamada Sala das Promessas, e uma possível confusão na identificação dos locais para ofertas de objetos, conforme podemos observar neste trecho do depoimento:

Giselle - Essa coisa do objeto que é dado, que na verdade nem está sendo dado para o Museu, mas que está sendo oferecido para Nossa Senhora. Ele tem uma outra carga simbólica, com significado.

Zilda - Ah, tem. Essa carga simbólica é muito forte.

Giselle - Então, eles são praticamente ex-votos. Não é isso? Uma promessa.

37 CUNHA, Zenilda Cristina da. Entrevista concedida a Erica Andreza Coelho. Aparecida, 10 jan. 2018, $1 \mathrm{~h} 33$ min 17 s. Som, Formato M4A.

38 RIBEIRO, Zilda Augusta. Depoimento concedido a Giselle Peixe e Silvia Bigareli. Aparecida, 2003. $60 \mathrm{~min} 58 \mathrm{~s}$. Som, Cor, Formato vídeo 8mm, com reprodução em DVD. 
Zilda - Exato! Eu acho que isso dá uma história muito bonita, paralela, dá uma história muito bonita, porque eles doam pedras e depois contam uma história daquela pedra. Interessante.

Giselle - Cada objeto tem isso.

Zilda - É. Essa dimensão de ex-voto é muito forte. Tanto que eles misturam um pouco Sala das Promessas com o Museu. Às vezes eles trazem peça para a Sala das Promessas, como ex-votos, e vêm e dizem que foi entregue no Museu, porque para eles o espaço ainda confunde muito a cabeça deles. Então, eles acham que deveria estar aqui porque eles doaram aqui, e não foi, foi na Sala das Promessas.

Giselle - É, nós temos falado sobre isso, um aspecto muito importante, quer dizer, até onde deve ser feita uma distinção nítida do que é Sala de Promessas, do que é o Museu, do que é o Bazar? Por onde entra esse objeto? Se entram primeiro pela Sala dos Milagres, depois vem para cá. Quer dizer, você está dizendo que para o romeiro muitas vezes isso não tem distinção.

Zilda - Não tem. Para ele, tudo ele colou lá, mas ele acha que colou aqui, trouxe para o Museu e até diz "- Mas eu entreguei para a senhora" e quando vê a peça está lá ou esteve lá. (RIBEIRO, 2003, informação verbal).

De maneira geral, era função do Museu identificar esse significado do objeto no momento da doação, mas, muitas vezes, acabavam com lacunas de informações, que com o tempo passaram a ter um novo tratamento com a implantação de um Termo de doação de bens móveis, no início da década de 1990, conforme mencionado anteriormente.

Em suma, essa antiga exposição do Museu Nossa Senhora Aparecida foi uma das primeiras criadas na região do Vale do Paraíba, com um valor histórico e artístico altamente significativo para a região e para o local em que estava instalado, buscando valorizar a devoção a Nossa Senhora Aparecida e cumprindo sua função didática e pedagógica.

Acreditamos que no início houve dificuldades para estabilização do Museu, tendo sido necessária mudança de endereço em um curto intervalo de tempo. Entretanto, com o apoio dos Missionários Redentoristas, respaldado pelo Contrato de Doação do Museu ao Santuário Nacional de Aparecida, a Profa. Conceição Borges e seu esposo Vicente Camargo receberam incentivos e colaborações para ampliação do Museu, ao ser instalado na Torre da Basílica Nova de Nossa Senhora Aparecida, em 1967, tendo se estabilizado e permanecendo nesse local até os dias atuais. 


\subsection{Museu dos Ciclos Socioeconômicos do Vale do Paraíba}

O Museu dos Ciclos Socioeconômicos do Vale do Paraíba, inaugurado no dia 20 de setembro de 1975, no 3ํandar da Torre Brasília - Santuário Nacional de Aparecida, foi idealizado pela Profa. Conceição Borges Ribeiro Camargo e seu esposo Vicente Camargo, em parceria com o Prof. Paulo Camilher Florençano, do município de Taubaté (SP), com apoio do Cardeal Dom Carlos Carmelo de Vasconcellos Motta, Arcebispo de Aparecida (SP), e autorização das autoridades eclesiásticas, para instalação do Museu na Torre do Santuário Nacional de Aparecida.

A Figura 52 retrata a inauguração do Museu dos Ciclos Socioeconômicos do Vale do Paraíba.

Figura 52: Inauguração do Museu dos Ciclos Socioeconômicos do Vale do Paraíba, 3ํo andar da Torre Brasília, 1975.

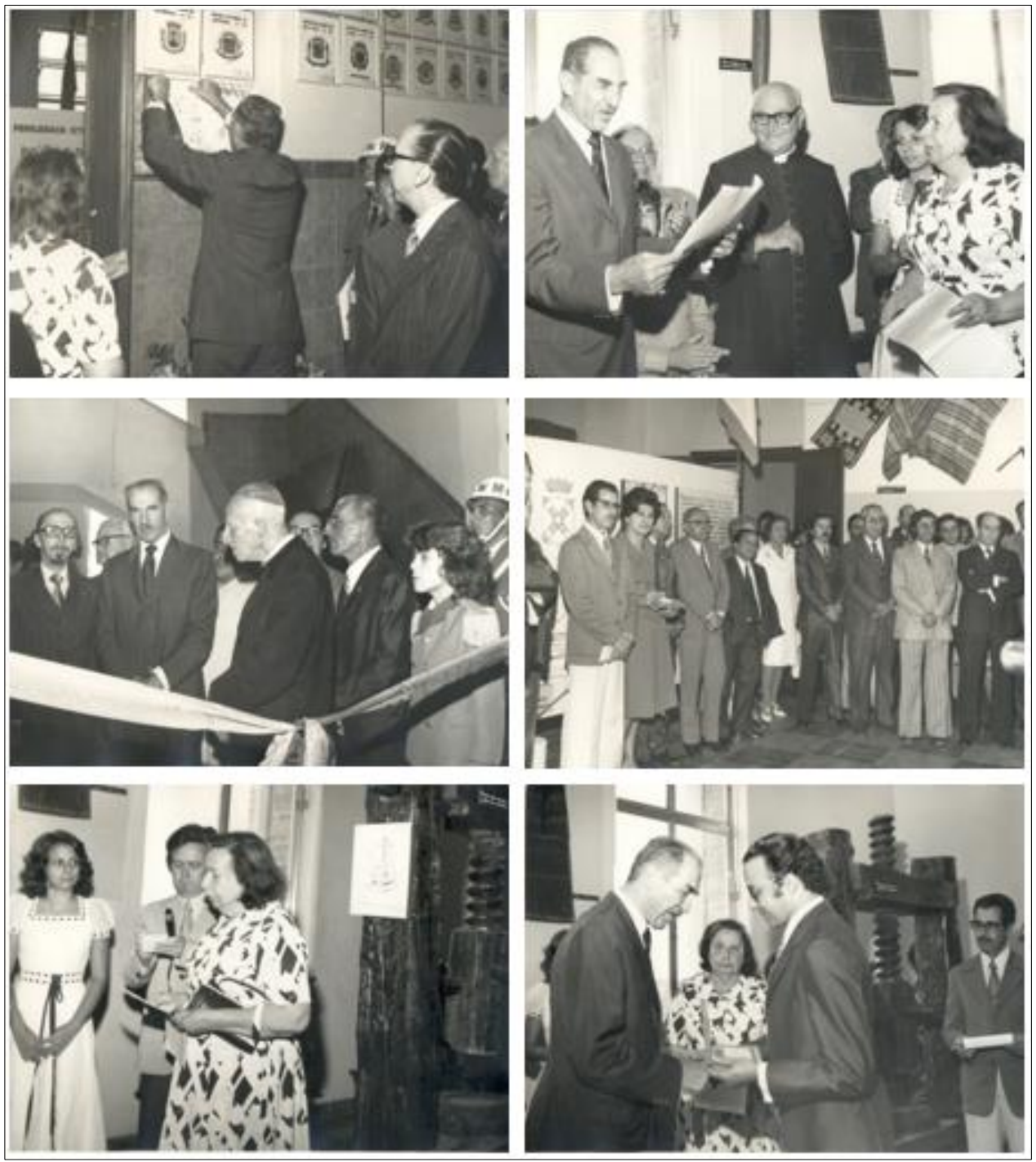

Fonte: MNSA/Santuário Nacional. 
De acordo com o Convite de Inauguração (1975), o Museu foi inaugurado durante as comemorações do sesquicentenário do nascimento de Dom Pedro II, contando com a presença de Dom Pedro de Orleans e Bragança, conforme podemos observar no livro de assinaturas da inauguração (Figura 53).

Figura 53: Livro de assinaturas da inauguração do Museu.

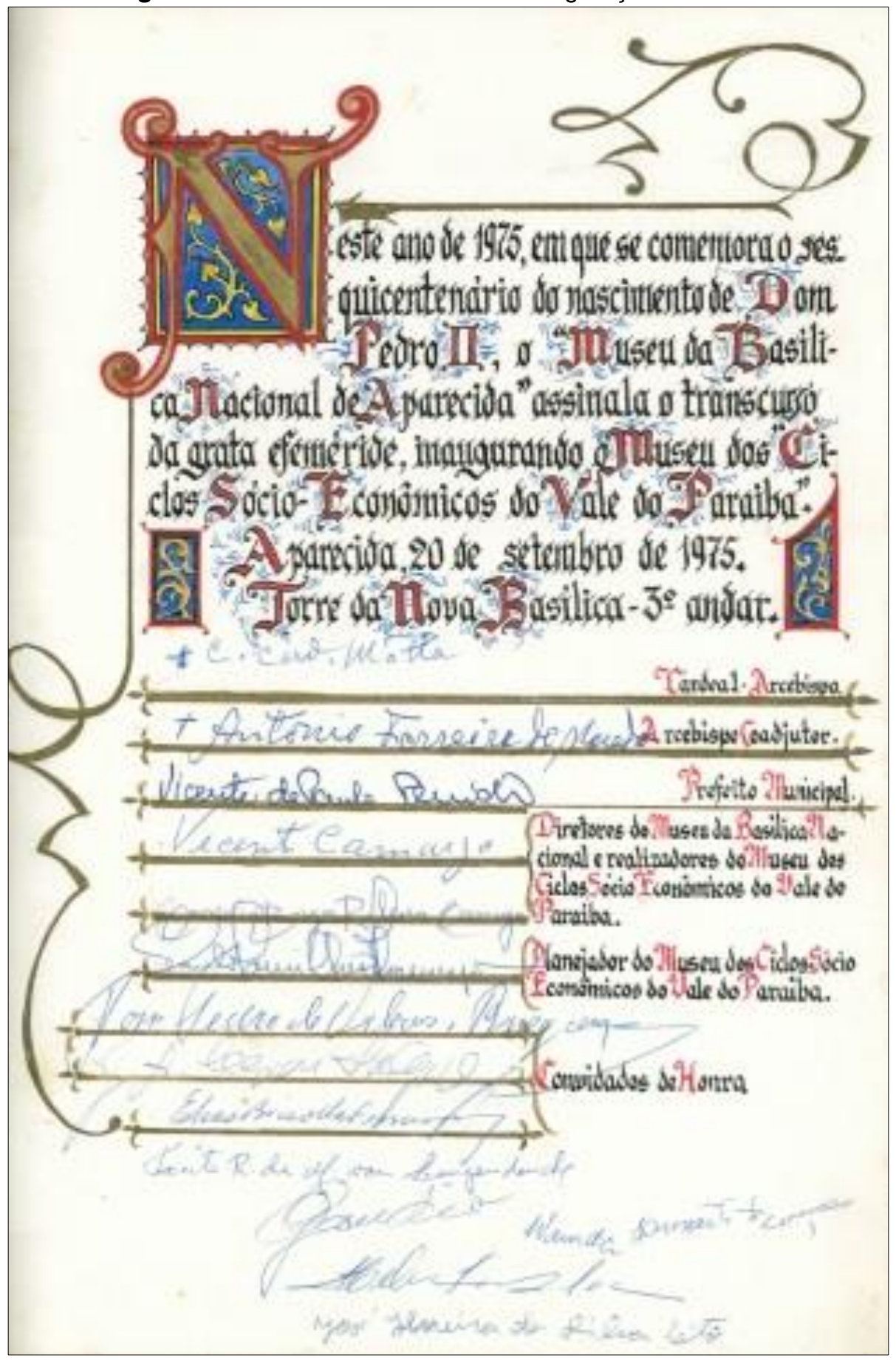

Fonte: MNSA/Santuário Nacional. 
Além de Dom Pedro de Orleans e Bragança, ao ato da inauguração diversas personalidades se fizeram presentes, como consta no jornal Santuário de Aparecida, de 05 de outubro de 1975:

[...] Se fizeram presentes: Dom Carlos Carmelo de Vasconcellos Motta, Cardeal Arcebispo; Dom Antônio Ferreira de Macedo, Arcebispo Coadjutor; Sua Alteza o Príncipe Dom Pedro Gastão de Orleans e Bragança; Comendador Vicente de Paulo Penido, Prefeito Municipal e esposa; Professor Gentil Vian, vice-Prefeito; Professor Paulo Camilher Florençano, planejador do Museu e esposa; Doutor Ataliba Nogueira, ex-secretário da Educação; Comendador Elias Brisolla Ferreira, Presidente da Sociedade dos Amigos da Padroeira do Brasil; Comendador José Augusto César Salgado, da Academia Paulista de Letras; Doutor Francisco Assis Barbosa, da Academia Brasileira de Letras; Benevides Beraldo da Ordem dos Cavaleiros de São Paulo; Padre José Pereira Neto; Professor Agostinho Ramos, representando o Instituto Histórico e Geográfico de São Paulo; Doutor Tácito R. de $\mathrm{M}$. von Zangendonck; Prefeitos, autoridades e representantes de Fábricas do Vale do Paraíba e de entidades culturais de São Paulo, Rio de Janeiro e Minas Gerais. (SANTUÁRIO DE APARECIDA, 1975)

Segundo o manuscrito para divulgação do novo Museu, após as oratórias, ofertou-se uma imagem fac-símile de Nossa Senhora Aparecida a Dom Pedro de Orleans e Bragança, tendo sido entregue por aparecidenses descendentes dos componentes da Guarda de Honra de Dom Pedro I a caminho do Ipiranga, conforme relato a seguir, que foi manuscrito pela Profa. Conceição Borges Ribeiro Camargo.

Neste ano de 1975, em que se comemora o sesquicentenário do nascimento de Dom Pedro II, o Museu da "Basílica Nacional de Aparecida" assinalou o transcurso da efeméride inaugurando no dia 20 de setembro 0 Museu dos "Ciclos Sócio-Econômicos do Vale do Paraíba".

Em frente à Nova Basílica, a Fanfarra do Ginásio La Salle saudou o Príncipe Dom Pedro Gastão de Orleans e Bragança, convidado de Honra e autoridades, com o Hino da Independência.

Tendo sido inaugurada uma placa comemorativa, os Diretores do Museu, Vicente Camargo e Professora Conceição Borges Ribeiro Camargo, receberam os convidados, tendo a Professora Conceição Borges saudado Sua Alteza Dom Pedro, lembrando as visitas da Princesa Isabel e do Conde d'Eu à antiga Capela de Aparecida.

Usou da palavra o Professor Paulo Florençano, planejador do Museu, apresentando-o.

Foram apresentados ao Príncipe Dom Pedro Gastão aparecidenses descendentes dos componentes da Guarda de Honra de Dom Pedro a caminho do Ypiranga e descendentes das jovens que no dia 6 de novembro de 1884 jogaram pétalas de rosas na Princesa Isabel, que em companhia de seu esposo o Conde d'Eu, visitaram Nossa Senhora Aparecida.

Da família aparecidense representada nesses descendentes, o Príncipe recebeu uma imagem fac-símile da verdadeira imagem de Nossa Senhora Aparecida, que no momento foi benzida por Sua Eminência o Cardeal Dom Carlos Carmelo de Vasconcellos Motta, bisneto do Visconde de Caeté, um estojo com placa de prata alusiva à inauguração, um ramalhete de rosas para a Princesa Dona Esperanza de Borbon de Orleans e Bragança.

Dom Antônio Ferreira de Macedo ofertou à Sua Alteza uma fotografia de seus pais, o Príncipe Dom Pedro de Alcântara Orleans e Bragança e Dona Maria Elisabeth que com sua filha Dona Francisca, vieram orar aos pés de 
Nossa Senhora Aparecida. Ladeando os ilustres visitantes, o Vigário Padre Francisco Wand e o Padre Macedo hoje Arcebispo Coadjutor.

Dona Conceição Borges contou que a Nova Basílica está ao lado da Praça Princesa Isabel.

Em seu agradecimento o Príncipe fez alusão ao fato de a inauguração ter sido realizada no ano do sesquicentenário do nascimento de Dom Pedro II, evocando uma vinda em Aparecida com seus pais, sendo recebido no solar do Comendador Augusto Marcondes Salgado, após a Missa na Basílica.

O Museu inaugurado no dia 20 de setembro está no $3^{\circ}$ andar da Torre da Nova Basílica. (CAMARGO, s. d.).

Esse Museu foi classificado pelos seus organizadores como um Museu Histórico, Didático e Pedagógico, com o intuito de apresentar a história socioeconômica da região do Vale do Paraíba, numa sequência cronológica de ciclos, desde a chegada do colonizador até o desenvolvimento industrial.

Nesse contexto, o Prof. Paulo Camilher Florençano, que também atuou nos museus Casa do Bandeirante e Casa do Grito em São Paulo, realizou um trabalho inédito e pioneiro no Vale do Paraíba, ao aplicar técnicas de caráter didático e funcional para criação do Museu dos Ciclos Socioeconômicos do Vale do Paraíba.

De acordo com o jornal Santuário de Aparecida de 05 de outubro de 1975, a história era apresentada no Museu "através de painéis dispostos de modo a estabelecer "itinerário obrigatório" aos visitantes, sendo neles fixados textos suscintos, pinturas, mapas, roteiros, quadros (alguns absolutamente originais e criados especialmente para o museu), fotografias e reproduções de gravuras, objetos ligados à história".

Além desses elementos visuais, havia objetos de grande porte contextualizando cada núcleo, bem como vitrines com acervos coletados, em sua maior parte, por Vicente Camargo, com o intuito de descrever a evolução do Vale do Paraíba.

Segundo a Profa. Conceição Borges, em manuscrito referente à História dos Ciclos Socioeconômicos, "o nosso tema é valorizar o Patrimônio Turístico das cidades valeparaibanas no circuito histórico social e econômico" (CAMARGO, 1992, p. 1).

Embora não seja possível fazer uma visita exploratória à exposição, conforme consta no Roteiro de observação para visitas a museus e exposições ${ }^{39}$, o acervo documental com parte do projeto expográfico, artigos de jornais e fotografias, são

\footnotetext{
${ }^{39}$ Roteiro desenvolvido pela Profa. Dra. Marília Xavier Cury.
} 
referências para análise da exposição, que ficou aberta ao público entre os anos de 1975 a 1993.

De maneira geral, a exposição era organizada por núcleos que abordavam os seguintes temas e acervos: Ciclos da Subsistência, com trinta e oito peças; Ciclos do Bandeirismo, com trinta e cinco peças; Ciclos da Cana de Açúcar, com onze peças; Ciclos do Café, com sessenta e três peças; Ciclos da Economia Mista, com cinco peças, e o Ciclo Industrial, com duas peças. Totalizando cento e cinquenta e quatro peças em exposição no $3^{\circ}$ andar da Torre Brasília.

A Figura 54 apresenta o texto de abertura da exposição, com características de uma ficha técnica, informando os nomes dos organizadores, o apoio oficial das autoridades eclesiásticas, assim como o planejamento e a elaboração dos textos, com sentido didático, desenvolvidos pelo Prof. Paulo Camilher Florençano, artista, historiador e museólogo.

Em relação à diagramação visual, foi realizada manualmente pelo pintor José Roberto dos Santos, sendo substituído posteriormente pelo pintor e professor Carlos Eduardo Murad, com auxílio do letrista Olavo Couto, responsável pela reprodução das etiquetas e textos produzidos pela Profa. Conceição Borges e o pelo Prof. Paulo Camilher Florençano.

Figura 54: Texto de abertura da exposição.

$$
\text { Este. Nuseu... }
$$

foi realizado pelo sr. Ticente bamargo e pela frofessora Goncicao Borges Ribcizo bamazgo, conservadores do Nuseu da Basilica Nacional dé lossa fenhoza Apareci. da, localizado no zandar da Torze, com autorizacão e apoio oficial das autoridades eclesiásticas da Arquidiocese de Apazecida:D. Cazlos bazuelo de vasconcellos lotta, D. D. Bazdeal Azcebispo e D. Antonio Ferzeiza de Ilacedo, Arcebispo boad jutor, e Padre Toé Potillo, Administrador Geral da Basilica. Oplanejaurento, a elabroza sâo dé textos e croquis, o sentido diadático e a dizecáo geral de sua instalasâo couberaun ao Professor Paulo Eamilher Filorencano, artista, historiador e museólogo, de. Taubate: Yeudo este 1) (usen resultado de equipe, o piutor Professor barloseduardo eo letrista Clavo bouto nerecem honzosa citacaio.

Fonte: MNSA/Santuário Nacional. 
As Figuras 55, 56 e 57 são referentes ao Ciclo da Subsistência. De acordo com a Profa. Conceição Borges R. Camargo (1992), o Ciclo da Subsistência abrange o período de 1639 a 1680, compreendendo a lavoura de subsistência, caça, pesca e criação de gado e de suínos em pequena escala.

Conforme Devide (2013), as colônias agrícolas foram implantadas com o intuito de incentivar a produção de cereais e legumes. Nesse contexto, "a vocação agropecuária inicialmente foi baseada em culturas de subsistência localizadas nas rotas do ciclo do ouro" (DEVIDE, 2013, p. 11).

De acordo com Marcondes (1998), os bens de subsistência representaram parcela significativa da produção na região do Vale do Paraíba, porém grande parte dos bens era consumida na fazenda produtora, não chegando a ser comercializada.

A Profa. Conceição Borges R. Camargo (1992) acrescenta que, nessa época, no Vale do Paraíba havia moradores vindos de São Paulo, Mogi das Cruzes, Angra dos Reis, São Vicente e, principalmente, portugueses.

De acordo com a autora, nas primitivas fazendas utilizaram-se força braçal dos índios e, mais raramente, de escravos africanos. Com o passar do tempo, no século XVIII já havia três vilas na região do Vale do Paraíba, sendo elas: Taubaté, Jacareí e Guaratinguetá, assim como dois povoados ligados ao patrimônio religioso, Pindamonhangaba e Tremembé, além de dois aldeamentos indígenas, Nossa Senhora da Escada e São José.

Nesse contexto, de acordo com Marcondes (1998), este crescimento abriu oportunidades de acumulação de riqueza para uma parcela da população, considerando que os comerciantes e produtores rurais beneficiaram-se das transformações econômicas na região.

Para o autor, "as estradas e o crescimento agrícola também favoreceram a expansão do comércio e de uma rede de suporte para as tropas de passagem pela região" (MARCONDES, 1998, p. 26).

Ainda segundo o autor, "os bens de subsistência eram cultivados não apenas para o consumo próprio da família do agricultor e seus escravos e agregados, mas se comercializava o excedente na região" (MARCONDES, 1998, p. 47).

De maneira geral, a encruzilhada de caminhos contribuiu com 0 desenvolvimento da agricultura regional, considerando que o cultivo dos bens de subsistência também estava aliado à produção de exportação. 
Nesse contexto, conforme Marcondes (1998), alguns cultivos permaneceram ao longo do período, sendo identificados como tradicionais produtos de subsistência, entre eles o milho, arroz, feijão e a farinha de mandioca, além do algodão e dos produtos exportáveis, como o fumo e aguardente.

Figura 55: Aspecto interno da exposição - Ciclo da Subsistência.

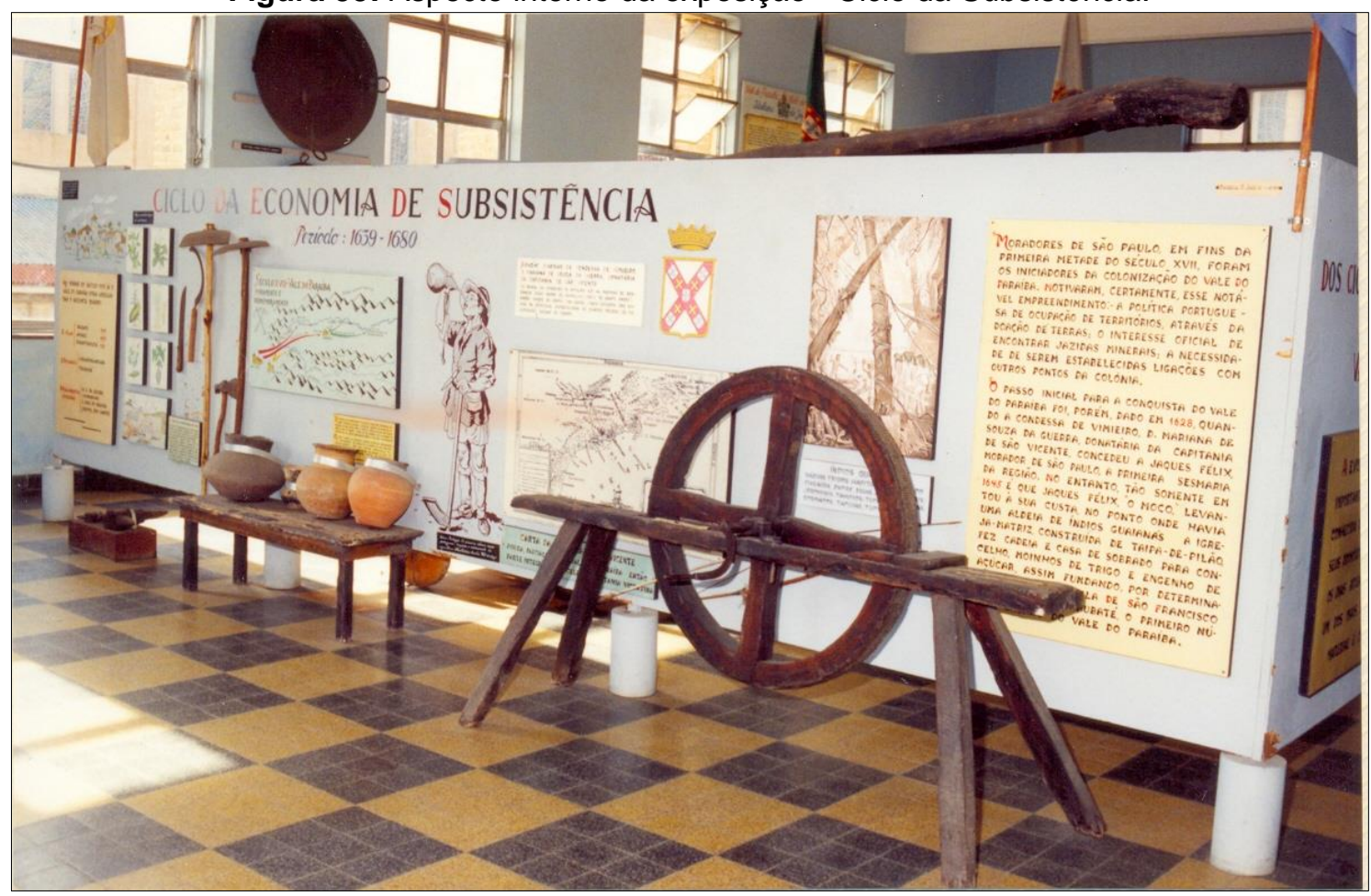

Fonte: MNSA/Santuário Nacional.

Figura 56: Aspecto interno da exposição - Ciclo da Subsistência.

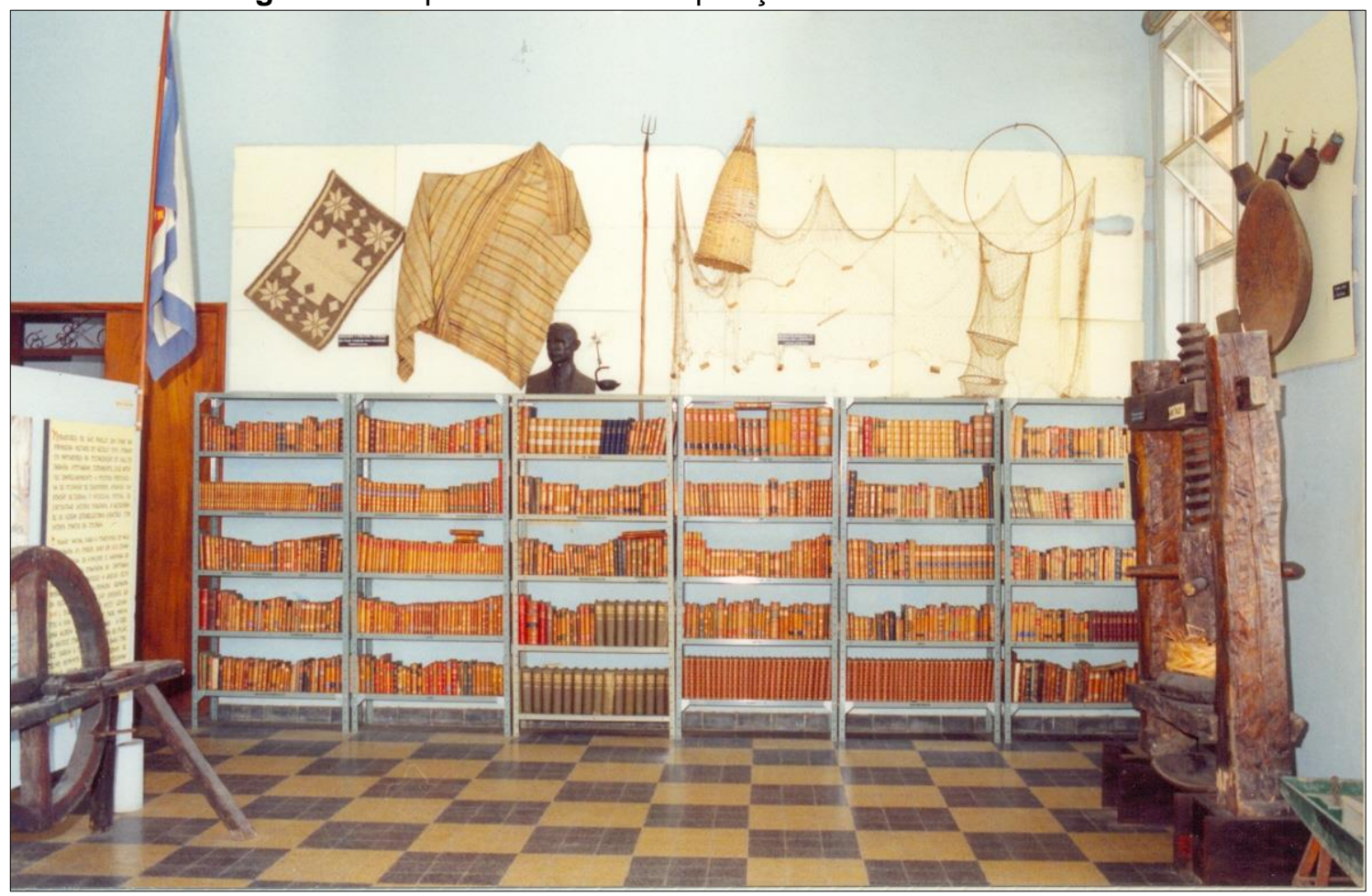

Fonte: MNSA/Santuário Nacional. 
Figura 57: Aspecto interno da exposição - Ciclo da Subsistência.

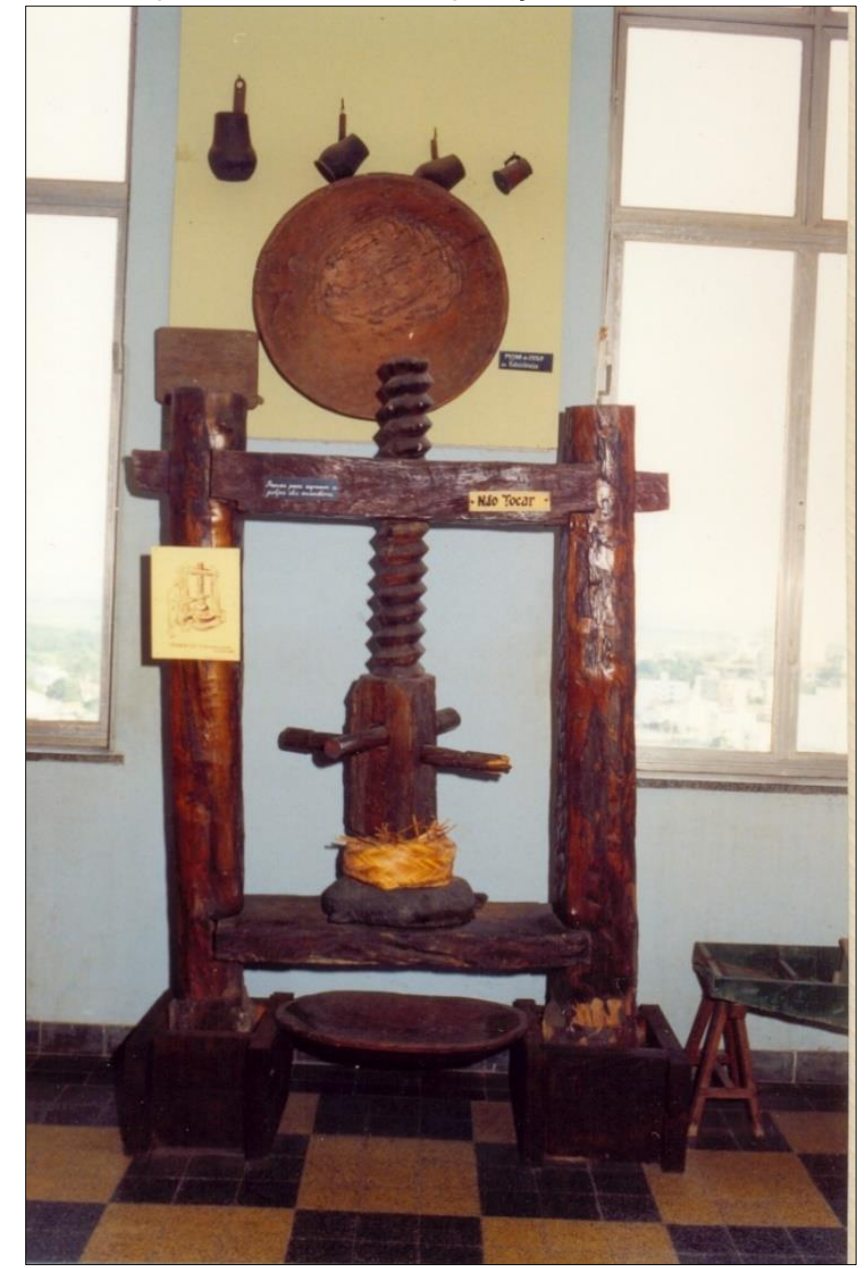

Fonte: MNSA/Santuário Nacional.

As Figuras 58, 59 e 60 são referentes ao Ciclo Bandeirista, dando início ao surgimento dos primeiros caminhos e povoamentos na região do Vale do Paraíba. Nesse sentido, os bandeirantes foram os precursores na configuração do espaço paulista.

De acordo com a Profa. Conceição Borges R. Camargo (1992), o mais expressivo roteiro bandeirista do século XVIII é o celebre Roteiro de Antonil - André João Antonil, que indica a trilha para a mineração. As vilas e povoados no Vale do Paraíba enviaram os bandeirantes em destino a Minas Gerais, tornando-os fundadores de futuras cidades para abastecimento dos núcleos, em virtude dos achados auríferos.

De acordo com Lima (2011), a "bandeira" pode-se relacionar a um costume tupiniquim, referido por Anchieta, ao levantar-se uma bandeira em sentido de guerra, mas também pode estar relacionada à partida de homens para aprisionamento e 
escravização indígena ou, até mesmo, à maneira em que foram organizadas as incursões ao interior.

Segundo o autor, "seja para fins de reconhecimento, seja para combater e escravizar indígenas, seja para efetuar buscas a pedras e metais preciosos, interessa verificar o seu revestimento oficial ou não" (LIMA, 2011, p. 16). Pois, de acordo com o autor, houve o ciclo das entradas sertanistas e o ciclo das bandeiras, sendo o primeiro comandado oficialmente pela Coroa; já o segundo ocorreu espontaneamente por particulares, excepcionalmente paulistas.

Figura 58: Aspecto interno da exposição - Ciclo Bandeirista.

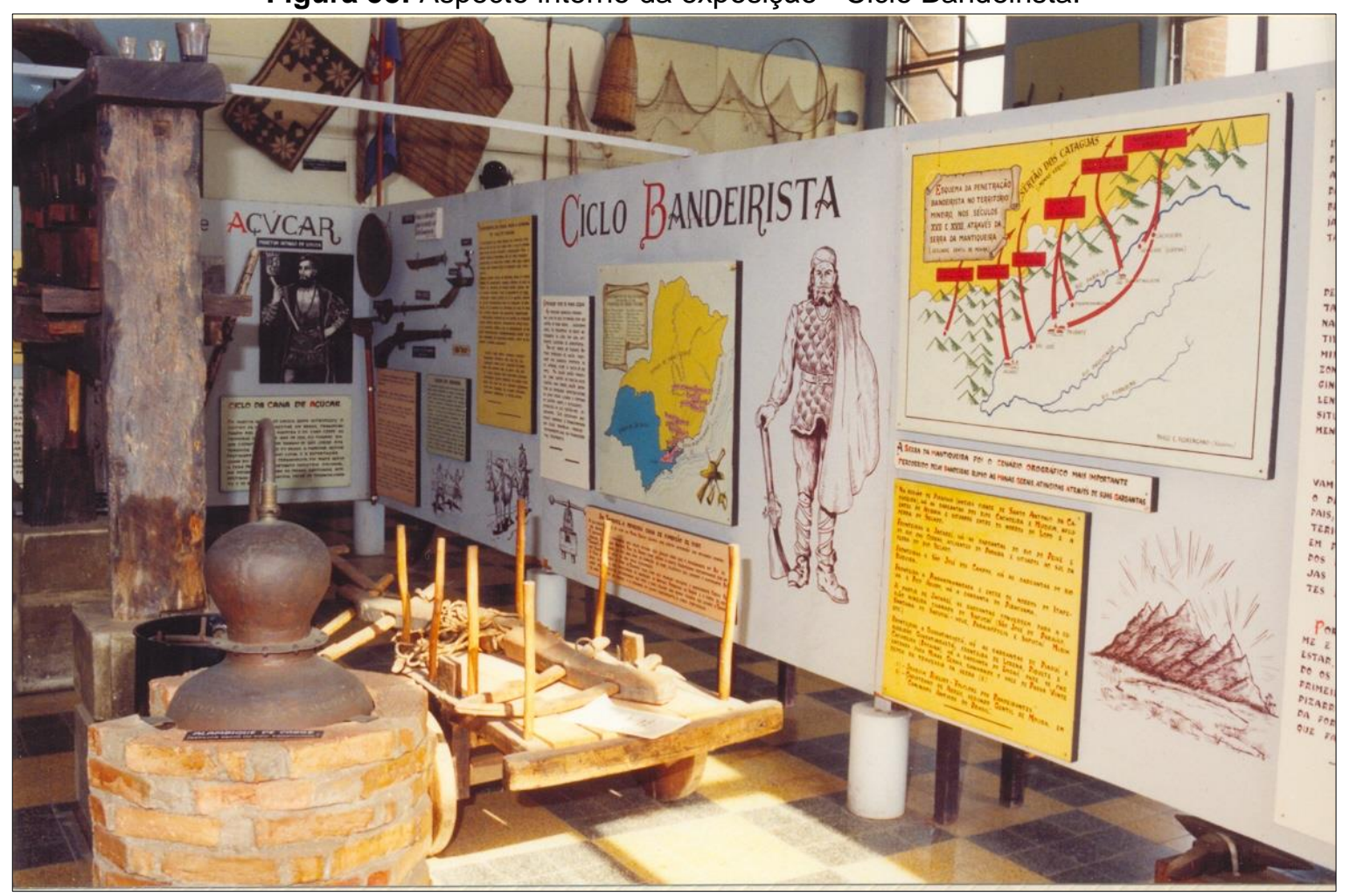

Fonte: MNSA/Santuário Nacional. 
Figura 59: Aspecto interno da exposição - Ciclo Bandeirista.

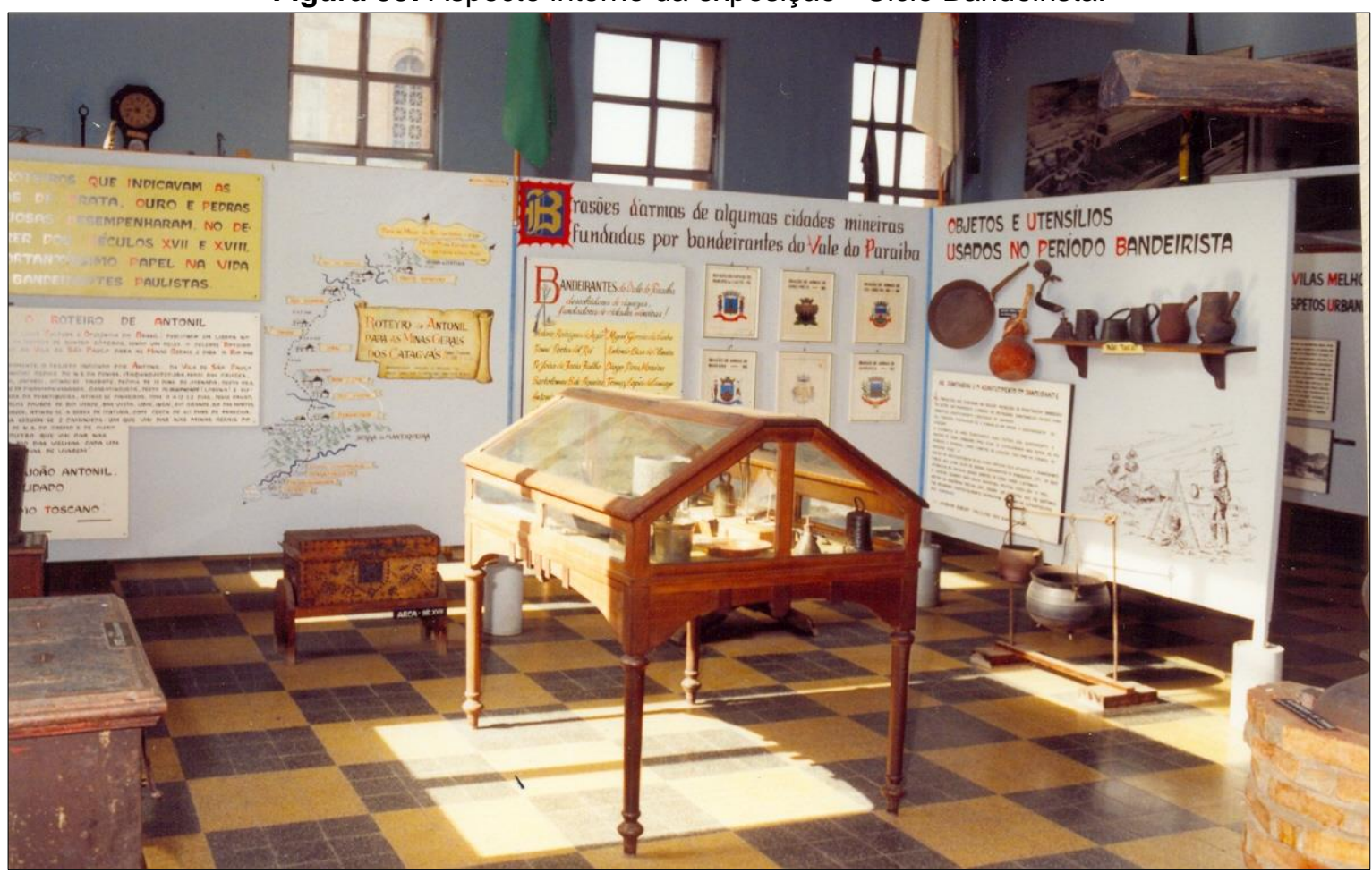

Fonte: MNSA/Santuário Nacional.

De maneira geral, o Ciclo Bandeirista representa as expansões territoriais, em especial no interior paulista, em virtude dos escassos recursos naturais, com a necessidade de buscar alternativas econômicas além da agricultura para exportação, associada ao aprisionamento de índios, no sentido de avançar nas buscas por metais e pedras preciosas. Nesse sentido, o bandeirismo foi um fenômeno que buscou sustentar a crescente economia de São Paulo, oferecendo mão-de-obra para produção agrária e pecuária.

De acordo com Lima (2011), as bandeiras se configuravam como a nova dinâmica econômica e sociocultural, estando atrelada ao apresamento indígena. E mais, "o esforço dos colonos em manter o funcionamento da escravidão indígena, peça fundamental para a evolução produtiva da região, mostra o quanto se dependia desta instituição que, de fato, era o elemento de ligação com o sistema colonial de exploração" (LIMA, 2011, p. 30). 
Figura 60: Aspecto interno da exposição - Ciclo Bandeirista.

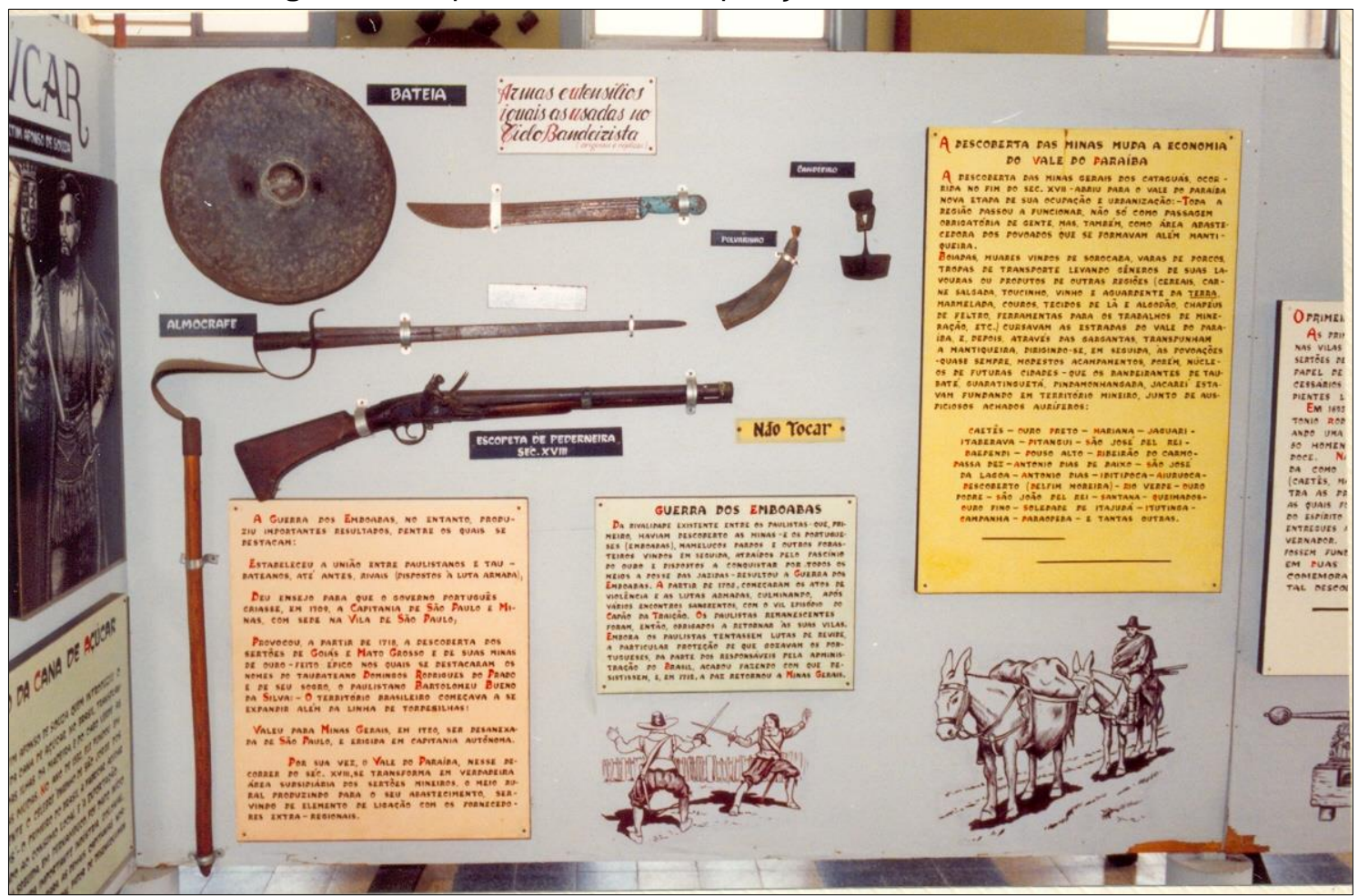

Fonte: MNSA/Santuário Nacional.

As Figuras 61, 62 e 63 são referentes ao Ciclo da Cana-de-Açúcar. De acordo com a Profa. Conceição Borges R. Camargo (1992), aproximadamente entre os anos de 1780 a 1830, as fazendas situadas no Vale do Paraíba, que se destacam no roteiro histórico, passaram a se formar como unidade de importância econômica, cultivando a cana para produção de aguardente, açúcar, e este, deste modo geral, sob forma de rapadura. De acordo com a autora, considera-se que a vinda de escravos africanos tenha sido um dos mais importantes fatores de desenvolvimento econômico da região. Com isso, inicia-se a fase de expressão econômica do Vale do Paraíba, que pode ser observada por meio das obras de Debret e do pintor austríaco Thomas Ender.

De maneira geral, os fazendeiros que eram proprietários de engenho tornamse personagens importantes para a política e administração do país. E, aos poucos, os aspectos urbanos vão se modificando, ampliando-se as residências com mais conforto e qualidade arquitetônica, assim como com a construção de igrejas. A autora também argumenta que, nesse período, o fator histórico e econômico era determinado pelo poder aquisitivo e teor cultural das famílias. 
Figura 61: Aspecto interno da exposição - Ciclo da Cana-de-Açúcar.

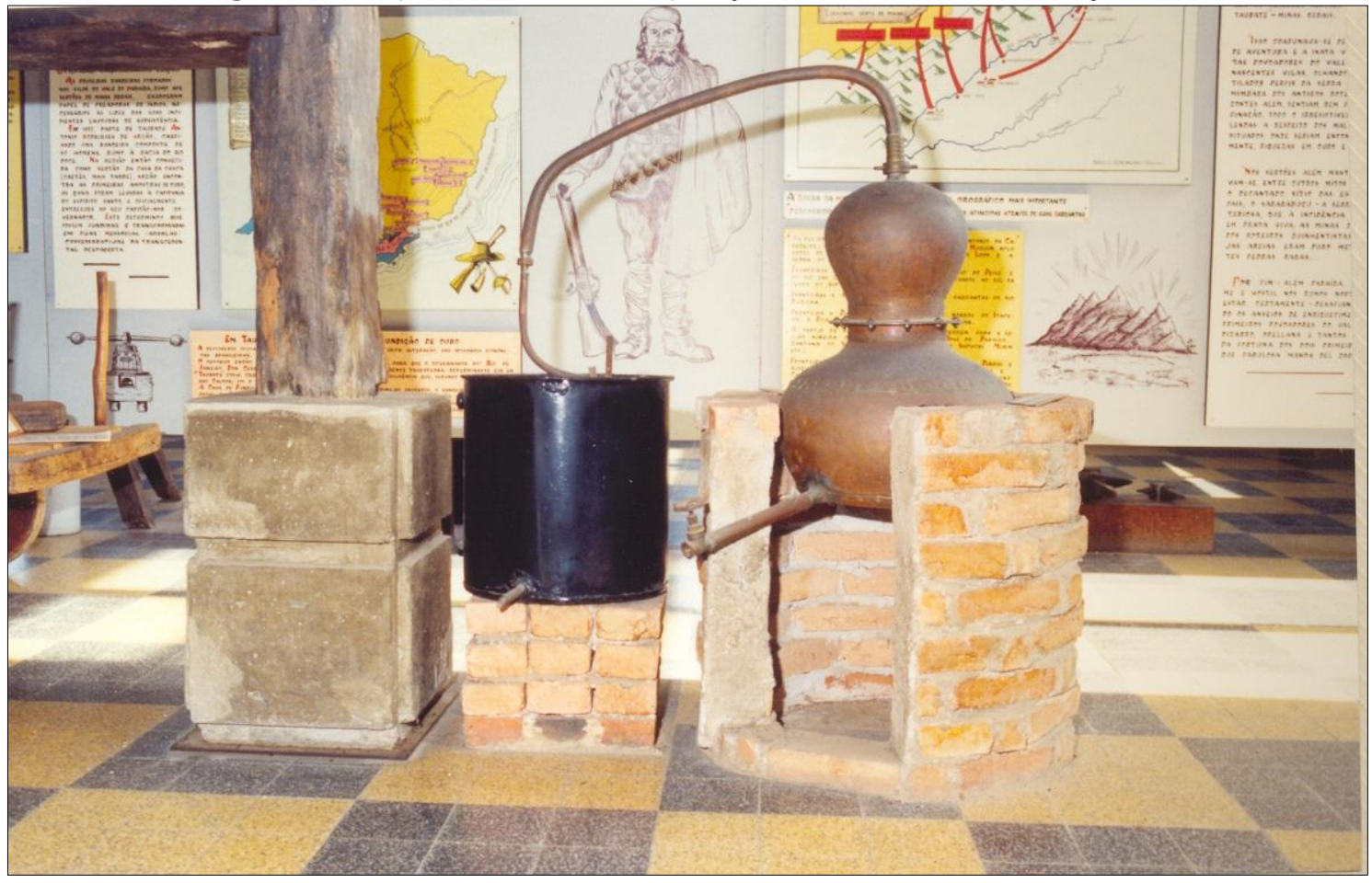

Fonte: MNSA/Santuário Nacional.

Segundo Marcondes (1998), com a decadência da mineração, o desenvolvimento do cultivo da cana-de-açúcar apontava para uma situação distinta em São Paulo, considerando a expansão da produção de derivados da cana que se destinavam na maioria das vezes ao mercado interno brasileiro, especialmente para as Minas. De acordo com o autor, "os senhores de engenho possuíam recursos mais elevados do que os produtores de subsistência" (MARCONDES, 1998, p. 53). Entretanto, com o passar do tempo e início do cultivo do café, o autor acrescenta que,

Os produtores de derivados de cana-de-açúcar perderam a preponderância da exportação para os cafeicultores a partir da terceira década do século XIX. Contudo, verificamos uma certa permanência da importância da produção de derivados de cana-de-açúcar, não sendo abandonados em favor da rubiácea. [...] De fato, em 1829, a grande maioria dos produtores da cana-de-açúcar, que continuaram no seu cultivo, realizaram sua produção aliada à do café. (MARCONDES, 1998, p. 49). 
Figura 62: Aspecto interno da exposição - Ciclo da Cana-de-Açúcar.

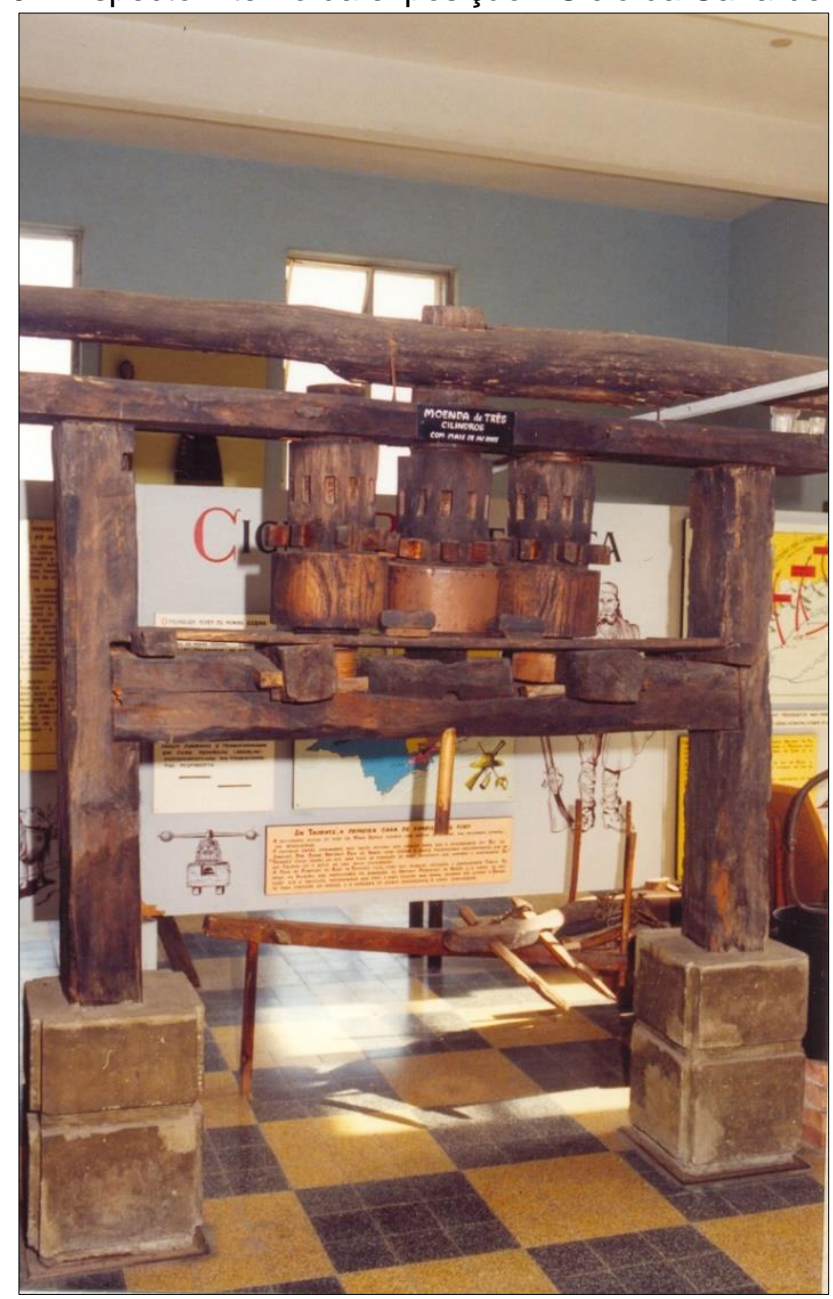

Fonte: MNSA/Santuário Nacional.

Figura 63: Aspecto interno da exposição - Ciclo da Cana-de-Açúcar.

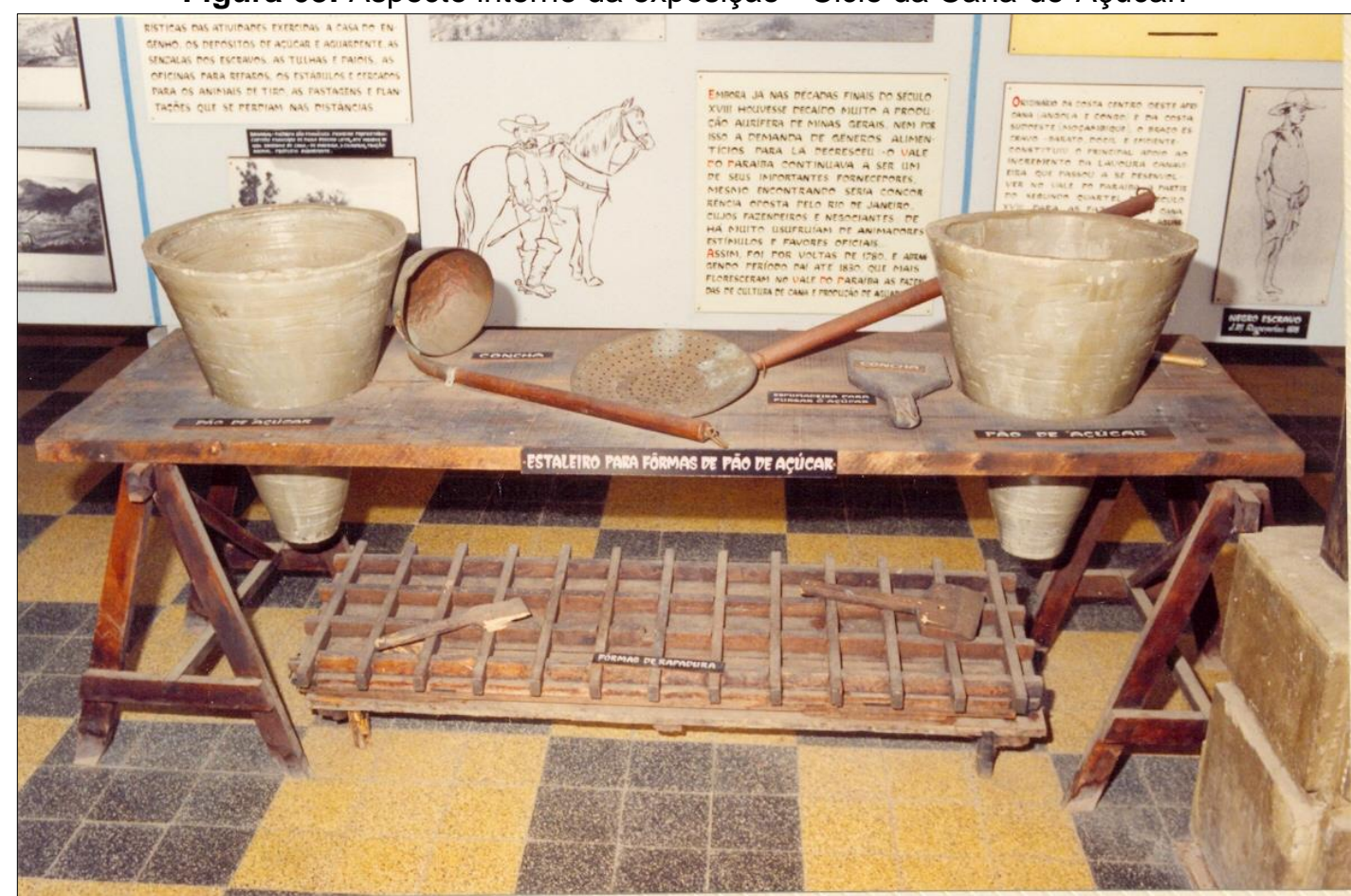

Fonte: MNSA/Santuário Nacional. 
Para Marcondes, a inauguração do Engenho Central, em 1884, foi o marco principal neste novo dinamismo da cana-de-açúcar. Todavia, "os montantes passíveis de inversão no cultivo do cafeeiro variavam de acordo com o porte do agricultor" (MARCONDES, 1998, p. 53).

As Figuras 64, 65 e 66 são referentes ao Ciclo do Café. De acordo com a Profa. Conceição Borges R. Camargo (1992), o Ciclo do Café trouxe ao Vale do Paraíba o seu esplendor econômico, formando uma aristocracia rural, composta também por Titulares do Império com diversos graus, tais como: Comendadores, Cavaleiros, Barões, Condes, Viscondes, que constituíram a base da sociedade do Vale do Paraíba.

De maneira geral, conforme Marcondes (1998), o cultivo do café assumiu papel fundamental no desenvolvimento econômico e demográfico na região do Vale do Paraíba durante o século XIX. De acordo com o autor, a introdução do cultivo do café condicionou-se pela existência prévia da atividade agrícola na região, seja de subsistência ou de exportação, baseando na cana-de-açúcar e no fumo (MARCONDES, 1998, p. 26).

Segundo Carrilho (2006, p. 60), "uma das áreas pioneiras de desenvolvimento da cultura do café teve origem no chamado Caminho Novo da Piedade", ou seja, uma ligação terrestre entre as províncias de São Paulo e do Rio de Janeiro que foi aberta no século XVIII.

De acordo com o autor, o caminho iniciado a partir do município de Lorena (SP) dava sequência pelos municípios de Silveiras, Areias, São José do Barreiro e Bananal, prosseguindo na direção do Rio de Janeiro, passando por Rio Claro, São João Marcos e Itaguaí. O autor acrescenta que "esta região, conhecida como o "fundo do vale", assistiu, durante o século XIX, a um vertiginoso processo de desenvolvimento, dando origem à formação de alguns dos mais ricos estabelecimentos de café daquele período" (CARRILHO, 2006, p. 60).

É preciso levar em consideração que a região, geograficamente falando, era favorável ao escoamento do café, por meio do município de Cunha (SP) com acesso aos portos em Paraty (RJ). Posteriormente, obtiveram-se maiores oportunidades de transporte do café, com a instalação de Estradas de Ferro.

Nesse contexto, conforme Marcondes (1998, p. 14), "embora grande número de povoações participasse desta atividade, a intensidade do cultivo do café 
apresentou distinções significativas no espaço, tanto no seu volume de produção quanto na estrutura produtiva (porte dos cafeicultores)".

Diante dessa perspectiva, segundo Marquese (2008), em 1822 a cafeicultura brasileira iniciou um arranque de produção, tornando o Brasil o maior produtor de café no mercado mundial.

O autor argumenta que houve uma grande transformação no Vale do Paraíba, que estava relativamente desocupado em 1800, passando a ser uma região escravista, ao mobilizar trabalhadores para o processo de ocupação e força de trabalho inicial nas fazendas de café do Vale do Paraíba. Ainda segundo o autor,

\begin{abstract}
À medida que, na década de 1820 , eram montadas as grandes unidades escravistas no Vale do Paraíba, somou-se, à progressiva aprendizagem das técnicas agrícolas, a construção de um saber local. O movimento pode ser acompanhado por meio dos impressos agronômicos. Até 1835, os escritos sobre a cafeicultura editados no Brasil cuidaram apenas de propagar as técnicas produtivas antilhanas, no mais das vezes retiradas d'O Fazendeiro do Brazil, sem se referirem concretamente à produção que estava em franco processo de crescimento no médio Vale do Paraíba. Os únicos que escreveram diretamente sobre a produção brasileira entre as décadas de 1820 e 1830 foram alguns viajantes estrangeiros, que estiveram nas províncias do Rio de Janeiro, São Paulo e Minas Gerais. (MARQUESE, 2008, p. 142).
\end{abstract}

Segundo Marquese (2008), entre as décadas de 1830 e 1840 aumentou substancialmente a quantidade de trabalhadores escravizados, considerando a progressiva especialização das fazendas de café do Vale do Paraíba. 
Figura 64: Aspecto interno da exposição - Ciclo do Café.

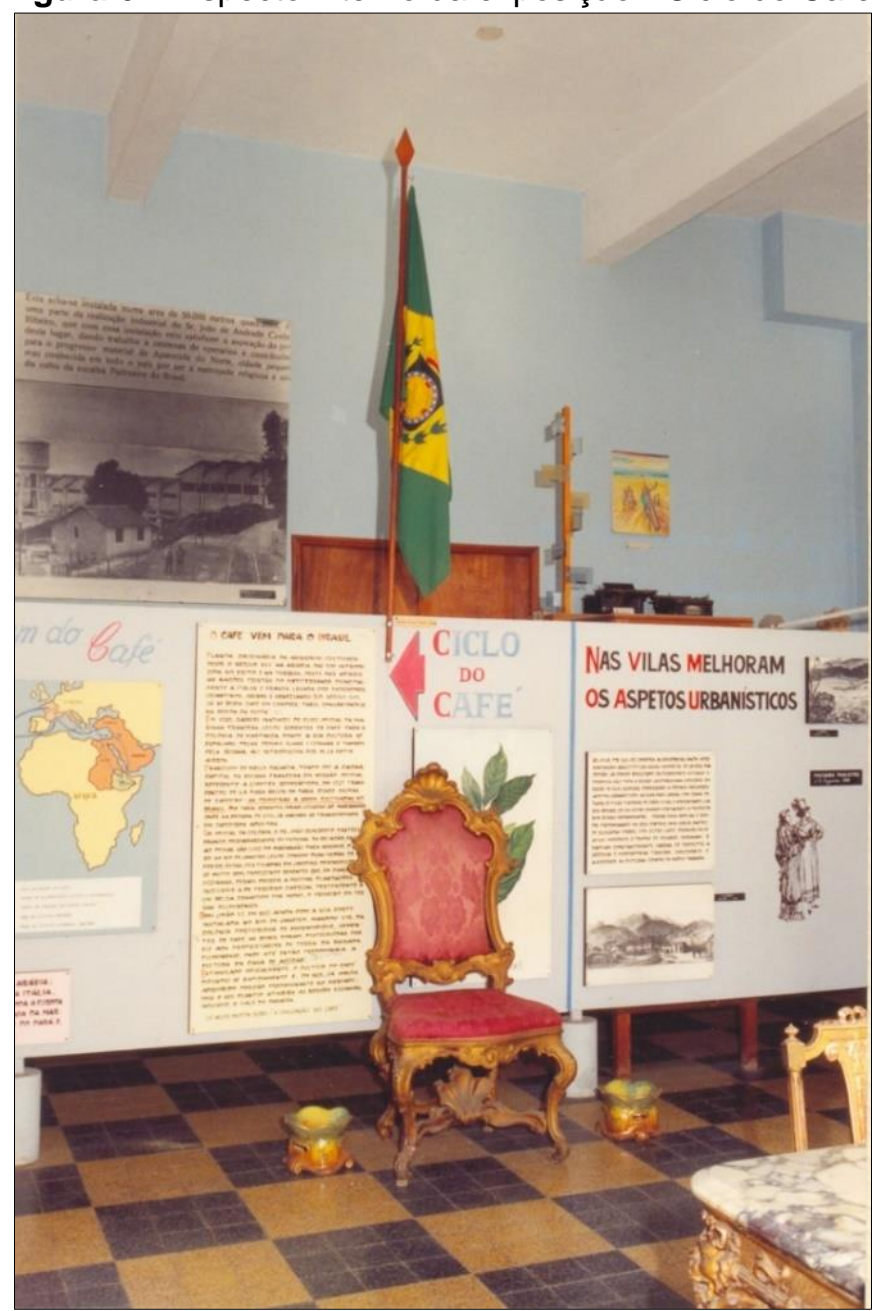

Fonte: MNSA/Santuário Nacional.

É preciso levar em consideração que, com o fim da escravidão, os proprietários de fazendas no Vale do Paraíba encontraram grande dificuldade em atrair imigrantes, ocasionando a queda de produtividade dos cafezais, assim como a devastação ambiental, em virtude do desmatamento.

Segundo Marquese (2008), o fim da escravidão trouxe a reconfiguração das relações de trabalho, além de uma profunda alteração na paisagem agrícola. Considerando que, "na última década do século XIX, à medida que fazendeiros e exescravos estabeleciam novos acordos nos sistemas de colonato e parceria, ganhava ímpeto um terceiro vetor de africanização da paisagem do Vale, presente desde que os primeiros cafezais foram abandonados ainda na primeira metade do século" (MARQUESE, 2008, p. 152).

De maneira geral, de acordo com Devide (2013, p. 5) "o ciclo cafeeiro diversificou a economia agrária, que passou a urbanoindustrial, porém, revelou disparidades dentro e fora do Vale do Paraíba, do século XIX aos anos 30 do século 
XX". Nesse contexto, o autor destaca que a crise escravista foi resolvida com o trabalho assalariado e na relação de colonato.

Figura 65: Aspecto interno da exposição - Ciclo do Café.

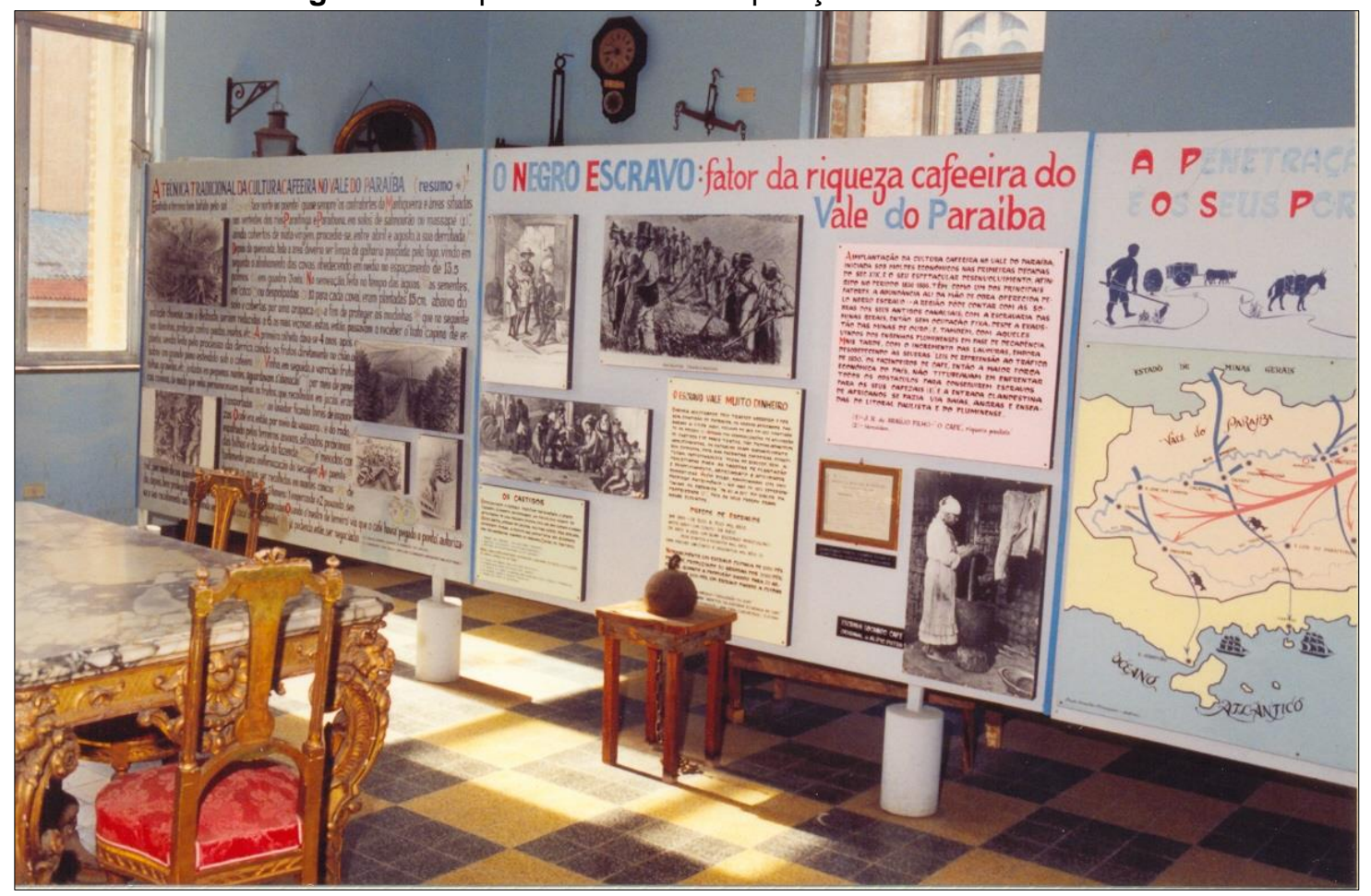

Fonte: MNSA/Santuário Nacional.

Dentro dessa perspectiva, conforme Marcondes (1998), em meados do século XIX a atividade canavieira ainda mantinha relevância, em especial no município de Lorena (SP), que apresentava maior expressão em relação ao restante do Vale do Paraíba.

Ao longo do século surgiram alternativas para o desenvolvimento econômico, como, por exemplo, o arroz e a pecuária. Entretanto, as atividades não foram capazes de restabelecer o padrão de desenvolvimento econômico e populacional que ocorreram durante o ciclo do café. 
Figura 66: Aspecto interno da exposição - Ciclo do Café.

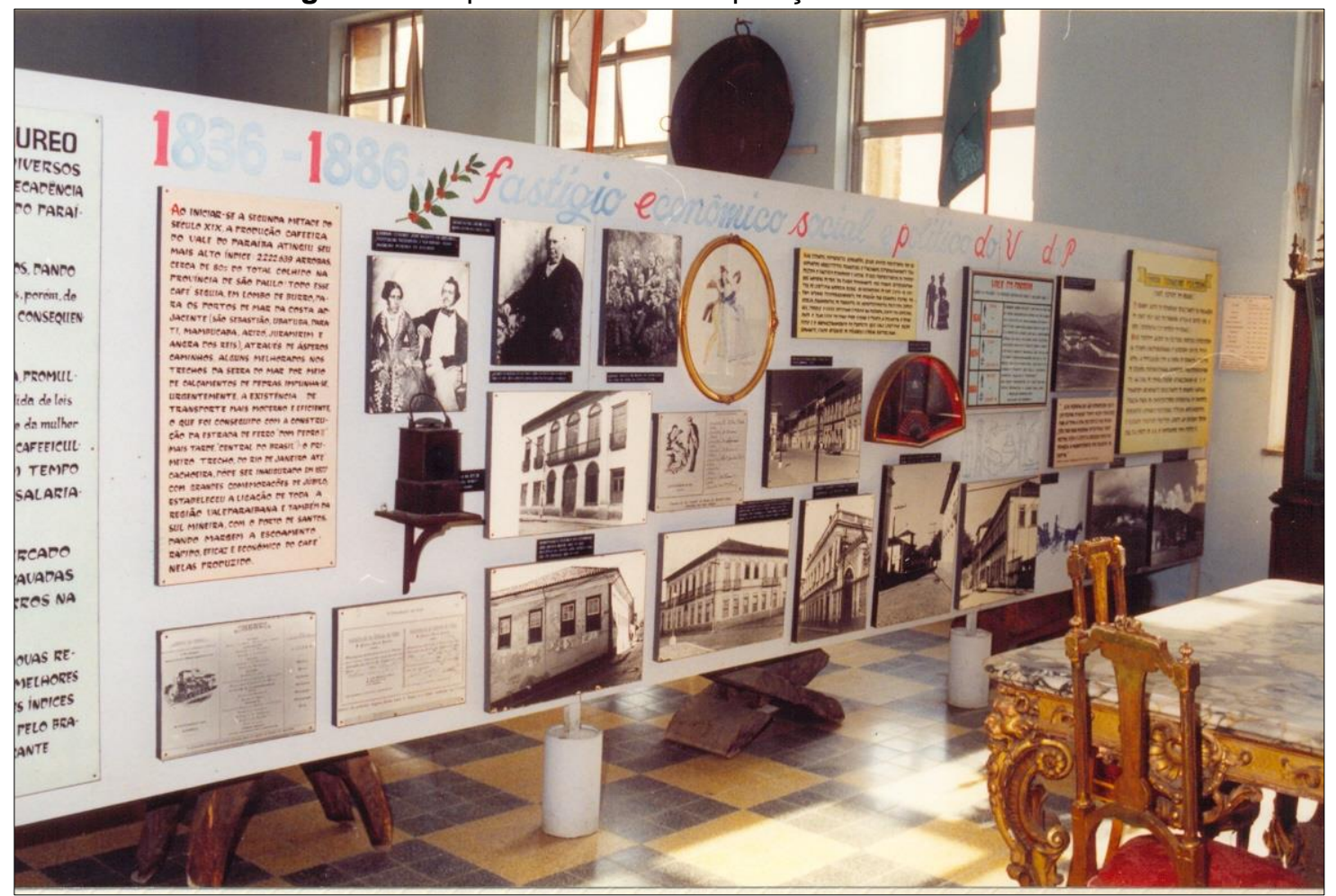

Fonte: MNSA/Santuário Nacional.

As Figuras 67, 68 e 69 são referentes ao Ciclo da Economia Mista. De acordo com a Profa. Conceição Borges R. Camargo (1992), o Ciclo da Economia Mista, também conhecido como Ciclo Agropecuário, surgiu a partir da estagnação econômica na região. Com isso, iniciam-se novas atividades ligadas à policultura e à pecuária.

Marquese (2008, p. 152) argumenta que "a pecuária foi o caminho que os exsenhores encontram para manter a integridade de suas propriedades e barrar a repartição de suas terras". De acordo com o autor, novos proprietários de terras também se beneficiaram com a crise financeira da abolição ao adquirirem fazendas de ex-senhores falidos e introduzir a nova atividade econômica. Desta forma, alteraram a configuração da paisagem ao adaptar as fazendas às novas funções pecuaristas.

Conforme a Profa. Conceição Borges R. Camargo (1992), além dos bovinos, também havia criações de suínos, ovinos, entre outros, bem como o desenvolvimento da prática de exposição de animais. Já em relação à policultura, havia lavouras de arroz, mandioca, batata, milho, feijão, frutas, hortaliças, etc. 
Figura 67: Aspecto interno da exposição - Ciclo da Economia Mista.

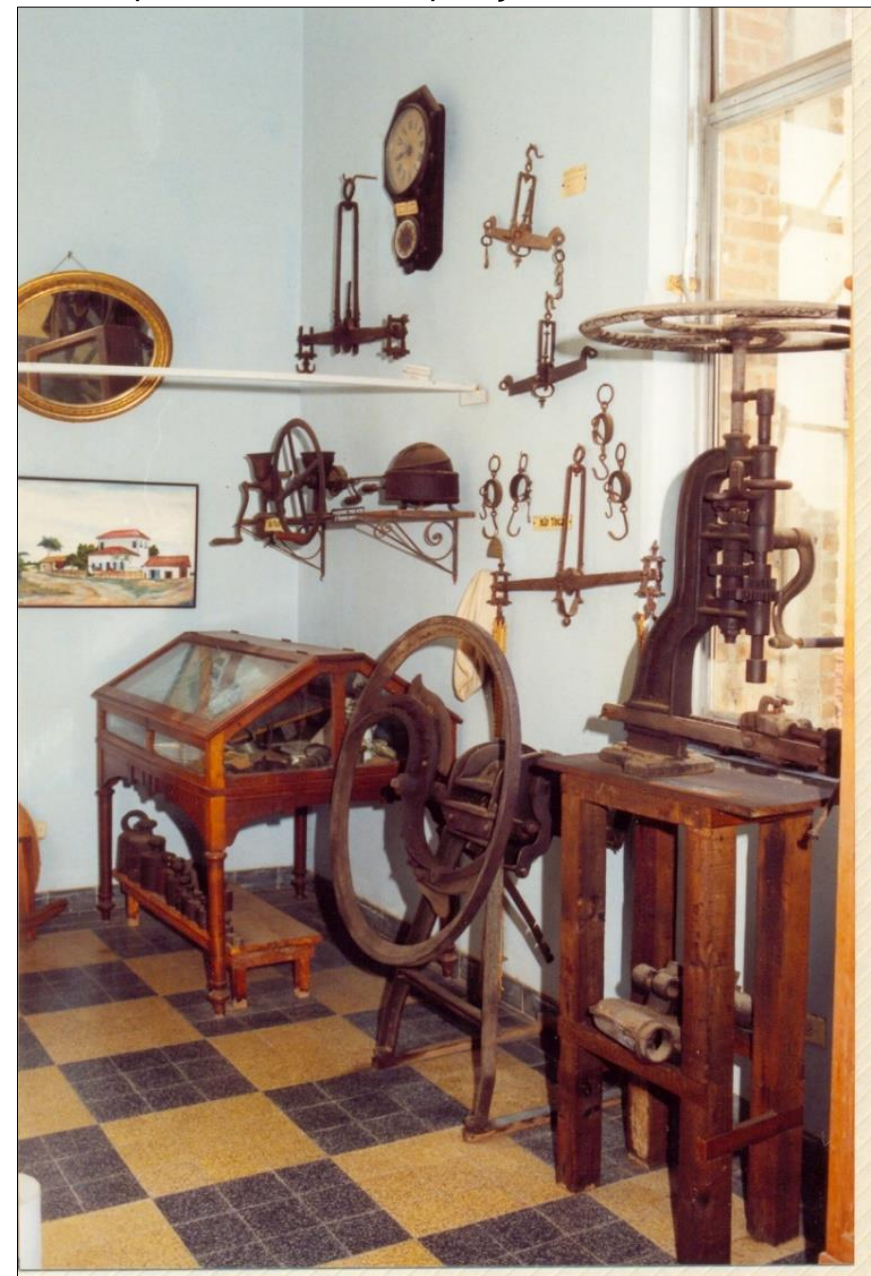

Fonte: MNSA/Santuário Nacional.

De acordo com Devide (2013, p. 12),

A utilização intensiva das várzeas, o advento da mecanização do solo, a construção e melhoria na qualidade das estradas rurais, obras de contenção das enchentes, os polders e a assistência técnica de órgãos oficiais asseguraram boas condições para 0 desenvolvimento agropecuário, gerando empregos e divisas aos municípios em uma entressafra de opções econômicas.

De acordo com o autor, a agricultura se diversificou na região Oeste de São Paulo, contribuindo para a transformação da estrutura produtiva estadual, garantindo assim a liderança do Vale do Paraíba no contexto nacional.

Entretanto, segundo Devide (2013), com a abolição da escravatura e a preferência dos imigrantes por regiões ainda não desbravadas do Oeste paulista, contribuíram ao longo do tempo para a diminuição da mão de obra, o que dificultou a expandir e consolidar a agricultura no Vale do Paraíba.

O autor argumenta que, "o fato do Vale do Paraíba exercer papel importante para consolidar o eixo econômico de Rio de Janeiro - São Paulo - Minas Gerais não 
garantiu investimentos para a agropecuária, sem contribuir de maneira significativa ao abastecimento dos centros econômicos, impulsionando mais a urbanização" (DEVIDE, 2013, p. 5).

Figura 68: Aspecto interno da exposição - Ciclo da Economia Mista.

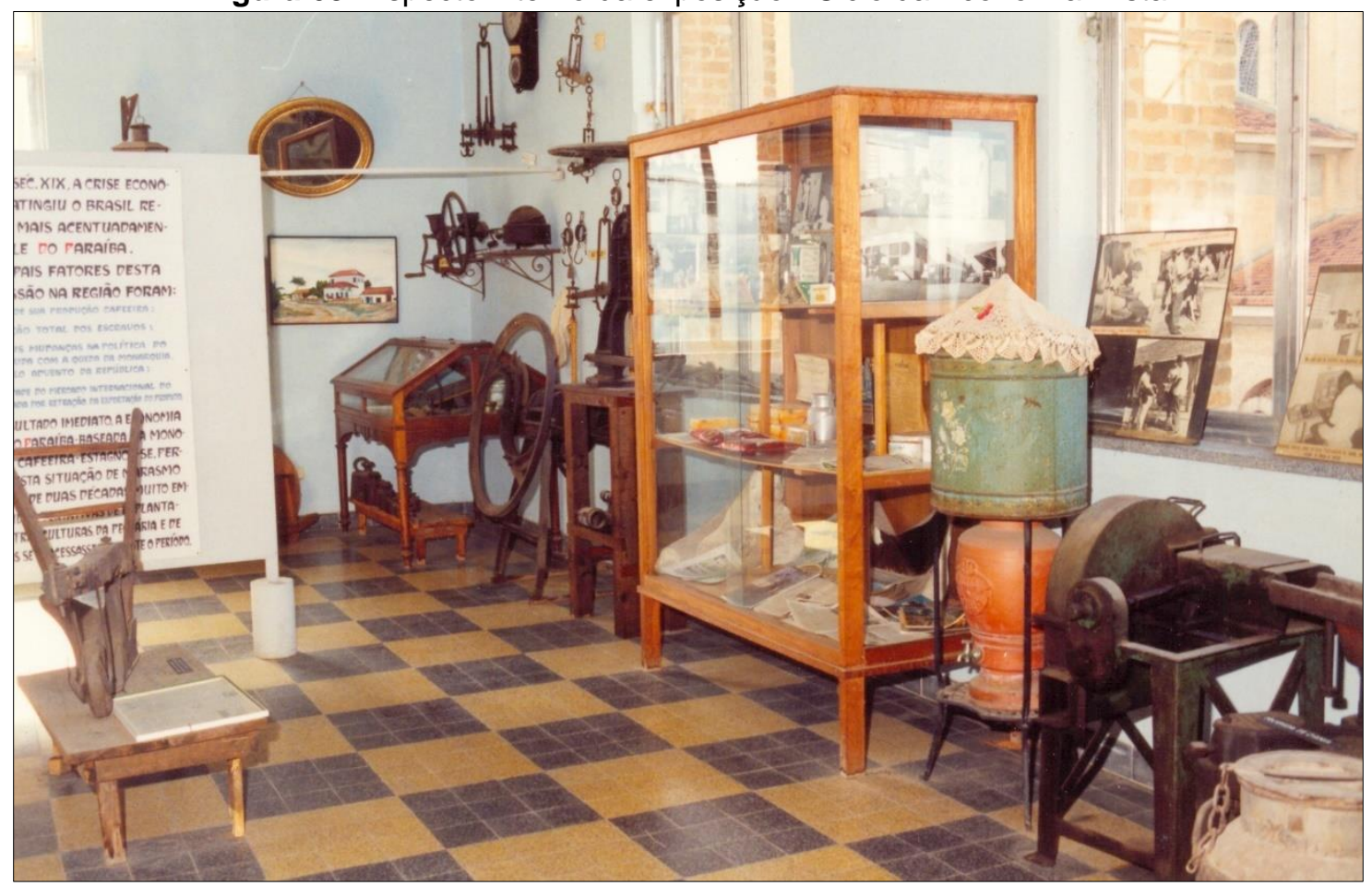

Fonte: MNSA/Santuário Nacional.

Figura 69: Aspecto interno da exposição - Ciclo da Economia Mista.

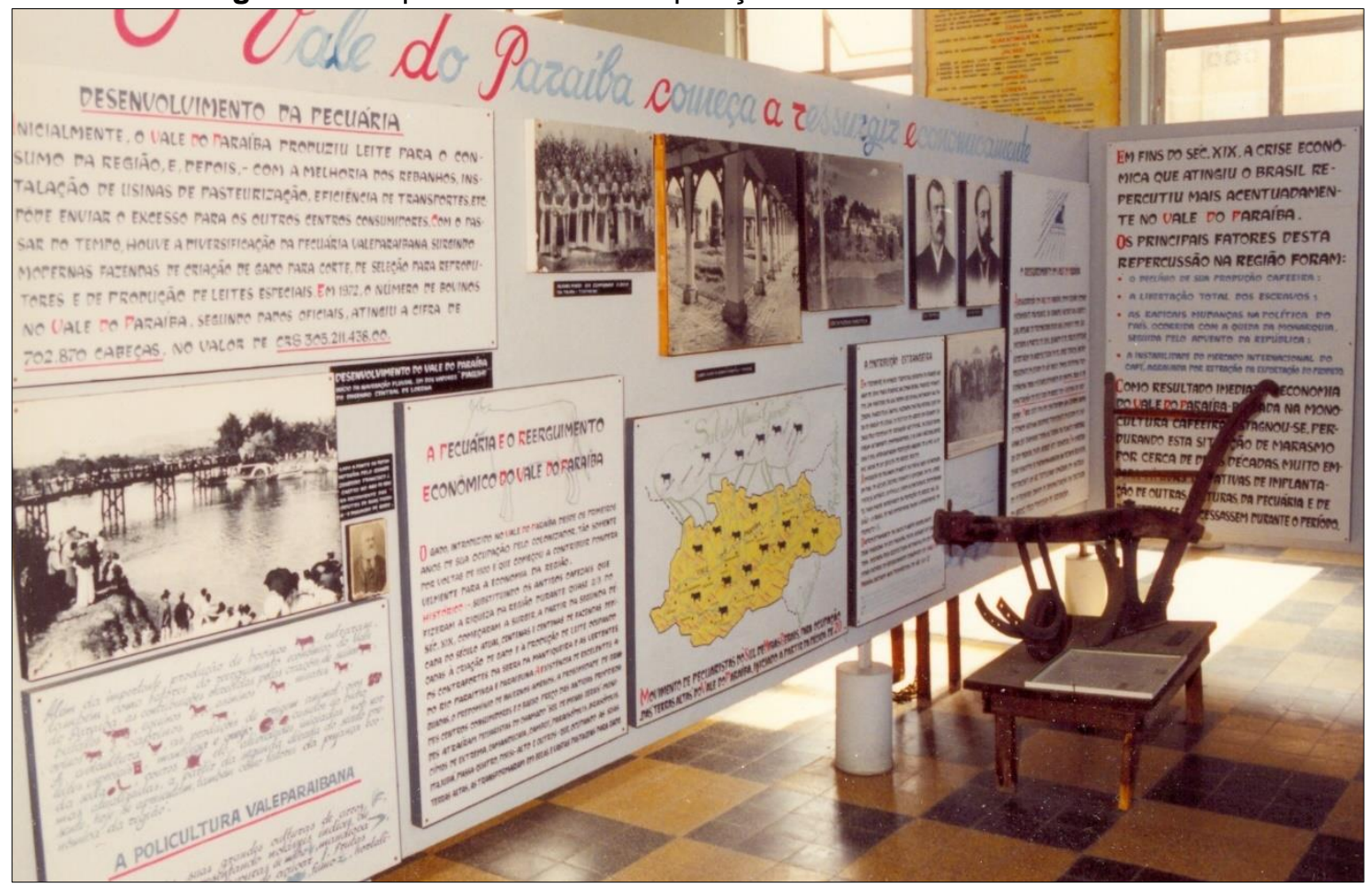

Fonte: MNSA/Santuário Nacional. 
As Figuras 70 e 71 são referentes ao Ciclo Industrial. De acordo com a Profa. Conceição Borges R. Camargo (1992), o Ciclo Industrial surgiu com o declínio da lavoura cafeeira, com isso as classes produtoras tiveram que procurar novas atividades lucrativas. Nesse contexto, as atividades industriais começaram a evoluir lentamente.

Segundo a autora, o progresso a partir das Guerras Mundiais e a construção das Estradas de Rodagem, no eixo Rio de Janeiro-São Paulo, foram fundamentais para o desenvolvimento industrial, considerando a instalação de grandes indústrias metalúrgicas, mecânicas, têxteis, química, etc., de projeção nacional e internacional, que transformou a vida urbana da região do Vale do Paraíba em meados do século XX em diante.

Devide (2013, p. 15) argumenta que:

A industrialização do Vale do Paraíba correu em três fases: iniciou nas duas
últimas décadas do século XIX; a segunda, entre as duas grandes guerras
(Jacareí, São José dos Campos, Taubaté e Guaratinguetá); e a fase atual,
mais dinâmica, iniciada com a Usina Siderúrgica de Volta Redonda e a
construção da Rodovia Presidente Dutra, se destacando os centros
tecnológicos em São José dos Campos, Jacareí, Caçapava, Cruzeiro,
Lorena e Pindamonhangaba, levando à concentração dos empregos e da
renda nessas cidades.

Segundo o autor, foi essa expansão industrial que consolidou a Região Metropolitana do Vale do Paraíba, contribuindo para a conurbação ao longo do eixo rodoferroviário entre Rio de Janeiro e São Paulo, tornando-se o principal corredor de produtos e serviços do Brasil, além de ampliar a comunicação através da Estrada de Ferro Central do Brasil. O autor acrescenta que outro fator decisivo para a industrialização foi a disponibilidade de capital de reserva, bem como a melhoria do nível de consumo da população. 
Figura 70: Aspecto interno da exposição - Ciclo Industrial.

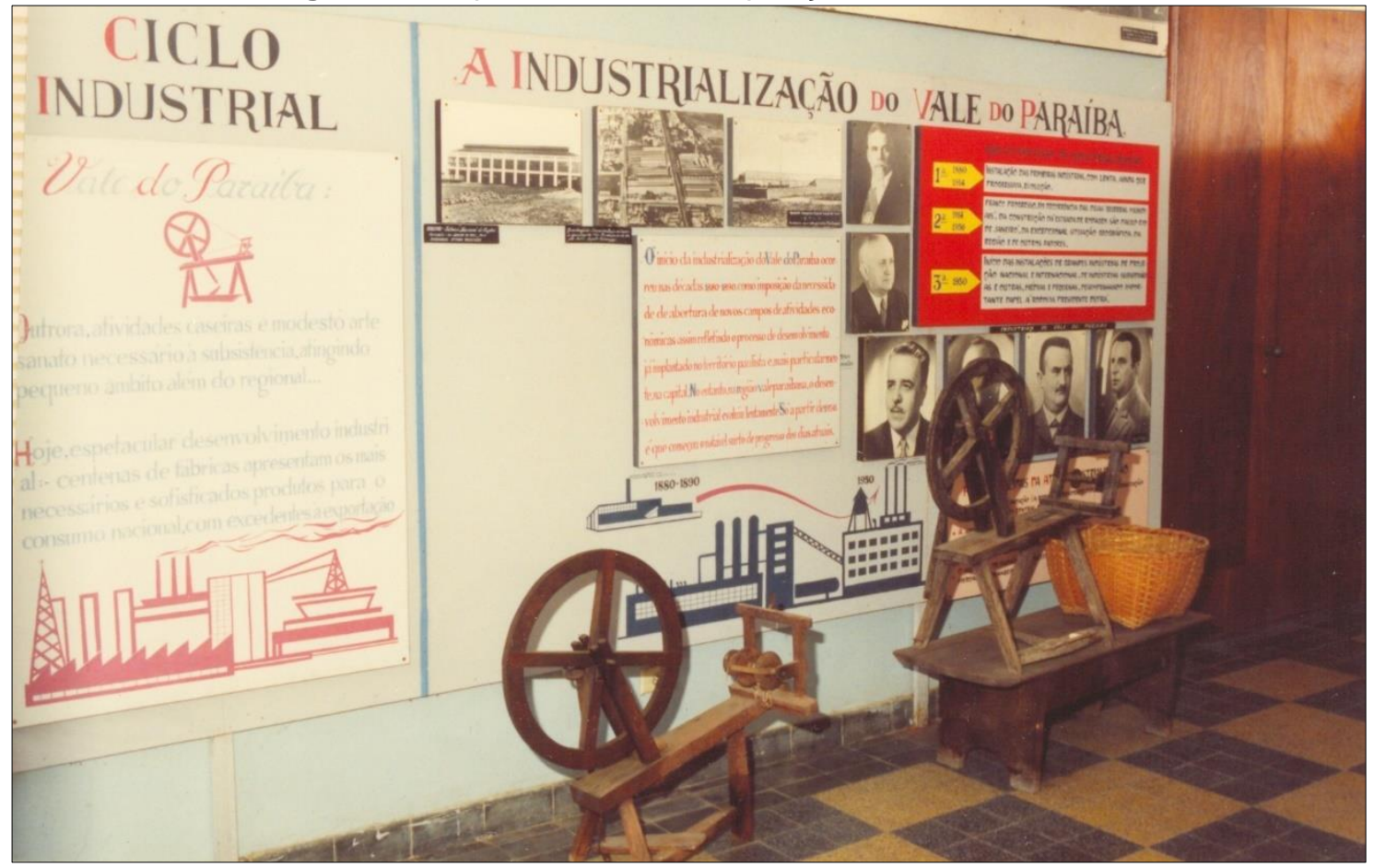

Fonte: MNSA/Santuário Nacional.

Figura 71: Aspecto interno da exposição - Ciclo Industrial.

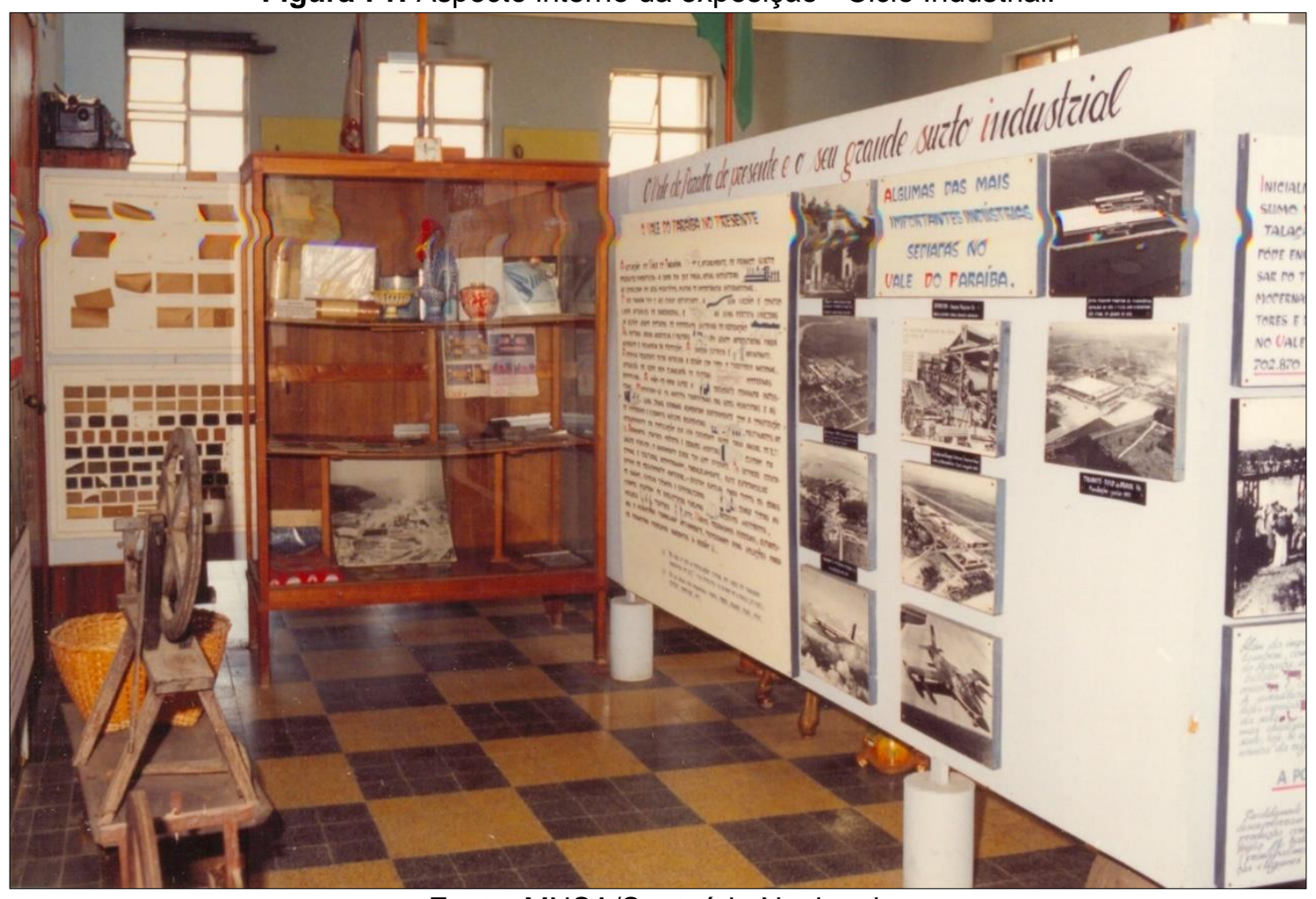

Fonte: MNSA/Santuário Nacional.

De maneira geral, de acordo com Devide (2013, p. 5), para maior compreensão das transformações no meio rural-urbano regional, "é necessária análise de como ocorreu a transição de sociedade rural conservadora, representada 
pela oligarquia cafeeira, para uma sociedade urbano-industrial, que fundamentou as desigualdades regionais ao longo do processo do crescimento econômico".

O autor acrescenta que houve uma crise econômica na década de 1980 que contribuiu com o esvaziamento regional iniciado na década de 1970, provocando transformações que limitaram a consolidação da macrometrópole Rio de Janeiro São Paulo. Dentro desse contexto, o autor considera que a transferência da capital para a região Centro-Oeste, colaborou com o deslocamento da frente agropecuária para o Oeste de São Paulo, assim como um progressivo esvaziamento político e econômico do Rio de Janeiro, além de um forte investimento na ocupação da região Central e Norte do país.

De maneira geral, o Museu dos Ciclos Socioeconômicos do Vale do Paraíba cumpria a sua função educativa de narrar toda evolução da região. E com o decorrer dos anos, no início da década de 1990, a Profa. Conceição Borges concebeu um novo núcleo, referente ao Ciclo da Ecologia, para complementar os Ciclos Socioeconômicos do Vale do Paraíba, embora esse núcleo não estivesse previsto no projeto original de criação do Museu. Diante dessa perspectiva, este núcleo abrangia os reinos: mineral, vegetal e animal; porém, não há registros fotográficos dessa parte da exposição.

De acordo com a Profa. Conceição Borges R. Camargo (1992), o intuito do Ciclo da Ecologia era o despertar para uma consciência ecológica, considerando os objetivos apresentados na "ECO 92" (Conferência das Nações Unidas sobre o Meio Ambiente e o Desenvolvimento), que ocorreu no Rio de Janeiro em junho de 1992.

Segundo a autora, essa seção dava ênfase especial ao Rio Paraíba do Sul, considerado poluído, em virtude dos resíduos químicos despejados pelas fábricas e demais resíduos das residências. O foco central era na recuperação do rio, considerando sua importância pelo surgimento da Imagem de Nossa Senhora Aparecida.

Enfim, observa-se em todo o Vale do Paraíba que há certo saudosismo por essa época antiga e histórica, principalmente, do ponto de vista turístico, que provém atrativos por meio de transformação das antigas fazendas de café em hotéis e pousadas, como parte do desenvolvimento regional.

Em relação ao planejamento e elaboração dos textos e croquis da exposição, que foram desenvolvidos com sentido didático, conforme mencionado anteriormente, 


\section{esses materiais foram desenvolvidos pelo Prof. Paulo Camilher Florençano, conforme estudos observados por meios das Figuras 72, 73 e 74.}

Figura 72: Croqui para elaboração da exposição.

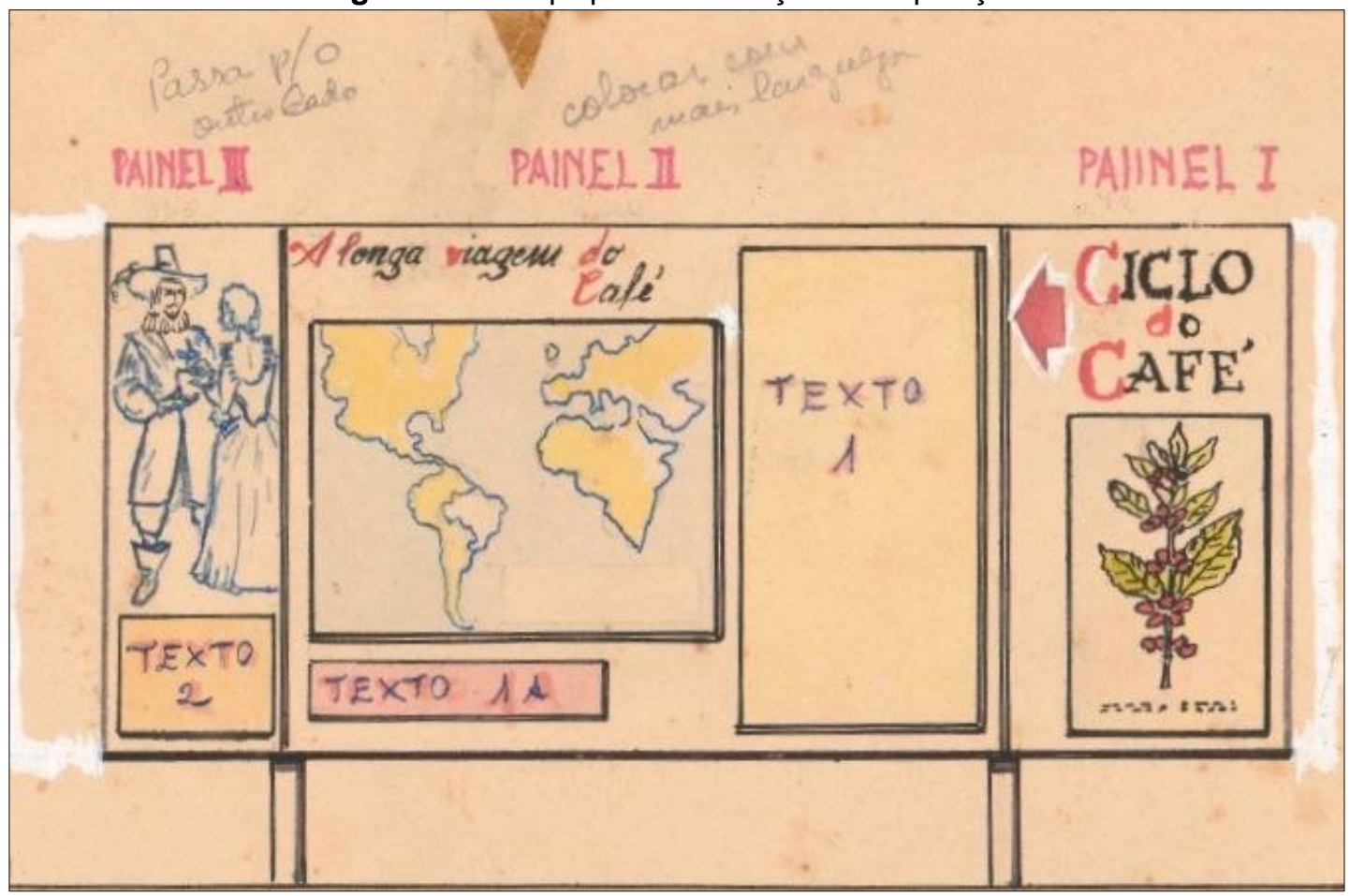

Fonte: MNSA/Santuário Nacional.

Figura 73: Croqui para elaboração da exposição.

A TECNICA TRADICIONAL, DA CULTURA CAFEEIRA NO VALE DO PARAIBA (TESUmO*) Escolhido o terreno bem batido pelo sol $\approx$ (face note ou poente) quasi sempre "os contrafortes da Mantiqueira eáreas situa-

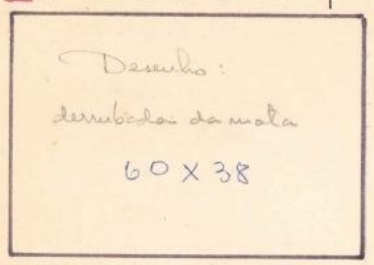
das nas vertentes dos rios Paraitinea e Parabuna, em solos de salmourão ou massape'(1)" ainda cobertos de mata-virgem, procedia-se, entre abril e agosto a sua derrubada $\$$. Depois da queimada, toda a àrea deveria ser limpa da gatharia poupada pelo fogo, vindo em sepuida o alinhamento das covas, obedecendo em media o espaçamento de 13,5 palmos $\mathrm{m}$, em

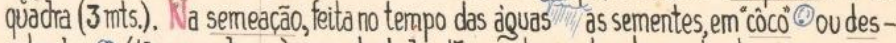
polpadas 10 (10 para cada cova) eram plantadas $15 \mathrm{cms}$. aboixo do solo e cobertas por uma arapuca a fim de proteger as mudinhas \& que na seguinte estacäoc chuvosa com o desbaste,

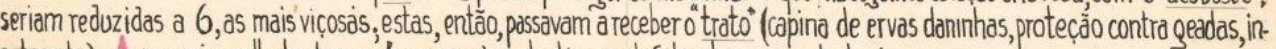
setos, etc). Aa primeira colheta dava-se 4 anos após o plantio, sendo feita pelo processo da derrica, , caindo os frutos diretamente no chäo, ous sobre um qrande pano extendido sobo cafeeiro

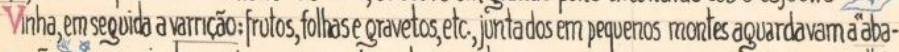
nação Y por meio de peneiras comuns, de modo que, nelas permanecessem apenas os frutoss, Que, recolhidos em jacas, eram transportados ar a lavador, ficando lives de impurezas. O café eтa,

\begin{tabular}{c} 
Codenta de coli' \\
$58 \times 32$ \\
\hline
\end{tabular}
entāo, por meio da vassoura /e do rôdo \% espalhado pelos terrelrosanexos, sitvados próximos das tühasedase

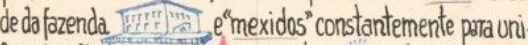

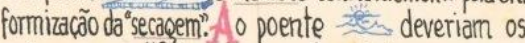
Qrâos ser recollinidos em montes cônicos de 1 mt., por meio de um aparetho de madeira a"vaca" \& operado por 3 homens (1 empurrando 2 puxando), sendo, depois, bem protegidos do sereno e dachuva sob coberturade encerados. Quando o "mestre do terreiro" via que o cáé havia "pegado o ponto,"

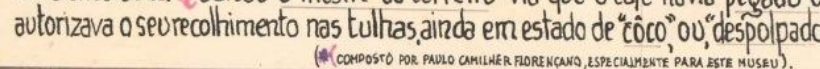

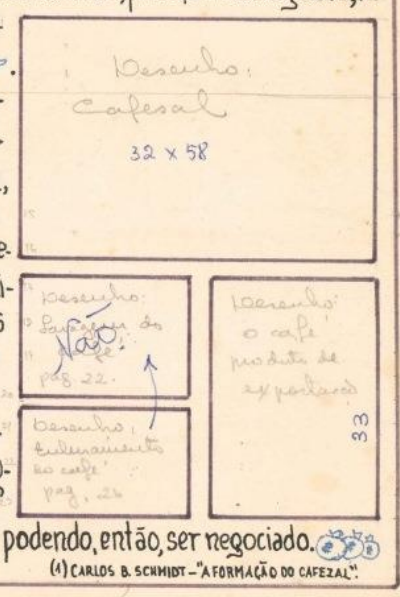


Figura 74: Croqui para elaboração da exposição.

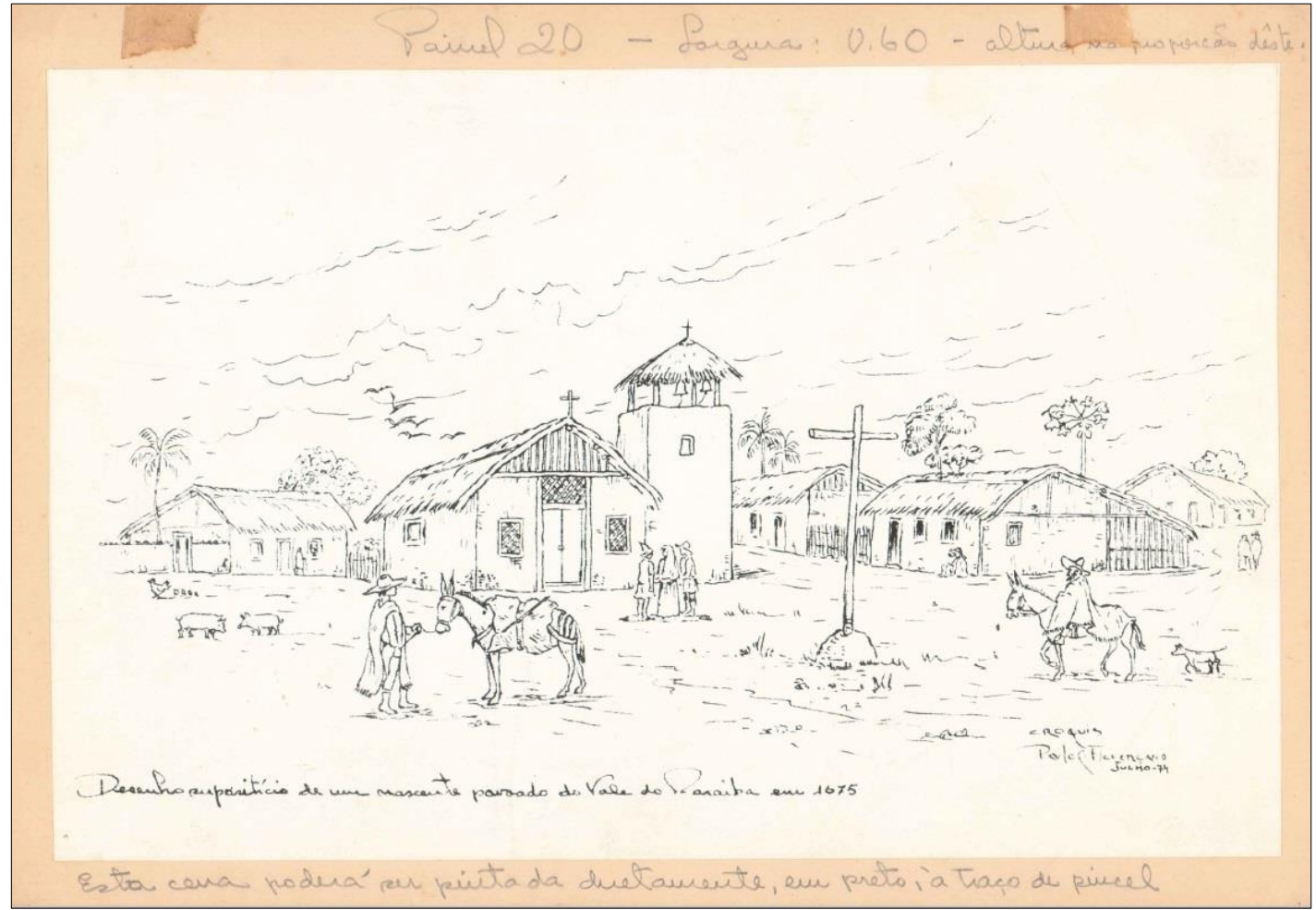

Fonte: MNSA/Santuário Nacional.

De maneira geral, toda a diagramação visual da exposição foi realizada manualmente por artistas, pintores e letristas. Entretanto, até chegar-se na versão final dos painéis, observamos, entre o levantamento documental, vários textos e listas de revisão para correções (Figura 75). 
Figura 75: Revisão nos textos para correções.

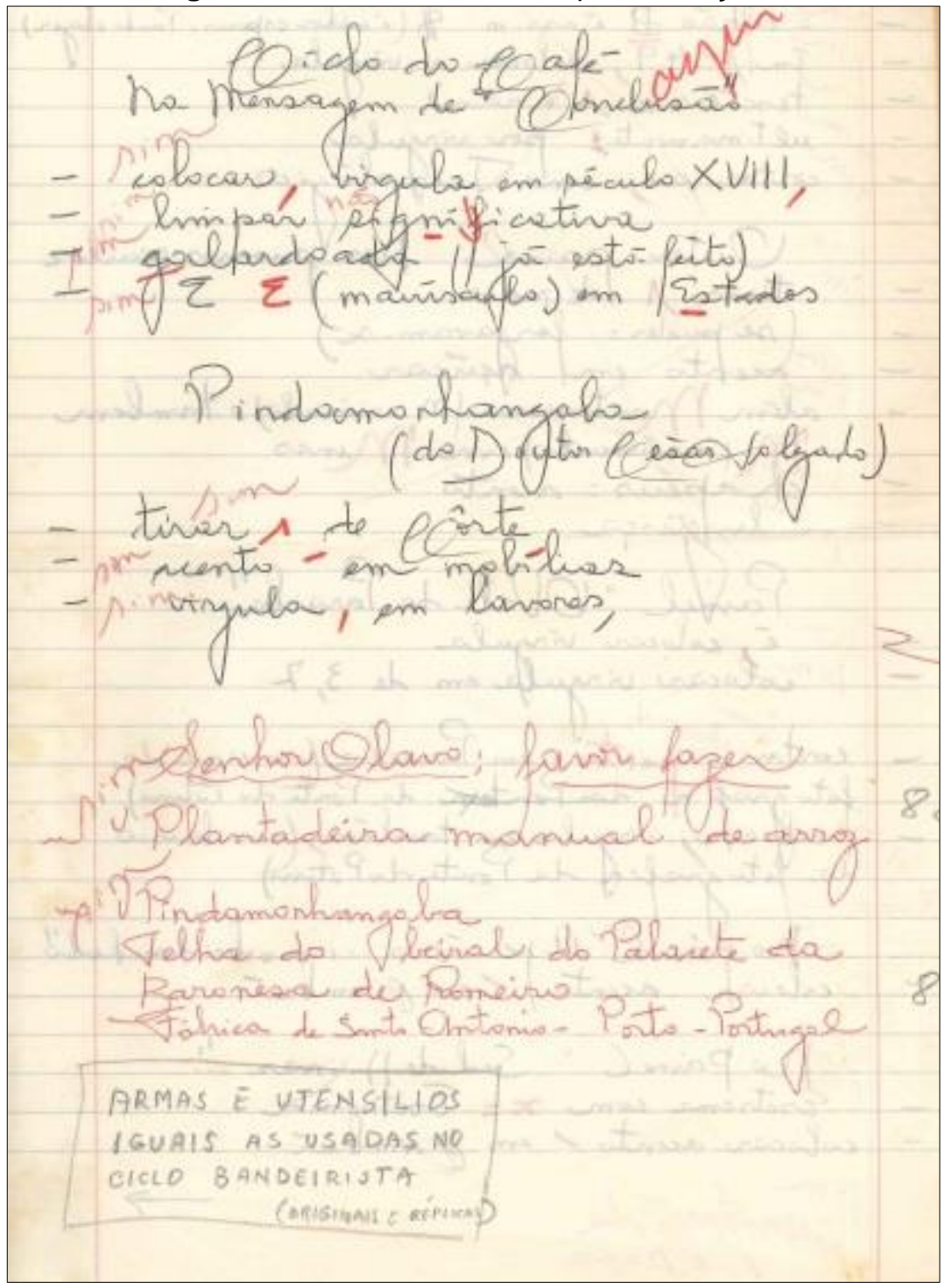

Fonte: MNSA/Santuário Nacional.

Após a montagem, observamos, por meio do levantamento documental, que várias alterações foram realizadas com o intuito de finalizar com melhor acabamento entre textos e acervos expostos, conforme anotações da Profa. Conceição Borges (Figura 76). 
Figura 76: Anotações para finalização da exposição.

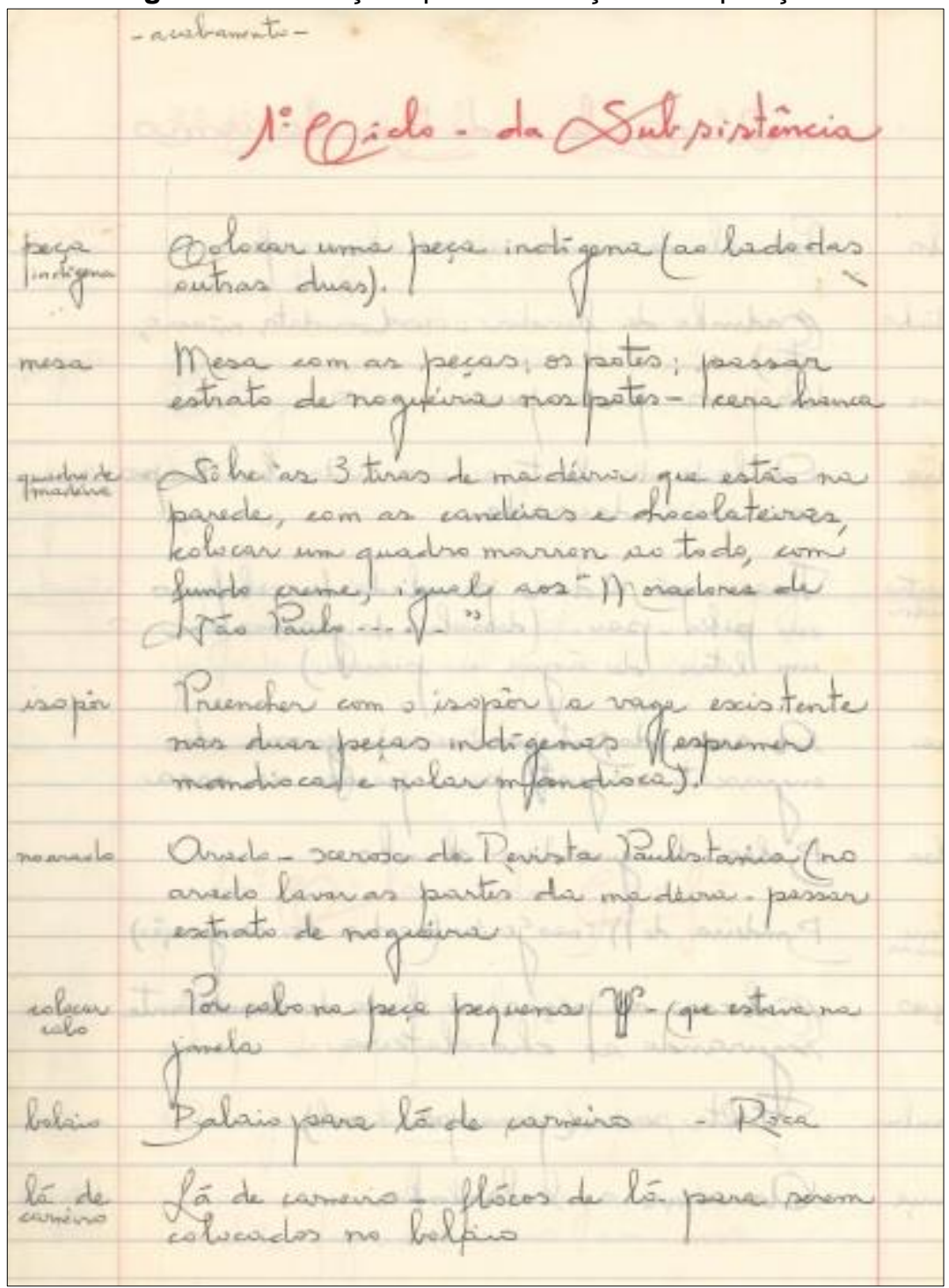

Fonte: MNSA/Santuário Nacional.

Conforme análise documental, o Museu dos Ciclos Socioeconômicos do Vale do Paraíba também foi incluído nas estatísticas nacionais, para o Cadastro de Museus, conforme podemos observar na correspondência entre Conceição Borges e o Sr. Manoel Diégues Junior, Diretor Geral do Departamento de Assuntos Culturais, em $1977^{40}$.

Enviamos a Vossa Senhoria, no dia 25 de julho do corrente ano, as 04 (quatro) fichas referentes ao Museu "Nossa Senhora Aparecida".

Hoje, remetemos as 04 (quatro) fichas referentes ao Museu dos "Ciclos Sócio-Econômicos do Vale do Paraíba", anexo ao Museu "Nossa Senhora Aparecida".

40 CAMARGO, C. B. R. [Carta] 22 out. 1977, Aparecida [para] DIÉGUES Jr., Manoel. Aparecida. 1 f. Envio de formulários sobre o Museu Nossa Senhora Aparecida e o Museu dos Ciclos SócioEconômicos do Vale do Paraíba. 
O Museu dos Ciclos é "Histórico-Didático e Pedagógico", mais visitado, estudado e pesquisado por professores, alunos, pesquisadores, historiadores, etc.

Consideramos grande honra receber um dia a visita de Vossa Senhora.

No dia 3 de setembro do corrente ano, professores e alunos da Faculdade de Turismo do Litoral Santista, em número de 75 estiveram no Museu dos Ciclos, anotando textos, tirando fotografias e se interessando mais no Ciclo do Café.

Aulas de museologia têm sido dadas neste Museu e já estão programadas visitas de universitários de Lorena, Cruzeiro, Taubaté, Pindamonhangaba.

Neste ensejo apresentamos a Vossa Senhoria, nossas cordiais saudações.

Com base nessa correspondência, podemos evidenciar a função didáticopedagógica do Museu ao ser mais frequentado por pesquisadores, historiadores, professores com grupos escolares, em especial alunos de nível superior de universidades da região, que frequentaram o Museu entre os anos de 1975 a 1993.

Em 1993, a Administração do Santuário Nacional de Aparecida solicita aos organizadores do Museu para que desocupem o $3^{\circ}$ andar da Torre Brasília, para uso administrativo do Santuário. Portanto, o acervo do Museu é transferido para armazenamento no Seminário Bom Jesus e iniciam-se negociações com a Prefeitura Municipal de Aparecida para construção e instalação do Museu em prédio próprio, conforme mencionado por Boas (1994), em artigo do jornal Valeparaibano de 02 de novembro de 1994.

A necessidade de se construir um local adequado à instalação do museu surgiu com a doação do acervo particular, pertencente à professora Conceição Borges Ribeiro Camargo, que o mantinha na torre da Basílica Nova. O local foi pedido pela administração da Basílica e transformado em escritório.

Com isso, o acervo, que retrata as diversas fases do ciclo sócio-econômico da região, desde o século 19 , vem sendo mantido guardado no Seminário Bom Jesus e na própria residência da professora. (BOAS, 1994, s. p.).

Inicialmente, o Prefeito Municipal de Aparecida, Sr. Antonio Márcio de Siqueira, demonstrou interesse em criar um Museu Municipal, conforme citado pela Profa. Conceição Borges Ribeiro Camargo (1994, s. p.), "a transferência do Museu deve-se ao idealismo do senhor Prefeito Municipal, Antonio Márcio de Siqueira, que está construindo um prédio especialmente para receber o Museu, um lugar histórico, atrás da Sacristia da antiga Basílica de Nossa Senhora Aparecida".

De acordo com a autora, que doou todo o acervo do Museu dos Ciclos Socioeconômicos do Vale do Paraíba para a Prefeitura Municipal de Aparecida, tanto o Vice-Prefeito Municipal, Sr. Carlos Roberto Chad e a Secretária de Educação e Cultura, Professora Thereza Galvão Pasin, se dedicaram para que a cidade tivesse um Museu Municipal. Entretanto, não foram encontrados registros que 
confirmassem tal instalação do Museu em prédio próprio, próximo à antiga Basílica de Nossa Senhora Aparecida.

Posteriormente, segundo Boas (1994), a antiga Estação Ferroviária de Aparecida passou a ser cogitada como um novo local para instalação do Museu, durante processo de solicitação para transformação da Estação Ferroviária em Centro Cultural.

O antigo prédio da estação ferroviária deverá ser transformado num Centro Cultural onde será instalado o Museu do Ciclo Sócio-Econômico do Vale do Paraíba e a Biblioteca Pública Municipal. As negociações entre a Prefeitura e a Rede Ferroviária Federal, iniciadas há seis meses, que têm por objetivo firmar um convênio no qual o município passa a usufruir, por tempo indeterminado do local, deverão estar concluídas até dezembro, quando deverá começar a reforma do prédio construído há mais de um século. A iniciativa do projeto partiu do prefeito Antonio Márcio de Siqueira e obteve aprovação unânime na Câmara. (BOAS, 1994, s. p.).

Podemos constatar tal intenção conforme publicado no Jornal da Arquidiocese, em 30 de julho de 1994,

O Museu dos Ciclos Econômicos do Vale do Paraíba, um grande e
expressivo acervo histórico e cultural da cidade, de propriedade da
Professora e Historiadora Conceição Borges Ribeiro Camargo, deverá
ganhar, em breve, uma sede própria. Com a doação de todo o acervo pela
Professora Conceição Borges Ribeiro Camargo ao município, é intenção do
Prefeito Mário Siqueira montá-lo na atual desativada Estação Ferroviária da
RFFSA. Para tanto, pedido de cessão do prédio da RFFSA foi encaminhado
à superintendência e ainda à presidência da estrada de ferro, pelo Prefeito
de Aparecida, aguardando-se para mais alguns dias a deliberação. O
encaminhamento do pedido teve boa acolhida. [...].

De maneira geral, observamos inicialmente um grande interesse por parte da Prefeitura Municipal de Aparecida em adequar um espaço na Estação Ferroviária para receber o acervo do Museu dos Ciclos Socioeconômicos do Vale do Paraíba, ao transformar o local desativado na época em um Centro Cultural, a exemplo do que aconteceu com as estações de Bananal e Cachoeira Paulista, municípios do Vale do Paraíba em São Paulo.

Entretanto, também não foram encontrados registros que comprovassem a efetivação do Museu no local, apesar do acervo ter sido transferido para um depósito na Estação Ferroviária, conforme relatado pelo Prof. Guido Braga, em 2017.41

${ }^{41}$ BRAGA, Guido Machado. Entrevista concedida a Víctor Hugo Barros e a Erica Andreza Coelho. Aparecida, 20 set. 2017, 33 min 08 s. Som, Formato MP3. 
Victor Hugo - E essa expansão do Museu? Antes o Museu funcionava em um andar só e depois ele passou a funcionar em dois. Como foi essa logística?

Prof. Guido - Era só no segundo. Mas, concomitante a esse do segundo andar, tinha o do terceiro também, que era da Dona Conceição, que era o Museu dos Ciclos Econômicos.

Erica - Essas obras pertenciam à coleção da Conceição ou foram emprestadas?

Prof. Guido - Do Ciclo? Não, eram dela, eram coletados por ela também. Tanto que, quando foi desativado o Museu, porque o Santuário precisou do terceiro andar, não sei para que, essas peças foram guardadas no Seminário Bom Jesus, com intenção de montar em algum lugar. E eu era diretor da Divisão de Cultura de Aparecida e fui lá ver.

[...] O diretor do Seminário na época, eu não me lembro quem era ele, pediu que retirasse de lá e eu infelizmente coloquei tudo dentro de um caminhão e levamos para um depósito da Prefeitura, atrás da Estação Ferroviária, e lá as coisas se perderam tudo, porque logo depois eu saí da Prefeitura, nunca mais eu soube do resultado, roubaram muita coisa também, não foi só estrago natural, foi apropriação indébita também, vamos chamar assim. (BRAGA, 2017, informação verbal).

Enfim, com esse relato do Prof. Guido Braga, tendemos a acreditar que 0 acervo do Museu dos Ciclos Socioeconômicos do Vale do Paraíba acabou se perdendo com o tempo, devido à falta de cuidado para conservação das peças, que garantisse um armazenamento apropriado, bem como pela Prefeitura Municipal de Aparecida não ter reaberto a exposição no novo local.

Retomando ao Roteiro de observação para visita a museus e exposição ${ }^{42}$, e buscando fazer uma análise retrospectiva quanto às informações disponibilizadas ao público entre os anos de 1975 a 1993, podemos definir que o Museu dos Ciclos Socioeconômicos do Vale do Paraíba tinha como tema geral retratar a evolução do Vale do Paraíba, apresentando a história socioeconômica da região, por meio de recortes temáticos e cronológicos, organizados por ciclos de desenvolvimento, desde a chegada do colonizador até a industrialização. Tratava-se de uma exposição de longa duração, embora sem um título específico.

Esses recortes conceituais abordavam os períodos do Ciclo da Subsistência, Ciclo do Bandeirismo, Ciclo da Cana-de-Açúcar, Ciclo do Café, Ciclo da Economia Mista e Ciclo Industrial, e por fim, o Ciclo da Ecologia, com o intuito de valorizar o patrimônio turístico das cidades do Vale do Paraíba no circuito histórico social e econômico.

\footnotetext{
${ }^{42}$ Roteiro desenvolvido pela Profa. Dra. Marília Xavier Cury.
} 
Em relação à divulgação do Museu, acreditamos que havia divulgação nas escolas da região e universidades, para agendamento de grupos, assim como durante a visita ao Mirante, os visitantes eram comunicados nos elevadores sobre as exposições que poderiam visitar no $3^{\circ}$ e $2^{\circ}$ andares da Torre.

Por meio dos registros documentais observamos que ambos os Museus, eram divulgados como atrações turísticas em Aparecida (SP), inclusive como entretenimento aos romeiros em visita à Basílica. Pois no acervo documental há folders turísticos indicando a localização do Museu e o conteúdo da exposição, assim como contém a divulgação de outros pontos turísticos na cidade de Aparecida. No Almanaque de Nossa Senhora Aparecida - Ecos Marianos, produzidos anualmente pela Editora Santuário, também há anúncios sobre o Museu.

Em relação ao funcionamento do Museu, o atendimento aos visitantes seguia o mesmo padrão da outra exposição no $2^{\circ}$ andar da Torre, considerando que a própria Profa. Conceição Borges fazia o acompanhamento dos grupos.

Não havia guarda-volumes ou áreas de descanso na exposição; nessa época, no Mirante da Torre, havia uma livraria pertencente à Editora Santuário, além de máquinas para venda de alimentos e bebidas. Enfim, o comércio desses alimentos acabava por colocar em risco o acervo do Museu, pois não havia uma proibição quanto ao consumo nos elevadores e ambientes expositivos.

De maneira geral, o espaço para visitação era amplo, com um único salão dividido por núcleos expositivos, bem organizados, no qual os próprios objetos de grande porte auxiliavam na organização do espaço, juntamente com os painéis textuais que conduziam o fluxo de visitação, estabelecendo um itinerário praticamente obrigatório ao visitante.

O trajeto proposto ao público era único, conduzindo o visitante a fazer uma apreciação da exposição de forma cronológica. Considerando que a distribuição do conceito expositivo no espaço era organizada de forma sequencial, em núcleos temáticos.

Nesse contexto, observamos que era dada grande importância aos objetos museológicos, devido à relevância deles para os temas propostos, considerando que os objetos eram os recursos evidenciados na história do Vale do Paraíba.

Em relação aos recursos expográficos, havia painéis com textos, pinturas, mapas, roteiros, quadros reproduzidos ou originais criados por artistas 
especialmente para o museu, assim como fotografias e reproduções de gravuras, contextualizando cada núcleo, que apresentava o Ciclo Socioeconômico.

A qualidade da comunicação visual era boa, embora realizada manualmente por pintores e letristas. De maneira geral, o texto apresentava boa legibilidade, com letras grandes, etiquetas informativas sobre os objetos, seguindo um padrão de estilo e cor. No texto inicial da exposição também constavam informações técnicas sobre a organização e os responsáveis pelo desenvolvimento, sendo caracterizado como ficha técnica.

O mobiliário seguia o mesmo padrão da exposição localizada no $2^{\circ}$ andar da Torre, vitrines de madeira e vidro, com prateleiras de vidro. Embora, os objetos de grande porte eram dispostos diretamente no chão. Alguns objetos eram fixados nos painéis, entre os textos, ou fixados nas paredes, conforme disponibilidade de espaço. Não havia uma iluminação direcionada, o salão possuía iluminação geral, mas também havia grande incidência de luz solar, que entrava pelas janelas das quatro paredes do salão da exposição.

Em relação à acessibilidade para portadores de necessidades especiais, consideramos apenas a acessibilidade para cadeirantes, pois havia dois elevadores de acesso ao Museu. Não foram encontrados registros de recursos para o atendimento de deficientes auditivos, visuais e de outras naturezas.

De maneira geral, a criação do Museu dos Ciclos Socioeconômicos do Vale do Paraíba partiu da iniciativa e patrocínio dos fundadores Conceição Borges e seu esposo Vicente Camargo, que eram também os responsáveis por percorrer várias cidades da região do Vale do Paraíba para aquisição de objetos, tendo recebido diversas doações.

Em suma, o crédito dos apoiadores para realização da exposição constava no texto inicial de apresentação, o qual citava Vicente Camargo e Conceição Borges Ribeiro Camargo como realizadores e conservadores do Museu, com apoio oficial das autoridades eclesiásticas da Arquidiocese de Aparecida, D. Carlos Carmelo de Vasconcellos Motta, Cardeal Arcebispo, D. Antônio Ferreira de Macedo, Arcebispo coadjutor, Padre Noé Sotillo, Administrador Geral da Basílica. Enfim, o planejamento e a elaboração dos textos e croquis, bem como a direção geral para montagem, foram realizados pelo Prof. Paulo Camiller Florenceno, com auxílio do Prof. Carlos Eduardo Murad e o letrista Olavo Couro, responsáveis pela produção dos painéis artísticos. 


\section{Capítulo 2 - As trajetórias do Museu: mudanças na gestão e reestruturação}

Neste capítulo será abordada a segunda fase do Museu, quando passou a ser administrado diretamente pelo Santuário Nacional de Aparecida. Essa fase será dividida em dois períodos: o primeiro de 1996 a 2003, momento em que ocorreu o falecimento da Profa. Conceição Borges, que continuava atuando no museu até então; e o segundo relativo às etapas de revitalização institucional do Museu até os dias atuais.

A revitalização iniciada em 2003 compreende a criação do Plano Museológico, a organização das coleções na Reserva Técnica e os processos de identificação e classificação do acervo, bem como o uso de Sistemas de Gerenciamento de Documentos, para catalogação dos objetos em software específico.

O método de pesquisa continua sendo o estudo de formação do acervo e coleções, com base nos documentos de entrada e doação de objetos, listas de inventário e fichas catalográficas. Assim como a realização de entrevistas semiestruturadas com ex-diretores, entre eles o Prof. Guido Machado Braga e a Profa. Zilda Augusta Ribeiro, esta última, trata-se de um depoimento já existente nos arquivos do Museu. Assim como entrevistas com ex-coordenadores do Museu e com Dom Darci Nicioli, que na época da revitalização era o Ecônomo/Administrador do Santuário Nacional, além do Padre Victor Hugo Silveira Lapenta, C.Ss.R., coordenador da Comissão dos Bens Culturais da Arquidiocese de Aparecida e da Profa. Tereza Pasin, que acompanhou a Profa. Conceição Borges em diversas atividades do Museu.

O método adotado para análise das entrevistas foi a transcriação e edição, conforme metodologia aplicada por José Carlos Meihy (2005), em seu Manual de História Oral, contendo trechos das entrevistas, bem como dos materiais audiovisuais pertencentes ao Museu, com intuito de examinar as diferentes gestões, sendo possível observar algumas permanências, continuidade de atividades, novos processos e projetos inovadores.

Em relação às fontes de pesquisa e bibliografia consultadas, as principais referências foram as listas de entrada de objetos do período de 1996 a 2002; as demais listas referentes aos anos de 2003 a 2018 foram inseridas no ANEXO B. O Sistema de Classificação do Acervo demonstra como os acervos e as coleções 
foram organizados a partir do estudo dos Thesaurus ${ }^{43}$, adaptado às especificidades do acervo do Museu Nossa Senhora Aparecida.

Também é referência o artigo de Souza (2008), um estudo sobre Museu e Memória no Vale do Paraíba, no qual a autora descreve alguns museus da região, incluindo o Museu Nossa Senhora Aparecida. Além desse artigo, Peixe e Bigareli (2016) fazem uma explanação histórica do Museu ao preparem o Catálogo Comemorativo dos 60 anos da instituição, lançado no dia 8 de setembro de 2016.

\subsection{Período de 1996 a 2003}

Com o falecimento dos fundadores, que deixaram em testamento o Museu Nossa Senhora Aparecida, este passou a ser administrado pelo Santuário Nacional, sendo o detentor de todo acervo, com respaldo legal do Contrato de Doação para o Santuário Nacional de Aparecida.

Nesse período o Santuário tinha como administrador e ecônomo o Padre Darci José Nicioli4" ${ }^{4}$ C.Ss.R. (Congregação do Santíssimo Redentor), atualmente Arcebispo da Arquidiocese de Diamantina (MG). Ele realizou mudanças importantes na forma de gestão do Santuário, promovendo a criação da Campanha dos Devotos, implantando a Revista de Aparecida, fundamental para o desenvolvimento, divulgação e continuação das obras de acabamento da Basílica de Nossa Senhora Aparecida e demais obras sociais realizadas pela instituição, conforme relatado em entrevista.

Aos poucos, é claro, nós fomos conhecendo mais de museografia, de museologia, e etc. E, por todo o acervo que temos, nós chegamos à conclusão, por que não organizar um museu à altura do Santuário Nacional? E ele então se inseriu, e todas essas mudanças que aconteceram na história do Santuário Nacional a partir dali dos anos 90, dos anos 2000. Nós tivemos um progresso muito grande, graças a Deus, dentro do Santuário Nacional, na sua organização. Então, nós também investimos no

43 Foram consultados vários Thesaurus para desenvolvimento do Sistema de Classificação, tais como: FERREZ, H. D.; BIANCHINI, M. H. Thesaurus para acervos museológicos. Rio de Janeiro: Fundação Nacional Pró-Memória; Museu Histórico Nacional, 1987.

OBJETS religieux, méthode d'analyse et vocabulaire. Canadá, França: Éditions de la Réunion des musées nationaux, 1994.

PERRIN, J. Thesaurus des objets religieux du culte catholique. Edition trilingue français, anglais, italien. Editions du Patrimoine, 1999.

ROCCA, S. V.; GUEDES, N. C.; ROQUE, M. I.; GUERREIRO, D. Thesaurus: Vocabulário de objetos do culto católico. Lisboa: Universidade Católica Portuguesa; Fundação da Casa de Bragança, 2004.

Também foi consultada a coleção de Normas de Inventário produzida pela Direção Geral do Patrimônio Cultural de Portugal, disponível em: $<$ http://www.matriznet.dgpc.pt/matriznet/NormasInventario.aspx>.

${ }_{44} \mathrm{NICIOLI}$, Darci José (Arcebispo de Diamantina). Entrevista concedida a Erica Andreza Coelho. Aparecida, 19 abr. 2018, 6 min 14 s. Som, Formato M4A. 
Museu Nossa Senhora Aparecida, pelo seu acervo, e porque os visitantes do Santuário Nacional merecem. O museu ajuda a contar a história de Nossa Senhora Aparecida. O museu ajuda a evangelizar. (NICIOLI, 2018, informação verbal).

Em relação à nova direção do Museu Nossa Senhora Aparecida, de acordo com o depoimento da Profa. Zilda Augusta Ribeiro ${ }^{45}$, concedido a Giselle Peixe e Silvia Bigareli em 2003, no início dos trabalhos de revitalização institucional, Zilda Ribeiro (2003, informação verbal) diz que, na época em que recebeu o convite para direção do Museu, em 1996, ela trabalhava voluntariamente no Arquivo do Santuário, além de ser diretora da Escola Municipal Marieta Braga, em Aparecida (SP).

A Profa. Zilda Augusta Ribeiro era professora, pesquisadora e escritora, membro do Instituto de Estudo Valeparaibanos. Atuou como diretora do Museu Nossa Senhora Aparecida entre os anos de 1996 a 2003, tendo realizado eventos especiais no Museu, conforme observado na Figura 77.

Figura 77: Diretora Zilda Augusta Ribeiro, à direita, durante celebração em preparação ao Natal, realizada no corredor de entrada da antiga exposição do $2^{\circ}$ andar da Torre Brasília.

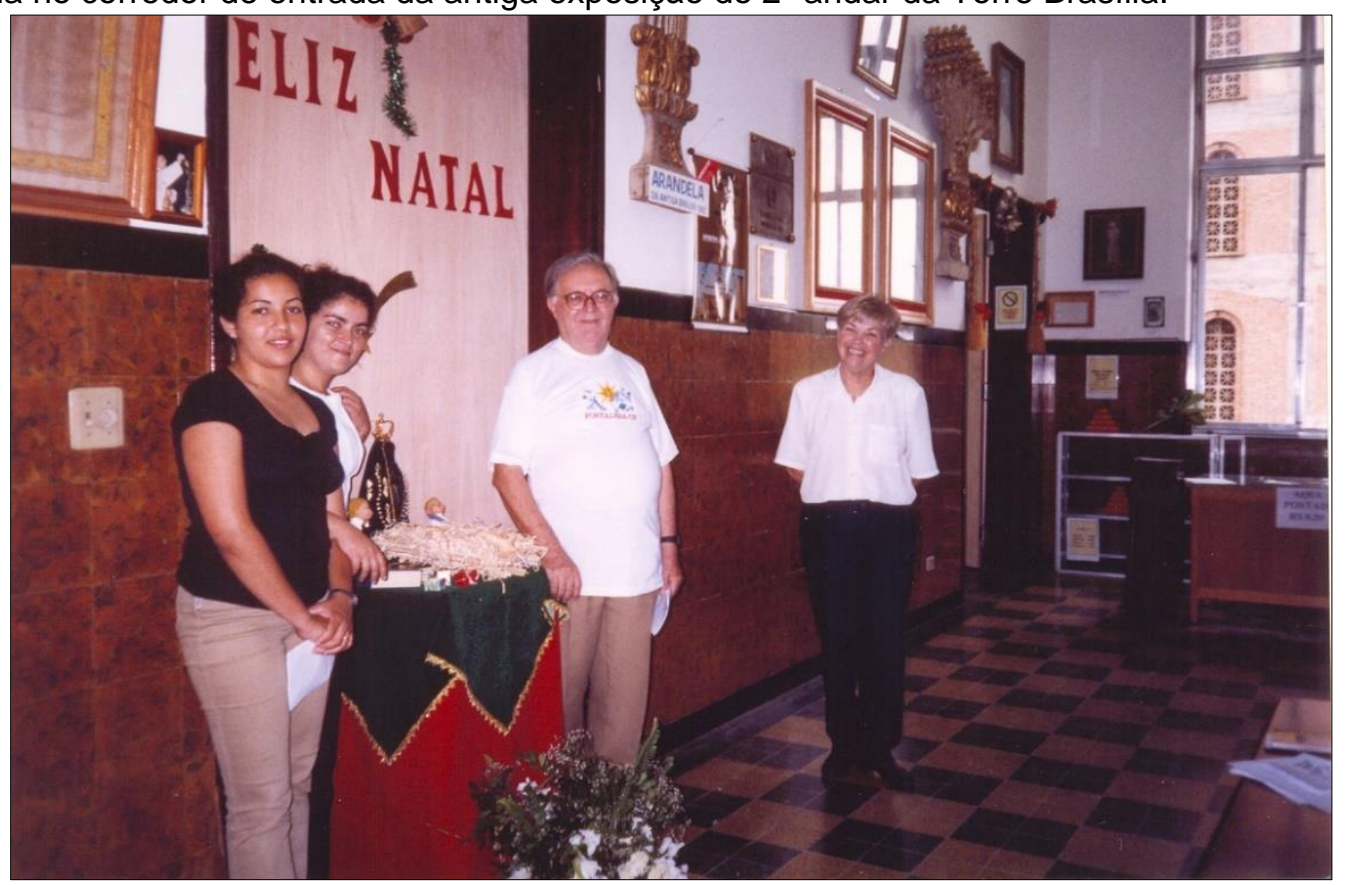

Fonte: MNSA/Santuário Nacional.

De acordo com a Profa. Zilda Ribeiro,

Quando faleceu a Dona Conceição Borges, o Padre Jadir me ofereceu o cargo de direção. Eu deixei a escola e vim dirigir o Museu. Vim completamente nula em termos de museologia, não conhecia nada, só

${ }^{45}$ RIBEIRO, Zilda Augusta. Depoimento concedido a Giselle Peixe e Silvia Bigareli. Aparecida, 2003. 60 mim 2 s., Som, Cor, Formato vídeo 8mm, com reprodução em DVD. 
conhecia o Museu, via como que estava, que podíamos fazer alguma coisa para melhorar a aparência dele, mas em termos de museu, de museologia, eu não sabia nada. (RIBEIRO, 2003, informação verbal).

A Profa. Zilda Ribeiro assume então, naquele momento, a direção do Museu Nossa Senhora Aparecida. Ao ser questionada por Giselle Peixe sobre a situação em que o Museu foi encontrado, Zilda explica a necessidade de reorganização do acervo e fornecimento de materiais para pesquisa, conforme trecho do depoimento a seguir:

Giselle - Zilda, quando você chegou ao Museu, você o encontrou numa determinada situação. Você sentiu necessidade de organizar, de interferir naquilo que você encontrou? Nesses anos em que você ficou à frente do Museu, quais são as principais mudanças que você implantou, quais as iniciativas que você tomou?

Zilda - Bom, em nível de exposição, nós procuramos - o pessoal que trabalhava comigo, um pessoal muito bom, trabalha ainda - então, nós procuramos colocar, em nível, como temáticas, sobre o encontro da imagem, tudo que se referisse ao encontro da imagem. A parte folclórica, tudo que se referia ao folclore. Então, essa disposição temática foi a primeira preocupação.

Giselle - Não estava assim, foi isso o que você viu?

Zilda - É, e também a parte de fotografias, arrumar, organizar o arquivo, porque chegavam os estudantes para fazerem pesquisas e eu não tinha noção de onde estava nada, ficava naquela busca, naquela procura. Então, eu comecei a organizar também essa parte para tornar mais fácil a pesquisa. Mas, sem obedecer aos critérios que hoje eu vejo que é o cuidado com o material [...].

Giselle - Zilda, você está falando de localizar material para fornecer para os estudantes. Quer dizer, então, existia ou ainda existe uma necessidade, vamos dizer, de grupos, era da cidade, como era isso? Como é que eles solicitavam esse tipo de material do Museu?

Zilda - Eram da cidade e eram também da região, sobretudo universitários. Uma procura muito grande para saber sobre Aparecida, saber sobre o encontro da Imagem, e não só, mas saber também sobre aspectos, determinadas entidades. Rádio Aparecida era motivo de procura pelos alunos de jornalismo. A Editora Santuário, eles queriam saber a história da Editora, dos jornais, do Jornal Santuário, dos Ecos Marianos, então era muita procura. Então, eu trouxe todos os Ecos Marianos que estavam no depósito lá em cima, justamente para que eles pudessem usar e folhear, nunca me preocupei em colocar luva, porque, como eu disse para você, o despreparo era grande.

Giselle - Mas, de todo jeito você reuniu o material que tinha informação para essas pessoas, quer dizer, o Museu já cumpria essa função de auxiliar a pesquisa.

Zilda - Após o primeiro encontro que nós tivemos sobre museologia, uma frase me marcou muito e eu procurei nortear a minha ação ligada por essa frase, era que "o museu sem preocupação com a educação não é museu". $\mathrm{E}$, de modo, que eu mandei ofício para todas as escolas, falando do acervo que nós tínhamos, colocando à disposição, marcando os dias de visitação em que eu estivesse para podermos dar essa noção para os alunos. E, como resultado, tem um trabalho no Museu de uma professora, ela veio 
com os alunos, os alunos fizeram a entrevista e, a partir dessa visita ao museu e da entrevista, eles fizeram um trabalho "Como organizar um museu", e trouxeram com fotografias, então, está arquivado no Museu esse trabalho, achei tão válido.

Giselle - Porque eles foram além, eles vieram procurar um determinado número de informação e fizeram.

Zilda - Alunos da sexta série, com entrevista, com toda preocupação sobre o que era restauro, como que procedia. E eles fizeram tudo, fizeram um documentário sobre a visita, sobre a parte de museu. Isso me trouxe muita alegria.

Giselle - Eu vejo, Zilda, que o Museu cumpria, cumpre, quer dizer, não há outras instituições na cidade que possam falar sobre a memória do lugar, ou existem? Não existe um arquivo municipal?

Zilda - Exato! Não, arquivo municipal não. Até ontem nós tivemos aquela reunião com o Padre Víctor Hugo sobre preservação dos bens culturais, ainda fiquei pensando, a Prefeitura tinha que ter um arquivo municipal, e acho que não tem nada, porque o pessoal de lá vem para cá.

Giselle - Para buscar aqui.

Zilda - Da Prefeitura vem pesquisar aqui. Então, acho que não tem nada.

Giselle - Isso é um ponto importante para discussão, de qual é a missão deste museu?

Zilda - Exato!

Giselle - Se ele deve permanecer, quer dizer, dar continuidade a esse tipo de trabalho que ele oferece, com relação à história da cidade também, das pessoas da cidade, ou se uma outra instituição na cidade vai ter que acabar assumindo isso. Porque, na verdade, ele vai além da própria história do Santuário. O material que ele guarda, ele tem um material relativo à cidade como um todo, as pessoas da cidade e das outras regiões, que acaba desaguando aqui através das doações.

Zilda - Isso é muito forte. [...]. (RIBEIRO, 2003, informação verbal).

Com esse trecho do depoimento, observamos a preocupação da Profa. Zilda Ribeiro em ter maior conhecimento sobre as peças constantes no acervo do Museu, assim como demais materiais documentais e fotográficos, frequentemente solicitados por pesquisadores e estudantes.

Em relação à característica do acervo, identificado de uma forma eclética e heterogenia, não ligada, necessariamente, ao sagrado, a Profa. Zilda Ribeiro complementa que,

É um acervo, eu costumo falar aqui, o acervo do Museu daria para fazer uns três, quatro museus, não é? Porque não tem uma tipologia. Quando eu falei para você dessa preocupação de ambientar as peças, nós procuramos fazer um pouco disso, mas o que tinha de peça que não tinha nada a ver com o sacro, você vê a quantidade de louça, de garfo, de faca, de arma. Então, veio muita coisa que não tinha nada a ver com o elemento sacro. Então ele se tornou uma mistura, o Museu é muito eclético. E que essa visão agora do padre Darci de separar, acho que vai ser muito interessante, porque vai ficar a parte só sacra desvinculada, desvinculada não, haverá 
uma vinculação em termos de entidade, de tudo, mas que fique esse acervo folclórico, histórico, que fique o doméstico, você vê quanta coisa que tem da cozinha brasileira. [...] Ferro de passar roupas, panela de ferro, eles traziam. E porque eu noto muito também a preocupação deles de que se coloque o nome da família, e a preocupação de que vindo para o Museu, vai perpetuar isso, é uma coisa que vai passar. E é muito importante para eles que eles vejam o nome da família. Interessante, é uma ânsia de perpetuação. (RIBEIRO, 2003, informação verbal).

Para ela, o Museu possuía um acervo eclético, com diversas tipologias, abrindo margem para criação de diversas exposições temáticas, a partir da iniciativa do Padre Darci José Nicioli, C.Ss.R., administrador e ecônomo do Santuário Nacional de Aparecida, em reestruturar o Museu. E era desta forma em que os visitantes se identificavam e se interessavam em fazer novas doações, devido à diversidade de objetos expostos, mantendo os registros e as informações de doação junto ao acervo, buscando perpetuar o nome da família por intermédio do objeto.

Pelas evidências documentais, observamos que na direção da Profa. Zilda Ribeiro deu-se continuidade ao preenchimento de um formulário para o recebimento de doações, com apoio dos funcionários contratados pelo Santuário Nacional, que haviam substituído, há algum tempo, os guardinhas mirins do período da Profa. Conceição Borges. Com isso, esses funcionários passaram a ter uma preocupação maior com a parte descritiva dos objetos, durante o preenchimento do Termo de Doação de Bens Móveis.

De acordo com a Profa. Zilda Ribeiro, eram onze funcionários contratados como recepcionistas, que também colaboravam com a limpeza do espaço e eram orientados por ela para fazer o acolhimento dos visitantes.

A Profa. Zilda Ribeiro ao ser questionada sobre o objetivo do Museu, diz que:

O objetivo do Museu Nossa Senhora Aparecida está ligado ao objetivo geral do Santuário, 'acolher bem também é evangelizar'. Para a concretização desse objetivo, funcionários e monitores são treinados para acolher o visitante, para orientá-lo quanto aos procedimentos e para esclarecer suas dúvidas. (RIBEIRO, 2006, p. 85).

Além dos treinamentos, os funcionários também a observavam em seu atendimento e buscavam aprender melhores formas de receber os visitantes.

[...] eu comecei a monitorar, dar informações, eu notava o interesse de alguns em ficar escutando, aprendendo. Isso também é uma coisa que eu não fiz, foi chegar e mudar com os funcionários. Mas, eles foram sentindo que alguma coisa tinha que mudar. Como, por exemplo, segunda-feira a abertura do Museu era às $8 \mathrm{~h}$ da manhã, os romeiros estavam entrando e eles estavam lavando o Museu, falei que não podia e o perigo. Estipulei que a limpeza seria feita um horário antes, então eles deveriam entrar mais cedo, a equipe de limpeza deveria entrar mais cedo. (RIBEIRO, 2003, informação verbal). 
Com base nesse relato, observamos que alguns procedimentos foram sendo melhorados, para garantir maior segurança ao acervo, assim como um melhor conforto ao visitante, ao alterar o horário de limpeza da exposição e proporcionar a qualificação no atendimento.

A Profa. Zilda Ribeiro relata também certo preconceito.

Eu mesmo brinco, "- Olha, eu estou no Museu, mas por enquanto estou fora da vitrine", brincando, porque é assim, bastante preconceito. Eles têm uma ideia, isso também foi uma proposta minha, tentar mudar o conceito de que museu é depósito de velharia. Eu lembro de um grupo que chegou de uma romaria organizada, e o guia, quando o elevador parou, ele falou assim "- Vocês querem ver museu, museu é coisa velha, depósito de velharia, e eu não vou entrar". E eu estava lá e falei "- Você que é o guia?", ele falou "Sou", "- Olha, eu vou falar para você, que o Museu nosso tem uma proposta de ser educativo, portanto, ele não é só um depósito de coisas velhas, são coisas do passado, que têm uma mensagem no presente e para o futuro também, porque quem não cultua o passado, não vai saber enfrentar o futuro", e fui falando, "- E eu acho que os guias, eles devem ter cursos de museologia também". Daí ele entrou, "- Olha, gostei viu, gostei" e saiu. Então, tínhamos esse trabalho de falar com eles tentando passar uma mensagem diferente desse preconceito, de que o museu é depósito de velharia. E falava, "- Para isso existem os antiquários, você vai lá ver, mas, aqui não". Uma coisa que traz uma mensagem do passado para você no presente, que tem que procurar. Esse cuidado que tem que ter. (RIBEIRO, 2003, informação verbal).

Durante a reorganização do Museu iniciada pela Profa. Zilda Ribeiro, foi criado também um Livro de Tombo, mas seu preenchimento logo foi interrompido, pois, de acordo com o relado da Profa. Zilda Ribeiro, havia uma intenção de ampliação do Museu por parte do administrador do Santuário, Padre Darci José Nicioli, C.Ss.R., e, portanto, a Profa. Zilda Ribeiro opta por aguardar a reestruturação para dar continuidade ao preenchimento do Livro de Tombo, que acabou não sendo retomado em nenhuma das gestões posteriores. Entretanto, Giselle Peixe identifica uma grande preocupação da Profa. Zilda Ribeiro em fazer o registro do acervo, conforme trecho do depoimento a seguir:

Giselle - Zilda, dentro desses trabalhos que estamos fazendo, vimos que você teve uma preocupação com o registro desse acervo. Queria que você contasse um pouco como foi esse processo, o que você encontrou quando você assumiu o Museu? Você até acabou de dizer que ele era originalmente um Museu particular.

Zilda - Então, particular. Esse registro foi feito pela direção anterior, era a Dona Conceição. E como começamos a notar que muita coisa que estava no registro, não estava no Museu. [...] De modo que esse registro nós estávamos sempre com ele nas mãos, mas eu passei a fazer a ficha do material novo que chegava, com a assinatura da pessoa que doava, tudo isso, era isso que nós tínhamos. Nós não tínhamos um livro de tombo, comecei a fazê-lo logo, mas depois o padre Darci falou que estava com ideia de ampliar o Museu. Eu parei de fazer esse registro, porque eu falei 
não sabia como ia ser esse procedimento. Então, vou ficar só com as fichas preenchidas na hora da doação.

Giselle - Isso foi uma iniciativa sua? Essa coisa dos termos de doação, um formulariozinho pronto.

Zilda - Não, já era, já vinha, eu encontrei isso. Mas, não havia muita preocupação descritiva. Começamos com mais preocupação descritiva, foi nesse sentido assim. (RIBEIRO, 2003, informação verbal).

Em relação aos Termos de Doação de Bens Móveis, que foram implantados ainda na gestão da Profa. Conceição Borges e continuados nas gestões posteriores, foram analisados, entre demais documentação do acervo, como as fichas catalográficas, e relacionados em listas anuais de entrada de objetos, organizados de acordo com os Termos de Doação de Bens Móveis entre os anos de 1996 a 2002, conforme pode ser observado entre os Quadros 4 a 10.

Quadro 4: Lista de entrada de objetos (1996)

\begin{tabular}{|c|c|c|c|c|}
\hline $\begin{array}{c}\text { № de } \\
\text { entrada }\end{array}$ & Descrição do Objeto & Data & Doador & $\begin{array}{l}\text { Responsável } \\
\text { Recebimento }\end{array}$ \\
\hline E-01/1996 & Fita métrica & 1996 & Sandra Maria Eugenio & - \\
\hline E-02/1996 & 40 Moedas (diversos países) & 1996 & $\begin{array}{c}\text { José Gonçalves da } \\
\text { Silva } \\
\end{array}$ & - \\
\hline E-03/1996 & Monjolo (miniatura) & $10 / 01 / 1996$ & Arthur Silvério & Heloísa Reis \\
\hline E-04/1996 & Pedra Cristal c/ suporte madeira & $14 / 01 / 1996$ & Maria Alves Cunha & Heloísa Reis \\
\hline E-05/1996 & Máquina de costura à mão & $17 / 01 / 1996$ & Geni Vitorian Sertório & Heloísa Reis \\
\hline E-06/1996 & $\begin{array}{c}\text { Relógio de pulso - Seiko - } \\
\text { Automatic }\end{array}$ & $21 / 01 / 1996$ & $\begin{array}{c}\text { Laurinda Soares de } \\
\text { Carvalho }\end{array}$ & Heloísa Reis \\
\hline E-07/1996 & $\begin{array}{c}\text { Toca fita de carro - Muntz Stereo } \\
\text { Pak }\end{array}$ & 05/02/1996 & Joel Joaquim de Brito & Heloísa Reis \\
\hline E-08/1996 & $\begin{array}{c}\text { Abridor de garrafa e saca-rolha - } \\
\text { formato chave }\end{array}$ & $10 / 02 / 1996$ & Afonso de Lara Ponse & $\begin{array}{l}\text { Danival } \\
\text { Mascarini }\end{array}$ \\
\hline E-09/1996 & $\begin{array}{c}1 \text { Cédula de } 1 \text { dolar } \\
\text { (Assinada pelo doador) }\end{array}$ & $10 / 03 / 1996$ & Pedro de Araújo & Heloísa Reis \\
\hline$E-10 / 1996$ & $\begin{array}{l}1 \text { Moeda } 1.000 \text { réis }(1938) / \\
2 \text { moedas } 1 \text { cruzeiro }(1945) / \\
1 \text { moeda } 2 \text { cruzeiros }(1946)\end{array}$ & $27 / 03 / 1996$ & $\begin{array}{l}\text { Amadeu Claro dos } \\
\text { Santos } \\
\end{array}$ & Heloísa Reis \\
\hline E-11/1996 & Cédulas antigas & $10 / 04 / 1996$ & $\begin{array}{l}\text { Francisco Monteiro } \\
\text { Silva } \\
\end{array}$ & Heloísa Reis \\
\hline E-12/1996 & 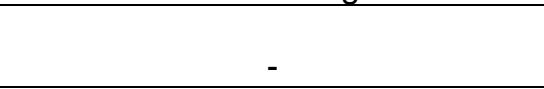 & 20/04/1996 & Joanides da Silva & $\begin{array}{c}\text { Danival } \\
\text { Mascarini }\end{array}$ \\
\hline$E-13 / 1996$ & Isqueiro de prata & $27 / 04 / 1996$ & $\begin{array}{c}\text { Adalberto Rodrigues } \\
\text { Sanvidu }\end{array}$ & $\begin{array}{l}\text { Danival } \\
\text { Mascarini }\end{array}$ \\
\hline$E-14 / 1996$ & Giramundo & $28 / 04 / 1996$ & $\begin{array}{c}\text { Antonia Ferreira da } \\
\text { Silva }\end{array}$ & Heloísa Reis \\
\hline$E-15 / 1996$ & $\begin{array}{c}\text { Máquina de costura - Vigorelli } \\
\text { (miniatura) }\end{array}$ & $12 / 05 / 1996$ & $\begin{array}{c}\text { Neusa Pastor Lopez } \\
\text { Saito }\end{array}$ & Heloísa Reis \\
\hline
\end{tabular}


"continuação"

\begin{tabular}{|c|c|c|c|c|}
\hline $\begin{array}{l}\text { № de } \\
\text { entrada }\end{array}$ & Descrição do Objeto & Data & Doador & $\begin{array}{l}\text { Responsável } \\
\text { Recebimento }\end{array}$ \\
\hline$E-16 / 1996$ & $\begin{array}{c}\text { 1 Moeda Walt Disney / } 1 \text { moeda } 1 \\
\text { cent dolar (1964) / } 1 \text { moeda } 1 / 2 \\
\text { dolar (1964) / 1 moeda } 1 \text { franco } \\
\text { (1960) }\end{array}$ & $12 / 05 / 1996$ & Maria José Silva & Heloísa Reis \\
\hline$E-17 / 1996$ & $\begin{array}{c}\text { Relevo em madeira Brasão } \\
\text { Aparecida }\end{array}$ & $18 / 05 / 1996$ & Vicente Sálvio Neto & $\begin{array}{c}\text { Danival } \\
\text { Mascarini }\end{array}$ \\
\hline$E-18 / 1996$ & Réplica capacete Ayrton Senna & 07/06/1996 & $\begin{array}{c}\text { Roberto Satoshi } \\
\text { Maeshiro }\end{array}$ & - \\
\hline$E-19 / 1996$ & Ferro de passar a gás - Yanes & $20 / 06 / 1996$ & Carmem Maria Lima & Heloísa Reis \\
\hline E-20/1996 & $\begin{array}{c}1 \text { Cédula cinco cruzeiros - Barão } \\
\text { do Rio Branco }\end{array}$ & $30 / 06 / 1996$ & José Angelo Borges & Heloísa Reis \\
\hline$E-21 / 1996$ & 1 Corrente/ 1 cruz & $15 / 07 / 1996$ & Maria Bezerra Brasil & Heloísa Reis \\
\hline$E-22 / 1996$ & Terço contas de cristal & $17 / 07 / 1996$ & $\begin{array}{c}\text { Maria da Conceição } \\
\text { Marques }\end{array}$ & Heloísa Reis \\
\hline$E-23 / 1996$ & Revólver - cabo de marfim & 24/07/1996 & $\begin{array}{l}\text { Maria José Naves do } \\
\text { Nascimento }\end{array}$ & Zilda Ribeiro \\
\hline E-24/1996 & $\begin{array}{l}1 \text { Cédula } 100 \text { cruzeiros (Dom } \\
\text { Pedro II) }\end{array}$ & 29/07/1996 & $\begin{array}{l}\text { Sebastian Ferreira } \\
\text { Araujo }\end{array}$ & Heloísa Reis \\
\hline E-25/1996 & Quadro - bordado (moldura verde) & 04/08/1996 & Rogéria Aparecida Tom & Heloísa Reis \\
\hline$E-26 / 1996$ & 1 Moeda 25 centavos $(1995-1996)$ & 08/08/1996 & Edvaldo e Maria Salete & Heloísa Reis \\
\hline E-27/1996 & $\begin{array}{c}3 \text { Moedas } 2.000 \text { réis }(1856-1926) / \\
1 \text { moeda } 500 \text { réis }(1850-1907)\end{array}$ & $17 / 08 / 1996$ & Paulo Laurinio & $\begin{array}{l}\text { Rogélio } \\
\text { Eugênio }\end{array}$ \\
\hline$E-28 / 1996$ & $\begin{array}{c}1 \text { Graveto pequeno cor verde / } \\
1 \text { graveto cor grafite }\end{array}$ & 27/08/1996 & José Maria Silva Filho & Heloísa Reis \\
\hline E-29/1996 & 2 Moedas 500 liras - italiana & 29/08/1996 & $\begin{array}{l}\text { Bassi Giancallo e } \\
\text { Rosalina }\end{array}$ & (1) \\
\hline E-30/1996 & 1 Aliança de ouro & 01/09/1996 & $\begin{array}{l}\text { Antônio Collado } \\
\text { Navarro }\end{array}$ & Heloísa Reis \\
\hline$E-31 / 1996$ & Almanaque Ecos Mariano (1934) & 08/09/1996 & José Ferminiano & Heloísa Reis \\
\hline$E-32 / 1996$ & $\begin{array}{c}\text { Ferro de Passar roupa - FAMA, } \\
\text { Rádio Motorrádio }\end{array}$ & $12 / 09 / 1996$ & $\begin{array}{l}\text { Balduino Soares da } \\
\text { Cruz }\end{array}$ & Heloísa Reis \\
\hline E-33/1996 & $\begin{array}{c}1 \text { Moeda } 20 \text { francos - França } \\
(1993)\end{array}$ & 26/09/1996 & $\begin{array}{l}\text { Domingos Marcelino } \\
\text { Antão }\end{array}$ & Heloísa Reis \\
\hline E-34/1996 & $\begin{array}{l}7 \text { Medalhas - Sagrada família, } \\
\text { Liga católica, } 50 \text { anos de Velco } \\
\text { 1930-1980, Lechonlogy, Sagrado } \\
\text { Coração de Jesus, Maria - } \\
\text { Apostolado da oração/ } 1 \text { moeda } \\
\text { peny (1949) / } 1 \text { moeda } 40 \text { réis } \\
\text { (Dom João IV) / } 1 \text { Moeda } 300 \text { réis } \\
\text { (Getúlio)/ } 1 \text { soldado da pátria }\end{array}$ & 29/09/1996 & $\begin{array}{l}\text { Iracema Simão dos } \\
\text { Passos }\end{array}$ & Heloísa Reis \\
\hline E-35/1996 & Cédulas? & 06/10/1996 & Dalva da Silva & Heloísa Reis \\
\hline E-36/1996 & $\begin{array}{c}\text { Relógio de bolso - Omega } \\
(12 / 12 / 1992)\end{array}$ & 09/10/1996 & $\begin{array}{l}\text { Genésio Miguel de } \\
\text { Lima }\end{array}$ & Zilda Ribeiro \\
\hline E-37/1996 & $\begin{array}{c}1 \text { Xícara (barra na boca azul e } \\
\text { branca) }\end{array}$ & 10/10/1996 & Maria Lázara de Jesus & Zilda Ribeiro \\
\hline$E-38 / 1996$ & $\begin{array}{l}1 \text { Manto de renda/ toalhinhas de } \\
\text { renda }\end{array}$ & $12 / 10 / 1996$ & Silvana Laurea Ribeiro & - \\
\hline
\end{tabular}




\begin{tabular}{|c|c|c|c|c|}
\hline $\begin{array}{c}\text { № de } \\
\text { entrada }\end{array}$ & Descrição do Objeto & Data & Doador & $\begin{array}{l}\text { Responsável } \\
\text { Recebimento }\end{array}$ \\
\hline E-39/1996 & $\begin{array}{l}4 \text { Cédulas } 5.000 \text { cruzeiros/ } 1 \\
\text { cédula } 1 \text { cruzeiro/ } 3 \text { cédulas } 50 \\
\text { cruzados novos/ } 1 \text { cédula } 200 \\
\text { cruzeiros/ } 1 \text { cédula } 100 \text { cruzeiros/ } \\
1 \text { cédula } 1.000 \text { cruzados/ } 1 \text { cédula } \\
10.000 \text { cruzeiros }\end{array}$ & $21 / 10 / 1996$ & $\begin{array}{l}\text { Jaílson de Oliveira } \\
\text { Prado }\end{array}$ & Heloísa Reis \\
\hline E-40/1996 & 1 Moeda 500 réis (1922) & $25 / 10 / 1996$ & Vinícius Costa Braga & $\begin{array}{c}\text { Danival } \\
\text { Mascarini }\end{array}$ \\
\hline E-41/1996 & Livro "O canto do Gato preto" & $26 / 10 / 1996$ & Virginia Parata Gregolin & - \\
\hline$E-42 / 1996$ & $\begin{array}{c}1 \text { Cédula } 5.000 \text { réis/ } 1 \text { cédula } \\
50.000 \text { réis }\end{array}$ & $27 / 10 / 1996$ & Eder Carlos Ferreira & Heloísa Reis \\
\hline E-43/1996 & Relógio de pulso - Eterna-Matic & $27 / 10 / 1996$ & Silvestre da Cruz & - \\
\hline E-44/1996 & Relógio de bolso - Omega & $29 / 10 / 1996$ & Maria Aparecida Faria & Heloísa Reis \\
\hline E-45/1996 & $\begin{array}{l}\text { Medalha Comemorativa VII } \\
\text { Centenário de Santo Antônio }\end{array}$ & 08/11/1996 & Maria Conceição & 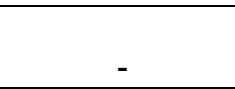 \\
\hline E-46/1996 & $\begin{array}{c}03 \text { Relógios de pulso feminino, } 9 \\
\text { Anéis/ Moedas antigas }\end{array}$ & 15/11/1996 & $\begin{array}{c}\text { Ducelina Carolina de } \\
\text { Oliveira }\end{array}$ & Zilda Ribeiro \\
\hline E-47/1996 & - & 08/12/1996 & Fortunato Vernier & Zilda Ribeiro \\
\hline E-48/1996 & Relógio de bolso - Roskoff Patent & $15 / 12 / 1996$ & Francisco de Paula & Heloísa Reis \\
\hline E-49/1996 & $\begin{array}{l}\text { Revólver Calibri } 32-\text { Smicht } \\
\text { (prata. Cabo marrom) }\end{array}$ & $15 / 12 / 1996$ & $\begin{array}{l}\text { Reducino Aparecido } \\
\text { Costa }\end{array}$ & Heloísa Reis \\
\hline E-50/1996 & Relógio - Olino (Olvino) & 29/12/1996 & $\begin{array}{l}\text { Maria Rosa Leme de } \\
\text { Oliveira }\end{array}$ & - \\
\hline$E-51 / 1996$ & Duplicador a Álcool & $25 / 10 / 1996$ & $\begin{array}{c}\text { Dirceia Martins } \\
\text { Carvalho (entregue } \\
\text { pelo Pe. Antônio } \\
\text { Clayton Sant'Ana) }\end{array}$ & Zilda Ribeiro \\
\hline
\end{tabular}

Fonte: MNSA/Santuário Nacional.

Em 1996 a Profa. Conceição Borges faleceu, e a partir desse ano observamos que os documentos de doação possuem assinatura da nova diretora, a Profa. Zilda Ribeiro, e dos demais funcionários do Museu.

No Quadro 4 notamos que há um grande número de relógios, além de cédulas e moedas, que aparentemente é a tipologia que mais cresceu nessa década. Dos cinquenta e um números de entrada de objetos que foram registrados no ano de 1996, dezenove foram identificados pela documentação do acervo, sendo

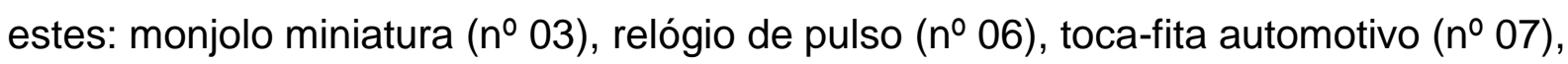
isqueiro ( $\left.n^{\circ} 13\right)$, giramundo ( $\left.n^{\circ} 14\right)$, máquina de costura ( $\left.n^{\circ} 15\right)$, relevo em madeira com o brasão do município de Aparecida ( $n^{\circ}$ 17), réplica do capacete de Ayrton Senna ( $\left.n^{\circ} 18\right)$, ferro de passar a gás ( $\left.n^{\circ} 19\right)$, terço ( $\left.n^{\circ} 22\right)$, ferro de passar ( $n^{\circ} 32$ ), rádio ( $n^{\circ} 32$ ), relógio de bolso ( $\left.n^{\circ} 36\right)$, relógio de pulso ( $\left.n^{\circ} 43\right)$, relógio de bolso ( $n^{\circ}$

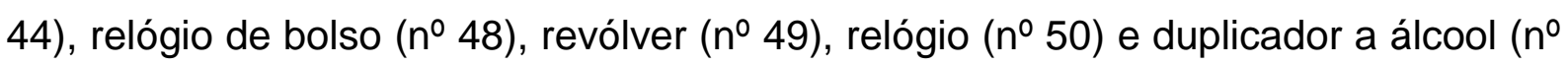
51). Tendo recebido, respectivamente, os seguintes números de inventário: 1.261, 
2.109, 0.913, 1.753, 3.264, 3.263, 0911, 3.222, 2.631, 2.770, 2.634, 3.265, 1.998,

$2.110,1.997,2.185,2.677,2.143$ e 0914.

Quadro 5: Lista de entrada de objetos (1997)

\begin{tabular}{|c|c|c|c|c|}
\hline $\begin{array}{l}\text { № de } \\
\text { entrada }\end{array}$ & Descrição do Objeto & Data & Doador & $\begin{array}{l}\text { Responsável } \\
\text { Recebimento }\end{array}$ \\
\hline E-01/1997 & Mille Fire & 1997 & Guilioni Angelo & - \\
\hline E-02/1997 & 1 Moeda 200 escudos - Portugal & 07/01/1997 & Armindo Cadima & $\begin{array}{c}\text { Danival } \\
\text { Mascarini }\end{array}$ \\
\hline E-03/1997 & $\begin{array}{c}1 \text { Moeda } 100 \text { guaranis }(1990) / 1 \\
\text { moeda } 1 \text { cruzeiro (1943)/ } 1 \text { moeda } \\
50 \text { centavos/ i moeda } 100 \text { réis } \\
(1938) / 1 \text { moeda One cent USA } \\
(1978)\end{array}$ & $12 / 01 / 1997$ & Elizete Prado & Zilda Ribeiro \\
\hline E-04/1997 & $\begin{array}{c}\text { Aparelho de carregar cartuchos } \\
\text { (espingarda) - Le Babet }\end{array}$ & $21 / 01 / 1997$ & Maurício Puras & Heloísa Reis \\
\hline E-05/1997 & Maquete Basílica Nova & $16 / 02 / 1997$ & Josimário Rocha & Heloísa Reis \\
\hline E-06/1997 & Revólver - cabo de marfim & 22/03/1997 & $\begin{array}{l}\text { Manoel Marcelino } \\
\text { Pimentel }\end{array}$ & Zilda Ribeiro \\
\hline E-07/1997 & Lamparina - tropeiros de Formiga & 22/03/1997 & $\begin{array}{c}\text { Marcionília Rodrigues } \\
\text { de Oliveira }\end{array}$ & Zilda Ribeiro \\
\hline E-01/1997 & $\begin{array}{l}1 \text { Moeda } 1 \text { cruzado novo - } \\
\text { Centenário República } 1889-1989\end{array}$ & 20/04/1997 & Ademar Estevão & Heloísa Reis \\
\hline E-09/1997 & $\begin{array}{l}\text { Pedra Ametista - } 70 \text { KG } \\
\text { aproximadamente }\end{array}$ & 24/04/1997 & Lino Santin & Heloísa Reis \\
\hline E-10/1997 & $\begin{array}{l}1 \text { Moeda } 500 \text { réis - Centenário da } \\
\text { Independência }\end{array}$ & 04/05/1997 & Maria Silva Reis & Heloísa Reis \\
\hline E-11/1997 & Relógio & $11 / 05 / 1997$ & $\begin{array}{c}\text { Valdemar Sérgio de } \\
\text { Oliveira }\end{array}$ & Zilda Ribeiro \\
\hline$E-12 / 1997$ & Correntes e medalhas & 07/06/1997 & Célia Saboia & Zilda Ribeiro \\
\hline$E-13 / 1997$ & Máquina fotográfica - Tuka DFV & 08/06/1997 & $\begin{array}{l}\text { Maria Matilde dos } \\
\text { Santos }\end{array}$ & Heloísa Reis \\
\hline E-14/1997 & $\begin{array}{l}1 \text { Cédula de } 2 \text { cruzeiros - } 2^{\text {a }} \\
\text { estampa - série } 764 . A \text { (Duque de } \\
\text { Caxias) }\end{array}$ & $19 / 06 / 1997$ & Pedro Renato Botacim & Heloísa Reis \\
\hline E-15/1997 & $\begin{array}{c}2 \text { Moedas } 2.000 \text { réis - Est. Un. } \\
\text { Brasil (1921 e 1928) }\end{array}$ & $13 / 07 / 1997$ & $\begin{array}{c}\text { Margarida Maria Jesus } \\
\text { Ribeiro }\end{array}$ & Heloísa Reis \\
\hline E-16/1997 & $\begin{array}{c}\text { Canastra pequena pintada de } \\
\text { cinza/verde/preto e marrom; } \\
\text { Porta-níquel+ } 1 \text { moeda } 20 \text { réis/ } 1 \\
\text { moeda } 40 \text { réis/ } 1 \text { moeda } 200 \text { réis }\end{array}$ & $16 / 07 / 1997$ & $\begin{array}{c}\text { Margarida Angélica do } \\
\text { Valle }\end{array}$ & Heloísa Reis \\
\hline E-17/1997 & Panela de cobre com duas alças & $26 / 07 / 1997$ & $\begin{array}{l}\text { Maria do Carmo de } \\
\text { Pádua }\end{array}$ & Heloísa Reis \\
\hline E-18/1997 & $\begin{array}{c}1 \text { Cédula } 1.000 \text { yen (Nippon } \\
\text { Ginko) }\end{array}$ & 07/08/1997 & Tatsuo Miyashita & - \\
\hline E-19/1997 & Pedra de Rebolo & 08/08/1997 & $\begin{array}{l}\text { Octávio Plácido } \\
\text { Germano }\end{array}$ & - \\
\hline E-20/1997 & $\begin{array}{l}\text { Madeira petrificada/ } 1 \text { colher de } \\
\text { pau }\end{array}$ & $16 / 08 / 1997$ & Atílio Sartóri de Oliveira & Zilda Ribeiro \\
\hline E-21/1997 & & 07/09/1997 & $\begin{array}{l}\text { Iracema Ferreira de } \\
\text { Souza }\end{array}$ & Zilda Ribeiro \\
\hline E-22/1997 & $\begin{array}{l}\text { Cartão de prata (placa de } \\
\text { homenagem?) }\end{array}$ & 21/09/1997 & Gilberto Coelho Gomes & Zilda Ribeiro \\
\hline E-23/1997 & $\begin{array}{l}\text { Imagem de Nossa Senhora do } \\
\text { Itati (Argentina?) }\end{array}$ & $? / 10 / 1997$ & Antônio Bueno Filho & Zilda Ribeiro \\
\hline
\end{tabular}




\begin{tabular}{|c|c|c|c|c|}
\hline $\begin{array}{l}\text { № de } \\
\text { entrada }\end{array}$ & Descrição do Objeto & Data & Doador & $\begin{array}{l}\text { Responsável } \\
\text { Recebimento }\end{array}$ \\
\hline E-24/1997 & 11 Cédulas brasileiras & 04/10/1997 & José Flávio Viana & Sônia Cristina \\
\hline E-25/1997 & 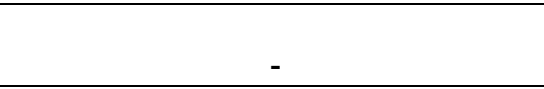 & $11 / 10 / 1997$ & $\begin{array}{l}\text { Maria da Conceição } \\
\text { Figueiredo }\end{array}$ & - \\
\hline E-26/1997 & Relógio - Lanco (1958) & $12 / 10 / 1997$ & Geraldo Dutra de Assis & Zilda Ribeiro \\
\hline E-27/1997 & $\begin{array}{l}5 \text { Cédulas } 1 \text { cruzeiro/ } 5 \text { cédulas } 2 \\
\text { cruzeiros/ } 1 \text { imagem plástico } \\
\text { (ilumina no escuro)/ } 1 \text { cédula } 1 \\
\text { dollar (PHIL, escrito de caneta) }\end{array}$ & $14 / 10 / 1997$ & Edson Luis da Silva & Heloísa Reis \\
\hline E-28/1997 & $\begin{array}{c}\text { Relógio de pulso feminino - } \\
\text { Relotex }\end{array}$ & 01/11/1997 & $\begin{array}{c}\text { Jacyra Cantarim } \\
\text { Batistela }\end{array}$ & Zilda Ribeiro \\
\hline E-29/1997 & Relógio & 20/11/1997 & $\begin{array}{c}\text { Cecília de Toledo } \\
\text { Neves }\end{array}$ & Zilda Ribeiro \\
\hline E-30/1997 & Relógio de pulso - Citizen (Japão) & 23/11/1997 & $\begin{array}{l}\text { Inácio Florentino de } \\
\text { Vasconcelos }\end{array}$ & - \\
\hline E-31/1997 & Máquina de Costura manual & 07/12/1997 & Maria Batista de Freitas & Zilda Ribeiro \\
\hline E-32/1997 & $\begin{array}{c}\text { Abajur em forma de casa (ex- } \\
\text { voto) }\end{array}$ & 13/12/1997 & Bruna Sassi Alessandri & Zilda Ribeiro \\
\hline E-33/1997 & 1 Moeda (símbolo Império) & 13/12/1997 & $\begin{array}{c}\text { Tânia Maria de Souza } \\
\text { Borges }\end{array}$ & 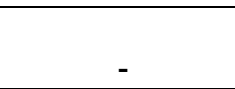 \\
\hline E-34/1997 & Lâmina de machado & $20 / 12 / 1997$ & $\begin{array}{c}\text { Sebastião Santino da } \\
\text { Silva }\end{array}$ & Zilda Ribeiro \\
\hline E-35/1997 & $\begin{array}{c}\text { Ecos Mariano - 1933, 1947, } 1948, \\
1949,1953,1954,1957 \text { e } 1960\end{array}$ & 23/12/1997 & Alésio Pivato & \\
\hline
\end{tabular}

Fonte: MNSA/Santuário Nacional.

O Quadro 5, com a relação de objetos de 1997, apresenta uma relação diversificada de objetos, com trinta e cinco números de entrada de objetos registrados. Desta relação, apenas quatro foram identificados por meio das fichas catalográficas, que possuem informações patrimoniais, sendo estes: ametista, máquina fotográfica, pedra de rebolo, ex-voto abajur em forma de casa. Tendo recebido, respectivamente, os seguintes números de inventário: 0641, 0907, 2.712 e 2.713 .

Quadro 6: Lista de entrada de objetos (1998)

\begin{tabular}{|c|c|c|c|c|}
\hline $\begin{array}{l}\text { № de } \\
\text { entrada }\end{array}$ & Descrição do Objeto & Data & Doador & $\begin{array}{l}\text { Responsável } \\
\text { Recebimento }\end{array}$ \\
\hline E-01/1998 & Colar indígena & 27/01/1998 & $\begin{array}{c}\text { Maria Neide Castro } \\
\text { Rezende Bezerra }\end{array}$ & Heloísa Reis \\
\hline E-02/1998 & $\begin{array}{l}\text { 1 Conchinha de ouro/ } 1 \text { garfo } \\
\text { deprata/ } 1 \text { colherinha de prata }\end{array}$ & 01/02/1998 & Laurita Ferraz & Zilda Ribeiro \\
\hline E-03/1998 & 2,41 Dólar canadense & 06/02/1998 & Pascuzzo Giovanni & - \\
\hline E-04/1998 & $\begin{array}{l}1 \text { Moeda } 1 \text { peso/ } 1 \text { moeda } 10 \\
\text { pesos/ } 1 \text { moeda } 50 \text { pesos/ } 1 \\
\text { moeda } 100 \text { pesos }\end{array}$ & $15 / 02 / 1998$ & $\begin{array}{l}\text { Maritza Castillo } \\
\text { Martinez }\end{array}$ & Heloísa Reis \\
\hline E-05/1998 & $\begin{array}{c}1 \text { Moeda } 100 \text { escudos - Portugal } \\
(1991)\end{array}$ & 18/02/1998 & $\begin{array}{l}\text { Luiza da Assunção } \\
\text { Cosseis Peixoto }\end{array}$ & Heloísa Reis \\
\hline
\end{tabular}




\begin{tabular}{|c|c|c|c|c|}
\hline $\begin{array}{l}\text { № de } \\
\text { entrada }\end{array}$ & Descrição do Objeto & Data & Doador & $\begin{array}{l}\text { Responsável } \\
\text { Recebimento }\end{array}$ \\
\hline E-06/1998 & $\begin{array}{l}\text { Relógio de bolso - Cortebert } \\
\text { prateado no } 2290403-5301 \\
\text { rubis - } 5 \text { emblemas }\end{array}$ & 02/03/1998 & $\begin{array}{l}\text { João Maria Pedroso } \\
\text { Ribeiro }\end{array}$ & Heloísa Reis \\
\hline E-07/1998 & $\begin{array}{l}4 \text { Cédulas } 100 \text { cruzeiros/ } 2 \\
\text { cédulas } 500.000 \text { cruzeiros/ } 8 \\
\text { cédulas } 1.000 \text { cruzeiros/ } 3 \\
\text { cédulas } 1.000 \text { cruzados/ } 1 \text { cédula } \\
500 \text { cruzados/ } 1 \text { cédula } 5.000 \\
\text { cruzados/ } 2 \text { cédulas } 10.000 \\
\text { cruzados/ } 3 \text { cédulas } 100.000 \\
\text { cruzeiros/ } 8 \text { cédulas } 5.000 \\
\text { cruzeiros/ } 1 \text { cédula } 5.000 \text { (?)/ } 1 \\
\text { cédula } 1.000 \text { cruzeiros reais }\end{array}$ & 03/03/1998 & $\begin{array}{l}\text { Maria Libano dos } \\
\quad \text { Santos }\end{array}$ & Heloísa Reis \\
\hline E-01/1998 & $\begin{array}{l}1 \text { Cédula } 2 \text { cruzeiros - } \\
\text { República dos E. U. B }\end{array}$ & $21 / 03 / 1998$ & $\begin{array}{c}\text { Vicente Rabelo } \\
\text { Fonseca } \\
\end{array}$ & Heloísa Reis \\
\hline E-09/1998 & $\begin{array}{c}3 \text { Moedas Holandesas/ } 1 \text { moeda } \\
\text { Noruega }\end{array}$ & 02/04/1998 & $\begin{array}{c}\text { Gysbertus A.M. Van } \\
\text { Hoesel }\end{array}$ & - \\
\hline E-10/1998 & $\begin{array}{c}\text { Chile }-1 \text { Moeda } 10 \text { pesos }(1997) / \\
1 \text { moeda } 50 \text { pesos }(1993) / 1 \\
\text { moeda } 100 \text { pesos }(1985)\end{array}$ & 05/04/1998 & Fábio Martins Jesus & Heloísa Reis \\
\hline$E-11 / 1998$ & $\begin{array}{c}1 \text { Moeda Portugal/ } 2 \text { moedas } \\
\text { Israel/ } 1 \text { moeda E.U.A/ } 2 \text { moedas } \\
\text { Argentina/ } 15 \text { moedas } 50 \\
\text { centavos Brasil (G.V)/ } 6 \text { moedas } 2 \\
\text { cruzeiros (1946)/ } 1 \text { moeda } 1908 \\
\text { (Coroa)/ } 2 \text { medas } 300 \text { réis/ } 2 \\
\text { moedas } 200 \text { réis/ } 1 \text { moeda } 400 \\
\text { réis }(1940) / 3 \text { moedas } 400 \text { réis } \\
(1936) / 1 \text { moeda } 20 \text { cruzeiro } \\
(1965) / 1 \text { moeda } 100 \text { réis (Prin.I)/ } \\
2 \text { moeda } 1.000 \text { réis/ } 6 \text { moedas } 20 \\
\text { centavos }(\mathrm{G} . \mathrm{V}) / 3 \text { moedas } 1.000 \\
\text { réis (Cent. Ind.)/ } 2 \text { moedas } 1.000 \\
\text { réis (1927)/ } 1 \text { moeda } 400 \text { réis } \\
\text { (1920)/ } 1 \text { moeda } 1869 \text { (coroa)/ } 1 \\
\text { moeda } 10 \text { centavos }\end{array}$ & $10 / 05 / 1998$ & Pedro Germino da Silva & Heloísa Reis \\
\hline E-12/1998 & Garrucha & 18/07/1998 & $\begin{array}{c}\text { Jorge Pereira de } \\
\text { Toledo }\end{array}$ & Zilda Ribeiro \\
\hline$E-13 / 1998$ & 2 Moedas & 28/07/1998 & $\begin{array}{c}\text { Ana Alexandina } \\
\text { Marques Nascimento }\end{array}$ & Heloísa Reis \\
\hline E-14/1998 & Imagem Santa Luzia & $31 / 07 / 1998$ & Berta Dalmético & Zilda Ribeiro \\
\hline$E-15 / 1998$ & $\begin{array}{c}1 \text { Cédula de } 2 \text { dólares } n^{\circ} \\
\text { B38833465A }\end{array}$ & $14 / 08 / 1998$ & $\begin{array}{c}\text { Claudemir Marcos } \\
\text { Petrafeza }\end{array}$ & Heloísa Reis \\
\hline E-16/1998 & $\begin{array}{c}\text { Moedas cruzeiro (1969) (1981)/ } \\
\text { cruzado (1986)/ cédulas cruzados } \\
\text { e cruzeiros?? }\end{array}$ & 23/08/1998 & $\begin{array}{c}\text { Hermínio Ferreira } \\
\text { Andrade }\end{array}$ & Heloísa Reis \\
\hline E-17/1998 & Ferro de passar roupa à brasa & 05/09/1998 & Maria Dias da Cruz & Zilda Ribeiro \\
\hline$E-18 / 1998$ & Relógio - Indes & $12 / 09 / 1998$ & Francisca Maria Araújo & Zilda Ribeiro \\
\hline E-19/1998 & $\begin{array}{c}\text { Ecos Mariano 1950, 1951, 1952, } \\
1961\end{array}$ & 26/09/1998 & $\begin{array}{l}\text { Ana Maria de Oliveira } \\
\text { Teodoro }\end{array}$ & Zilda Ribeiro \\
\hline E-20/1998 & Anél de formatura Massagista & $11 / 10 / 1998$ & Manoel Pereira da Silva & Zilda Ribeiro \\
\hline E-21/1998 & Relógio Mondaine & $11 / 10 / 1998$ & $\begin{array}{c}\text { Homero Soares dos } \\
\text { Reis }\end{array}$ & Zilda Ribeiro \\
\hline
\end{tabular}




\begin{tabular}{|c|c|c|c|c|}
\hline $\begin{array}{l}\text { № de } \\
\text { entrada }\end{array}$ & Descrição do Objeto & Data & Doador & $\begin{array}{l}\text { Responsável } \\
\text { Recebimento }\end{array}$ \\
\hline E-22/1998 & $\begin{array}{c}\text { Relógio de bolso - Mondaine } \\
\text { ancre } 17 \text { rubis }\end{array}$ & $12 / 10 / 1998$ & $\begin{array}{c}\text { Homero Soares dos } \\
\text { Reis }\end{array}$ & 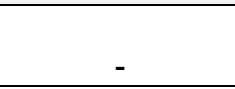 \\
\hline$E-23 / 1998$ & $\begin{array}{c}3 \text { Colares de pérolas/ } 2 \text { colares } \\
\text { pedra magnética }\end{array}$ & $15 / 10 / 1998$ & Luisa Maria Carvalho & Heloísa Reis \\
\hline E-24/1998 & $\begin{array}{l}\text { Moedas e cédulas cruzeiros e } \\
\text { cruzados }\end{array}$ & 22/10/1998 & Geraldo Joaquim Silva & Heloísa Reis \\
\hline E-25/1998 & Toalha de banquete (1868) & 19/11/1998 & Maria da Glória Gomes & Zilda Ribeiro \\
\hline E-26/1998 & Relógio de bolso - Cyma (1956) & $22 / 11 / 1998$ & $\begin{array}{c}\text { Sebastião Olavo da } \\
\text { Silva }\end{array}$ & Heloísa Reis \\
\hline E-27/1998 & Relógio - Minerva & 04/12/1998 & Oscar Lamen & - \\
\hline
\end{tabular}

Fonte: MNSA/Santuário Nacional.

Em 1998, conforme podemos observar no Quadro 6, há grande recorrência de doações de cédulas e moedas, sendo difícil a identificação exata dos objetos na coleção, pois eram depositados no mesmo local sem critérios de separação ou atribuição do doador.

Nesse ano, com registro de vinte e sete números de entrada de objetos, apenas a escultura de Santa Luzia (no 14) foi possível localizar entre as fichas catalográficas do acervo, tendo recebido o número de inventário 0601.

Quadro 7: Lista de entrada de objetos (1999)

\begin{tabular}{|c|c|c|c|c|}
\hline $\begin{array}{l}\text { № de } \\
\text { entrada }\end{array}$ & Descrição do Objeto & Data & Doador & $\begin{array}{l}\text { Responsável } \\
\text { Recebimento }\end{array}$ \\
\hline$E-01 / 1999$ & $\begin{array}{c}1 \text { Medalha } 600 \text { Lecie / } 1 \text { moeda } 70 \\
\text { lecie }\end{array}$ & - & Pollate Raju..el & 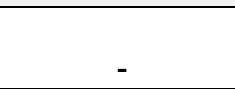 \\
\hline E-02/1999 & Relógio - Cênova & - & $\begin{array}{l}\text { Marcelo Alexandre B. } \\
\text { Camargo }\end{array}$ & Zilda Ribeiro \\
\hline E-03/1999 & 1 Dente de Marfim & - & $\begin{array}{l}\text { Tenente Aviador José } \\
\text { Fernando P. Motta }\end{array}$ & Zilda Ribeiro \\
\hline E-04/1999 & Corisco - Pedra Indígena & - & $\begin{array}{c}\text { Benedito Domingos } \\
\text { Figueredo }\end{array}$ & Zilda Ribeiro \\
\hline E-05/1999 & 1 Pedra indígena (machadinho) & - & Arari Silvério Borges & Zilda Ribeiro \\
\hline E-06/1999 & $\begin{array}{l}\text { Quadro de Aparecida antiga } \\
(1930+\text { ou }-)\end{array}$ & 09/01/1999 & $\begin{array}{l}\text { Helina de Oliveira } \\
\text { Santos }\end{array}$ & Zilda Ribeiro \\
\hline E-07/1999 & Garrucha 2 canos & $10 / 01 / 1999$ & Lenilda P. dos Santos & - \\
\hline E-01/1999 & $\begin{array}{c}1 \text { Moeda } 2.000 \text { réis (1929)/ } 1 \\
\text { moeda } 1 \text { escudo (1974) }\end{array}$ & $23 / 05 / 1999$ & Alan Felipe dos Santos & Heloísa Reis \\
\hline E-09/1999 & $\begin{array}{c}\text { Cinzeiro (10 do lote distribuído em } \\
1962)\end{array}$ & $11 / 06 / 1999$ & $\begin{array}{l}\text { Antônio Almeida de } \\
\text { Oliveira }\end{array}$ & Zilda Ribeiro \\
\hline E-10/1999 & Candeia de ferro fundido & $11 / 07 / 1999$ & Luis Cardoso Pinto & Zilda Ribeiro \\
\hline E-11/1999 & Par de alianças de ouro $18 \mathrm{~K}$ & $15 / 07 / 1999$ & $\begin{array}{l}\text { Antônio Donizete } \\
\text { Silveira }\end{array}$ & Zilda Ribeiro \\
\hline$E-12 / 1999$ & $\begin{array}{l}\text { Relógio de pulso - Orient } \\
\text { (fundo verde/ } 21 \text { jeiwels) }\end{array}$ & 24/07/1999 & Manoel José Soares & Heloísa Reis \\
\hline$E-13 / 1999$ & Relógio de pulso -Sigand & $12 / 08 / 1999$ & $\begin{array}{c}\text { Lucinda Maria da } \\
\text { Rocha }\end{array}$ & Zilda Ribeiro \\
\hline E-14/1999 & $\begin{array}{l}\text { Medalha dourada com dois } \\
\text { corações em relevo (1970) }\end{array}$ & 15/08/1999 & Guilhermina de Souza & Zilda Ribeiro \\
\hline
\end{tabular}




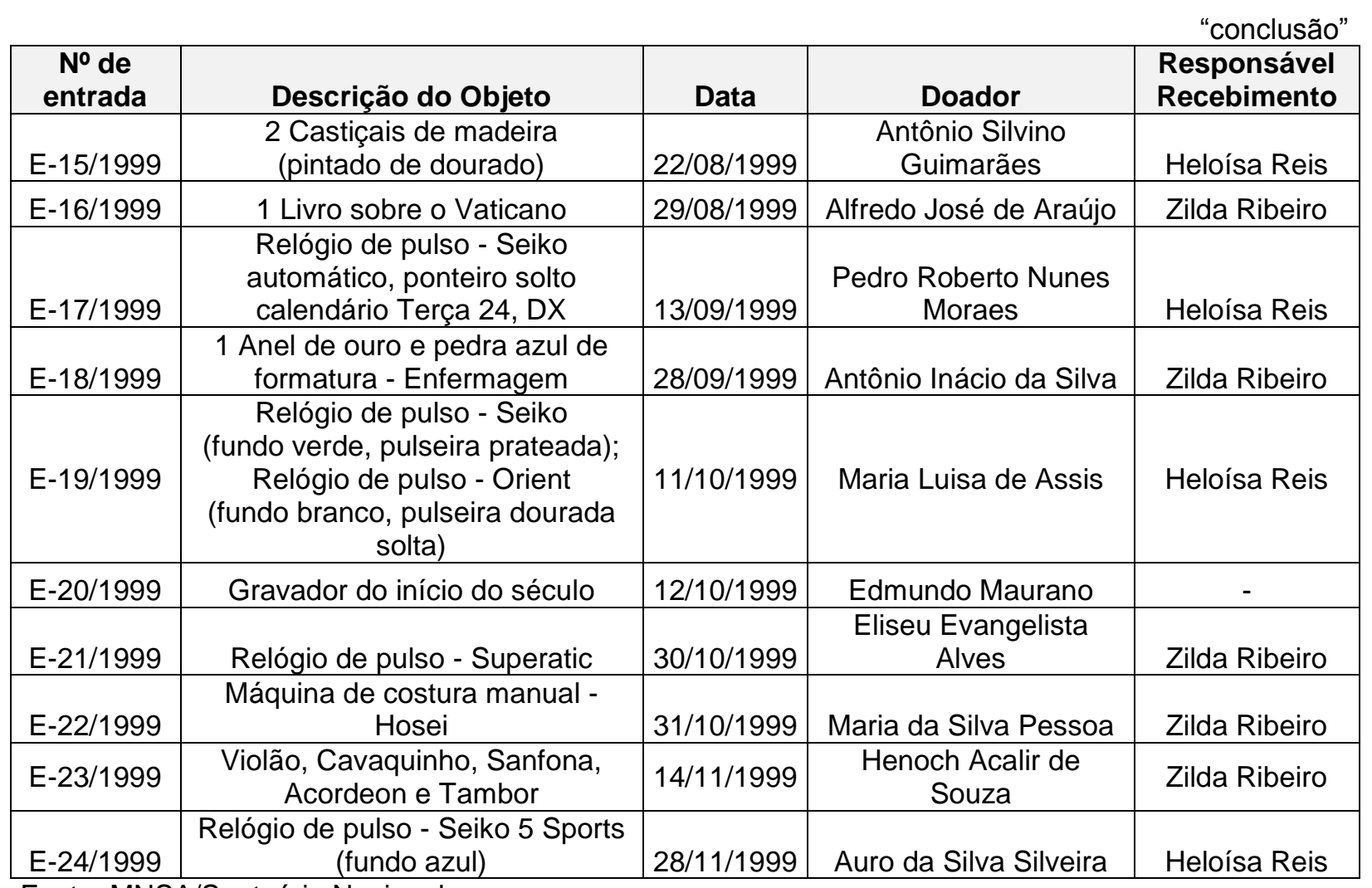

Fonte: MNSA/Santuário Nacional.

No Quadro 7, observamos que os relógios novamente são o destaque de doações no ano de 1999, além de uma doação de instrumentos musicais, com alguns itens na atual exposição de longa duração no $2^{\circ}$ andar da Torre.

Dessa relação com vinte e quatro números de entrada de objetos, apenas oito foram localizados, sendo que cinco são os instrumentos musicais de um mesmo doador. Segue a identificação do acervo documentado: dente de marfim ( $n^{\circ}$ 03),

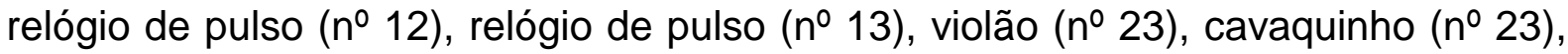
sanfona ( $n$ - 23), acordeon ( $n$ - 23), tambor ( $n^{\circ} 23$ ). Tendo recebido, respectivamente, os seguintes números de inventário: 3.228, 2.097, 2.170, 1.415, 1.416, 1.417, 1.418 e 1.419 .

Quadro 8: Lista de entrada de objetos (2000)

\begin{tabular}{|c|c|c|c|c|}
\hline $\begin{array}{c}\text { № de } \\
\text { entrada }\end{array}$ & Descrição do Objeto & Data & Doador & $\begin{array}{c}\text { Responsável } \\
\text { Recebimento }\end{array}$ \\
\hline E-01/2000 & Notas e moedas antigas & $18 / 01 / 2000$ & $\begin{array}{c}\text { Maria Aparecida } \\
\text { Pereira }\end{array}$ & - \\
\hline E-02/2000 & $\begin{array}{c}\text { Máquina de costura (Lemens } \\
\text { Muller Dresde - Trade Mark) }\end{array}$ & $06 / 02 / 2000$ & $\begin{array}{c}\text { Seminário Santo } \\
\text { Afonso }\end{array}$ & Heloísa Reis \\
\hline E-03/2000 & Relógio (Omega) ferradura & $29 / 04 / 2000$ & José Vicente da Silva & - \\
\hline E-04/2000 & Relógio (Pricerne (?)) & $16 / 05 / 2000$ & Maria de Oliveira & - \\
\hline E-05/2000 & Fóssil - Peixe & $25 / 05 / 2000$ & Nelson Campagnolla & Heloísa Reis \\
\hline
\end{tabular}


"conclusão"

\begin{tabular}{|c|c|c|c|c|}
\hline $\begin{array}{l}\text { № de } \\
\text { entrada }\end{array}$ & Descrição do Objeto & Data & Doador & $\begin{array}{l}\text { Responsável } \\
\text { Recebimento }\end{array}$ \\
\hline$E-06 / 2000$ & Pedra cristal & $23 / 07 / 2000$ & $\begin{array}{l}\text { Olivar Rodrigues } \\
\text { Pereira }\end{array}$ & Michele \\
\hline E-07/2000 & Pedra & $19 / 08 / 2000$ & $\begin{array}{c}\text { Regina Maria Oliveira } \\
\text { Rodrigues }\end{array}$ & - \\
\hline$E-08 / 2000$ & Monjolo & $20 / 08 / 2000$ & Pedro Donizeti Alves & Heloísa Reis \\
\hline E-09/2000 & Armadilha de caçador & $24 / 08 / 2000$ & $\begin{array}{c}\text { Otávio de Apparecida } \\
\text { Bellini }\end{array}$ & Heloísa Reis \\
\hline$E-10 / 2000$ & $\begin{array}{l}\text { Livro: Club regatas Vasco da } \\
\text { Gama }\end{array}$ & $26 / 08 / 2000$ & Pedro José de Araújo & Michele \\
\hline$E-11 / 2000$ & Relógio (década de 30) & 09/09/2000 & Umbilina Demes & Michele \\
\hline$E-12 / 2000$ & Espada & $10 / 09 / 2000$ & Ílson Álvaro Teixeira & Michele \\
\hline$E-13 / 2000$ & Arma de fogo (século XVIII alemã) & $23 / 09 / 2000$ & $\begin{array}{c}\text { Damião Ambrósio dos } \\
\text { Santos }\end{array}$ & Michele \\
\hline$E-14 / 2000$ & Relógio - Orient três estrelas & $24 / 09 / 2000$ & José Francisco Batista & Michele \\
\hline$E-15 / 2000$ & $\begin{array}{c}\text { Relógio despertador - Marca } \\
\text { Alerta (alemã) }\end{array}$ & $20 / 10 / 2000$ & Agmar Ramos & - \\
\hline$E-16 / 2000$ & Uma xícara e um pires & $21 / 10 / 2000$ & $\begin{array}{c}\text { Teresinha Lacerda } \\
\text { Azevedo }\end{array}$ & Michele \\
\hline$E-17 / 2000$ & Fotos, roupas e um colar cabelo & $11 / 11 / 2000$ & Alcides Brás & - \\
\hline$E-18 / 2000$ & Relógio de pulso & $13 / 011 / 2000$ & $\begin{array}{c}\text { Lindaura dos Reis } \\
\text { Pereira }\end{array}$ & Heloísa Reis \\
\hline$E-19 / 2000$ & Cédula de 1000 tysiaczlotych & $18 / 12 / 2000$ & Ramos Assis da Silva & Heloísa Reis \\
\hline
\end{tabular}

Fonte: MNSA/Santuário Nacional.

Nos anos 2000, observamos um número menor de doações, se comparado aos anos anteriores. Mesmo assim, notamos que no Quadro 8 os relógios continuaram sendo os objetos mais doados.

Dessa relação, com dezenove números de entrada de objetos que foram registrados no ano de 2000, apenas dois objetos foram identificados no acervo, sendo um monjolo ( $n \div$ 08) e a armadilha de caçador ( $n^{\circ}$ 09). Tendo recebido, respectivamente, os seguintes números de inventário: 0647 e 2.663. Alguns objetos foram encaminhados para a Sala das Promessas, como por exemplo, algumas fotos, roupas e um colar ( $\mathrm{n} \times 17)$.

Quadro 9: Lista de entrada de objetos (2001)

\begin{tabular}{|c|c|c|c|c|}
\hline $\begin{array}{c}\text { No de } \\
\text { entrada }\end{array}$ & Descrição do Objeto & Data & Doador & $\begin{array}{c}\text { Responsável } \\
\text { Recebimento }\end{array}$ \\
\hline E-01/2001 & $\begin{array}{c}\text { Imagem N. S. A em nicho } \\
\text { metálico }\end{array}$ & $12 / 01 / 2001$ & Benedita Rosário & Zilda Ribeiro \\
\hline E-02/2001 & Terço trabalhado em pedras & $14 / 01 / 2001$ & Marcos Alves Cunha & Zilda Ribeiro \\
\hline E-03/2001 & Moeda 200 réis & $15 / 04 / 2001$ & $\begin{array}{c}\text { Cícero Moreira de } \\
\text { Araújo }\end{array}$ & Zilda Ribeiro \\
\hline E-04/2001 & $\begin{array}{c}\text { Relógio despertador alemão 1910 } \\
\text { e 1 barrete p/ manto de imagem }\end{array}$ & $17 / 05 / 2001$ & Sabrina Maduro Kube & Zilda Ribeiro \\
\hline E-05/2001 & $\begin{array}{r}1 \text { barrete pedra ônix p/ prender } \\
\text { manto de imagem }\end{array}$ & $17 / 05 / 2001$ & Zoraide Panagio & Zilda Ribeiro \\
\hline
\end{tabular}




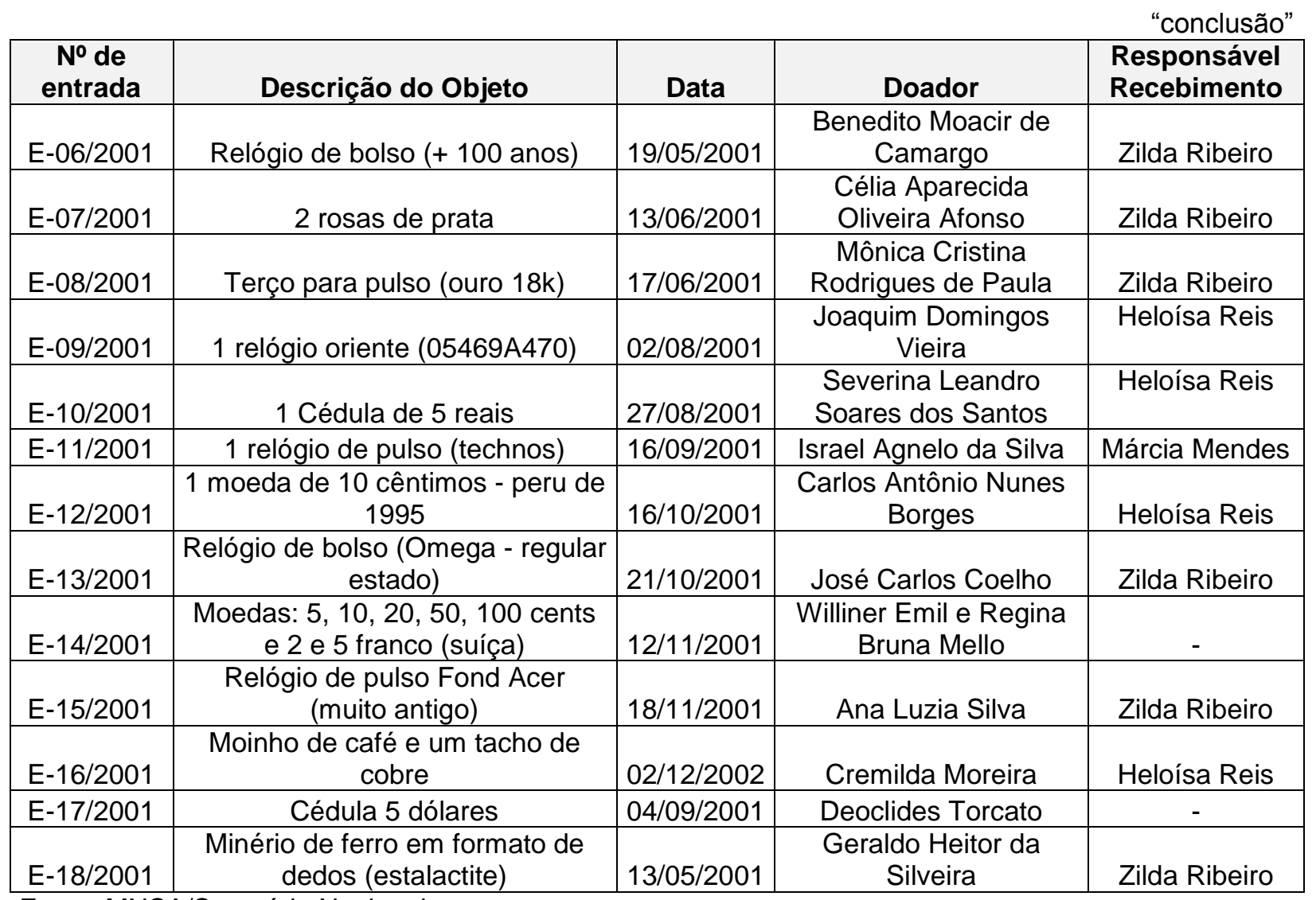

Fonte: MNSA/Santuário Nacional.

O Quadro 9, com a relação de objetos de 2001, apresenta alguns objetos devocionais, mas o relógio ainda continua sendo destaque entre as doações.

Ao verificar fichas catalográficas de documentação do acervo, apenas dois objetos foram identificados dessa relação com dezoito números de entrada que foram registrados no ano de 2001, sendo estes: terço ( $\left.n^{\circ} 02\right)$ e o minério de ferro, com formato de estalactite ( $n-18$ ). Tendo recebido, respectivamente, os seguintes números de inventário: 0241 e 11.082.

Quadro 10: Lista de entrada de objetos (2002)

\begin{tabular}{|c|c|c|c|c|}
\hline $\begin{array}{c}\text { No de } \\
\text { entrada }\end{array}$ & Descrição do Objeto & Data & Doador & $\begin{array}{c}\text { Responsável } \\
\text { Recebimento }\end{array}$ \\
\hline E-01/2002 & $\begin{array}{c}\text { Máquina de escrever } \\
\text { (Rhemington ou roial) }\end{array}$ & $17 / 01 / 2002$ & Mirian Silveira Faveron & Heloísa Reis \\
\hline E-02/2002 & $\begin{array}{c}\text { Imagem de Santo Antônio, Frei } \\
\text { Galvão, dinheiro antigo e 2 fotos }\end{array}$ & $22 / 04 / 2002$ & Edson Luiz da Silva & Márcia Mendes \\
\hline E-03/2002 & 1 estrela (aparelho de tortura) & $05 / 05 / 2002$ & Hebert Diarlen & Heloísa Reis \\
\hline E-04/2002 & Cédulas antigas & $12 / 07 / 2002$ & $\begin{array}{c}\text { Francisco Carlos } \\
\text { Rocha Martins }\end{array}$ & Márcia Mendes \\
\hline E-05/2002 & $\begin{array}{c}\text { Uma cédula de 100 guaranis } \\
\text { Recalole }\end{array}$ & - \\
\hline E-06/2002 & $\begin{array}{c}\text { Uma cédula de 1 astral da } \\
\text { Argentina }\end{array}$ & $14 / 07 / 2002$ & $\begin{array}{c}\text { Rebaña Rojas } \\
\text { Rdson Pavão }\end{array}$ & - \\
\hline
\end{tabular}




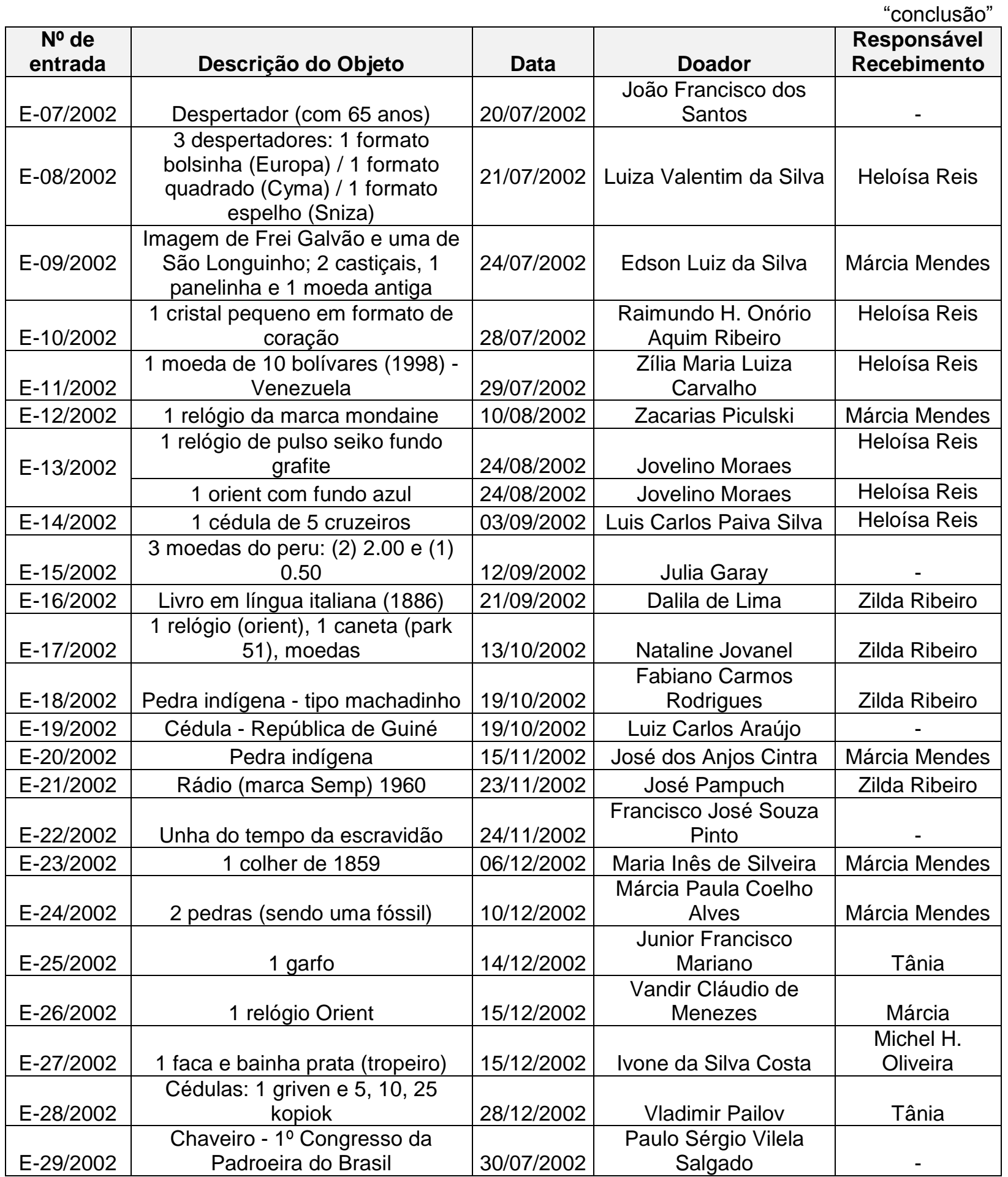

Fonte: MNSA/Santuário Nacional.

No ano de 2002, observamos a entrada de objetos diversificados, tendo sido registrado vinte e nove números de entrada de objetos. A partir do estudo do Quadro 10 e as fichas catalográficas, foi possível localizar apenas seis objetos no acervo do Museu, sendo estes: máquina de escrever $\left(n^{\circ} 01\right)$, relógio de pulso $\left(n^{\circ} 13\right)$, relógio de pulso ( $\left.n^{\circ} 13\right)$, rádio $\left(n^{\circ} 21\right)$, relógio $\left(n^{\circ} 26\right)$ e chaveiro comemorativo do $1^{\circ}$ 
Congresso da Padroeira do Brasil ( $n^{\circ}$ 29). Tendo recebido, respectivamente, os seguintes números de inventário: 2.276, 2.103, 2.102, 1.623, 2.101 e 0299.

De maneira geral, observamos que entre os anos de 1996 e 2002 foi doada uma grande quantidade de cédulas, moedas e relógios, além de outros materiais diversos, para complementar as coleções do Museu.

Nesse período, com a reorganização iniciada pela Profa. Zilda Ribeiro, alguns objetos foram retirados da exposição e enviados para um depósito no $11^{\circ}$ andar da Torre, assim como demais objetos que estavam em mau estado de conservação. Desta forma, foi possível organizar melhor as novas doações que eram recebidas, seguindo as temáticas da exposição.

Em relação aos tipos de públicos identificados pela Profa. Zilda Ribeiro, foram caracterizados dois tipos de públicos, os que frequentam o Museu durante a semana e os que frequentam nos finais de semana, conforme observado no trecho do depoimento a seguir:

Giselle - Como eram essas visitas? Como é esse público do Museu nesses anos? Como é que você o caracteriza? Além desses estudantes que você já mencionou, quem é que visita o Museu?

Zilda - Nós temos dois tipos de público, o público da semana e o público do final de semana.

Giselle - São distintos.

Zilda - São distintos. O público durante a semana é um público mais exigente, é um público mais preparado. E o público de final de semana é um público que ele nem sabe o que é museu. [...]. Depois a maneira de nós conduzirmos, já começando no elevador, que eu também procurei fazer isso. Porque antes o elevador não pertencia, não fazia parte, ele simplesmente levava o romeiro lá em cima e despejava os que queriam ficar no museu, porque também não eram todos que desciam, despejavam a turma ali. Depois a gente começou, no Museu que começava a visita. Então, íamos acolhendo, passando algumas informações, aí começou a melhorar também, porque tudo vai da maneira que você acolhe. Se você não acolher bem, eles chegam chutando, esse público de sábado e domingo. Agora, de durante a semana é um público diferente, já vem porque quer visitar o Museu, vêm em busca de alguma coisa, que no final de semana é mais difícil. Tem também, mas o grande público é aquele público que passa por passar no Museu. E, às vezes, gosta, graças a Deus, acaba gostando e acaba voltando, e até surpreendendo. Que, às vezes, você vê a pessoa entrar e não vê sair. De repente você entra e a pessoa está lá há duas horas, mergulhado, querendo conhecer, querendo saber. Então, os tipos de pergunta também, tão inesperadas. (RIBEIRO, 2003, informação verbal).

Com isso, observamos que, aos finais de semana, devido ao grande fluxo de visitação, em virtude das romarias de diversas regiões do país, a exposição do Museu era mais frequentada aos sábados e domingos, caracterizada como um 
ponto turístico após a visitação ao Mirante da Torre. Já durante a semana, com menor número de visitação, o público permanecia por períodos mais longos, assim como a presença de grupos escolares que faziam atividades específicas e realização de pesquisas para trabalhos escolares.

Ainda sobre o perfil do público visitante, Giselle Peixe questiona Zilda Ribeiro: quem é no geral esse romeiro que vem a Aparecida? A partir dessa indagação, Zilda Ribeiro complementa que esse romeiro, visitante do Museu, é alguém que tem uma fé ou uma herança familiar, pois os familiares já vinham anteriormente; então, começou a visitar o Museu desde a época em que era criança. Zilda Ribeiro acrescenta que "há sempre essa fé em Nossa Senhora Aparecida. Então, o romeiro é essencialmente um devoto de Nossa Senhora. E essa fé ou é herança ou é adquirida através de uma graça que ele tem alcançado. Fez uma promessa, alcançou uma graça. Então, ele vem agradecer" (RIBEIRO, 2003, informação verbal).

De maneira geral, observamos que a Profa. Zilda Ribeiro empenhou-se em reorganizar o acervo em exposição e criar novos procedimentos para qualificar o trabalho do Museu, dando continuidade aos registros das novas doações por meio do Termo de Oferecimento de Bens Móveis.

Em sua gestão, a equipe de funcionários, que era composta por onze recepcionistas, foi orientada por ela em como fazer o acolhimento dos visitantes, assim como manter a organização e limpeza do espaço expositivo, em horários anteriores à abertura da visitação.

Acreditamos que, nesse período, boa parte do acervo foi reorganizado em núcleos temáticos, e alguns que estavam em mau estado de conservação foram encaminhados para um depósito no 11ํandar da Torre; alguns foram encaminhados para restauro em São Paulo, conforme relatado pelo Prof. Guido Machado Braga em entrevista concedida a Victor Hugo Barros e Erica Andreza Coelho, durante a semana da Primavera dos Museus, em $2017^{46}$.

De acordo com o Prof. Guido Braga, o restauro de algumas peças do Museu e do Santuário foi realizado na gestão da Profa. Zilda Ribeiro, "ela que descobriu o Renato Rinaldi e propôs ao padre Darci para ele vir. E ele veio fazer a restauração dos mosaicos. [...]. Depois foi restaurada a tela da Coroação [...]. Obras do Chico

\footnotetext{
${ }^{46}$ BRAGA, Guido Machado. Entrevista concedida a Victor Hugo Barros e a Erica Andreza Coelho. Aparecida, 20 set. 2017, 33 min 08 s. Som, Formato MP3.
} 
Santeiro também, que ele restaurou [...]" (BRAGA, 2017, informação verbal). Infelizmente, a qualidade das restaurações realizadas nessa época não o agradou, de acordo com a percepção do Prof. Guido Braga, sobre o trabalho realizado.

Em suma, observamos que no final da gestão da Profa. Zilda Ribeiro houve uma grande preocupação com a conservação dos objetos em exposição, com a busca de profissionais que pudessem colaborar com a recuperação de algumas peças mais deterioradas, que retornam para exposição após o tratamento. Notamos, também, que essas atividades de restauração foram continuadas na gestão posterior.

Além dessa questão da conservação do acervo, bucou-se também profissionais na área de museologia para realização de um diagnóstico institucional e início dos planejamentos para reestruturação do Museu. Nesse contexto, a museóloga Ana Silvia Bloise apresentou, em novembro de 2002, uma Proposta de Trabalho.

Segundo a museóloga,

Foi com grande surpresa que fiz a primeira visita ao Museu da Basílica de N.SA. Aparecida. Na verdade, não podia imaginar encontrar um conjunto tão numeroso e diversificado de objetos, raros e ricos, simples e verdadeiros, documentos importantes de nossa história e da arte sacra enfim um conjunto documental de grande importância do ponto de vista do patrimônio cultural.

A exposição permanente do Museu ocupa área de cerca de 350 metros quadrados, uma sala simples, de pé direito alto e grandes janelas. Nota-se um volume grande de objetos para aquele espaço, parecendo que a exposição foi sendo construída pela adição de objetos que foram tomando todos os lugares disponíveis, à medida que entravam para o acervo do Museu.

O número de visitantes é bem alto, maior do que o que recebe a maioria dos museus brasileiros. Esta situação positiva de público e o ambiente nos estimulam a pensar logo em fazer várias soluções práticas - um trabalho a ser feito no sentido de melhorar vitrines, iluminação, reagrupar e valorizar os objetos deste acervo. (BLOISE, 2002, p. 11).

Para Ana Silvia Bloise, após o levantamento diagnóstico, o trabalho museológico precisaria ir além da reorganização estética solicitada pela administração do Santuário, pois se tratava de um projeto mais complexo a ser desenvolvido em três áreas: pesquisa-conhecimento, preservação-conservação e comunicação-divulgação.

Como um processo de trabalho que se inicia de dentro para fora, é necessário primeiramente agir nas áreas de pesquisa, documentação e conservação do acervo do Museu, para em seguida transformar as ações 
de comunicação, através de novas conceituações museológicas e construções expositivas. (BLOISE, 2002, p. 17).

Portanto, a reestruturação do Museu foi planejada para ser executada em etapas e de forma multidisciplinar. Os objetivos do trabalho incluíram o inventário do acervo em exposição, análise do estado de conservação dos objetos e levantamento de subsídios para uma próxima etapa do projeto, considerando o trabalho de uma equipe especializada para definição de metas e atividades.

De acordo com a proposta da museóloga Ana Silvia Bloise, as ações de inventário do acervo em exposição também incluíram a higienização básica, registros fotográficos dos objetos, quantificação dos objetos por categoria, análise do estado de conservação e indicação de intervenções preventivas e restaurativas, análise de documentações existentes, além do levantamento histórico do Museu.

A metodologia de trabalho obedeceu aos princípios teórico-metodológicos da Museologia, seguindo normas preconizadas pelo Conselho Internacional de Museus (ICOM - International Council of Museums, traduzido do inglês), a partir da contratação de profissionais especializados para realização do projeto museológico e museográfico de forma interdisciplinar.

De maneira geral, a reestruturação do museu, a partir do diagnóstico inicial, foi estabelecida dentro de um plano de ação com metas a serem realizadas em curto e médio prazo.

De acordo com a museóloga,

Toda ação museológica só faz sentido porque é realizada para contribuir para o desenvolvimento humano. É para o público visitante e para a comunidade do Santuário que o trabalho museológico é realizado. Atualmente o Museu é considerado um espaço de pesquisa, lazer, fruição e também de educação, onde experiências e vivências positivas devem ocorrer. A intenção de um projeto museológico e museográfico expositivo é transformar a visita em um momento único, se possível numa experiência relevante e transformadora para todo e cada visitante em particular. (BLOISE, 2002, p. 12).

Ainda segundo a autora,

Toda ação museológica visa atender à comunidade que frequenta o Museu e facilitar seu contato com o Patrimônio Cultural. Ela se fundamenta no conhecimento deste Patrimônio, tendo como meta preservá-lo e fazer com que este seja interpretado e valorizado como uma Herança artística, cultural, religiosa, histórica, natural ou cultural, que recebem desta ou das gerações que os antecederam. (BLOISE, 2002, p. 12, grifo do autor).

Após o diagnóstico apresentado pela museóloga, foi constatado que grande parte dos objetos doados e expostos não apresentavam uma relação com o tema 
principal do Museu, que era a devoção a Nossa Senhora Aparecida, merecendo, portanto, espaços de comunicação à parte. Desta forma, o tema principal, que é a Padroeira do Brasil, deveria ser visualmente o destaque maior do Museu, podendo ser trabalhado tanto como objeto de culto, como pelo seu valor histórico e cultural na formação de identidade.

Observamos, também, no diagnóstico, que foi apontada uma grande variedade de estilos mobiliários e apresentações, na qual os objetos eram dispostos em grande quantidade e sobre suportes diversos: armários de madeira e vidro, mesas, paredes ou diretamente sobre o chão. As etiquetas do acervo eram dispostas de maneira não uniforme e por vezes interferindo na leitura dos objetos. Além de várias coleções fora de contexto, como, por exemplo, a coleção de cédulas que chamava muita a atenção dos visitantes, porém, apenas pela curiosidade.

A partir deste diagnóstico, iniciam-se os planejamentos de reestruturação institucional, que se desenvolvem durante a direção do Prof. Guido Machado Braga.

\subsection{Período de 2003 a 2006}

Em 2003, o Prof. Guido Machado Braga (Figura 80) assume o cargo de diretor do Museu Nossa Senhora Aparecida, cargo este exercido entre os anos de 2003 a 2006. Guido Machado Braga cursou licenciatura em Desenho Geral e Pedagógico, na Escola Caetano de Campos, em São Paulo, além de ter frequentado vários cursos livres no Liceu de Artes de Ofícios.

No Rio de Janeiro, buscou o aperfeiçoamento em dramaturgia, estudando com Paschoal Carlos Magno no renomado Teatro Duse. Atuou como professor de desenho e artes, e orientou grupos de teatro de escolas em Aparecida (SP). Foi Diretor Municipal de Cultura em Aparecida (SP) e Diretor do Museu Nossa Senhora Aparecida. Atualmente também é reconhecido por suas obras artísticas (desenhos, pinturas, esculturas, instalações sobre telas e recortes em diversos materiais).

Em entrevista realizada em 2017, o Prof. Guido Braga é questionado sobre sua percepção do Museu, em que estado ele foi encontrado no início de sua gestão.

Na verdade, eu não encontrei, encontraram. Dom Darci, Padre Darci na época, me chamou porque que eu tinha saído da Prefeitura Municipal, eu era o diretor da Divisão de Cultura da Prefeitura, mas houve uma transformação dentro do governo e eu saí. Ele então aproveitou a oportunidade e me chamou para fazer parte da equipe do Museu. Eu vim com maior satisfação, porque estava dentro das minhas atividades também, eu sou formado em Educação Artística, Desenho Geral, Desenho Pedagógico e Artes Plásticas, tenho essas formações todas. Eu aproveitei a 
chance de poder trabalhar tudo isso que eu tinha de conhecimento dentro de um espaço que tinha que ser dinâmico, porque até então o museu não oferecia grandes oportunidades de outras atividades dentro dele.

Hoje, você sabe que o museu não é apenas um local que guarda coisas velhas, é um local de múltiplas atividades, você pode criar muitas atividades, como outros museus que a gente conhece fazem. Eu vim para cá, então, ocupar o lugar inclusive de Dona Zilda, professora Zilda Ribeiro, que já tinha sido a diretora, logo depois da Dona Conceição [...]. (BRAGA, 2017, informação verbal).

Figura 78: Diretor Guido Machado Braga organizando a vitrine de relógios na antiga exposição do 2 o andar da Torre Brasília.

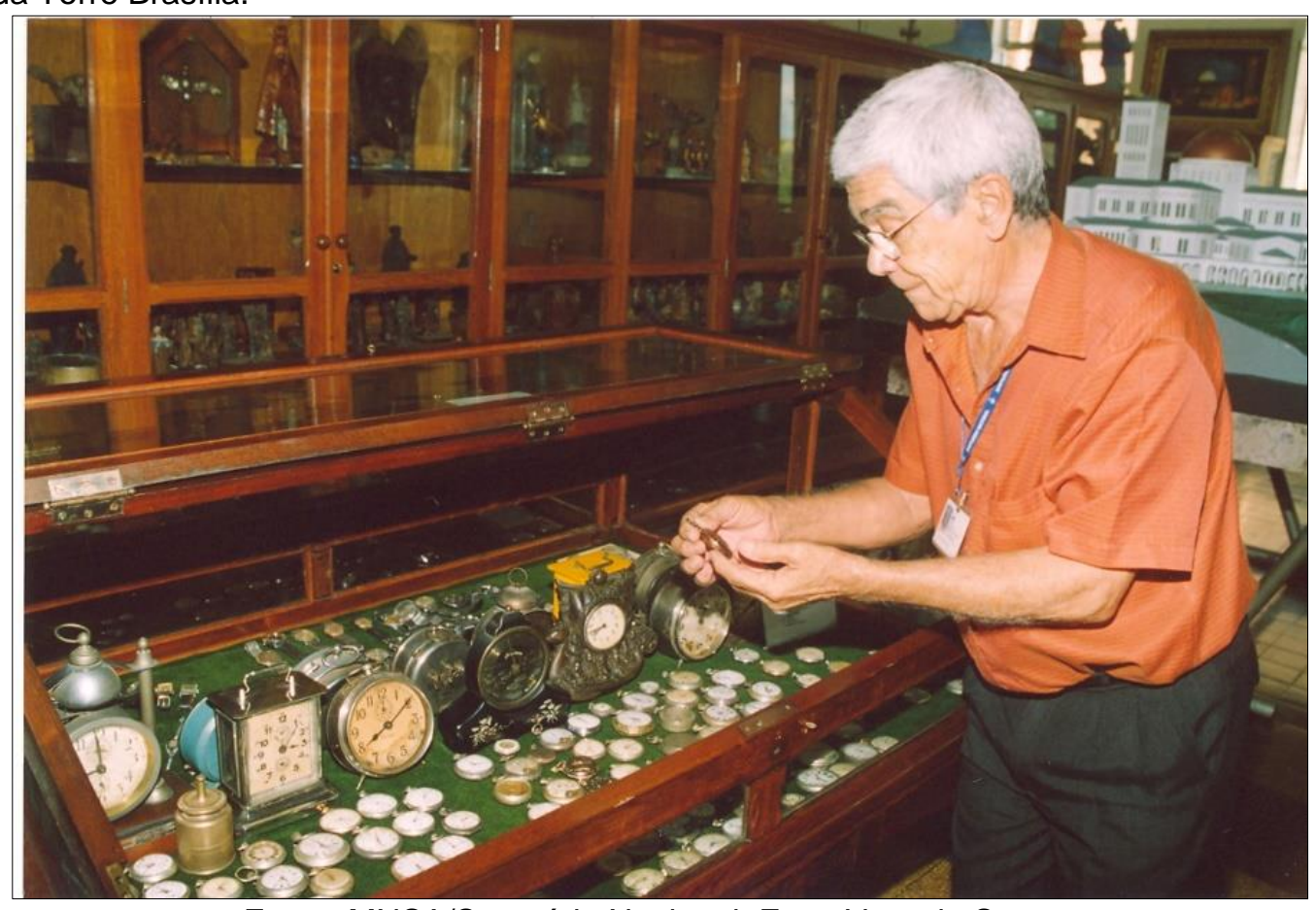

Fonte: MNSA/Santuário Nacional. Foto: Vera de Souza.

Em relação à situação anterior do Museu, quando as exposições estavam localizadas em outros endereços, Braga (2017, informação verbal) diz que chegou a colaborar na organização, inclusive, na limpeza de peças em exposição. De acordo com Guido Braga, a Profa. Conceição Borges, além de organizadora de museu, ela era, principalmente, especialista em arqueologia indígena.

O autor ainda acrescenta que,

Ela reunia uma série de qualidades, ela era pesquisadora, historiadora, escritora, poetisa. Então, ela me chamava sempre, a mim e a professora Glória Freitas, quando ela tinha que fazer alguma viagem para estudos ou trabalhos assim de prospecção, ela nos chamava para acompanhá-la. Então, eu aprendi muito com ela, apesar de ela ter um temperamento meio difícil. Mas, ela era uma sumidade. (BRAGA, 2017, informação verbal).

A partir de 2003, algumas manutenções foram realizadas na exposição, conforme observado na Figura 78, durante organização da vitrine de relógios, considerada uma tipologia com frequentes doações, ficando atrás apenas da 
coleção de numismática, conforme relatado por Guido Braga no trecho da entrevista a seguir.

\begin{abstract}
Victor Hugo - O senhor, nesse período em que esteve aqui, houve alguma mudança no acervo significativa na visão do senhor? Por exemplo, nós recebemos uma doação importante de uma determinada peça, de uma determinada coleção?
\end{abstract}

Prof. Guido - Não, que eu me lembre não. Havia doação, porque todo dia havia doações. Mas, os romeiros doavam muita moeda, muita coisa assim.

Erica - O que era muito procurado na época, tinha uma grande coleção, chamava bastante a atenção.

Prof. Guido - Era mais comum muita moeda, alguns traziam coisas mais significativas.

Erica - E, nessa época, recebiam as doações e já colocavam em exposição ou tinha uma sala?

Prof. Guido - Não, tinha uma sala onde era examinada a doação, ia para reserva técnica, [...]. Era a reserva técnica onde o Cesar trabalhava, 0 Michel trabalhava.

Erica - Estava iniciando o trabalho de conservação do acervo.

Prof. Guido - Eles examinavam tudo, se tivesse que fazer uma limpeza eles faziam, e depois, se houvesse interesse, vinha para o museu para exposição. Mas, como já tinha muita coisa parecida, então eles permaneceram na reserva, que dá para fazer mais uns dez museus. (BRAGA, 2017, informação verbal).

Em relação à montagem de exposições temporárias, Guido Braga relata como era o desenvolvimento de instalações temáticas, em áreas isoladas no interior da exposição. O diretor do Museu, com auxílio do escultor Américo Costa, compôs um diorama com peças de madeira, de barro e com isopor, para contextualizar o encontro da Imagem de Nossa Senhora Aparecida.

Eu tenho um primo que é escultor, Américo Costa, ele fez para mim as
figuras dos três pescadores em argila, ele fez a canoa de madeira, de
mogno, colocou em cima. Fiz os barrancos usando muito isopor, que é leve
e se presta para esse tipo de trabalho, eu fiz a Serra da Mantiqueira como
cenário e ele fez para mim, então, aquele diorama ficou bonito e os
romeiros vinham, olhavam e punham até moeda. (BRAGA, 2017,
informação verbal).

Nesse período, durante a gestão de Guido Braga, o administrador e ecônomo do Santuário, Pe. Darci José Nicioli, C.Ss.R., colaborou com o desenvolvimento do Museu, ao iniciar o processo de revitalização institucional e contratação de consultoria museológica. Com isso, observamos que o Museu Nossa Senhora Aparecida acompanha uma tendência de especialização dos museus, se distanciando dos Museus Históricos, e articulando novas ações para melhor trabalhar com a produção de conhecimento. 
Com a aprovação da Proposta de Trabalho, apresentada a partir do diagnóstico da museóloga Ana Silvia Bloise, inicia-se, portanto, a revitalização institucional, no período de junho a setembro de 2003, por meio da consultoria realizada pela Fundação Patrimônio Histórico da Energia de São Paulo (FPHESP).

De maneira geral, com o intuito de alcançar os objetivos definidos no projeto, contratam-se profissionais encarregados da supervisão, sendo a museóloga Giselle Marques Leite, que será referenciada neste trabalho como Giselle Peixe, contratada como Supervisora do projeto, assim como Maria Silvia Bigareli, contratada para ser coordenadora local e fazer acompanhamento das atividades.

Inicialmente, buscou-se implantar novas rotinas de trabalho, com o acervo no interesse de inventariar os objetos, buscando sua correta identificação e a reunião do conhecimento existente sobre o acervo, incluindo atividades técnicas para conservação das peças.

O local definido para adequação do espaço e instalação da equipe técnica foi o $8^{\circ}$ andar da Torre (Figura 79), com uma área livre de $90 \mathrm{~m}^{2}$, contendo uma sala úmida para as atividades de higienização. Entretanto, observamos que a princípio não havia armários para acondicionamento do acervo, ou seja, os objetos que começaram a ser documentados a partir de 2003 eram também higienizados, fotografados e, após os processos de documentação, retornavam para a exposição no $2^{\circ}$ andar.

Figura 79: Área de trabalho - 8o andar.

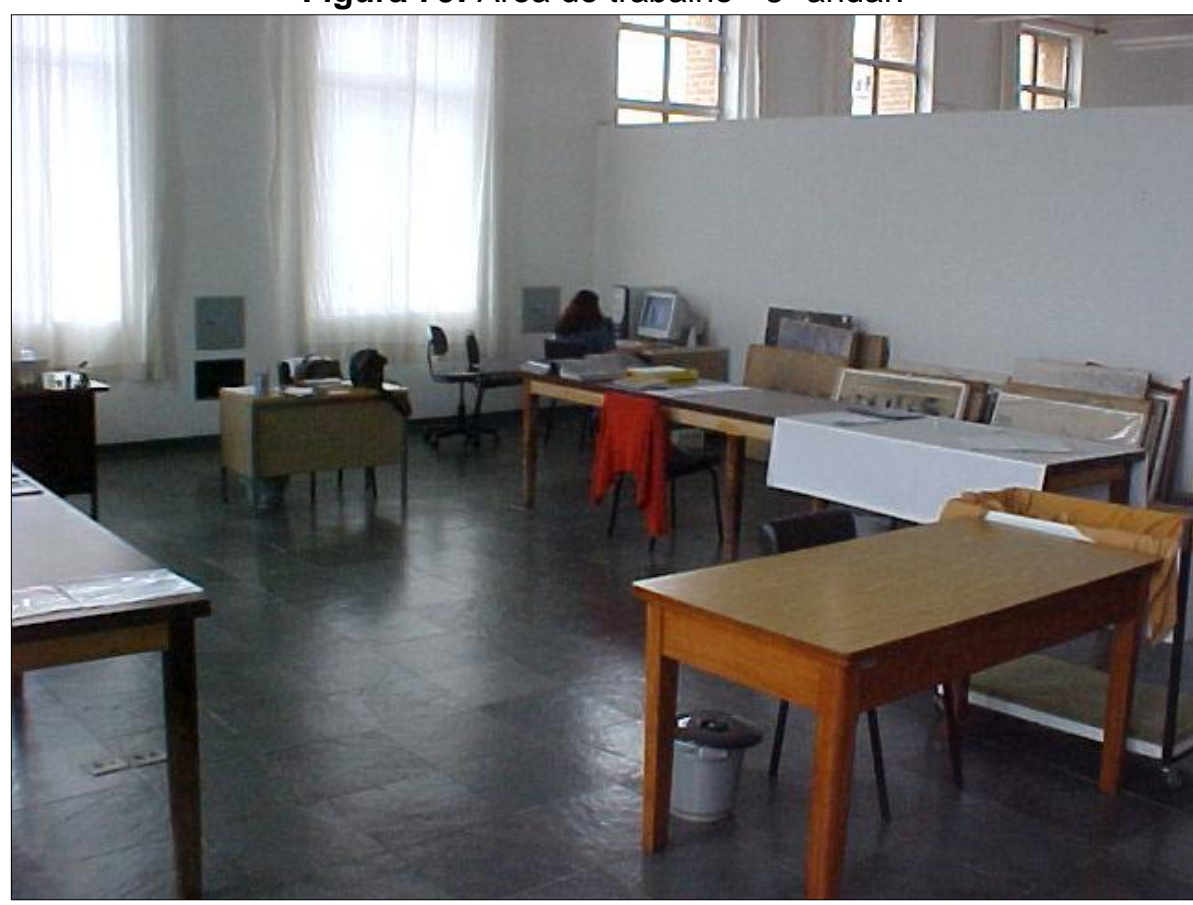

Fonte: MNSA/ Santuário Nacional. 
Apesar de não haver condições para armazenamento do acervo, foram instaladas mesas de trabalho com computadores, armários e arquivos de documentação, para realização dos treinamentos e demais atividades, bem como a aquisição de materiais de trabalho e os primeiros livros para formação de uma biblioteca técnica de apoio à pesquisa e catalogação do acervo.

De acordo com o Relatório Final de Prestação de Serviços Especializados, inicialmente a metodologia de trabalho foi o treinamento dos estagiários para o manuseio e higienização do acervo, seguindo o processo de documentação.

A cada lote de objetos retirados da exposição, selecionados segundo os materiais de suporte, a equipe foi treinada para a limpeza, segundo as técnicas adequadas e os materiais a serem empregados. $O$ objetivo era colocar a equipe em contado com toda a variedade de materiais constitutivos do acervo, quais sejam: pinturas, porcelanas, vidros, cerâmicas, materiais de origem animal, tecidos, metais, madeiras, etc. (RAMOS, 2003, p. 9).

Nesse contexto, para que fosse possível instaurar o processo inicial dos trabalhos, foram realizados diversos treinamentos, conforme a metodologia a seguir:

- Seleção do lote de objetos segundo o seu suporte;

- Aula teórica com indicação bibliográfica, relativa às características físicoquímicas e técnica de produção da obra;

- Segmento prático, iniciado com demonstrações dos restaurados e, logo após, continuidade pelo grupo até o domínio da técnica, a partir de vários exemplares com diferentes graus de dificuldade. (RAMOS, 2003, p. 10).

De acordo com o Relatório Final de Prestação de Serviços Especializados, a equipe recebeu treinamentos segundo as tipologias de acervos discriminadas abaixo:

Pintura de cavalete: higienização mecânica utilizando trinchas, com remoção de acúmulo de poeira no verso da obra (um dos principais agentes de deterioração), remoção de insetos e descupinização;

Numismática: higienização mecânica e química utilizando solução de amônia $(\mathrm{NH} 4 \mathrm{OH})$, água destilada e texapon (detergente neutro), passando depois para a neutralização;

Imaginária (madeira e barro): higienização mecânica com trinchas e através de uma massa que penetra em orifícios de difícil acesso e química utilizando pequenos cotonetes ligeiramente umedecidos com água destilada e texapon;

Prataria: seguindo os mesmos procedimentos de tratamento de Numismática;

Loucas e Porcelanas: Uso de cotonetes ligeiramente umedecidos com água destilada e texapon;

Cerâmica Arqueológica: higienização mecânica com trinchas e através de uma massa que penetra e retira o excesso de poeira e materiais de origem graxa; 
Tecidos: higienização mecânica com trinchas e sucção;

Minérios (pedras lapidadas, pedras em estado bruto, vidros): higienização através de uma ação química com água destilada e texapon e em alguns casos aplicação de solução oleosa em pequenas quantidades;

Materiais de Origem Orgânica (osso, marfim, chifre, cascos, couro): higienização mecânica e em alguns casos química usando água destilada e texapon;

Papéis (pinturas, fotografias, documentos): uso de trinchas e, dependendo da forma de montagem, desinfestação da obra, quando possível. (RAMOS, 2003, p. 10-11).

Em relação aos treinamentos para conservação das peças, "o restaurador de obras de arte Renato Rinaldi, responsável da equipe pela área de Conservação, procedeu ao treinamento entre os dias 10 de junho e 03 de julho de 2003, em regime intensivo" (RAMOS, 2003, p. 9).

Os treinamentos foram realizados em conjunto com a equipe do Centro de Documentação e Memória (CDM), como, por exemplo, o treinamento que foi ministrado pelo conservador de acervo Leandro Lopes de Melo, da equipe da FPHESP, realizado nos dias 16 e 17 de julho. Para esse treinamento, além dos estagiários, também foram convidados os responsáveis pelo Museu e pelo CDM, assim como demais membros da Comissão de Bens Culturais da Igreja da Arquidiocese de Aparecida.

Desta forma, a nova metodologia de trabalho, a partir dos treinamentos realizados pela FPHESP com profissionais especializados, iniciaram os processos de pesquisa, documentação, higienização, processos fotográficos do acervo e demais atividades técnicas, conforme observados nas Figuras 80 e 81.

De acordo com Poulot (2013, p. 24),

A pesquisa erudita constitui, em princípio, a finalidade das aquisições, das exposições e de toda a atividade documental que Ihes são inerentes. Os conhecimentos produzidos no museu estão associados tanto à coleção quanto à equipe de conservação; além disso, a importância de tal saber varia em função da qualidade destas. 
Figura 80: Treinamento FPHESP.

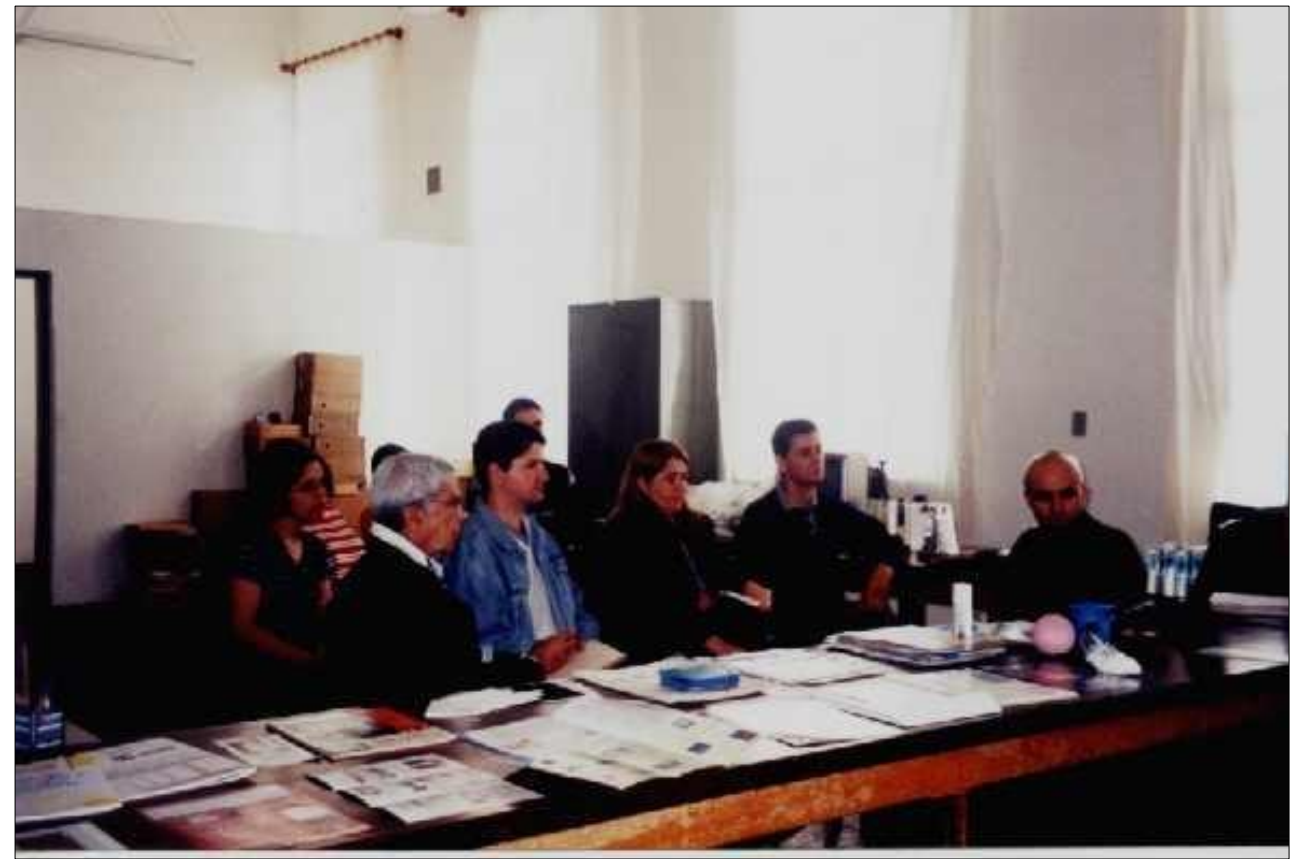

Fonte: MNSA/ Santuário Nacional.

Figura 81: Documentação do acervo.

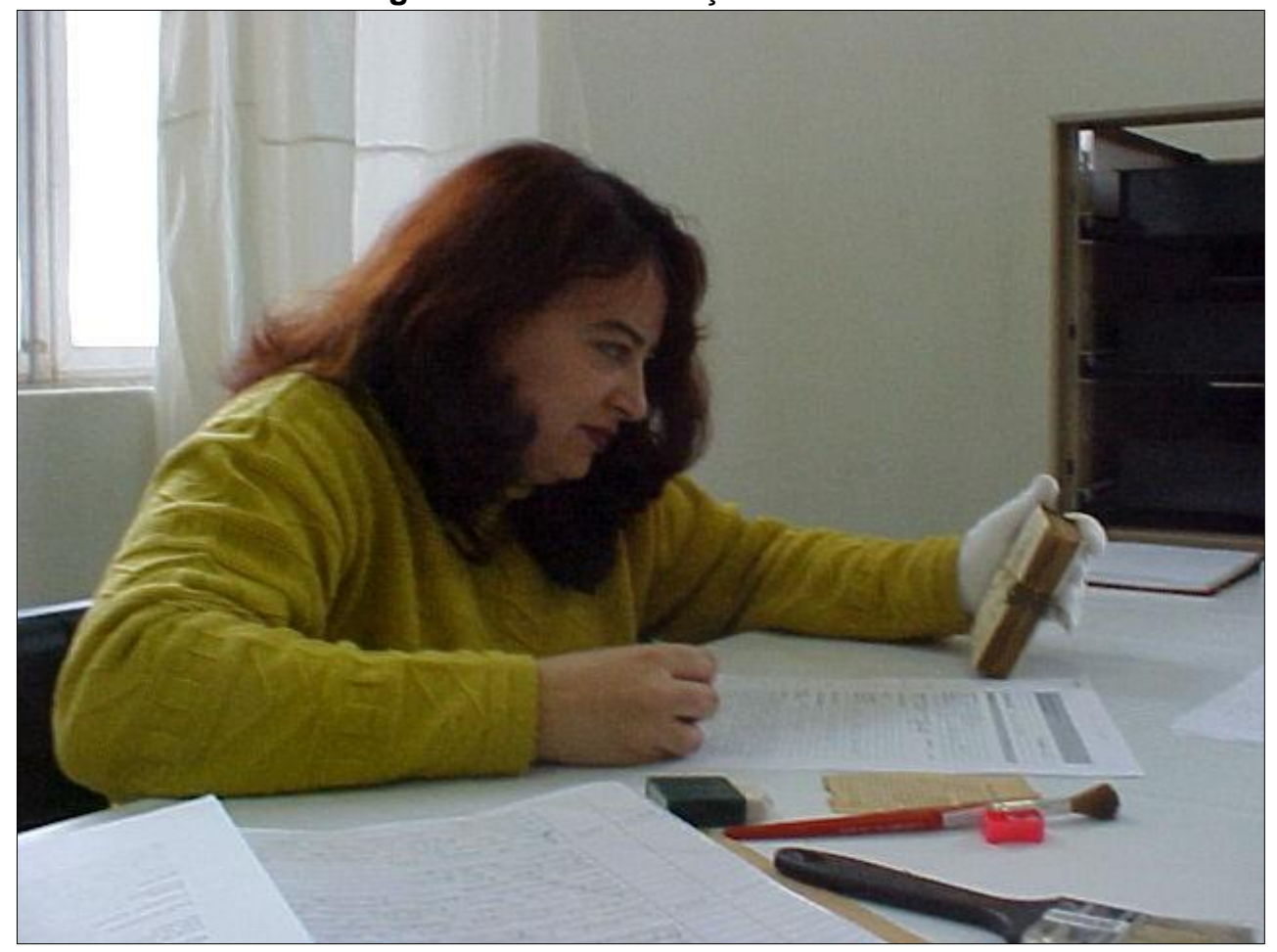

Fonte: MNSA/ Santuário Nacional.

Conforme o Relatório Final de Prestação de Serviços Especializados, durante os quatro meses de execução do projeto foram realizadas atividades importantes "visando à construção de um Museu com projeto museológico consistente, que defina seu papel institucional e suas estratégias de ação, a partir da qualificação de 
seu quadro funcional e da normalização de seus atividades e procedimentos" (RAMOS, 2003, p. 3).

Observamos que, com o intuito de fazer um diagnóstico geral da instituição, paralelamente também foram realizadas pesquisas complementares, entre elas "pesquisas relativas ao histórico institucional, a constituição do acervo, levantamentos sobre a devoção a Nossa Senhora Aparecida, a formação da cidade, seus artistas, a Congregação Redentorista, entre outros assuntos" (RAMOS, 2003, p. 33).

Durante o levantamento geral do acervo exposto, realizou-se uma contagem estimativa dos objetos, de acordo com a disposição do mobiliário na exposição, contabilizando aproximadamente 5.669 objetos, não tendo sido consideradas as peças armazenadas no depósito do $11^{\circ}$ andar.

Nesse contexto, com o intuito de mapear o acervo e organizar o processo de documentação, os núcleos foram agrupados por paredes (parede 1, 2, 3 e 4) e por corredores (centro/esquerda, centro, centro/direita), conforme consta no Relatório Final de Prestação de Serviços Especializados (RAMOS, 2003, p. 88-94). Desta forma, os armários e vitrines foram mapeados pelo grupo de trabalho, para a correta localização dos acervos e quantificação estimada dos objetos por núcleos de vitrines, segundo a disposição do mobiliário na área expositiva, conforme apresentado no Quadro 11.

Quadro 11: Quantificação dos objetos em exposição.
\begin{tabular}{|l|c|}
\hline \multicolumn{1}{|c|}{ Localização na exposição } & Quantificação dos objetos \\
\hline Parede 1 & 437 \\
\hline Parede 2 & 655 \\
\hline Parede 3 & 385 \\
\hline Parede 4 & 642 \\
\hline Corredor central & 1.113 \\
\hline Corredor à direita & 2.030 \\
\hline Corredor à esquerda & 407 \\
\hline Total geral (aproximado) & $\mathbf{5 . 6 6 9}$ \\
\hline
\end{tabular}

Fonte: COELHO, 2019.

A Parede 1, à esquerda da entrada da sala da exposição, apresentava pinturas, arandelas, documentos emoldurados, mobiliários, duas vitrines com esculturas e dois armários com objetos indígenas, material arqueológico e fósseis. $\mathrm{E}$, sobre os armários, havia objetos de grande porte, complementando a coleção de 
etnologia e exemplares da coleção de zoologia. Nessa seção, identificada como Parede 1, foram quantificados 437 objetos.

Dando sequência, na Parede 2 havia dois armários e uma vitrine, contendo objetos da cultura caipira e tropeira, bem como artesanato regional e cerâmica figurativa. Sobre os armários havia réplicas dos Profetas de Aleijadinho, bem como uma roca. Na vitrine ao lado, havia objetos utilitários de escritório e, sobre ela, a réplica do capacete de Ayrton Senna. Nessa seção havia também um harmônio, um relógio, esculturas, mobiliários e pintura, quantificados em 655 objetos.

$\mathrm{Na}$ Parede 3 havia seis armários e três vitrines, apresentando objetos religiosos e indumentária, além de imaginárias. Os outros núcleos eram compostos por objetos relativos à escravidão e à Revolução de 1932. Sobre os armários havia ânforas, tocheiros, esculturas, oratórios, relógio, rádio, remo e, na parede, pinturas e gravuras. As vitrines baixas apresentavam utilitários femininos diversos, o histórico do aparecimento da Imagem de Nossa Senhora e peças relacionadas ao padre redentorista Vítor Coelho de Almeida. Nessa seção, identificada como Parede 3, foram quantificados 385 objetos.

$\mathrm{Na}$ sequência, na Parede 4, havia pinturas, gravuras, documentos emoldurados, além de peças de mineralogia e um cofre, assim como dois armários e uma vitrine contendo objetos religiosos, coroas e a coleção de mineralogia. E na vitrine havia fragmentos do nicho da imagem de Nossa Senhora Aparecida, por ocasião do atentado ocorrido em 1978, além de uma réplica da imagem, para contextualizar o ocorrido. Nesta seção, identificada como Parede 4, foram quantificados 642 objetos.

Na parte central da sala da exposição, havia três corredores entre armários e vitrines. No corredor à esquerda, havia quatro vitrines, uma mesa e a maquete do projeto original do arquiteto Benedito Calixto de Jesus Netto para construção da Basílica Nova. As vitrines apresentavam objetos da Terra Santa, presépios, cerâmica figurativa e uma grande coleção de relógios, quantificados em 407 objetos nessa seção.

No corredor central, havia dez armários, sendo que os cinco primeiros armários desta sequência apresentavam a coleção de imaginária. Os demais armários apresentavam as coleções de prataria litúrgica e prataria doméstica, além das louças e porcelanas. Nessa seção, identificada como corredor central, foram quantificados 1.113 objetos. 
No corredor à direita, havia seis vitrines contendo a coleção de numismática, composta por cédulas e moedas, nacionais e estrangeiras, além de objetos relacionados à Segunda Guerra Mundial, totalizando 2.030 objetos nessa seção.

De acordo com o Relatório Final de Prestação de Serviços Especializados, os núcleos de objetos tratados inicialmente foram caracterizados como: "Artes visuais; Objetos cerimoniais; Comunicação - documentos; Caça e guerra (objetos de origem indígena); Objetos pecuniários (numismática); Interiores; Objetos pessoais" (RAMOS, 2003, p. 36).

Em relação à categorização e tipologia do acervo, considerando o histórico da coleta assistemática, bem como a reunião das coleções sem uma política de aquisição bem definida, pois a instituição adotava o procedimento de aceitar todo objeto que era oferecido, observa-se que o conceito do museu foi embasado segundo o qual:

[...] o valor dos objetos reside na sua antiguidade, raridade ou exotismo, o acervo hoje existente é constituído de objetos representativos de variados temas, de diversas regiões do país, de diferentes grupos culturais, épocas, etc., sem uma linha condutora que o caracterize. Tal ecletismo, sem uma exposição didaticamente organizada, imprime ao acervo a marca da curiosidade, desvinculada muitas vezes do caráter de documento e fonte de informação. (RAMOS, 2003, p. 39).

Ramos (2003, p. 41), complementa que "trata-se, portanto, de coleção bastante eclética, diversificada nos temas e materiais, cuja categorização somente poderá ser concluída após o inventário geral do acervo e pesquisa mais aprofundada do histórico da coleta e do significado de cada objeto".

Após o mapeamento dos acervos e coleções em exposição, iniciou-se o processo de movimentação para o $8^{\circ}$ andar da Torre, mediante o registro em folha própria (Figura 82), com o intuito de manter o controle das peças selecionadas para documentação contendo os campos: № de ordem; № do objeto; objeto; localização; data da retirada; horário; responsável; acompanhante (museu); data da devolução; horário; responsável; acompanhante. Essa ficha de movimentação do acervo era assinada pelo técnico da FPHESP responsável pela atividade e um representante do Museu Nossa Senhora Aparecida, que acompanhava a retirada do acervo da exposição. 
Figura 82: Ficha de movimentação do acervo.

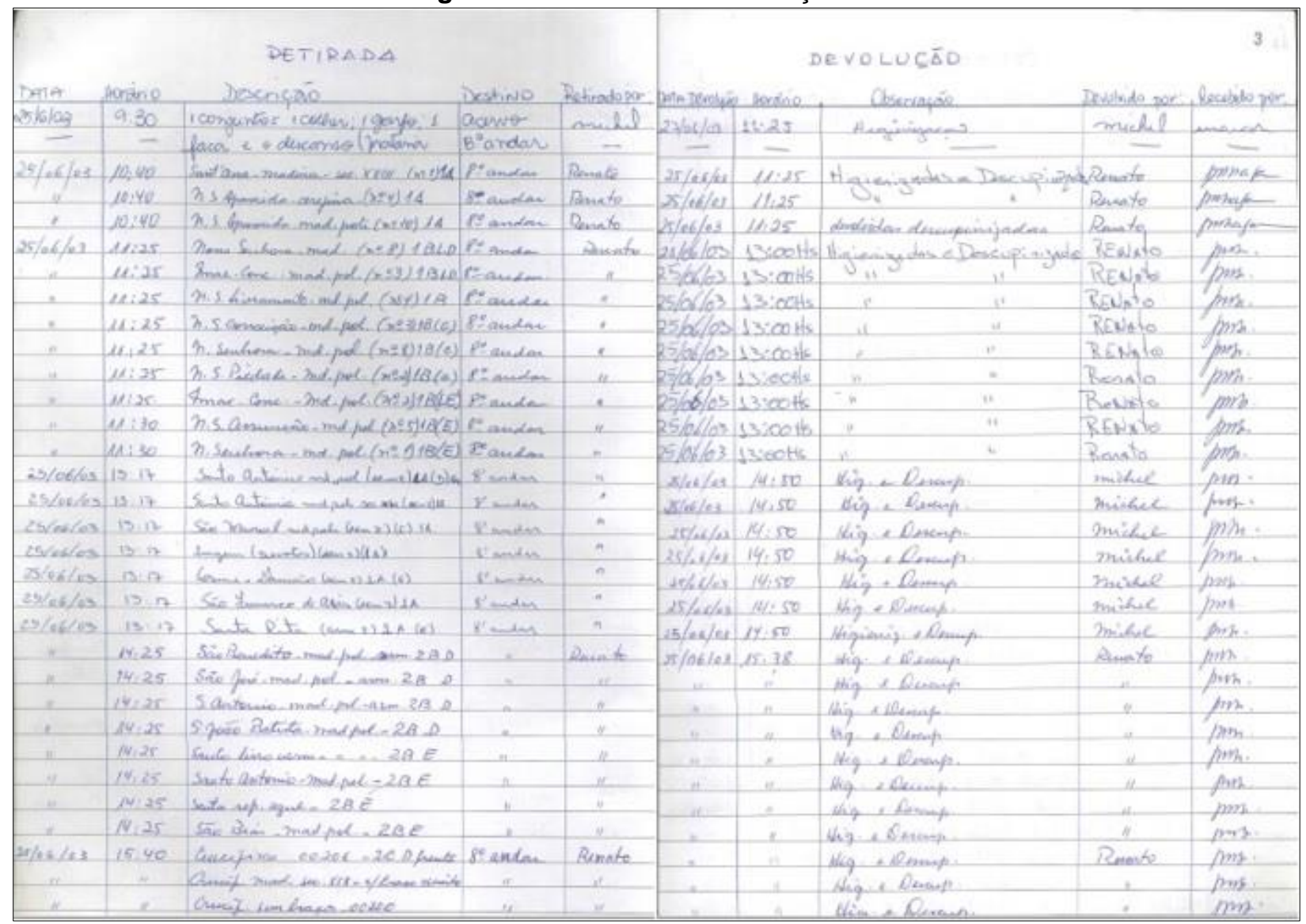

Fonte: MNSA/ Santuário Nacional.

Posteriormente, com o intuito de inventariar os objetos, criou-se ficha catalográfica (ANEXO C) e um contínuo processo de documentação, conforme consta no Relatório Final de Prestação de Serviços Especializados.

Esta ferramenta de registro foi desenhada com campos necessários também a uma catalogação mais aprofundada, visando fornecer, sempre que possível, o maior número de informações sobre as peças estudadas. A equipe foi treinada em exercícios práticos de medição, descrição, identificação, havendo fornecimento de bibliografia especializada para fundamentação dos trabalhos. (RAMOS, 2003, p. 15).

Com a movimentação dos objetos, era também realizada uma avaliação do estado de conservação e um processo de limpeza. Uma vez higienizado, o objeto passava pelo processo de documentação e pesquisa, incluindo as fotografias detalhadas do acervo.

Em relação à conservação do acervo, foram identificados problemas diversificados, com causas e intensidades do dano diferentes.

As várias mudanças, a falta de orientação geral sobre conservação de objetos, as condições climáticas de manuseio, iluminação, forma de expor, limpeza inadequada, ataques de insetos, provocaram, no correr do tempo, 
danos comprometedores aos objetos, alguns deles irreparáveis. (RAMOS, 2003, p. 55).

Tendo sido identificadas infestações biológicas, degradação por luz, por agentes mecânicos, por agentes químicos, agentes climáticos e intervenções inadequadas. De maneira geral, os agentes de degradação foram minimizados e alguns eliminados, a partir de atitudes de preservação, entre eles, "exposição adequada dos objetos; armazenamento técnico com acondicionamento apropriado; treinamento de todas as pessoas envolvidas com o acervo; adequação do ambiente expositivo; conscientização geral" (RAMOS, 2003, p. 71).

A definição dos lotes de objetos a serem tratados foi baseada na temática para uma futura exposição relacionada a devoção a Nossa Senhora Aparecida. Com isso, optou-se por dar prioridade a coleção de imaginária, considerando o número expressivo da coleção, bem como a qualidade artística e o interesse museológico. Também foram selecionados demais objetos vinculados à temática religiosa.

Paralelamente aos trabalhos realizados na exposição, buscou-se organizar o depósito localizado no $11^{\circ}$ andar. Nesse depósito armazenavam-se objetos que não estavam expostos devido ao estado de conservação ou, simplesmente, por não haver espaço suficiente para exposição no $2^{\circ}$ andar.

Construíram-se, portanto, algumas estantes de madeira para organização do acervo. Então, os objetos eram movimentados para a área técnica no $8^{\circ}$ andar para higienização, documentação e fotografia, e posteriormente retornavam para $011^{\circ}$ andar, por não haver as condições para armazenamento no $8^{\circ}$ andar.

Os resultados finais apresentados pela FPHESP, quanto à conservação do acervo durante os quatro meses de trabalho, foram "659 objetos higienizados, 174 objetos descupinizados, 679 objetos descritos quanto ao estado de conservação e avaliados quanto à prioridade para restauração" (RAMOS, 2003, p. 35). Em relação à documentação, cerca de 679 objetos foram catalogados, fotografados e inseridos em banco de dados.

De maneira geral, consideramos que a documentação museológica é imprescindível para registrar as peças constantes no acervo, para que se possa dar conta deste patrimônio que está sob a responsabilidade do Museu, garantindo assim sua salvaguarda e apoio às demais atividades de comunicação da instituição.

Nesse contexto, Ramos (2003), em seu relatório final da Fundação Patrimônio Histórico da Energia de São Paulo, diz que a documentação do Museu Nossa 
Senhora Aparecida merece, portanto, atenção especial quanto à "Criação de fluxo documental; Criação de sistema de registro adequado ao fluxo; Capacitação de todos os envolvidos com o acervo para a aplicação dos procedimentos traçados" (RAMOS, 2003, p. 52).

Desta forma, os esquemas a seguir (Figuras 83 e 84) dão um exemplo de um fluxo documental simples, assim como o fluxo de entrada de objetos que era realizado pelo Museu, conforme consta no Relatório da Fundação Patrimônio Histórico da Energia de São Paulo. 
Figura 83: Fluxo de entrada de objetos.

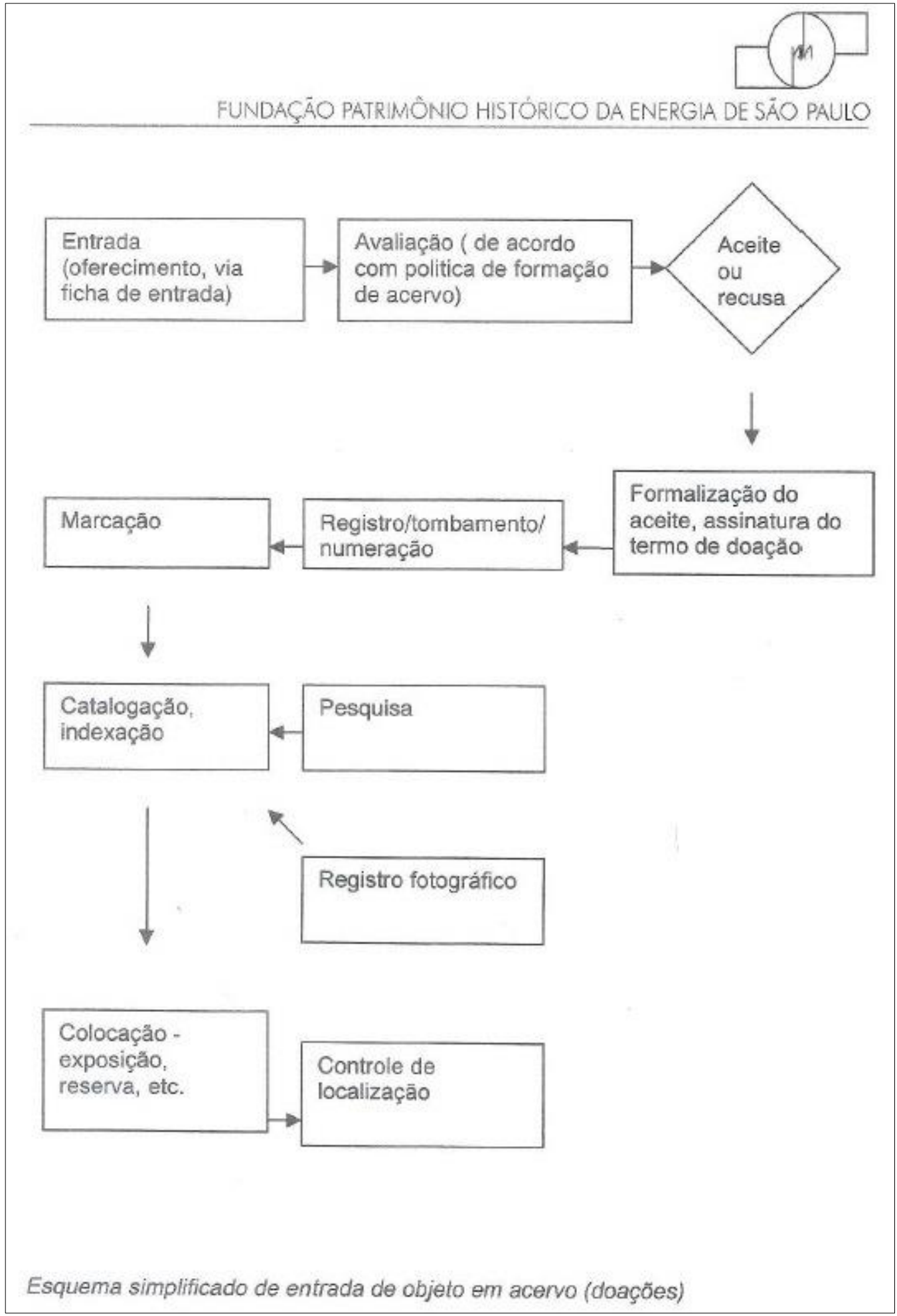

Fonte: RAMOS, 2003, p. 53. 
Figura 84: Fluxo de entrada de objetos identificado pela FPHESP.

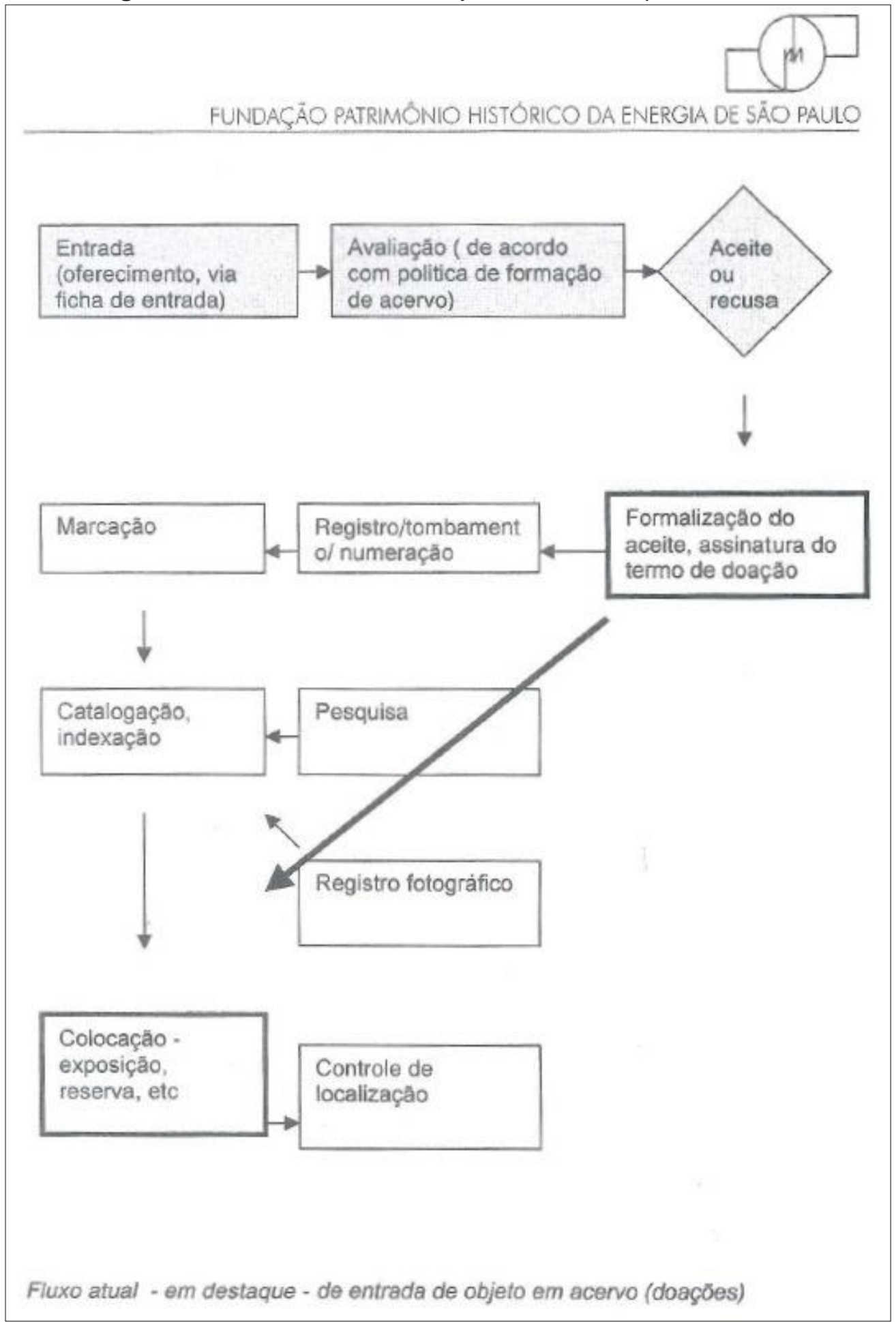

Fonte: RAMOS, 2003, p. 54.

A reorganização do fluxo de entrada de objetos, a partir do fluxo identificado pela FPHESP, pautou as novas atividades com o acervo, que passou a ser direcionado para armazenamento e posterior triagem para avaliação da Comissão de Acervo do Museu, dando sequência ao processo de catalogação, ao invés de ser inserido diretamente na exposição, conforme era o método anterior. 
Com o diagnóstico da FPHESP, constatou-se que o Museu anteriormente não possuía uma política criteriosa para recebimentos de doações, pois foram identificadas na exposição algumas placas contendo a informação: aceita-se a oferta de objetos antigos de valor histórico ou artístico, para o engrandecimento do acervo deste museu; observada em fotografias da exposição.

Com isso, reuniu-se no espaço expositivo um acervo eclético, sem roteiro de leitura, prejudicando, inclusive, a comunicação museológica, refletindo uma visão de museu desalinhada das concepções contemporâneas, conforme consta no Relatório Final de Prestação de Serviços Especializados.

De maneira geral, o resultado final dos trabalhos indicou que,

O Museu necessita instituir um projeto museológico que defina sua missão, sua área de interesse, seus objetivos e forma de atuação, suas linhas de acervo. Sobre essas definições deve apoiar a política de aquisições, baseada em mecanismos de avaliação que respeitem esses critérios" (RAMOS, 2003, p. 74).

Com o intuito de valorizar o expressivo acervo da religiosidade popular e diversidade cultural brasileira, que merecem ser preservados, pesquisados e explorados, buscando a reafirmação de nossa identidade.

Em suma, o Relatório Final de Prestação de Serviços Especializados finaliza visando um direcionamento aos processos do Museu, obedecendo às preocupações com conceituação, salvaguarda, comunicação e ação cultural, tais como:

- Construção de um projeto museológico, que discuta e explicite a missão do museu, seus objetivos, sua forma de ação, seu objeto de interesse, suas linhas de acervo, fundamentando toda a atuação do museu, seja na formulação de uma política de aquisição, seja no âmbito interno na formulação das políticas de conservação, documentação e segurança, seja ainda na sua extroversão. O projeto proporá a estrutura organizacional, programas de ação e indicará um programa de funções para ocupação do espaço;

- Continuidade ao processo de salvaguarda das coleções via inventário do acervo e instaurando um sistema documental de gerenciamento que garanta a adequada identificação dos objetos e o controle das coleções (processo acompanhado de programa de higienização e identificação do estado de conservação das peças);

- Projeto de instalação de Reserva Técnica, para armazenamento do acervo baseado em modernos critérios de controle climático, de mobiliário e acondicionamento de objetos, visando a proteção das peças em geral e, em particular, o atendimento das necessidades de reorganização da exposição de longa duração;

- Instalação de áreas de trabalho apropriadas para as rotinas de identificação do acervo, higienização e acondicionamento de peças e demais atividades técnicas; 
- Instalação de programa de restauração dos objetos danificados, apoiado na política de acervo e em critérios museológicos;

- Projeto de segurança geral para o Museu (áreas de exposição, reserva, áreas administrativas, áreas de acesso público);

- Projeto museográfico-expositivo para as comemorações do Centenário da Coroação de Nossa Senhora Aparecida, baseado nos novos critérios adotados, e incorporado o viés educativo;

- Projeto museográfico para $\circ 2^{\circ}$ andar da Torre (atual instalação do Museu), com adequação do espaço em função do projeto museológico geral, atendendo a uma proposta expositiva e às necessidades e funções técnicas e administrativas definidas para o Museu. (RAMOS, 2003, p. 77).

Em 2004, Giselle Peixe, a museóloga responsável pelo projeto da FPHESP, inicia uma nova consultoria junto com Silvia Bigareli, por meio de um novo contrato com a empresa Enfoque Consultoria e Pesquisa em História, representada por Fernanda Cristina Scalvi, com o intuito de dar continuidade às atividades técnicas para reestruturação do Museu.

Criam, portanto, o Plano Museológico com um novo projeto museográfico, e o Museu contrata, efetivamente, os estagiários, que iniciaram os trabalhos junto com o projeto desenvolvido pela PFHESP, para fazerem a catalogação e conservação do acervo, assim como passam a orientar e realizar novos treinamentos com demais funcionários do Museu, que atuavam na orientação de público e atendimento na exposição.

Dom Darci José Nicioli47, ao ser questionado sobre 0 trabalho das consultoras, relata em entrevista que é tudo maravilhoso.

Se insere em todo esse esquema do Santuário Nacional. A visita ao mirante, a visita à cúpula, o próprio Museu, a Sala das Promessas. Então, são riquezas do Santuário Nacional. E tudo isso é muito importante numa visão grande de Santuário. Santuário é isto, é lugar de encontro de pessoas. A pessoa deve sair do Santuário Nacional enriquecida na sua espiritualidade e enriquecida na sua cultura. Daí é maravilhoso o trabalho realizado por essas senhoras, elas nos ajudaram com o conhecimento que têm a deixar esse museu na magnitude, na estatura que nós o conhecemos hoje. Nós não podemos ser factótuns. A igreja tem mania de fazer tudo por sua própria conta. É preciso que nós lancemos mãos de profissionais competentes para nos ajudar a exercer a nossa função de evangelização. (NICIOLI, 2018, informação verbal).

Nesse período, desenvolvem, portanto, um projeto expográfico para o $1^{\circ}$ andar da Torre, com a temática relacionada a devoção a Nossa Senhora Aparecida, com o intuito de encerrar a antiga exposição no $2^{\circ}$ andar.

47 NICIOLI, Darci José (Arcebispo de Diamantina). Entrevista concedida a Erica Andreza Coelho. Aparecida, 19 abr. 2018, 6 min 14 s. Som, Formato M4A. 
De acordo com Dom Darci José Nicioli, "creio que Museu de Arte Sacra são muitos no Brasil, e é claro, estando aqui no Santuário, e até por causa do nosso acervo, nós precisamos, óbvio, cuidar deste acervo e mostrá-lo ao povo, é uma riqueza imensa o que temos" (NICIOLI, 2018, informação verbal).

Entretanto, Dom Darci José Nicioli complementa que,

Sim, devemos investir na ala de arte sacra. Mas, o Museu não deve ficar muito restrito. Portanto, tantos outros departamentos do próprio Museu foram criados, até devido ao próprio acervo que temos e serão criados ainda. Acredito que até nascerá uma terceira etapa do Museu Nossa Senhora Aparecida. E olha que nós temos mais de 300 mil pessoas, deve ser o Museu mais visitado do Brasil, se não é o, é um dos mais visitados do Brasil. Então, é claro todo esse acervo precisa necessariamente ser cuidado, mostrado e incrementado. (NICIOLI, 2018, informação verbal).

Para essa exposição, inaugurada em 2005, apenas uma pequena parcela do acervo relacionada a devoção a Nossa Senhora Aparecida foi selecionada para exibição, sendo necessário criar uma Reserva Técnica definitiva, para armazenar as coleções e acervos não expostos.

Nesse contexto, com o término do projeto firmado entre a empresa Enfoque Consultoria e Pesquisa em História e o Santuário Nacional de Aparecida, finalizado com a inauguração da exposição, os estagiários da PFHESP são contratados pelo Santuário para dar continuidade às atividades técnicas, visando a preservação das coleções e acervos do Museu.

Iniciam, portanto, um processo de movimentação do acervo para a nova reserva técnica no 5ํadar da Torre, no período de novembro de 2005 a março de 2006. A princípio, não foram adquiridos novos armários para armazenamento, ou seja, os objetos eram retirados do armário no $2^{\circ}$ andar, movimentados para uma mesa no $5^{\circ}$ andar, para realização dos processos de documentação e aguardavam a movimentação do mesmo armário para a reserva técnica e, assim, serem armazenados novamente.

Entretanto, o armazenamento procurou seguir alguns critérios de classificação das tipologias e tipos de materiais das coleções, visto que não mais se apresentariam de forma estética expositiva, mas sim organizadas de acordo com sua classificação e tipologia de materiais.

As Figuras 85 e 86 constatam como eram os ambientes de trabalho e armazenamento do acervo na área técnica do Museu, no 5o andar da Torre. 
Figura 85: Área de trabalho - 5o andar.

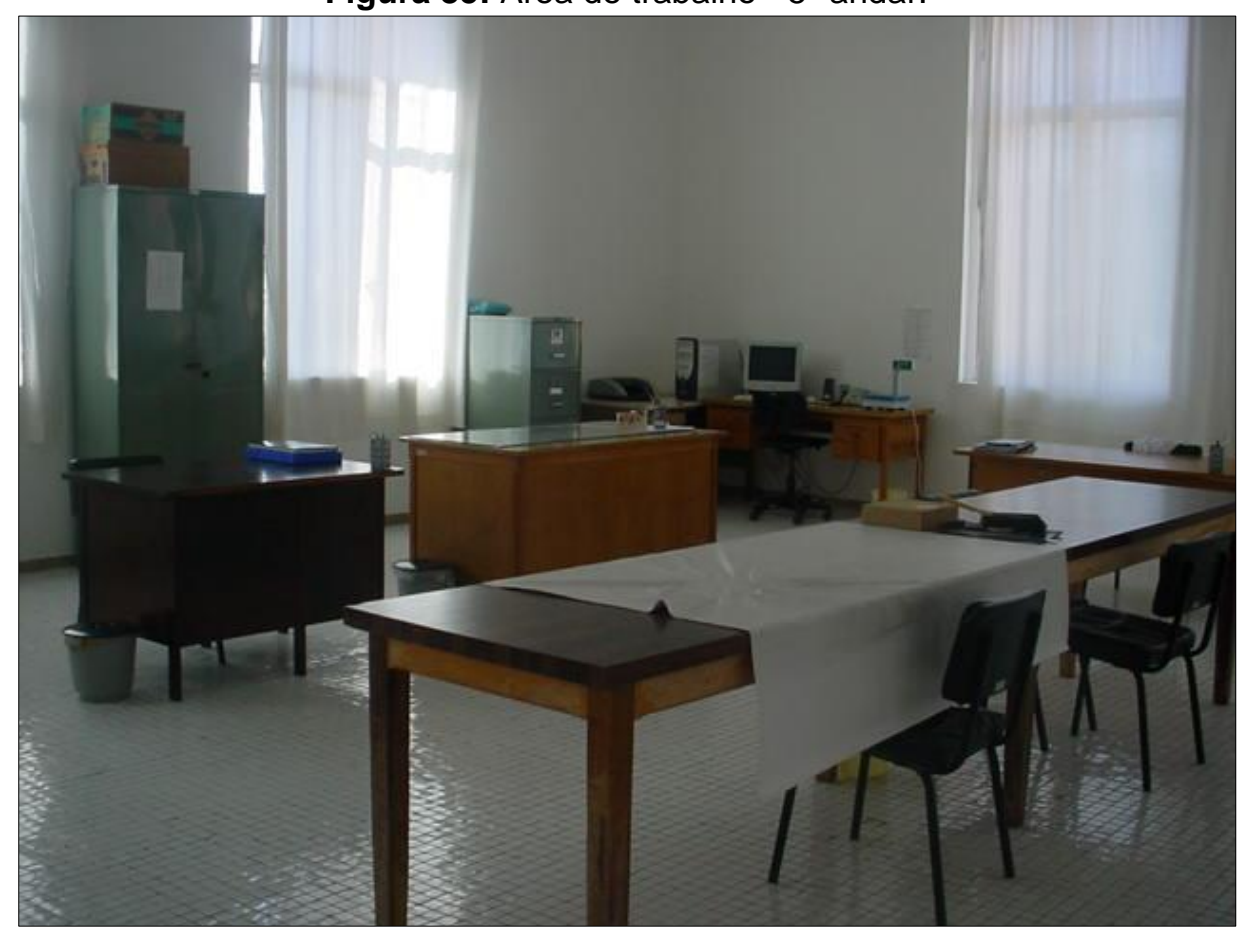

Fonte: MNSA/ Santuário Nacional

Figura 86: Reserva Técnica - 5ํandar.

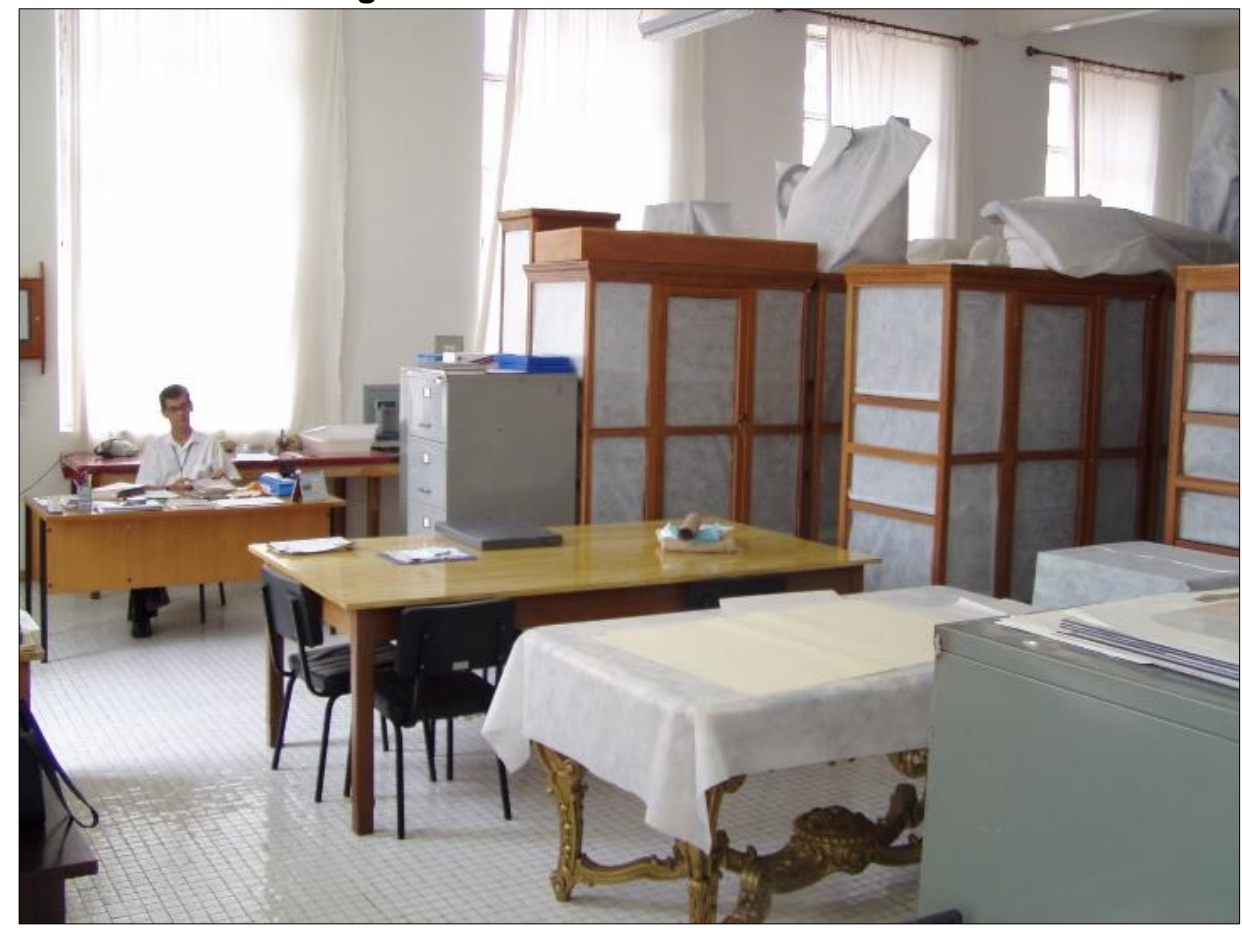

Fonte: MNSA/ Santuário Nacional.

Em relação à doação de novos objetos, observamos um aumento expressivo de entrada de objetos, provavelmente devido a um controle maior das doações e sua devida documentação de aquisição. Entretanto, observamos que alguns desses 
documentos foram preenchidos de forma incompleta, não sendo possível atribuir a data em que chegaram nem quem foi o responsável pelo recebimento.

Da relação de objetos que podem ser observados no Quadro 30 - ANEXO B, onze números de entrada de objetos são referentes aos relógios de bolso, pulso e despertador, totalizando cerca de catorze peças. Já em relação à coleção de numismática, cerca de quarenta e sete números de entrada foram identificados, entre cédulas e moedas, nacionais e internacionais, entretanto não foi possível quantificar o montante de peças, pois os Termos de Doação de Bens Móveis foram preenchidos de maneira incompleta, sem muitos detalhes.

Nesse ano também foram ofertadas algumas armas brancas e arma de fogo entre punhais, canivetes e garrucha, assim como minerais, objetos de uso pessoal, joias, além de objetos da cultura tropeira e demais peças.

Do total dessa lista do ano de 2003, foi possível identificar vinte e seis objetos da lista, considerando a análise de oitenta e nove Termos de Doação de Bens Móveis, referentes aos objetos que foram doados em 2003, vinte e nove objetos foram identificados pela documentação do acervo e fichas catalográficas, sendo estes: medalha de prata ( $n^{\circ}-07$ ), sabre com cinto ( $n^{\circ}$ 42), moeda ( $n^{\circ}-43$ ), despertador ( $n^{\circ} 53$ ), chapéu de boiadeiro e relógio de algibeira ( $n^{\circ} 55$ ), estribo feminino ( $n^{\circ} 55$ ), moedas ( $n^{\circ}$ 59), moeda ( $n^{-}$60), relógio de bolso com corrente ( $n^{\circ}$ 61), bule de porcelana ( $n^{\circ}$ 63), moeda ( $n^{\circ}$ 65), ponta de flecha indígena ( $n^{\circ}$ 66), máquina fotográfica ( $n^{\circ}$ 67), canivete ( $n^{\circ}$ 68), cédula ( $n^{\circ}$ 69), relógio de algibeira ( $n^{\circ}$ 74), candeia ( $\left.n^{\circ} 75\right)$, moedas em moldura ( $n^{\circ} 76$ ), xícara e pires ( $n^{\circ} 77$ ), paliteiro ( $\left.n^{\circ} 78\right)$, moedas ( $n^{\circ} 80$ ), punhal de prata com bainha ( $n^{\circ} 82$ ), moeda ( $n^{\circ} 84$ ), cédula ( $n^{\circ} 87$ ), cédula ( $n^{\circ}$ 88), um quadro e um pano de amostra ( $n^{\circ}$ - 89). Tendo recebido, respectivamente, os seguintes números de inventário: 9.988, 1.841, 8.343, 1.831, $1.880,1.881,9.989,1.0511,10.512,8.746,2.178,1.041,8.459,1.822,11.675$, 7.986, 2.012, 3.360, 2.894, 1.149, 1.833, 2.573, 2.574, 1.823, 10.175, 7.931, 7.902, 3.271 e 11.673.

Em relação à lista de entrada dos objetos em 2004, que podem ser observados no Quadro 31 - ANEXO B, verificamos que a maioria das doações foram de cédulas e moedas e foi possível identificar cento e um objetos, sendo a maioria da coleção de numismática e bonecos artesanais.

Dos oitenta e seis números de entrada de objetos que foram registrados no ano de 2004, cento e três objetos foram identificados pela documentação do acervo, 
sendo estes: moeda ( $\mathrm{n}^{\circ} 02$ ), cédulas e moedas ( $n^{\circ} 04$ ), moedas ( $\mathrm{n}^{\circ} 06$ ), cédula ( $\mathrm{n}^{\circ}$ 09), escultura face de Cristo ( $n-10$ ), relógio de pulso ( $n \div 12$ ), tinteiro em porcelana ( $\left.n^{\circ} 15\right)$, moedas ( $\left.n^{\circ} 16\right)$, escultura de Nossa Senhora Aparecida ( $n^{\circ} 17$ ), machadinho ( $n^{\circ} 20$ ), cédula ( $\left.n^{\circ} 21\right)$, candeia ( $\left.n^{\circ} 22\right)$, tesoura ( $\left.n^{\circ} 23\right)$, livro Manual do Cristão Devoto (n 24), quadro comemorativo dos 25 anos da coroação de Nossa Senhora ( $n$ ㅇ 26), bonecas artesanais ( $n^{\circ}$ 27), cédula ( $n^{\circ}$ 29), relógio de algibeira ( $n^{\circ} 31$ ), relógios de pulso ( $n^{\circ}$ 33), xícara ( $n^{\circ}$ 34), moeda ( $n^{\circ}$ 35), relógio de algibeira ( $n^{\circ}$ 36), moeda ( $n^{\circ} 37$ ), luminária ( $n^{\circ} 38$ ), par de castanholas ( $n^{\circ} 38$ ), pilão com mão de pilão

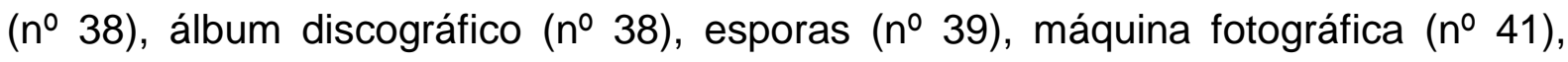
relógio de pulso ( $n^{\circ} 42$ ), vitrola ( $\left.n^{\circ} 46\right)$, relógio carrilhão ( $\left.n^{\circ} 47\right)$, máquina de timbrar ( $n^{\circ}$ 48), relógio ( $n^{\circ}$ 49), cédulas e moedas ( $n^{\circ}$ 51), livreto ( $n^{\circ} 52$ ), livro Segundo Catecismo ( $n^{\circ} 52$ ), máquina fotográfica ( $n^{\circ} 52$ ), relógio de pulso ( $\left.n^{\circ} 54\right)$, relógio de parede ( $\left.n^{\circ} 55\right)$, cédula ( $\left.n^{\circ} 56\right)$, estojo com moedas ( $\left.n^{\circ} 58\right)$, copos de vidro ( $n^{\circ} 59$ ), cédula ( $n^{\circ} 61$ ), moeda ( $\left.n^{\circ} 66\right)$, concha batismal ( $\left.n^{\circ} 67\right)$, terço ( $\left.n^{\circ} 68\right)$, moedas $\left(n^{\circ} 70\right)$, cédula ( $n-71$ ), relógio de algibeira ( $n$ ำ72), relógio de pulso ( $n$ - 73), relógio de pulso ( $n^{\circ}$ 74), recibo de assinatura dos Ecos Marianos ( $n^{\circ}$ 76), relógio de pulso com corrente ( $n^{\circ} 77$ ), moeda ( $n^{\circ} 80$ ), máquina de moer carne ( $n^{\circ}$ 82) e moeda ( $n^{\circ}$ 84). Tendo recebido, respectivamente, os seguintes números de inventário: 9.019, 8.957, 9.001, 9.183, 9.274, 10.983, 10.984, 10.985, 0986, 10.987, 8.705, 8.706, 8.709, 8.705, 8.706, 8.709, 7.771, 1.820, 2.122, 2.208, 9.777, 3.216, ARQ-006, 7.770, $3.359,11.676,1.882,1.817,2.856$ até 2.879, 8.324, 1.837, 2.144, 2.145, 2.147, 2.150, 2.158, 2.159, 2.160, 1.883, 10.712, 11.426, 9.467, 1.845, 1.843, 1.844, 1.842, 1.487, 1.832, 2.194, 3240, 1.895, 1.897, 1.916, 7.787, 7.788, 7.790, 7.791, 8.458, $1.876,1.877,1839,2.191,1.885,7.827,1.838,1.836,8.115,9.859,1.920,2.174$, 9.031, 7.932, 11.432, 11.443, 11.441, 2.572, 11.446, 2.575, 2.196 e 8.760.

Nesse período, com a revitalização institucional, na medida em que os objetos eram doados, ficavam armazenados em um armário de triagem para posterior avaliação por uma Comissão de Acervo, que contribuía para alinhar critérios de incorporação ou não ao acervo do Museu, embora sem definir uma política de aquisição.

A Comissão de Acervo era composta pela equipe técnica do Museu, professores envolvidos em assuntos culturais no município de Aparecida (SP) e na região do Vale do Paraíba, profissionais que atuavam em outras instituições museológicas, além de membros da Congregação do Santíssimo Redentor e do 
departamento jurídico do Santuário Nacional de Aparecida, para formalizar o parecer da Comissão sobre os itens avaliados.

Portanto, conforme ocorriam as reuniões da Comissão de Acervo ${ }^{48}$, os objetos aprovados eram documentados logo em seguida ou separados para encaminhamento para outras instituições.

De maneira geral, com as reuniões da Comissão de Acervo foi possível observar que alguns objetos que constam na lista não foram aceitos, a partir da documentação existente, que constam o parecer de cada objeto avaliado, bem como a assinatura dos membros da Comissão presentes na reunião.

A partir dessa análise, em relação aos objetos constantes na lista de 2005, que podem ser observados no Quadro 32 - ANEXO B, foi possível localizar cento e oitenta e três objetos, sendo a maioria da coleção de numismática. Dessa relação consideramos um alto número de objetos catalogados, pois foram localizados setenta e sete números de entrada de objetos, totalizando cento e cinquenta e cinco objetos documentados, sendo estes: cédulas ( $n^{\circ} 03$ ), terço em prata e madrepérola cédula ( $n^{\circ} 04$ ), balança cédula ( $n^{\circ} 06$ ), garrafa com carro de boi cédula ( $n^{\circ} 07$ ), moedas ( $n^{\circ} 09$ ), medalha comemorativa Visita do Papa João Paulo II cédula ( $n^{\circ}$ 10),

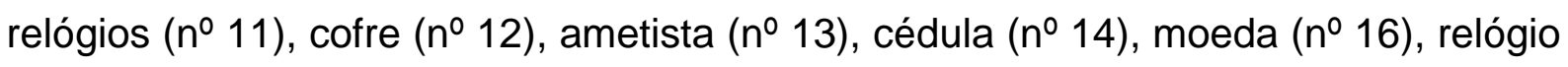
de bolso ( $n^{\circ} 20$ ), paramentos litúrgicos ( $\left.n^{-} 24\right)$, garrucha ( $n^{\circ}$ 26), cédulas ( $n^{\circ} 29$ ), escultura Nossa Senhora Aparecida e medalha com corrente ( $n^{\circ}$ 32), relógio de pulso ( $n^{\circ} 33$ ), relógios de pulso ( $n$ 운), relógio de bolso ( $\left.n^{\circ} 36\right)$, máquina de costura e óculos ( $n^{\circ}$ 39), relógios de pulso ( $n^{\circ}$ 40), tacho e caçambas ( $n^{\circ} 41$ ), relógio de parede ( $n^{\circ} 43$ ), amianto ( $\left.n^{\circ} 44\right)$, relógio de bolso com corrente ( $\left.n^{\circ} 45\right)$, cristal e

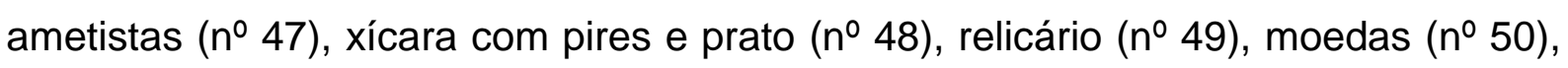
cédula e moedas ( $n^{\circ} 57$ ), taça ( $n^{\circ} 58$ ), moeda ( $n^{\circ}$ 60), xícaras com pires ( $n^{\circ} 62$ ), terço ( $n^{\circ} 63$ ), cédulas ( $n^{\circ}$ 64), cédula ( $n^{\circ} 68$ ), nível de marceneiro ( $\left.n^{\circ} 71\right)$, talheres de prata ( $n^{\circ}$ 73), medalhas ( $n^{\circ}$ 76) e relógio de bolso ( $n^{\circ}$ 77). Tendo recebido, respectivamente, os seguintes números de inventário: 7.792, 7.793, 7.794, 7.795, 7.802, 7.813, 7.826, 7.828, 7.866, 7.872, 7.873, 7.874, 7.875, 7.876, 7.878, 7.978, $7.988,7.991,7.895,7.903,7.905,7.906,7.907,7.908,7.909,7.916,7.917,7.935$, 7936, 7.967, 7.972, 7.973, 7.974, 7.975, 7.977, 7.978, 7.982, 7.988, 7.991, 7.992,

48 As reuniões da Comissão foram interrompidas no período de 2007 a 2014. Os objetos recebidos nesse período ficaram armazenados em armários de triagem e na Sala de Quarentena, aguardando avaliação. Com a nova gestão do Santuário Nacional, assim como a nova gestão do Museu, as reuniões da Comissão de Acervo voltaram a ocorrer semestralmente a partir de 2015. 
7.994, 8.032, 8.033, 8.034, 8.035, 8.036, 8.037, 8.038, 8.042, 8.043, 8.050, 8.051, 8.052, 8.082, 8.083, 8.092, 8.094, 8.095, 8.096, 8.097, 8.098, 8.099, 8.100, 8.101, $8.102,8.103,8.104,8.105,8.106,8.107,8.117,1.816,1.819,1.818,8.917,8.943$, $1.821,11.427,11.428$ (relógios), 1.878, 11.678, 2.562, 2.563, 2.553, 1.890, 1.921 até $1.937,11.677,7.894,7.896,7.897,7.899,2.197,2.198,2.121,2.118,2.119$, $2.120,2.176,2.199,2.116,2.117,2.112$ até $2.115,2.175,2.202,2.343,2.339$, 2.340, 2.342, 2.341, 8.702, 8.710, 8.702, 2.559 até 2.561, 2.348, 1.0217, 2.346, 2.347, 2.565 até $2.571,2.564,2.546,2.551,2.552,2.554$ até 2.558 e 2.537 .

Em 2006, fase de transição de gestão do Museu e com uma nova exposição de longa duração no $1^{\circ}$ andar da Torre, inaugurada em novembro de 2005, observamos grande número de entrada de objetos, com recorrência na doação de cédulas, moedas e relógios.

Por meio da lista de objetos de 2006, que podem ser analisados no Quadro 33 - ANEXO B, observamos que oitenta e um números de entrada de objetos que foram registrados no ano de 2006, sessenta e sete objetos foram identificados pela documentação do acervo, sendo estes: estojo com caneta, sinete e porta-lápis ( $n^{\circ}$ 02), quadra (selos) - comemorativo aos 75 anos da Coroação da imagem de NSA (no 13), envelope do $1^{\circ}$ dia de circular - comemorativo aos 75 anos da Coroação da imagem de NSA (ํㅜ 14), medalha comemorativa da coroação 1904 ( $n^{\circ}$ 15), lampião ( $n^{\circ}$ 16), véus umerais, dalmáticas e véu de cálice ( $n^{\circ}$ 20), figuras de presépio ( $n^{\circ}$ 21), pedra - xisto ( $n^{\circ}$ 24), medalha ( $n^{\circ}$ 26), conjunto de café ( $n^{\circ}$ 28), relógios despertadores e seringa com estojo ( $n^{\circ} 30$ ), cédulas ( $n^{\circ} 35$ ), cédula ( $n^{\circ} 38$ ), quadro da Revolução de 1932 (no 39), escultura de N. S. Aparecida de bronze (no 41),

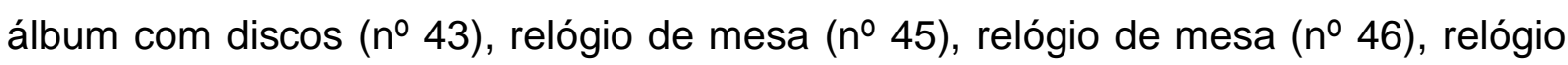
de algibeira ( $n^{\circ} 52$ ), relógio de pulso ( $n^{\circ}-53$ ), moeda ( $n^{\circ} 58$ ), cédula ( $n^{\circ}$ 61), cédula ( $n^{\circ}$ 62), medalha comemorativa do encontro da Imagem NSA - 250 anos - ( $n^{\circ}$ 66), moedas ( $n^{\circ}$ 68), faca de seringueiro ( $n^{\circ}$ 71), casula e estola - Papa João Paulo II ( $n^{-}$72), relógio de bolso ( $n^{\circ}$ 73), relógio de pulso feminino (nํ77) e cédulas ( $n^{\circ}$ 78). Tendo recebido, respectivamente, os seguintes números de inventário: 2.550, 3.164, $3.130,11.679,3.238,2.401$ até $2.404,11.425,2.547,2.538,2.545,3.009,3.010$, $3.002,6.780,6.792,6.804,6.947,6.961,6.987,6.995,7.180,7.229,7.398,7.438$, $7.454,7.467,7.488,7.511,7.524,7.539,7.583,7.592,7.622,7.650,7.672,7.684$, $7.702,7.716,7.733,7.987,2.539,2.543,11.681,2.548,2.549,11.429,11.439$, 
9.466, 7.900, 7.833, 11.680, 8.609, 8.610, 8.623, 8.651, 9.143, 9.275, 10.070, 2.544, 2.542, 11.430, 11.447, 7.904 e 8.071.

Notamos também que a doação de joias se torna bastante evidente a partir de uma mudança na expografia que passou a exibir a Domus Aurea, um espaço de contemplação do sagrado, com inúmeras joias doadas pelos devotos de Nossa Senhora, que propõe a interpretação de Maria como Casa de Ouro.

Para Giselle Peixe e Silvia Bigareli (2016, p. 24),

Este ambiente expositivo assimila principalmente as invocações a Nossa Senhora recitadas nas Ladainhas Lauretanas, que trazem as imagens de Casa de Ouro, jardim fechado, rosa mística, espelho de justiça, vaso espiritual, porta do céu; evoca o azul do manto de Nossa Senhora, que a tudo envolve e guarnece, como escudo celeste, e incorpora o ouro na sua simbologia do divino, do sublime, do eterno.

Com base no estudo das listas de entrada de objetos e observação das fichas catalográficas, consideramos que apenas alguns itens constantes nessas listas anuais foram incorporados ao acervo do Museu entre os anos de 2003 a 2006.

Atualmente, as reuniões da Comissão de Acervo seguem uma linha temática, ligada a devoção a Nossa Senhora Aparecida. Com isso, o Museu passa a adotar novos critérios para aquisição dos objetos, modificando o hábito das gestões anteriores em inserir as doações nas vitrines da exposição, por não haver uma Comissão que avaliasse a incorporação do acervo ao Museu.

De maneira geral, a Comissão de Acervo também se tornou responsável por avaliar objetos procedentes da Sala das Promessas, para incorporação ao acervo do Museu.

Segundo as consultoras Giselle Peixe e Silvia Bigareli (2004, p. 10), responsáveis por instituir a Comissão de Acervo, "o Museu tem ainda papel fundamental na preservação das manifestações de fé concretizadas no pagamento de promessas, fenômeno que se dá na Sala dos Milagres e em outros pontos do Santuário".

Desta forma, atribui-se ao Museu a tarefa de seleção, conservação e apresentação de parte desses testemunhos, pois é necessário considerar o caráter documental desses objetos, tornando-os merecedores de estudos e apresentação museológica. 


\subsection{Período de 2006 a 2018}

A partir de 2006, dando sequência ao processo de revitalização institucional e adequação do espaço de visitação e armazenamento do acervo, o Museu Nossa Senhora Aparecida passou a ser administrado por diversos profissionais ligados ao Turismo, Marketing, História e Gestão.

As transições entre as administrações do Museu ocorreram, principalmente, entre os anos de 2011 e 2014, até adequar-se ao formato atual, com uma gestão compartilhada entre a Área de Atendimento e Área Técnica do Museu.

Esta fase mais recente do Museu Nossa Senhora Aparecida é marcada por uma intensa capacitação da equipe de trabalho, tanto no sentido de qualificar o processo de tratamento e documentação do acervo, quanto no atendimento ao público, ao buscar oferecer novas propostas de comunicação.

Nos itens a seguir serão abordadas as diferentes administrações do Museu, consideradas como período de transição, até chegar à atual gestão. Também serão abordados os processos de reestruturação da Reserva Técnica e tratamento do acervo, a partir da capacitação da equipe, complementada por visitas técnicas em outras instituições museológicas, que colaboraram com a modernização do Museu.

Por fim, será abordado o sistema de classificação e documentação do acervo, que foi instituído durante o processo de revitalização institucional, a partir de estudo do Thesaurus e adaptação de acordo com as características dos acervos e coleções do Museu Nossa Senhora Aparecida. E serão apresentados estudos sobre os novos acervos, que foram identificados por meio de registros e fichas catalográficas, considerando o processo de organização e triagem das doações ou incorporações ao acervo por meio de transferências internas pela Sala das Promessas. É preciso levar em consideração que, inicialmente, não havia uma política de aquisição de acervos bem definida, mas a atuação da Comissão de Acervo do Museu corroborou para definição de critérios para aceitação ou não aceitação das novas doações, para incorporação ao acervo do Museu.

\subsubsection{Gestão compartilhada e qualificação técnica}

Com o término da gestão do Professor Guido Machado Braga em 2006, Michel Henrique de Oliveira, formado em Turismo pelo Centro Universitário Salesiano de São Paulo - UNISAL, torna-se supervisor do Museu Nossa Senhora Aparecida. 
Michel Henrique de Oliveira iniciou suas atividades no Museu como estagiário contratado pela Fundação Patrimônio Histórico da Energia de São Paulo (FPHESP), passando pelas funções de Recepcionista, Auxiliar Administrativo, Supervisor, Gerente e Coordenador da Área Técnica, entre os anos de 2002 a 2014. Posteriormente, formou-se Técnico em Conservação e Restauração pelo Centro Técnico Templo da Arte, e realizou diversos cursos na área de museologia e conservação preventiva, tais como: conservação de papéis, fotografias, têxtil, numismática, madeira, metais, acondicionamento de acervo, entre outros.

Durante a sua gestão, a empresa Jequitibá Cultural, tendo por sóciasproprietárias as consultoras Giselle Peixe e Silvia Bigareli foi responsável por diversos projetos em parceria com o Museu, tais como: capacitação da equipe técnica e contratação de estagiários para realização de inventário e documentação (2007-2009), implantação de reserva técnica climatizada (2008), revitalização do Mirante da Torre (2008), ampliação da Domus Aurea (2011) e expografia para o $2^{\circ}$ andar da Torre (2012).

Nesse período, o acervo que estava exposto na antiga exposição do $2^{\circ}$ andar da Torre havia sido movimentado para a Reserva Técnica no $5^{\circ}$ andar da Torre. Portanto, houve a necessidade de formar uma nova equipe de trabalho para dar continuidade ao tratamento das coleções.

A partir desse ponto de análise, as consultoras Giselle Peixe e Silvia Bigareli iniciam uma nova etapa para capacitação da equipe do Museu, com a contratação de estagiários para realização de inventário e documentação do acervo, entre os anos de 2007 a 2009.

O programa de treinamentos dos novos estagiários e demais colaboradores do Museu seguiu conforme o cronograma definido pelas consultoras, abordando os seguintes assuntos: conservação do acervo; atendimento ao público; identificação e documentação das coleções; acondicionamento do acervo e demais orientações sobre instituições de memória em espaços religiosos e acervos de arte sacra.

A seguir, serão listadas as oficinas e palestras realizadas no Museu Nossa Senhora Aparecida em parceria com a empresa Jequitibá Cultural:

- Oficina sobre conservação de acervos, realizada por Gedley Belchior Braga, entre os dias 12 e 14 de novembro de 2007;

- Oficina sobre museus e públicos especiais, realizada por Nelson Batista, nos dias 26 e 27 de novembro de 2007 ; 
- Oficina para identificação e documentação da coleção de numismática, realizada por Ângela Maria Gianeze Ribeiro, nos dias 06 e 07 de dezembro de 2007;

- Oficina para identificação e documentação da coleção de armaria e munições, realizada pelo oficial Magno Sérgio Dias, do Museu de Polícia Militar de São Paulo, entre os dias 29 e 30 de janeiro de 2008, tendo retornado, posteriormente, no dia 04 de agosto de 2008, para realizar intervenções nos acervos para remoção de componente explosivo, garantindo, assim, mais segurança e conservação das peças;

- Oficina para identificação e documentação da coleção de arqueologia, realizada por Margarida Davina Andreatta, nos dias 13 e 14 de março de 2008;

- Palestra sobre produção artística e cultural, realizada por Silvia Bigareli, no dia 14 de abril de 2008;

- Palestra sobre liturgia e acervos de Arte Sacra, realizada por Giselle Peixe, no dia 19 de maio de 2008;

- Palestra sobre leitura de imagem, realizada por Silvia Bigareli, no dia 29 de outubro de 2008;

- Palestra sobre instituições de memória em espaços religiosos, realizada por Giselle Peixe no dia 06 de novembro de 2008;

- Palestra sobre ação educativa, realizada por Silvia Bigareli, no dia 17 de novembro de 2008; e, por fim,

- Palestra sobre turismo religioso, realizada pelo Prof. Dr. Júlio Moreno, no dia 16 de fevereiro de 2009.

Durante o período de capacitação, a equipe do Museu Nossa Senhora Aparecida e os estagiários da empresa Jequitibá Cultural, participaram de palestras e oficinas oferecidas pelo Sistema Estadual de Museus de São Paulo (SISEM-SP), tais como: palestra sobre ação educativa, realizada pela Profa. Marília Xavier Cury, no município de Guaratinguetá (SP), no dia 24 de outubro de 2008; palestra sobre museus e turismo, realizada no município de Guaratinguetá (SP), no dia 20 de maio de 2009; oficina sobre acondicionamento de acervo, realizada na cidade de Pindamonhangaba (SP), no dia 10 de novembro de 2009, entre outros treinamentos que foram realizados posteriormente.

A Figura 87 refere-se à oficina realizada por Ângela Maria Gianeze Ribeiro, da seção de numismática do Museu Paulista da USP, nos dias 06 e 07 de dezembro de 2007, para identificação e documentação da coleção de numismática. 
Figura 87: Oficina sobre a coleção de numismática.

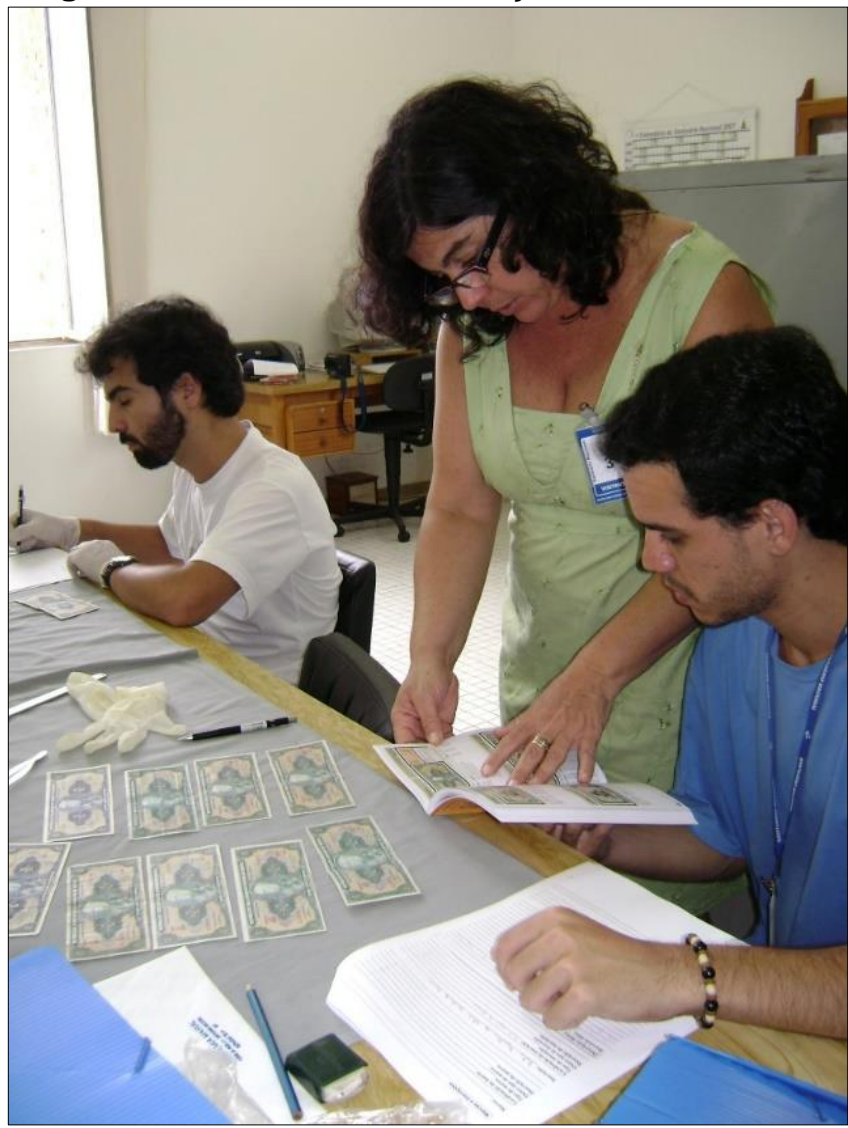

Fonte: MNSA/ Santuário Nacional.

Figura 88: Visita técnica ao Museu Paulista da USP.

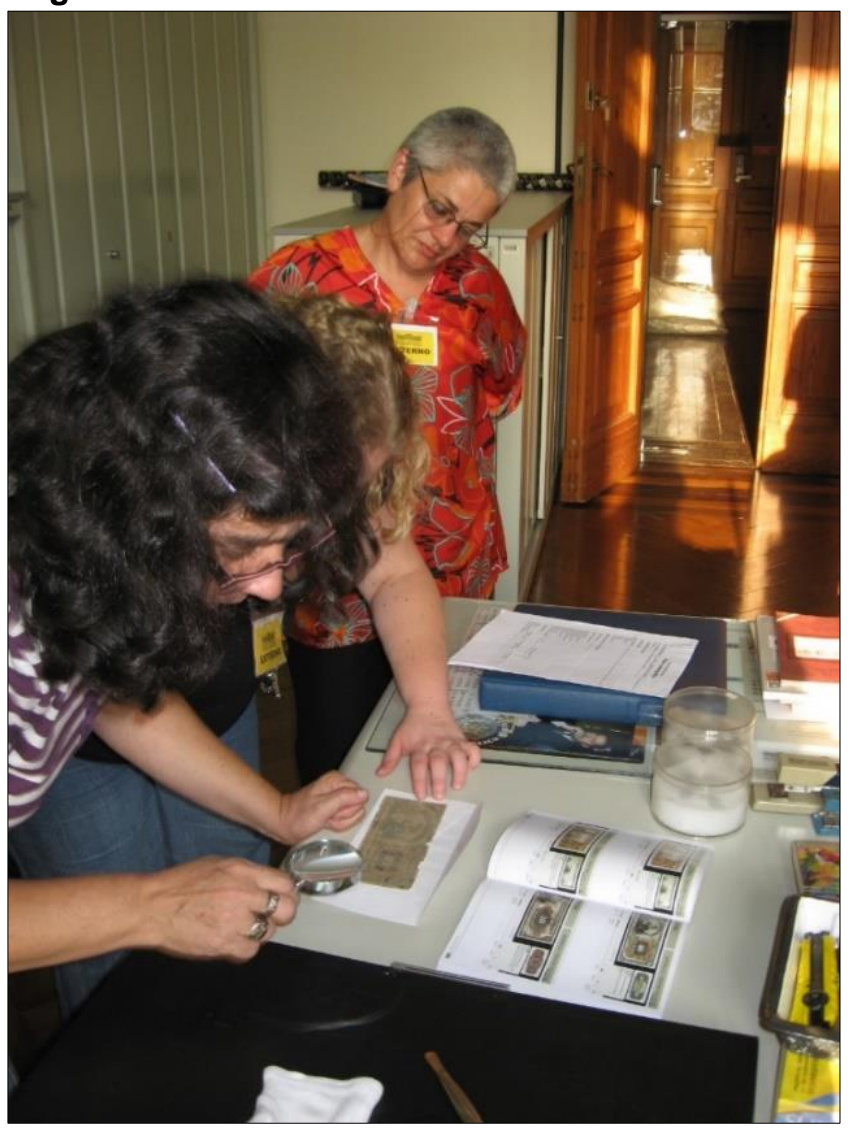

Fonte: MNSA/ Santuário Nacional. 
A Figura 88 refere-se à visita técnica realizada na seção de numismática do Museu Paulista da USP, realizada em outubro de 2008, para pesquisa de obras raras e análise do processo de acondicionamento do acervo em reserva técnica, com o intuito de orientar a equipe do Museu Nossa Senhora Aparecida sobre o processo de documentação e armazenamento das coleções de cédulas e moedas nacionais e internacionais.

A oficina de numismática proporcionou que a equipe do Museu Nossa Senhora Aparecida pudesse classificar as coleções conforme nacionalidade do acervo, assim como as especificações das tipologias do acervo nacional, de acordo com pesquisas bibliográficas nos catálogos Cédulas do Brasil - 1833 a 2007 e Livro das moedas do Brasil - 1643 a 2004, ambos de autoria de Cláudio Amato, Irlei Neves e Júlio Schütz. ${ }^{49}$

De acordo com o Relatório Geral de Numismática $(2009)^{50}$, a princípio foi realizada uma triagem do acervo, organizando-o por valor monetário, estado de conservação e, posteriormente, a quantificação dos itens por tipologias. A partir desse tratamento inicial, foram quantificadas 25.956 moedas, sendo 23.312 nacionais e 2.644 internacionais. Em relação às cédulas, foram quantificadas 7.344, sendo 6.998 nacionais e 346 internacionais.

De maneira geral, durante a oficina a equipe do Museu foi capacitada a identificar, catalogar, higienizar e acondicionar o acervo de numismática, contando com o apoio de uma equipe de estagiários contratados pela empresa Jequitibá Cultural.

Após a visita técnica no setor de numismática do Museu Paulista da USP, iniciou-se o processo de documentação do acervo, considerando um exemplar de cada tipologia como ficha catalográfica matriz. Segundo o Relatório Geral de Numismática (2009), "para a seleção das moedas, o critério estabelecido pelas consultoras, gestor e equipe técnica, foi um recorte de $10 \%$ da quantificação geral de cada tipologia, por ano e estado de conservação". Entretanto, no decorrer do processo de documentação, observamos que o critério foi modificado para os casos

\footnotetext{
49 AMATO, C.; NEVES, I. S.; SCHÜTZ, J. E. Cédulas do Brasil - 1833 a 2007. 4르 ed. São Paulo: Desktop Soluções Gráficas, 2007.

${ }^{49}$ AMATO, C.; NEVES, I. S.; SCHÜTZ, J. E. Livro das moedas do Brasil - 1643 a 2004. 11aㅡ ed. São Paulo: Stampato, 2004.

50 COELHO, E.; RODRIGUIES, G. T.; OliVEIRA, M. Relatório Geral de Numismática. 2009, (documento eletrônico). Fonte: Museu Nossa Senhora Aparecida.
} 
com mais de cem exemplares da mesma tipologia, sendo documentados apenas dez exemplares, considerando a similaridade no acervo.

As moedas documentadas foram acondicionadas em envelopes de papel específicos, normalmente utilizados por colecionadores. Os envelopes foram identificados com número de inventário, nacionalidade, valor monetário, material, data e tipologia, para auxiliar na identificação após o armazenamento na Reserva Técnica.

Em relação ao acervo de cédulas nacionais, a documentação foi iniciada em novembro de 2009, após a triagem realizada para organização por tipologias. Nesse contexto, foram quantificadas 7.280 cédulas nacionais, tendo sido documentadas 1.187 exemplares.

Segundo o Relatório Catalogação Cédulas Nacionais (2010) ${ }^{51}$, "para a seleção das cédulas, o critério estabelecido pela equipe técnica e o coordenador Michel, foi um recorte de 20 unidades de cada tipologia em melhor estado de conservação". Entretanto, observamos que durante a documentação o critério não se aplicou a todas as tipologias, pois algumas não havia vinte exemplares, tendo sido selecionadas apenas 10 itens para documentação, ou um número menor, de acordo com a quantidade de acervo de cada tipologia.

Em relação ao armazenamento das cédulas, foram utilizados envelopes de acetato, com papel neutro no interior, para proteção da cédula e identificação do número de inventário.

Os mesmos critérios foram aplicados ao acervo de cédulas e moedas internacionais, porém foram classificadas apenas por nacionalidade e valor monetário, considerando que não havia bibliografia suficiente para orientar a classificação conforme as tipologias monetárias de cada país.

De maneira geral, com o processo de documentação concluído, a maior parte do acervo classificada como excedente foi encaminhada para a sede do Banco Central do Brasil, em São Paulo, após organização por grupos e tipologias. ${ }^{52}$

A Figura 89 refere-se à oficina para identificação e documentação da coleção de arqueologia, realizada por Margarida Davina Andreatta, da seção de arqueologia do Museu Paulista da USP, nos dias 13 e 14 de março de 2008.

51 COELHO, E.; RODRIGUIES, G. T. Relatório Catalogação Cédulas Nacionais, 2010, (documento eletrônico). Fonte: Museu Nossa Senhora Aparecida.

${ }^{52}$ Conforme os relatórios de cédulas e moedas excedentes, realizados pela equipe técnica do Museu Nossa Senhora Aparecida. 
Nessa oficina, o acervo foi agrupado por artefatos cerâmicos e líticos, para melhor classificação dos objetos. Entre a coleção de líticos foram identificados: pontas de flechas, lâminas de machado, mão de pilão e seixos.

Em relação aos artefatos cerâmicos, em sua maioria, foram identificados fragmentos com pintura ornamental e textura na parte externa, além de urnas funerárias e vasilhas, sendo que são poucas as peças que foram preservadas na sua integridade, preservando, inclusive, porções de terra no interior.

Figura 89: Oficina sobre a coleção de arqueologia.

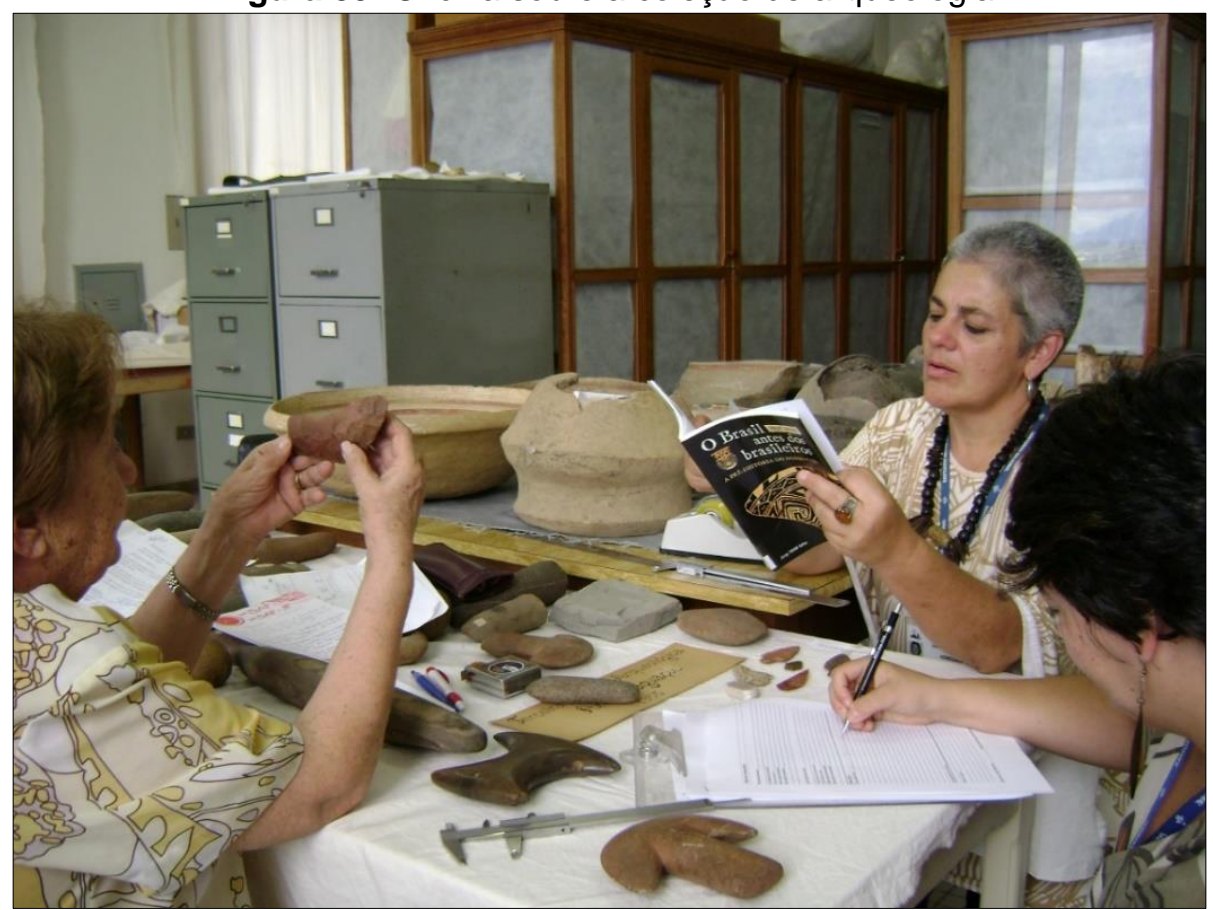

Fonte: MNSA/ Santuário Nacional.

A Figura 90 refere-se à oficina para identificação e documentação da coleção de armaria e munições, realizada pelo oficial Magno Sérgio Dias, do Museu de Polícia Militar do Estado de São Paulo, entre os dias 29 e 30 de janeiro de 2008. 
Figura 90: Oficina sobre a coleção de armaria.

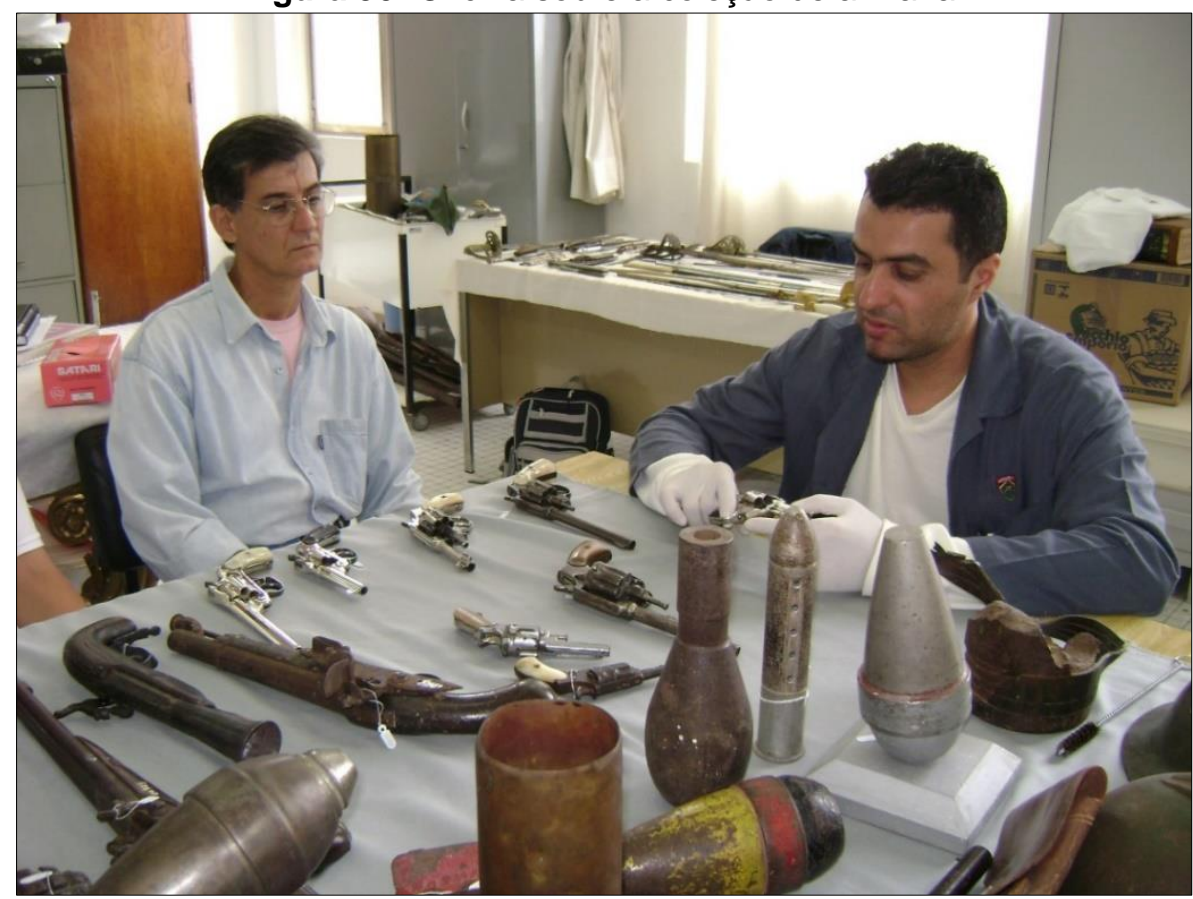

Fonte: MNSA/ Santuário Nacional.

Nessa oficina o acervo foi organizado entre armas brancas e armas de fogo, para classificação por tipologias, tais como: espadas, sabres, punhais, revólveres, garruchas, espingardas, granadas, morteiros, entre outros. Após o processo de identificação, foram demonstrados procedimentos de higienização com o uso de produtos específicos (exemplo: óleo Molykote) utilizados pelo Museu de Polícia Militar do Estado de São Paulo.

Posteriormente, no dia 04 de agosto de 2008, o oficial Magno Sérgio Dias retornou ao Museu Nossa Senhora Aparecida para revisar as fichas catalográficas, bem como realizar a higienização do acervo, além de processos interventivos nos objetos com componente explosivo, para remoção desses elementos, garantindo assim mais segurança e conservação das peças, tornando-as inutilizáveis como armas de fogo.

Ainda em 2008, foi realizada uma visita técnica ao Museu de Polícia Militar do Estado de São Paulo (Figura 91), com o intuito de conhecer o processo de armazenamento do acervo, bem como o desenvolvimento de suportes personalizados para cada objeto. 
Figura 91: Visita técnica ao Museu de Polícia Militar do Estado de São Paulo.

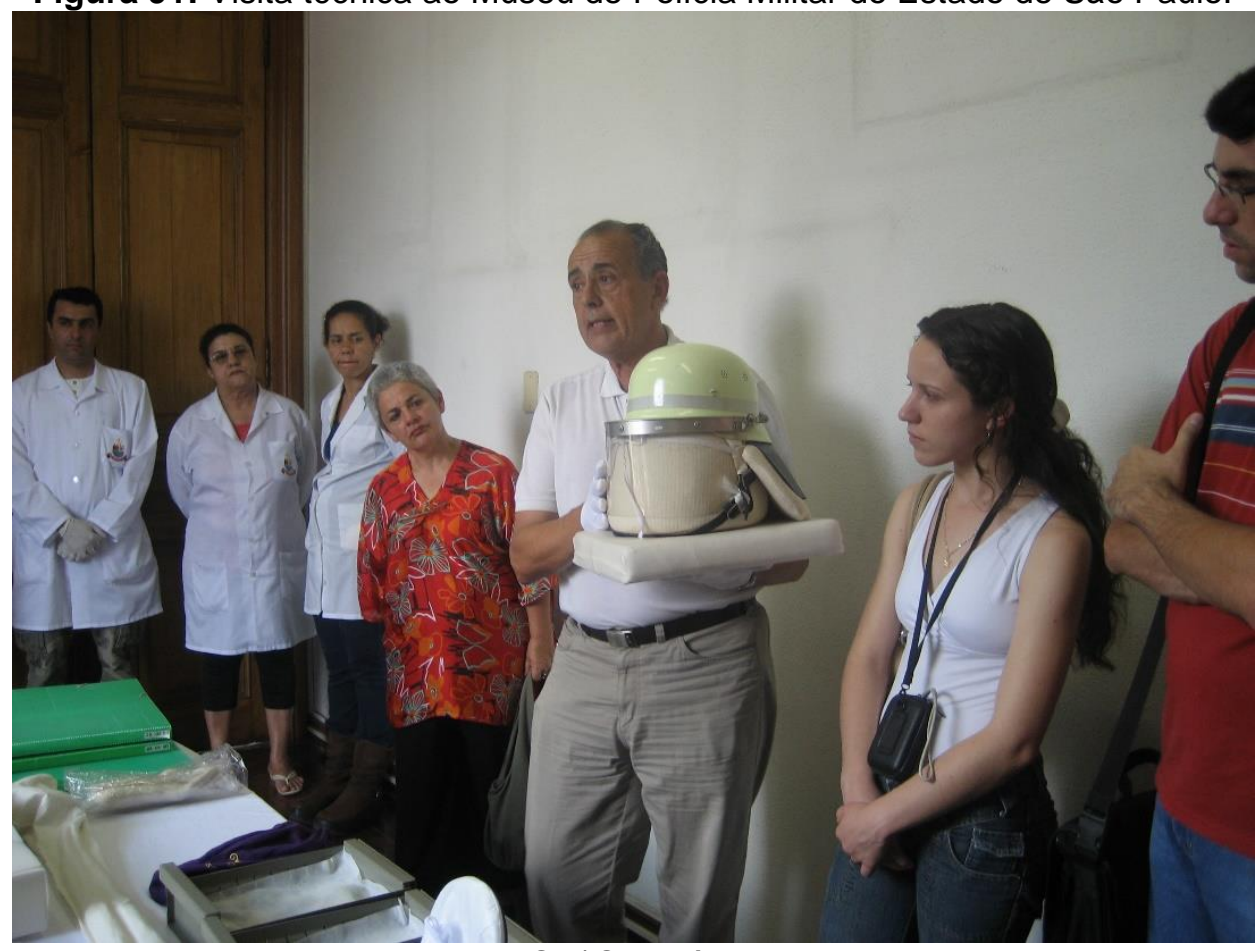

Fonte: MNSA/ Santuário Nacional.

De maneira geral, com a qualificação da equipe técnica do Museu, houve a necessidade de qualificar também o espaço de trabalho e armazenamento de acervo. Para isso, Giselle Peixe e Silvia Bigareli apresentaram um novo projeto para implantação de uma área técnica com reserva técnica climatizada, que foi aprovado pela Administração do Santuário em 2008.

A nova Área Técnica localizada no $3^{\circ}$ andar (Figura 92) foi planejada seguindo padrões para o tratamento do acervo, com controle de climatização, apresentando a seguinte divisão do espaço para o desempenho das atividades: Sala de Triagem do acervo; Sala de Higienização; Sala de Quarentena; Sala de Documentação; e Reserva Técnica.

Posteriormente, com aumento de equipe, também foram instaladas a Sala de Curadoria e o Laboratório de Restauro, no local onde inicialmente era a sala administrativa da Área Técnica do Museu. 
Figura 92: Área Técnica - 3o andar da Torre.

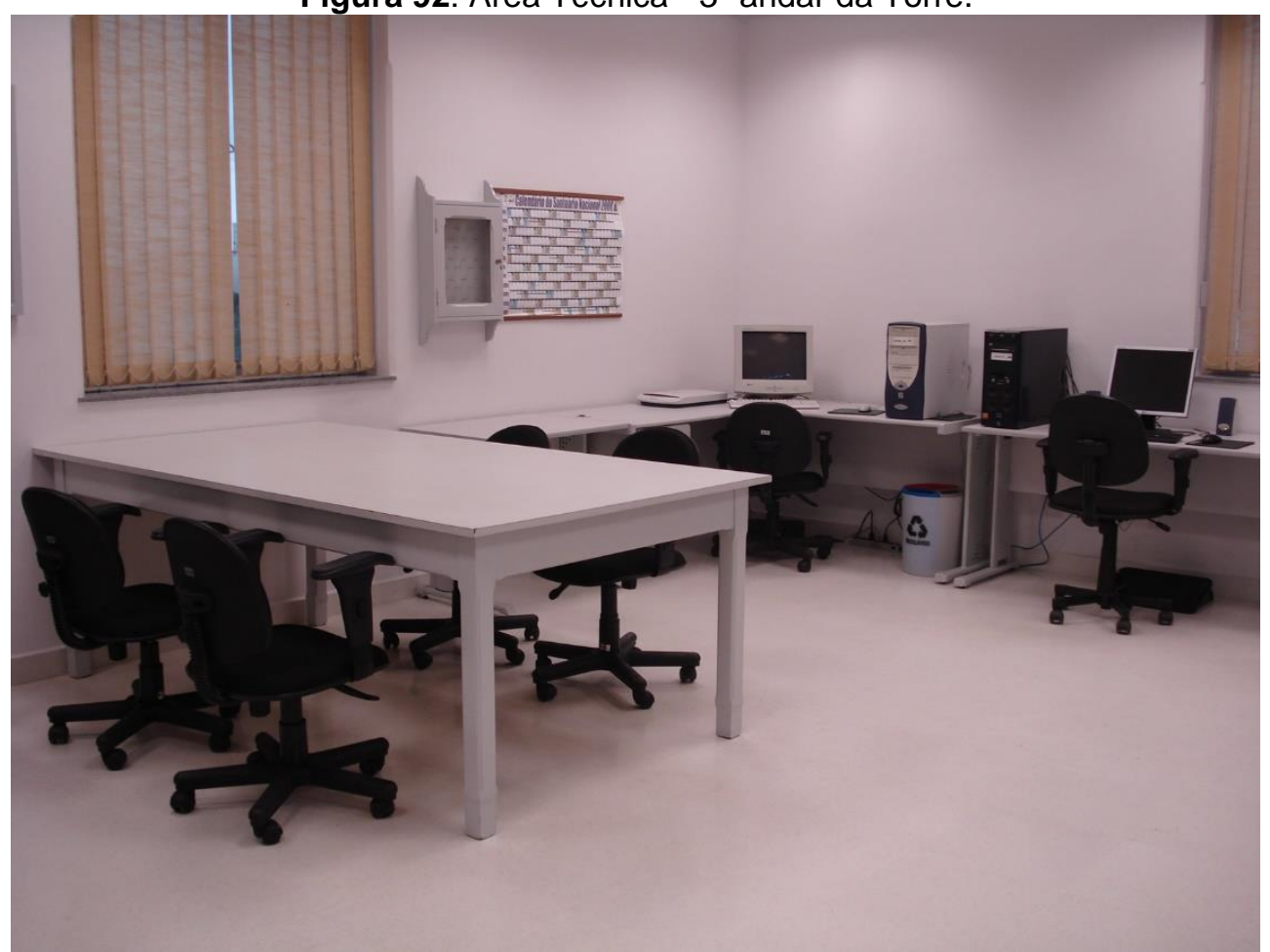

Fonte: MNSA/ Santuário Nacional. Foto: Erica Coelho.

Conforme podemos observar na planta da Área Técnica do Museu (Figura 93), há uma ampla sala destinada para a Reserva Técnica, que foi acrescida de mobiliários específicos para as tipologias de acervos.

Nesse contexto, a partir do mês de agosto de 2008, iniciaram-se, portanto, as transferências de materiais de trabalho e documentos administrativos. E, em setembro, os acervos e coleções começaram a ser movimentados aos poucos, após estudo do espaço para agrupamento das coleções.

O critério para organização foi baseado nas tipologias e materiais, para garantir a conservação dos objetos. E o processo de movimentação do acervo finalizado em outubro de 2008, contendo o mapeamento por mobiliário e listagens com a localização de cada peça. 
Figura 93: Planta - Área Técnica do Museu.

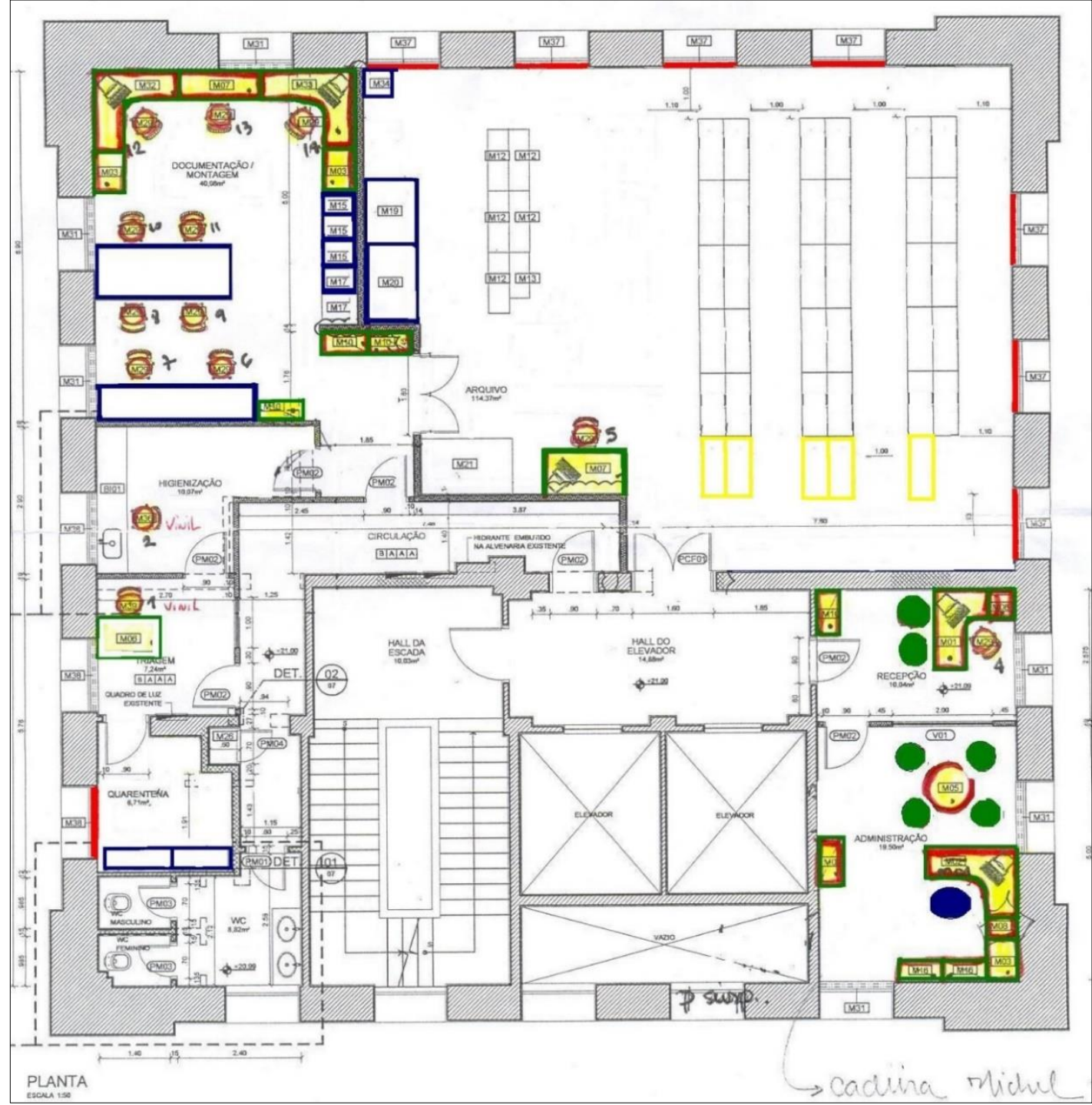

Fonte: MNSA/ Santuário Nacional.

Durante os processos de movimentação do acervo para acondicionamento na Reserva Técnica climatizada, conforme observado na Figura 94, foram realizados estudos de mobiliário de acordo com as tipologias dos objetos. Desta forma, foi possível identificar as coleções para se estudar o espaço necessário para o armazenamento, já prevendo espaço para o crescimento das coleções a partir das novas aquisições.

Nesse processo foram organizadas as coleções de prataria (doméstica e litúrgica), objetos de uso doméstico, objetos religiosos, paramentos, alfaias litúrgicas, imaginária (diversos materiais), objetos de tropeiros, armaria e munições, objetos relacionados à Revolução Constitucionalista de 1932 e Segunda Guerra Mundial, arte popular, artesanatos diversos, ex-votos, coleções de mineralogia e petrologia, louças e porcelanas, objetos arqueológicos (cerâmica e líticos), objetos procedentes 
da Basílica Velha, objetos procedentes da Sala das Promessas, além de demais doações ao Santuário Nacional de Aparecida, que foram incorporados ao acervo do Museu.

Figura 94: Reserva Técnica - 3o andar.

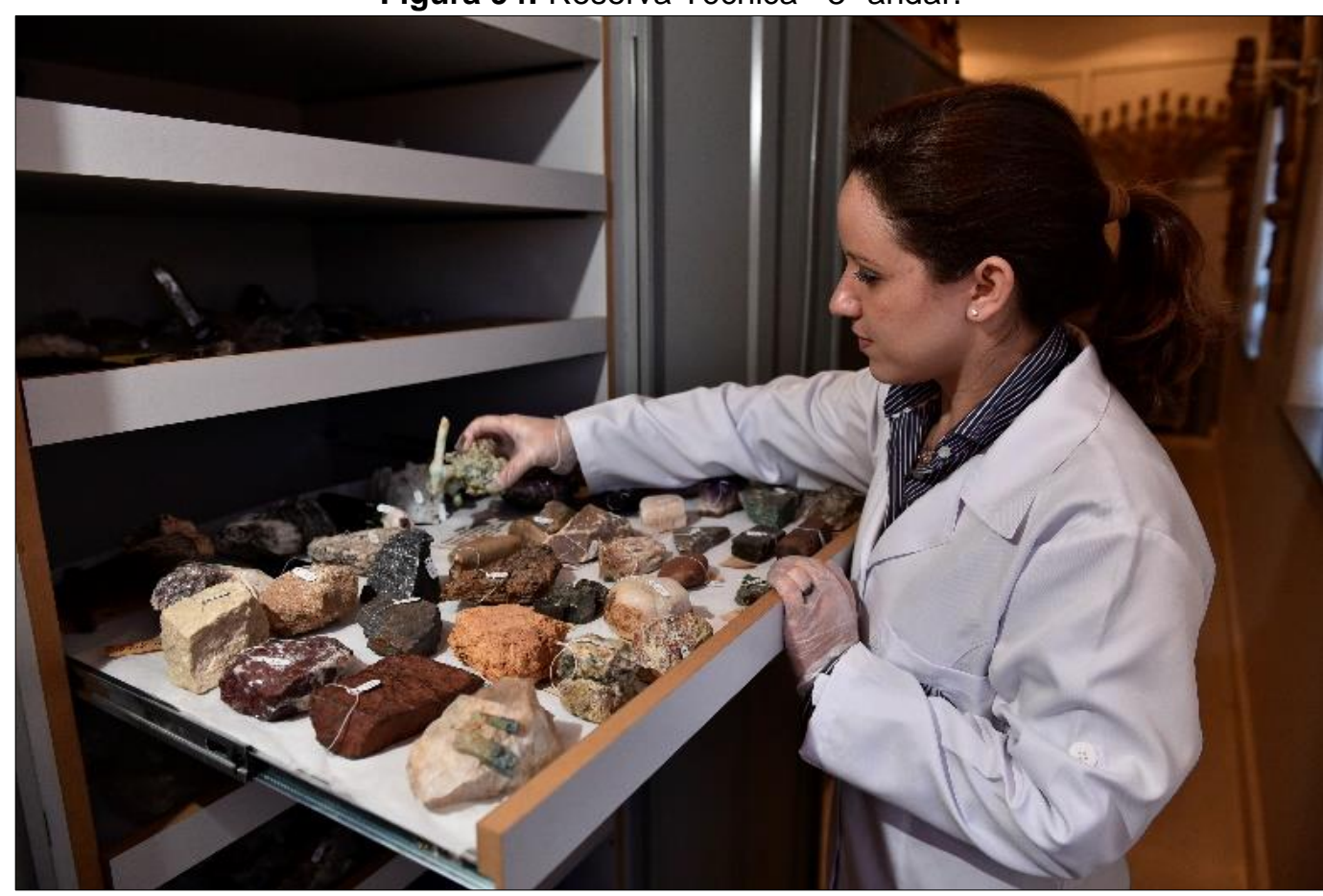

Fonte: MNSA/ Santuário Nacional - Foto: Thiago Leon.

Considerando as obras de revestimento interno do Santuário, criou-se uma nova coleção denominada Acervo Santuário Nacional (ASN), no qual foram agrupados estudos e protótipos desenvolvidos para o Nicho de Nossa Senhora, para a Porta Santa, entre outras obras de autoria do artista sacro Cláudio Pastro.

$\mathrm{Na}$ coleção ASN, também estão incluídos os objetos litúrgicos de uso nas celebrações eucarísticas do Santuário que necessitam de restauro e, para tanto, a Área Técnica do Museu se responsabiliza pelos processos de documentação, laudos técnicos e encaminhamento para restauro e posterior retorno à Igreja, para que voltem ao uso, não sendo considerados como objetos museológicos, embora passem pelo mesmo processo de documentação.

De acordo com Hugues de Varine (2012, p. 63-64),

[...] o inventário, qualquer que seja o método utilizado para realizá-lo, provoca frequentemente uma dinâmica de valorização dos elementos do patrimônio, em especial dos objetos, que serão oferecidos à municipalidade, a uma instituição cultural ou a uma associação, quer a título gratuito, quer, mais raramente, mediante uma contrapartida financeira. Se um museu existe localmente ou nas redondezas, seremos tentados a aceitar e a depositar esses objetos em suas coleções, mesmo que seja apenas para colocá-los em reserva segura. 
Para armazenamento do acervo foram adquiridos mobiliários específicos de aço (estantes, armários, arquivos, mapotecas, trainéis fixos e móveis), que receberam numeração de 1 a 55 . Em relação aos objetos de grande porte, que estavam no antigo depósito no $11^{\circ}$ andar, não foram movimentados para a nova Reserva Técnica no $3^{\circ}$ andar, por falta de espaço físico para armazenamento.

Entretanto, em 2015, com a nova administração do Santuário, bem como a nova administração da Academia Marial de Aparecida, instalada no $11^{\circ}$ andar, o espaço utilizado como depósito pelo Museu precisou ser desocupado para iniciar obras de infraestrutura para a biblioteca e reserva técnica da Academia Marial de Aparecida, que possui um grande acervo e estudos sobre Mariologia, além de uma reserva técnica com esculturas e pinturas relacionadas a devoção a Nossa Senhora.

Com isso, o acervo do Museu que estava até então no $11^{\circ}$ andar, foi transferido para $08^{\circ}$ andar e posteriormente para $012^{\circ}$ andar, em uma sala para armazenamento provisório, conforme necessidade da instituição para realização de obras na Torre, permanecendo nesta sala provisória no $12^{\circ}$ andar até 0 planejamento de um novo espaço para ampliação da Reserva Técnica do Museu Nossa Senhora Aparecida.

De maneira geral, após as obras de revitalização da Área Técnica do Museu, a empresa Jequitibá Cultural, em meados de 2008, desenvolveu um novo projeto para elaboração de recursos museográficos para exposição no Mirante da Torre Brasília, que foi doada pelo Presidente Juscelino Kubitschek de Oliveira, em 1960, medindo aproximadamente 110 metros de altura com a cruz.

O projeto expográfico foi solicitado para as consultoras, considerando que o Santuário Nacional de Aparecida já havia iniciado obras de adequação para oferecer acessibilidade aos visitantes, pois os elevadores não atingiam o Mirante, sendo necessário utilizar mais dois lances de escadas, conforme consta na publicação da Revista de Aparecida do mês julho de 2008.

As obras de acessibilidade ainda contam com a chegada do elevador até o último andar da Torre Brasília, onde fica o Mirante. Essa obra foi planejada para que todos que visitam a Casa da Mãe possam também conhecer o Mirante, que oferece uma visão privilegiada da cidade de Aparecida [...]. (REVISTA DE APARECIDA, 2008, p. 15).

Além de adequação do espaço com elevadores, durante a reforma também foi instalado um sistema de ar-condicionado, para oferecer maior conforto aos visitantes. 
Os trabalhos realizados por Giselle Peixe e Silvia Bigareli compreendiam 0 detalhamento técnico dos painéis, com uma composição de quatro painéis e estruturação de uma linha do tempo, relatando os principais acontecimentos. Entre os trabalhos estava inclusa a criação de desenhos em aquarela, que foram feitos pelo artista George Rembrandt Gutlich e reproduzidos nas quatro faces superiores do Mirante e nos cantos, para ilustrar os painéis com a linha do tempo. E, também, a criação de um vídeo com o intuito de aproximar os fatos e lugares, por meio de fotografias antigas e contemporâneas.

Com a elaboração dos recursos museográficos, uma linha do tempo foi desenvolvida com o intuito de narrar a história da cidade de Aparecida (SP), assim como um panorama do crescimento do maior Santuário Mariano do mundo, comungando o passado e o presente com os cenários interiores e as paisagens externas miradas pelas janelas.

O quadro 12 descreve os temas abordados na linha do tempo.

Quadro 12: Linha do tempo no Mirante da Torre

\section{Linha do tempo no Mirante da Torre}

\begin{tabular}{|c|l|}
\hline Século 11 & Evidências da ocupação indígena no Vale do Paraíba \\
\hline Século 16 & Primeiras expedições de exploração do Vale \\
\hline 1630 & Fundação de Guaratinguetá \\
\hline 1717 & Encontro da Imagem de Nossa Senhora Aparecida \\
\hline Século 18 & Período do ouro em Minas Gerais \\
\hline 1733 & Primeira capela no Porto do Itaguaçu \\
\hline 1745 & Edificação da capela no Morro dos Coqueiros \\
\hline 1825 & Elevação da capela a Santuário \\
\hline $1850-1870$ & Apogeu do ciclo cafeeiro no Vale \\
\hline 1877 & Estrada de Ferro do Norte \\
\hline 1884 & Doação da coroa de ouro a Nossa Senhora Aparecida pela Princesa Isabel \\
\hline 1888 & Inauguração da atual Matriz Basílica \\
\hline 1890 & Início da industrialização no Vale \\
\hline 1894 & Chegada dos Padres Redentoristas \\
\hline 1900 & Fundação do jornal "O Santuário" \\
\hline 1904 & Coroação da Imagem de Nossa Senhora Aparecida \\
\hline 1905 & Morro do Cruzeiro \\
\hline 1906 & Elevação de Aparecida à categoria de Vila \\
\hline 1908 & Elevação da igreja a Basílica Menor \\
\hline 1928 & Emancipação de Aparecida da cidade de Guaratinguetá \\
\hline 1930 & Declaração de Nossa Senhora Aparecida Padroeira do Brasil \\
\hline 1946 & Lançamento da pedra fundamental da Nova Basílica \\
\hline 1951 & Criação da Rádio Aparecida \\
\hline & \\
\hline
\end{tabular}


"conclusão"

\begin{tabular}{|c|l|}
\hline \multicolumn{2}{|c|}{ Linha do tempo no Mirante da Torre } \\
\hline 1951 & Inauguração da Rodovia Presidente Dutra \\
\hline 1955 & Início da construção da Basílica Nova \\
\hline 1958 & Instalação da Arquidiocese de Aparecida \\
\hline 1967 & Oferta da Rosa de Ouro para o Santuário \\
\hline 1972 & Inauguração da Passarela da Fé \\
\hline 1980 & Visita do Papa João Paulo II - Consagração da Basílica Nova \\
\hline 1984 & Basílica Nova - elevação a Santuário Nacional \\
\hline 1998 & Inauguração do Centro de Apoio aos Romeiros \\
\hline 2005 & Criação da TV Aparecida \\
\hline 2007 & Visita do Papa Bento XVI - \\
\hline 2007 & Realização da V Conferência do Episcopado Latino-Americano e do Caribe \\
\hline
\end{tabular}

Fonte: MNSA/Santuário Nacional.

Com o passar dos anos e com novos acontecimentos no Santuário Nacional de Aparecida, houve a necessidade de atualização da linha do tempo, com acréscimo de um novo painel na lateral dos elevadores, narrando os principais fatos ocorridos entre os anos de 2011 a 2017, conforme consta no Quadro 13.

Quadro 13: Linha do tempo no Mirante da Torre

\begin{tabular}{|c|l|}
\hline \multicolumn{2}{|c|}{ Linha do tempo no Mirante da Torre } \\
\hline 2011 & Inauguração do Centro de Eventos \\
\hline 2012 & Início das obras da Cúpula Central \\
\hline 2012 & Inauguração do Hotel Rainha do Brasil e Cidade do Romeiro \\
\hline 2013 & Visita do Papa Francisco a Aparecida \\
\hline 2014 & Inauguração dos Bondinhos Aéreos \\
\hline 2016 & Inauguração do Campanário, desenho de Niemeyer \\
\hline $1717-2017$ & Jubileu dos 300 anos do Encontro da Imagem de Nossa Senhora Aparecida \\
\hline
\end{tabular}

Fonte: COELHO, 2019.

De maneira geral, de acordo com o texto introdutório da exposição feito por Giselle Peixe e Silvia Bigareli, a exposição no Mirante convida os visitantes a fazerem um passeio contemplativo, considerando o tempo e o espaço, assim como a devoção a Nossa Senhora Aparecida e as transformações que ocorreram a partir desse culto, especialmente em seu Santuário.

Essa exposição, basicamente, é composta por painéis em uma linha do tempo ilustrada, que foram instalados acima das janelas do Mirante. Há também faixas azuis, abaixo dos painéis, com as indicações geográficas, e também demais informações sobre localidades e edificações que podem ser observadas por meio da vista panorâmica. 
Nas paredes, entre as janelas, foram instalados três televisores para exibição de um vídeo composto por fotografias históricas e contemporâneas, com o intuito de aproximar os fatos e lugares, proporcionando a apreciação de um movimento contínuo que redesenha os espaços e a própria história da devoção a Nossa Senhora.

Em destaque, nos cantos, há grandes reproduções de gravuras realizadas pelo artista George Rembrandt Gutlich, que narram a origem da devoção e as imagens das Basílicas, como centro da devoção a Nossa Senhora Aparecida.

O espaço foi reinaugurado em outubro de 2008, sendo possível observar, de uma área de 324 metros quadrados, uma grande parte do Vale do Paraíba, com uma visão privilegiada do Rio Paraíba do Sul e da Rodovia Presidente Dutra, que corta a cidade de Aparecida.

As Figuras 95 e 96 retratam o espaço do Mirante da Torre Brasília antes da reforma e após a revitalização, com os novos recursos expográficos.

Figura 95: Mirante da Torre Brasília antes da reforma.

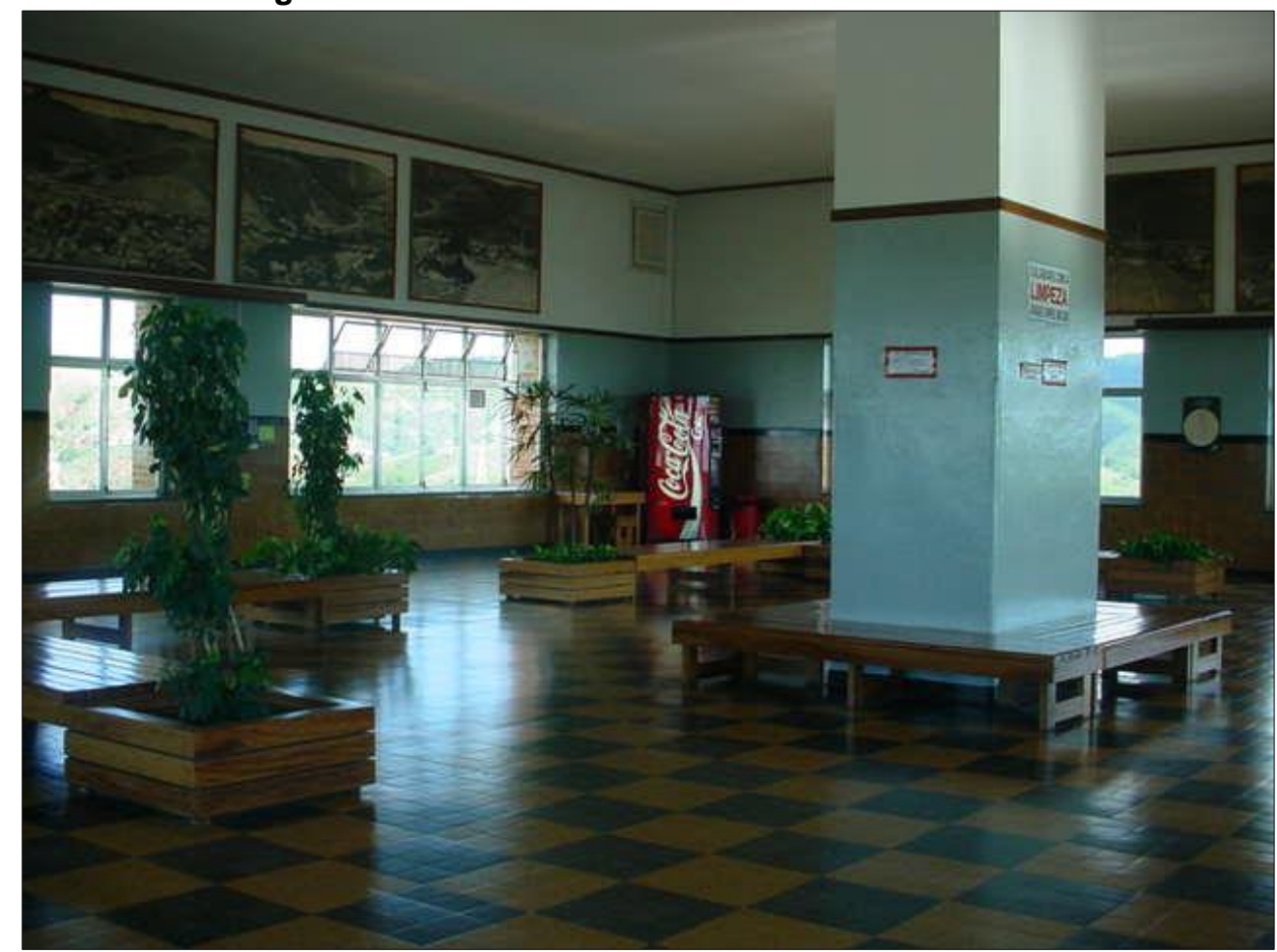

Fonte: MNSA/ Santuário Nacional 
Figura 96: Mirante da Torre Brasília após a revitalização.

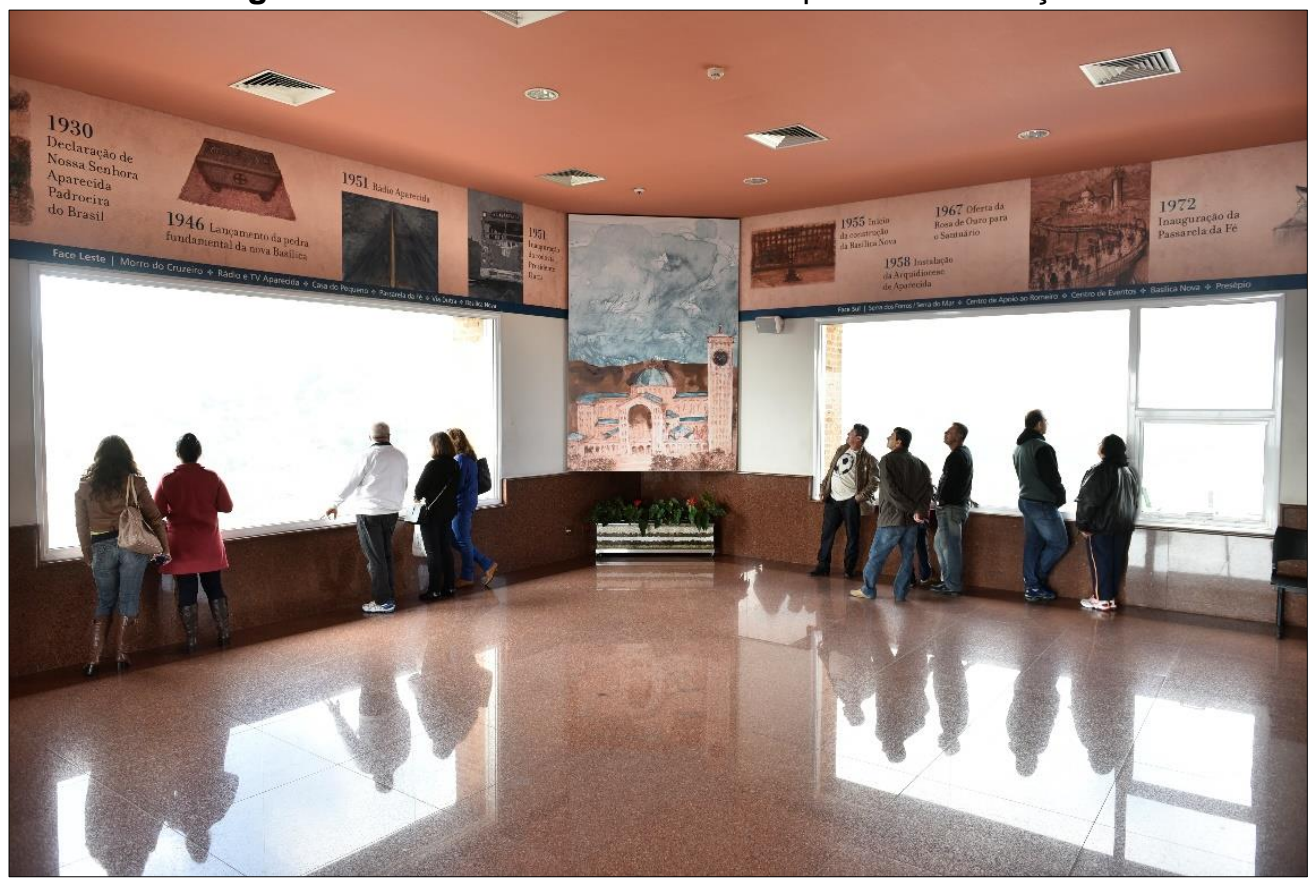

Fonte: MNSA/ Santuário Nacional. Foto: Thiago Leon.

Outra obra importante que ocorreu na Torre Brasília foi a ampliação de uma das salas na exposição do $1^{\circ}$ andar, com o intuito de intensificar a atmosfera mística e de religiosidade da Domus Aurea. Trata-se de uma sala que contém objetos preciosos recebidos pelo Santuário em devoção a Nossa Senhora, localizada na área final de exposição Rainha do Céu, Mãe dos Homens: Aparecida do Brasil.

A partir desse contexto, a empresa Jequitibá Cultural foi contratada para desenvolver novos painéis artísticos, bordados com joias, para ampliação da sala. De acordo com Peixe e Bigareli (2012), esse espaço foi criado com o intuito de propiciar um recolhimento para contemplação e vivência da presença de Maria. Esta incorporação da mística mariana é proporcionada pela conceituação da sala, que emprega a cor dourada e o azul. Nesse contexto, o ouro que compõe os bordados significa o divino, o sublime, o eterno; e o azul, a proteção do manto de Maria, tudo envolvendo, como escudo celeste.

Conforme Peixe e Bigareli (2012), outros aspectos desta mística são representados pelas ladainhas de Nossa Senhora e de outros cânticos e textos instalados nas paredes. Assimilando, principalmente, as imagens de Casa de Ouro, jardim fechado, rosa mística, espelho de justiça. O intuito é suscitar a emoção nos visitantes por meio das cores, da trilha sonora e demais recursos expositivos, como a transparência, o reflexo, a noção de profundidade. 
Inicialmente, a Domus Aurea foi concebida por Giselle Peixe e Silvia Bigareli com quatro vitrines nos cantos da sala, onde estão expostas joias e objetos preciosos como as Rosas de Ouro ofertadas pelos Papas Paulo VI, Bento XVI e Francisco, assim como objetos litúrgicos: cálices, âmbulas e ostensório; além das coroas comemorativas. Há também uma vitrine circular central, com vidro e espelho, que reproduz um denso conjunto de joias pelo reflexo e iluminação vinda do teto, representando um poço, que significa fonte de vida, purificação e mergulho no mistério.

É importante considerar que o acesso à Domus Aurea se dá através de um arco de rosas, feitas com folhas desidratadas. Vale lembrar que a rosa é considerada símbolo do amor divino e atributo da pureza de Maria.

Segundo Peixe e Bigareli (2012), com a ampliação da Domus Aurea, foram instalados três grandes arcos nas paredes com ricos bordados executados com joias ofertadas, lembrando a união com o Divino, assim como símbolos de Maria, mediadora da reconciliação. Há também quatro vitrines suspensas do teto, como coroa de luz, lembrando a Jerusalém Celeste e o Cristo, luz que clareia o Mundo.

Já a trilha sonora traz sons de floresta, com ruídos de água e pássaros, sugerindo a riqueza, diversidade e plenitude de vida. De acordo com Peixe e Bigareli (2012), esses novos elementos que foram empregados na ambientação da Domus Aurea remetem às ideias de água, luz, natureza, buscando provocar sensações e imagens ligadas ao aspecto feminino do Sagrado.

De maneira geral, as obras para ampliação da Domus Aurea iniciaram-se em novembro de 2011, tendo sido realizada pela equipe da Marcenaria Taniguchi, de São Paulo (SP). Entretanto, os desenhos bordados com as joias começaram a ser desenvolvidos em março de 2011, por um grupo de quatro mulheres, e levaram dez meses para conclusão, a partir de um desenho de base, com liberdade criativa.

A reinauguração da Domus Aurea ocorreu no dia 15 de fevereiro de 2012, conforme pode ser observado na Figura 97. 
Figura 97: Domus Aurea (Casa de Ouro).

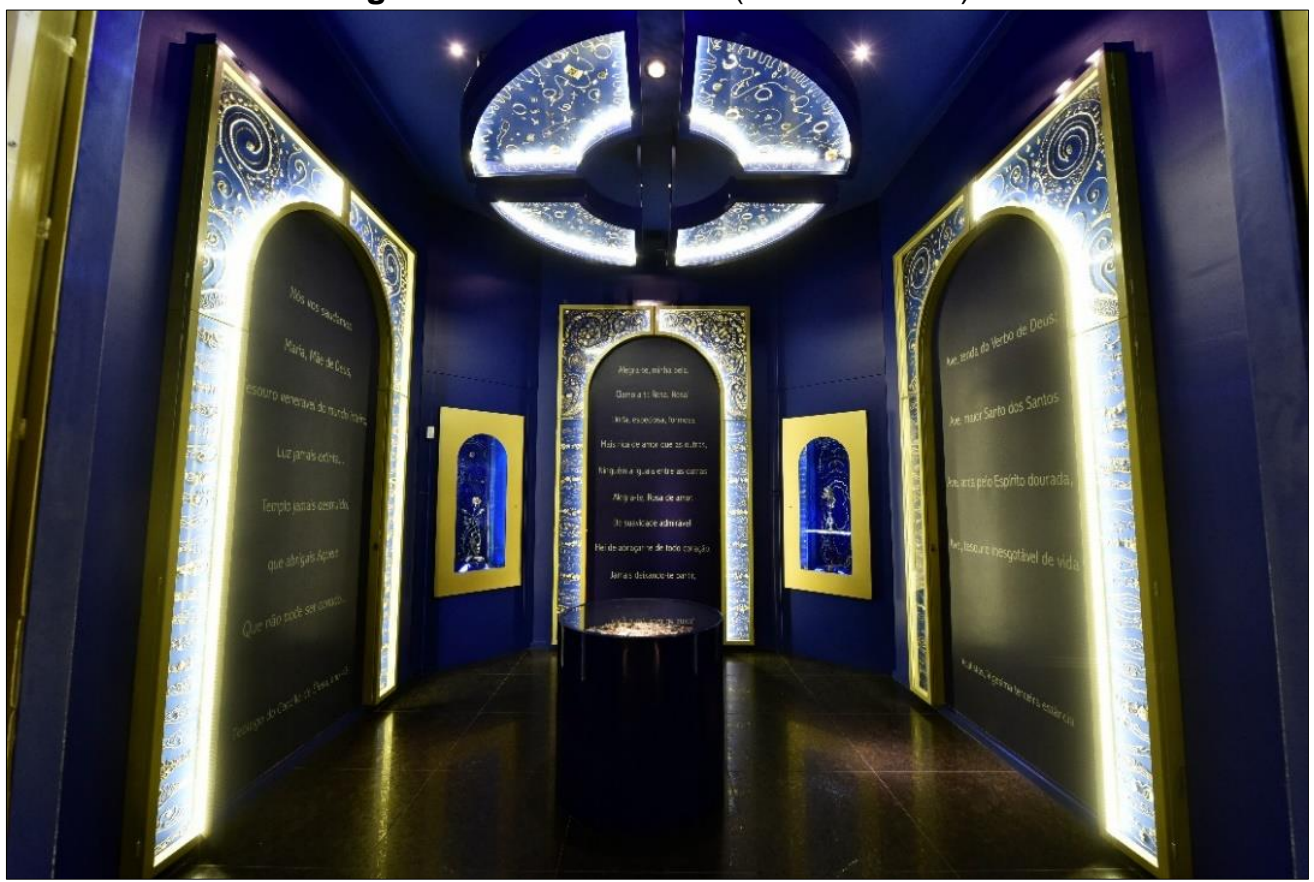

Fonte: MNSA/ Santuário Nacional. Foto: Thiago Leon.

Ainda em 2011, devido às grandes demandas de atividades e aumento do quadro de colaboradores, o administrador e ecônomo do Santuário Nacional de Aparecida, Pe. Luiz Cláudio Alves de Macedo, C.Ss.R., dividiu a administração do Museu Nossa Senhora Aparecida entre Área de Atendimento e Área Técnica.

Nesse período de transição, Michel Henrique de Oliveira ficou responsável apenas pela Área Técnica do Museu, permanecendo na coordenação do setor até finais do ano de 2014. Foi durante sua gestão (2006-2014) que houve um considerável avanço na catalogação do acervo, em virtude dos diversos treinamentos para identificação e documentação das coleções, assim como o apoio das equipes de estagiários contratados pela empresa Jequitibá Cultural. Ainda em sua gestão foi desenvolvido o projeto de expografia para o $2^{\circ}$ andar da Torre, que será abordado no Capítulo 3 desta dissertação.

A partir da decisão da Administração do Santuário, ao dividir os departamentos do Museu, a Área de Atendimento contou com três coordenadores entre os anos 2011 a 2019, sendo eles: Zenilda Cristina da Cunha, entre 01/05/2011 a 01/05/2012; Ana Cristina Bueno Borges, entre 02/05/2012 a 10/07/2012; e Jonatas Veloso Ribeiro dos Santos, a partir de 01/08/2012 até a data atual.

Zenilda Cristina da Cunha foi orientadora de visitas em atrativos culturais nos espaços públicos de visitação, bem como responsável pela elaboração de roteiros diferenciados, curso realizado pelo Serviço Nacional de Aprendizagem Comercial - 
SENAC, de Guaratinguetá (SP). Licenciada em História, pelo Centro Universitário Salesiano de São Paulo - UNISAL, Lorena (SP), com formação que envolve o Turismo Cultural, pesquisas investigativas e ensino-aprendizagem. Licenciou em Escolas Estaduais, no Ensino Fundamental, Médio e Educação de Jovens e Adultos. Atualmente, exerce a função de Assessora em Monitoria Histórica Religiosa (Simbolismo e Arte Sacra), no Santuário Nacional de Aparecida.

Antes de coordenar a equipe de atendimento do Museu nos anos de $2011 \mathrm{e}$ 2012, Zenilda Cunha já trabalhava no Santuário Nacional de Aparecida e acompanhava os trabalhos artísticos de Cláudio Pastro, que estavam sendo desenvolvidos para o revestimento interno das paredes, pisos e cúpula da Basílica.

De acordo com Zenilda Cunha, uma de suas primeiras atividades na Secretaria de Pastoral foi reunir informações sobre o Santuário, conforme consta no trecho da entrevista a seguir 53 :

Em 2006, quando eu entrei, a Cláudia queria fazer um projeto da Pastoral
reunindo todas as informações do Santuário com os departamentos, o que
cada departamento fazia, qual o objetivo, e também com alguns dados do
Cláudio Pastro, que já estava saindo na Revista de Aparecida. E ela ficou
responsável de fazer isso para ter um documento na Pastoral, e me pediu
para fazer um relatório de todos os departamentos. Nesses dados, eu
coloquei também do Cláudio Pastro e foi aí que eu conheci o Cláudio
pessoalmente. [...], ele estava pintando o hall da Torre, foi aí que eu o
conheci, eu ficava sozinha na Central e fui conversando com Cláudio Pastro
e ele foi dando dicas de bibliografia. (CUNHA, 2018, informação verbal).

$\mathrm{Na}$ administração de Zenilda Cunha, a equipe de atendimento do Museu foi reestruturada, com contratação de mais monitores para oferecer melhor atendimento aos visitantes. Entretanto, paralelamente aos trabalhos desenvolvidos no Museu, havia um novo projeto iniciado por Cláudio Pastro, o qual Zenilda Cunha deu continuidade, que estava relacionado ao monitoramento no Santuário, com o intuito de explicar as simbologias das obras de arte sacra criadas por Cláudio Pastro, que passaram a compor o revestimento interno da Basílica.

A partir de 2012, este serviço de monitoramento passou a ser oferecido como cortesia aos hóspedes do Hotel Rainha do Brasil, que compõe o Complexo do Santuário, conforme relatado por Zenilda Cunha.

A partir de 2011, que eu tinha entrado no Museu, eles já estavam tendo
essa conversa, participavam de reuniões do próprio Hotel, de fazer com que
essas visitas se tornassem uma cortesia do Hotel, para poder atrair mais
gente, um serviço, mas hoje ainda é cortesia para poder apresentar o

${ }^{53}$ CUNHA, Zenilda Cristina da. Entrevista concedida a Erica Andreza Coelho. Aparecida, 10 jan. 2018, $1 \mathrm{~h} 33$ min 17 s. Som, Formato M4A. 
Santuário. Eu fiquei o período que eu tinha aqui, quando lançou o Hotel eu saí, eu saí em maio de 2012 aqui do museu, quando fiquei locada na Secretaria de Pastoral, especificamente para tomar conta das monitorias do Hotel e também do Santuário. Eu ficava na Secretaria, os padres que chegavam, bispos, cardeais, o próprio Cláudio Pastro, porque a minha prova foi fazer para ele a visita. Então, para tudo eu já estava ali e fazíamos a visita monitorada. [...]. Tinha um segmento que o padre passava e tudo mais. Eu ficava no Museu, basicamente nos meses que eu fiquei no atendimento, porque era uma forma nova que eles estavam implantando de melhorar o atendimento. (CUNHA, 2018, informação verbal).

A administração de Ana Cristina Bueno Borges durou apenas três meses, não apresentando, portanto, grandes transformações ou projetos desenvolvidos, pois sua atuação anterior estava relacionada à área financeira, e logo a administração do Santuário realizou novas mudanças na gestão do Museu.

A partir de agosto de 2012, Jonatas Veloso Ribeiro dos Santos assumiu a coordenação da equipe de atendimento do Museu. Jonatas Veloso Ribeiro dos Santos é formado em Marketing pela Universidade Metodista de São Paulo, participou de treinamento pelo Instituto Disney (O jeito Disney de encantar clientes), bem como do Programa de Seminários Avançado em Gestão e Conhecimento Empresarial pela Fundação Armando Alvarez Penteado - FAAP. Atualmente cursa o Master of Business Administration (MBA) Executivo de Liderança em Gestão Comercial, pela Franklin Covey.

Ao assumir a coordenação da equipe de atendimento do Museu, Jonatas Veloso depara-se com a finalização de um projeto iniciado por Michel Henrique de Oliveira, em parceria com a empresa Jequitibá Cultural, referente à nova exposição no $2^{\circ}$ andar da Torre, considerando que o espaço estava desativado desde 2005. Esse novo projeto resultou na exposição de longa duração $O$ Museu e suas Histórias, inaugurada em 03 de outubro de 2012. Esta exposição será abordada no capítulo 3 desta dissertação.

$\mathrm{Na}$ ocasião, após a inauguração da nova exposição, Jonatas Veloso reestruturou a equipe de atendimento, que passou a atuar nas duas exposições. A nova equipe se empenhou em desenvolver projetos educativos em parceria com a Secretaria de Educação do município de Aparecida (SP), bem como em conjunto com o Hotel Rainha do Brasil, com o oferecimento de visitas monitoradas aos hóspedes.

Em 2013, Cesar Augusto Maia, que foi o responsável pelo primeiro tombamento do acervo no início da década de 1990, retorna ao Museu, desta vez assumindo a Curadoria das exposições temporárias, principalmente no hall da Torre 
e demais locais, como no subsolo da Basílica, Centro de Eventos Padre Vítor Coelho de Almeida, Hotel Rainha do Brasil e Morro do Cruzeiro. Nessa época, a equipe técnica do Museu era composta por dois auxiliares técnicos e o coordenador, Michel Henrique de Oliveira, que auxiliavam o curador na seleção de acervos, produção de textos, concepção da diagramação visual e montagem das exposições temporárias.

Em 2014, Erica Andreza Coelho, autora desta dissertação, que atuava na equipe do Museu Nossa Senhora Aparecida desde o ano de 2006, torna-se responsável pela Área Técnica do Museu, considerando as mudanças na gestão do Santuário Nacional.

A Figura 98 representa o atual organograma do Museu Nossa Senhora Aparecida, com a reestruturação entre coordenação de atendimento e coordenação de reserva técnica.

Figura 98: Organograma do Museu Nossa Senhora Aparecida.

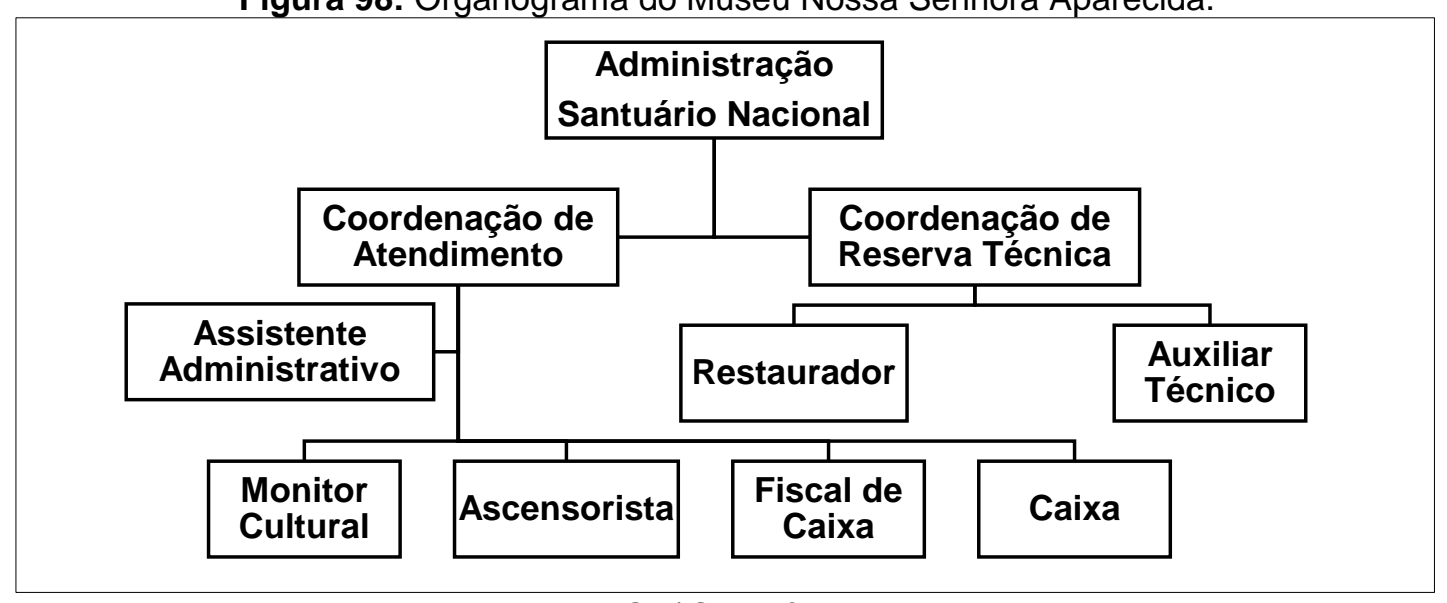

Fonte: MNSA/ Santuário Nacional.

Erica Andreza Coelho é formada em História pelo Centro Universitário Salesiano de São Paulo - UNISAL, com especialização em Gestão Cultural pelo Serviço Nacional de Aprendizagem Comercial - SENAC, e nesse momento, mestranda em Museologia na Universidade de São Paulo - USP. A pesquisadora iniciou suas atividades no Santuário Nacional de Aparecida como Menor Aprendiz, passando pelas funções de Auxiliar de Marketing, Agente Cultural, Auxiliar Técnico de Museu, Técnica em Conservação de Acervos e, atualmente, Coordenadora de Reserva Técnica, entre os anos de 2005 até a data atual.

Com essa nova gestão do Museu Nossa Senhora Aparecida, compartilhada entre Jonatas Veloso Ribeiro dos Santos e Erica Andreza Coelho, as consultoras Giselle Peixe e Silvia Bigareli permaneceram prestando serviços, tais como a 
coordenação editorial do catálogo comemorativo do Museu Nossa Senhora Aparecida (2016), com produção de folders em três idiomas.

Nesse contexto, considera-se que o ano de 2016 foi especial para a instituição, pois celebrou o Jubileu de 60 anos do Museu Nossa Senhora Aparecida, tendo sido desenvolvidas diversas atividades em comemoração ao aniversário do Museu.

Inicialmente, o ano foi marcado pelo recebimento de uma importantíssima doação de imagens paulistas do século XVII, composta por 54 imagens de barro e de madeira. Esta coleção, denominada Santa Gertrudes, foi reunida pelo colecionador Sr. Ladi Biezus, que realizou a oferta em memória de seus pais, que eram devotos de Nossa Senhora Aparecida.

As obras ofertadas receberam destaque na exposição do $2^{\circ}$ andar da Torre. A exposição Coleção Santa Gertrudes de Imagens Paulistas do século XVII será abordada no capítulo 3 desta dissertação.

Outra importante oferta em 2016 foi realizada pela Sra. Sandra Brecheret Pellegrini, filha do escultor modernista Victor Brecheret, que também realizou obras de arte sacra, entre elas as esculturas denominadas Madona, Pietá e Anjo, que foram ofertadas ao Museu Nossa Senhora Aparecida e hoje estão em exposição no $2^{\circ}$ andar da Torre.

Durante as comemorações dos 60 anos do Museu Nossa Senhora Aparecida, além das obras de adequação da exposição do $2^{\circ}$ andar, para incorporar as novas coleções ofertadas, também foi realizada uma série de atividades direcionadas ao público escolar do município de Aparecida (SP), tais como: concurso de redação com as turmas do $5^{\circ}$ e $6^{\circ}$ anos da rede municipal de ensino, visitas monitoradas com todas as escolas da rede municipal, em parceria com a Secretaria Municipal de Educação, além de uma premiação aos vencedores do concurso de redação, no mesmo dia em que houve uma palestra com o Prof. Ms. Ideval Costa, do Museu de Geociências da USP, sobre fósseis, contextualizando o acervo do Museu Nossa Senhora Aparecida.

E, mais recentemente, entre os anos de 2017 e 2018, as consultoras Giselle Peixe e Silvia Bigareli desenvolveram um novo projeto referente à expografia do Circuito de Visitação à Cúpula, com três módulos expositivos nos corredores superiores da Nave Norte e Cúpula Central do Santuário, sendo dois módulos inaugurados em 18 de outubro de 2017, e o outro módulo referente à construção do 
Santuário foi finalizado em 04 de julho de 2018, com o desenvolvimento do roteiro desse circuito em três idiomas (português, inglês e espanhol).

O Circuito de Visitação à Cúpula será abordado no capítulo 3 desta dissertação.

\subsubsection{Sistema de classificação e documentação do acervo}

Com o intuito de fazer a documentação do acervo de maneira mais organizada, Giselle Peixe e Silvia Bigareli desenvolveram um sistema de classificação do acervo, baseando-se na classificação do Thesaurus, porém delimitando-se as categorias de acordo com as características do acervo do Museu Nossa Senhora Aparecida, compilando, assim, os termos específicos que poderiam ser utilizados, bem como a sua correta classificação.

Para desenvolvimento desse sistema de classificação, conforme citado anteriormente, foram utilizados como referência o Thesaurus para acervos museológicos, desenvolvido pelo Museu Histórico Nacional; o Thesaurus vocabulário de objectos do culto católico, no contexto português; Thesaurus des objets religieux du culte catholique, uma edição trilíngue nos idiomas francês, inglês e italiano, da Caisse Nationale des Monuments Historiques et dês Sites, da França; Objets religieux, méthode d'analyse et vocabulaire, uma edição da reunião de museus nacionais do Canadá e França; além da coleção de Normas de Inventário, produzida pela Direção Geral do Patrimônio Cultural de Portugal.

De acordo com o Relatório Final de Prestação de Serviços Especializados,

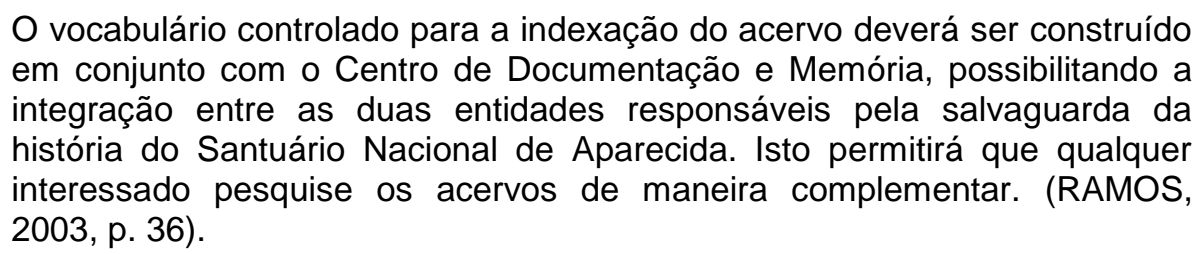

O Quadro 14 demonstra o grupo principal para classificação do acervo desenvolvido por Giselle Peixe e Silvia Bigareli.

Quadro 14: Classificação do acervo

\begin{tabular}{|l|l|}
\hline \multicolumn{2}{|c|}{ Classificação do acervo } \\
\hline 1 & Estruturas/construção \\
\hline 2 & Interiores \\
\hline 3 & Objetos pessoais \\
\hline 4 & Comunicação \\
\hline
\end{tabular}




\begin{tabular}{|c|l|}
\hline \multicolumn{2}{|c|}{ Classificação do acervo } \\
\hline 5 & Lazer, recreação, entretenimento, desporto \\
\hline 6 & Transporte e distribuição \\
\hline 7 & Ferramenta e equipamento de trabalho, comunicação, ciência e tecnologia \\
\hline 8 & Armaria, equipamentos de defesa, munições e acessórios \\
\hline 9 & Embalagem e recipiente \\
\hline 10 & Penitência e castigo \\
\hline 11 & Objetos não-classificáveis \\
\hline 12 & Arqueologia \\
\hline 13 & Amostras/Fragmentos/Remanescentes \\
\hline
\end{tabular}

Fonte: COELHO (2019).

O sistema de classificação completo apresenta os grupos de cada uma das treze classes do sistema de classificação do acervo do Museu Nossa Senhora Aparecida.

Nesse contexto, o Quadro 15 apresenta a Classe 1, referente à estrutura e construção. Considerando o estudo do acervo do Museu, nesta classe foram identificados, principalmente alguns elementos e fragmentos da Basílica Velha, tais com: pisos, ladrilhos, fechaduras, entre outros elementos.

Quadro 15: Classe 1 - Estruturas/construção

\begin{tabular}{|l|l|}
\hline $\mathbf{1}$ & Estruturas/construção \\
\hline 1.1 & Abrigo \\
\hline 1.2 & Edificação \\
\hline 1.3 & Componente, elemento e fragmento de edificação \\
\hline 1.4 & Outra estrutura \\
\hline
\end{tabular}

Fonte: MNSA/Santuário Nacional.

O Quadro 16 apresenta a Classe 2, referente aos interiores, que compreende mobiliários e acessórios. Nesta classe, apesar das diversas subclasses, poucos foram os objetos identificados na categoria de mobiliários, entre eles há cadeiras e genuflexórios com valor histórico agregado, pois se trata de peças utilizadas pelos Papas João Paulo II, Bento XVI e Francisco.

Quadro 16: Classe 2 - Interiores

\begin{tabular}{|l|l|}
\hline $\mathbf{2}$ & Interiores \\
\hline 2.1 & Mobiliário \\
\hline 2.1 .1 & Mobiliário civil \\
\hline 2.1 .1 .1 & Móvel acessório de adorno e serviço doméstico \\
\hline 2.1 .1 .2 & Móvel de apoio \\
\hline 2.1 .1 .3 & Móvel de função combinada \\
\hline
\end{tabular}




\begin{tabular}{|c|c|}
\hline & "cono \\
\hline 2 & Interiores \\
\hline 2.1 .1 .4 & Móvel de guarda \\
\hline 2.1.1.5 & Móvel de repouso \\
\hline 2.1.1.6 & Móvel para escrita, leitura, desenho \\
\hline 2.1.1.7 & Móvel para higiene e toalhete \\
\hline 2.1 .2 & Mobiliário religioso \\
\hline 2.1 .2 .1 & Altar e seu entorno \\
\hline 2.1.2.2 & Fechamento e separação interna de igreja \\
\hline 2.1.2.3 & Móvel de igreja para sentar e ajoelhar \\
\hline 2.1 .2 .4 & Móvel de confrarias, congregações e paróquias \\
\hline 2.1 .2 .5 & Móvel funerário \\
\hline 2.1.2.6 & Móvel para procissão e devoção \\
\hline 2.1 .2 .7 & Móvel ligado à ablução e aspersão \\
\hline 2.1.2.8 & Móvel ligado à Eucaristia \\
\hline 2.1 .2 .9 & Móvel ligado à pregação, leitura e canto \\
\hline 2.1 .2 .10 & Móvel ligado a outros sacramentos \\
\hline 2.1.2.11 & Móvel ligado às oferendas e coleta \\
\hline 2.1.2.12 & Móvel para guarda de objetos litúrgicos, tecidos e vestes litúrgicas \\
\hline 2.1.2.13 & Móvel para iluminação \\
\hline 2.2 & Acessório de interiores \\
\hline 2.2 .1 & Guarnição e coberturas de piso, portas e janelas \\
\hline 2.2 .2 & Guarnição de móveis \\
\hline 2.3 & Condicionador de temperatura \\
\hline 2.4 & Objeto de iluminação \\
\hline 2.4.1 & Acessório para iluminação \\
\hline 2.4 .2 & Luminária \\
\hline 2.5 & Utensílio doméstico \\
\hline 2.5 .1 & Objeto decorativo \\
\hline 2.5 .2 & Objeto e equipamento para serviços e manutenção doméstica \\
\hline 2.5 .3 & Objeto para manutenção de tecidos \\
\hline 2.5.4 & $\begin{array}{l}\text { Objeto e recipiente para conservação, preparação, } \\
\text { serviço e consumo de alimentos e bebidas }\end{array}$ \\
\hline 2.5.4.1 & Conservação \\
\hline 2.5.4.2 & Consumo/ serviço \\
\hline 2.5.4.3 & Preparação \\
\hline 2.5 .5 & Objeto para trabalhos de agulha \\
\hline 2.5 .6 & Recipiente para plantas e flores \\
\hline
\end{tabular}

Fonte: MNSA/Santuário Nacional.

Entre os demais acessórios de interiores, foram localizados no acervo algumas luminárias e acessórios para iluminação, como lustres, lanternas, arandelas, castiçais, candelabros, candeias, etc. Entretanto, as coleções de utensílios domésticos são mais expressivas, compreendendo diversos conjuntos de 
porcelana para jantar, café e chá, além de talheres e outros objetos para serviços e manutenção doméstica, assim como outros objetos decorativos.

O Quadro 17 apresenta a Classe 3, referente aos objetos pessoais, consta acervo de indumentária civil e religiosa, além de objetos de adorno, artigo de auxílio e conforto, higiene, tabagismo, bem como para viagem. Nessa classe foram identificadas diversas peças de indumentária religiosa, especialmente as vestes e acessórios, tais como: casula, dalmática, capa magna, estola, mitra, solidéu, barrete, meia, calçado, chapéu, etc. Nas outras subclasses também foram identificados objetos no acervo do Museu, em especial os objetos de adorno.

Quadro 17: Classe 3 - Objetos pessoais

\begin{tabular}{|l|l|}
\hline 3 & Objetos pessoais \\
\hline 3.1 & Acessório de indumentária \\
\hline 3.2 & Indumentária \\
\hline 3.2 .1 & Indumentária civil \\
\hline 3.2 .1 .1 & Acessórios \\
\hline 3.2 .1 .2 & Peças de Indumentária \\
\hline 3.2 .2 & Indumentária cerimonial/religiosa/ritual \\
\hline 3.2 .2 .1 & Acessório de indumentária religiosa \\
\hline 3.2 .2 .2 & Cobertura religiosa \\
\hline 3.2 .2 .3 & Meia e calçado religioso \\
\hline 3.2 .2 .4 & Veste religiosa \\
\hline 3.2 .3 & Indumentária militar \\
\hline 3.3 & Objeto de adorno \\
\hline 3.4 & Objeto e artigo de auxílio e conforto pessoal \\
\hline 3.5 & Objeto e artigo de toalete, higiene e cuidado pessoal \\
\hline 3.6 & Objeto e artigo para tabagismo \\
\hline 3.7 & Objeto e artigo para viagem/campanha \\
\hline
\end{tabular}

Fonte: MNSA/Santuário Nacional.

O Quadro 18 apresenta a Classe 4, referente aos objetos de comunicação, composta pelas subclasses arte, documento, insígnia/símbolo pessoal, instrumento musical, objeto pecuniário/meio de troca, objeto cerimonial e objetos de publicidade e propaganda.

A classe Comunicação compreende o maior grupo de acervos documentados do Museu, com considerável número de esculturas religiosas, seguindo pelo conjunto de objetos pecuniários com uma expressiva coleção de cédulas e moedas, nacionais e internacionais, além dos documentos postais que, a princípio, foram apenas quantificados, com uma parte menor do acervo documentado. 
Quadro 18: Classe 4 - Comunicação

\begin{tabular}{|c|c|}
\hline 4 & Comunicação \\
\hline 4.1 & Artes \\
\hline 4.1 .1 & Artes gráficas \\
\hline 4.1 .2 & Artes Visuais \\
\hline 4.1 .3 & Desenho \\
\hline 4.1 .4 & Escultura \\
\hline 4.1 .4 .1 & Escultura de vulto \\
\hline 4.1.4.1.1 & Busto \\
\hline 4.1.4.1.2 & Cabeça (exceto figura religiosa) \\
\hline 4.1.4.1.3 & Estátua (exceto figura religiosa) \\
\hline 4.1.4.1.4 & Estatueta \\
\hline 4.1.4.1.5 & Grupo escultórico \\
\hline 4.1.4.1.6 & Escultura religiosa \\
\hline 4.1.4.1.6.1 & Crucifixo \\
\hline 4.1.4.1.6.2 & Divino \\
\hline 4.1.4.1.6.3 & Figuras Religiosas \\
\hline 4.1.4.1.6.4 & Esculturas religiosas não identificadas \\
\hline 4.1.4.1.6.5 & Nossa Senhora \\
\hline 4.1.4.1.6.6 & Santas \\
\hline 4.1.4.1.6.7 & Santos \\
\hline 4.1.4.1.6.8 & Jesus \\
\hline 4.1.4.1.6.9 & Atributos de escultura religiosa \\
\hline 4.1.4.1.6.10 & Presépios \\
\hline 4.1.4.1.6.11 & Mártires \\
\hline 4.1 .5 & Estampa \\
\hline 4.1 .5 .1 & Gravura \\
\hline 4.1 .5 .2 & Impresso \\
\hline 4.1 .6 & Relevo \\
\hline 4.1 .7 & Pintura \\
\hline 4.2 & Documento \\
\hline 4.2 .1 & Correspondência \\
\hline 4.2 .2 & Documentos Oficiais \\
\hline 4.2 .3 & Fotografias \\
\hline 4.2 .4 & Livros \\
\hline 4.2 .5 & Outros \\
\hline 4.2 .6 & Revistas \\
\hline 4.3 & Insígnia/símbolo pessoal \\
\hline 4.4 & Instrumento musical \\
\hline 4.4 .1 & Acessório musical \\
\hline 4.4 .2 & Instrumento de sopro \\
\hline 4.4 .3 & Automatofone \\
\hline 4.4 .4 & Instrumento de corda \\
\hline 4.4 .5 & Instrumento eletroacústico \\
\hline
\end{tabular}




\begin{tabular}{|c|c|c|}
\hline & & "continuação" \\
\hline 4 & Comunicação & \\
\hline 4.4 .6 & Instrumento composto & \\
\hline 4.4 .7 & Instrumento de percussão & \\
\hline 4.4 .8 & Instrumento de teclado & \\
\hline 4.5 & Objeto pecuniário/meio de troca & \\
\hline 4.5 .1 & Moeda & \\
\hline 4.5.1.1 & Coleção/conjunto & \\
\hline 4.5 .1 .2 & Nacional & \\
\hline 4.5.1.2.1 & Colônia & \\
\hline 4.5.1.2.2 & Reino Unido & \\
\hline 4.5.1.2.3 & Império & \\
\hline 4.5.1.2.4 & República & \\
\hline 4.5.1.2.4.1 & Réis & \\
\hline 4.5.1.2.4.2 & Cruzeiro I & \\
\hline 4.5.1.2.4.3 & Cruzado & \\
\hline 4.5 .1 .2 .4 .4 & Cruzado Novo & \\
\hline 4.5.1.2.4.5 & Cruzeiro II & \\
\hline 4.5.1.2.4.6 & Cruzeiros Reais & \\
\hline 4.5 .1 .2 .4 .7 & Real & \\
\hline 4.5 .1 .3 & Estrangeira & \\
\hline 4.5 .2 & Cédula & \\
\hline 4.5 .2 .1 & Nacional & \\
\hline 4.5.2.1.1 & Império & \\
\hline 4.5.2.1.2 & República & \\
\hline 4.5.2.1.2.1 & Réis & \\
\hline 4.5.2.1.2.2 & Cruzeiro I & \\
\hline 4.5.2.1.2.3 & Cruzado & \\
\hline 4.5.2.1.2.4 & Cruzado Novo & \\
\hline 4.5.2.1.2.5 & Cruzeiro II & \\
\hline 4.5.2.1.2.6 & Cruzeiros Reais & \\
\hline 4.5.2.1.2.7 & Real & \\
\hline 4.5 .2 .2 & Estrangeira & \\
\hline 4.5 .3 & Documento de câmbio & \\
\hline 4.5 .4 & Documento de sociedade por ação & \\
\hline 4.5 .5 & Documento postal & \\
\hline 4.5.5.1 & Selo postal & \\
\hline 4.5 .5 .2 & Máximo postal & \\
\hline 4.5 .5 .3 & Envelopes & \\
\hline 4.5 .6 & Outros & \\
\hline 4.6 & Objeto cerimonial & \\
\hline 4.6 .1 & Objeto comemorativo & \\
\hline 4.6 .2 & Objeto de culto & \\
\hline
\end{tabular}




\begin{tabular}{|l|l|}
\hline 4 & Comunicação \\
\hline 4.6 .2 .1 & Caixa e cofre para guarda de objetos litúrgicos \\
\hline 4.6 .2 .2 & Objeto funerário \\
\hline 4.6 .2 .3 & Objeto ligado à ablução, aspersão e incensamento \\
\hline 4.6 .2 .4 & Objeto ligado à consagração das igrejas, altares e porta santa \\
\hline 4.6 .2 .5 & Objeto ligado à Eucaristia \\
\hline 4.6 .2 .6 & Objeto ligado à procissão \\
\hline 4.6 .2 .7 & Objeto ligado ao altar \\
\hline 4.6 .2 .8 & Objeto ligado aos outros sacramentos \\
\hline 4.6 .2 .9 & Objeto ligado aos ritos do Natal e Páscoa \\
\hline 4.6 .2 .10 & Objeto ligado às oferendas e coleta \\
\hline 4.6 .2 .11 & Tecido e guarnição litúrgica \\
\hline 4.6 .3 & Objeto de devoção pessoal \\
\hline 4.6 .4 & Ex-voto \\
\hline 4.7 & Publicidade e propaganda \\
\hline
\end{tabular}

Fonte: MNSA/Santuário Nacional.

Há também grande quantidade de objetos cerimoniais, com alguma temática comemorativa, assim como os objetos de culto, sendo a maioria procedente da Basílica Velha ou que compõem a coleção do Acervo Santuário Nacional (ASN), procedentes da Sacristia do Santuário Nacional de Aparecida.

O Quadro 19 apresenta a Classe 5, referente aos objetos de lazer, recreação, entretenimento e desporto. Nessa classe foram identificadas coleções de bonecas e alguns jogos.

Quadro 19: Classe 5 - Lazer, recreação, entretenimento, desporto

\begin{tabular}{|l|l|}
\hline $\mathbf{5}$ & Lazer, recreação, entretenimento, desporto \\
\hline 5.1 & Brinquedo \\
\hline 5.2 & Jogo \\
\hline 5.3 & Objeto e equipamento esportivo \\
\hline
\end{tabular}

Fonte: MNSA/Santuário Nacional.

O Quadro 20 apresenta a Classe 6, referente aos objetos de transporte e distribuição. Nessa classe foram identificados alguns acessórios de transporte terrestre, especialmente relacionados à cultura tropeira, tais como estribos e caçambas.

Quadro 20: Classe 6 - Transporte e distribuição

\begin{tabular}{|l|l|}
\hline $\mathbf{6}$ & Transporte e distribuição \\
\hline 6.1 & Acessório de transporte aéreo, fluvial, marítimo e terrestre \\
\hline 6.2 & Meio de transporte aéreo \\
\hline
\end{tabular}

"continua" 
"conclusão"

\begin{tabular}{|l|l|}
\hline 6 & Transporte e distribuição \\
\hline 6.3 & Meio de transporte fluvial e marítimo \\
\hline 6.4 & Meio de transporte terrestre \\
\hline
\end{tabular}

Fonte: MNSA/Santuário Nacional.

O Quadro 21 apresenta a Classe 7 , referente às ferramentas e equipamentos de trabalho, comunicação, ciência e tecnologia. Nessa classe foram identificados objetos relacionados aos artesãos, comunicação escrita, comunicação sonora e visual, demais equipamentos de medição e registro, além de apetrechos de caça e pesca, maquinaria e equipamentos de uso em geral.

Quadro 21: Classe 7 - Ferramenta e equipamento de trabalho, comunicação, ciência e tecnologia

\begin{tabular}{|l|l|}
\hline $\mathbf{7}$ & $\begin{array}{l}\text { Ferramenta e equipamento de trabalho, } \\
\text { comunicação, ciência e tecnologia }\end{array}$ \\
\hline 7.1 & Ferramenta e equipamento de artes do espetáculo \\
\hline 7.2 & Ferramenta e equipamento de artistas/artesãos \\
\hline 7.3 & Ferramenta e equipamento de atividade comercial \\
\hline 7.4 & Ferramenta e equipamento de comunicação escrita \\
\hline 7.5 & Ferramenta e equipamento de comunicação sonora/visual \\
\hline 7.6 & Ferramenta e equipamento de fiação/tecelagem \\
\hline 7.7 & $\begin{array}{l}\text { Ferramenta e equipamento de medição, registro, } \\
\text { observação, processamento }\end{array}$ \\
\hline 7.8 & Ferramenta e equipamento agrícola \\
\hline 7.9 & Ferramenta e equipamento de telecomunicação \\
\hline 7.10 & Ferramenta e equipamento médico \\
\hline 7.11 & Ferramenta e equipamento e petrechos de caça e pesca \\
\hline 7.12 & Ferramenta e equipamento para metalurgia \\
\hline 7.13 & Ferramenta e equipamento para mineração \\
\hline 7.14 & Ferramenta e equipamento para silvicultura \\
\hline 7.15 & Ferramenta e equipamento para pecuária e veterinária \\
\hline 7.16 & Maquinaria \\
\hline 7.17 & Ferramenta e equipamento de uso geral \\
\hline
\end{tabular}

Fonte: MNSA/Santuário Nacional.

O Quadro 22 apresenta a Classe 8, referente aos objetos de armaria, equipamentos de defesa, munições e acessórios. Após o treinamento com o oficial Magno Sérgio Dias, do Museu de Polícia Militar do Estado de São Paulo, foi possível identificar e classificar as coleções, conforme as categorias da Classe 8, organizando especialmente entre as armas brancas e armas de fogo. Alguns objetos indígenas foram classificados como arma branca de haste ou de arremesso. Também foram identificados diversos tipos de munições e alguns acessórios de armaria. 
Quadro 22: Classe 8 - Armaria, equipamentos de defesa, munições e acessórios

\begin{tabular}{|l|l|}
\hline $\mathbf{8}$ & Armaria, equipamentos de defesa, munições e acessórios \\
\hline 8.1 & Acessório de armaria \\
\hline 8.2 & Arma branca \\
\hline 8.2 .1 & Arma branca de arremesso \\
\hline 8.2 .2 & Arma branca de choque \\
\hline 8.2 .3 & Arma branca de haste \\
\hline 8.3 & Arma de arremesso \\
\hline 8.4 & Arma de choque \\
\hline 8.5 & Arma de fogo \\
\hline 8.6 & Arma de sopro \\
\hline 8.7 & Arma defensiva/Equipamento de defesa \\
\hline 8.8 & Máquina de guerra \\
\hline 8.9 & Munição e acessórios \\
\hline 8.10 & Outra \\
\hline
\end{tabular}

Fonte: MNSA/Santuário Nacional.

O Quadro 23 apresenta as Classes 9 e 10, sem subclasses, que se referem, respectivamente, às embalagens e recipientes, bem como penitência e castigo. Já a Classe 11, foi atribuída aos objetos não-classificáveis, podendo ser organizados entre artefatos de múltiplo uso, objetos com função desconhecido ou mesmo objetos sem classe.

Quadro 23: Classe 9 - Embalagem e recipiente; Classe 10 - Penitência e castigo; Classe 11 - Objetos não classificáveis

\begin{tabular}{|l|l|}
\hline $\mathbf{9}$ & Embalagem e recipiente \\
\hline $\mathbf{1 0}$ & Penitência e castigo \\
\hline $\mathbf{1 1}$ & Objetos não classificáveis \\
\hline 11.1 & Artefato de múltiplo uso \\
\hline 11.2 & Objeto com função desconhecida \\
\hline 11.3 & Objetos sem classe \\
\hline
\end{tabular}

Fonte: MNSA/Santuário Nacional.

O Quadro 24 apresenta a Classe 12, referente aos objetos da coleção de arqueologia, podendo ser classificados como objetos líticos ou objetos cerâmicos. Após a capacitação realizada pela Profa. Dra. Margarida Andreatta, entre os objetos líticos foram documentados pontas de flechas, mãos de pilão, lâminas de machado e seixos. Já os objetos cerâmicos, em sua maioria, há fragmentos, algumas urnas funerárias e travessas.

Quadro 24: Classe 12 - Arqueologia

\begin{tabular}{|l|l|}
\hline $\mathbf{1 2}$ & Arqueologia \\
\hline 12.1 & Lítico \\
\hline 12.2 & Cerâmica \\
\hline
\end{tabular}

Fonte: MNSA/Santuário Nacional. 
O Quadro 25 apresenta a Classe 13, referente às amostras, fragmentos e objetos remanescentes. A coleção de mineralogia foi classificada como amostra mineral, recebendo subdivisões, conforme consultoria realizada em parceria com o Museu de Geociências da Universidade de São Paulo, que ocorreu em 2016, a partir de oficinas ministradas por Ideval Souza Costa e Miriam Della Posta de Azevedo.

Quadro 25: Classe 13 - Amostras/Fragmentos/Remanescentes

\begin{tabular}{|c|c|}
\hline 13 & Amostras/Fragmentos/Remanescentes \\
\hline 13.1 & Amostras \\
\hline 13.1.1 & Animal \\
\hline 13.1 .2 & Mineral \\
\hline 13.1.2.1 & Coleção de minerais \\
\hline 13.1.2.1.1 & M1 - Elementos Nativos \\
\hline 13.1.2.1.2 & M2 - Sulfetos \\
\hline 13.1.2.1.3 & M3 - Haloides \\
\hline 13.1.2.1.4 & M4 - Óxidos \\
\hline 13.1.2.1.5 & M5 - Carbonato \\
\hline 13.1.2.1.6 & M6 - Sulfatos \\
\hline 13.1.2.1.7 & M7 - Fosfatos \\
\hline 13.1.2.1.8 & M8 - Silicatos \\
\hline 13.1.2.1.9 & M9 - Espeleotemas \\
\hline 13.1.2.1.10 & M10 - Artificiais / sintéticos \\
\hline 13.1.2.1.11 & M11 - Minérios \\
\hline 13.1.2.1.12 & M12 - Não identificado \\
\hline 13.1.2.2 & Coleção de gemas \\
\hline 13.1.2.3 & Coleção de rochas \\
\hline 13.1.2.3.1 & R10 - Rochas ígneas ou magmáticas \\
\hline 13.1.2.3.2 & R20 - Rochas sedimentares \\
\hline 13.1.2.3.3 & R30 - Rochas metamórficas \\
\hline 13.1.2.4 & Coleção de fósseis \\
\hline 13.1 .3 & Vegetal \\
\hline 13.2 & Fragmentos \\
\hline 13.2 .1 & Identificados \\
\hline 13.2 .2 & Não identificados \\
\hline 13.3 & Remanescentes \\
\hline
\end{tabular}

Fonte: MNSA/Santuário Nacional.

O Sistema de Classificação apresentado pautou o processo de documentação do acervo do Museu Nossa Senhora Aparecida. A princípio foi desenvolvido um banco de dados no Microsoft Office Access, com o intuito de fazer uma documentação informatizada.

Posteriormente, o Santuário Nacional de Aparecida adquiriu um sistema de gerenciamento de documentos, considerando que os sistemas de informação 
auxiliam nos processos de documentação, garantindo maior segurança dos dados, facilidade nas pesquisas do acervo, bem como reunindo o máximo de informação sobre os objetos em um único local.

Conforme apontado por Heloísa Barbuy (2008, p.36-37), em relação à documentação museológica, "o objetivo principal é constituir uma base ampla de informações, que alimente pesquisas e ações de curadoria, tanto da própria instituição como externas, e se alimente, por sua vez, das pesquisas realizadas sobre o acervo institucional ou em torno dele".

Diante desse contexto, o Santuário Nacional de Aparecida adquiriu um sistema para o Gerenciamento Eletrônico de Documentos - GED, com nome comercial DOCman, para implantação em vários setores do Santuário, conforme publicado pelo Jornal do GED em 2004.

\footnotetext{
Movida pela necessidade de manter seus documentos controlados em tempo real, o GED apareceu como a melhor opção para gerenciar e armazenar documentos.

O sistema de GED no Santuário atende à área jurídica, engenharia e também o CDM - Centro de Documentação e Memória, além do Museu. (JORNAL DO GED, 2004, p. 3).
}

De acordo com o Jornal do GED, "a documentação do acervo do CDM é formada por fotografias, vídeos e documentos referentes à memória do Santuário. No Museu, o GED controla o acervo de peças, desde suas informações básicas até o histórico de tramitação e restauração" (JORNAL DO GED, 2004, p. 3).

Inicialmente optou-se por configurar a Ficha Catalográfica do Museu Nossa Senhora Aparecida, agrupando as fichas: Identificação, Conservação, Dados Patrimoniais, Exposições, Histórico e Pesquisa e, por fim, Movimentação.

O Sistema DOCman foi utilizado no período de 2006 a 2017; posteriormente, foi substituído pelo Sistema Pergamum (Figura 99), e sua implantação ocorreu em março de 2018, com toda a migração dos dados que estavam inseridos no DOCman.

Ambos os sistemas foram customizados de acordo com a Ficha Catalográfica desenvolvida em 2003, disponível no ANEXO C. 
Figura 99: Sistema de Catalogação "Pergamum".

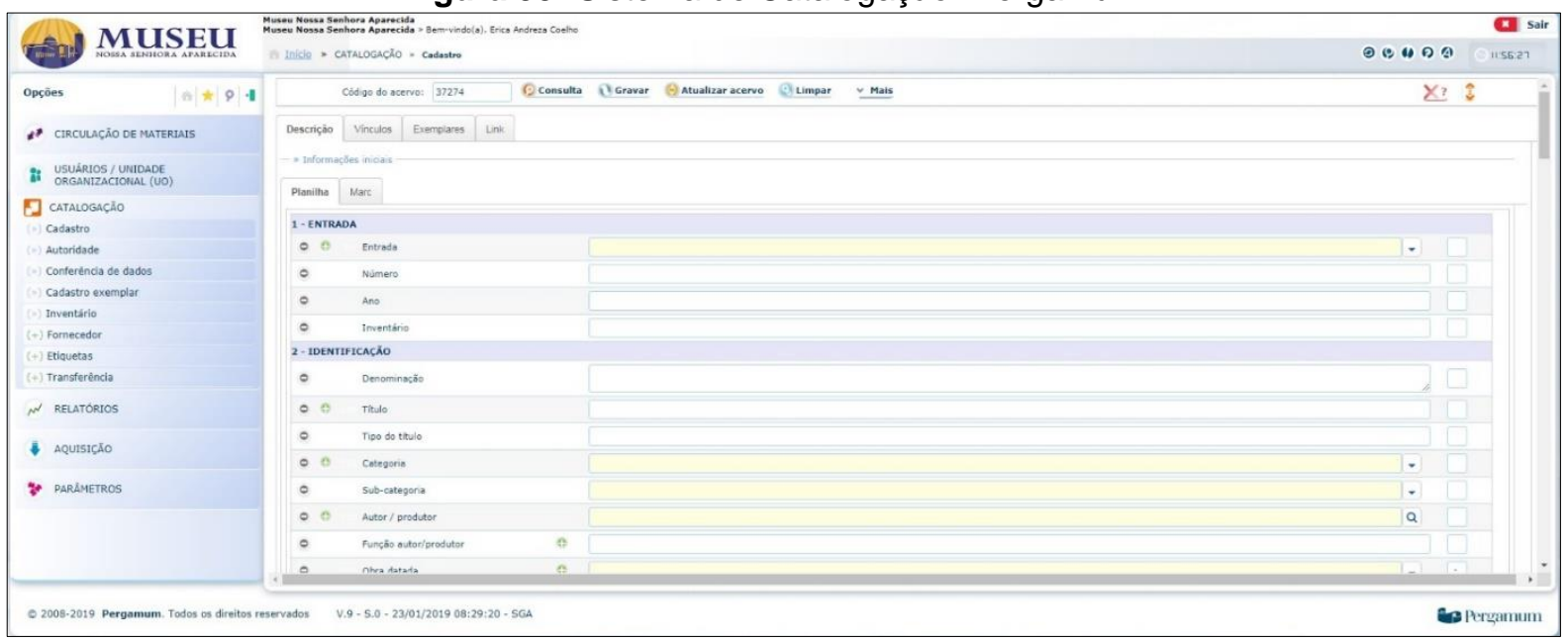

Fonte: MNSA/Santuário Nacional.

Com o Sistema Pergamum, a quantidade de fichas foi reduzida, permanecendo os mesmos campos para documentação do acervo. Portanto, a Ficha de Identificação, nesse novo formato, passou a incluir também as informações das Fichas de Conservação, Dados Patrimoniais e Histórico e Pesquisa.

Além do campo referente à conservação que consta na Ficha Catalográfica, também foi configurada uma Ficha de Conservação separadamente, para controle de versão do estado de conservação do acervo, assim como para inclusão das informações referentes aos processos de intervenção e restauração. Entretanto, mesmo de forma separada, há possibilidade de manter vínculos com a Ficha Catalográfica principalmente, mantendo a mesma denominação e número de inventário.

A Ficha de Exposição foi configurada para que as Fichas Catalográficas dos objetos selecionados para as exposições temporárias e exposições de longa duração fossem vinculadas a uma única ficha da referida exposição.

A Ficha de Movimentação, também com controle de versão, foi configurada de modo a constar todo o percurso do acervo do Museu, considerando como localização inicial a exposição no $2^{\circ}$ andar, conforme mapeamento realizado em 2003, para quantificação do acervo em exposição. Em relação aos objetos que possuem documentação de doação, constam a procedência do doador como localização inicial, e todo o percurso feito pelo objeto até o seu aceite após avaliação da Comissão de Acervo do Museu e armazenamento na Reserva Técnica. 
Nesse contexto, com a revitalização institucional do Museu Nossa Senhora Aparecida, foi instituído um novo documento para recebimento de doações, sendo denominado Termo de Oferecimento de Bem, disponível no ANEXO D.

De maneira geral, identificamos que, durante o processo de adaptação da equipe em relação ao novo procedimento para documentação das doações, alguns desses Termos de Oferecimento de Bens não foram preenchidos complemente, deixando lacunas sobre a procedência e demais informações sobre os doadores.

A partir de 2011, iniciou-se, portanto, um trabalho de organização de todos os documentos referentes às antigas ofertas, incluindo os Termos de Doação de Bens Móveis e os recentes Termos de Oferecimento de Bens, com o intuito de reunir os documentos de forma cronológica, contribuindo, assim, para melhor gestão do arquivo do Museu.

Durante esse processo, identificamos que os documentos receberam uma nova etiqueta no campo superior direito, com o intuito de atribuir um número de registro crescente, de acordo com a sequência cronológica em que os objetos foram doados.

Após análise das listas de entrada de novos objetos, observamos uma redução no número de doações com o passar dos anos. Acreditamos que a nova expografia no 1ํandar da Torre Brasília, que será apresentada no Capítulo 3, com um caráter temático sobre a história e devoção a Nossa Senhora Aparecida, possa ter influenciado, de certa maneira, no comportamento dos visitantes, em relação ao interesse em ofertar novas doações, até mesmo porque a antiga exposição, que era repleta de curiosidades de diversas áreas do conhecimento, foi desativada para organização e documentação do acervo.

A partir desse ponto de análise, verificamos que apenas dezessete números de entrada de objetos foram registrados no ano de 2007 (a relação completa de objetos pode ser verificada no Quadro 34 - ANEXO B). Desses objetos, apenas doze foram identificados pela documentação do acervo, sendo estes: castiçal (no 01), medalhas Papa João Paulo II ( $n^{\circ}$ 02), selo comemorativo Papa João Paulo II (no 03), selo comemorativo Papa João Paulo II (no 04), selo comemorativo Papa João Paulo II (no 05), fotocópias Papa Bento XVI (no 07), medalhas Papa Bento XVI ( $n^{\circ}$ 08), medalha comemorativa Papa Bento XVI (no 09), medalha comemorativa Papa Bento XVI ( $n$ - 10), medalha comemorativa Papa Bento XVI ( $n^{\circ}$ 11), terço ( $n^{\circ}$ 13) e terço ( $n^{\circ}$ 
14). Tendo recebido, respectivamente, os seguintes números de inventário: 11.682 , 2.745, 2.610, 2.611, 2.612, 3.092, 2.617, 2.613, 2.614, 2.615, 2.618 e 2.619.

Em relação aos objetos ofertados em 2008 (Quadro 35 - ANEXO B), analisamos que dos trinta e quatro números de entrada de objetos registrados no ano de 2008, cerca de vinte e seis objetos foram identificados pela documentação do acervo, sendo estes: mitra ( $n^{\circ} 02$ ), cruz peitoral ( $\left.n^{\circ}-03\right)$, cruz peitoral ( $n^{\circ} 04$ ), solidéu ( $\mathrm{n}^{\circ}$ 05), mitra ( $\mathrm{n}^{\circ}$ 06), medalha ( $\mathrm{n}^{\circ}$ 08), medalha ( $\mathrm{n}^{\circ}$ 09), medalha ( $\mathrm{n}^{\circ}$ 10), escultura Nossa Senhora Aparecida ( $n^{\circ}$ 12), vestes corais ( $n^{\circ}$ 13), faixa ( $n^{\circ}$ 14),

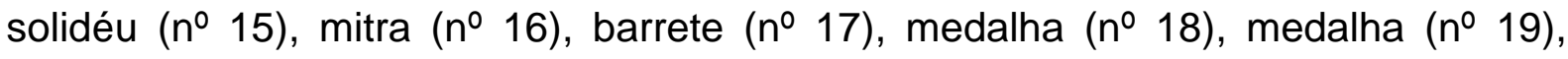
escultura NSA - em metal ( $n^{\circ} 20$ ), livro de missa e fita mariana ( $\left.n^{\circ} 21\right)$, relógio de bolso ( $n \div 22$ ), manto de NSA ( $\left.n^{\circ} 24\right)$, escultura Nossa Senhora Aparecida - em pedra sabão ( $n^{\circ} 26$ ), escultura Santa Rita - em pedra sabão ( $\left.n^{\circ} 27\right)$, copos de licor com decalque ( $n \div 31$ ), estola ( $n \div 33$ ) e quartzo ( $n \div 34)$. Tendo recebido, respectivamente, os seguintes números de inventário: 3.004/01 até 05, 11.685, 11.684, 2.851, 11.362, $3.005 / 01$ até $05,2.965,2.966,11.683,11.434,11.149,11.686,11.687,11.688$, 0753, 0754, 3.227 e 2.834.

Em relação aos objetos ofertados em 2009 (Quadro 36 - ANEXO B), verificamos trinta e um registros de entrada de objetos, sendo que apenas quinze objetos foram identificados pela documentação do acervo, entre eles: relicário com fragmento da escultura de NSA ( $n^{\circ}$ 02), escultura Divino Espírito Santo (n-0 03), medalha do Papa Bento XVI ( $n \div 04$ ), couro de jaguatirica ( $\mathrm{n}^{\circ}$ 05), couro de sucuri ( $n^{\circ}$ 06), relógio de pulso feminino ( $n^{\circ}$ 07), escultura Nossa Senhora Aparecida ( $n^{0}$ 12), escultura Nossa Senhora do Pantanal ( $n^{\circ}$ 13), crucifixo ( $n^{\circ}$ 15), câmera filmadora ( $n^{\circ}$ 17), escultura de Nossa Senhora Aparecida ( $n^{\circ}$ 21), casco de tracajá - tartaruga (no 22), manual e fita da congregação ( $\left.n^{\circ} 23\right)$, balança ( $\left.n^{\circ}-25\right)$ e serra ( $\left.n^{\circ} 26\right)$. Tendo recebido, respectivamente, os seguintes números de inventário: 1.886, 0697, 11.689, 0636, 0642, 11.442, 0700, 11.360, 11.692, 11.693, 0655, 11.106, 11.690, 11.691 e 11.709 .

Em 2010, houve uma considerável redução no número de ofertas, (observadas no Quadro 37 - ANEXO B). Nesse ano, apenas onze números de entrada de objetos foram registrados, sendo seis objetos identificados pela documentação do acervo e análise de fichas catalográficas: medalha Papa Paulo VI ( $\left.n^{\circ} 02\right)$, escultura Nossa Senhora da Conceição ( $\left.n^{\circ} 04\right)$, rádio ( $\left.n^{\circ} 06\right)$, relógio de bolso ( $\left.n^{\circ} 07\right)$, máquina de costura ( $\left.n^{\circ} 09\right)$ e relógio de bolso ( $n^{\circ}$ 10). Tendo recebido, 
respectivamente, os seguintes números de inventário: 11.694, 0428, 1.695, 11.431, 11.696 e 11.435.

Em relação aos objetos que foram ofertados em 2011 (Quadro 38 - ANEXO $B)$, verificamos onze números de entrada de objetos. Ao analisar documentação do acervo, notamos que foram catalogados onze objetos; entretanto, a maioria compõe um grupo de objetos entregues ao Museu por Dom Darci José Nicioli, constantes nos Termos de Oferecimento de Bem números 10 e 11, discriminados no Quadro 37 - ANEXO B.

De maneira geral, embora o número de objetos catalogados corresponda ao número de doações, localizamos apenas o estojo com moedas comemorativas ( $n^{\circ}$ 01), relógio de parede ( $n^{\circ} 05$ ), relógios de pulso ( $n^{\circ}$ 09), folhinhas - santinho relíquia (no 10) e conjunto com medalhas e moedas ( $n^{\circ}$ 11). Tendo recebido, respectivamente, os seguintes números de inventário: 11.697, 11.105, 11.438, 11.440, 11.444, 11.445, 0738, 0739, 0748, 0749, 0750.

Por meio da lista de entrada de objetos em 2012 (Quadro 39 - ANEXO B), observamos dezesseis números de entrada de objetos registrados. Desse total, cerca de catorze objetos foram identificados pela documentação do acervo, sendo estes: xícaras com pires ( $n^{\circ} 03$ ), folhinha - santinhos relíquia ( $n^{\circ}$ 07), pedra - basalto ( $n^{\circ}$ 08), pintura em metal ( $n \div 09$ ), jornal ( $\left.n^{\circ}-10\right)$, fragmento de algema ( $\left.n^{\circ} 11\right)$, pedra ( $n^{\circ}$ 12), máquina de calcular ( $n^{\circ}$ 14), medalhas comemorativas ( $n^{-15}$ ), papiros e conjunto filatélico (n-16). Tendo recebido, respectivamente, os seguintes números de inventário: 11.702, 11.703, 11.704, 11.099, 11.700, 11.168, 11.708, 11.705, 11.701, 11.706, 11.698, 11.699, 11.152 e 11.707.

Em relação aos objetos que foram ofertados em 2013 (Quadro 40 - ANEXO B), observamos que cinquenta e dois números de entrada de objetos foram registrados. Desse montante, cento e setenta e um foram identificados pela documentação do acervo, sendo estes: escultura Menino Jesus sobre pedestal ( $n^{\circ}$ 01), medalha ( $\mathrm{n}^{\circ}$ 02), gravadores de áudio ( $\mathrm{n} \div 03$ ), escultura Nossa Senhora Aparecida ( $n^{\circ} 08$ ), imagens sacras diversas e máquina fotográfica ( $n^{\circ} 09$ ), cortador de cabelo (n-10), artesanato representando camarão (n-12), presépios, selo de chumbo e selo Papa Bento XVI (no 13), pintura: Jogo de xadrez (no 15), pintura: Transladação de Jesus (no 17), escultura Santa Rita de Cássia (no 19), faqueiro com 51 peças ( $n$ - 22), relógios de bolso (no 23), bolsa com bomba, descanso talher e abridor de carta ( $\left.n^{\circ} 24\right)$, coroas ( $\left.n^{\circ} 25\right)$, tecas e caixas de hóstia ( $\left.n^{\circ} 26\right)$, pedra ( $n^{\circ}$ 
34), relicário (no 35), lembrança da Rosa de Ouro (no 36), caixa com diversos objetos ( $\mathrm{n}^{-40}$ ), fichas de telefone ( $\mathrm{n}^{\circ} 41$ ), rocha ( $n$ - 43), telégrafo ( $n$ - 44), escultura de Nossa Senhora Aparecida ( $n^{\circ}$ 45), máquina de escrever portátil ( $n^{\circ}$ 46), projetor ( $n^{\circ}$ 47), máquina de calcular ( $\left.n^{\circ} 48\right)$, folhinha - santinho relíquia ( $n^{\circ}$ 49) e medalha ( $n^{\circ}$ 50). Tendo recebido, respectivamente, os seguintes números de inventário: 11.359, $11.913,11.914,11.915,11.916,11.111$ até $11.125,11.917,11.159,11.126,11.127$, $11.128,11.129,11.168,11.169,11.918,11.170,11.172$ até 11.215, 11.217, 11.218, 11.219, 11.216, 11.153, 11.154, 11.155, ASN-0208, 0209, 0210, 0211, 11.919, $11.156,11.157,11.837$ até $11.912,11.920,11.921,11.131,11.363,11.922,11.923$, $11.924,11.158$ e 11.925.

Em relação aos objetos que foram ofertados em 2014 (Quadro 41 - ANEXO B), verificamos que sessenta e três números de entrada de objetos foram registrados. Desse total, apenas trinta e um objetos foram identificados pela documentação do acervo, sendo estes: relógio, lâmpada de carbureto e telégrafo ( $\mathrm{n}^{\circ}$ 01), medalha ( $n^{\circ}$ 02), apoio de ferro para engraxar ( $\left.n^{\circ} 11\right)$, relógio de parede ( $n^{0}$ 17), escultura Nossa Senhora Aparecida ( $n^{\circ}$ 20), caixa com 12 peças ( $n$ ํㅡㄹ), máquinas fotográficas ( $n^{\circ}$ 26), escultura Menino Jesus com globo ( $n-29$ ), moedas e medalhas comemorativas ( $n^{\circ} 31$ ), conjunto com bule, leiteira e açucareiro ( $n^{\circ} 46$ ), medalha ( $n^{\circ}$ 49), caneca de vidro azul ( $n^{-} 50$ ), calculadora ( $n^{\circ} 52$ ), medalha comemorativa ( $n^{\circ}$ 53), prato ( $n^{\circ}$ 55), pilão com mão de pilão (no 57), máquina fotográfica ( $n^{\circ}$ 58) e cordão com medalhas (no 59). Tendo recebido, respectivamente, os seguintes números de inventário: 11.433, 11.926, 11.927, 11.928, 11.929, 11.930, 11.361, $11.931,11.932,11.933,11.934,11.935,11.936,11.937,11.938,11.354,11.355$, $11.356,11.357,11.358,11.939,11941,11.949,11.942,11.943,11.944,11.448$, $11.945,11.946,11.947,11.948$.

Em relação à doação de objetos, por meio da lista de entrada (Quadro 42 ANEXO B), observamos que, dos quarenta e nove números de entrada de objetos registrados, apenas vinte e cinco objetos foram identificados pela documentação do acervo, sendo estes: máquinas fotográficas ( $n^{\circ}$ 03), espora ( $n^{\circ}$ 07), máquina fotográfica ( $n^{\circ}$ 09), pintura: Sagrada Face ( $n^{\circ}$ 11), mineral ( $n^{\circ}$ 13), fotografia ( $n^{\circ}$ 14), livro das horas da Virgem Nossa Senhora ( $n^{\circ}$ 15), vaso ( $n^{\circ}$ 18), mata-borrão, caneta pena e tinteiro ( $n^{0}$ 21), relógio de parede (no 22), escultura Nossa Senhora da Conceição ( $n^{\circ} 23$ ), par de estribos ( $n^{\circ} 26$ ), cuia ( $n^{\circ} 27$ ), navalhas ( $n^{\circ} 33$ ), pedra ( $n^{\circ}$ $35)$, debulhador de milho ( $n^{\circ} 37$ ), faqueiro ( $n^{\circ} 38$ ), medalha comemorativa ( $n^{\circ} 41$ ), 
travessa ( $\left.n^{\circ} 42\right)$, medalha ( $\left.n^{\circ} 44\right)$, folheto de oração ( $\left.n^{\circ} 47\right)$ e harpa ( $\left.n^{\circ} 48\right)$. Tendo recebido, respectivamente, os seguintes números de inventário: 12.016, 12.017, 12.038, 12.018, 12.019, 12.021, 12.022, ASN-0269, 12.023, 12.024, 12.025, 12.036, 12.026, 12.027, 12.028, 12.029, 12.030, 12.020, 12.037, 12.039, 12.031, 12.034, 12.033, 12.032, 12.035 .

Por meio da lista de entrada de objetos em 2016 (Quadro 43 - ANEXO B), notamos que cinquenta e seis números de entrada de objetos foram registrados. Entretanto, apenas trinta e quatro objetos foram identificados pela documentação do acervo, sendo estes: medalha ( $\mathrm{n}^{\circ}$ 02), conjunto com bule, chaleira, leiteira, açucareiro e bandeja ( $n^{\circ} 03$ ), espingarda e garrucha ( $\left.n^{\circ} 04\right)$, livro de oração ( $\left.n^{\circ} 06\right)$, álbum de fotografia ( $n-0$ 13), casula ( $n$ ㅇ 16), moringa ( $n \div$ 19), medalhas comemorativas e moedas ( $\left.n^{\circ} 21\right)$, balança ( $\left.n^{\circ} 22\right)$, medalhas comemorativas $\left(n^{\circ} 23\right)$, goiaca ( $n^{\circ}$ 28), medalha ( $n^{\circ}$ 29), medalha ( $n^{\circ}$ 30), máquina fotográfica ( $\left.n^{\circ} 33\right)$, candelabro ( $\left.n^{\circ} 35\right)$, bloco de notas Cardeal Motta ( $\left.n^{\circ} 36\right)$, Lembrança do Congresso Eucarístico Internacional do Rio de Janeiro ( $\left.n^{\circ} 37\right)$, oratório de parede com recipiente para água benta ( $n^{\circ}$ 41), medalha ( $\mathrm{n}^{\circ}$ 44), álbum de moedas comemorativas ( $n \div 46)$, medalha comemorativa ( $n \div$ 49), máquina fotográfica ( $n \div 53$ ), folha de selos ( $\left.n^{\circ} 55\right)$ e folha de cheque ( $\left.n^{\circ} 56\right)$. Tendo recebido, respectivamente, os seguintes números de inventário: 12.297, 12.305, 12.303, 12.304, 12.292, 12.293, $11.940,12.513,12.280$ até $12.290,12.313,12.298,12.301,12.295,12.273,12.299$, $12.302,12294,12.291,12.296,12.274,12.278,12.275,12.300,12.276,12.279$.

Em relação aos objetos ofertados em 2017 (Quadro 44 - ANEXO B), analisamos que sessenta e sete números de entrada foram registrados, considerando que noventa e oito objetos foram identificados pela documentação do acervo, devido aos grupos de objetos doados por um mesmo doador. Segue a lista de objetos catalogados, que foram identificados por meio da documentação do acervo com o número de entrada: placas de homenagens, diplomas e condecorações ( $n^{\circ} 01$ ), pasta dos correios com conjunto filatélico ( $n^{\circ} 02$ ), relicário com relíquia de osso ( $\left.n^{\circ} 03\right)$, moedas ( $\left.n^{\circ} 05\right)$, livro ( $\left.n^{\circ} 06\right)$, cunhos descaracterizados e medalhas comemorativas ( $n \div 0$ 07), escultura Menino Jesus de Praga ( $n \div 0$ 08), condecorações ( $n \div 0$ 09), bolsa feminina de metal ( $n \div$ 10), escultura Nossa Senhora Aparecida ( $n^{\circ}$ 14), placas de homenagens ( $n^{\circ}$ 17), escultura Nossa Senhora Aparecida (n 18), Quadro: Padroeira do Brasil - plantas naturais prensadas ( $\left.n^{\circ} 19\right)$, Bíblia ( $\left.n^{\circ} 20\right)$, filmadora ( $\left.n^{\circ} 24\right)$, navio Escola Brasil - miniatura ( $\left.n^{\circ} 26\right)$, jarra e bacia 
( $n^{\circ}$ 49), cunhos e medalhas ( $n^{\circ}$ 50), réplica da espada do Duque de Caxias ( $n^{\circ}$ 51), placa Marinha do Brasil ( $n^{\circ}$ 52), medalha ( $n^{\circ}$ 53), escultura Bandeirante ( $n^{-}$54), álbum de moedas Olimpíadas Rio 2016 ( $n^{\circ}$ 55), terço e livro ( $n^{\circ}$ 59), conchas ( $n^{\circ}$ 61), crucifixo com base ( $n^{\circ}$ 62), baú de metal ( $n^{\circ}$ 63), moedas ( $n^{\circ}$ 64), diploma de Honra ao Mérito ( $n^{\circ}$ 65) e quadro Nossa Senhora Aparecida ( $n^{\circ}$ 67). Tendo recebido, respectivamente, os seguintes números de inventário: 11.205 até 11.264, 12.277, $12.431,12.435,12.436,12.317$, ASN-0292, 12.306 até 12.312, 12.429, 12.426, 12.314, 12.315, 12.316, 12.414, 12.514, 12.437, 12.432, ASN-0309, 12.438, 12.421, ASN-0306, ASN-0308, ASN-0321, ASN-0307, 12.428, 12.433, 12.434, 12.439, $12.425,12.427,12.430,12.423,12.515$.

Em relação aos objetos ofertados em 2018 (Quadro 45 - ANEXO B), observamos que os mesmos permanecem aguardando a avaliação da Comissão de Acervo do Museu, para incorporação ao Museu. Embora, identificamos que alguns objetos foram documentados para serem expostos no Circuito de Visitação à Cúpula, entre eles estão os objetos: Pasta dos Correios - Jubileu 300 anos (01), Tijolinho - Campanha dos Devotos (10), 3 Vitrais Basílica Nova e 1 tijolo Basílica Velha (14), 3 Tijolinhos - Campanha dos Devotos (15). Tendo recebido, respectivamente, os seguintes números de inventário: 12.277, ASN-0349/01, ASN0357/01, ASN-0357/02, ASN-0357/03, ASN-0360, ASN-0349/02.

Ao relacionarmos e analisarmos as listas de doações de objetos, desde o início da década de 1990 até 2018, observamos uma recorrência de certos itens e tipologias de acervos, dando margem para o apronfundamento de novos estudos sobre a cultura material. Com isso, torna-se possível repensar o estudo sobre a história do Museu, a partir da formação dessas coleções, focando na questão da produção do conhecimento.

De maneira geral, esses registros se tornam uma forma de apropriação, permitindo estudos de práticas sociais e retomando questões da identidade cultural. E, com a exposição desses acervos, o Museu contribui com a produção, difusão e socialização do conhecimento dos temas que ele aborda, com o intuito de atender as diversas demandas e suas funções sociais, em especial, contribuindo com a evangelização do seu público visitante, o que difere de outros Museus. 


\section{Capítulo 3 - Propostas de comunicação: o sagrado no museu}

Neste capítulo serão analisados os ambientes expositivos do Museu Nossa Senhora Aparecida, com o desenvolvimento de quadros que apresentam os elementos que compõem as exposições (APÊNDICE A), que servirão mais como fonte de informação do que propriamente como argumento teórico para discussão.

De maneira geral, buscou-se compreender como se construíram os processos comunicacionais com análise delimitada pelas exposições de longa duração. E foram quatro exposições que mais recentemente marcaram as transformações no Museu, a partir do processo de revitalização institucional: na primeira, inaugurada em 2005, buscou-se a criação de um espaço que contextualizasse a presença de Maria e a história do encontro da Imagem de Nossa Senhora Aparecida nas águas do Rio Paraíba do Sul e os inúmeros milagres ocorridos após esse fato. A segunda exposição, inaugurada em 2012, apresenta as relações do homem com o sagrado, com seu cotidiano, com sua expressão e com a natureza ao seu redor. A terceira exposição, inaugurada em 2016 no mesmo local da exposição anterior, apresenta imagens paulistas do século XVII. E, por fim, a quarta exposição trata-se de um circuito composto por três módulos expositivos, inaugurados entre 2017 e 2018 . Este Circuito de Visitação à Cúpula Central da Basílica de Aparecida foi concebido durante as celebrações dos 300 anos do encontro da Imagem de Nossa Senhora Aparecida, compreendendo a finalização das obras do artista sacro Cláudio Pastro, responsável pelo revestimento artístico dos pisos, paredes e cúpula da Basílica de Nossa Senhora Aparecida.

Para estudo e descrição dessas exposições, foi utilizado o roteiro de observação e análise desenvolvido pela Profa. Marília Xavier Cury, conforme mencionado anteriormente, com o intuito de elencar os vários núcleos temáticos das exposições, assim como demais tópicos de análise. Essa metodologia é aplicada em pesquisas de diferentes níveis, desde iniciação científica até pós-doutoramento.

Foi fundamental para compreensão das transformações que ocorreram ao longo do tempo o exame da Proposta Museológica Institucional, composta também por uma proposta expositiva e de ação educativa, bem como os projetos museográficos referente às exposições: Rainha do Céu, Mãe dos Homens: Aparecida do Brasil, localizada no $1^{\circ}$ andar da Torre; e a exposição O Museu e suas Histórias, localizada no $2^{\circ}$ andar da Torre. 
O catálogo da exposição Mestres Santeiros Paulistas do século XVII na Coleção Santa Gertrudes também contribuiu para melhor compreensão da coleção formada pelo colecionador Ladi Biezus, que foi exposta inicialmente no Museu de Arte Sacra de São Paulo, no período de 21 de fevereiro de 2016 a 19 de junho de 2016. Atualmente essa coleção encontra-se exposta no $2^{\circ}$ andar da Torre, no Santuário Nacional de Aparecida, com o título Coleção Santa Gertrudes de Imagens Paulistas do século XVII, inaugurada em 08 de julho de 2016, no Museu Nossa Senhora Aparecida.

E, por fim, foi fundamental o estudo dos projetos museográficos que compõem o Circuito de visitação à cúpula, com três módulos expositivos localizados no corredor superior da Nave Norte e na Cúpula Central do Santuário.

De maneira geral, Heloisa Barbuy (1995) argumenta que as exposições possuem um grande poder de difusão de imagens superior aos dos meios escritos ou impressos. Portanto, o estudo das exposições é importante por tratar de representações materializadas da sociedade e, conforme apontado pela autora, é possível inferir alguns aspectos desta sociedade, assim como os valores e práticas a partir do estudo de suas representações. Para Heloisa Barbuy (1995, p. 36),

[...] as exposições constituem, para além do projeto pedagógico de seus organizadores, uma forma de expressão (de representação), que encontra na materialidade visualmente apreensível, o código de comunicação em vigor. $E$ isto como decorrência das crenças que realmente se tem, ligadas às novas formas de perceber o mundo.

Deste modo, conceber e montar uma exposição, para Marília Xavier Cury (2005), significa construir e oferecer uma experiência para o público. Para a autora, "a exposição é a ponta do iceberg que é o processo de musealização, é a parte que visualmente se manifesta para o público e a grande possibilidade de experiência poética por meio do patrimônio cultural" (CURY, 2005, p. 35).

Ainda segundo a autora, é por meio das exposições que os museus se apresentam para a sociedade, podendo afirmar a sua missão institucional. A partir desta perspectiva pretendemos fazer uma reflexão sobre a museologia e o sagrado, por meio das propostas de comunicação do Museu Nossa Senhora Aparecida.

\subsection{Exposição Rainha do Céu, Mãe dos Homens: Aparecida do Brasil}

O Museu Nossa Senhora Aparecida manteve até 2005, no $2^{\circ}$ andar da Torre, uma exposição de caráter permanente, exibindo a maior parte do seu acervo. 
Entretanto, essa mostra foi desativada após implantação de um novo projeto expográfico para $01^{\circ}$ andar da Torre. Com isso, em 28 de novembro de 2005, foi inaugurada a exposição Rainha do Céu, Mãe dos Homens: Aparecida do Brasil (Figura 100), a partir do processo de reestruturação institucional.

Figura 100: Inauguração exposição Rainha do Céu, Mãe dos Homens: Aparecida do Brasil - 1ำ andar da Torre Brasília, Santuário Nacional de Aparecida.

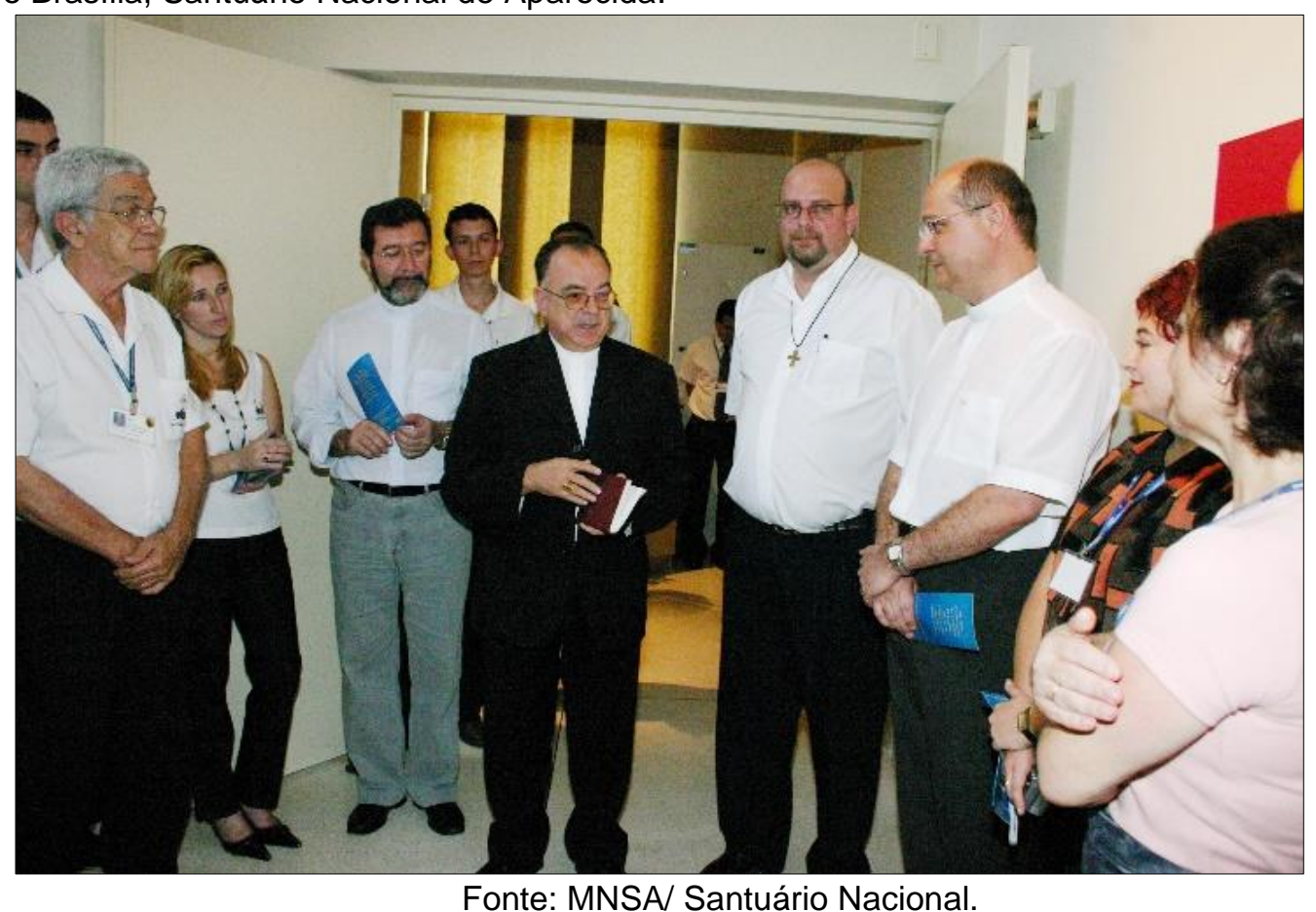

De acordo com o Projeto Museográfico desenvolvido por Giselle Peixe e Silvia Bigareli,

A exposição Rainha do Céu, Mãe dos Homens: Aparecida do Brasil pretende, sob um viés evangelizador, comunicar aspectos culturais, antropológicos, artísticos, da devoção a Maria, enfaticamente sob a invocação Aparecida, de modo que o visitante romeiro se reconheça como parte integrante desse contexto. (PEIXE; BIGARELI, 2004, p. 25).

Essa exposição temática do Museu Nossa Senhora Aparecida tem Maria como figura central e busca referenciar seu papel para a fé cristã, seja em sua dimensão humana, como no sentido teológico, conforme exposto por Peixe e Bigareli (2004). Desta forma, a exposição pretende demonstrar a importância da devoção a Maria, destacando especialmente a devoção a Nossa Senhora Aparecida, como um fenômeno religioso. Segundo Souza (2008, p. 87), "o espaço é totalmente dedicado a expor imagens de Maria [...] objetos que são relativos aos milagres por ela promovidos na região; alguns exemplares de objetos doados por 
fiéis que obtiveram graças, material que reconta um pouco da trajetória e da construção do santuário".

A Figura 101 apresenta a planta da exposição Rainha do Céu, Mãe dos Homens: Aparecida do Brasil, com acesso pela lateral esquerda, seguindo o roteiro por núcleos. Os números inseridos na Figura indicam os núcleos temáticos que serão descritos a seguir.

Figura 101: Planta - Exposição 1ำ andar.

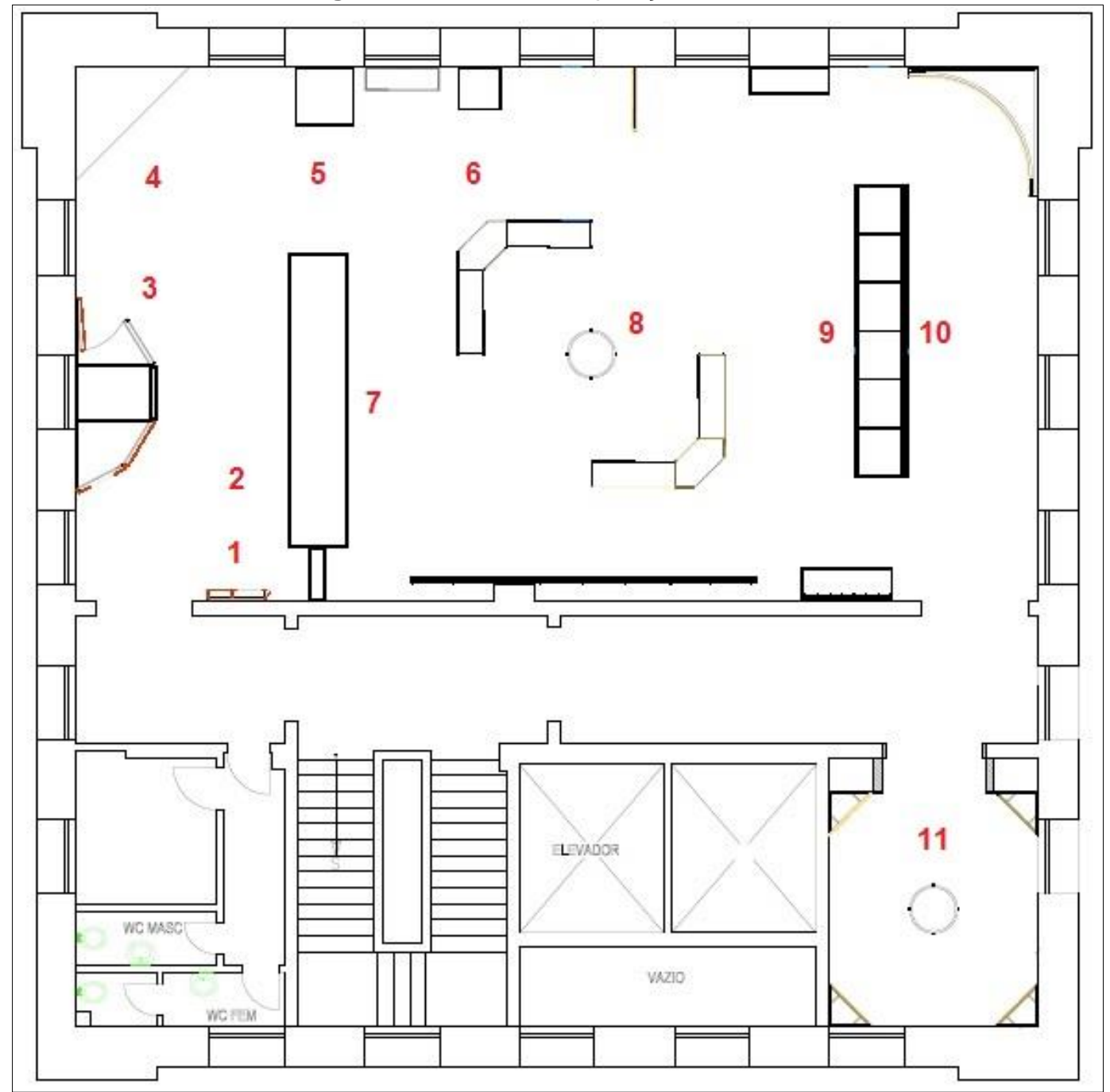

Fonte: MNSA/ Santuário Nacional.

A concepção do projeto expositivo faz referência ao feminino, à pureza e à luz. Desta forma, as curadoras optaram por barrar a entrada de luz solar direta, como era na antiga exposição, não apenas considerando a necessidade de conservação das coleções, mas também o conforto público e, principalmente, mantendo uma iluminação dirigida para objetos em destaque. 
Outra questão importante, se comparada com a antiga exposição, foi o percurso realizado com os mobiliários, no intuito de evitar a segmentação do espaço, conduzindo o público conforme o roteiro temático. Desta forma, a sala principal foi organizada em ambientes, porém com a parte superior livre, favorecendo a ventilação e mantendo a amplitude da sala. Para a diagramação visual da exposição, optou-se por painéis estreitos e altos; as vitrines foram planejadas para garantir a segurança e conservação preventiva dos acervos, porém explorando formatos diferentes, seguindo o mesmo estilo, mas sem muita repetição.

Os ambientes da sala possuem uma sequência, mas oferecem a possibilidade de circulação independente, conforme o interesse do público, com isso não se torna monótona, pois cada núcleo temático possui características próprias. Podemos constatar isso pela escolha das cores e os recursos expográficos (vitrines e painéis). De acordo com Peixe e Bigareli (2004), essas escolhas de tons de bege, verde, vermelho e azul têm a função de ambientar os temas, conforme os significados de cada núcleo.

Os núcleos iniciais usam tons de terra para significar os aspectos terrenos e
humanos de Maria; no núcleo das invocações, relativo aos aspectos
celestes e gloriosos da figura de Maria, será usado o azul; a partir dos
temas relativos à descoberta da imagem, será utilizado o verde claro em
sua associação com as águas. No núcleo central, nas paredes internas será
empregado o vermelho-carmin, significando o calor da devoção e da
emoção interior. O verde apresenta-se em variações nos demais núcleos
relativos à devoção a Aparecida (PEIXE; BIGARELI, 2004, p. 20).

Como recursos expográficos, há elementos ilustrativos que foram reproduzidos em grande formato, para dar destaque aos detalhes, explorando desta forma o pé direito da sala de exposição que possui aproximadamente cinco metros de altura. E, considerando que o ambiente foi projetado para não haver luz natural, o projeto de iluminação contempla luz amena e uniforme para a sala principal, com alguns destaques pontuais.

Em relação à proposta de sonorização, há dois ambientes com trilha sonora; na sala principal, há músicas instrumentais com intensidade baixa e suave. Já na área de finalização da exposição, o conceito adotado pelas curadoras está na diferenciação deste ambiente do restante da exposição. A sala remete às cores de Nossa Senhora e seu manto, sendo o azul escuro e o dourado, em um ambiente mais escuro, com o intuito de suscitar a emoção no público. Diante desse conceito, a sonorização propõe um ambiente mais aconchegante, com a sensação de 
interioridade, presença divina e proteção materna; para isso, há uma trilha sonora com sons da natureza, pássaros e de água.

De maneira geral, o roteiro expositivo do $1^{\circ}$ andar da Torre Brasília é dividido em onze núcleos temáticos (que podem ser analisados no Apêndice 1 - Quadro 26). $\mathrm{Na}$ concepção dessa exposição, segundo as curadoras, foi adotada uma leitura mais poética que narrativa, diferenciando-se, assim, de outras exposições tradicionais de arte sacra. Nesta exposição "imagens e textos bíblicos se sucedem divididos em núcleos temáticos abertos a diferentes níveis de leitura. Os objetos selecionados não ilustram temas; estão tão presentes no imaginário de todo brasileiro que personificam as ideias por si” (PEIXE; BIGARELI, 2004, p. 18). Essa interpretação sugere uma exposição destinada a um público uniformizado em torno da figura do "romeiro" familiarizado com o tema.

$\mathrm{Na}$ introdução da exposição, logo no corredor de entrada, com acesso pelas escadas ou pelo elevador, encontra-se o título da exposição e três ilustrações criadas pelo artista e ex-diretor do Museu, Prof. Guido Machado Braga, que representam o encontro da imagem de Nossa Senhora Aparecida e a devoção popular. Logo em seguida, há o balcão de recepção com acesso à sala de apoio dos colaboradores, além da ficha técnica da exposição.

O primeiro núcleo é destinado a reviver experiências próximas com Maria; há um texto de apresentação, que faz referência a Maria como figura central no projeto de Salvação e na vida da Igreja. Nesse núcleo se destacam a representação do Espírito Santo, a primeira peça do acervo, visualizada em um painel de madeira sobre o texto de apresentação, assim como as figuras de Jesus recém-nascido e de um Cristo Crucificado, lembrando-se do mistério da Encarnação e Redenção de Jesus.

Com o auxílio de letra de música e textos poéticos conhecidos do grande público frequentador da Basílica de Aparecida, reproduzidos em placas de vidro sobre painéis de madeira, pretende-se aproximar o visitante com a emoção religiosa, reavivando as ligações mais próximas dos devotos com Maria.

No segundo núcleo, a figura de Maria é apresentada em sua dimensão humana e terrena, compreendida como um elemento fundamental na história da salvação, por ter aceitado essa missão de gerar o Cristo. Para o entendimento histórico são apresentados textos canônicos e apócrifos, especialmente fragmentos 
dos Evangelhos, considerados como fontes principais para entender a presença de Maria (conforme podemos observar na Figura 102).

De acordo com as curadoras, "embora pouco citada nos Evangelhos, Maria tem sua presença marcada desde a anunciação do nascimento de Jesus até após a morte do Cristo. Mãe do Messias, é apresentada como mulher humilde, de fé, livre, autônoma, primeira cristã e mãe da Igreja" (PEIXE; BIGARELI, 2004, p. 27).

Nesse núcleo destacam-se as imagens de Sant'Ana Mestra, São Joaquim, Nossa Senhora Menina, assim como outras imagens que representam a anunciação, a gravidez e o nascimento de Jesus. E, por fim, as dores de Nossa Senhora, a Via-Sacra e o Calvário, por meio das imagens do Bom Jesus, Senhor dos Passos, Cristo Crucificado, Nossa Senhora das Dores e Nossa Senhora da Piedade. São obras datadas desde o século XVII até o século $X X$, que demonstram a devoção do povo à mãe de Deus.

Figura 102: Núcleo sobre Maria - Exposição "Rainha do Céu, Mãe dos Homens: Aparecida do Brasil.”

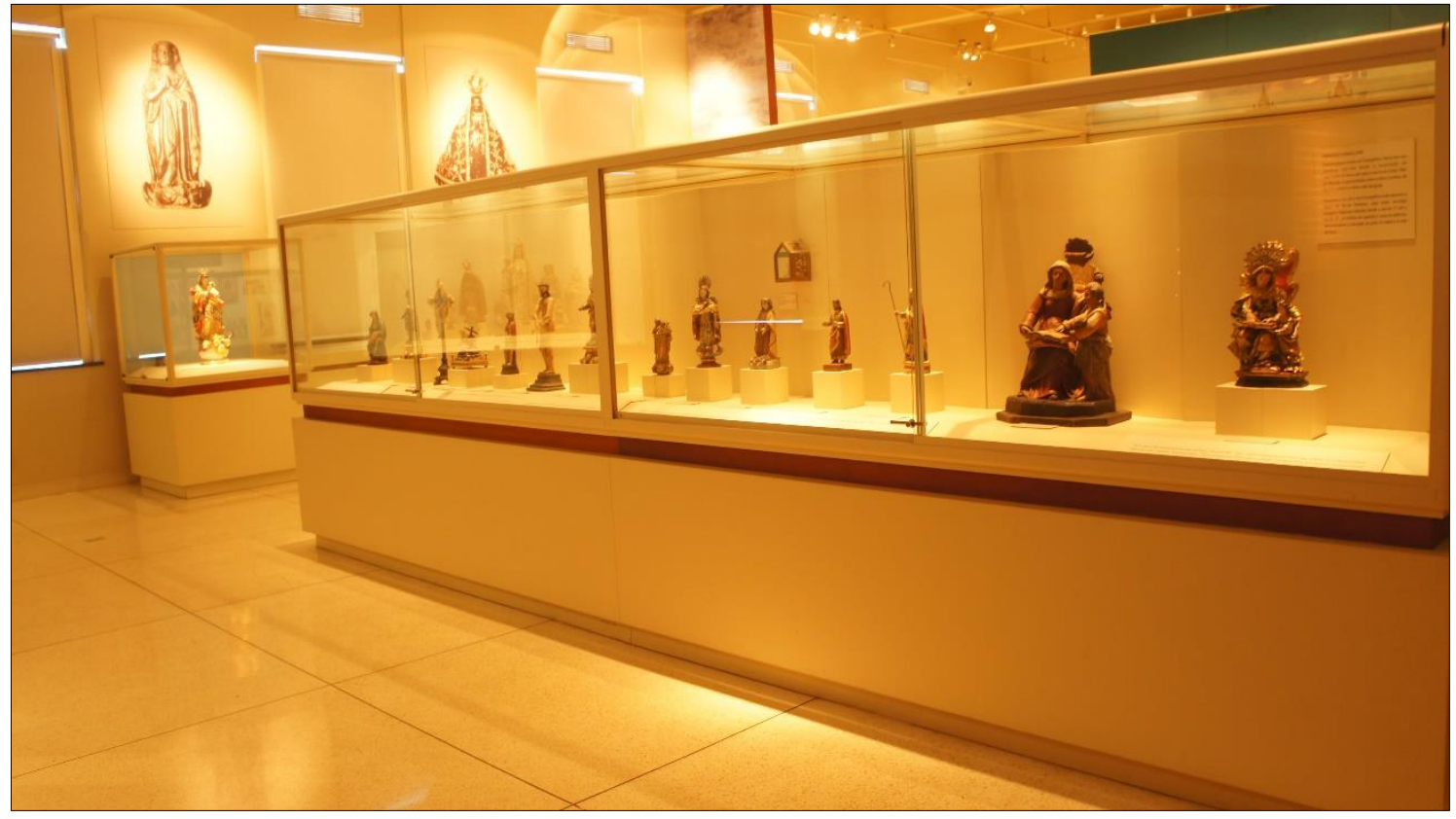

Fonte: MNSA/ Santuário Nacional. Foto: Erica Coelho.

No terceiro núcleo são abordados os Dogmas Marianos, demonstrando assim as verdades de fé estabelecidas pela Igreja. Portanto, no corredor de entrada à esquerda, há um texto sobre painel de madeira que descreve os quatro Dogmas Marianos: Mãe de Deus, A Virgindade Perpétua, Imaculada Conceição de Maria e Assunção de Maria. 
Mãe de Deus

A primeira verdade sobre Maria foi definida pelo Concílio de Éfeso em 431, e definiu que a Virgem Maria é verdadeiramente Mãe de Deus, Teotókos, pois deu à luz segundo a carne aquele que é o verbo de Deus. É celebrado na liturgia em $1^{\circ}$ de janeiro.

A Virgindade Perpétua

O segundo dogma foi instituído no terceiro Concílio de Latrão, de 649, pelo Papa Martinho I, e define a Virgindade Perpétua de Maria, virgem antes, durante e depois de dar à luz a Cristo.

Imaculada Concepção: Imaculada Conceição de Maria

A terceira verdade foi definida pelo Papa Pio IX no dia 08 de dezembro de 1854, por meio da Bula Ineffabilis Deus, e pronuncia que Maria foi, desde o primeiro instante da sua concepção, preservada e imunizada de toda a mancha do pecado original, por graça de Deus Todo-Poderoso.

Assunção de Maria

O quarto dogma Mariano foi definido pelo Papa Pio XII, em 1950, e declara que a Virgem Maria, terminada sua vida terrena, foi elevada, assunta à glória celeste, em corpo e alma. Celebrado em 15 de agosto. (PEIXE; BIGARELI, 2004, p. 30).

No quarto núcleo (Figura 103) são apresentadas algumas das diversas invocações que Maria recebeu ao longo do tempo, na tradição cristã, revestida dos aspectos de sua figura como Mãe de Deus, da Igreja e dos homens. De maneira geral, o culto a Maria iniciou-se nos primeiros séculos do Cristianismo e manifesta-se em diversas formas.

De acordo com as curadoras, "as invocações são muitas, mas uma só é a Virgem, revestida de atributos que a identificam como santa, figura dolorosa e gloriosa, protetora, intercessora, virgem, rainha, fonte de sabedoria, libertadora, mãe de Deus e dos homens" (PEIXE; BIGARELI, 2004, p. 31).

Nesse núcleo destacam-se imagens de Nossa Senhora das Graças, Nossa Senhora do Rosário, Nossa Senhora da Penha, Nossa Senhora das Dores, especialmente Nossa Senhora da Conceição, entre outras invocações. Ao fundo da vitrine, mostrando por meio de uma reprodução adesivada, há algumas denominações de Nossa Senhora, retratando essa devoção universal, no tempo e no espaço. 
Figura 103: Núcleo sobre as invocações de Maria - Exposição "Rainha do Céu, Mãe dos Homens: Aparecida do Brasil."

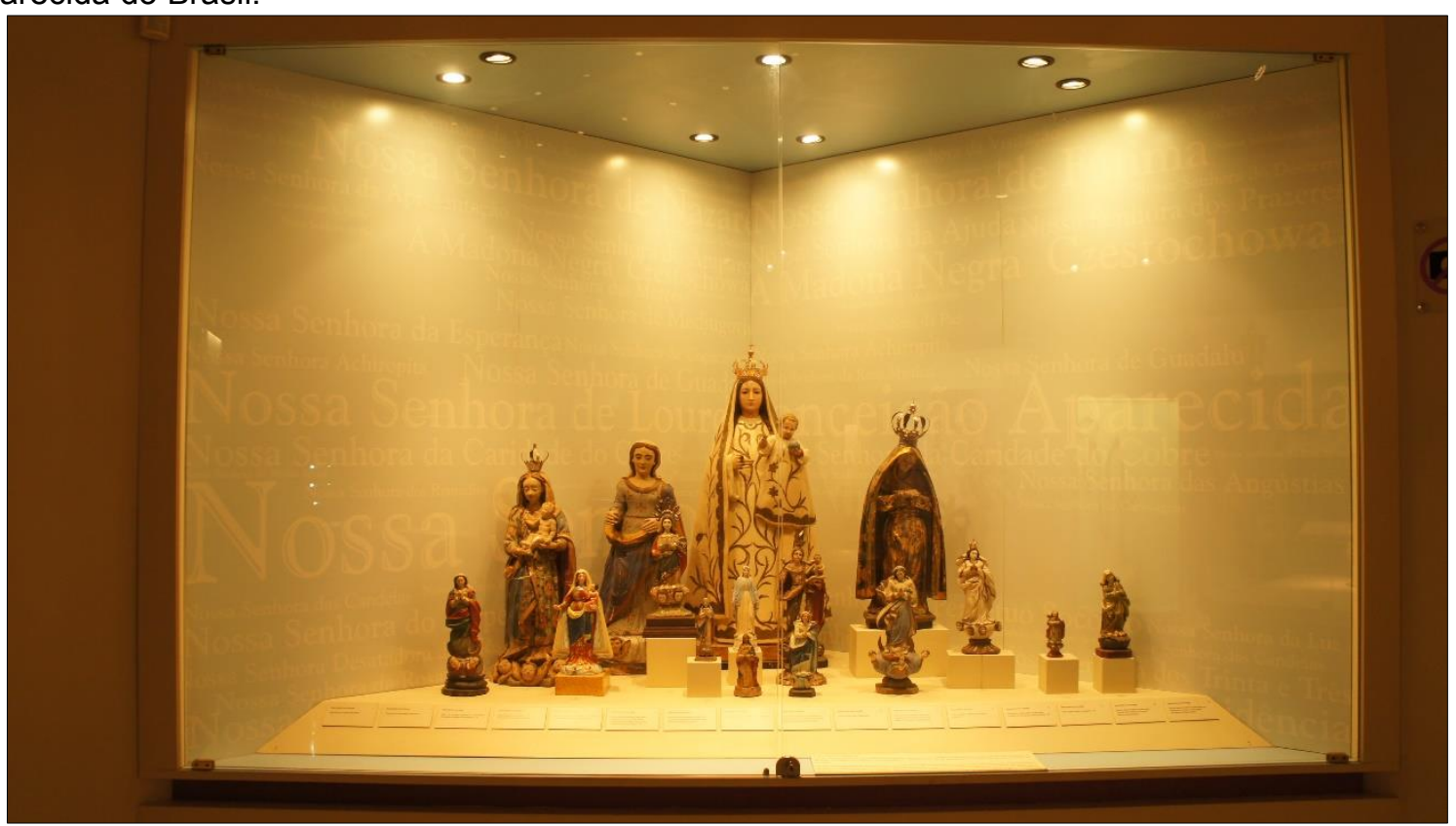

Fonte: MNSA/ Santuário Nacional. Foto: Erica Coelho.

No quinto núcleo, há uma vitrine dedicada a Nossa Senhora da Conceição, dando destaque a essa invocação de Maria, abordando a influência da tradição portuguesa na devoção à Imaculada Conceição, conforme consta no texto da curadoria:

A devoção à Imaculada Conceição de Maria é anterior à proclamação do dogma, em 1854. Desde o século VIII os cristãos já reconheciam e festejavam a pureza da mãe de Deus, a única criatura humana isenta e preservada do pecado original.

No Brasil, desde o descobrimento, numerosos eram os oratórios, ermidas e capelas nos quais se venerava a Imaculada Virgem Maria, a Senhora da Conceição.

Em 1646, o reino de Portugal foi dedicado à Virgem Imaculada e a festa da Conceição de Maria passou a ser celebrada de forma oficial e obrigatória também em todas as colônias. Protetora do Brasil no período colonial, foi proclamada por D. Pedro I Padroeira do Império Brasileiro. (PEIXE; BIGARELI, 2004, p. 35).

No sexto núcleo há um painel explicativo sobre a iconografia dessa invocação, e compondo uma vitrine estão uma imagem fac-símile de Nossa Senhora da Conceição com seus atributos, o manto utilizado na Coroação de Nossa Senhora em 1904 e uma réplica da coroa doada pela Princesa Isabel.

A Figura 104 apresenta o quinto e sexto núcleo da exposição. 
Figura 104: Núcleo sobre Nossa Senhora da Conceição - Exposição "Rainha do Céu, Mãe dos Homens: Aparecida do Brasil."

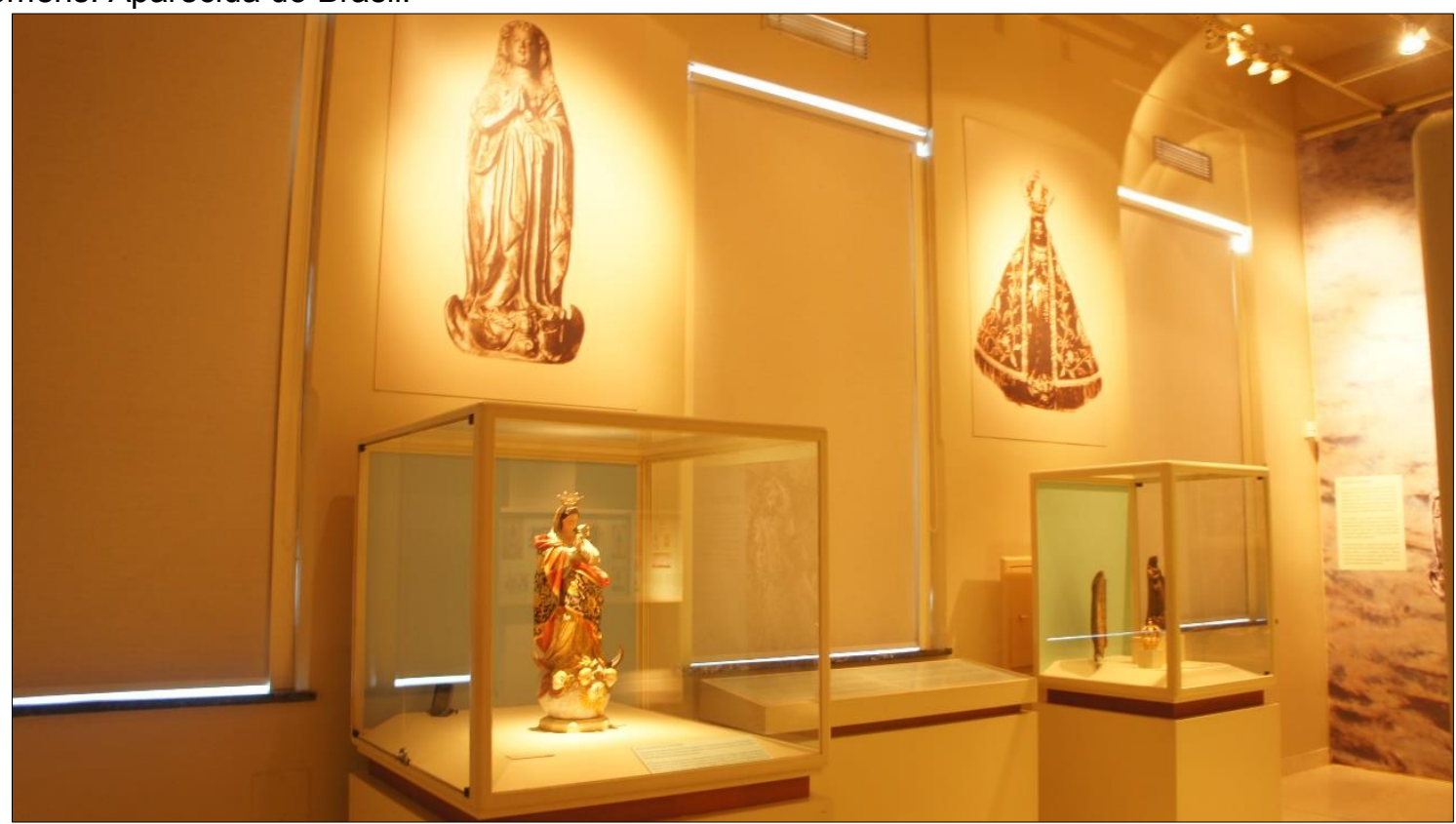

Fonte: MNSA/ Santuário Nacional. Foto: Erica Coelho.

Dando sequência a esse núcleo, há painéis fotográficos com a imagem de Nossa Senhora da Conceição Aparecida, inicialmente sem os atributos, e depois com manto e coroa. De acordo com Peixe e Bigareli (2004, p. 36),

Nossa Senhora da Conceição é representada de pé, sobre o globo terrestre, com as mãos unidas em oração; com os pés esmaga uma serpente, símbolo cristão do pecado original. Sob os pés também aparecem a lua crescente e anjos. Em torno da cabeça, muitas vezes aparece uma coroa de doze estrelas.

Já a representação de Nossa Senhora Aparecida como a conhecemos hoje se trata de uma imagem de Nossa Senhora da Conceição enegrecida, devido ao tempo em que ficou no rio, somando-se às fuligens das velas, tendo como atributos um manto triangular e coroa.

Segundo Peixe e Bigareli (2004, p. 37), "não se pode precisar quando o manto foi incorporado à escultura original, mas o primeiro documento escrito sobre ela, o Livro de Tombo da paróquia de Guaratinguetá, datado de 1757, já menciona a existência de um manto carmim para a imagem milagrosa".

A seguir, há também um painel ilustrando o encontro da imagem, com reprodução de uma imagem das águas do Rio Paraíba do Sul. Na face oposta do painel, há um texto contextualizando as intervenções que a imagem de Nossa Senhora Aparecida recebeu no decorrer do tempo para sua preservação, bem como 
descrevendo o restauro que foi realizado após o atentado de 1978, que fragmentou a imagem em mais de 160 pedaços.

Sobre as intervenções, Giselle Peixe e Silvia Bigareli descrevem que

\begin{abstract}
A imagem, desde seu achamento nas águas do rio, passou por várias intervenções que buscavam integrar as partes fragmentadas. Desde os primeiros tempos de sua devoção, no século XVIII, já trazia em torno do pescoço cordões de ouro para reforçar a colagem da cabeça ao tronco.

A primeira restauração aconteceu em 1946, acrescentando-se as madeixas laterais do cabelo, que se juntavam aos ombros.

Em 1950, foi feita nova colagem do pescoço, introduzindo-se também um pino para sustentação, além de uma pátina com extrato de nogueira.

Em 1965, uma trinca na base do pescoço foi colada.

Em 1978, um atentado, que consternou o país, reduziu a peça a mais de 160 pedaços. A reconstituição foi feita no Museu de Arte de São Paulo MASP, por Maria Helena Chartuni. (PEIXE; BIGARELI, 2004, p. 39-40).
\end{abstract}

No sétimo núcleo (Figura 105), em uma grande vitrine compartilhada com o núcleo inicial, há várias imagens de Nossa Senhora Aparecida, confeccionadas com materiais diversos, como barro, gesso, madeira e metal, retratando como a devoção foi incorporada na cultura popular.

Há também outros objetos do cotidiano que demonstram como essa representação foi disseminada pelo país e no exterior, sendo encontrada em produtos artesanais ou industriais, como, por exemplo, reproduções em souvenir e demais representações impressas, que foram inspiradas em estampas de santinhos, desde o século 19, na Europa, organizados por tipologias e pelos elementos que foram incorporados no decorrer dos anos, em todo tipo de objeto, podendo ser lembrada e venerada. 
Figura 105: Núcleo sobre as representações de Nossa Senhora Aparecida - Exposição "Rainha do Céu, Mãe dos Homens: Aparecida do Brasil".

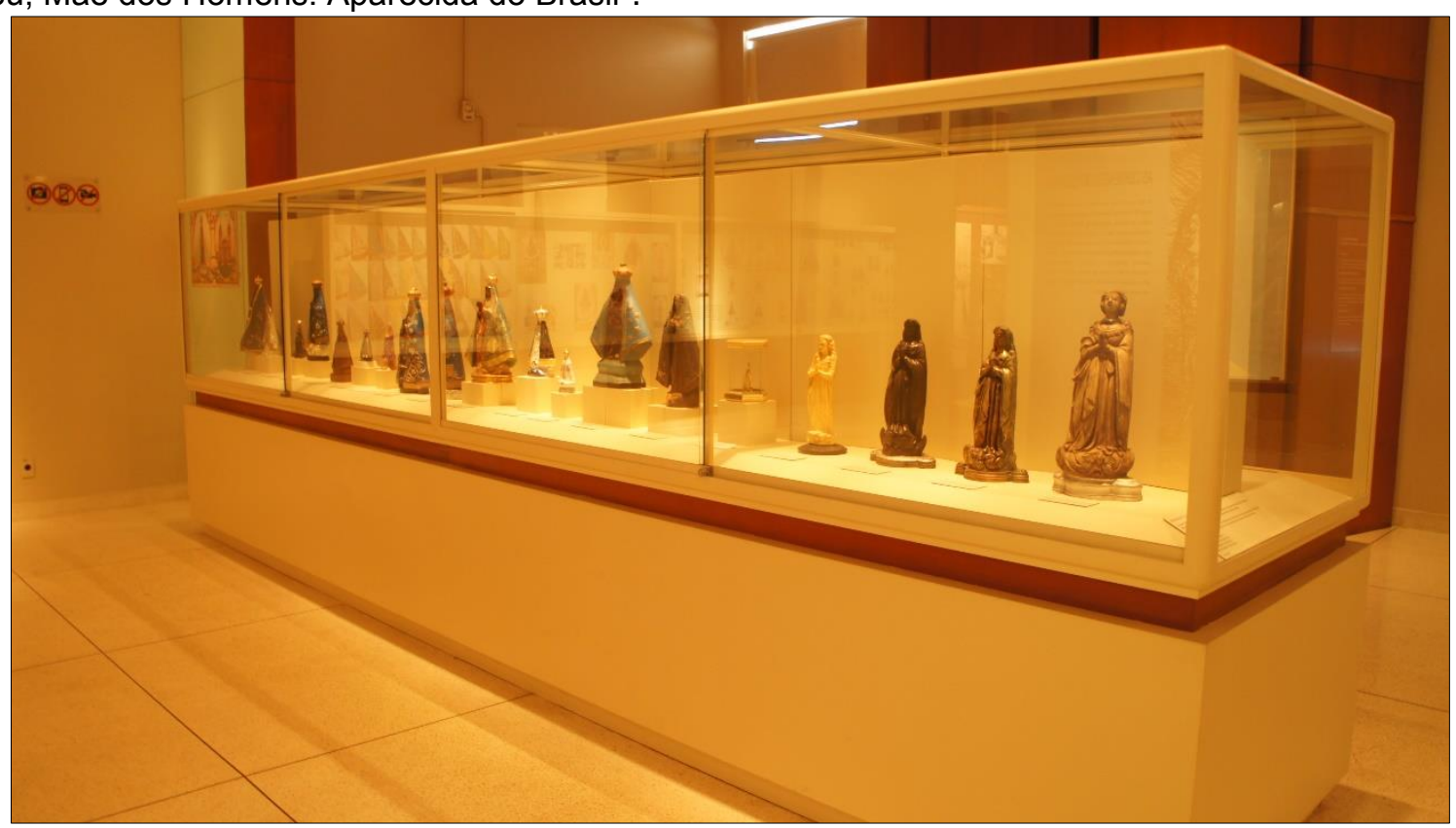

Fonte: MNSA/ Santuário Nacional. Foto: Erica Coelho.

Em destaque nesse núcleo, além de uma representação de uma estampa francesa de Nossa Senhora Aparecida com cútis branca, há também copos, pratos e vasos, que foram decorados com figuras da Basílica, de Nossa Senhora e encontros temáticos, como, por exemplo, o Congresso Mariano.

Conforme o texto de curadoria, "as estampas de Nossa Senhora Aparecida, impressas em gráficas brasileiras, serviram de inspiração para muitos artistas, que as reproduziram em tela para devoção ou em agradecimento a graças alcançadas" (PEIXE; BIGARELI, 2004, p. 42).

No oitavo núcleo (Figura 106), na área central da exposição, apresenta-se a interioridade da devoção do fiel. Nesse núcleo há uma composição de ex-votos, em diversos materiais e formatos, enfatizando o agradecimento da religiosidade popular.

De acordo com Peixe e Bigareli (2004, p. 45), "as peças, fotografias e pedidos escritos expressam todo tipo de necessidade, angústia e agradecimento, seja pela saúde, amor, relacionamento, libertação de vícios, questões financeiras, aquisição de bens materiais, sucesso na carreira". Ainda segundo as curadoras, os objetos feitos nos mais diversos materiais e formas de expressão, de maneira artesanal ou industrial, "representam, na fé simples do povo, os dramas, as provações e as conquistas dos devotos que põem sob a proteção maternal e o poder de Nossa Senhora seus anseios mais profundos" (PEIXE; BIGARELI, 2004, p. 45). 
A vitrine central é considerada o âmago do núcleo, contendo, além de exvotos, algumas reproduções de cartas e pedidos realizados a Nossa Senhora Aparecida, permitindo estabelecer uma ligação com a área final da exposição, que possui outra vitrine circular, também trabalhada com elementos de devoção.

Figura 106: Núcleo sobre a devoção - Exposição "Rainha do Céu, Mãe dos Homens: Aparecida do Brasil."

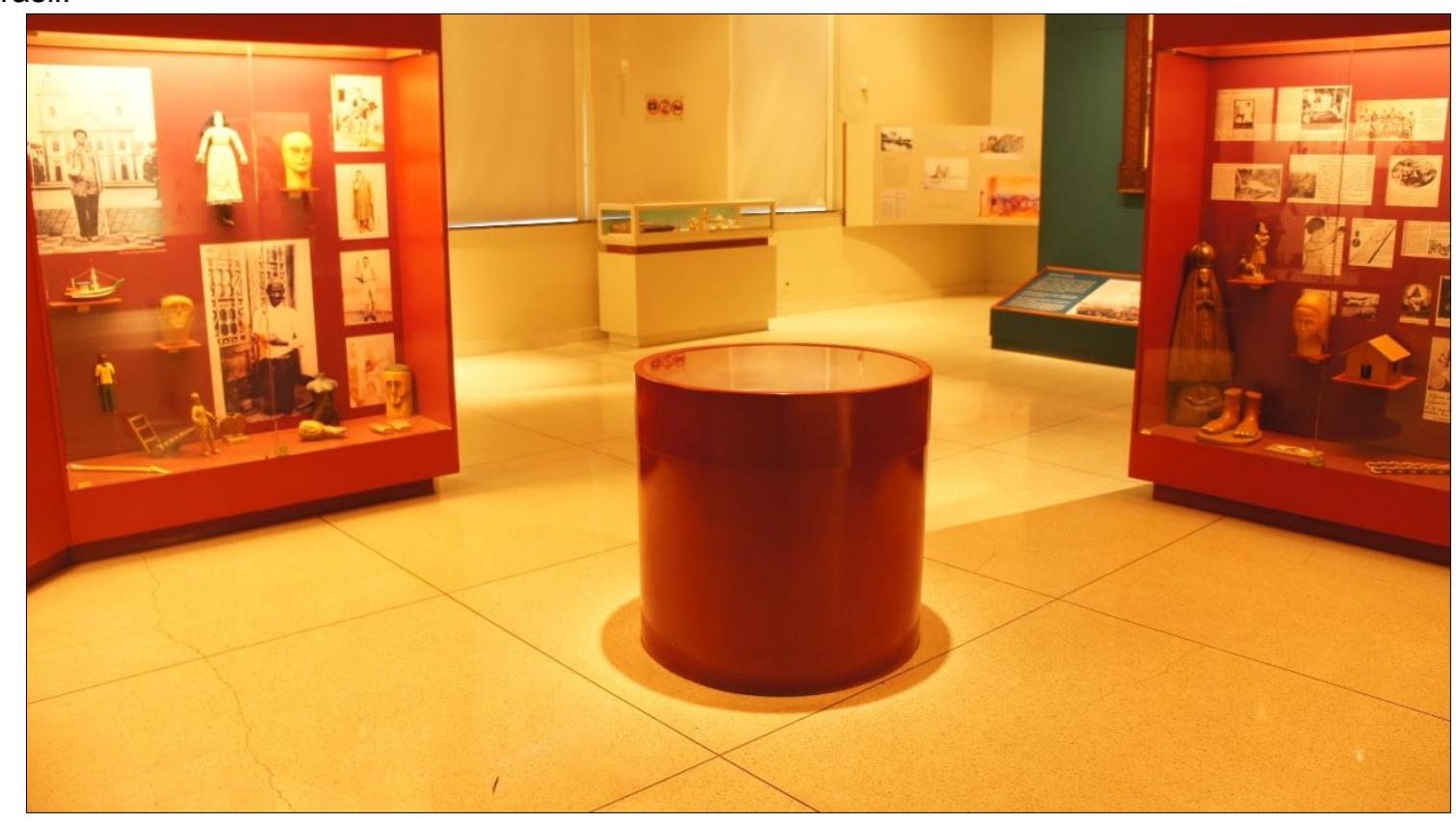

Fonte: MNSA/ Santuário Nacional. Foto: Erica Coelho.

Na parte externa, no oitavo núcleo também há reproduções de gravuras retratando os milagres de Nossa Senhora Aparecida, tendo como destaque os objetos-testemunhos, representados pelas correntes atribuídas ao milagre do escravo liberto e a pedra da entrada da Basílica Velha, com a marca da ferradura do cavalo, atribuído ao milagre do cavaleiro ateu.

De acordo com o texto de curadoria, além da pesca milagrosa, na qual foi encontrada a imagem de Nossa Senhora, são quatro milagres mais conhecidos, sendo estes:

Milagre das velas

No primitivo oratório no Porto de Itaguaçu, primeiro local de devoção da imagem de Aparecida, o povo se encontrava numa noite reunido em oração. Durante o canto do terço, as velas do local apagaram-se repentinamente e sem motivo, pois a noite estava serena. Houve espanto entre os devotos e quando Silvana da Rocha procurou acendê-las novamente, elas se reacenderam por si, prodigiosamente.

As correntes do escravo

Um dos milagres mais conhecidos ocorreu em meados do século XIX. Um escravo de nome Zacarias fugiu da casa do seu senhor, em Curitiba. Refugiado no Vale do Paraíba, foi recapturado por um capitão-do-mato. Ao passar por Aparecida, o escravo pediu para entrar na Capela, no que foi 
atendido. Ao pedir a proteção de Nossa Senhora, as correntes de ferro que o prendiam quebraram-se e caíram. O capitão-do-mato comunicou o fato ao senhor do escravo, que the concedeu alforria. Zacarias permaneceu prestando serviços na Capela, mais tarde Basílica de Aparecida.

O cavaleiro ateu

Um cavaleiro, passando por Aparecida vindo de Cuiabá, e dizendo não acreditar nos milagres de Nossa Senhora Aparecida, quis desafiar a fé dos romeiros, entrando na igreja a cavalo. Ao tentar subir de montaria a escada do templo, a ferradura do cavalo cravou-se na pedra ao lado do primeiro degrau, de modo que 0 animal não podia mais erguer as patas. Arrependido, desceu do cavalo e entrou na Igreja com as mãos postas e pediu a Nossa Senhora que o perdoasse, acreditando em seus milagres e em seu grande poder.

\section{A menina cega}

No ano de 1874, Gertrudes Vaz e sua filha cega vieram de Jaboticabal a Aparecida, numa viagem que durou três meses, pois a menina queria muito visitar Nossa Senhora. Ao chegarem à entrada da cidade, dona Gertrudes percebeu que tanto sacrifício tinha valido a pena:

- Olhe, mamãe, a capela da Santa, disse a menina. (PEIXE; BIGARELI, 2004, p. 43-44).

No nono núcleo da exposição, exalta-se a Rainha do Brasil por meio de uma grande tela do pintor italiano Rosalbino Santoro, que retrata a Coroação de Nossa Senhora Aparecida em 1904 (Figura 107), já citada anteriormente nesta dissertação.

Abaixo da grande tela, há textos e fotografias que complementam o contexto histórico da Coroação, fornecendo elementos sobre a Basílica Velha, retratada por outra tela com a Praça Nossa Senhora Aparecida, de autoria do Irmão Bento, um dos primeiros missionários redentoristas alemães que chegaram em Aparecida no final do século 19.

Nesse núcleo há também uma vitrine com a almofada que acompanhava a coroa doada pela Princesa Isabel, além dos protótipos das coroas finalistas do concurso realizado em 2004, em comemoração ao Centenário da Coroação. 
Figura 107: Núcleo que retrata a Coroação de Nossa Senhora Aparecida - Exposição "Rainha do Céu, Mãe dos Homens: Aparecida do Brasil."

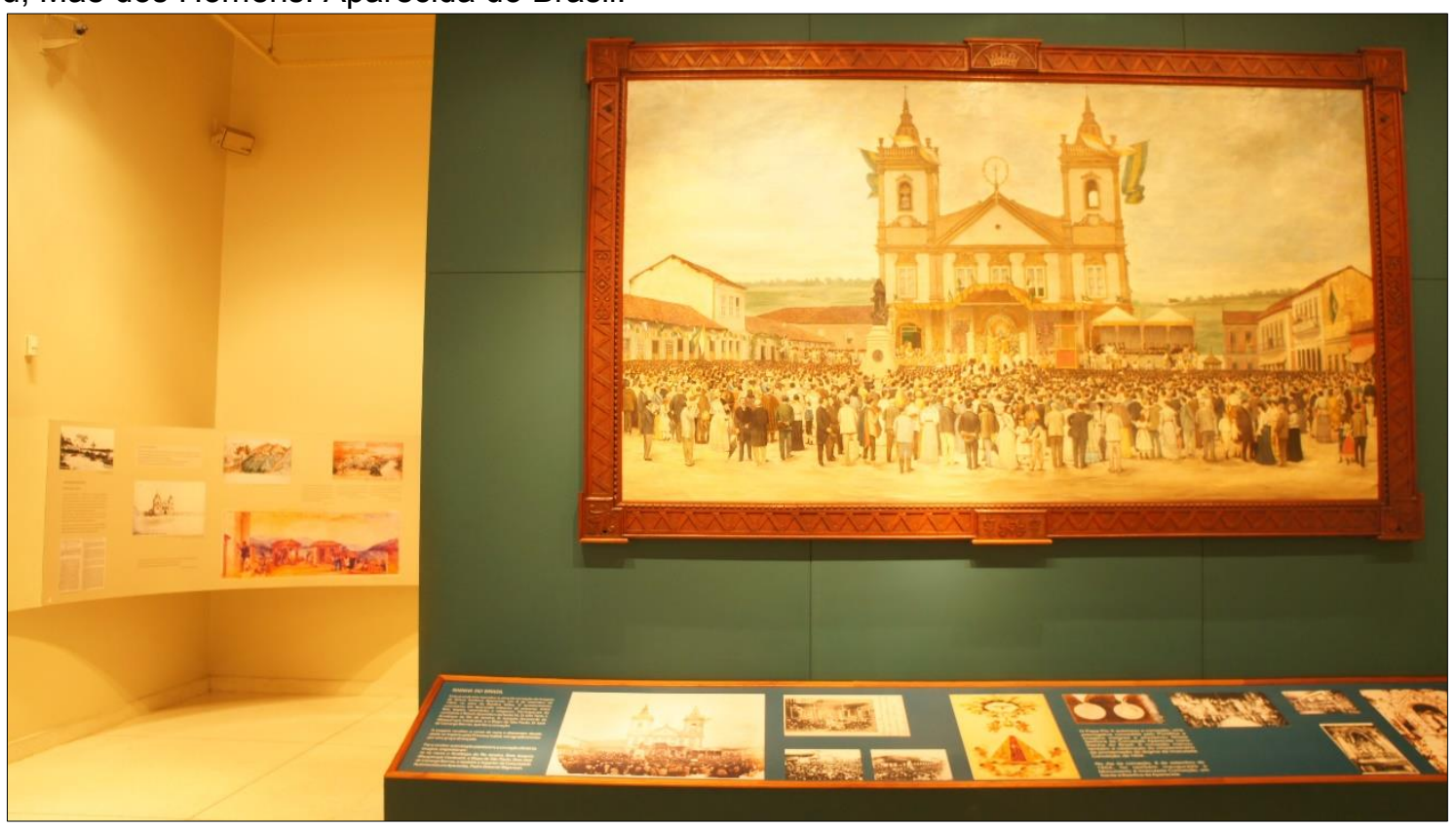

Fonte: MNSA/ Santuário Nacional. Foto: Erica Coelho.

O décimo núcleo (Figura 108), localizado atrás da grande tela da Coroação, aborda, por meio de painéis fotográficos, um breve histórico sobre a devoção a Nossa Senhora e o desenvolvimento do município de Aparecida-SP.

De acordo com Peixe e Bigareli (2004, p. 48),

O desenvolvimento do povoado, em torno da devoção à Padroeira, foi marcado pelo crescimento intenso da peregrinação, pela construção da Basílica Velha, pela instalação das diversas congregações religiosas na cidade, pela abertura da estação ferroviária, pela chegada dos Missionários Redentoristas, pela consolidação do culto, com a Coroação como "Rainha do Brasil" em 1904 - e pela emancipação política.

É importante considerar a vinda dos Missionários Redentoristas em 1894, para cuidar do serviço religioso e da administração do Santuário, bem como a evangelização dos romeiros, por meio da criação de veículos de comunicação impressa e radiodifusão, que foi ampliada com a mídia televisiva e portal na internet.

Ainda nesse núcleo expositivo, há outros fatos marcantes, como a construção e ampliação da Basílica, assim como início das obras de revestimento, além de um texto explicativo sobre a criação da Arquidiocese de Aparecida.

Há também um texto sobre as principais peregrinações da imagem de Nossa Senhora Aparecida e os festejos para a Proclamação de Nossa Senhora Aparecida como Padroeira do Brasil, em 1931, e também, a visita do Papa João Paulo II para a sagração da Basílica, em 1980, e a bênção e envio da Rosa de Ouro ofertada pelo 
Papa Paulo VI, por ocasião do jubileu dos 250 anos do encontro da Imagem de Nossa Senhora Aparecida.

Figura 108: Núcleo histórico - Exposição "Rainha do Céu, Mãe dos Homens: Aparecida do Brasil."

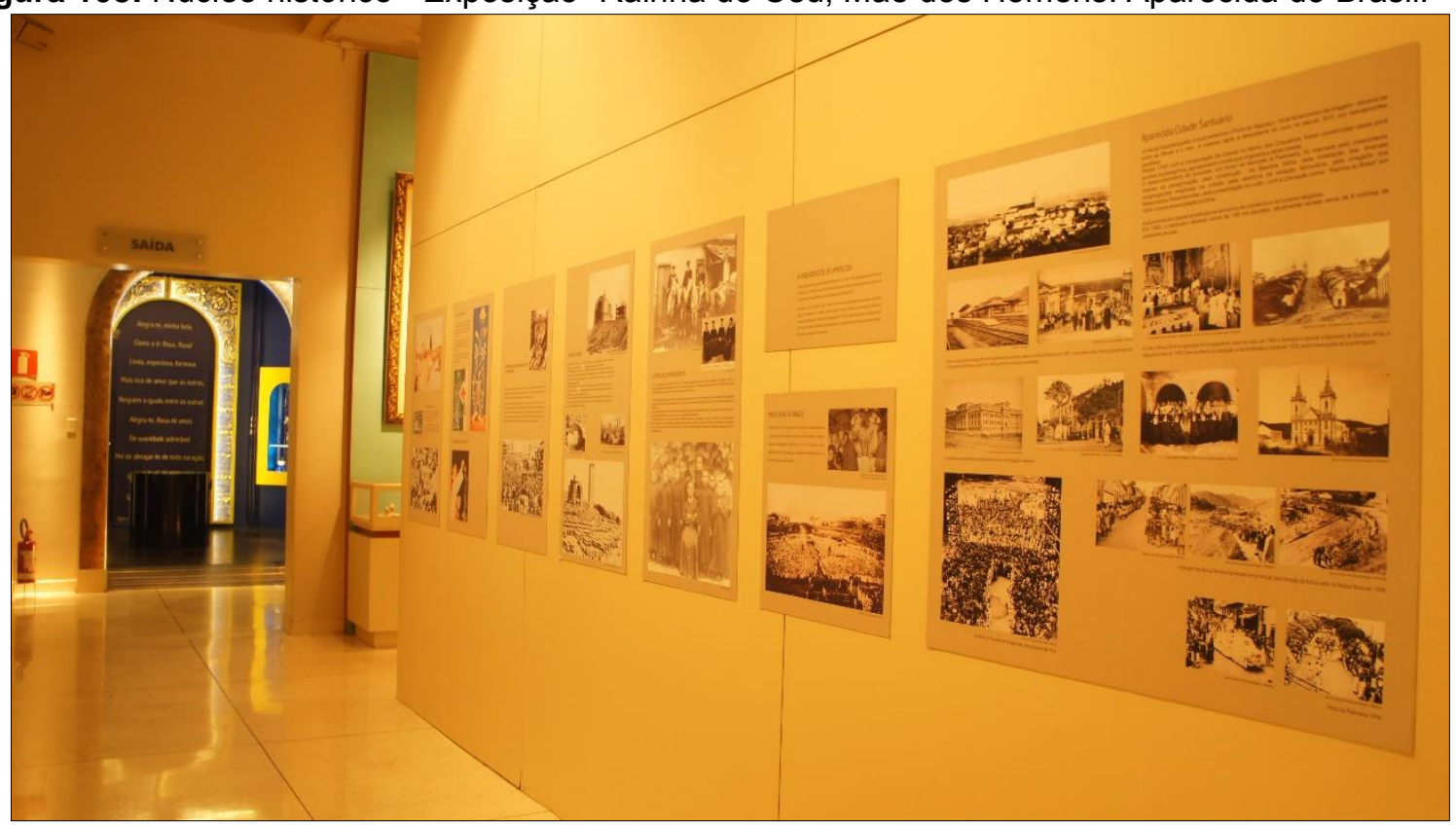

Fonte: MNSA/ Santuário Nacional. Foto: Erica Coelho.

E, finalmente, no décimo primeiro núcleo, área de conclusão da exposição, pretende-se mostrar uma atmosfera mística, formada por bens preciosos ofertados ao Santuário, que retratam a devoção a Maria, vista como "bela flor do jardim divino, sede da sabedoria, reflexo da justiça de Deus" (PEIXE; BIGARELI, 2016. p. 57).

Conforme o texto de curadoria,

Maria é celebrada pelos místicos, pelos iletrados, pelos poetas, pelos filósofos, pelos teólogos, pelos cristãos em geral. Sua grandeza reside toda a graça de ter sido eleita, entre os humanos, para os planos de Deus. Como Casa de Ouro, acolheu na terra, no santuário de seu corpo e de seu coração, o Filho de Deus encarnado. (PEIXE; BIGARELI, 2016. p. 57).

Esse núcleo, abordado anteriormente nesta dissertação, é denominado "Domus Aurea", ou seja, Casa de Ouro, e apresenta nas paredes alguns textos poéticos e cânticos, assim como vários painéis bordados com joias, incorporando aspectos da mística mariana, além de som ambiente, que busca suscitar a emoção do visitante.

De acordo com Souza (2008. p. 89-90),

A intenção dessa exposição, por conseguinte, é contar como Maria é vista através dessas imagens, de seus milagres e graças concedidas. Os objetos doados também são documentos, provas de que pessoas alcançaram graças por intermédio dela. Nesse sentido, o objeto do museu perde seu valor de uso: um maço de cigarros ali exposto não é apenas uma 
embalagem descartável, mas é o testemunho de um fato ocorrido e que, por evidenciar isso, torna-se apto de estar ali. As joias, embora mantenham intrinsecamente o valor monetário, pois são de ouro ou de prata expostas, são mais que representações de riqueza, reforçam a ideia de que Maria é essa riqueza perante a humanidade; revelam a intenção de compreender o corpo dessa mulher santa como algo místico, precioso, valioso, não materialmente, mas espiritualmente.

Nesse contexto, as imagens e os textos bíblicos se sucedem, abrindo diversas formas de leitura, nas quais os objetos não ilustram os temas, pois estão presentes no imaginário das pessoas, fazendo com que as ideias se personifiquem por si mesmas.

\section{Síntese analítica do conjunto de elementos da exposição}

Conforme mencionado anteriormente, a metodologia de observação e análise utilizada para descrever as exposições do Museu Nossa Senhora Aparecida foi desenvolvida por Marília Xavier Cury, organizada como um Roteiro de observação para visitas a museus e exposições.

O intuito desta síntese é fazer uma reflexão quanto à eficácia e qualidade da exposição Rainha do Céu, Mãe dos Homens: Aparecida do Brasil, a partir do estudo do conjunto de elementos que a compõem.

Em relação à localização e funcionamento do Museu, observamos que em todo o Santuário Nacional há placas de sinalização indicando a visitação ao Mirante e Museu, na Torre Brasília. Já na parte externa da Torre, há sinalização sobre os horários de atendimento, que são diferenciados para os dias de semana, finais de semana e feriados, assim como indicação de valores dos ingressos na parte externa da bilheteria, no hall da Torre.

Observamos que, somando-se a essa comunicação visual, há funcionários do Museu em frente aos elevadores no hall da Torre, para recepção e direcionamento dos visitantes à bilheteria e organização das filas de acesso aos elevadores, que também são utilizados pelos demais funcionários dos departamentos administrativos localizados na Torre.

Em relação ao espaço físico da exposição, situada no $1^{\circ}$ andar da Torre, o qual abrigava a Sala das Promessas até a década de 1970, conforme relatado no capítulo 1 desta dissertação, notamos que a princípio era necessário que o ascensorista indicasse aos visitantes a direção da entrada, pois a sala de 
encerramento da exposição fica mais próxima dos elevadores, do que a porta de entrada. Atualmente, com a nova exposição no $2^{\circ}$ andar, a maioria dos visitantes utiliza as escadas para acessarem a exposição no $1^{\circ}$ andar, com exceção de cadeirantes, idosos, pessoas com mobilidade reduzida e pais que portam carrinhos de bebês, que têm acesso preferencial pelos elevadores.

De maneira geral, a exposição foi organizada com um corredor inicial, seguindo à esquerda dos elevadores, o qual apresenta o título da exposição, com algumas ilustrações sobre a pesca milagrosa da Imagem de Nossa Senhora Aparecida e representação da devoção popular. Ao final do corredor há o balcão de recepção, com a ficha técnica à esquerda, dando acesso à ampla sala da exposição. Não foram localizados guarda-volumes aos visitantes, embora ao lado da recepção há acesso a uma sala de apoio e banheiros, não abertos ao público.

Em relação à acessibilidade, desde 2008 os elevadores da Torre Brasília têm o Mirante (16 andar) como destino inicial da visita, possibilitando que cadeirantes e pessoas com mobilidade reduzida façam a visita completa ao Mirante e Museu. Apesar da adequação do espaço físico, não foram encontrados registros sobre demais recursos para acessibilidade de deficientes auditivos, visuais e de outras naturezas.

Diferentemente da antiga exposição, no $2^{\circ}$ andar, que apresentava um grande acúmulo de objetos em exposição, inclusive sobre os armários, fixados nas paredes ou suspensos do teto, a exposição Rainha do Céu, Mãe dos Homens: Aparecida do Brasil exibe poucas peças do acervo, conforme o conceito temático de cada núcleo, dando destaque aos objetos por meio de recursos expográficos como suportes cúbicos e iluminação direcionada. Com isso, identificamos a importância dada aos objetos museológicos, considerando a relevância deles para o contexto de cada núcleo, organizado com vitrines de formatos e cores diferentes, de acordo com o conceito temático.

O espaço para visitação é amplo, com uma sala dividida por núcleos expositivos, bem organizados, que conduzem o fluxo de visitação de maneira cronológica e sequencial, embora o trajeto proposto ao público não seja único, pois a divisão dos núcleos temáticos permite que os visitantes transitem de forma independente, conforme o interesse.

Como recursos expográficos, além das vitrines e nichos nas paredes, há painéis fotográficos e textuais, adesivados sobre placas ou gravados em vidro. 
Em relação à qualidade da comunicação visual, percebemos um equilíbrio entre as cores, fontes dos textos e reprodução das imagens, dando contraste ao conteúdo, ao escolher o bege como cor de fundo dos painéis. As etiquetas dos acervos também seguem uma padronização, assim como os textos de apoio no interior das vitrines.

Observamos que as cortinas fixas barram a entrada de luz natural, ao mesmo tempo que contribuem para o equilíbrio entre as cores das paredes e dos mobiliários. Com isso, a iluminação foi planejada de maneira geral para a sala da exposição, com alguns focos pontuais, para dar destaque a determinados elementos textuais e objetos.

$\mathrm{Na}$ área de finalização, em uma pequena sala anexa, ao lado dos elevadores, está a Domus Aurea, que possui uma concepção diferenciada do restante da exposição. Em um ambiente mais escuro, na cor azul do manto de Nossa Senhora, essa sala possui uma climatização para dar ênfase nessa mudança de espaço físico. Como recurso expográfico, há um grande arco de rosas feitas com folhas desidratadas, artesanato típico do cerrado brasileiro, relacionando a figura de Maria como Rosa Mística. Nessa sala há uma sonorização específica, remetendo à natureza, com sons de floresta, pássaros e água.

Outro fator que diferencia esse ambiente do restante da exposição é o próprio mobiliário, em outro estilo, na cor dourada nas laterais e azul ao centro, considerando o tema e as características dos objetos expostos, sendo estes joias doadas pelos devotos em sinal de agradecimento a Nossa Senhora por uma graça alcançada, além de objetos litúrgicos de valor histórico e artístico, ofertados pelos Pontífices em momentos comemorativos ou trazidos pelos primeiros Missionários Redentoristas que vieram em missão pastoral para administrar o novo Santuário.

Em relação à segurança do espaço, observamos que, nas primeiras visitas exploratórias para realização desta dissertação, havia um segurança patrimonial em frente a Domus Aurea. Atualmente, não há mais esse posto da segurança patrimonial do Santuário, pois o espaço é supervisionado pelo recepcionista do Museu, com respaldo das câmeras de vigilância e alarmes. Há ainda elementos de segurança contra incêndio, como extintores, sensores de fumaça e hidrante, como padronização de todos os andares da Torre.

Conforme mencionado anteriormente, a Ficha Técnica da exposição está localizada próximo ao balcão de recepção, ao lado da sala de apoio dos 
funcionários. Nela constam as ações discriminadas para cada parte do projeto expositivo, bem como os profissionais envolvidos, além dos agradecimentos gerais às demais pessoas que colaboraram de alguma forma com as pesquisas e 0 desenvolvimento do projeto. De maneira geral, a exposição é uma realização do Santuário Nacional de Aparecida, não constando na ficha técnica demais créditos de apoio financeiro.

Considerando o conjunto de elementos apresentados, acreditamos que a exposição é harmoniosa, apresentado equilíbrio nas cores, recursos expográficos, iluminação, sonorização, passando uma ideia de unidade, mesmo ao dar destaque na sala de finalização da exposição.

De maneira geral, observamos inteligibilidade na composição dos núcleos, sendo facilmente interpretada pelos diversos públicos. É possível constatar, também, que o espaço é condizendo com o tema central da exposição, bem como com as propostas temáticas dos núcleos.

Embora a exposição não tenha recebido uma manutenção significativa desde a sua inauguração, em 2005, observamos que os recursos expográficos atendem as demandas informacionais, assim como as expectativas dos visitantes, que vão em busca, principalmente, dos objetos-testemunhos dos milagres de Nossa Senhora Aparecida, assim como das Rosas de Ouro ofertadas pelos Pontífices Paulo VI, Bento XVI e Francisco.

A partir dessa perspectiva de infraestrutura, fica evidente a necessidade de manutenção, observada pelo desgaste do piso, que apresenta trincas relacionadas ao pouco tempo de secagem do piso de granilite, além da falta de climatização na sala principal, podendo causar algum desconforto aos visitantes e funcionários, em dias de grande movimento, devido à falta de circulação de ar.

Em suma, acreditamos que o conjunto de elementos analisados nesta dissertação é suficiente para o público compreender a proposta expositiva, que tem Maria como figura central, valorizando o patrimônio religioso e a devoção a Nossa Senhora Aparecida, assim como valorizando também a participação do público, que se identifica, principalmente, com o núcleo central da exposição, onde reúnem objetos representativos da devoção do fiel.

Enfim, acreditamos que a exposição Rainha do Céu, Mãe dos Homens: Aparecida do Brasil, foi estrategicamente planejada, não apenas para oferecer um novo ambiente de entretenimento aos visitantes, mas, principalmente, para 
contextualizar a devoção a Nossa Senhora Aparecida, valorizando o acervo do Museu Nossa Senhora Aparecida.

\subsection{Exposições 0 Museu e suas Histórias e Coleção Santa Gertrudes de Imagens Paulistas do século XVII}

Inaugurada no dia 03 de outubro de 2012, a exposição O Museu e suas Histórias exibe objetos representativos das coleções do Museu, organizados por tipologia, contextualizando as relações do homem com o sagrado, suas formas de expressão, sua vida cotidiana e doméstica, assim como no universo do trabalho e sua relação com o meio ambiente.

A concepção dessa exposição partiu de uma demanda do público, que tinha um sentimento de pertencimento e questionava, frequentemente, onde estavam os outros objetos que ficavam em exposição no Museu.

Para Peixe e Bigareli (2016, p. 26), essa nova exposição "reapresenta as coleções do Museu, organizadas tematicamente, numa amostragem que busca indicar as potencialidades do acervo e de sua exploração cultural".

A Figura 109 apresenta a planta da exposição O Museu e suas Histórias, com acesso central, seguindo-se pelo corredor à esquerda, com roteiro organizado por núcleos. Conforme pode ser observado na planta, logo em frente aos elevadores há a recepção, com uma pequena mesa à direita.

Após algumas visitas exploratórias, observamos que sempre há um recepcionista e eventualmente monitores, que fazem o acolhimento dos visitantes, colocando-se à disposição para o caso de dúvidas. Porém, as visitas monitoradas ocorrem apenas com agendamento prévio.

Logo em frente aos elevadores há uma porta dupla de vidro, com acesso à sala principal da exposição, com a identificação do Museu, adesivada com letra de recorte na parte superior, sendo esta: Museu Nossa Senhora Aparecida.

O fluxo da exposição inicia-se pelo corredor à esquerda, seguindo-se com nichos nas paredes e estantes móveis, dispostas por núcleos temáticos. Há painéis com trilhos próximos das paredes, que servem como elementos decorativos, informativos, pois alguns possuem textos, além de bloquear as janelas, impedindo, assim, a iluminação natural. 
Figura 109: Planta - Exposição $2^{\circ}$ andar.

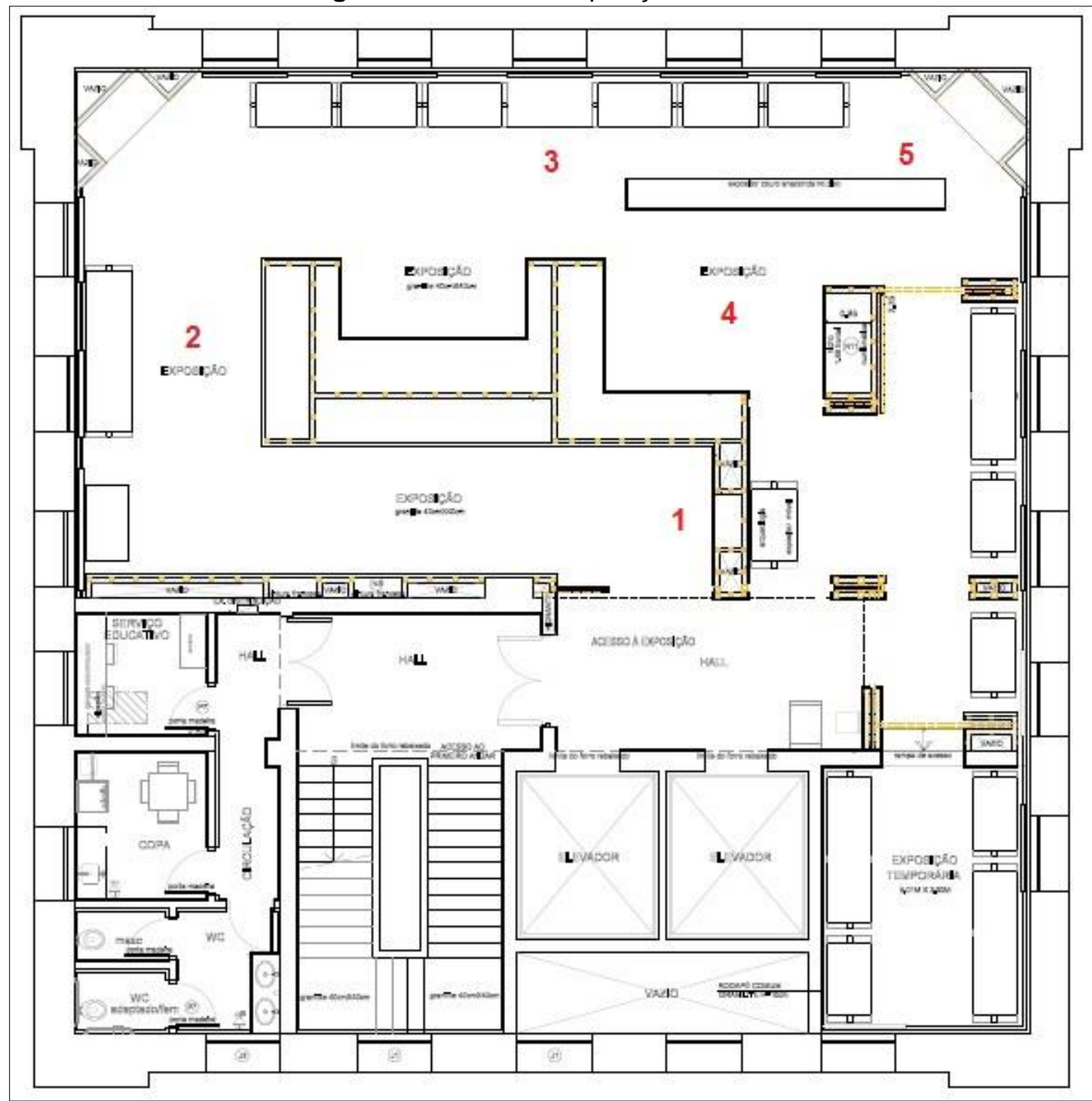

Fonte: MNSA/ Santuário Nacional.

A Figura 109 apresenta a planta da exposição O Museu e suas Histórias. Os números inseridos na Figura indicam os núcleos temáticos que serão descritos a seguir.

Conforme pode ser observado na Figura, o corredor da lateral direita possui paredes duplas entre os módulos com vitrines, proporcionando mobilidade e maior diversidade no layout da exposição, abrindo e fechando acessos para a saída. Esse corredor de finalização da exposição foi concebido dessa maneira com o intuito de realizar exposições temporárias, sem impedir o fluxo de visitação e sem comprometer a temática principal da exposição.

De acordo com Peixe e Bigareli (2016, p. 26), "a área para mostras temporárias possibilita o tratamento aprofundado dos temas do acervo e a produção de conhecimento, impulsionados pelas ações de investigação a serem 
empreendidas pela equipe do Museu". As curadoras complementam que "as novas abordagens a este patrimônio - e sua valorização pela pesquisa e comunicação expositiva - revelam o interesse do Santuário Nacional pela evangelização e acolhimento de seus visitantes através dos bens da cultura" (PEIXE; BIGARELI, 2016, p. 26).

São vários os elementos que compõem a exposição (no Apêndice A - Quadro 27, podemos verificá-los). No primeiro núcleo, logo após a porta de entrada à direita, há uma vasilha de cerâmica, que remete aos objetos escavados dos sítios arqueológicos no município de Aparecida com auxílio da Professora Conceição Borges Ribeiro Camargo, que também reuniu outros objetos de interesse histórico e artístico, coletados e adquiridos na região, originando uma coleção diversificada. Essa peça arqueológica, portanto, ao ser posicionada no primeiro nicho da exposição, representa uma das primeiras coleções formadas pela Professora Conceição Borges Ribeiro Camargo.

Em seguida há o texto de curadoria O Museu e suas Histórias, que aborda a fundação do Museu, assim como os locais em que foi instalado ao longo dos anos, e os diretores que sucederam a Professora Conceição Borges Ribeiro Camargo, sendo estes a Professora Zilda Ribeiro e o Professor Guido Braga.

Figura 110: Núcleo histórico - Exposição "O Museu e suas Histórias".

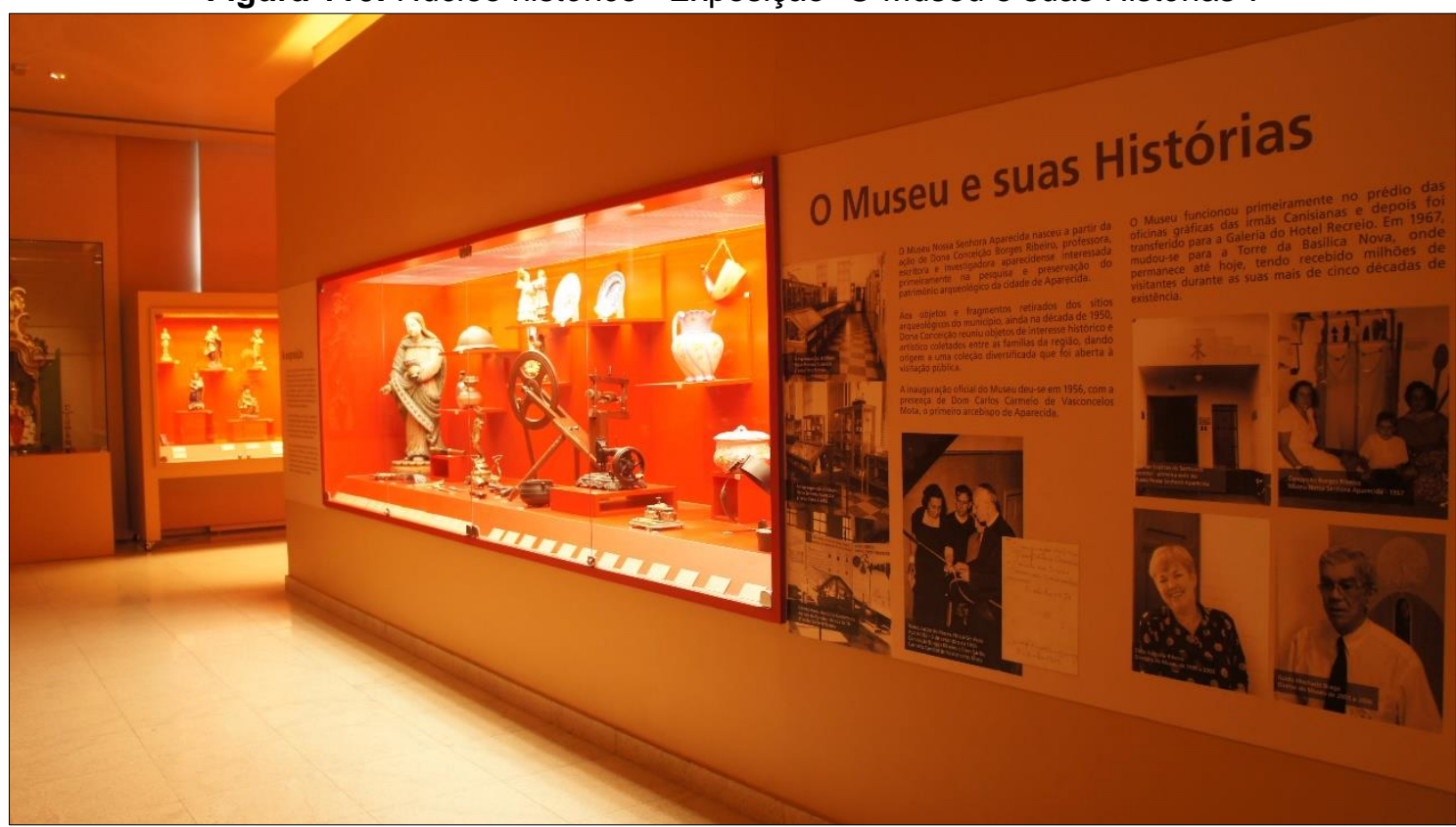

Fonte: MNSA/ Santuário Nacional. Foto: Erica Coelho.

O segundo nicho desse núcleo exibe uma miscelânea de objetos com o intuito de retratar as coleções do Museu que foram formadas ao longo dos mais de 60 anos 
da instituição, relembrando sua origem como um museu eclético, conforme podemos observar na Figura 110. De acordo com o texto de curadoria,

O acervo do Museu Nossa Senhora Aparecida formou-se segundo uma visão de museu como reprodução do mundo, onde todos os aspectos da presença humana estão representados. As doações aqui acolhidas constituíram um patrimônio museológico de caráter amplo e diversificado que expressa a forma como o homem se relaciona com os objetos criados por sua sociedade. (PEIXE; BIGARELI, 2012, p. 2).

Em destaque nesse núcleo há objetos que remetem à presença indígena, à escravidão, ao tropeirismo, além de objetos de louça de uso cotidiano e decorativos, ferramentas de trabalho, que remetem também à Revolução Constitucionalista de 1932 e a devolução popular, fazendo uma conexão com o próximo núcleo expositivo.

A partir dessa introdução, que busca agrupar uma miscelânea de objetos, retratando como era a antiga exposição do Museu, há um painel textual, apresentando a exposição com este recorte conceitual temático, referenciando as relações do homem com o mundo a sua volta.

Nesse contexto, o segundo núcleo retrata o "Homem e o Sagrado", expondo objetos ligados à espiritualidade no contexto católico. Há, portanto, no corredor inicial à esquerda, dois nichos que dão destaque às pinturas com representação de Santo Antônio e São Bernardino de Sena. De acordo com Peixe e Bigareli (2016, p. 52), "cumpre mencionar ainda os dois painéis europeus representando santos franciscanos, possivelmente da medieval Escola de Paris, trazidos da Itália para Aparecida pelo seu primeiro Arcebispo, Dom Carlos Carmelo de Vasconcelos Motta".

Ao final do corredor há uma vitrine com uma grande cúpula de vidro, dando destaque a um oratório que faz referência ao culto doméstico. As vitrines em sequência apresentam imagens de culto coletivo, normalmente presentes em oratórios domésticos e nos altares das igrejas e capelas, representando santos e invocações de Nossa Senhora que inspiram a fé dos católicos. Conforme abordado por Peixe e Bigareli (2016, p. 26),

A coleção de arte sacra do Museu Nossa Senhora Aparecida formou-se inicialmente com materiais coletados na região de Aparecida e do Vale do Paraíba, e ao longo do tempo foi sendo acrescida de exemplares de todo o país, trazidas por visitantes do Museu e devotos. O conjunto aqui apresentado é parte da coleção mais ampla, representativa de várias épocas, locais, materiais e níveis de expressão. 
Nesse núcleo, conforme podemos observar nas Figuras 111, 112 e 113, há uma composição de imagens de culto coletivo e de culto doméstico, bem como a imaginária popular do Vale do Paraíba conhecida como "paulistinhas", que são imagens religiosas características do Estado de São Paulo. Segundo Peixe e Bigareli (2016, p. 28),

O Vale do Paraíba testemunhou a existência de muitos santeiros que trabalhavam a madeira e o barro. Destaca-se a figura de Benedito Amaro de Oliveira, o Dito Pituba, da cidade de Santa Isabel, cuja produção foi intensa e distribuiu-se em várias cidades do Vale, da metade do século 19 até 1926. Pituba é o representante de inúmeros outros artistas imaginários da região.

Ainda nessa vitrine, também há pequenas imagens feitas em nó-de-pinho, com alguns traços primitivos de herança africana, porém sem referência de doador e procedência, retratando o anonimato das peças que compõem o acervo do Museu.

Figura 111: Núcleo o homem e o sagrado - Exposição "O Museu e suas Histórias".

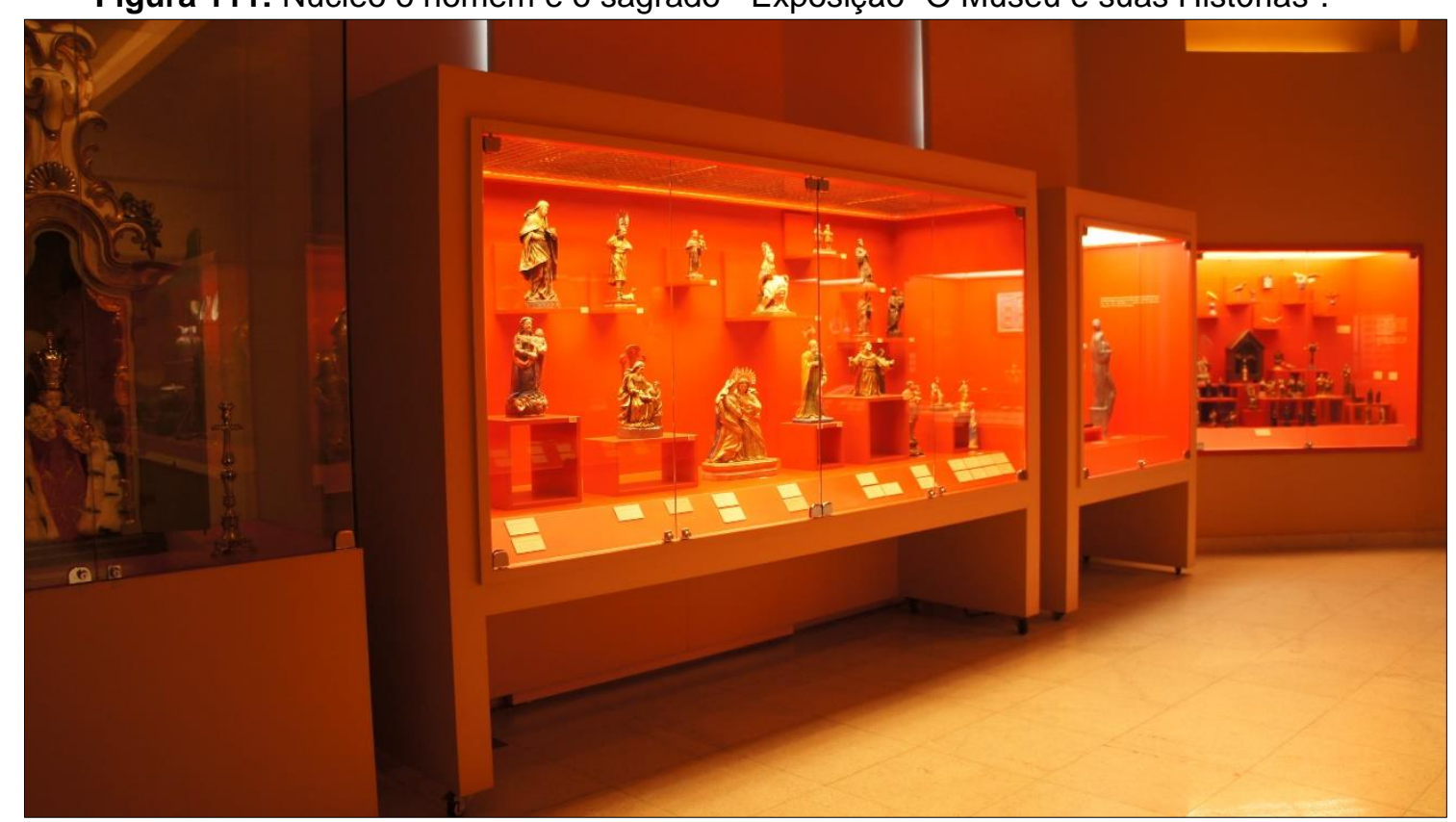

Fonte: MNSA/ Santuário Nacional. Foto: Erica Coelho.

Nesse núcleo também estão reunidos objetos de devoção popular e da liturgia católica, dentre eles destacando-se os ex-votos deixados na Sala de Promessas pelos devotos de Nossa Senhora Aparecida, sendo depois incorporados ao acervo do Museu pelo seu interesse documental e artístico, pois retratam a manifestação de fé do povo expressa materialmente nos objetos. 
Figura 112: Núcleo o homem e o sagrado - Exposição "O Museu e suas Histórias".

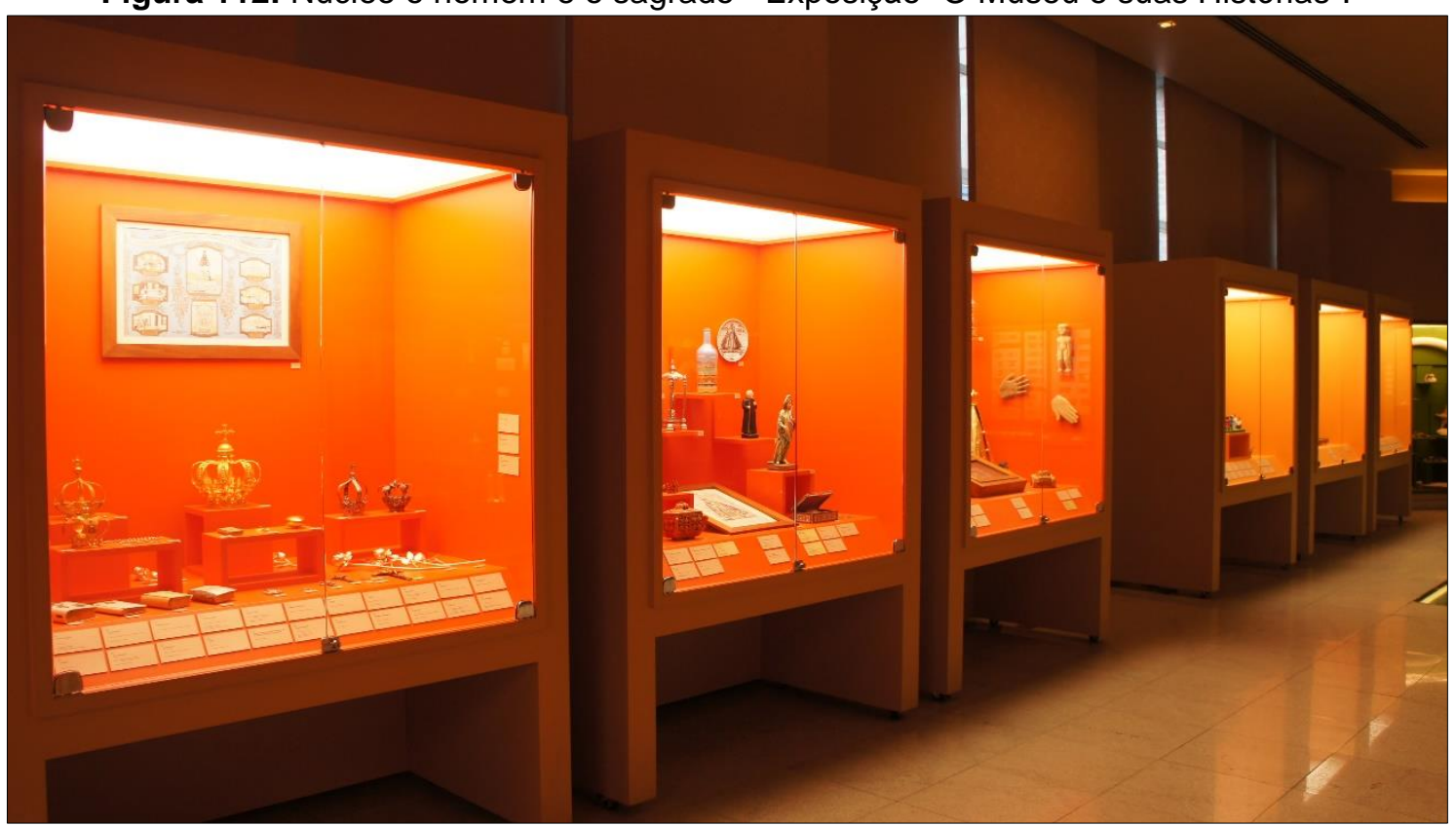

Fonte: MNSA/ Santuário Nacional. Foto: Erica Coelho.

Figura 113: Núcleo o homem e o sagrado - Exposição "O Museu e suas Histórias".

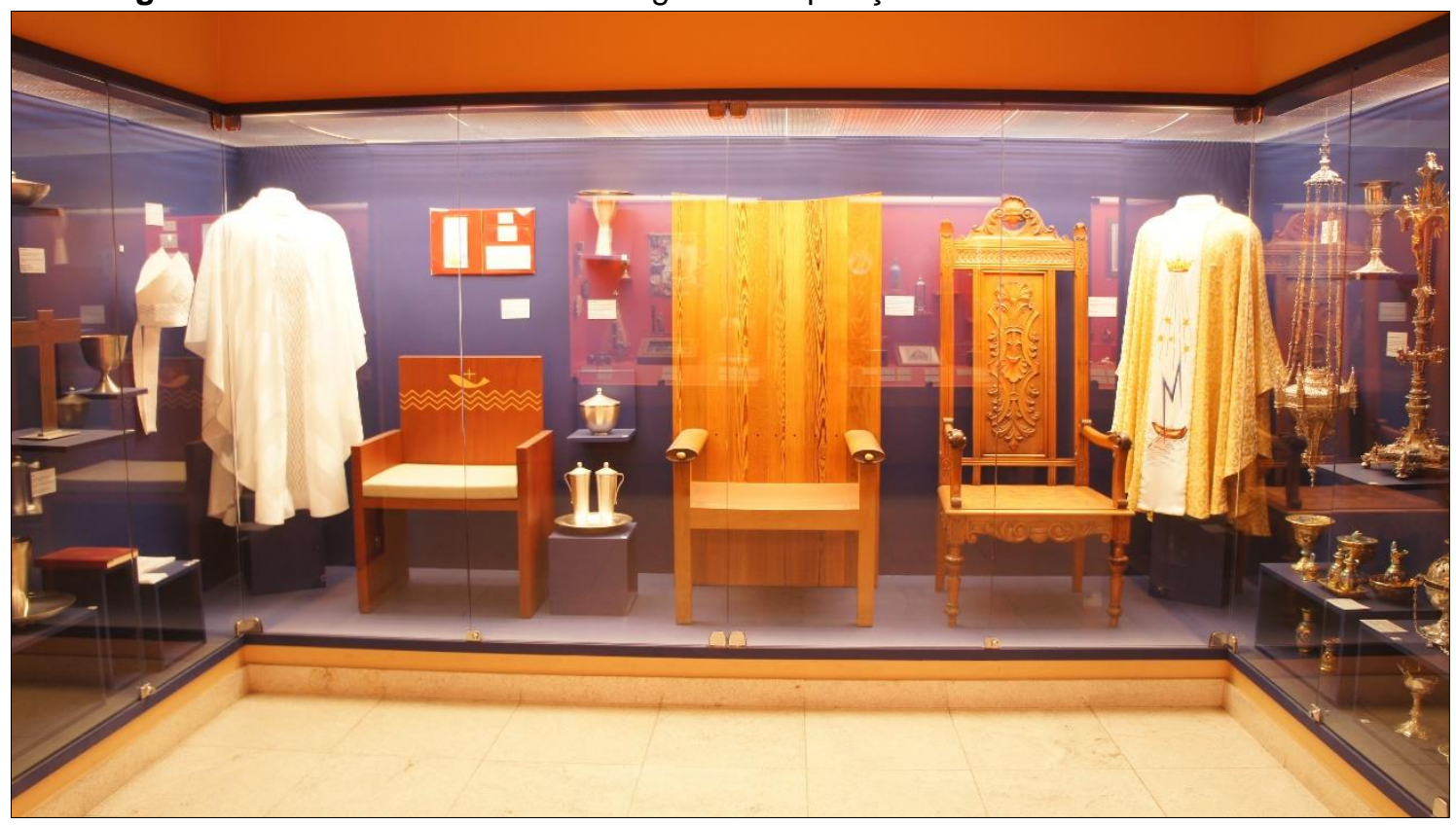

Fonte: MNSA/ Santuário Nacional. Foto: Erica Coelho.

Em destaque nesse núcleo, em uma sequência de três vitrines, há medalhas e pingentes de devoção, Terços, estampas de Nossa Senhora Aparecida com a representação dos milagres, lembranças de viagens a lugares considerados sagrados, além de outros objetos domésticos que trazem imagens expressando a devoção.

Nesse segmento da exposição, há um grande nicho que reúne materiais ligados à liturgia católica, representando o culto oficial da Igreja, entre eles objetos e 
alfaias litúrgicas. Destacam-se outras peças de interesse histórico, tais como paramentos e tronos papais, que foram utilizados pelos Pontífices São João Paulo II, Bento XVI e Francisco, em visita a Aparecida (SP), nos anos de 1980, 2007 e 2013, respectivamente.

O terceiro núcleo retrata o "Homem e Expressão", dando destaque aos objetos representativos da coleção de arte popular (Figura 114). De acordo com Peixe e Bigareli (2016, p. 29-30), nesse núcleo expositivo,

A arte popular se materializa nas figuras de barro (queimadas ou não), procedentes da região vale-paraibana e nordestina. Também estão presentes pequenas esculturas em madeira. As figuras retratam temas da realidade brasileira, trazendo o universo do trabalho, celebrações (folguedos, presépio, casamento) e outras expressões culturais.

Figura 114: Núcleo o homem e expressão - Exposição "O Museu e suas Histórias".

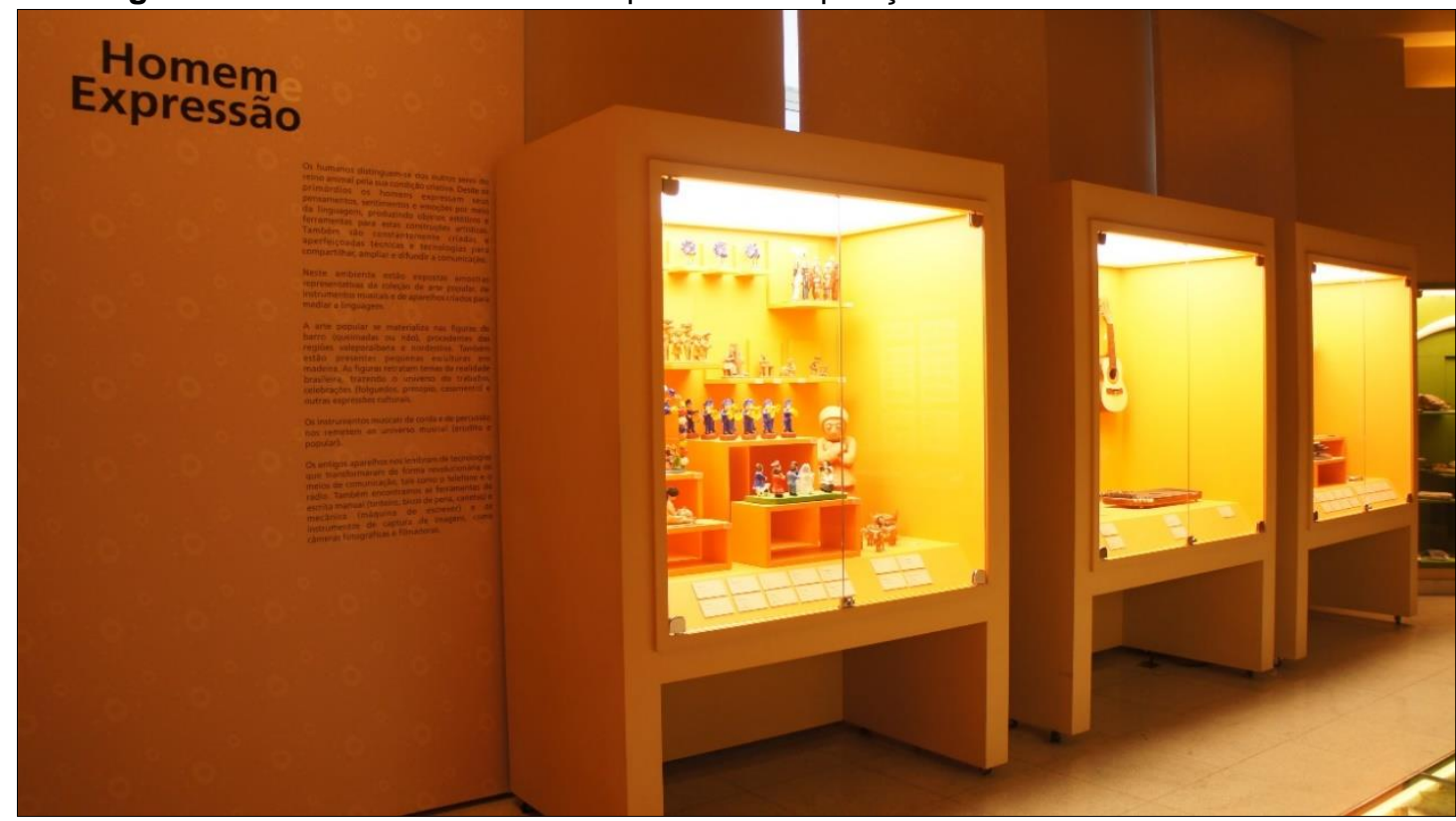

Fonte: MNSA/ Santuário Nacional. Foto: Erica Coelho.

Dando sequência, há uma vitrine com instrumentos musicais de corda e percussão (erudito e popular). E há outra vitrine com equipamentos desenvolvidos para mediar a linguagem e comunicação, conforme observado na Figura 115. Segundo Peixe e Bigareli (2016, p. 30),

Os antigos aparelhos nos lembram de tecnologias que transformaram de forma revolucionária os meios de comunicação, tais como o telefone e 0 rádio. Também encontramos as ferramentas de escrita manual (tinteiro, bicos de pena, canetas) e mecânica (máquina de escrever) e os instrumentos de captura de imagens, como câmeras fotográficas e filmadoras. A vitrola traz à memória os característicos sons dos discos de vinil, substituídos hoje pela limpeza sonora dos arquivos digitais. 
Figura 115: Núcleo o homem e expressão - Exposição "O Museu e suas Histórias".

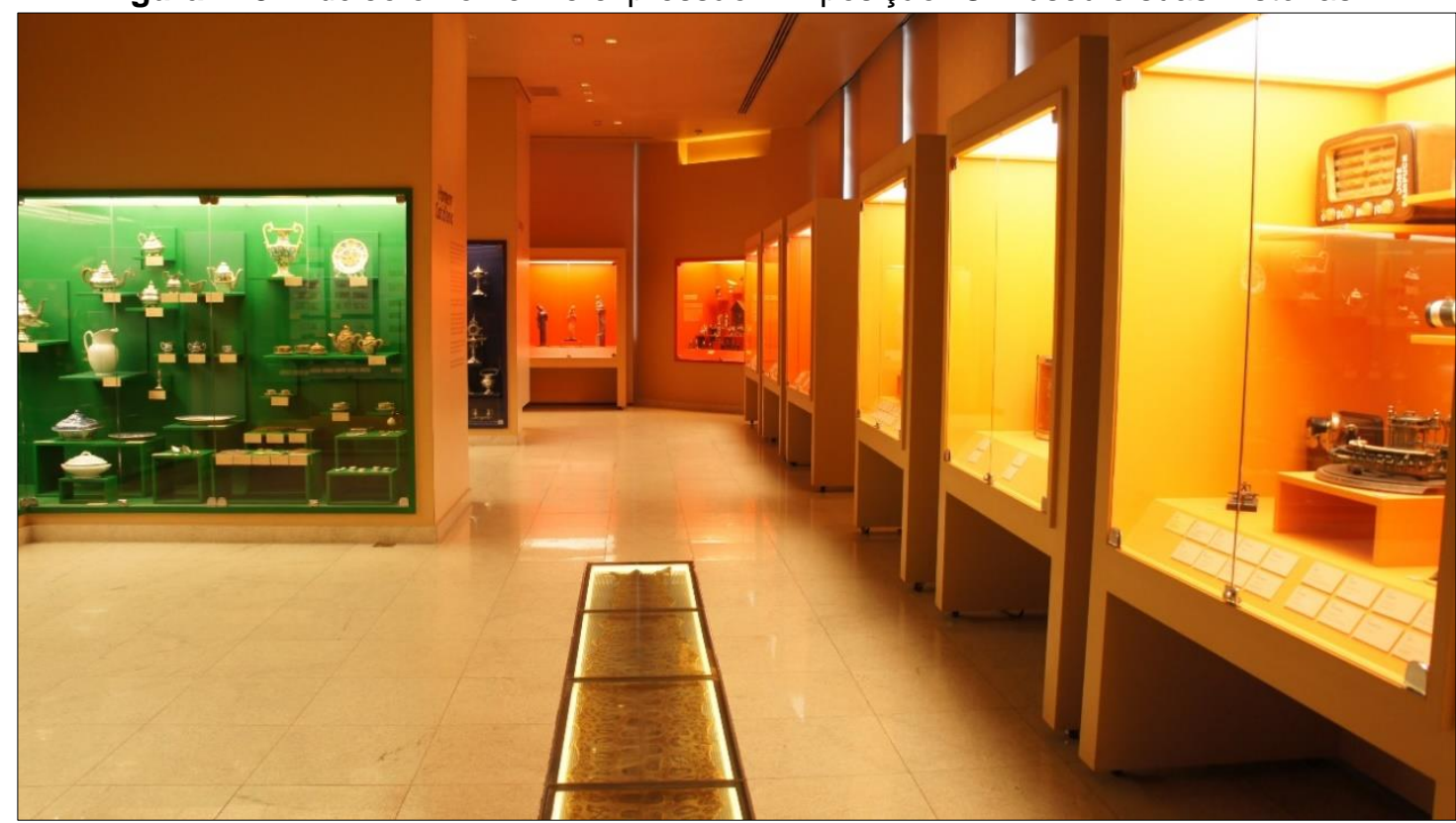

Fonte: MNSA/ Santuário Nacional. Foto: Erica Coelho.

O quarto núcleo (Figura 116) retrata o "Homem e o Cotidiano". Nele, as curadoras argumentam que "em constante busca de conhecimento e de melhorias tecnológicas, o ser humano cria, entre outras tantas invenções, utensílios para o seu corpo, para a sua casa, para os seus ambientes de trabalho, enfim, para organizar e embelezar o seu próprio ser e os seus afazeres" (PEIXE; BIGARELI, 2016, p. 30).

Em destaque nesse núcleo estão presentes alguns objetos com funcionalidades práticas, oferecendo também uma composição mais estética, de uso pessoal, assim como utilitários domésticos e ferramentas de trabalho, como, por exemplo, acessórios pessoais, conjuntos de louças e prataria, numismática e objetos da cultura tropeira, alguns destes não mais em uso pela sociedade atual, considerando as modificações dos hábitos, usos e costumes.

Segundo Peixe e Bigareli (2016, p. 30),

Dos objetos de uso pessoal, para vestir ou usar junto ao corpo, temos acessórios exemplares dos gêneros masculino e feminino, tais como: relógios de bolso, aparelho de barbear, óculos, pentes de adorno de cabelos, luva, leques, bolsas, relógios de pulso, etc.

Dentre os objetos domésticos destacam-se: a prataria, a louça e outros utensílios característicos da cultura caipira, tais como tachos de cobre e panelas de ferro.

Do acervo de instrumentos de trabalho destacamos as máquinas de costura e os ferros de passar roupa.

Nesse núcleo há também objetos da cultura tropeira, que foi fundamental para o desenvolvimento da região do Vale do Paraíba. As curadoras complementam que "o extinto Museu dos Ciclos Econômicos, sediado nesta Torre, continha objetos 
significativos da cultura tropeira, hoje integrados ao acervo deste Museu, tais como: caçambas, estribos cincerros, panelas de ferro, etc." (PEIXE; BIGARELI, 2016, p. 30).

Figura 116: Núcleo o homem e cotidiano - Exposição "O Museu e suas Histórias".

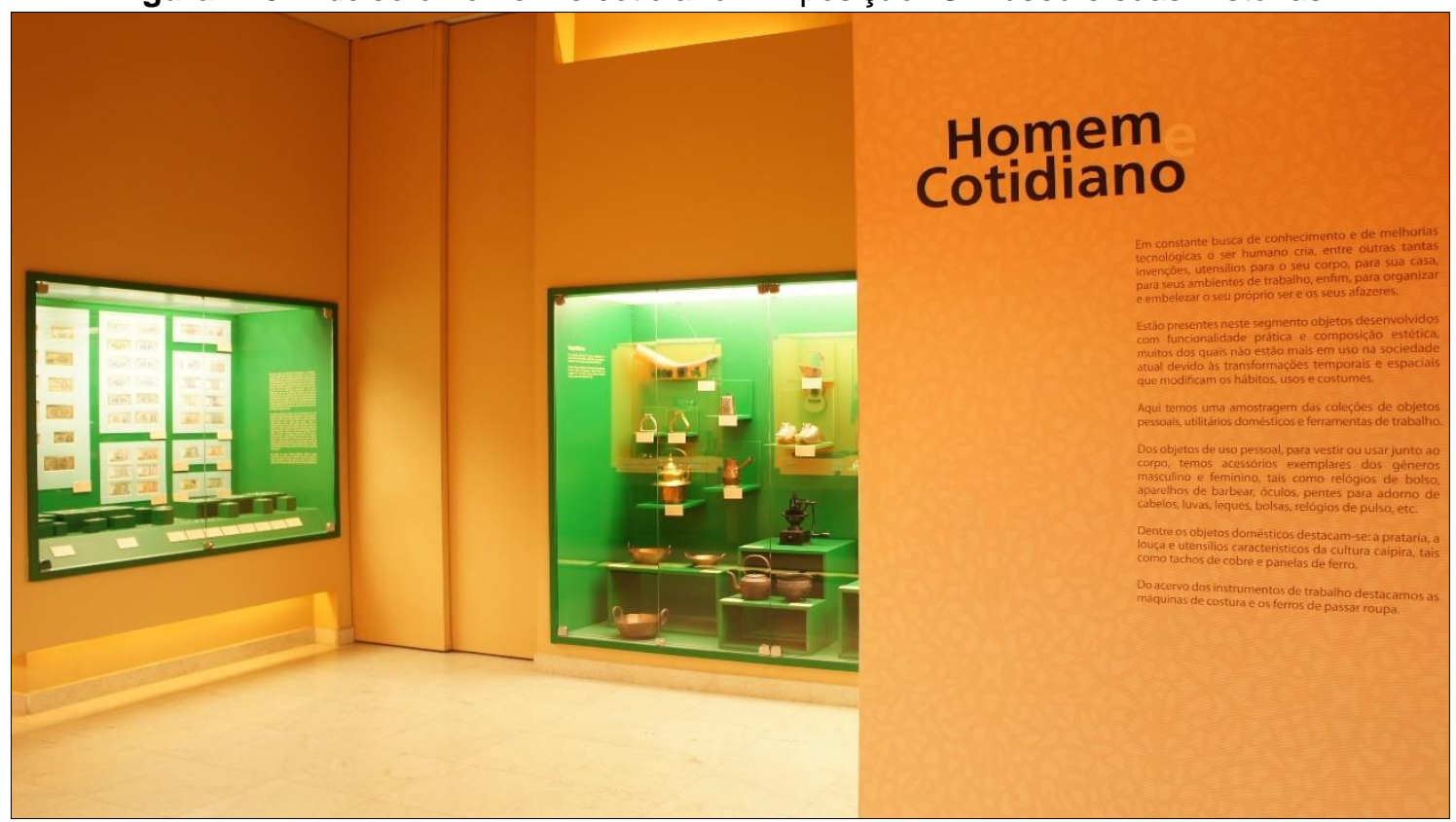

Fonte: MNSA/ Santuário Nacional. Foto: Erica Coelho.

Em sequência há um nicho dedicado à coleção de numismática que, após algumas visitas exploratórias e de observação, verificamos que esse núcleo atrai a atenção da maioria dos visitantes. Segundo as consultoras, "na amostragem desta área da exposição, veremos parte do acervo de moedas e cédulas de nosso país, do período colonial ao atual (República)" (PEIXE; BIGARELI, 2016, p. 32). Portanto, por se tratar de uma pequena amostragem de uma das maiores coleções do Museu, observamos que os visitantes se sentem motivados a fazer novas ofertas para completar a coleção exposta. Entretanto, conforme análise documental dos objetos ofertados e a avaliação da Comissão de Acervo do Museu, notamos que esses objetos não são mais aceitos para incorporação ao acervo do Museu, embora continuem sendo os objetos mais ofertados.

O quinto núcleo (Figura 117) retrata o "Homem e o Ambiente". De acordo com as curadoras, "assim como a produção da cultura material se modifica com o passar do tempo, a relação do homem com o ambiente em que vive também registra profunda transformações" (PEIXE; BIGARELI, 2016, p. 32). 
Figura 117: Núcleo o homem e a natureza - Exposição "O Museu e suas Histórias".

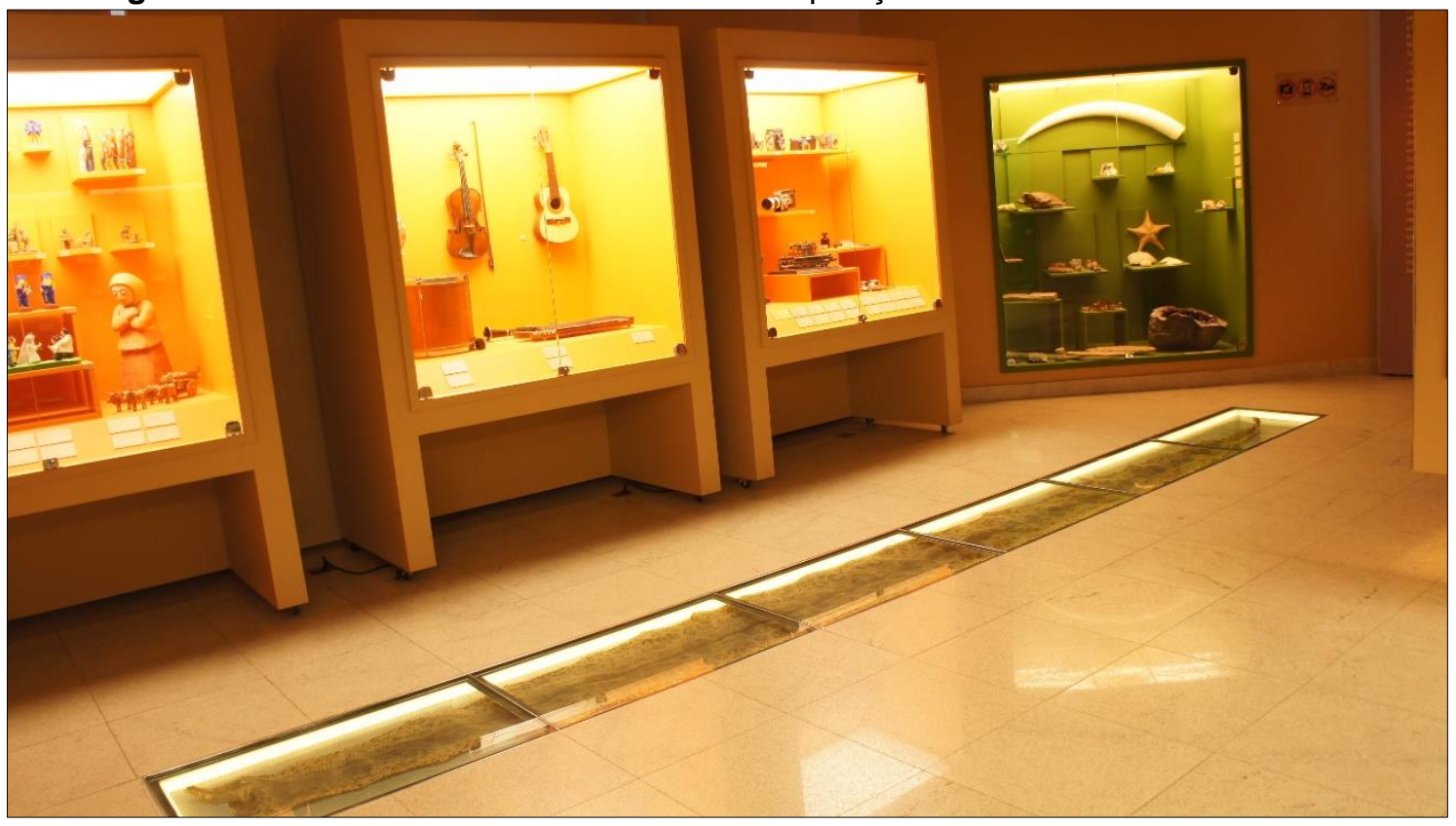

Fonte: MNSA/ Santuário Nacional. Foto: Erica Coelho.

Nesse núcleo estão expostos exemplares do acervo referentes à coleção de amostras naturais (conchas, corais, fósseis, animais preservados e minerais), que remetem ao colecionismo nos séculos 16 e 17, em que a coleta e exibição dessas amostras naturais estavam ligadas às manifestações de curiosidade, domínio e apropriação da natureza, conforme argumentam Peixe e Bigareli (2016).

Nos séculos 16 e 17 os homens exibiam suas coleções procedentes das explorações e descobrimentos nos denominados Gabinetes de Curiosidades (ou Quarto as Maravilhas), estas se destacavam pela multiplicidade, raridade e estranheza dos objetos expostos. Estes gabinetes são precursores da criação dos Museus. (PEIXE; BIGARELI, 2016, p. 32).

Em destaque nesse núcleo e encerrando a sala principal da exposição, há um nicho no piso exibindo um couro de sucuri de aproximadamente seis metros de comprimento, que atrai a curiosidade de todos os visitantes, especialmente as crianças.

Conforme mencionado anteriormente, e observado na planta da exposição (Figura 109), dando sequência a esse núcleo, há outro ambiente expositivo destinado às exposições temporárias. Nesse corredor de finalização da exposição, há paredes móveis, alterando o layout da exposição para facilitar a montagem e desmontagem das exposições temporárias, sem interferir no fluxo de visitação da sala principal de exposição.

Inicialmente, nessa área foi concebida uma exposição sobre a presença indígena no Vale do Paraíba, especialmente por meio dos artefatos que foram 
encontrados nos sítios arqueológicos do município de Aparecida (SP). A exposição muito apreciada pela população local permitia uma boa articulação com os grupos escolares da região, tendo permanecido até o início de 2016, quando o Santuário de Aparecida recebeu uma importante coleção de imagens paulistas, que transformou esse ambiente destinado às exposições temporárias em uma nova sala para outra exposição de longa duração.

De acordo com Peixe e Bigareli (2016, p. 33),

Em 2016, reuniram-se ao acervo de imaginária do Museu as peças ímpares da coleção de Ladi Biezus, um amante da arte seiscentista paulista que durante décadas adquiriu, conservou e colecionou esculturas religiosas. Da coleção, composta de cinquenta e quatro peças, fazem parte esculturas atribuídas a importantes mestres imaginários paulistas, como o beneditino Frei Agostinho de Jesus (c. 1600-1661), um dos primeiros escultores brasileiros conhecidos.

Essa nova exposição, que recebeu o título Coleção Santa Gertrudes de Imagens Paulistas do século XVII, nasceu a partir de desejo do colecionador, Sr. Ladi Biezus, em expor para um público amplo um grupo de imagens paulistas reunidas e pesquisadas por ele há mais de quarenta anos, a Coleção Santa Gertrudes, que recebeu esse nome devido à primeira aquisição ser uma escultura de Santa Gertrudes.

A princípio a coleção foi exposta no Museu de Arte Sacra de São Paulo, no período de 21 de fevereiro de 2016 a 19 de junho de 2016, com o título Mestres Santeiros Paulistas do século XVII na Coleção Santa Gertrudes, com curadoria de Maria Inês Lopes Coutinho. De acordo com o Museu de Arte Sacra de São Paulo, "a exposição propõe uma análise aprofundada nas características escultóricas das peças, no intuito de desvendar quem eram os mestres santeiros por trás dessa rica produção artística, no estado de São Paulo". ${ }^{4}$

Com o encerramento dessa exposição temporária, outro desejo do colecionador era realizar uma exposição no Santuário Nacional de Aparecida, por sua devoção a Nossa Senhora Aparecida e em memória de seus pais. De acordo as palavras de D. Raymundo Damasceno e D. Darci Nicioli, que se encontram no catálogo da exposição organizada pelo curador Antonio Carlos Suster Abdalla (2016, p. 9), "o Santuário Nacional de Nossa Senhora Aparecida, no âmbito das celebrações jubilares dos 300 anos do encontro da imagem de Nossa Senhora

${ }^{54}$ MUSEUDEARTESACRA. Exposição - Mestres Santeiros Paulistas do Século XVII na Coleção Santa Gertrudes. Disponível em: <http://www.museuartesacra.org.br/pt/exposicoes/show/mestressanteiros-paulistas-do-seculo-xvii-na-colecao-santa-gertrudes>. Acesso em 25 mar. 2018. 
Aparecida, louva e agradece ao Sr. Ladi Biezus pela significativa exposição e por sua dedicação à verdadeira arte que plenifica a vida".

A Figura 118 apresenta a entrada da Exposição Coleção Santa Gertrudes de Imagens Paulistas do século XVII, no segundo andar da Torre Brasília, logo na sequência do núcleo expositivo que retrata as relações do homem e o ambiente, que finaliza a exposição O Museu e suas Histórias.

Figura 118: Exposição Coleção Santa Gertrudes de Imagens Paulistas do século XVII.

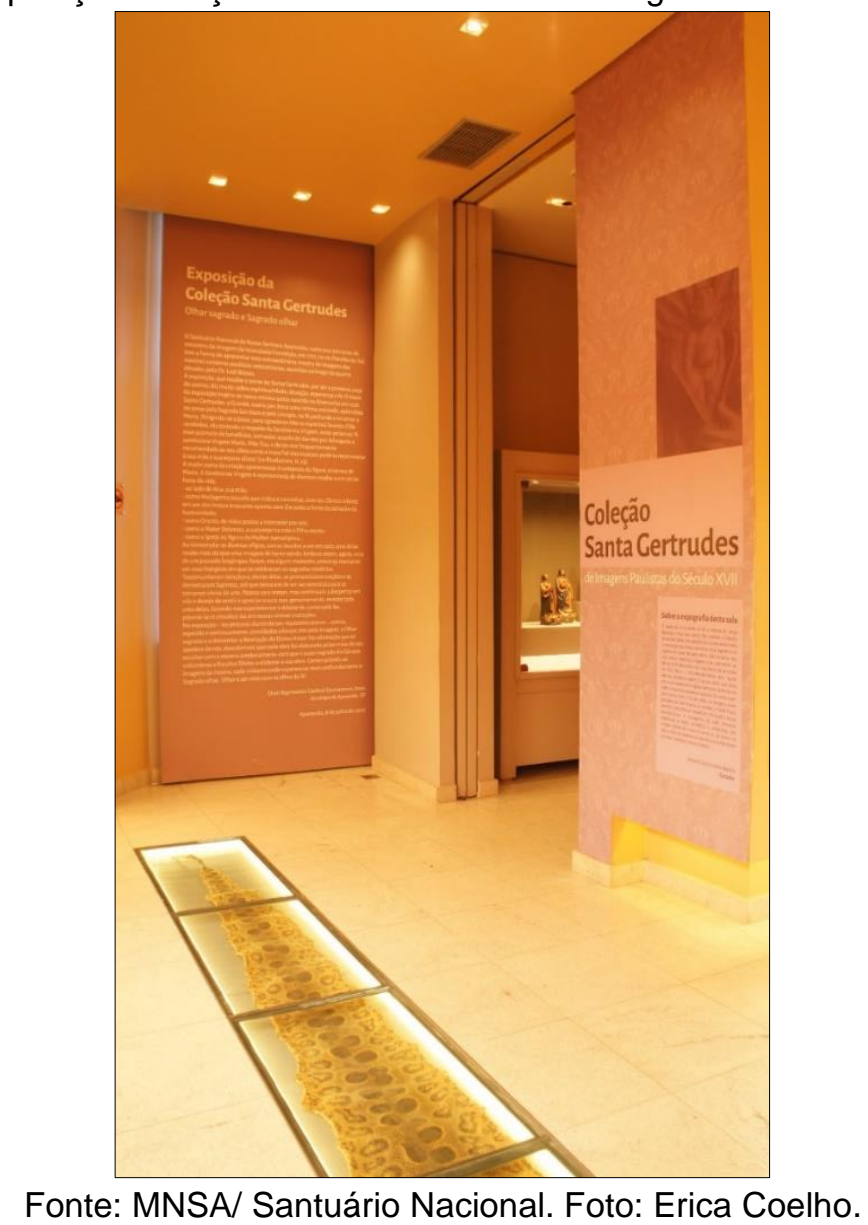

Para Abdalla (2016, p. 10), responsável pela curadoria da exposição no Museu Nossa Senhora Aparecida, "a Coleção Santa Gertrudes, de Ladi Biezus, constitui, de fato, autêntico resumo de um olhar devocional e amoroso. Cada imagem acrescentada à coleção foi buscada com meticulosidade e conhecimento, fazendo com que se integrasse harmoniosamente ao conjunto". Ainda de acordo com o curador, "expostas ao público, as imagens finalmente serão vistas em locus consagrado, cumprindo assim a vocação original pensada por seus criadores há mais de três séculos: próximas dos fiéis, como objetos de orações e pedidos, a 
servir de intercessão visível e de ponte de ligação com o Invisível" (ABDALLA, 2016, p. 11).

De maneira geral, cinquenta e quatro obras compõe a coleção, e grande parte delas possui como suporte o barro policromado, mas também há peças em madeira com policromia. E, de acordo com a curadora Maria Inês Lopes Coutinho, "da totalidade de 54 obras, 44 são em barro e 10 em madeira. São produções de apurado conhecimento técnico, com tratamento artístico requintado. Há a predominância de imagens femininas" (ABDALLA, 2016, p. 22). Nesse contexto, conforme palavras do colecionador Ladi Biezus,

Se examinarmos o elenco das cinquenta e quatro imagens que constituem a
coleção, conclui-se que há uma esmagadora maioria de imagens da Virgem
Maria sobre outras representações masculinas, como aquelas do Bom
Jesus da Pedra Fria, ou de São João Evangelista, por exemplo. Cinco
imagens de figuras masculinas e quarenta e nove de figuras femininas,
quarenta e uma da Virgem Maria e oito de santas como Santa Engrácia (do
Busto Relicário) ou Santa Gertrudes, essa é a variedade da coleção. [...]
As imagens são distribuídas em seis grupos bem distintos, mas de obras
respectivamente afins. Resta um grupo que reúne imagens para as quais
não foi possível identificar características que permitam concluir que
pertencem a um mesmo grupo, dentre os identificados ou não. (ABDALLA,
2016, p. 46).

Podemos observar os elementos que compõem a exposição (em detalhe no Apêndice A - Quadro 28). A partir dessa análise, identificamos que as obras que compõem a coleção giram em torno de Frei Agostinho de Jesus e seu círculo espiritual-estético, conforme concepção do colecionador para agrupamento dos acervos na coleção, apresentando também demais exemplares de seis artistas identificados e estilos diferenciados.

Portanto, há obras assinadas e outras que foram atribuídas como imagens "do Frei Agostinho de Jesus, do Mestre de Sorocaba, do Mestre do "Cabelinho Xadrez", do Mestre de Angra, do Mestre de Pirapora de Bom Jesus e do Mestre do "Bolo-de-noiva", artistas-santeiros identificados ou presumidos [...]" (ABDALLA, 2016, p. 11).

Os núcleos temáticos referentes às atribuições de autoria das obras, conforme citado por Abdalla, se apresentam sequencialmente no espaço da exposição (cf. as Figuras 119 a 124). 
Figura 119: Núcleo Frei Agostinho de Jesus - Exposição "Coleção Santa Gertrudes de Imagens Paulistas do século XVII".

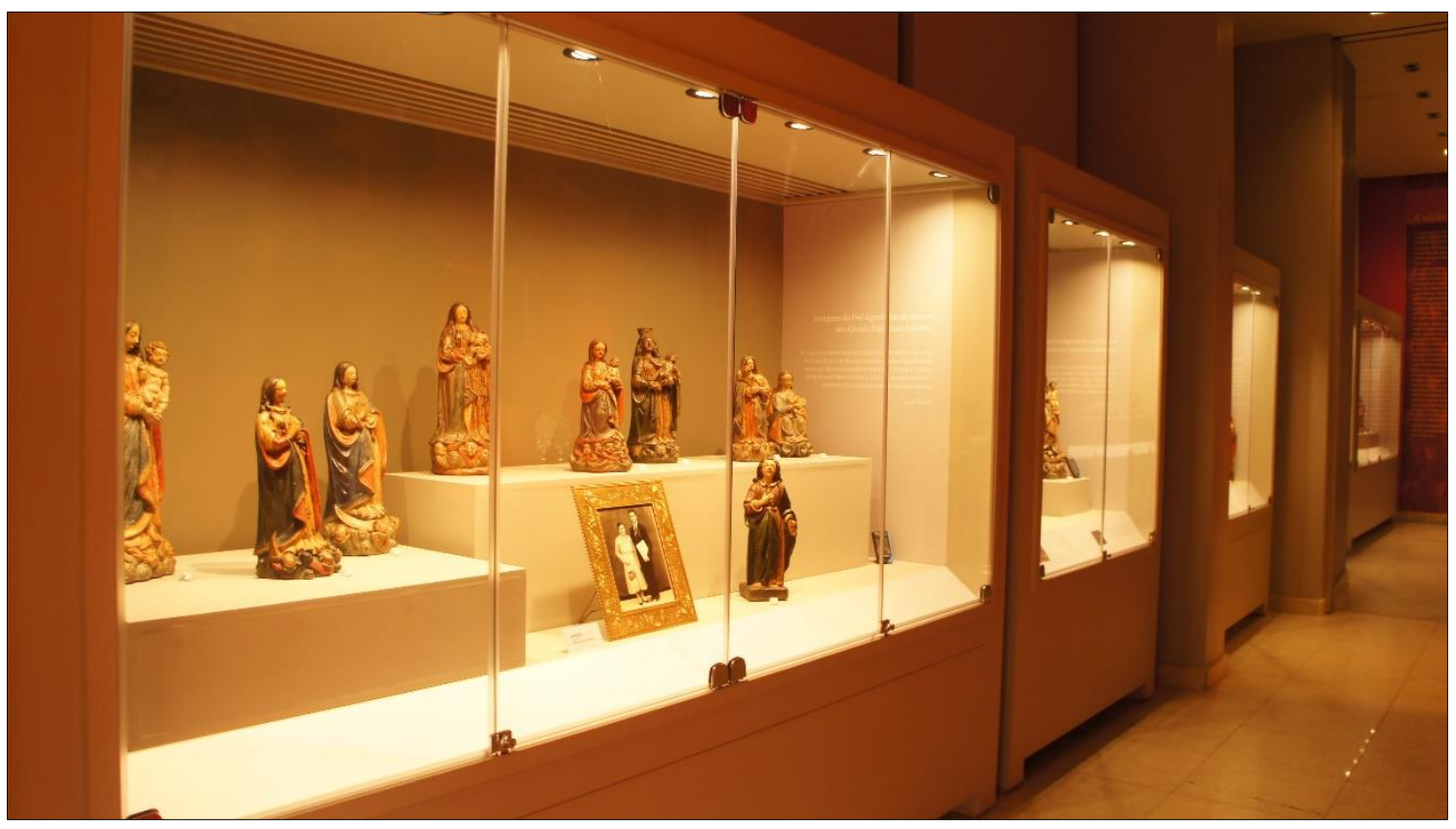

Fonte: MNSA/ Santuário Nacional. Foto: Erica Coelho.

Figura 120: Núcleo Mestre do "Cabelinho Xadrez" - Exposição "Coleção Santa Gertrudes de Imagens Paulistas do século XVII".

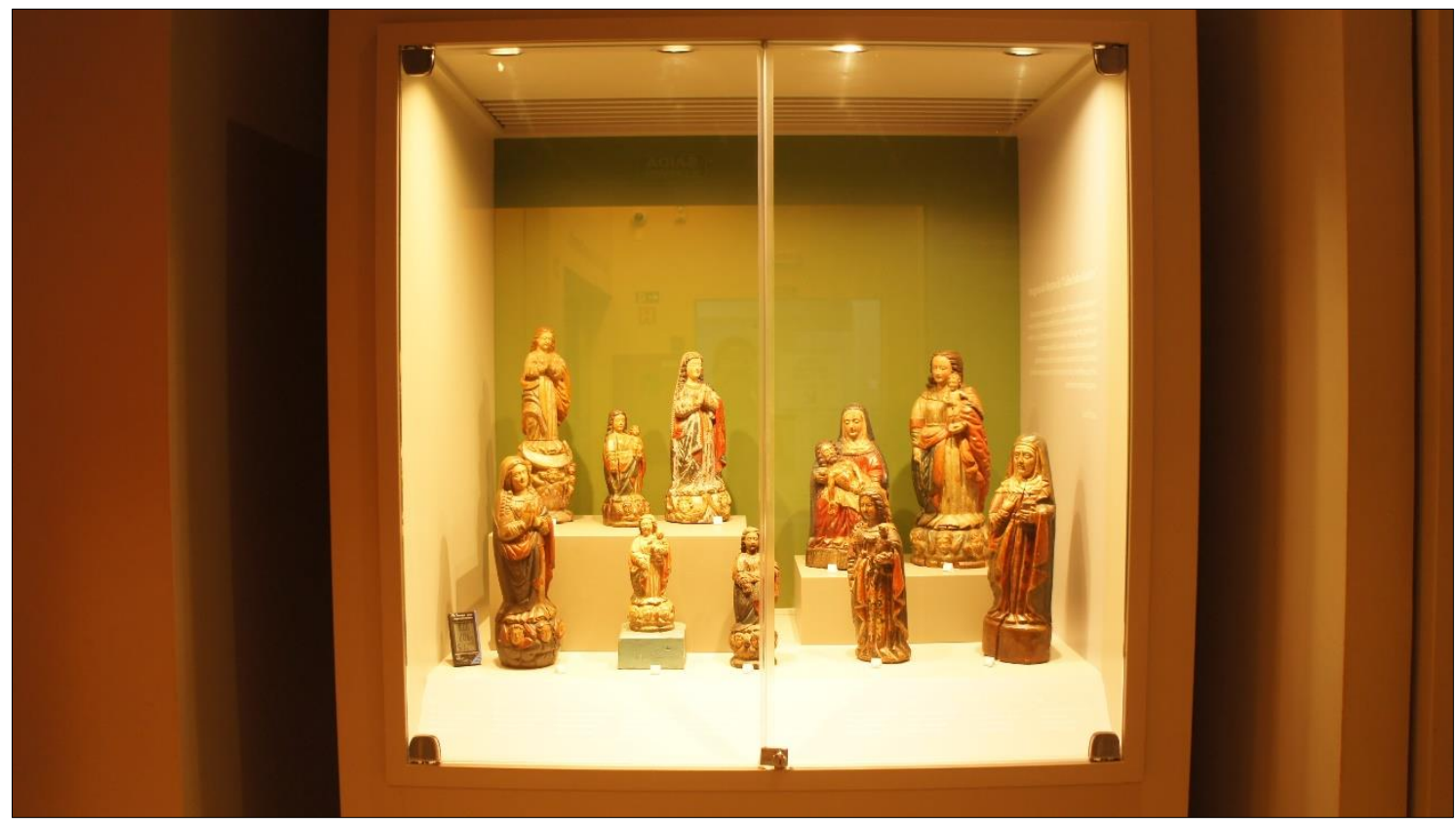

Fonte: MNSA/ Santuário Nacional. Foto: Erica Coelho. 
Figura 121: Núcleo Mestre de Angra - Exposição "Coleção Santa Gertrudes de Imagens Paulistas do século XVII".

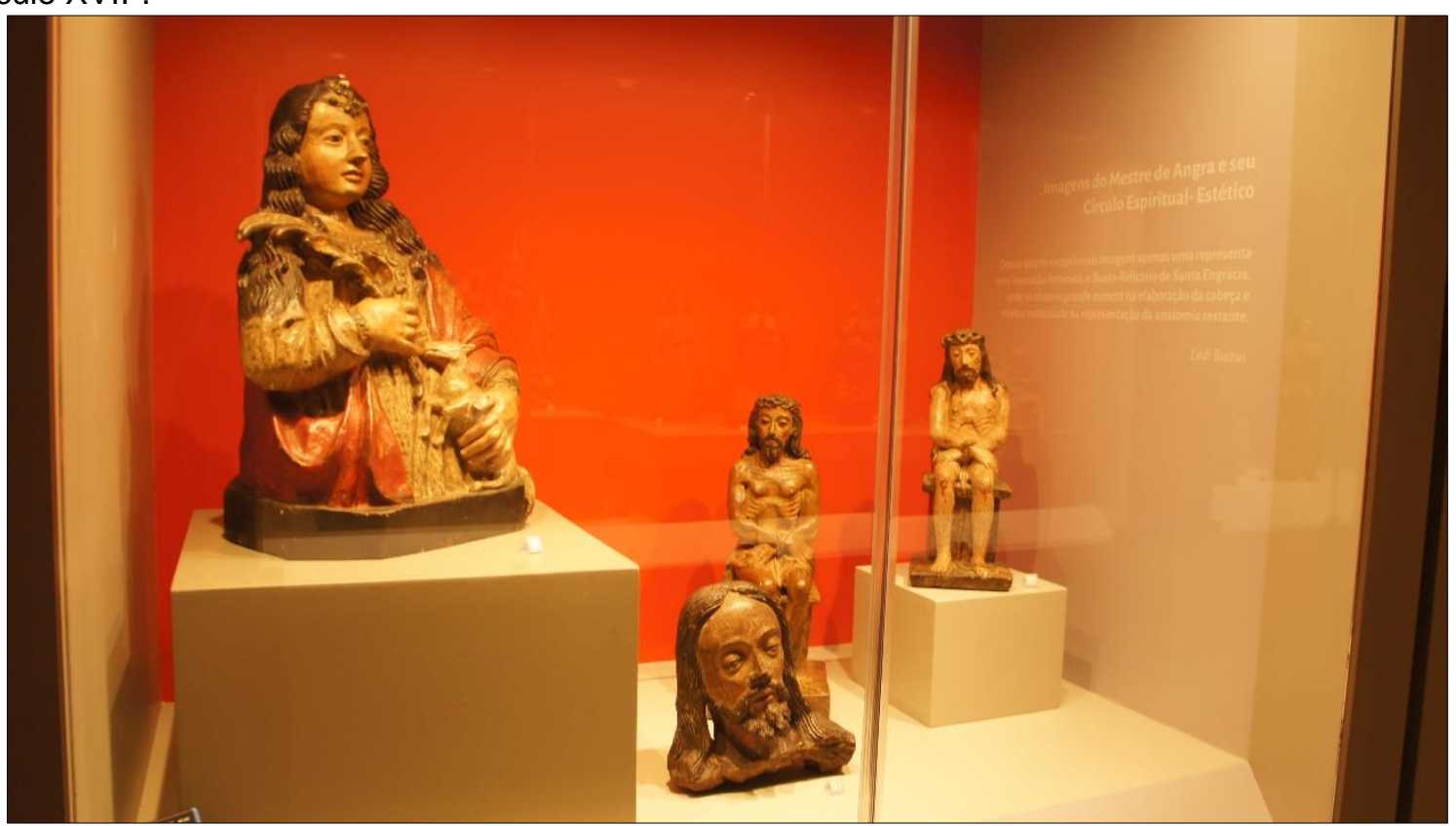

Fonte: MNSA/ Santuário Nacional. Foto: Erica Coelho.

Figura 122: Núcleo Mestre de Sorocaba - Exposição "Coleção Santa Gertrudes de Imagens Paulistas do século XVII".

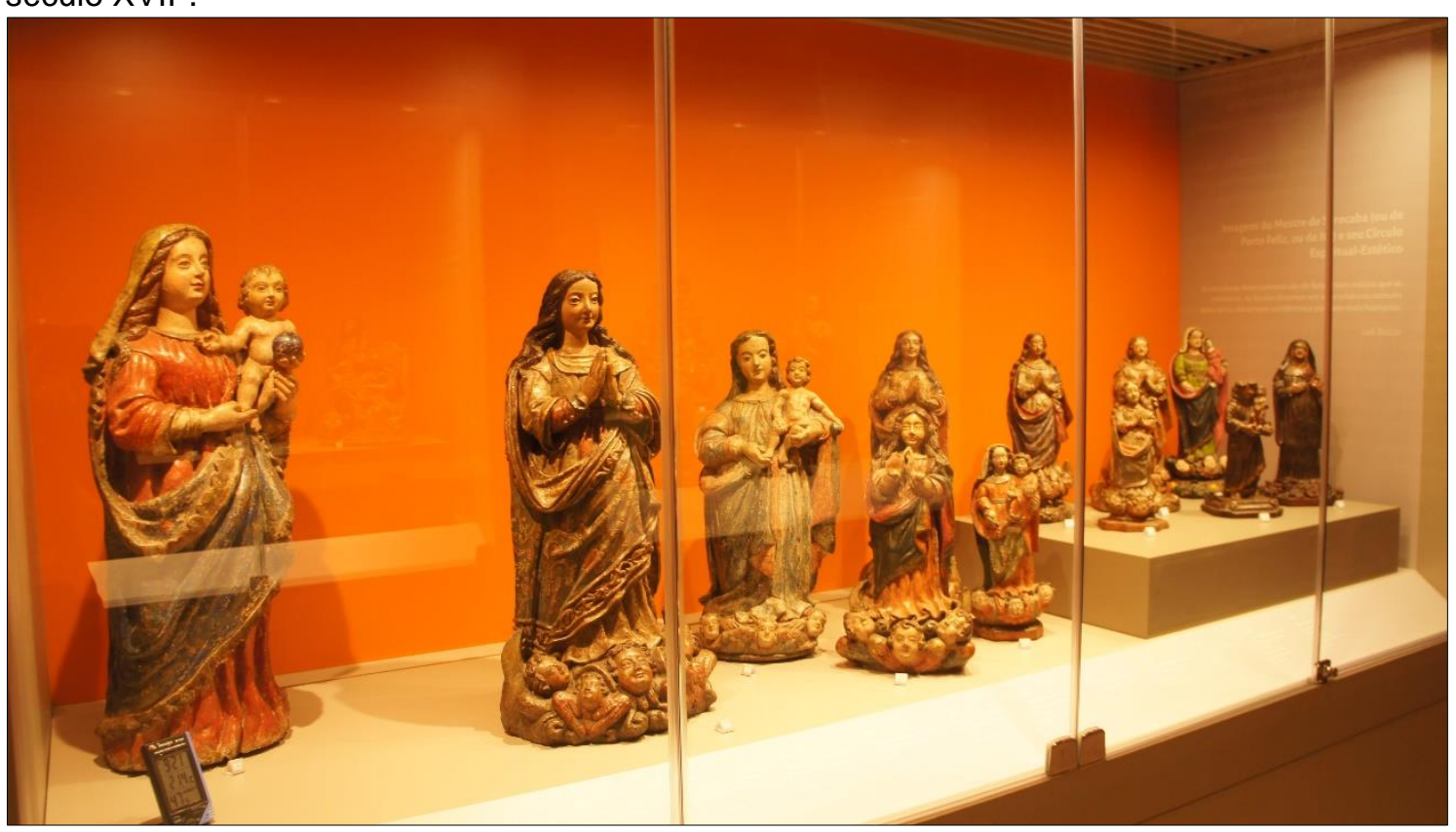

Fonte: MNSA/ Santuário Nacional. Foto: Erica Coelho. 
Figura 123: Núcleo Mestre de Pirapora de Bom Jesus e do Mestre do "Bolo-de-noiva" - Exposição "Coleção Santa Gertrudes de Imagens Paulistas do século XVII".

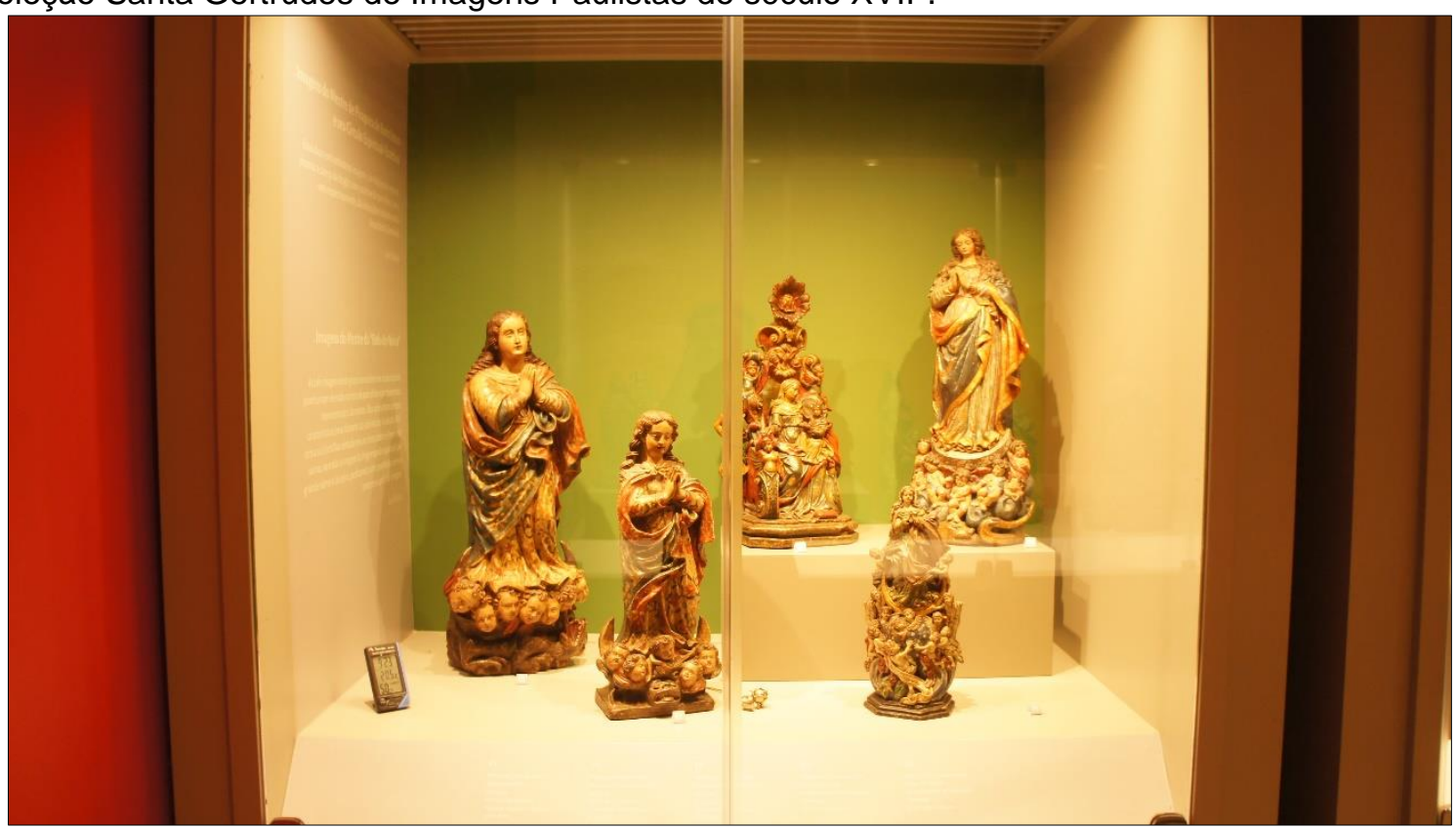

Fonte: MNSA/ Santuário Nacional. Foto: Erica Coelho.

Figura 124: Núcleo de artistas não identificados - Exposição "Coleção Santa Gertrudes de Imagens Paulistas do século XVII".

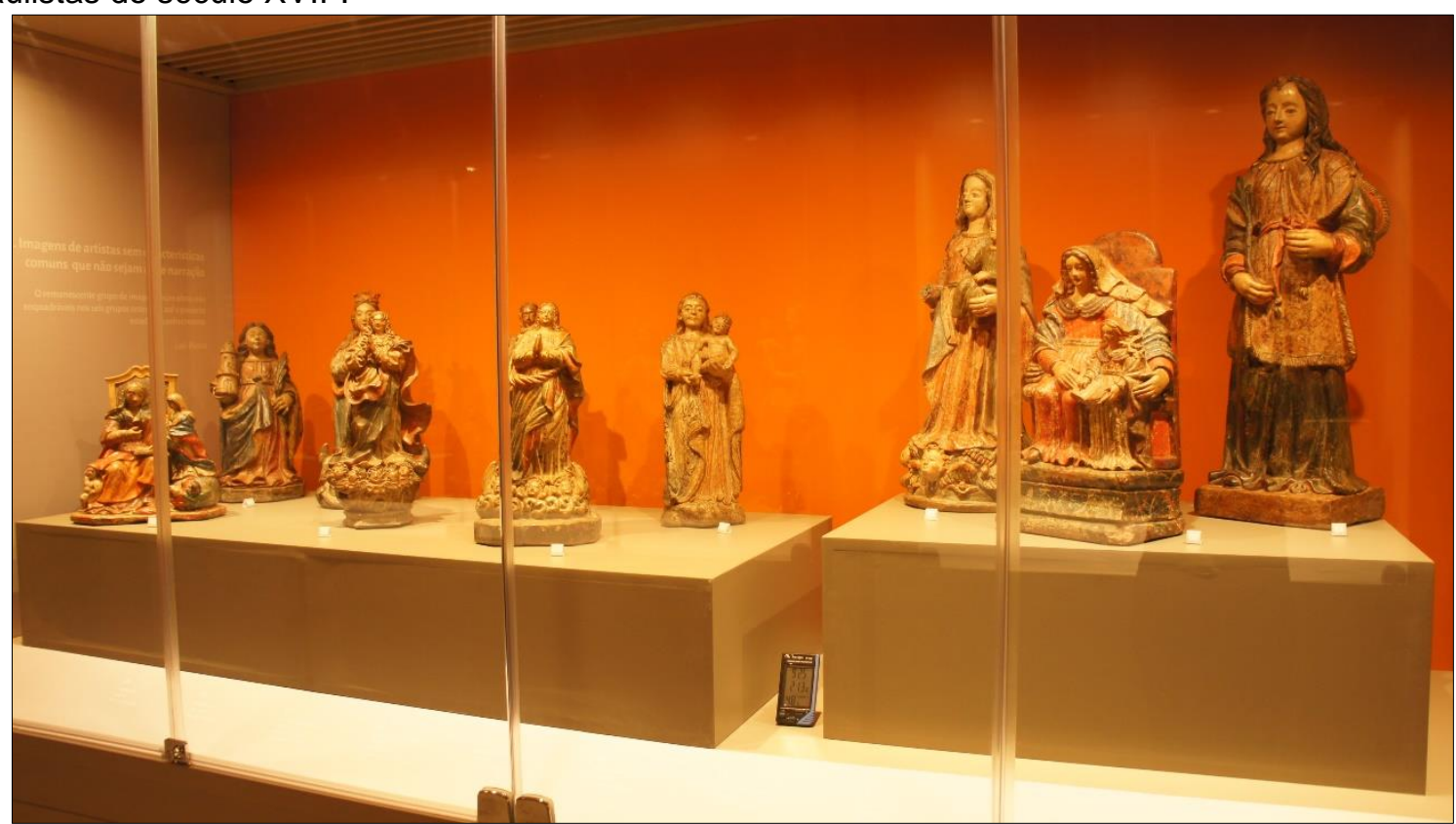

Fonte: MNSA/ Santuário Nacional. Foto: Erica Coelho. 
Para Maria Inês Lopes Coutinho, conforme consta no catálogo da exposição, organizado por Abdalla, o estilo vigente dessas obras é predominantemente barroco, com características regionais diferenciadas. "A análise da execução da obra, não só do ponto de vista estilístico como também do ponto de vista técnico, é fundamental para a identificação ou provável atribuição do artista" (ABDALLA, 2016, p. 19).

Nessa coleção observa-se que há predominância de imagens da Virgem Maria, em diversas de suas invocações. Com isso, nota-se certa fixação no arquétipo feminino e de busca incessante pela figura maternal. Para Abdalla (2016, p. 10), é "importante destacar que o colecionador, de maneira apropriada, qualifica positivamente o culto mariano" nas mais variadas devoções.

Entretanto, de acordo com Ladi Biezus, "a elevada incidência de imagens femininas na coleção sugere a necessidade de restaurar compensatoriamente a presença em boa parte perdida do Feminino Sagrado. Essa seria uma consonância com o impulso presente em toda a nação luso-brasileira" (ABDALLA, 2016, p. 58).

Ainda segundo o colecionador, "a própria recuperação da imagem da Imaculada Conceição das águas do Paraíba atesta uma inspiração e simbologia saudável de algo mais amplo, a recuperação do Arquétipo do Feminino como nação" (ABDALLA, 2016, p. 59).

Diante dessa perspectiva, Abdalla observa que a recorrência predominante da imagem do Feminino na coleção, que, segundo o colecionador, nunca foi programada, pode sugerir uma saudável motivação de tolerância e de pluralidade ideológica, bem como o quanto parece indicar para o Brasil o pequeno episódio ligado ao encontro da Imagem de Nossa Senhora Aparecida.

Conforme publicação no website do Santuário de Aparecida, a exposição Coleção Santa Gertrudes de Imagens Paulistas do Século XVII foi inaugurada no Museu Nossa Senhora Aparecida em 8 de julho de 2016. E considera-se que, "além do valor histórico e religioso de cada uma das 54 peças da exposição, há também a contextualização do período artístico em que se acredita que a Imagem da Padroeira do Brasil tenha sido modelada". ${ }^{5}$

De acordo com o texto da curadora Maria Inês Lopes Coutinho, conforme consta no catálogo da exposição, organizado por Abdalla,

${ }^{55}$ A12. Santuário inaugura exposição "Coleção Santa Gertrudes de Imagens Paulistas do Século XVIl". Disponível em: <http://www.a12.com/santuario/imprensa/releases/santuario-inauguraexposicao-colecao-santa-gertrudes-de-imagens-paulistas-do-seculo-xvii>. Acesso em 25 mar. 2018. 
No conjunto das peças de barro produzidas no período colonial paulista, há um expoente que é nada menos que a Padroeira do Brasil, Nossa Senhora da Conceição Aparecida. Apesar de não fazer parte dessa exposição, apresenta características da época colonial, mesmo material e autoria atribuída ao principal artista da mostra. Ela deve ser analisada à luz da arte e da fé, diferentemente de uma obra que pertence ao acervo de um museu ou a uma coleção particular. (ABDALLA, 2016, p. 18).

Para que fosse possível fazer essa contextualização e análise artística, optouse, no Museu Nossa Senhora Aparecida, por expor uma imagem fac-símile de Nossa Senhora Aparecida ladeada a imagem de Nossa Senhora da Conceição, atribuída a Frei Agostinho de Jesus, para comparação dos estilos, considerando que há estudos que atribuem a autoria da Imagem de Nossa Senhora Aparecida ao mesmo escultor ou escola artística, conforme podemos observar (Figura 125).

Figura 125: Núcleo Frei Agostinho de Jesus - Exposição "Coleção Santa Gertrudes de Imagens Paulistas do século XVII".

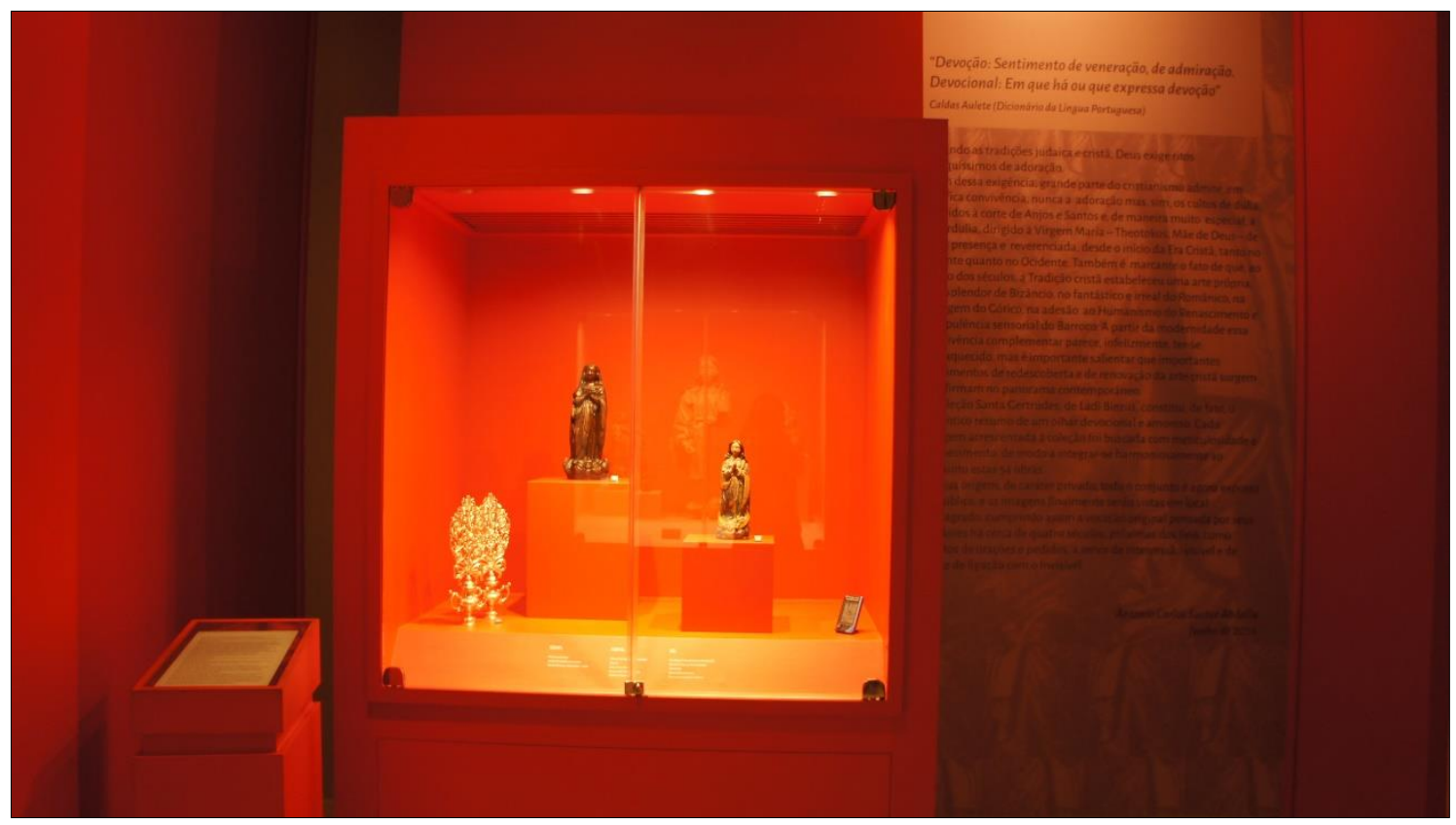

Fonte: MNSA/ Santuário Nacional. Foto: Erica Coelho.

No ínterim desses estudos, segundo o texto de Maria Inês Lopes Coutinho, que consta no catálogo da exposição organizado por Abdalla,

O Museu de Arte Sacra de São Paulo participou do IX Congresso Mariológico realizado no Santuário Nacional de Aparecida/SP, em setembro de 2015. Nesse encontro, fez-se comentário sobre um estudo comparativo de partículas de barro. O teste foi aplicado na imagem de Nossa Senhora da Conceição Aparecida e no barro oriundo da cidade de Santana de Parnaíba. O resultado demonstrou semelhança nas partículas avaliadas. (ABDALLA, 2016, p. 19).

De maneira geral, o estudo indica que o período artístico em que se acredita que a imagem de Nossa Senhora Aparecida tenha sido produzida é o mesmo 
período de outras obras atribuídas a Frei Agostinho de Jesus ou a algum de seus discípulos. E, conforme os estudos comentados pelo Museu de Arte Sacra de São Paulo, os testes realizados por meio de partículas de barro demonstram semelhanças com o barro oriundo da cidade de Santana de Parnaíba. Enfim, nessa cidade havia o Mosteiro de Parnaíba, onde Frei Agostinho de Jesus trabalhou por volta de 1650, local em que foram encontradas várias obras de sua autoria. Portanto, fatos históricos, estilos artísticos e estudos do material indicam a possível autoria da verdadeira imagem de Nossa Senhora Aparecida.

\section{Síntese analítica do conjunto de elementos das exposições}

Assim como apresentado no tópico anterior, o intuito desta síntese é fazer uma reflexão quanto à eficácia e qualidade da exposição O Museu e suas Histórias, assim como da exposição Coleção Santa Gertrudes de Imagens Paulistas do século $X V I I$, a partir do estudo do conjunto de elementos que compõem as exposições, ambas localizadas no $2^{\circ}$ andar da Torre Brasília.

No que se refere à infraestrutura e acessibilidade nas salas de visitação, conforme já mencionado, os elevadores conduzem os visitantes primeiramente ao 16ํaㅁ, onde está o Mirante da Torre, garantindo acessibilidade aos cadeirantes e pessoas com mobilidade reduzida. Embora nessas exposições também não tenham sido encontrados recursos para visitantes com deficiência auditiva, visual ou de outras naturezas.

As salas expositivas apresentam climatização controlada, sendo possível observar a presença de aparelhos termo-higrômetro no interior das vitrines, para monitoramento das variações de temperatura e umidade relativa.

Em relação à segurança física, nas visitas exploratórias e de observação, foi presenciada segurança patrimonial apenas no início de expediente, para abertura das salas expositivas. Entretanto, observamos atualmente que os próprios funcionários do Museu têm acesso às chaves para abrir as salas de exposição, não necessitando mais do acompanhamento de um segurança patrimonial. Observamos que foi uma mudança na política institucional, no que se refere aos postos e atribuições dos seguranças.

A segurança predial também é respaldada pela instalação de câmeras de vigilância, sensores contra incêndio e alarmes de segurança. Também identificamos 
a sinalização na entrada da exposição e nos ambientes internos, com imagens orientando a não utilização de celulares e não realização de fotografias e filmagens, para garantir a segurança e preservação das peças.

Em relação à organização do espaço físico, na saída do elevador, à direita, há uma pequena mesa de recepção, com a presença constante de um recepcionista e, eventualmente, alguns monitores. Não sendo necessárias instruções dos ascensoristas para os visitantes acessarem a sala da exposição, pois são prontamente recepcionados, embora observamos que, no interior do elevador, tanto na subida ao Mirante, quanto na descida ao $2^{\circ}$ andar, várias informações são comunicadas pelos ascensoristas.

De maneira geral, a exposição O Museu e suas Histórias está organizada na área principal da sala, com corredor inicial à esquerda, composto por nichos nas paredes e estantes móveis, além de painéis instalados em trilhos que cobrem as janelas, barrando a luz natural e compondo o ambiente com elementos decorativos, que remetem aos padrões de certos detalhes do acervo. Alguns desses painéis apresentam textos de apoio, conforme o conceito expositivo dos núcleos próximos.

Em relação à organização do acervo, estão bem organizados sobre cubos vazados e suportes no interior dos nichos e vitrines. A iluminação é indireta, pois há filtros e grades que distribuem a iluminação no interior dos mobiliários, sem focos de iluminação para destaque, além da iluminação geral da sala, no teto e nas sancas superiores e inferiores, tornando o ambiente mais agradável.

Observamos que o conceito expositivo é facilmente identificado pelos painéis textuais, que possuem textos de apresentação dos núcleos, conforme a temática abordada. O roteiro expositivo é sequencial, com harmonia entre os acervos expostos, de acordo com a sequência dos núcleos. Com isso, identificamos a importância dada aos objetos museológicos, devido à relevância deles no contexto temático de cada núcleo, que apresenta um layout limpo, porém com destaque a determinadas peças do acervo.

Como recursos expográficos, além dos nichos e vitrines, diferenciadas por cores fortes e vibrantes, observamos painéis textuais ou texturizados com padrões que dão harmonia ao ambiente, pois se equilibram com os tons de bege da parede, do teto e o fundo dos painéis, garantindo assim uma boa qualidade da comunicação visual, considerando que os textos seguem um padrão de fonte, tamanho e cor. 
No interior das vitrines também há textos de apoio, adesivados com letras de recorte, dando contraste às cores das vitrines. Há também etiquetas com numeração próxima aos objetos, com legendas instaladas na parte inferior das vitrines, que apresentam uma inclinação chanfrada para facilitar a leitura. Em apenas alguns casos, em que há uma grande quantidade de objetos, foi necessária a fixação das legendas em uma das laterais da vitrine, por falta de espaço na parte inferior.

Notamos que essa exposição não apresenta sonorização como recurso expográfico, conforme observado nas outras exposições do Museu.

A Ficha Técnica encontra-se sobre o balcão da recepção, ao lado do elevador, listando os profissionais envolvidos na elaboração da exposição, bem como o grupo de funcionários que compunham a equipe do Museu na época da inauguração da exposição, em 2012. De maneira geral, a exposição foi financiada pelo Santuário Nacional de Aparecida, dando destaque aos Missionários Redentoristas que zelam e administram o Santuário.

Ao analisar esse conjunto de elementos, observamos que há harmonia entre os núcleos, recursos expográficos e iluminação, embora as cores fortes das vitrines acabam dando evidência à poeira e sujidades, sendo possível observar também alguns desgastes nas pinturas, provavelmente ocasionados com a movimentação do acervo para manutenção e limpeza.

De maneira geral, há inteligibilidade na composição dos núcleos, sendo complementados com textos de apoio. Desta forma, acreditamos que os elementos estudados são suficientes para compreensão do público sobre a proposta da exposição O Museu e suas Histórias, que valoriza a relação do homem com o sagrado, sua expressão, seu cotidiano e sua relação com a natureza.

Em relação à exposição Coleção Santa Gertrudes de Imagens Paulistas do século XVII, situada na área de finalização do ambiente expositivo, no $2^{\circ}$ andar, observamos uma grande mudança logo na entrada do corredor, pois a concepção de iluminação é totalmente diferente, com poucas luzes, com focos pontuais em determinadas peças do acervo. Já a área central do corredor também possui pouca iluminação, com os focos de luz direcionados aos painéis textuais.

O mobiliário segue o mesmo padrão da outra sala de exposição, porém há uma adaptação na parte superior das vitrines, que chega até o teto. O mobiliário segue um padrão de cor cinza, porém na parte interna, ao fundo, há cores que remetem aos conjuntos da coleção, conforme referência de autoria das obras. 
Essa mudança nas vitrines, em comparação com as vitrines da outra sala, foi necessária, considerando que cada vitrine foi climatizada individualmente, com o intuito de garantir a maior estabilidade possível em relação às variações de temperatura e umidade relativa, que é sistematicamente controlada pelos funcionários do Museu, e equipamentos de telemetria, que informam diretamente o Departamento de Infraestrutura, sobre as eventuais alterações climáticas.

Nessa sala também observamos densos painéis textuais, que cobrem as paredes desde o teto até próximo ao piso, o que de certa forma acaba não sendo muito atrativo aos visitantes, devido ao excesso de informação. Esses painéis não seguem um padrão harmonioso, pois há texturas que remetem aos detalhes de peças do acervo, com os textos sobrepostos na cor branca. Identificamos, também, que os painéis possuem tons de cinza diferentes, além de um painel vermelho ao fundo, dando certo destaque ao texto do colecionador, entre os grupos de vitrines com tons de cinza. Há apenas uma vitrine na cor vermelha, logo no início da exposição, na lateral direita, dando destaque a uma imagem fac-símile de Nossa Senhora da Conceição Aparecida, em comparação a uma imagem de Nossa Senhora da Conceição, atribuída a Frei Agostinho de Jesus.

Em relação à organização do acervo, observamos certa harmonia entre os núcleos, pois seguem um mesmo padrão de posicionamento com inclinação, não apresentando os objetos de maneira frontal. Como recursos expográficos, há caixas retangulares, com grandes proporções, para dar destaque aos grupos de objetos, e não às peças específicas, conforme na outra sala expositiva.

De maneira geral, a diagramação visual é carregada de textos nos painéis, com pequenos textos de apoio nas laterais internas das vitrines, que abordam os núcleos temáticos, conforme organização de autoria das obras. Já os dados técnicos sobre os objetos foram diagramados em uma única etiqueta adesivada na parte inferior, distribuída de forma equilibrada em toda a extensão do chanfro da vitrine, embora a visualização acabe sendo um pouco dificultada, considerando o texto com fonte na cor branca sobre um fundo cinza claro. O mesmo ocorre com os textos de apoio nas laterais internas das vitrines.

Apesar desses itens apresentados, que podem se tornar pontos de melhoria no futuro, acreditamos que o conjunto de elementos analisados é suficiente para o público compreender a proposta expositiva. Esse conjunto consegue atrair a atenção 
dos visitantes por concentrar, em uma pequena sala, uma coleção representativa de um período histórico e artístico.

Em relação aos créditos, próximo à porta de saída da sala, que dá acesso novamente ao balcão de recepção, há uma Ficha Técnica relacionada aos profissionais envolvidos na elaboração da exposição.

Assim como as demais exposições de longa duração, essa exposição também foi financiada pelo Santuário Nacional de Aparecida, que fez grandes investimentos de infraestrutura para garantir a climatização interna das vitrines, com constante monitoramento.

Em suma, acreditamos que a exposição Coleção Santa Gertrudes de Imagens Paulistas do século XVII veio engrandecer e somar às demais coleções do Museu Nossa Senhora Aparecida, especialmente por valorizar a coleção de imagens religiosas, dando ênfase ao sagrado nas exposições museológicas.

\subsection{Exposição Circuito de Visitação à Cúpula}

O Circuito de Visitação à Cúpula foi criado com o intuito de rememorar a grande celebração do Tricentenário do encontro da Imagem de Nossa Senhora Aparecida, em 2017. O circuito, composto por três módulos expositivos e o mirante da cúpula central da Basílica, foi inaugurado em 18 de outubro de 2017, alguns dias após a abertura da cúpula central, para que se pudesse admirar a criação artística de Cláudio Pastro.

Dividido em duas fases de montagem, em um primeiro momento o circuito foi concebido com o módulo expositivo 300 Anos de Bênçãos e de Graças, na entrada do corredor superior da Nave Norte e Corações aos Céus: Criação, Beleza e Redenção, no corredor circundando a cúpula. Foi apenas em meados de 2018 que foi finalizado o terceiro módulo expositivo, referente ao início da exposição, segundo o critério cronológico, que foi instalado na entrada do corredor superior da Nave Norte, sendo necessária a transferência do módulo 300 Anos de Bênçãos e de Graças para o corredor de saída. Este módulo inicial da exposição, inaugurada no dia 04 de julho de 2018, recebeu o título Basílica Nacional: A construção de um sonho.

O acesso ao piso superior da Nave Norte se dá por meio de elevadores, a seguir por escadas ou plataformas para pessoas com mobilidade reduzida ou cadeirantes. No final do corredor há outro lance de escadas, assim como 
plataformas para acessibilidade à grande cúpula da Basílica (parcialmente apresentada na lateral esquerda da Figura 126).

A Figura 126 apresenta a planta do Circuito de Visitação à Cúpula. Os números inseridos na Figura indicam os módulos e núcleos temáticos que serão descritos a seguir.

O grande ápice desse circuito é a própria cúpula central da Basílica, que pode ser admirada com uma distância de poucos metros. Na parte interior desse mirante, em um corredor que circunda a cúpula, encontra-se o segundo módulo da exposição, composto por painéis textuais e fotográficos, adesivados sobre grandes placas de vidro, e também com reproduções de imagens adesivadas nas paredes, além de textos sobre os arcos que dão acesso ao corredor para admiração da cúpula.

Já o terceiro módulo, representado na planta pelo corredor inferior, assim como primeiro módulo, é composto por painéis de vidro fixados em placas de madeira, sobre as vitrines, contendo textos de apoio e imagens que contextualizam os temas abordados na exposição, conforme detalhamento a seguir.

Figura 126: Planta - Circuito de Visitação à Cúpula.

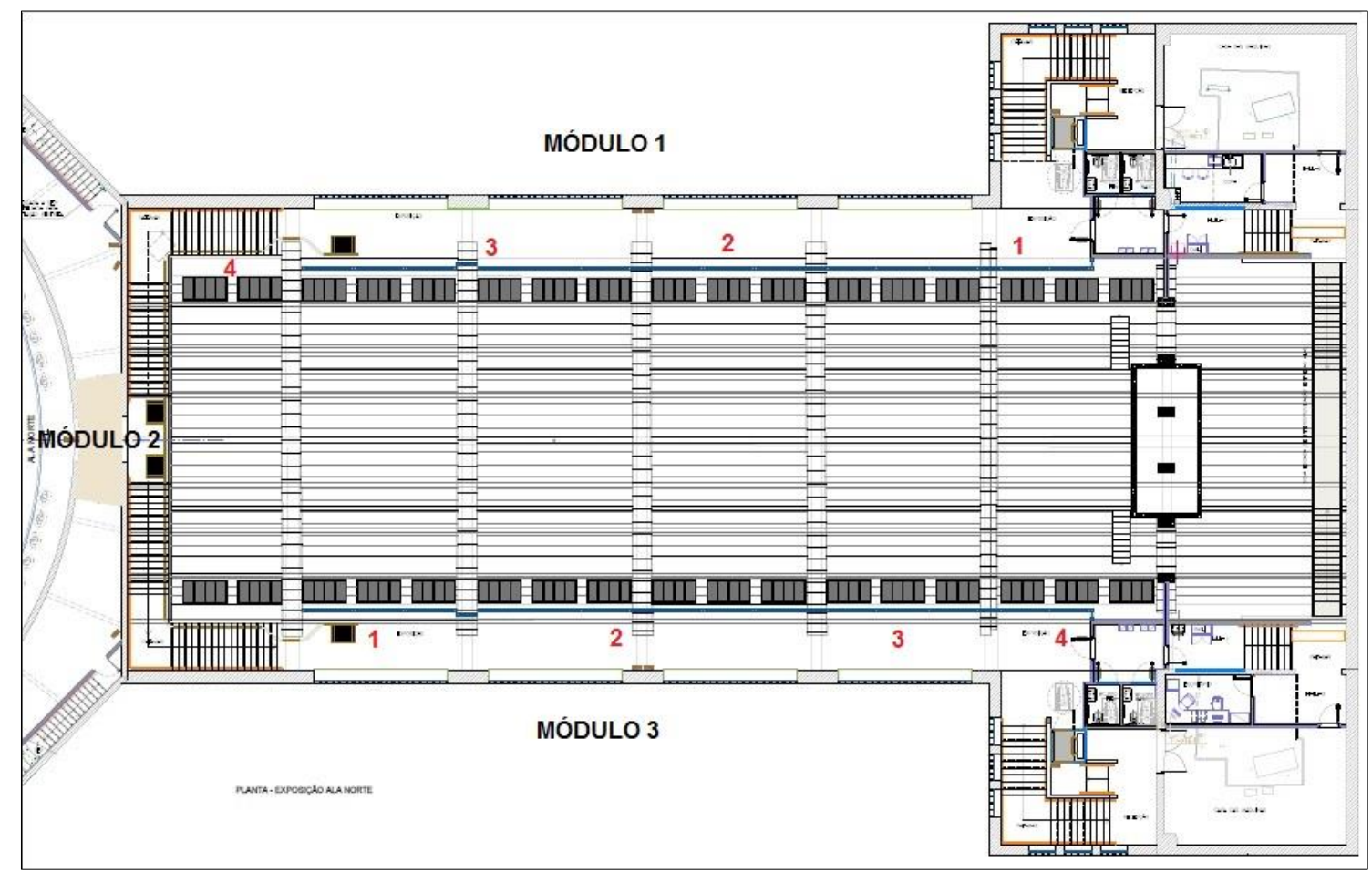

Fonte: MNSA/ Santuário Nacional.

A Figura 127 registra o momento de apresentação do Circuito de Visitação à Cúpula, idealizado por Giselle Peixe e Silvia Bigareli, durante as comemorações de 
inauguração, que também contemplou o lançamento do livro Santuário de Aparecida, com autoria de Fabio Colombini e Cláudio Pastro. O livro busca registrar o legado artístico de Cláudio Pastro, eternizado no maior Santuário Mariano do mundo.

Figura 127: Inauguração do Circuito de Visitação à Cúpula.

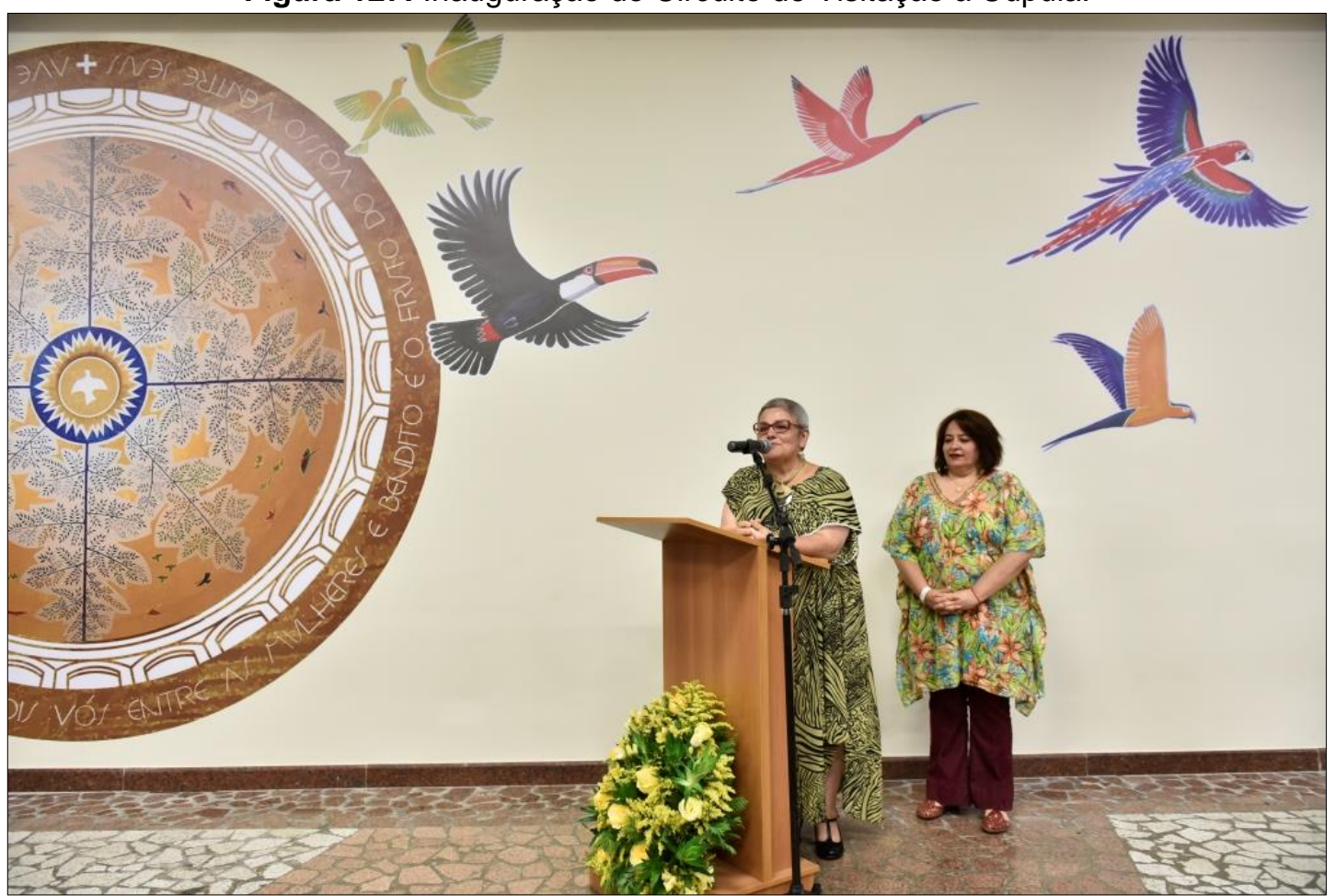

Fonte: MNSA/ Santuário Nacional. Foto: Thiago Leon.

São vários os elementos que compõem a exposição (no Apêndice A - Quadro 29, podemos verificá-los). O primeiro módulo da exposição, que recebeu o título Basílica Nacional: A construção de um sonho, é composto por catorze painéis de vidros adesivados, três TVs e quatro núcleos com dezessetes vitrines.

O texto de apresentação do módulo expositivo pode ser observado contextualizando a construção da Nova Basílica (Figura 128). 
Figura 128: Primeiro módulo expositivo do circuito de visitação à cúpula, "Basílica Nacional: A construção de um sonho".

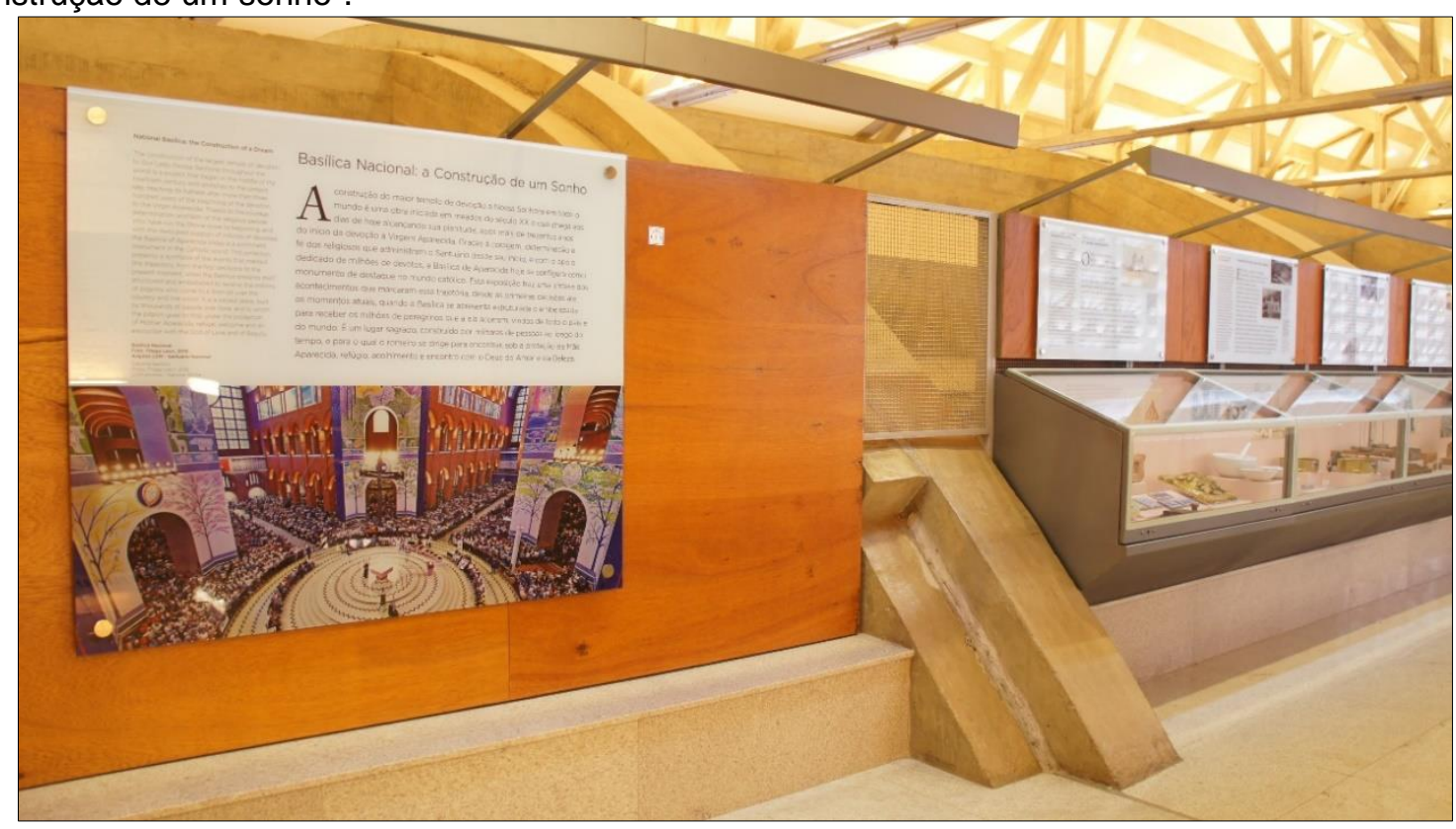

Fonte: MNSA/ Santuário Nacional. Foto: Erica Coelho.

No primeiro núcleo (Figura 129), organizado em cinco vitrines sequenciais, destacam-se objetos procedentes da Basílica Velha, como pisos e azulejos, fechadura com chave, tijolo e ornamento decorativo. Assim como objetos relacionados à Basílica Nova, como os elementos para estudo do solo, tijolos da construção e do revestimento, assim como objetos que remetem às ações específicas da Campanha dos Devotos, imprescindível para manutenção das obras de infraestruturas e obras assistenciais realizadas pelo Santuário Nacional de Aparecida. 
Figura 129: Primeiro núcleo - "Basílica Nacional: A construção de um sonho".

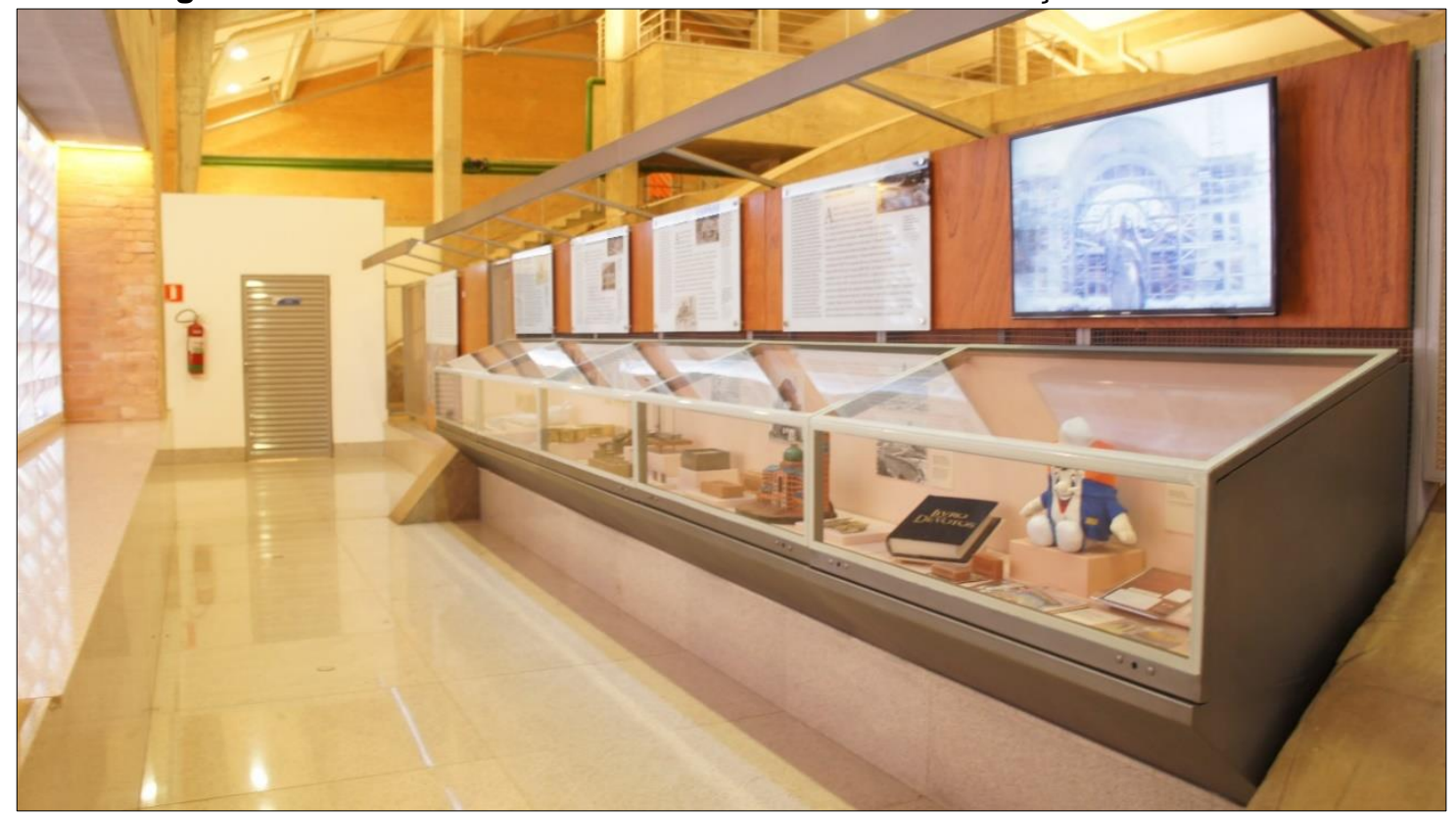

Fonte: MNSA/ Santuário Nacional. Foto: Erica Coelho.

Em relação aos painéis que acompanham o roteiro da exposição, o texto de curadoria do primeiro painel está relacionado à construção da primeira capela em pau-a-pique e posteriormente outra capela no alto do Morro dos Coqueiros, que foi inaugurada em 1745. Após um século, o templo passou por reformas e ampliações, sendo inaugurado em 1888, com o intuito de atender o crescente número de romeiros.

O texto de curadoria do segundo painel aborda a escolha do terreno para a Nova Basílica, pois com o passar do tempo torna-se necessária uma igreja maior. Vários locais foram cogitados para a implantação desse novo templo e, finalmente, o Morro das Pitas foi escolhido.

O texto de curadoria do terceiro painel informa que a pedra fundamental deste novo templo foi lançada em 1946. O arquiteto Benedito Calixto de Jesus Netto foi responsável por elaborar o projeto, dando início às obras de preparação do terreno em 1952 e, em 1955, é entronizada na praça da nova Basílica a Imagem de Nossa Senhora da Assunção.

O texto de curadoria do quarto painel dá continuidade às obras que foram iniciaram pela Nave Norte em 1955. A primeira Missa se realizou em 1959, com a obra em andamento. A partir de então, o atendimento aos peregrinos passou a ser feito na igreja em construção. A sagração do templo foi feita pelo Papa São João Paulo II, em 1980, quando o Pontífice o declara "Basílica Menor". 
Por fim, sobre a quinta vitrine, encerrando esse núcleo, há uma televisão que exibe um vídeo histórico, composto por fotografias, legendas, recortes de outros vídeos e animações, retratando, assim, as obras de construção do maior templo mariano do mundo.

No segundo núcleo (Figura 130), estão as amostras do piso, do telhado e dos azulejos do revestimento, que retratam as obras de Cláudio Pastro, assim como elementos que compõem a antiga Porta Santa, além de estudos da nova Porta Santa e protótipos do nicho de Nossa Senhora Aparecida, juntamente com uma imagem fac-símile, e demais amostras dos azulejos do revestimento, representado a arte sacra dos painéis laterais e principais das Naves Norte e Sul.

Figura 130: Segundo núcleo - "Basílica Nacional: A construção de um sonho".

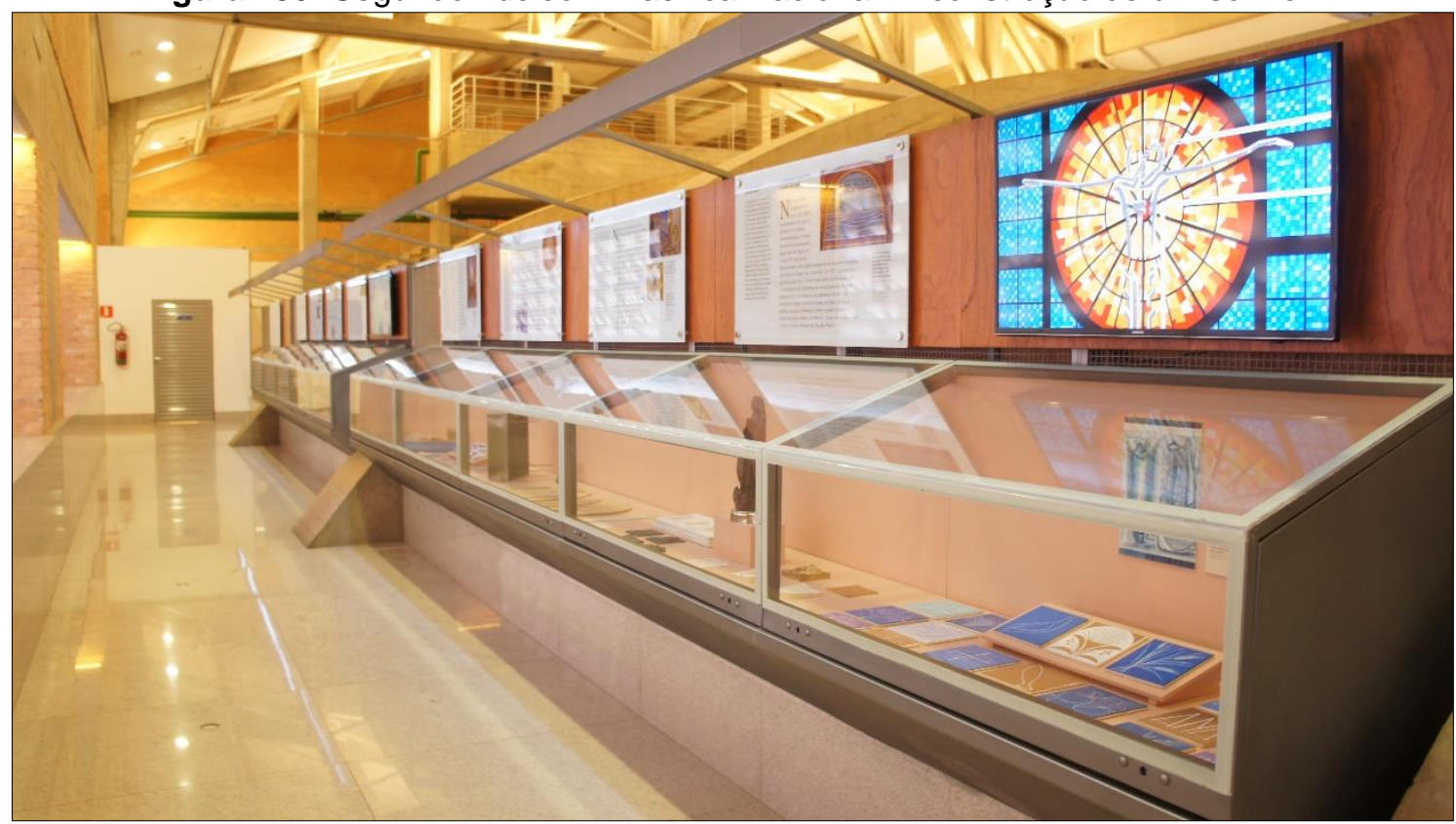

Fonte: MNSA/ Santuário Nacional. Foto: Erica Coelho.

Nesse segundo núcleo há mais quatro painéis textuais, com ilustrações, além de outra televisão que exibe um vídeo referente às obras de revestimento da Basílica, composto por fotografias e animações que transitam entre os projetos de Cláudio Pastro, para as obras finalizadas, no interior da Basílica.

No início desse núcleo, o texto de curadoria do quinto painel apresenta a Campanha dos Devotos em 1999, que possibilitou a contratação do artista Cláudio Pastro para conceber o projeto artístico da Basílica. De maneira geral, observamos que a rica simbologia presente no Santuário é uma arte didática e de introdução aos mistérios do Sagrado. 
O texto de curadoria do sexto painel está relacionado à simbologia que consta nos azulejos da Nave Norte, inaugurada em 2005. Esse texto informa que, abaixo da cena central, criada por Pastro para ser instalada sobre a Porta Santa, há a representação do Cristo Pantocrator, como uma composição de faixas decorativas que trazem elementos da simbologia cristã.

O texto de curadoria do sétimo painel aborda a Nave Sul da Basílica, na qual se destaca $O$ Portal da Virgem, onde está o nicho com a Imagem original de Nossa Senhora Aparecida. Na composição artística de Cláudio Pastro, há uma grande faixa dourada na vertical, com as figuras de três arcanjos, expressando a ligação entre o Divino e o humano.

O texto de curadoria do oitavo painel contextualiza o encontro da imagem de Nossa Senhora, considerando que, na rampa que dá acesso ao Trono da imagem de Nossa Senhora Aparecida, há painéis com azulejos representando o milagre do encontro da imagem aparecida nas águas do Rio Paraíba do Sul em 1717. Já na rampa de saída há a representação dos outros milagres conhecidos do grande público frequentador. Nas laterais que dão acesso ao Trono da imagem, há painéis com as invocações da Ladainha de Nossa Senhora.

Por fim, sobre a décima vitrine, encerrando esse núcleo, está a segunda televisão que exibe um vídeo sobre as obras de revestimento da Basílica, a partir das criações artísticas de Cláudio Pastro, transitando dos projetos para fotografias atuais, com elementos animados e uma trilha sonora comovente.

No terceiro núcleo (Figura 131), estão os azulejos das demais Naves Leste e Oeste e amostras dos vitrais. Além de azulejos referentes ao revestimento das capelas internas (Capela de São José e Capela do Santíssimo), e ex-votos referenciando os demais espaços da Basílica, como, por exemplo, a Sala das Promessas. Há também objetos que remetem à presença do clero, considerando os bispos, cardeais e padres redentoristas que participaram do processo de construção da Basílica. 
Figura 131: Terceiro núcleo - "Basílica Nacional: A construção de um sonho".

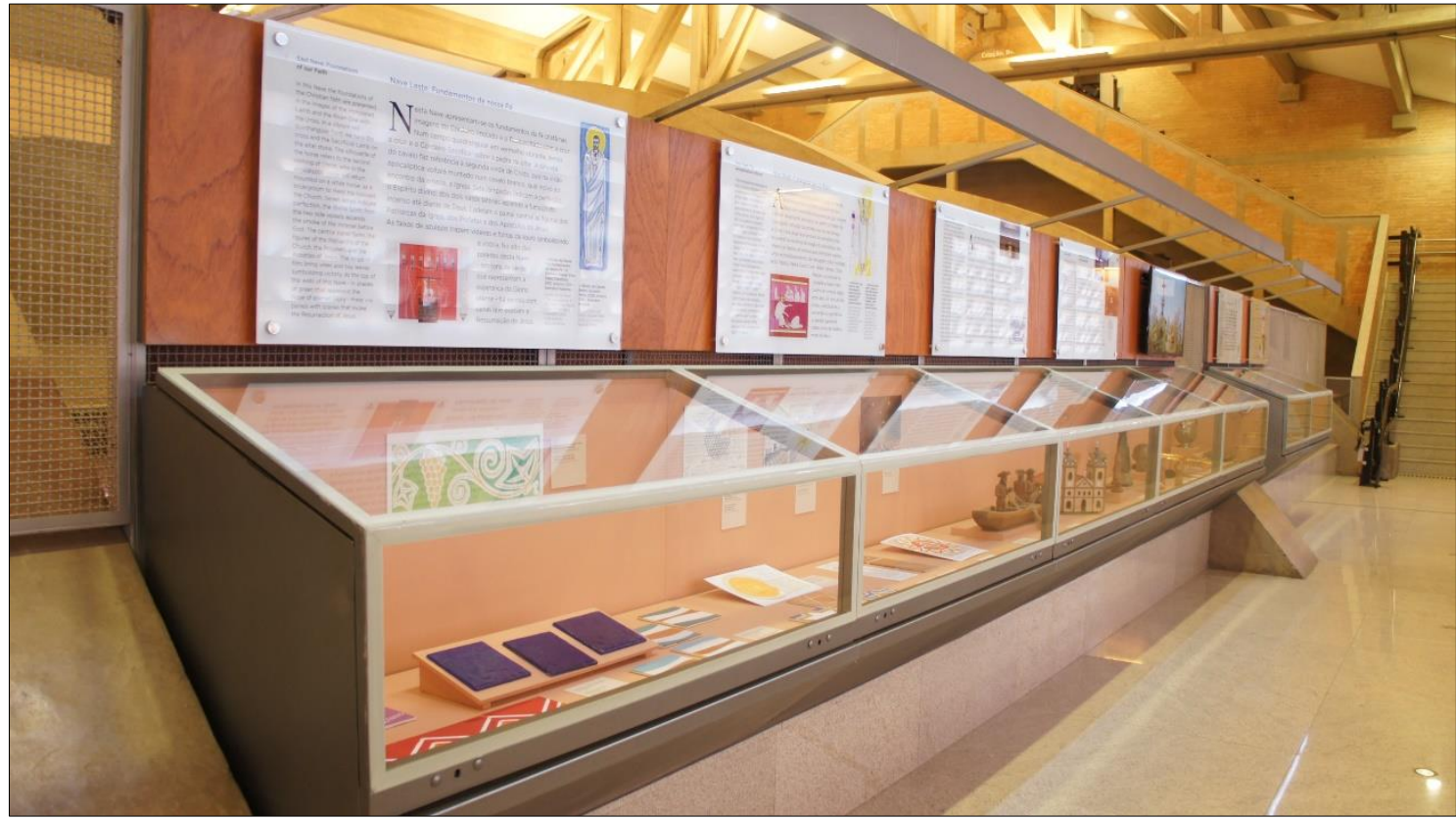

Fonte: MNSA/ Santuário Nacional. Foto: Erica Coelho.

Nesse núcleo há mais quatro painéis textuais e com ilustrações sobre as vitrines, bem como uma terceira televisão que transmite um vídeo informativo sobre todo o Complexo do Santuário Nacional, com um grande mapa interativo mostrando a localização dos locais mais visitados, complementados com textos informativos, em transições com animação.

No início desse núcleo, o texto de curadoria do nono painel aborda os fundamentos da fé cristã nas imagens do Cordeiro Imolado e o Ressuscitado com a cruz, que compõem o revestimento da Nave Leste da Basílica. Na concepção de Cláudio Pastro, ladeiam esse painel central as figuras dos Patriarcas da Igreja, dos Profetas e dos Apóstolos de Jesus.

O texto de curadoria do décimo painel apresenta a mensagem evangelizadora da Igreja em terras brasileiras, sendo referenciada no painel da Nave Oeste da Basílica, por intermédio daqueles que aqui viveram e deram testemunho de sua fé.

$O$ texto de curadoria do décimo primeiro painel está associado às capelas internas do Santuário. A primeira capela a ser construída foi a Capela das Velas, tendo recebido o tratamento artístico em 2004. Já a Capela do Santíssimo foi concluída em 2007, e estão presentes em seu retábulo cinco mosaicos italianos com a representação dos quatro evangelistas e o Cordeiro Pascal, presenteados pelo Papa São João Paulo II, em 1980. Na Capela de São José, destaca-se o grande 
painel de azulejos representando o sonho de São José, do artista Cláudio Pastro; nas paredes, há dois relevos do escultor Adélio Sarro.

O texto de curadoria do décimo segundo painel, por sua vez, faz referência às capelas localizadas nas extremidades da colunata. Na Capela da Ressurreição, inaugurada em 2007, estão os restos mortais dos Bispos e Arcebispos de Aparecida, além do Memorial dos Devotos. A Capela do Batismo, localizada na outra extremidade da colunata da Esplanada João Paulo II, foi inaugurada em 2010.

Por fim, sobre a décima quinta vitrine, encerrando esse núcleo, está a terceira televisão que exibe um vídeo informativo sobre o Complexo do Santuário Nacional, sinalizando os principais pontos turísticos de interesse do grande público frequentador, contendo informações adicionais.

Encerrando esse módulo expositivo, o quarto núcleo (Figura 132) exibe diversos objetos relacionados aos acontecimentos de destaque no Santuário, como as visitas dos Papas, contendo alguns objetos que perteceram aos Bispos e Cardeais da Arquidiocese de Aparecida, e que remetem a presença dos Papas no Santuário, assim como uma réplica do decreto de consagração como Basílica Menor, em 1980.

Figura 132: Quarto núcleo - "Basílica Nacional: A construção de um sonho".

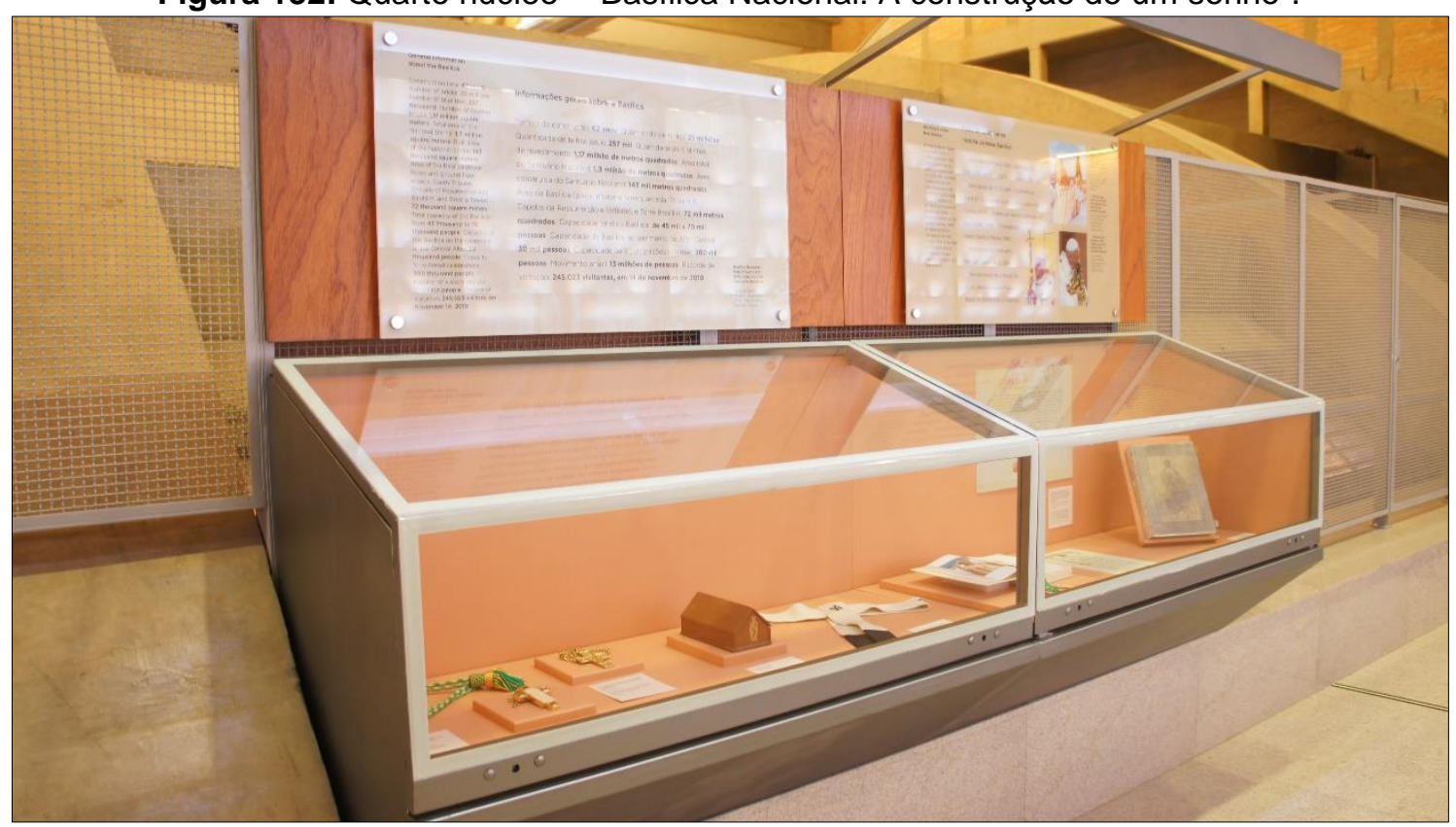

Fonte: MNSA/ Santuário Nacional. Foto: Erica Coelho.

O texto de curadoria do décimo terceiro painel traz informações gerais sobre a Basílica, como o tempo de construção, a quantidade de tijolos e de telhas azuis, sua área total, bem como demais áreas construídas do Santuário Nacional, incluindo 
pisos inferior e térreo, arcada, Tribuna Sul, Capelas da Ressurreição e do Batismo, e Torre Brasília. Além da capacidade total de pessoas, tanto no interior quanto em celebrações externas, tendo recebido 13 milhões de pessoas no ano de 2017.

E, por fim, o texto de curadoria do décimo quarto painel contextualiza a visita do Papa João Paulo II, para Sagração da Basílica em 1980; visita do Papa Bento $\mathrm{XVI}$, em virtude da V Conferência Geral da América Latina e do Caribe, ocorrida em 2007, bem como a visita do Papa Francisco, por ocasião da Jornada Mundial da Juventude, em 2013, no Rio de Janeiro.

O segundo módulo expositivo do Circuito de Visitação à Cúpula possui o título Corações aos Céus: Criação, Beleza e Redenção, e está localizado no corredor interno da cúpula central. Esse módulo é composto por cinquenta painéis que retratam as obras artísticas de Cláudio Pastro, desde sua concepção, produção, montagem e finalização das obras para revestimento interno da cúpula e colunas do Baldaquino, apresentando apenas três vitrines com amostras das tésseras e de azulejos utilizados no revestimento do Baldaquino.

Figura 133: Segundo módulo expositivo do circuito de visitação à cúpula, "Corações aos Céus: Criação, Beleza e Redenção".

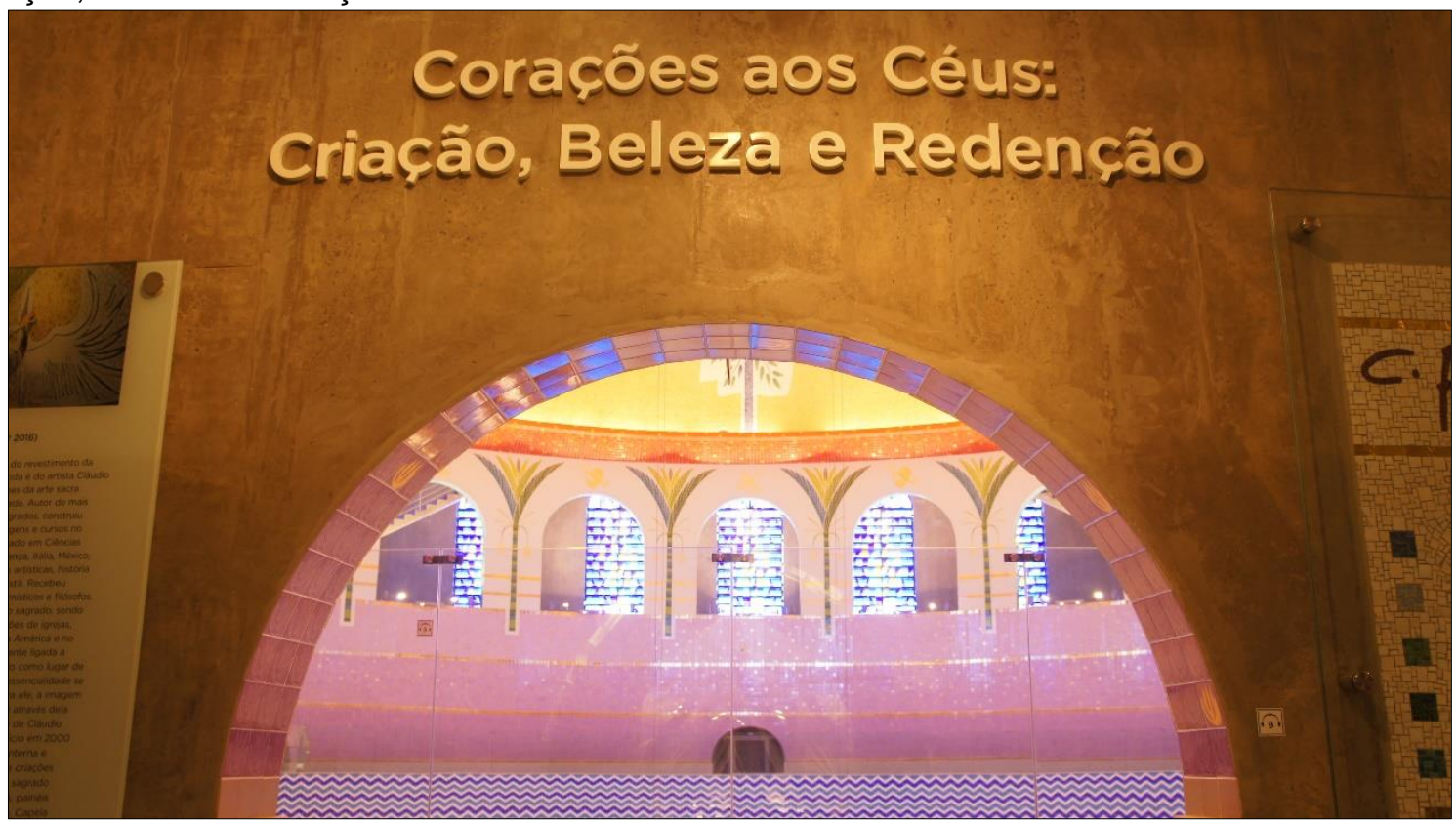

Fonte: MNSA/ Santuário Nacional. Foto: Erica Coelho.

A entrada desse módulo expositivo permite o acesso à grande Cúpula Central da Basílica Nacional, sobre o altar central da Igreja, onde ocorrem as principais celebrações do Santuário. Além desse arco de entrada (Figura 133), há ainda outros sete arcos ao redor dessa circunferência, possibilitando que os visitantes percorram 
entre os corredores internos e externos, onde há painéis explicativos sobre a concepção artística de Cláudio Pastro na criação do Baldaquino, assim como o significado simbólico de cada elemento.

De acordo com Giselle Peixe e Silvia Bigareli (2017, p. 1),

O Grande Baldaquino é formado pela cúpula central, seu capitel e suas quatro colunas ou paredes de sustentação, coroando o altar, centro essencial da Basílica, espaço sagrado da Água Viva, do Amor, do encontro nupcial do Cordeiro Pascal com sua amada, que é a Igreja. E a Igreja são os peregrinos, os convidados à ceia do Senhor para celebrar a Eterna Aliança. Ao alto, a exuberância da grande cúpula nos convida a celebrar a criação em toda a sua beleza e majestade. Do Altíssimo também descem os Anjos sobre as paredes de sustentação do baldaquino, para auxiliar os homens em sua redenção, em seu caminho em busca da Jerusalém Celeste. Nas quatro colunas, entre os grandes arcos das quatro naves, podemos contemplar imagens da natureza em seu esplendor e mistério, como a criação humana e de todos os seres viventes, prova da relação de amor de Deus com o homem. E aqui no Santuário Nacional esta celebração se dá por intermédio da fauna e da flora brasileiras. Ao centro está Cristo, aquele que É, a grande Luz que vivifica os quatro cantos da terra.

Alguns dos painéis expositivos circundam, por meio de um corredor, a Cúpula Central da Basílica (conforme observados nas Figuras 134 a 136).

Figura 134: Segundo módulo expositivo do circuito de visitação à cúpula, "Corações aos Céus: Criação, Beleza e Redenção".

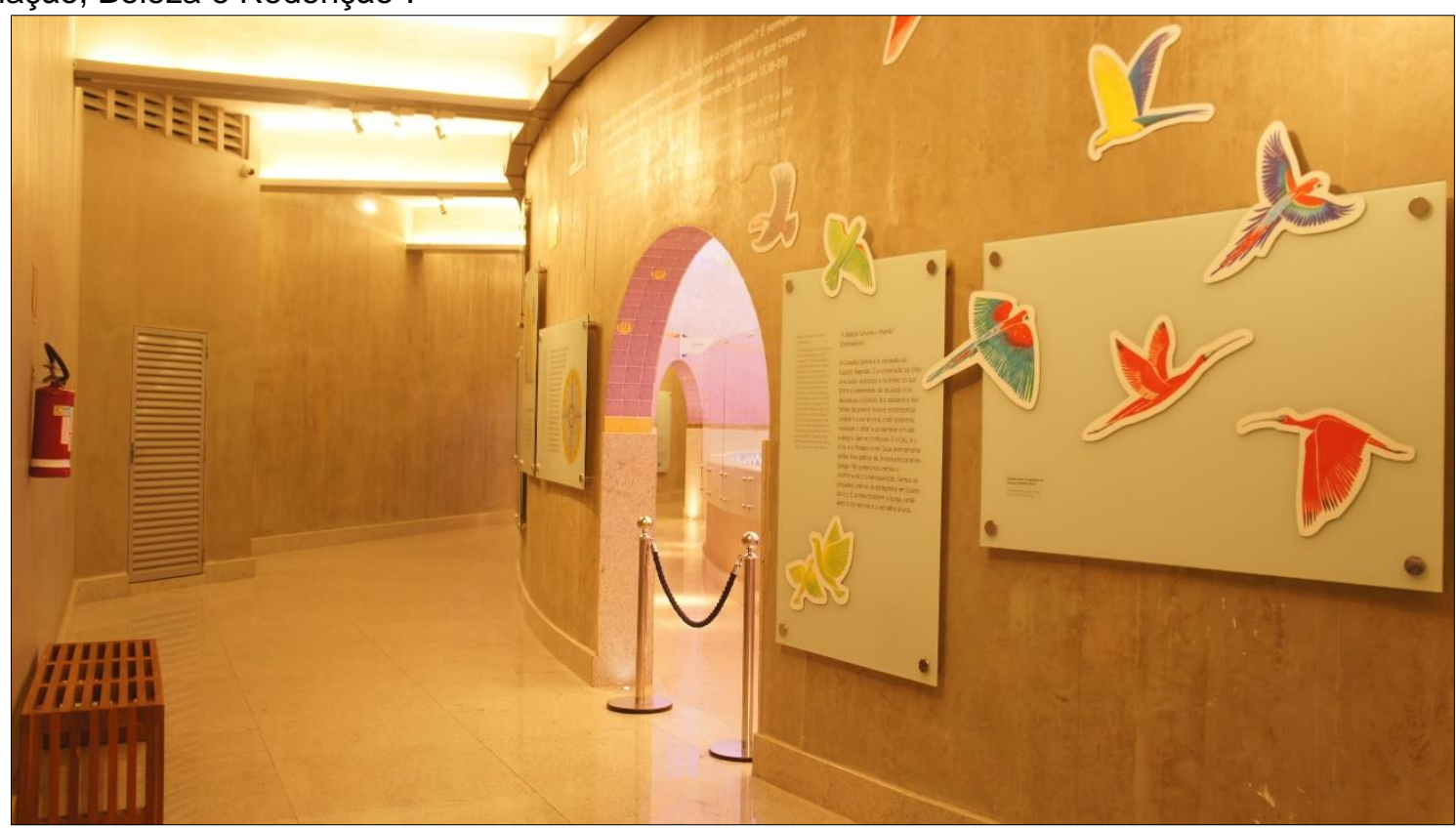

Fonte: MNSA/ Santuário Nacional. Foto: Erica Coelho. 
Figura 135: Segundo módulo expositivo do circuito de visitação à cúpula, "Corações aos Céus: Criação, Beleza e Redenção".

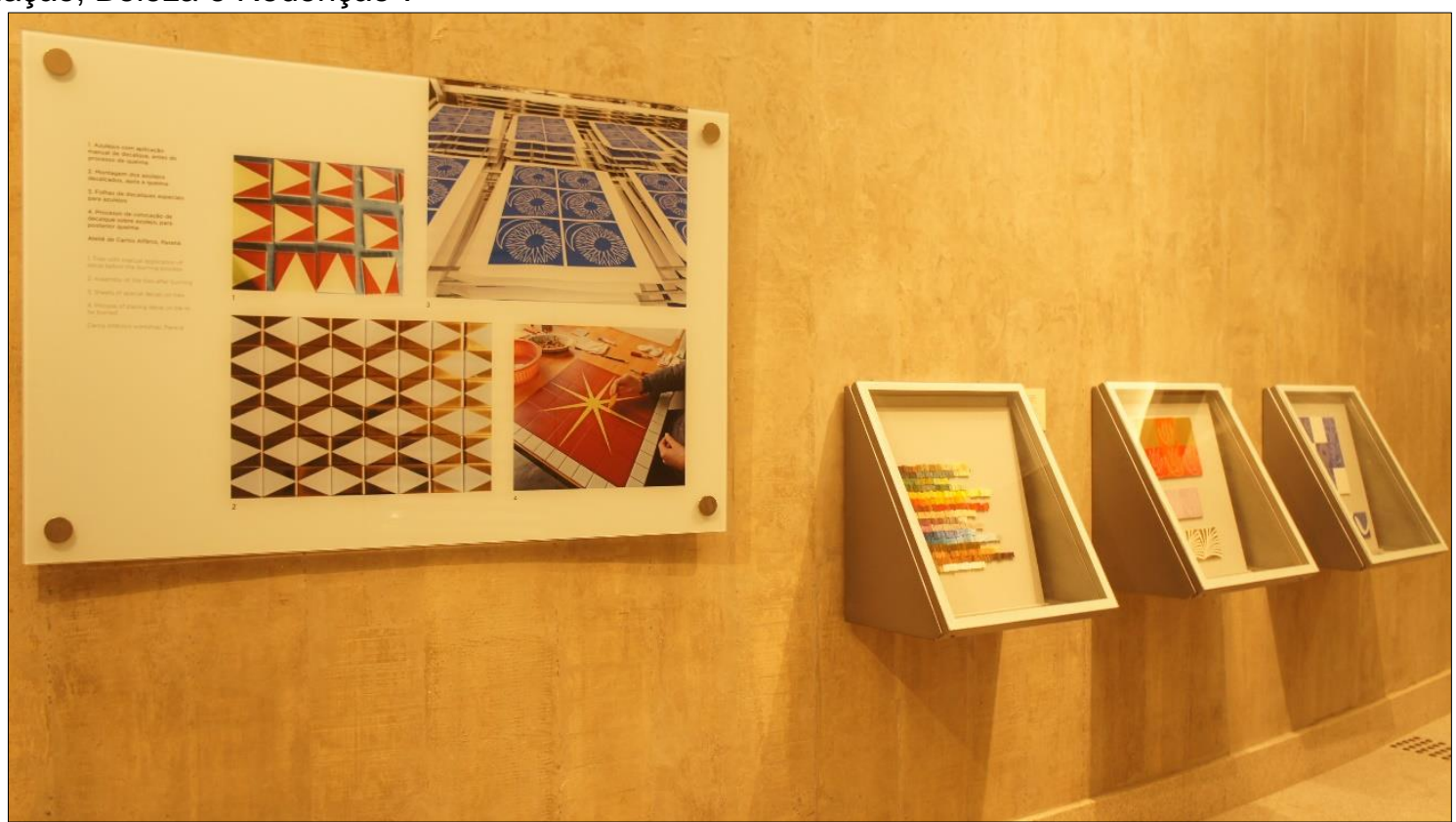

Fonte: MNSA/ Santuário Nacional. Foto: Erica Coelho.

Figura 136: Segundo módulo expositivo do circuito de visitação à cúpula, "Corações aos Céus: Criação, Beleza e Redenção".

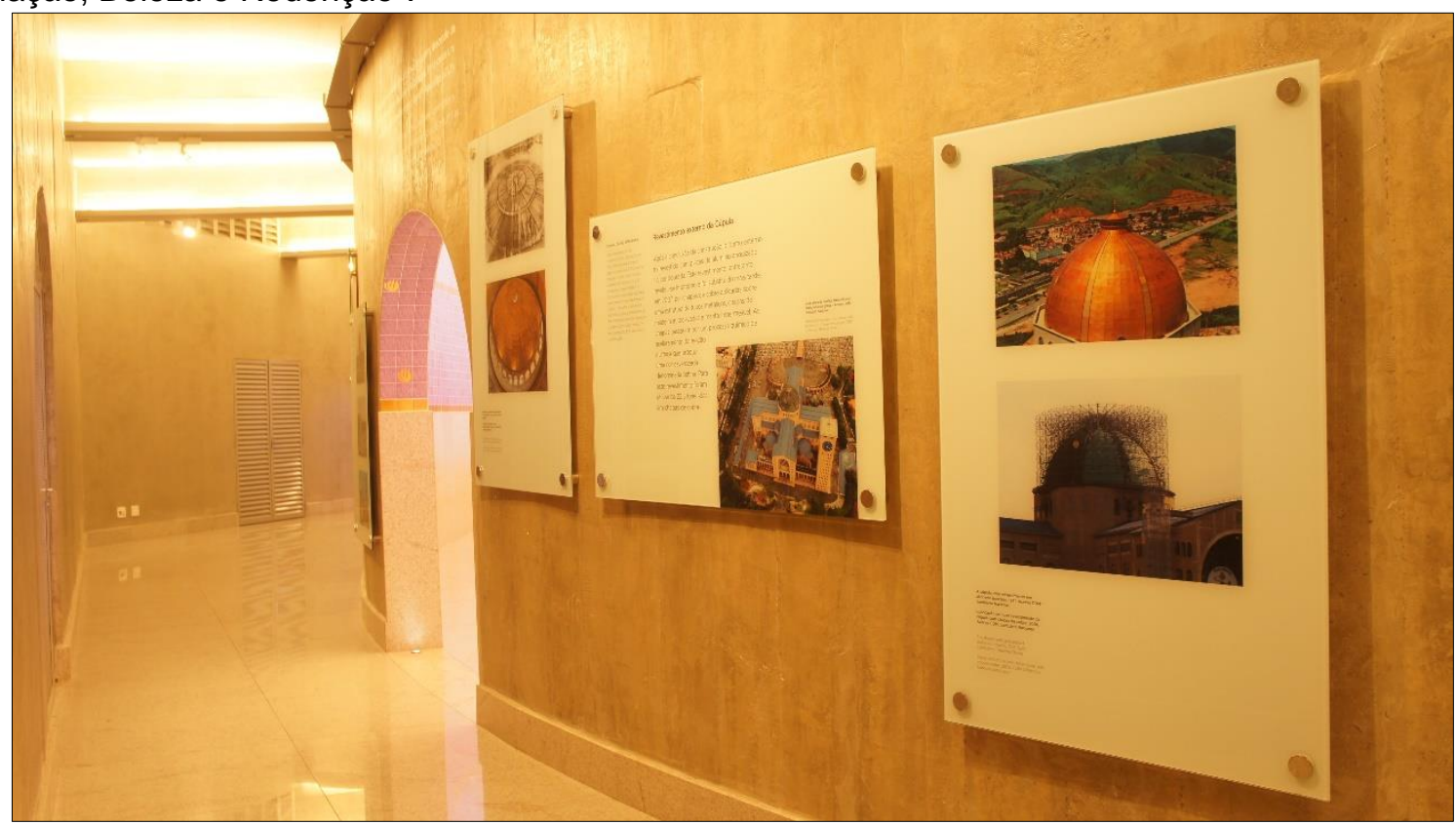

Fonte: MNSA/ Santuário Nacional. Foto: Erica Coelho.

Já o terceiro módulo da exposição, denominado 300 Anos de Bênçãos e de Graças, foi posteriormente transferido para o corredor de saída da Nave Norte. Esse módulo expositivo, considerado como um Memorial do Jubileu dos 300 anos, é composto por dez painéis e quatro núcleos de vitrines, conforme observamos na Figura 137. 
Figura 137: Terceiro módulo do circuito de visitação à cúpula, "300 Anos de Bênçãos e de Graças".

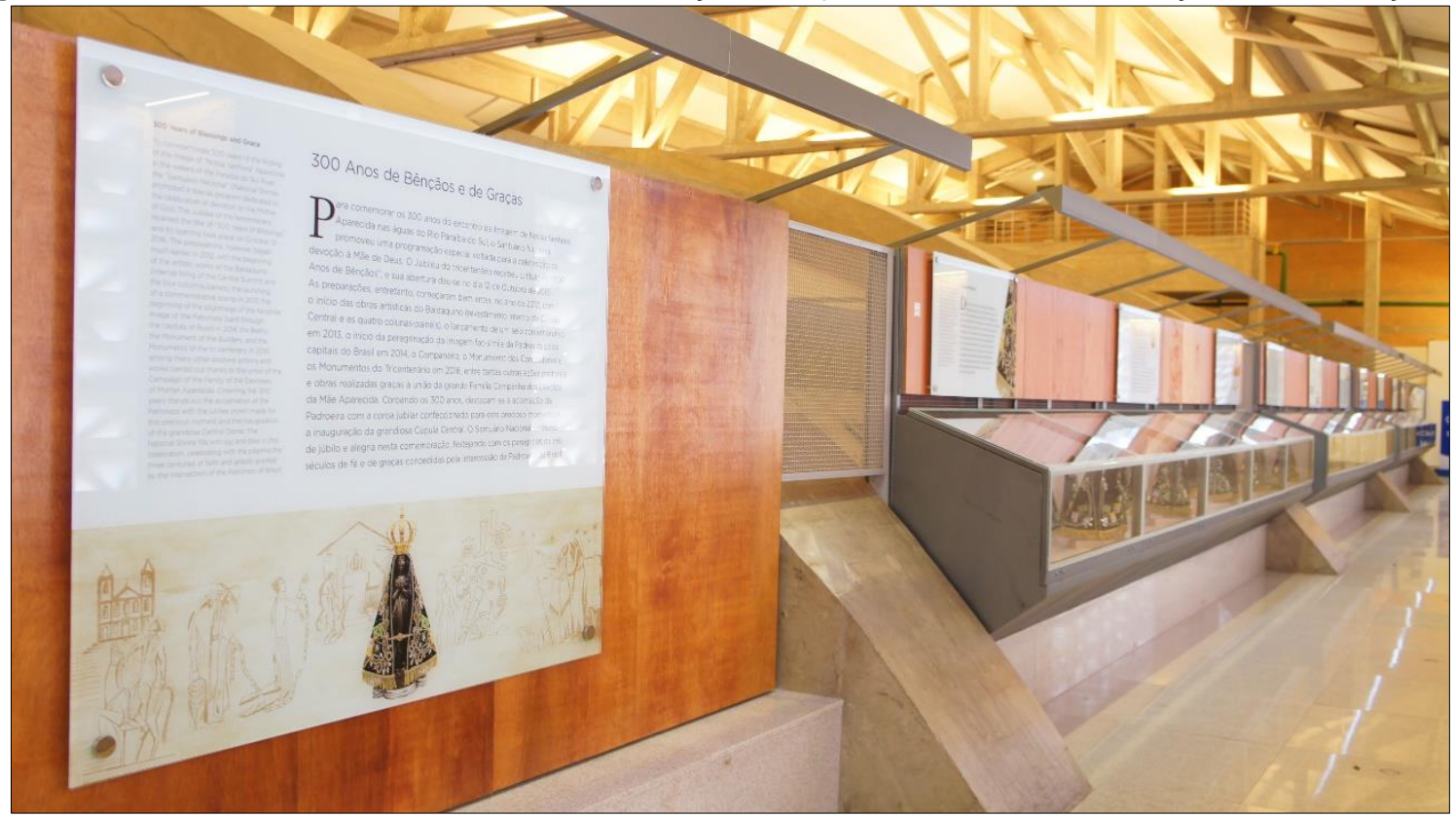

Fonte: MNSA/ Santuário Nacional. Foto: Erica Coelho.

No primeiro núcleo (Figura 138) estão os mantos da coleção de "Mantos do Jubileu", incluindo o manto oficial utilizado na celebração solene do dia 12 de outubro de 2017, assim como a réplica da coroa jubilar.

Figura 138: Primeiro núcleo - Exposição "300 Anos de Bênçãos e de Graças".

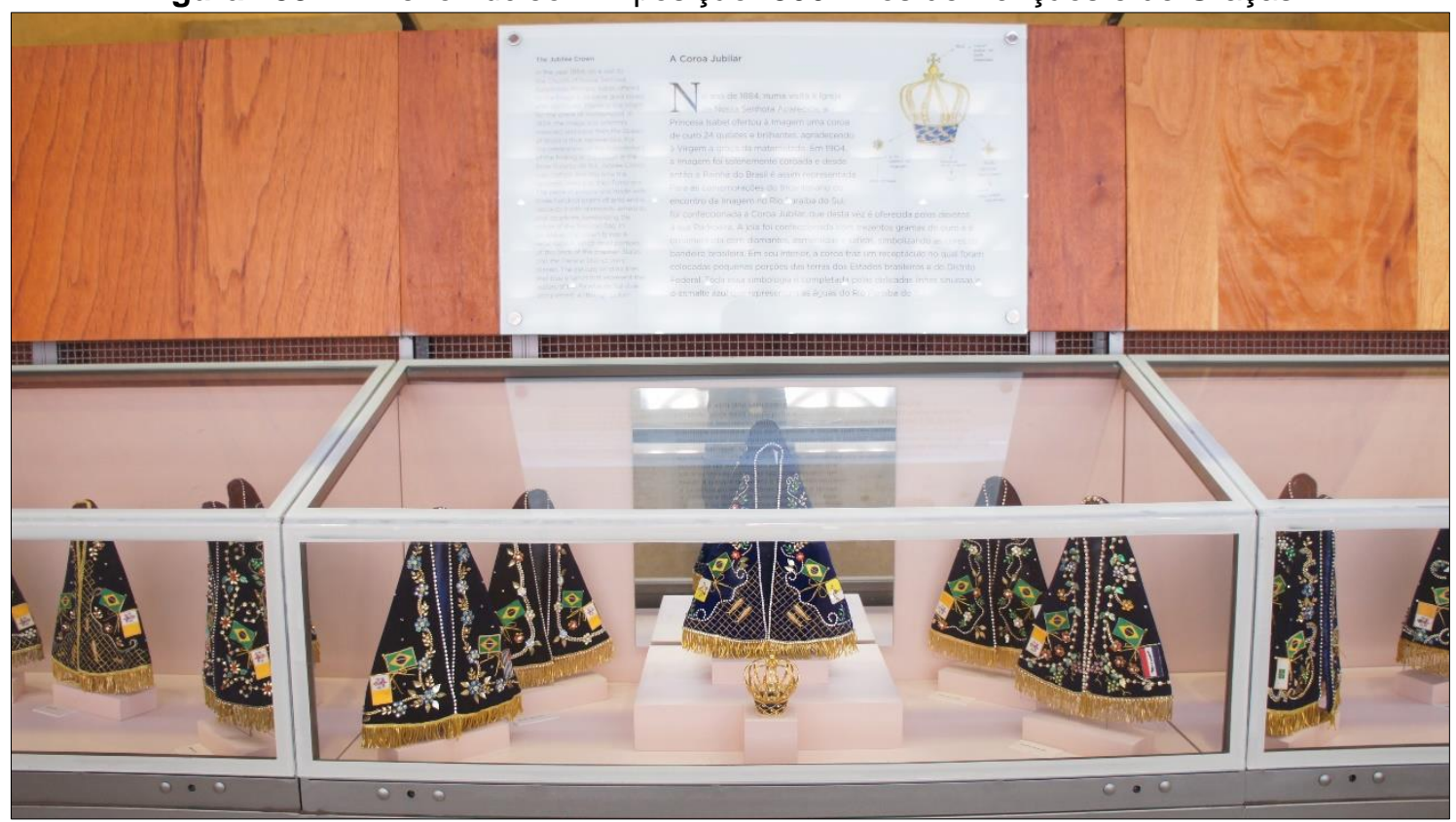

Fonte: MNSA/ Santuário Nacional. Foto: Erica Coelho.

Em relação aos painéis que acompanham o roteiro da exposição, há dez temáticas que fazem alusão aos eventos e comemorações relacionados ao Jubileu. O texto de curadoria do primeiro painel se refere à Imagem Peregrina, abordando 
que, entre os anos de 2014 e 2017, a imagem fac-símile de Nossa Senhora Aparecida percorreu todas as capitais do país. E para essas visitas especiais foram confeccionados mantos para a imagem contendo a bandeira de cada Estado e do Distrito Federal. Com isso, formou-se a coleção dos Mantos do Jubileu, contendo 27 mantos personalizados, acrescidos dos mantos utilizados no dia 12 de outubro de 2017.

O texto de curadoria do segundo painel faz referência à Coroa Jubilar para as comemorações do Tricentenário do encontro da Imagem. Essa coroa foi confeccionada em ouro, ornamentada com diamantes, esmeraldas e safiras, que representam as cores da bandeira brasileira. O diferencial dessa coroa é que ela traz um receptáculo na parte inferior, no qual foram colocadas pequenas porções das terras dos Estados brasileiros e do Distrito Federal. Ainda de forma simbólica, há linhas sinuosas e esmalte azul, que representam as águas do Rio Paraíba do Sul.

O texto de curadoria do terceiro painel faz menção ao Carimbo Comemorativo, lançado pelos Correios em 12 de outubro de 2016, junto com um selo personalizado para o evento, dando início ao Ano Jubilar. O carimbo estampou as correspondências da agência dos Correios do município de Aparecida (SP), a partir do lançamento até o final do mês de outubro de 2016.

No segundo núcleo (Figura 139) estão as porções de terras das capitais dos estados brasileiros e do Distrito Federal, organizadas de acordo com as regiões Norte, Nordeste, Centroeste, Sul e Sudeste. Essa coleção, em especial, contribui para construção da coroa jubilar, pois no dia 12 de cada mês, durante a Cerimônia da Coroação, a coroa jubilar era preenchida pelas porções de terra de três Estados, em cada cerimônia. De forma que, na Coroação Jubilar, dia 10 de outubro de 2017, a coroa já estava composta com terras de todas as capitais do país. 
Figura 139: Segundo núcleo - Exposição "300 Anos de Bênçãos e de Graças".

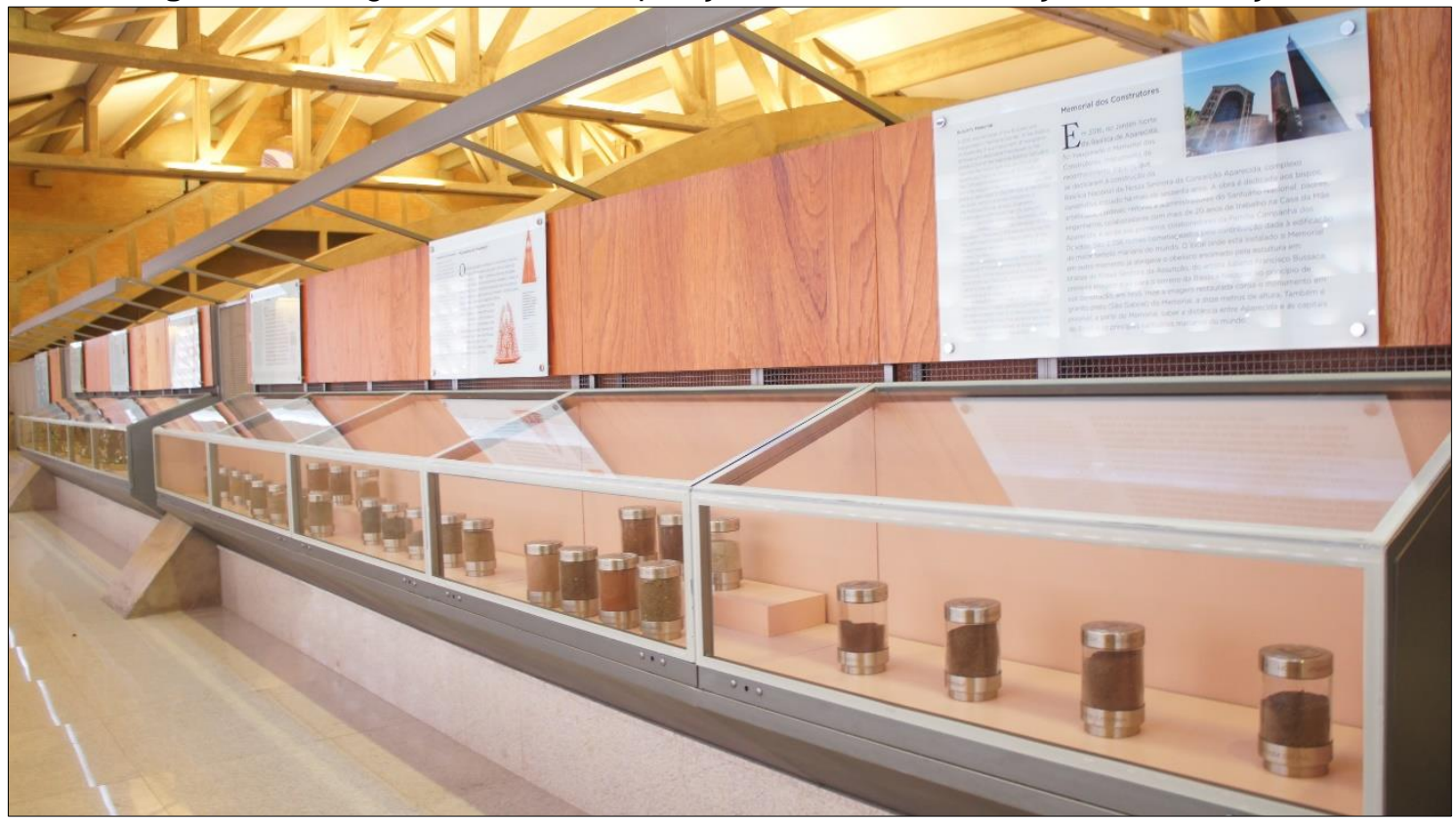

Fonte: MNSA/ Santuário Nacional. Foto: Erica Coelho.

O texto de curadoria do quarto painel aborda o Campanário, que foi inaugurado em 24 de dezembro de 2016. Possuindo 37,5 metros de altura, sua estrutura sustenta treze sinos holandeses feitos em bronze. Os sinos foram concebidos por Cláudio Pastro, responsável por grande parte das obras do Santuário. De acordo com a concepção de Pastro, os sinos são dedicados a cada um dos doze apóstolos, sendo o décimo terceiro dedicado a São José e à Virgem Maria, homenageando também a Campanha dos Devotos.

O texto de curadoria do quinto painel está relacionado ao Monumento do Tricentenário, um conjunto composto por três monumentos que foram instalados nos jardins do Vaticano e na sede da CNBB, em Brasília, assim como no jardim do Santuário Nacional de Aparecida. Os três monumentos em aço corten e bronze, confeccionados em Verona, na Itália, são de autoria de Cláudio Pastro e celebram o Jubileu do encontro da Imagem, representando a pesca milagrosa. De acordo com a concepção de Pastro, a barca representa a Igreja, e a pesca, o milagre abundante da figura do Cristo.

O texto de curadoria do sexto painel faz menção ao Memorial dos Construtores, inaugurado em 2016 no jardim norte do Santuário Nacional de Aparecida. Trata-se de um monumento para reconhecer os colaboradores que se dedicaram à construção da Basílica. De maneira geral, a obra é dedicada aos bispos, arcebispos, cardeais, reitores e administradores do Santuário, padres, 
engenheiros e demais colaboradores com mais de vinte anos de trabalho na Basílica, além dos primeiros devotos que colaboraram com a Família Campanha dos Devotos. Nesse Memorial, há um obelisco com uma escultura de bronze de Nossa Senhora da Assunção, feita por Francisco Bussaca, trata-se da primeira imagem instalada no terreno, no início da construção em 1955.

No terceiro núcleo (Figura 140), estão as ânforas de água das principais bacias hidrográficas do Brasil. São 37 ânforas expostas de um total de 79, que foram ofertadas pela Marinha do Brasil ao Santuário Nacional de Aparecida, no dia 01 de outubro de 2017, primeiro dia da Novena Solene.

As ânforas em exposição exibem as águas do Rio São Mateus, Rio Doce, Rio Itapemirim, Rio Piraí, Rio Paraíba do Sul dos estados do RJ e SP, Rio Muriaé, Rio Macaé, Rio de Contas, Rio Jaguaribe, Rio São Francisco, Rio Jequitinhonha, Rio Mundaú, Rio Capibaribe, Rio Beberibe, Rio Coruripe, Rio Manguaba, Água da praia fluvial do Jacaré, Rio Tapajós das regiões de Santarém-PA, Manaus-AM, e da região de Salvação-PA, Rio Amazonas, Rio Parnaíba, Rio Uruguai, Rio Paraguai, Rio Araguaia, Rio Tocantins, Rio Tietê (Barra Bonita-SP), Rio Paranapanema, Rio Grande, Rio Paraná, Rio Iguaçu, Rio Solimões, Rio Madeira, Rio Negro, Rio Amazonas, Rio Poti e Rio Xingu.

Figura 140: Terceiro núcleo - Exposição "300 Anos de Bênçãos e de Graças".

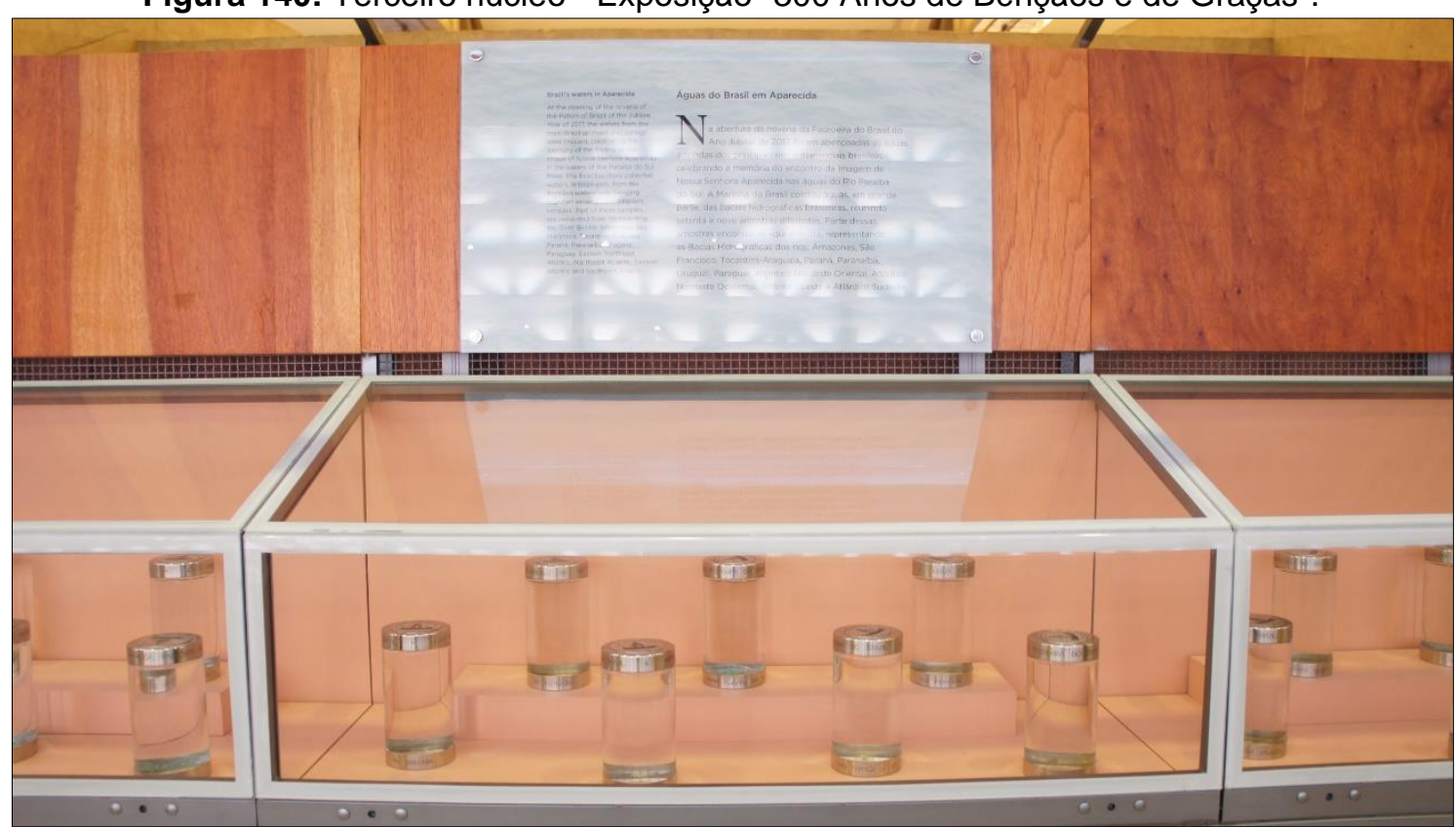

Fonte: MNSA/ Santuário Nacional. Foto: Erica Coelho.

O texto de curadoria do sétimo painel está associado à Medalha Comemorativa do Jubileu, também criada por Cláudio Pastro e modelada pelos 
designers da Casa da Moeda Nelson Neto Carneiro e Erika Takeyana. A medalha foi cunhada nos metais prata dourada, prata e bronze, perpetuando, assim, a memória das celebrações jubilares. A medalha traz a Imagem de Nossa Senhora Aparecida numa das faces e, no reverso, há a representação da pesca, com o primeiro nome que o país recebeu, "Terra de Santa Cruz", e, posteriormente, "Brasil".

O texto de curadoria do oitavo painel contextualiza uma das ações realizadas durante a abertura da Novena da Padroeira do ano jubilar de 2017, representando as águas do Brasil em Aparecida. Para essa ocasião, foram recolhidas as águas dos principais rios e mananciais brasileiros, relembrando o encontro da Imagem nas águas do Rio Paraíba do Sul. A coleção é composta por 79 ânforas coletadas pela Marinha do Brasil, mas apenas algumas amostras foram escolhidas para exposição.

O texto de curadoria do nono painel apresenta a Ladainha de Nossa Senhora, uma obra de Cláudio Pastro instalada nas rampas de acesso ao nicho de Nossa Senhora Aparecida. A obra é composta por vinte e oito painéis com aproximadamente quatro metros de altura, que representam as invocações de Maria presentes na tradicional Ladainha, o cântico de louvor à Mãe de Deus.

Encerrando o Circuito de Visitação à Cúpula, no quarto núcleo desse módulo (Figura 141) estão diversos objetos que fazem menção ao Jubileu dos 300 anos do encontro da Imagem de Nossa Senhora Aparecida, tornando-se, então, um núcleo memorial do Jubileu.

Figura 141: Quarto núcleo - Exposição "300 Anos de Bênçãos e de Graças".

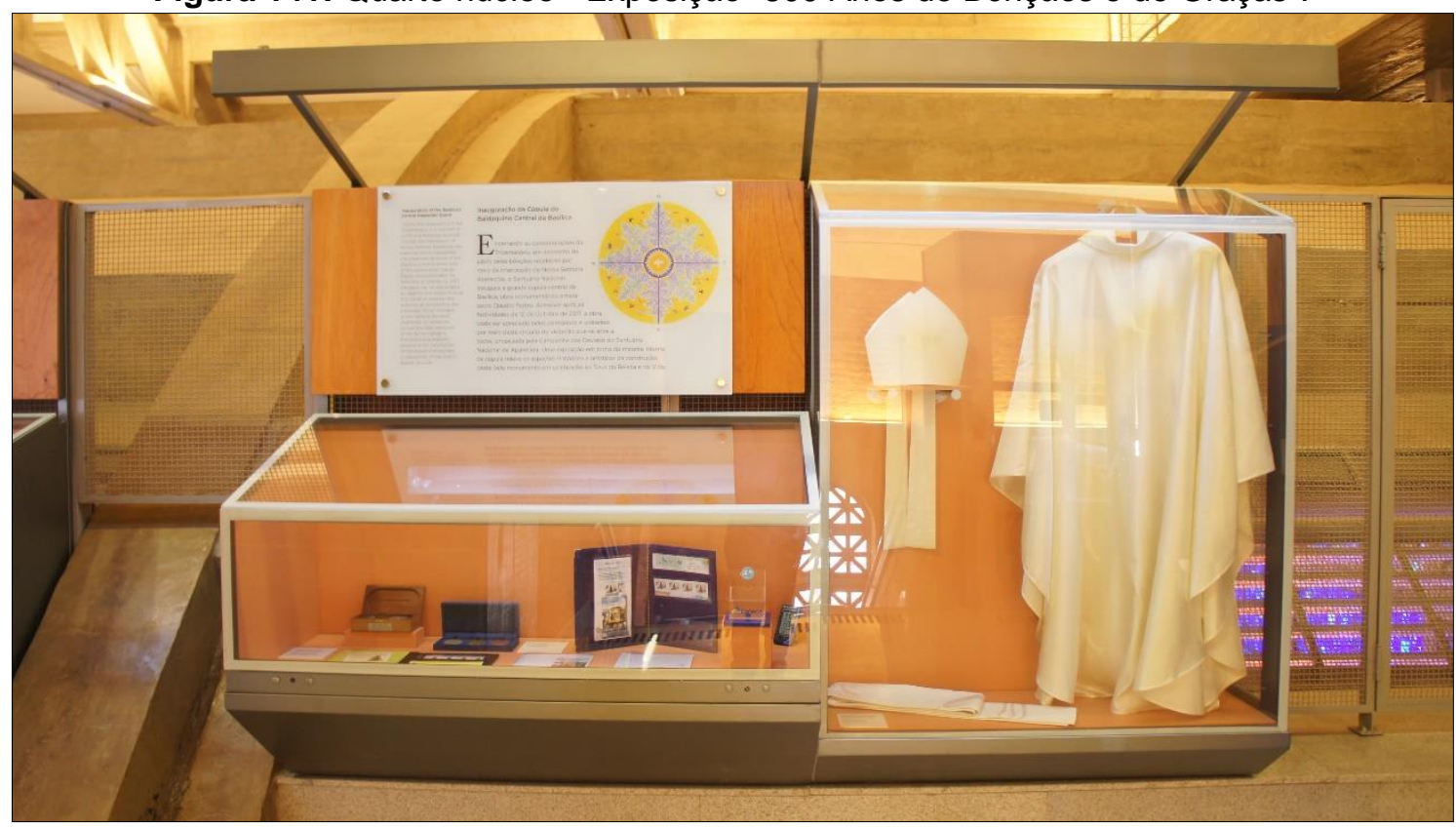

Fonte: MNSA/ Santuário Nacional. Foto: Erica Coelho. 
Nesse espaço estão em exibição os paramentos criados especificamente para esse momento, sendo eles a casula, mitra e estola. Há também as três medalhas comemorativas (bronze, prata e prata dourada) com seus respectivos cunhos de produção, que foram lançados na Novena da Padroeira em 2016, para abertura do Jubileu, objetos estes ofertados pela Casa da Moeda do Brasil, bem como a pasta especial dos Correios contendo o conjunto filatélico relativo ao Jubileu do Tricentenário do encontro da imagem de Nossa Senhora Aparecida, e uma réplica do carimbo dos Correios, que foi utilizado nas postagens durante o mês de outubro de 2016, no município de Aparecida.

Nesse núcleo de finalização da exposição está o décimo painel, com um texto de curadoria sobre o Grande Baldaquino, formado na área central da Basílica, que é composto pela cúpula, seu capitel e as quatro colunas ou paredes de sustentação que coroam o altar, espaço sagrado considerado como centro essencial da Basílica.

De maneira geral, este núcleo procura sintetizar as ações realizadas para o Jubileu do Tricentenário do encontro da imagem de Nossa Senhora Aparecida.

\section{Síntese analítica do conjunto de elementos da exposição}

Conforme apresentado nos tópicos anteriores, o intuito desta síntese é fazer uma reflexão quanto à eficácia e qualidade do Circuito de Visitação à Cúpula, organizado em três módulos expositivos, com temáticas específicas.

É importante considerar que, diferentemente das outras exposições analisadas, o acesso ao Circuito de Visitação à Cúpula não se dá por meio dos elevadores da Torre Brasília. Normalmente, os visitantes são orientados pelos funcionários do Museu, que se encontram no hall da Torre, ou mesmo na bilheteria, quando é oferecido o pacote promocional para visitação de todas as exposições.

Além dessa comunicação verbal, que foi analisada nas visitas exploratórias e de observação, é necessário registrar toda a comunicação visual empregada pelo Santuário Nacional, no sentido de informar os visitantes sobre o acesso à cúpula. Há placas de sinalização em diversos pontos externos e no subsolo do Santuário, além de painéis de vidro próximo às escadas com identificação sobre o acesso à bilheteria no subsolo.

Observamos também que ambas as bilheterias oferecem 0 pacote promocional para visitação das exposições do Museu, Mirante e Circuito de 
Visitação à Cúpula. Há também uma terceira bilheteira localizada na marquise do Centro de Apoio ao Romeiro, que serve mais como ponto de informações, mas também faz a divulgação dos espaços expositivos e venda de ingressos.

No que se refere à infraestrutura e acessibilidade dos ambientes do Circuito de Visitação à Cúpula, há dois elevadores, sendo um específico para subida, dando acesso à recepção do circuito e ao corredor de entrada do primeiro módulo expositivo. Já o outro elevador, ao lado da Loja Oficial, fica no final do corredor de saída, normalmente utilizado para deixar os visitantes em frente à Porta Santa ou no subsolo, conforme preferência dos visitantes.

Além dos elevadores, há lances de escadas e também duas plataformas para acessibilidade de cadeirantes e pessoas com mobilidade reduzida, sendo a primeira plataforma na vertical e a segunda sobre o lance de escadas que levam à grande cúpula.

Um serviço diferencial que foi observado nesse circuito, e que ainda não há nas exposições do Museu e no Mirante, é o serviço de audioguia em três idiomas (português, inglês e espanhol), que proporciona explicações sobre os núcleos expositivos, especialmente na parte central, onde contém explicações sobre as simbologias das obras de Cláudio Pastro que compõem o Baldaquino.

Em relação à segurança física, nas primeiras visitas exploratórias e de observação foi verificada segurança patrimonial. Entretanto, atualmente, observamos a presença de funcionários do Museu na bilheteria, na recepção e na parte superior, próximo à cúpula, para auxiliar os visitantes que necessitam da utilização das plataformas de acessibilidade.

A segurança predial também é respaldada pela instalação de câmeras de vigilância, sensores contra incêndio e extintores de incêndio. A preservação do acervo também é garantida pela instalação de janelas venezianas translúcidas, que barram os raios solares, sem bloquear totalmente a luz natural. Entretanto, também identificamos nas vitrines a instalação de filtros de proteção solar contras os raios ultravioletas, que contribuem com a conservação das peças.

Em relação à organização do espaço físico, as vitrines são contínuas, sem divisões internas entre os núcleos compostos por cinco vitrines, sendo apenas o último núcleo composto por duas vitrines. Em relação à organização do acervo, estão bem organizados, conforme a temática proposta em cada núcleo, considerando a harmonia entre os painéis textuais, adesivados em placas de vidro, 
sobre painéis de madeira, que se relacionam harmoniosamente com a arquitetura do circuito, com tijolos aparentes e elementos em concreto, que fazem artisticamente a sustentação do telhado.

De maneira geral, o Circuito de Visitação à Cúpula é organizado em dois corredores na parte superior da Nave Norte, com acesso à cúpula central e ao corredor interno, circundante à cúpula, na qual está o módulo expositivo referente à construção da cúpula e ao desenvolvimento artístico do baldaquino, com as obras de Cláudio Pastro.

Observamos que os conceitos dos módulos expositivos são identificados nos painéis de apresentação de cada área, além dos demais textos dos núcleos, conforme a temática abordada. O roteiro expositivo é sequencial, apresentando uma harmonia entre os acervos expostos, assim como os painéis textuais. Dessa maneira, identificamos a importância dada aos objetos museológicos, que foram cuidadosamente selecionados para representar os diversos momentos das obras de construção da Basílica, assim como as demais coleções que foram formadas em virtude das comemorações do Jubileu do Tricentenário do encontro da Imagem de Nossa Senhora Aparecida.

Como recursos expográficos, além das vitrines com acervos e os painéis textuais, há três televisores com vídeos, compostos por fotografias, legendas e figuras com animação, integrando com o contexto do núcleo expositivo. No interior das vitrines há legendas sobre os objetos em exposição.

Notamos que o circuito apresenta a sonorização dos vídeos, embora independentes, havendo certa interferência entre as trilhas sonoras, assim como a sonorização do próprio Santuário, pois, durante o horário de visitação, diversas celebrações ocorrem no altar central, sendo inevitável a presença dessa sonorização, mesmo com a utilização de equipamentos de audioguia.

A Ficha Técnica do circuito encontra-se no final do segundo módulo expositivo, próximo às escadas que dão acesso da cúpula ao corredor de saída, onde está o terceiro módulo expositivo. Na Ficha Técnica estão relacionados os profissionais envolvidos na elaboração da exposição, assim como os funcionários do Museu que trabalhavam no período em que os dois primeiros módulos foram concebidos em 2017. 
Assim como as demais exposições de longa duração, o Circuito de Visitação à Cúpula também foi financiado pelo Santuário Nacional de Aparecida, sob a responsabilidade do Museu Nossa Senhora Aparecida.

Em suma, ao analisar esse conjunto de elementos, observamos que há harmonia entre os núcleos, os recursos expográficos e a iluminação. Considerando, especialmente, a harmonia que os núcleos têm com a própria arquitetura da Basílica, compondo uma iluminação equilibrada, com fitas de LED sobre as vitrines e painéis com tonalidades claras, embora a iluminação natural, que ultrapassa as janelas com venezianas translúcidas, acaba sendo refletida nos vidros dos painéis e vitrines, dificultando a leitura em alguns pontos.

De maneira geral, há inteligibilidade na composição dos núcleos expositivos, que se complementam com os textos de apoio, etiquetas explicativas e vídeos animados. Dessa forma, acreditamos que os elementos estudados são suficientes para que o público compreenda a proposta de cada núcleo expositivo que compõe o Circuito de Visitação à Cúpula.

\subsection{Síntese sobre as exposições do Museu Nossa Senhora Aparecida}

Os objetos de matriz religiosa, em sua essência, possuem uma presença natural na vida religiosa das sociedades. Nesse sentido, é importante lembrar que as exposições do Museu Nossa Senhora Aparecida foram instaladas em edifícios de natureza religiosa, o que contribuiu com o vínculo Sagrado na formação das coleções, pois observamos que o acervo litúrgico continuou a crescer, ora por doações, ora por transferências da Sacristia ou Secretaria de Pastoral do Santuário, inclusive tendo como procedência a antiga Basílica de Nossa Senhora Aparecida. Essa incorporação, contudo, ocorreu inicialmente como um sistema de depósito, com o intuito de organizar os ambientes de Sacristia e Secretaria de Pastoral, e garantir as mesmas condições de conservação que é dada aos objetos museológicos.

Ao longo do tempo, as aquisições realizadas pelos organizadores do Museu, somadas à contribuição dos Missionários Redentoristas para a transferência de objetos sagrados ao Museu, foram consideradas como uma solução permanente de valorização do patrimônio, garantindo desta forma a conservação de acervos que poderiam se deteriorar ou estavam em vias de se perder. 
É importante considerar que a conservação dos objetos sagrados que tenham passado pelo processo de musealização, em alguns casos, não foram destituídos de sua função inicial, pois, mesmo passando por um critério de classificação técnica e exposição museológica, tais objetos não perderam a sua função litúrgica, conforme observamos com os objetos em exposição na Domus Aurea.

De modo a não privar o clero do uso das alfaias necessárias às celebrações litúrgicas, a documentação do acervo foi separada dos demais objetos incorporados ao Museu, criando-se, assim, uma nova coleção de acervos que poderiam exercer sua função no culto católico. Essa coleção foi denominada Acervo Santuário Nacional (ASN).

A coleção ASN era compreendida inicialmente por conjuntos de objetos que serviram - e alguns ainda servem - ao culto na Basílica de Aparecida. A coleção é composta por bens transferidos por iniciativa ou autorização do próprio clero, seja de proveniência da Basílica de Aparecida ou presentes recebidos, tais como ostensórios, cálices, patenas, âmbulas, caldeirinhas com aspersório, tecas, crucifixos, etc. Todavia, a categoria de objetos documentados como ASN passou a compreender também demais objetos não litúrgicos, tendo o Santuário como origem, ou seja, a partir de transferências internas de diversos objetos que necessitavam de um espaço de armazenamento, sabendo que na reserva técnica do Museu os objetos estariam conservados.

Num contexto geral, a musealização dos acervos foi uma opção imediata para promover a salvaguarda dos bens culturais da Igreja ligados ao culto católico. Entretanto, a maioria desses acervos permaneceu longe dos olhares dos visitantes, armazenados na reserva técnica do Museu.

Vinculados à coleção ASN, o museu armazena, também, objetos que já não servem mais ao culto, pelo desuso ou por conta do estado de conservação. Contudo, muitos deles são enviados para restauro, embora não necessariamente irão retornar à sua função, permanecendo na reserva técnica do Museu.

Enfim, consideramos que a transferência dos objetos ligados ao culto católico para o Museu proporciona melhores condições de documentação e salvaguarda dos acervos, com controle de saída para empréstimo à Secretaria de Pastoral do Santuário, que eventualmente necessita colocar em uso algumas das peças enviadas ao Museu, consolidando a influência de o museu estar instalado em um Santuário. 
Em relação à exposição Rainha do Céu, Mãe dos Homens: Aparecida do Brasil, observamos que a narrativa expositiva procura evidenciar o percurso da devoção a Maria, a partir de diversas invocações. As obras selecionadas se relacionam com o tema sagrado e permitem documentar aspectos do culto a Maria, dando destaque à figura de Nossa Senhora da Conceição, em especial a devoção a Nossa Senhora Aparecida.

A concepção da exposição foi desenvolvida a partir da necessidade de o Santuário ter um ambiente que narrasse a história do encontro da Imagem de Nossa Senhora Aparecida e dos testemunhos de fé e devoção.

Subordinada à temática religiosa, o projeto expográfico, que foi realizado após a revitalização institucional, seguiu uma estrutura tipológica, admitindo as categorias: esculturas, pinturas, objetos decorativos, reproduções de gravuras, estampas e fotografias. A exposição coloca em destaque os objetos-testemunhos dos milagres de Nossa Senhora, além de objetos alusivos à Coroação e ao Centenário da Coroação da Imagem de Nossa Senhora Aparecida.

O percurso conclui-se na Domus Aurea, onde se exibe uma grande coleção de ourivesaria. A sala possui um caráter místico, considerando que a curadoria pretendeu evitar o deslumbre pelos objetos preciosos, concentrando-se em sua simbologia. Desta forma, o objetivo principal da sala é abordar o sentido simbólico do ouro, além de fazer a salvaguarda dos objetos sacros.

$\mathrm{Na}$ Casa de Ouro, além das inúmeras correntes, anéis, brincos e pingentes que formam elementos bordados nos painéis de tecido, estão as coroas comemorativas do Centenário da Coroação e do Jubileu dos 300 anos do encontro da Imagem de Nossa Senhora Aparecida, e também objetos com função ritual, tais como um ostensório, cálices e patenas e as Rosas de Ouro ofertadas pelos Pontífices em visita à Basílica de Aparecida.

Essa coleção de objetos rituais litúrgicos, que estão expostos na Casa de Ouro e compõem a coleção ASN, embora inseridas no ambiente expositivo e tenham recebido um tratamento museológico, ainda não foram destituídas da sua função relacionada ao culto, e porventura são requeridas para celebrações solenes, especialmente nas Celebrações da Páscoa, Corpus Christi e Novena Solene de Nossa Senhora Aparecida.

De maneira geral, essa sala foi concebida para propiciar um momento de relacionamento com o Sagrado, enfatizado pela mudança de ambiente, incluindo a 
mudança climática (ar-condicionado com baixa temperatura), sonora (sons de natureza, pássaros e água) e visual (relacionando a simbologia das cores azul e dourada, utilizadas nas paredes e vitrines).

Entretanto, com o passar dos anos, a partir da inauguração dessa exposição com temática Mariana, os visitantes começaram a questionar o novo arranjo museográfico, considerando que, em visitas anteriores ao Museu, recordavam da diversidade de coleções seguindo um discurso enciclopédico, com características de gabinetes de curiosidades.

Deste modo, perante o interesse e a curiosidade dos visitantes em relação aos acervos que não mais estavam em exposição, pensou-se em criar um novo ambiente expositivo, com outros núcleos temáticos que complementassem o contexto religioso, oferecendo uma solução mais permanente que atendesse as frequentes perguntas dos visitantes sobre os objetos armazenados na reserva técnica. Com isso, optou-se por expor uma grande parcela de objetos não religiosos, caracterizando o espaço como um ambiente mais informativo.

Subordinado à uma temática que busca abordar as relações do homem com o sagrado, com o seu cotidiano, sua expressão e sua relação com a natureza, o projeto da nova exposição O Museu e suas Histórias concentrou-se em atender as expectativas dos visitantes, remetendo-se à antiga configuração da exposição, organizada pela Professora Conceição Borges Ribeiro Camargo. Vale lembrar que, diferentemente de outros museus, o Museu Nossa Senhora Aparecida possui uma característica diferenciada de público, pois a maioria dos visitantes são os devotos de Nossa Senhora que vêm ao Santuário em romarias anuais. Portanto, trata-se de um público recorrente.

Apesar da natureza diversificada do acervo, a exposição O Museu e suas Histórias foi organizada com critérios temáticos e os núcleos foram pensados com o intuito de valorizar o patrimônio, de acordo com o discurso expositivo. Com isso, essa nova exposição foi concebida com uma distribuição tipológica, reunindo acervos de uso doméstico, decorativos, coleções de numismática, amostras minerais e animais, acervos da cultura tropeira, instrumentos musicais, ferramentas de comunicação, arte popular, devoção popular, relacionando, também, com as demais peças religiosas ou com função litúrgica, compreendendo as coleções de imaginária, pinturas, alfaias, indumentária, objetos de culto e objetos devocionais. 
No que se refere especificamente aos acervos com temática religiosa na exposição $O$ Museu e suas Histórias, alguns nichos dão destaque às pinturas de Santo Antônio de Pádua e São Bernardino de Sena, provenientes da Escola de Paris, que foram ofertados pelo Cardeal Motta. Na sequência há um oratório com uma imagem fac-símile do Menino Jesus de Praga, ofertada pelo Cardeal Dom Damasceno, em virtude de sua visita pastoral ao Santuário do Menino Jesus de Praga. Nesse oratório há ainda um livro de oração e um Terço, ladeados por dois castiçais de prata, que compõem um conjunto procedente da antiga Basílica de Nossa Senhora Aparecida. De maneira geral, consideramos que esse núcleo evoca o cariz religioso, pela forma em que os acervos foram posicionados, e, embora os objetos tenham sido musealizados, ainda possuem essa essência de objetos sacros, causando comoção nos visitantes.

Em sequência há núcleos ligados ao culto privado e culto coletivo, onde há coleções de imaginárias de pequeno e médio porte, típicas do uso em oratório, e, logo à frente, outra vitrine com imaginárias de grande porte destinadas ao culto coletivo nas Igrejas. A exposição também coloca em destaque o conjunto de "imagens paulistinhas", que são pequenas esculturas produzidas na região do Vale do Paraíba, em São Paulo.

Na sequência há três núcleos ligados a devoção popular e expressão dos fiéis, por meio dos objetos votivos, contextualizado por acervos de pouco valor material, mas cheios de significado simbólico. O arranjo museográfico do núcleo ligado à liturgia coloca em destaque a presença dos Pontífices em Aparecida, dispondo as alfaias e objetos rituais, além de móveis e paramentos que foram utilizados pelos Papas João Paulo II, Bento XVI e Francisco, intrínsecos de valor documental, litúrgico e simbólico.

Afastando-se da ambientação religiosa, mas orientados por um mesmo propósito de evidenciar as relações do homem, há núcleos expositivos distintos do contexto, no qual o destaque é dado a um couro de cobra com aproximadamente seis metros, colocado em um expositor no piso, logo após o núcleo de liturgia. Esse expositor no piso faz uma separação dos núcleos expositivos, que passa a contextualizar as relações do homem com o ambiente, seu cotidiano e sua expressão.

De um modo geral, a exposição é caracterizada pela qualidade e variedade de objetos expostos, em um discurso coerente, apesar de não seguir apenas uma 
única temática, como ocorre na exposição Rainha do Céu, Mãe dos Homens: Aparecida do Brasil. Embora, mais recentemente, o ambiente expositivo tenha sido preparado para acolher a Coleção Santa Gertrudes de Imagens Paulistas do Século $X V I I$, composta por cinquenta e quatro imagens distribuídas em seis grupos distintos e o último grupo que reúne imagens em que não foi possível a identificação de autoria.

A maioria das imagens desta exposição gira em torno de Frei Agostinho de Jesus, com obras assinadas e datadas e outras que foram atribuídas como imagens do Frei Agostinho de Jesus, do Mestre de Sorocaba, do Mestre do "Cabelinho Xadrez", do Mestre de Angra, do Mestre de Pirapora de Bom Jesus e do Mestre do "Bolo-de-noiva". De maneira geral, os núcleos temáticos foram divididos conforme as atribuições de autoria das obras. Nessa coleção observamos a predominância de imagens da Virgem Maria, em diversas de suas invocações, constituindo o olhar devocional do colecionador Ladi Biezus.

Em relação ao Circuito de Visitação à Cúpula, os três módulos expositivos foram desenvolvidos para ambientar ambos os corredores superiores da Nave Norte e corredor, circundando a cúpula central da Basílica, que é marcada simbolicamente com a arte sacra de Cláudio Pastro. A iniciativa de criação deste circuito partiu da direção pastoral e econômica do Santuário, pois havia a intenção de abrir o espaço para a visitação pública. Portanto, a ideia deste conteúdo expográfico surgiu para complementar a visitação.

No que se infere ao roteiro expositivo do Circuito de Visitação à Cúpula, notamos que se seguiram critérios informacionais, embora também tenham sido inseridos objetos de matriz religiosa, porém com critérios cronológicos das etapas de construção da Basílica e as comemorações do Jubileu do Tricentenário do encontro da Imagem de Nossa Senhora Aparecida.

O discurso museológico foi divido em núcleos temáticos, marcando as principais atividades realizadas durante as comemorações do Jubileu do Tricentenário do encontro da Imagem de Nossa Senhora Aparecida. De maneira geral, a linha temática buscou enfatizar a construção de um dos maiores santuários católicos do mundo, ilustrada por objetos ligados à construção e revestimento da Basílica, contextualizando a importância dos religiosos redentoristas que se preocuparam em oferecer um novo edifício digno da Padroeira do Brasil para acolher o crescente número de peregrinos. 
O acervo exibido no primeiro módulo compreende exemplares de tijolos da construção do Santuário, amostra da Antiga Basílica como pisos, chaves e fechaduras, elementos de terraplanagem do Morro das Pitas, pisos e azulejos do revestimento interno da Nova Basílica, telha, protótipos dos elementos decorativos concebidos por Cláudio Pastro, além de objetos votivos, objetos pertencentes aos Missionários Redentoristas, Bispos e Cardeais da Arquidiocese de Aparecida ou utilizados por Papas em visita à Basílica.

O segundo módulo é composto por painéis textuais com ilustrações, contendo apenas algumas amostras de azulejos e tésseras que revestem o baldaquino, no final do roteiro expositivo.

O acervo em exposição no terceiro módulo compreende as ações desenvolvidas durante as celebrações do Jubileu do Tricentenário do encontro da Imagem de Nossa Senhora Aparecida. A exposição serviu de duplo propósito, no sentido de inventariar e valorizar o acervo relacionado às celebrações do Jubileu, entre eles a coleção de mantos, de terras, de águas e de objetos comemorativos, como medalhas, selos e indumentária religiosa alusiva ao tema do evento.

É importante mencionar que a formação da coleção de águas das principais bacias hidrográficas contou com o apoio da Marinha do Brasil, embora sem caráter de acervo religioso. A coleção se relaciona com o evento religioso em si, assim como a coleção de terras das capitais dos Estados brasileiros, que foram recolhidas para compor a coroa jubilar.

De um modo geral, apesar das diferenças entre as exposições, observamos que os conceitos expositivos corresponderam a um objetivo comum de valorizar o patrimônio sagrado, relacionado a devoção a Nossa Senhora Aparecida (e a outros santos e santas) ou ligados ao culto católico, especialmente provenientes da Basílica de Nossa Senhora Aparecida, em posse do Museu Nossa Senhora Aparecida. 


\section{Capítulo 4 - A Museologia e o Sagrado}

A musealização de objetos ligados ao culto católico e à devoção constitui uma categoria própria da cultura material do Homem e da sua relação com o Sagrado, caracterizada por temas e simbologias diversas. Nessa perspectiva, o objetivo desse capítulo é analisar o objeto como documento, considerando a cultura material como importante fonte de informação.

De maneira geral, ao analisarmos a produção internacional e brasileira sobre a relação entre ciência e documento, observamos que a estabilização da informação em publicações e trabalhos científicos permite validar os estudos realizados. Nessa perspectiva, é importante considerar os espaços de criação do conhecimento científico, entre eles o Museu, visto como um Laboratório (MENESES, 1994; CETINA, 1999), além de ser um espaço de difusão do conhecimento produzido.

A partir desse ponto de análise, o trabalho no laboratório é explorar como os objetos se transformam em documentos históricos, considerando que o laboratório é o local para o desenvolvimento de documentos, e estes, por sua vez, são produtos do conhecimento (informação verbal) ${ }^{56}$.

\subsection{O objeto como documento}

Inicialmente, Meneses (1994) pressupõe que o museu (laboratório da história) tenha algo relacionado com o universo do conhecimento, por sua natureza, levando em consideração as tarefas educacionais do museu com referência ao conhecimento, assim como as responsabilidades sociais e políticas. Mas há também a problemática do conhecimento na exposição museológica, considerando, por sua vez, certo perfil de museu, bem como a sua natureza institucional e a pertinência de explorar coleções de objetos materiais.

O laboratório, nesse contexto, é considerado como um espaço virtual para estabilização da informação, um local extensivo à experiência nele realizada, ou seja, uma sala de estoque com propriedades particulares, que são necessárias quando a vida social é representada através de experimentos (informação verbal). ${ }^{57}$

\footnotetext{
56 Reflexões feitas durante as aulas da disciplina Aspectos institucionais do objeto, do documento e da narrativa científica: as unidades de criação de cultura e organização da informação, ministrada pelas Professoras Dra. Marília Xavier Cury e Dra. Bianca Souza, entre os meses de março e maio de 2019. PPGMUS - Universidade de São Paulo, 2019.

${ }^{57}$ Cf. nota 56 desta dissertação.
} 
Diante dessa perspectiva, ao interpretar o museu como um laboratório, é possível refletir a partir das seguintes questões: o que o museu quer informar? 0 que o museu expõe? O que a exposição causa no público? Quais são os dispositivos utilizados e os resultados no público? Qual o poder que esse dispositivo exerce sobre os demais dispositivos? O que determina as nossas ações?

Essas questões nos ajudam a refletir acerca dos objetos museológicos que agem o tempo todo, considerando que os documentos podem ser usados para contar histórias em detrimento de outras, pois a exposição manipula os documentos. Por isso, é importante analisar o entorno do objeto para conhecer sua biografia, o contexto ao qual está inserido, e não apenas o objeto em si (informação verbal). 58

Meneses (1994) questiona se ainda há, entre nós, a relevância e utilidade no papel que os museus com acervos possam desempenhar na sociedade. Positivamente $o$ autor complementa que estamos rodeados por coisas materiais que são indispensáveis para nós, e são esses elementos que formam a "cultura material", atuante na produção e reprodução social.

Segundo o autor, os artefatos, por exemplo, não são apenas produtos, mas vetores de relações sociais, com apropriação de segmentos da natureza física, por isso é necessário entender este fenômeno complexo de apropriação social. Nesse contexto, o autor afirma que o museu é um recurso estratégico para o alargamento e aprofundamento dessa consciência. De maneira geral, é por meio das exposições museológicas que nos defrontamos com essa cultura material, com suas múltiplas significações e funções.

Para Meneses (2002, p. 29),

O conhecimento não mais se produz especulativamente a partir de pressupostos teológicos, teóricos ou filosóficos, mas do sensível é que se chega ao inteligível: daí a consolidação das coisas materiais como documentos, fontes de informação. Desta postura surgem traços que marcam o museu ainda hoje. Antes de mais nada, a própria noção de coleção, não como um conjunto disparatado de objetos, mas como uma série sistematicamente organizada de "fontes".

A partir dessa análise, Heloisa Barbuy (2008, p. 34) argumenta que "de fato, se tratados do ponto de vista histórico, os artefatos são, sem dúvida alguma, poderosos portadores de informações, mesmo individualmente, mas, sobretudo, enquanto integrantes de sistemas culturais configurados materialmente". Por isso, o museu deve levar em consideração a sociedade na qual ele está imerso, pois cabe a

${ }^{58}$ Cf. nota 56 desta dissertação. 
ele relacionar passado e presente, por meio da preservação dos artefatos, possibilitando sua leitura.

De acordo com a autora,

Não se trata, no entanto, de abordar qualquer problemática histórica a partir de fontes materiais. Embora isto também possa ser feito, a questão essencial é que o exame de universos materiais traz problemáticas novas, muitas vezes relacionadas a dimensões não percebidas quando se examinam fontes relacionadas apenas a ideias abstratas e não a expressões materiais da cultura. (BARBUY, 2001, p. 25).

Buckland (1997), ao refletir sobre as noções de "cultura material" na antropologia cultural e "objeto-como-signo" na semiótica, apresenta visões de Paul Otlet e Suzanne Briet sobre o que deveria ser considerado um "documento", no escopo da Ciência da Informação. Para Buckland (1991), os cientistas da informação, no movimento de "documentação", tiveram uma grande preocupação para definir apropriadamente o termo "documento", com o intuito de melhorar a gestão de recursos de informação.

De acordo com o autor,

Paul Otlet e outros desenvolveram uma visão funcional do "documento" e discutiram se, por exemplo, escultura, objetos de museu e animais vivos poderiam ser considerados "documentos". Suzanne Briet igualou "documento" com evidências físicas organizadas. (BUCKLAND, 1997, p. 804, tradução nossa).

Segundo o autor, Paul Otlet enfatizou a necessidade da definição de documento e documentação, com o intuito de incluir "objetos naturais, artefatos, objetos contendo traços de atividades humanas, objetos como modelos projetados para representar ideias e obras de arte, bem como textos" (BUCKLAND, 1991, p. 354, tradução nossa).

O autor complementa que,

A abordagem documentalista era usar "documento" como um termo genérico para denotar qualquer recurso de informação física, em vez de limitá-lo a objetos contendo texto em mídias físicas específicas, como papel, papiro, pergaminho ou microformas. (BUCKLAND, 1991, p. 354, tradução nossa).

Briet $^{59}$ (1951 apud BUCKLAND, 1997, p. 806, tradução nossa) argumenta que "um objeto se torna documento quando ele é tratado como documento, por exemplo, como um sinal físico ou simbólico, preservado ou gravado, destinado a representar, reconstruir ou demonstrar um fenômeno físico ou conceitual".

${ }^{59}$ BRIET, S. Qu'est-ce que la documentation. Paris: EDIT, 1951. 
O documento para Briet pode ser compreendido como sendo um "nó em uma rede", para que se conheça o todo, não apenas uma parte. Mas restringe de algum modo, pois se entende que nem tudo é documento, há uma seleção que define o que será reconhecido como documento.

O "documento brietiano" é, deste modo, um conjunto de provas ou fatos estabelecidos a partir de redes institucionais de linguagem. Em outras palavras, temos que o documento só pode ser definido dentro de uma rede ou várias redes de relações indexais, onde o objeto-documento é transformado como objeto semiótico dentro de uma rede de produção (informação verbal). ${ }^{60}$

É evidente que para Briet (1951) nem tudo é considerado um documento, porém as fotografias e os catálogos, assim como demais elementos catalogados, tornam-se documentos, partindo-se da premissa de que as publicações e trabalhos científicos estabilizam o conhecimento produzido.

É importante considerar que as regras de Briet para determinar quando um objeto se tornou um documento não são claras. De acordo com Buckland (1997, p. 806, tradução nossa), podemos inferir, a partir da discussão de Briet, que:

(1) Existe materialidade: objetos físicos e sinais físicos somente;

(2) Existe intencionalidade: pretende-se que o objeto seja tratado como evidência;

(3) Os objetos precisam ser processados: eles precisam ser transformados em documentos; e

(4) Existe uma posição fenomenológica: o objeto é percebido como um documento.

Entretanto, Murguia (2010, p. 132) argumenta que "qualquer objeto pode vir a ser documento", além de poder ser classificado como objetos diversos ao mesmo tempo, por exemplo, objetos artísticos, religiosos e históricos (MURGUIA, 2010). De acordo com o autor, o arranjo das coisas pressupõe uma classificação, "uma disposição relacional, na qual os objetos não ficam mais isolados na sua curiosidade, mas adquirem significação pelos vínculos que se querem mostrar [...]" (MURGUIA, 2010, p. 133).

É fundamental para esta análise compreender que é muito ampla a problemática da diversidade de documentos. Nesse contexto, Michael Buckland aborda três perspectivas para pensar a informação: informação como processo (ato de informar), informação como conhecimento (mostrar os fatos) e informação como coisa (objetos são informativos). A partir dessa análise, o autor reflete acerca do

60 Cf. nota 56 desta dissertação. 
documento e sua materialidade, partindo da ideia de que a documentação é a prática de produção e organização de documentos (informação verbal). ${ }^{61}$

Murguia também aborda os três conceitos de informação citados por Buckland:

Informação como processo (ato de comunicar), informação como
conhecimento (entendido não como ação, mas como objetos, capaz de
modificar). Esses dois conceitos têm como característica serem intangíveis.
Porém, existe um terceiro conceito que é a informação como coisa, este
sim, tangível. A informação como coisa não é o processo e nem o
conhecimento em si mesmo, mas a representação física deles. (MURGUIA,
2010 , p. 124-125).

A partir desse contexto, segundo Buckland (1991), os objetos são potencialmente informativos. Para o autor, "em um sentido significante, a informação é usada como evidência na aprendizagem - como a base para a compreensão" (BUCKLAND, 1991, p. 353, tradução nossa).

O autor ainda argumenta que, ao persistir na noção de informação como evidência, ou coisas das quais podemos nos informar, examina-se mais especificamente os dados (armazenados em computador) ou textos e documentos (incluindo-se objetos, imagens e sons passíveis de se comunicar). Desta forma, reconhecer que o conceito de materialidade é fundamental para bem entender a informação e o processo social e cultural que a gera e reproduz. Portanto, é preciso reforçar a ideia de que a documentação é um meio de materialização da informação e que merece ser investigado, pois essa materialização traz relações sociais que nos indicam como grupos e sujeitos sociais geram e reproduzem o conhecimento contido nos documentos (informação verbal). ${ }^{62}$

Murguia (2010) complementa que não devemos destacar unicamente o caráter textual do documento, mas é necessário colocar qualquer objeto em igualdade de condições na sua constituição como documento.

De acordo com o autor,

Comumente acreditamos que o que diferencia um documento escrito de um objeto documento é sua intencionalidade de registro. O primeiro foi feito para informar algo, enquanto o segundo foi feito para qualquer coisa (embora possa vir a informar posteriormente). Por outro lado, estrelas, arcos do triunfo, quipos, ábacos são objetos feitos propositalmente para informar, e, no entanto, não são textuais. Poderíamos afirmar, então, que objetos são documentos porque um processo institucional assim o decide. Se assim for, como é decidido? (MURGUIA, 2010, p. 132).

61 Cf. nota 56 desta dissertação.

${ }^{62}$ Cf. nota 56 desta dissertação. 
Nessa perspectiva, de acordo com Briet (1951) os documentos podem ser reproduzidos em diversos formatos (desenhos, aquarelas, pinturas, estátuas, fotografias, filmes), posteriormente esses documentos poderão ser selecionados, analisados, descritos, traduzidos. Enfim, os documentos que se relacionam com o evento tornam-se objetos de uma classificação científica.

Tendo em vista essa análise, compreendemos que a elaboração de classificações e de ordenação aprimora a capacidade de o homem conhecer e identificar o mundo. Assim, a ciência moderna busca identificar a verdade e a manipula de forma que seus resultados possam ser estabilizados em uma documentação científica (informação verbal). ${ }^{63}$

Para Buckland (1991, p. 354, tradução nossa),

[...] objetos que não são documentos, no sentido normal de serem textos, podem mesmo assim serem recursos de informação, informação-comocoisa". O autor argumenta que "objetos são coletados, armazenados, recuperados e examinados como informações, como base para se tornarem informados.

No caso do documento, segundo Murguia (2010, p. 137), "se relaciona com as instituições além dos valores, usos e apropriações que estabelecem através dos seus acoplamentos em torno da verdade. A leitura, a informação inferida do documento estará também sempre dentro de um ambiente institucional". Nesse contexto, o documento seria fruto de um processo produtivo classicamente representado por trabalhadores que executam suas atividades em instituições, como museus, bibliotecas, arquivos, etc., são nesses espaços que se organizam o conhecimento produzido pela sociedade, considerando que o documento traz enunciados que tratam de uma materialidade de ordem institucional (informação verbal). ${ }^{64}$

Em cada caso, é razoável analisar as informações contidas nos documentos observados, seja na forma de testemunho, linguagem dos documentos ou na produção de objetos materiais, que é dada em uma investigação. Desta forma, a unidade documental tende a crescer, na medida em que a quantidade de documentos também aumenta, o que contribui para o aperfeiçoamento das técnicas de documentação, que, segundo Briet (1951), surge como "uma técnica cultural" de um novo tipo.

${ }^{63}$ Cf. nota 56 desta dissertação.

${ }^{64} \mathrm{Cf}$. nota 56 desta dissertação. 
Buckland também reflete acerca da documentação, que inicialmente foi denominada bibliografia. Para o autor, esse termo não foi suficiente para dar conta da produção de informação, que não se limita apenas aos documentos escritos (informação verbal). ${ }^{65}$

A partir desse contexto, segundo Meneses (1994, p. 12), é preciso considerar a função documental dos objetos, pois a documentação garante "a democratização da experiência e do conhecimento humanos e da fruição diferencial de bens", assim como possibilita fazer com que a mudança passe a ser inteligível.

De acordo com Briet (1951), a documentação moderna tornou-se um dos fatores mais eficazes de produtividade em todas as áreas, tornando-se cada vez mais uma técnica, como uma habilidade especializada, o que requer do documentalista o conhecimento dessa especialidade, que ele assiste profissionalmente.

A autora ainda argumenta que

O trabalho documental - baseado na especialização cultural - corresponde a uma atividade que especificamente não mais precisa ser demonstrada. $O$ que chamamos de "técnica documentada" é uma combinação de técnicas que são originalmente combinadas e depois multiplicadas e aplicadas. (BRIET, 1951, p. 21, tradução nossa).

Com isso, conforme abordado pela autora, a descrição esquemática ou iconográfica dos documentos é ampliada, gerando catálogos que levaram em consideração as áreas geográficas e linguísticas, com alguns deles alcançando proporções continentais.

\subsection{Reflexões sobre a musealização de objetos ligados ao culto católico e à devoção}

O que se pretende com este exercício reflexivo é compreender o processo de musealização de objetos ligados ao culto católico e à devoção, considerando que a participação da Igreja no fenômeno colecionista antecede a instituição do museu nos moldes em que conhecemos hoje.

Desde o século $\mathrm{XIX}$, os tesouros eclesiásticos já tinham como prática a salvaguarda, conservação e exposição museográfica, como um método educacional e de difusão cultural. Embora alguns objetos de culto e alfaias litúrgicas continuavam reservados ao espaço sagrado. É válido considerar que a religião tem necessidade

${ }^{65}$ Cf. nota 56 desta dissertação. 
de materializar o mundo sagrado, seja por meio de estátuas, objetos ou lugares, com o intuito de aproximar as pessoas do mundo sagrado (ELIADE, 1992).

Neste sentido, de acordo com Roque (2011), é importante refletir sobre os objetos materiais colocados a serviço do culto religioso, os quais adquiriram uma característica sacra, chegando ao limite da intocabilidade de alguns objetos litúrgicos.

Segundo a autora,

\begin{abstract}
Não obstante e como tem vindo a ser referido, no cristianismo este conceito de sagrado, no sentido mais convencional e transversal aos vários contextos religiosos, apenas surge aplicado a coisas (ou a pessoas) no contexto da vida sacramental. Pessoas e objectos são apartados do uso comum através do rito consagratório, isto é, ao serem "sagradas". Desta forma, o âmbito semântico dos termos sacro, sagrado ou sacralidade, quando aplicados aos objectos litúrgicos, só se esclarece através da análise do contexto do ritual e da correspondente acção simbólica. (ROQUE, 2011, p. 184).
\end{abstract}

Para Roque (2011), a apresentação de objetos litúrgicos ou devocionais como um documento de culto ocorreu de forma tardia na museologia, mas foi um fator importante ao longo da evolução dos tesouros eclesiásticos. Todavia, François Mairesse (2018) argumenta que, a partir de uma perspectiva integrativa da museologia, é possível considerar o sagrado como uma das categorias da musealidade, embora a noção de sagrado não apareça diretamente na museologia, apesar de que muitos museus se dedicam às manifestações do sagrado, levando em consideração suas coleções originárias, de fato oriundas de espaços sagrados ou até mesmo relacionadas ao culto, por exemplo, pinturas, objetos de culto, etc.

De acordo com o autor, com o tempo o museu passa a produzir algumas qualidades sagradas, sendo necessário refletir sobre a relação museu-temploreligião em nível institucional. No que tange à relação patrimônio-musealidadesagrado, o autor questiona como a musealização é influenciada pela sacralidade do objeto e como ocorre a construção da noção de sagrado no museu. No que se refere à epistemologia na relação entre museologia-sagrado-teologia, o autor questiona se a definição do sagrado, na museologia, é semelhante à da filosofia, antropologia ou teologia. Assim como a constituição do sagrado no contexto museológico, considerando a premissa da relação homem-realidade na qual a museologia se baseia.

Segundo Rita Capurro (2018, tradução nossa), em geral há dois elementos na museologia que reúnem as ideias do museu e do sagrado, são eles: a arquitetura e 
o processo de musealização. Mas, do ponto de vista religioso, há ações diferentes e específicas, no que se refere ao sagrado e o profano, considerando que o senso secular de religiosidade nos museus está presente nos principais museus nacionais.

Para a autora, a questão da arquitetura é visível no elo entre o templo grego e, em particular, a fachada dos primeiros museus nacionais, levando em consideração a conexão original entre a palavra Museu e as Musas do Olimpo. Já o segundo elemento, que trata do processo de musealização, considera a entrada do objeto ao Museu, semelhante ao processo de "sacralização", ou seja, a criação de um objeto sagrado. Desta forma, analisando de maneira antropológica, a autora afirma que a categoria do sagrado pode ser aplicada aos museus, embora apenas por semelhanças.

Em linhas gerais, para discorrer sobre esse tipo de processo de musealização, é necessário, primeiramente, verificar se o sagrado pode ser e como deve ser musealizado. Para isso, de acordo com Maria Isabel Roque (2011), é preciso estudar a preservação e exposição de objetos referentes às práticas religiosas, partindo-se da premissa de que o sentido do sagrado é musealizável, conhecer como esse tipo de musealização tem sido feito e refletir sobre esse tipo de processo.

A partir dessa análise, entendemos que o processo de musealização de objetos de matriz religiosa tem por objetivo a conservação e valorização dos bens culturais da Igreja, que não se encontram em uso habitual e acabam sendo destituídos da sua característica de objeto religioso. De acordo com Roque (2011), os critérios que evolvem a transformação de um objeto religioso em objeto museológico situam-se na esfera da história da arte, não abordando demais estudos sobre religião, teologia ou liturgia.

Marília Xavier Cury (2018), em seu trabalho com os indígenas Kaingang, faz uma reflexão sobre o sagrado no museu, pois a ideia de patrimônio continua a se apropriar de objetos sagrados no ambiente museológico. Segundo a autora, "no caso do sagrado no museu, os indígenas nos ensinam o conhecimento da espiritualidade. $\mathrm{O}$ conhecimento e as práticas espirituais desses povos indígenas são mantidos pela tradição, as culturas fortalecidas e refeitas" (CURY, 2018, p. 61, tradução nossa).

$\mathrm{Na}$ perspectiva do sagrado na relação com os objetos, a autora defende a ideia de que a curadoria é uma atividade museal que, nos museus etnográficos e 
indígenas, envolvem os Pajés indígenas como curadores, trabalhando na curadoria de objetos e coleções (CURY, 2017).

A autora ainda argumenta que "não são os museus que tornam o objeto sagrado, mas são objetos sagrados para as culturas indígenas que fazem do museu um lugar para novos aprendizados" (CURY, 2018, p. 63, tradução nossa). Também em referência à curadoria de objetos, segundo a autora, os Pajés indígenas são ativos na orientação quanto à curadoria de objetos sagrados. Portanto, é de extrema importância que os profissionais de museus, ao trabalhar com objetos sagrados, se preparem com profundo respeito pelo conhecimento indígena.

Nesse contexto, de acordo com Cury (2018), a Museologia pode contribuir com processos colaborativos como a curadoria museológica, considerando que, ao colocar a espiritualidade indígena como eixo, é possível nos afastar de certas concepções, com o intuito de quebrar paradigmas nos quais os museus tratam o sagrado, assim como a ideia de patrimônio quando se apropria de objetos sagrados. Pois as concepções de artes sacras podem ser limitadas, assim como outras categorias patrimoniais de lugares, objetos e práticas.

A autora complementa que hoje vivenciamos grandes mudanças, e com os processos colaborativos na Museologia, é possível conhecer outras perspectivas de vida que devem ser respeitadas pelos museus.

Nesse sentido, porém, em referência à Igreja Católica, Maria Isabel analisa a maneira como o museu se refere ao sagrado, a forma como exprime o pensamento imaterial, os sentimentos religiosos, e como referenciar os objetos litúrgicos e devocionais numa apresentação museológica. Segundo a autora, "a musealização do objecto religioso é atualmente encarada como uma das soluções mais eficazes para a preservação [...]" (ROQUE, 2011, p. 11).

A autora considera que a museologia do patrimônio católico, veiculando os aspectos da sua ligação ao sagrado, não ultrapassou ainda o perímetro eclesiástico. Com isso, podemos observar a influência do clero na formação de Museus de Arte Sacra e tesouros eclesiásticos, normalmente instalados em igrejas, mosteiros, conventos ou demais ambientes administrados pelo clero.

De acordo com Lynn Maranda (2018, tradução nossa), exemplos de interconexão entre religião e museu são evidenciados por templos que foram originalmente construídos como locais sagrados de religião, mas que agora são museus. Contudo, para Rita Capurro (2018), a reutilização de igrejas como museus, 
assim como o ato de hospedar um museu em uma igreja, é uma das questões mais difíceis a serem abordadas.

A conversão em museus de muitos edifícios religiosos que perderam sua função original cria um possível equívoco sobre a santidade do lugar, ainda mais quando o processo de musealização é feito por uma instituição religiosa, e quando o propósito do edifício é um museu de objetos religiosos. (CAPURRO, 2018, p. 50, tradução nossa).

Para a autora, "há uma responsabilidade específica de manter a separação entre a dimensão do sagrado e a do profano, e isso é mais difícil, pois a linguagem formal do prédio e a natureza das coleções lembram um contexto completamente sagrado" (CAPURRO, 2018, p. 51, tradução nossa).

Para Lynn Maranda (2018, p. 119, tradução nossa),

À sua maneira, ambas as entidades (religião e museu) são atribuídas com os atributos emocionais de um templo - a religião representa o templo da fé e o museu, o da ciência. Ambos têm seus sacerdotes, seus próprios níveis de espiritualidade, suas relíquias, sua doutrina, suas escrituras e seus discípulos. No entanto, eles são distintos.

A partir desse contexto, compreendemos que as edificações de memória religiosa (conventos e igrejas) apresentam grande influência sobre os objetos (documentos) que abrigam e expõem. Conforme apontado por Carpio (2000, p. 33), "a edificação, nestes casos, impõe uma sacralização sobre o objeto museal e o público sente-se envolvido".

Varine (2012) também menciona um sentido espiritual que há na relação entre o divino e humano. De acordo com o autor,

Outro caso típico, igualmente já invocado, mas ao qual eu volto frequentemente porque Ihe atribuo uma grande importância, é o da arte religiosa ou sacra, arquitetura, escultura, objetos, ornamentos, cerimônias. Os museus estão cheios de objetos e de obras pertencentes à esfera religiosa, qualquer que seja a crença em questão. Do mesmo modo, muitos monumentos, grandes e pequenos, que constituem o patrimônio de um território, quer se trate da Europa, da Índia ou da América Latina, são templos, catedrais, capelas, etc. O visitante, como o historiador da arte ou o político local, assim como a maioria da população do território, considera esses objetos ou edifícios por seu valor estético, sua filiação a um estilo, sua antiguidade e seu lugar na história da arte ou das ideias, sua celebridade, sua raridade, etc. Ora, existe um sentido escondido na maioria deles, aquele que the foi dado por quem o encomendou, pelo autor, pelo usuário, que é um sentido espiritual, o sentido da relação entre o divino e o humano. Há ainda uma história invisível, aquela de todos os praticantes que utilizaram o monumento ou objeto, ou que o utilizam ainda. (VARINE, 2012, p. 67-68). 
De um modo geral, segundo Poulot (2013), o museu expõe objetos com o intuito de desempenhar um papel na reflexão social, fornecendo elementos de reconhecimento, interpretação e compreensão. Para o autor,

[...] o museu não mostra a arte, a ciência ou a sociedade, mas a construção desses componentes através da "musealidade". Nesse sentido, a elaboração museográfica faz parte do que é representado pelo museu; sua leitura implica, em particular, uma história da história (da arte, da crítica, da ciência, da museologia), assim como um saber das maneiras usuais de agir. (POULOT, 2013, p. 137).

A partir desta análise, verificamos que a proximidade com o contexto religioso, sob tutela e influência do clero, permite que o acervo fique sujeito ao cumprimento de suas funções litúrgicas, conforme abordado por Roque (2011). Segundo a autora, "a questão central da museologia é, neste contexto, identificar a forma como o museu recontextualiza os conteúdos funcionais, semânticos e simbólicos deste patrimônio ligado ao sagrado" (ROQUE, 2011, p. 15), para a correta musealização dos acervos.

Essa análise, conforme mencionado por Dias, Silva e Campos (2017), mesmo que não parta de pressupostos religiosos, dá ênfase à base documental literária, não deixando de destacar que elas precisam ser "complementadas pela cultura material, pela iconografia, pela epigrafia, pela estatuária votiva e cultural presentes na arquitetura antiga e reveladas principalmente pela arqueologia". (DIAS; SILVA; CAMPOS, 2017, p. 10).

De acordo com os autores,

1) existem teorias e métodos para se identificar e analisar os traços materiais relativos ao sagrado na cultura material;

2) esses traços materiais relativos ao sagrado devem ser analisados em seus contextos de produção, uso e achado, pois

3) o sagrado é parte de um sistema simbólico sem o qual não é possível entendê-lo [...] (DIAS; SILVA; CAMPOS, 2017, p. 117).

Segundo Roque (2011), atualmente os museus se preocupam com a exposição de objetos em relação à sua função sagrada anterior, considerando seu significado e os aspectos materiais, formais e históricos, que passam a ser apropriados pela sociedade como um capital cultural coletivo. Entretanto, essa transferência ao museu depende de um processo de dessacralização dos objetos, para a integração dos acervos em um discurso museológico. Todavia, esse processo não garante a correta musealização dos acervos litúrgicos. Nesse contexto, de acordo com Eliade (1992, p. 18), "manifestando o sagrado, um objeto 
qualquer torna-se outra coisa e, contudo, continua a ser ele mesmo, porque continua a participar do meio cósmico envolvente".

Roque (2011) diz que, ao definir a política de atuação do museu, é necessário averiguar a forma em que o projeto museológico assume a memória religiosa, considerando a vivência litúrgica e o significado dos objetos de culto. Nesse sentido, compreendemos que há uma relação do sagrado com as práticas e instituições religiosas.

A partir desse ponto de análise, o trabalho de Godoy (2018), apresentado no

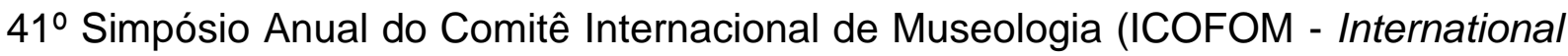
Committee for Museology, traduzido do inglês) intrinsicamente relacionado com a pesquisa dessa dissertação, buscou analisar a Basílica de Nossa Senhora Aparecida, com o intuito de elucidar questões sobre a expressão material da religião, em especial a arte sacra nos espaços religiosos, com institucionalização católica. $O$ autor partiu de uma abordagem dos estudos da museologia e da cultura material, considerando que em uma Igreja Católica todos os lugares são sagrados, porém alguns deles são mais sagrados que outros.

Em sua comunicação, Godoy (2018) abordou o Museu Nossa Senhora Aparecida e a influência de sacerdotes, bispos e teólogos na administração da instituição, que apresenta uma coleção religiosa e histórica associada à biografia da Imagem milagrosa.

De acordo com o autor, "alguns objetos são definidos como relíquias dessa devoção, tais como a pedra e a corrente que provam milagres [...]. As cadeiras dos Papas, roupas, pinturas e presentes são descartados como objetos de interesse histórico, mas para muitos visitantes também são relíquias" (GODOY, 2018, p. 79, tradução nossa).

Em relação à chamada Sala das Promessas, um local dedicado a recolher e exibir os ex-votos, é apresentado pelo autor como um lugar comum em santuários católicos. Entretanto, na Basílica de Aparecida, esse espaço tem o intuito de validar os milagres atribuídos a essa devoção particular.

De maneira geral, seu trabalho tem uma abordagem comparativa entre os dois locais - o Museu Nossa Senhora Aparecida e a Sala das Promessas instalados no mesmo edifício, a Basílica de Nossa Senhora Aparecida. O autor se concentrou nas relações entre a museologia e a teologia, a partir da seguinte reflexão: "Se o sagrado é o tema de ambos, os modos como o Museu e a Sala das 
Promessas os exibem são certamente distintos" (GODOY, 2018, p. 79, tradução nossa).

Para Godoy (2018, p. 80, tradução nossa),

O conceito de "complexo de exposições" pode ser facilmente transposto para o Santuário Nacional de Aparecida, levando em consideração algumas de suas especificidades, como a doação voluntária da maior parte de sua coleção. Essa comparação é mais evidente em espaços como o "Museu de Nossa Senhora Aparecida" ou o "Salão das Promessas", onde objetos específicos são selecionados para mostrar um conceito e um comportamento religioso institucionalizado sustentado pelo clero, que neste caso é o seu curador. Os objetos doados pelo peregrino, uma figura exótica, são a origem das exposições catalogadas pelos sacerdotes, que depois usam os objetos para ensinar aos peregrinos como ter fé.

O autor argumenta que a construção da Basílica de Aparecida busca ser um "complexo de exposições" capaz de ensinar a religião católica ao visitante através da arte. Nesse contexto, o autor cita a figura de Cláudio Pastro como o principal artista sacro responsável pelas obras de construção da Basílica entre os anos de 1999 a 2016.

De acordo com Godoy (2018, p. 81, tradução nossa),

O artista costuma fazer uma enorme diferença entre a arte sacra e a arte religiosa. O segundo é classificado como uma arte representativa e temática sobre a religião, e o primeiro é categorizado como a verdadeira arte religiosa, porque pode promover uma experiência espiritual através da beleza.

De um modo geral, Andrade (1993), ao referir-se aos artistas que procuram descobrir nas igrejas o credo de um novo estilo, complementa que:

É de crer que a Igreja, quando se acentuar com mais firmeza esse
movimento nacionalista da arte, que ainda vage nos linhos da infância,
enfim realizando o belo arquitetônico de fundo tradicional, é de crer que a
Igreja saiba se aproveitar dele e nos dê ainda templos nossos, capelas
brasileiras onde a comoção religiosa da raça palpite, como num lar
avoengo, desfiando, sob a proteção do nosso católico passado, o rosário
das oblações ao Senhor". (ANDRADE, 1993, p. 95-96).

A partir dessa análise, com a prática de musealização da arte sacra ou de acervos ligados ao culto e à devoção, acabamos por valorizar os objetos, e "essa valorização poderá ocorrer com a transferência do objeto de seu contexto para o contexto dos museus" (CURY, 2005, p. 24). De acordo com a autora, o processo de musealização inicia-se com a valorização seletiva dos objetos, todavia continua no conjunto de ações que buscam transformar o objeto em documento. 
De um ponto de vista mais estritamente museológico, Desvalées e Mairesse (2013, p. 56-57) definem que "a musealização é operação de extração, física e conceitual, de uma coisa de seu meio natural ou cultural de origem, conferindo a ela um estatuto museal - isto é, transformando-a em musealium ou musealia, em um 'objeto de museu' que se integre no campo museal".

De acordo com os autores,

\begin{abstract}
Um objeto de museu não é somente um objeto em um museu. Por meio de mudança de contexto ou do processo de seleção, de "thesaurização" e de apresentação, opera-se uma mudança do estatuto do objeto. Seja este um objeto de culto, um objeto utilitário ou de deleite, animal ou vegetal, ou mesmo algo que não seja claramente concebido como objeto, uma vez dentro do museu, assume o papel de evidência material ou imaterial do homem e de seu meio, e uma fonte de estudo de exibição, adquirindo, assim, a realidade cultural específica. (DESVALÉES; MAIRESSE, 2013, p. $57)$.
\end{abstract}

Desvalées e Mairesse (2013) complementam que a musealização atribui um valor documental ao objeto, desviando o museu da perspectiva do templo para aproximá-lo à do laboratório. É por essa razão que a musealização é considerada um processo científico, que compreende o conjunto de atividades do museu (preservação, pesquisa e comunicação).

Em síntese, conforme abordado por Cury (2005, p. 26),

Entende-se o processo de musealização como uma série de ações sobre os objetos, quais sejam: aquisição, pesquisa, conservação, documentação e comunicação. $O$ processo inicia-se ao selecionar um objeto de seu contexto e completa-se ao apresentá-lo publicamente por meio de exposições, de atividades educativas e de outras formas. Compreende, ainda, as atividades administrativas como pano de fundo desse processo.

De maneira geral, o museu, como o percebemos hoje, possui funções diversificadas. E a musealização dos objetos sagrados, nesse contexto, implica um procedimento de transferência, no qual ele é retirado do seu contexto inicial para the conferir uma nova funcionalidade.

Em suma, nesse processo é adicionada ao objeto a qualidade de símbolo, de representação ou a conotação com algo que o transcende, mas que, nesse documento é materializado, gerando conhecimento e difundindo informações por meio das exposições museológicas (ROQUE, 2010).

De acordo com Eliade (1991), o simbolismo está presente em todo o pensamento religioso e acrescenta um novo valor a um objeto, sem prejudicar seus valores próprios. Segundo o autor, "as Imagens, os arquétipos, os símbolos são 
diversamente vividos e valorizados: o produto dessas múltiplas atualizações constitui em grande parte os 'estilos culturais'” (ELIADE, 1991, p. 172).

Para Eliade (1991) é a presença das Imagens e dos símbolos que conserva as culturas "abertas". De acordo com o autor, "se as Imagens não fossem ao mesmo tempo uma "abertura" para o transcendente, acabaríamos por sufocar qualquer cultura, por maior e admirável que a supuséssemos" (ELIADE, 1991, p. 174).

De um modo geral, segundo Meneses (2005, p. 25), em uma exposição museológica os objetos são vistos como suportes de significações, "capazes de portar sentido estabelecendo uma mediação de ordem existencial (e não cognitiva) entre o visível e o invisível, outros espaços e tempos, outras faixas de realidade".

De acordo com o autor, "relíquia, semióforo, objetos históricos: seus compromissos são essencialmente com o presente, pois é no presente que eles são produzidos ou reproduzidos como categoria de objeto e é às necessidades do presente que eles respondem" (MENESES, 2005, p. 26). Por isso o museu deve inseri-los no quadro de análise, com o intuito de desvendar a sua construção, transformação, usos e funções.

Enfim, de acordo com Meneses (2005), o estudo da cultura material não busca produzir uma história das fontes e de seus significados, mas sim uma história da sociedade na dimensão material de sua produção e reprodução. 


\section{Considerações Finais}

Este trabalho partiu do pressuposto enunciado "a museologia e o sagrado", cuja validação resulta a partir dos estudos de formação do acervo e do processo de musealização de objetos do culto católico e devocionais, que foram acrescidos de objetos diversos ao longo de mais de sessenta anos, atendendo ao caso particular do Museu Nossa Senhora Aparecida, criado pela Professora Conceição Borges Ribeiro Camargo, em 1956, instalado atualmente no Santuário Nacional de Nossa Senhora Aparecida.

Não obstante, no curso do tempo, os objetos religiosos pertencentes ao Museu foram incorporados ao acervo em consequência do desuso, doações e aquisições, e até mesmo por obsolescência, pelo fato de perderem a prática ritual. Desta forma, o valor cultural dos artefatos deriva da sua existência como um objetodocumento, testemunho de fé e devoção. É nesse contexto que a musealização surge como uma forma privilegiada de preservação e valorização do patrimônio religioso.

Levando em consideração esses aspectos, a prática museológica realizada pela Professora Conceição Borges Ribeiro Camargo ocorreu entorno da devoção a Nossa Senhora Aparecida, numa esfera religiosa, tendo como lugar-sede um convento e demais edifícios pertentes à Congregação do Santíssimo Redentor, cabendo-Ihe criar propostas comunicacionais subordinadas à história local, com narrativas sobre o encontro da Imagem de Nossa Senhora Aparecida, contextualizas pelos objetos-testemunho dos milagres e demais ex-votos ofertados pelos visitantes devotos de Nossa Senhora.

Em virtude dessa essência peculiar na criação do Museu Nossa Senhora Aparecida, se comparado aos demais museus criados na época, entendemos que grande parte do acervo inicial, que foi adquirido ou ofertado, está relacionada ao culto católico ou à devoção. Percebemos que, ao longo dos anos, a formação das coleções resultou do vínculo intrínseco com a chamada Sala das Promessas, pela proximidade de localização e similaridade na constituição do acervo. Contudo, não atendendo apenas ao conteúdo religioso, mas formando-se coleções ecléticas, com aspectos significativos das relações do homem com seu cotidiano, sua expressão, as relações do homem com a natureza, a partir de uma visão etnográfica. 
Ao longo da história do Museu Nossa Senhora Aparecida, observamos, também, que ocorreu a integração de numerosos bens provenientes da Antiga Basílica de Nossa Senhora Aparecida. Nesse contexto, a musealização ocorreu com o intuito de conservar esses acervos que entraram em desuso ou que foram substituídos por novos objetos rituais. Todavia, a atitude museológica da Basílica de Aparecida também está relacionada a uma função pastoral, de valor catequético, considerando que, inicialmente, o Cardeal Motta foi um dos grandes responsáveis por intermediar essa transição de acervos aos cuidados do Museu, com o intuito de salvaguardar e valorizar os bens culturais da Igreja.

É importante considerar que muitos dos objetos litúrgicos que ingressaram nesse universo museológico adquiriram a qualidade de obras de arte, sendo privados do seu sentido original, com função religiosa. Por isso, foram importantes os novos arranjos museográficos realizados a partir de 2003, com o intuito de comunicar o sentido litúrgico e devocional dos acervos.

Dessa forma, a revitalização institucional do Museu é marcada por um novo ordenamento do acervo, com a implantação de um sistema de classificação e novos procedimentos de documentação museológica, que contribuiu com a organização das coleções e novas propostas de comunicação com temática religiosa e caráter didático-pedagógico, disponibilizando novos espaços para compartilhamento de informações e construção de conhecimento.

Essa requalificação do Museu, a partir da consultoria técnica, incentivou a investigação e o estudo das coleções, com a valorização dos objetos religiosos, que ilustram discursos e privilegiam o valor histórico e estético, em sentido litúrgico e devocional. Dentro desse contexto, a consultoria foi responsável por acompanhar, de certo modo, toda a atividade museológica desenvolvida no período de 2003 a 2018, por meio da realização de projetos, inclusive com iniciativas promovidas pelos Missionários Redentoristas, responsáveis pela administração do Santuário Nacional de Aparecida e, consequentemente, do Museu.

De maneira geral, pela observação dos aspectos apresentados nesta dissertação, buscamos refletir sobre as relações do Santuário Nacional de Aparecida com a atuação do Museu Nossa Senhora Aparecida, a partir de questões como: qual o perfil das aquisições e doações realizadas? Como ocorre a inserção de objetos, em especial objetos sagrados, no espaço museológico? Como são realizados os processos museológicos que garantam a preservação dos acervos? Quais são os 
públicos do Museu e como se relacionam com os objetos expostos? Analisando, desta forma, as políticas de aquisição e formação de acervo, assim como as práticas institucionais para qualificação profissional e realização dos processos museológicos e propostas comunicacionais, com análise delimitada pelas exposições de longa duração.

A pesquisa compreendeu, também, a alocação do Museu, o estudo de formação das coleções, com base nos documentos de entrada e doação de objetos, listas de inventário e fichas catalográficas, bem como a constituição de seu lugarsede, de acordo com os locais em que o Museu foi sendo instalado com o passar do tempo, considerando a cultura material, os registros documentais, fotográficos e audiovisuais como importantes fontes de informações.

Com a instalação do Museu na Basílica, observamos que o fluxo de visitação passou a aumentar constantemente, devido às grandes romarias e à busca por entretenimento. Desta forma, ampliou-se o número de doações de acervo ao Museu, as quais passaram a ser inseridas nas vitrines no ato da doação.

No contexto geral, observamos uma relação entre o Museu e a chamada Sala das Promessas, também conhecida como Sala dos Milagres ou Quarto dos Milagres, com coleções de acervos religiosos e devocionais, que foram reunidos por meio da oferta de ex-votos (objetos que remetem a uma promessa ou graça alcançada). Acreditamos que a Sala dos Milagres possa ter sido um estímulo para a criação do Museu, considerando que esses agrupamentos de objetos materiais podem ser entendidos como museus ou embriões de museus e podem ter influenciado de certa maneira a própria formação das coleções do Museu Nossa Senhora Aparecida.

Levando-se em conta o que foi observado, verificamos que atualmente a Sala das Promessas continua sendo uma fonte de aquisição de acervos, pois alguns objetos são transferidos para o Museu, após a seleção e análise por uma comissão técnica e aprovação dos Missionários Redentoristas.

De maneira geral, entendemos que, para os organizadores do Museu, todas as seções estavam incompletas, o que abriu margem para a incorporação de objetos de todos gêneros, que eram doados. Desta forma, o Museu foi caracterizado com um conceito de museu abrangente e eclético, devido ao recolhimento e à exposição de objetos de diversas áreas do conhecimento.

Com base nessas informações, observamos um grande esforço dos organizadores para receber novas doações, pois no início não havia uma política 
definida para aquisição de acervos. Com isso, acreditamos que o conceito de Museu dos organizadores definiu as características das doações, bem como a dinâmica para incorporações e baixas, considerando que se tratava de uma instituição de caráter particular.

A pesquisa sugeriu também algumas similaridades com os Museus Históricos Pedagógicos do Estado de São Paulo e permitiu estabelecer relações, devido ao contexto histórico-cultural do período em que foram criados, pois foram implantados a partir de 1956, apresentando semelhanças de mobiliários utilizados nas exposições e a forma de expor os objetos.

Com base no levantamento documental e entrevistas realizadas, observamos que era costume a Professora Conceição Borges ir até as residências, em bairros rurais, em busca de peças para a coleção de imaginárias, que foram adquiridas ou coletadas em capelas e hoje compõem um riquíssimo acervo de arte sacra. Esse aspecto foi destacado como um procedimento de curadoria.

É importante considerar que, durante a gestão da Professora Conceição Borges Ribeiro Camargo, o Museu Nossa Senhora Aparecida já estava incluído nas análises do Governo Federal, no que se refere aos levantamentos estatísticos. Observamos, pois, a presença de documentos reportados ao Instituto Brasileiro de Geografia e Estatística (IBGE), ao Departamento de Assuntos Culturais do Ministério da Educação e Cultura (DAC-MEC), assim como ao Comitê Brasileiro do Conselho Internacional de Museus (ICOM - International Council of Museums, traduzido do inglês), no Rio de Janeiro.

No que se refere à documentação do acervo, verificamos um procedimento de tombamento no início da década de 1990. Embora identificado como um registro tardio e com divergências de informações, o cadastramento do acervo em Livro de Tombo permitiu a checagem de parte das coleções. Nesse período, também foi instituído o Termo de Doação de Bens Móveis. Observamos que esses documentos receberam, posteriormente, uma etiqueta com numeração em ordem crescente, com base na cronologia das datas de doação, auxiliando no estudo e na análise dos objetos que foram documentados e permanecem salvaguardados no Museu.

De maneira geral, o conjunto de termos de doação possibilitou um estudo sobre o acervo, ainda que de forma assistemática, pois os documentos não informam o destino das peças no museu, sua localização atual, o estado de 
conservação e, por vezes, não há descrição do objeto doado, o que dificultou estabelecer correlações entre os acervos e os registros.

Em relação ao estudo das antigas exposições, buscamos analisar alguns aspectos, essencialmente por meio das fontes documentais e iconográficas, conforme estudo realizado por Heloísa Barbuy. A partir dessa perspectiva, as fontes primárias trouxeram materiais para discussão e obtenção de informações empíricas, com interação entre imagens e textos. Já a metodologia de análise das exposições foi baseada no Roteiro de observação para visitas a museus e exposições, desenvolvido por Marília Xavier Cury.

Desta forma, observamos que havia uma grande diversidade de tipologias de acervos e coleções em exposição, constituindo-se, além do projeto pedagógico de seus organizadores, as representações sociais de forma interativa com seus visitantes. Em relação à organização do acervo, notamos que havia um grande acúmulo de objetos em exposição, inclusive sobre os armários, fixados nas paredes ou suspensos do teto, ou seja, a exposição ocupava todo o espaço disponível, embora de forma organizada, conforme o conceito adotado pela Profa. Conceição Borges. Entretanto, considerando a maneira em que eram tratados e expostos, alguns objetos ficavam destituídos de seu valor de informação e testemunho.

De maneira geral, ao analisar esse conjunto de elementos, acreditamos que, apesar da quantidade de objetos em exposição nesse período, o espaço era condizente com a proposta da Profa. Conceição Borges, que era evidenciar a devoção a Nossa Senhora Aparecida, bem como apresentar as diversas áreas do conhecimento, organizados por núcleos temáticos.

Em relação às trajetórias do Museu Nossa Senhora Aparecida, a partir de 1996, notamos que a instituição passou a ser administrada diretamente pelo Santuário Nacional de Aparecida, devido ao falecimento da fundadora.

Em um primeiro momento foram estudadas as mudanças na gestão, abrangendo o período de 1996 a 2003. Nesse período a administração empenhouse em reorganizar o acervo em exposição e criou novos procedimentos para qualificar o trabalho do Museu, além de ter se preocupado com a conservação dos objetos em exposição, buscando profissionais que pudessem colaborar com a recuperação de algumas peças mais deterioradas.

Posteriormente, analisamos as etapas de revitalização institucional do Museu, entre os anos 2003 a 2018, que compreenderam a criação do Plano 
Museológico, novos projetos expograficos, implantação de reserva técnica climatizada, a organização das coleções e os processos de identificação e classificação do acervo, profissionalização das equipes de trabalho, bem como o uso de Sistemas de Gerenciamento de Documentos, para catalogação dos objetos.

De modo geral, o plano museológico não separa os objetos religiosos dos demais acervos que coexistem no mesmo espaço de armazenamento, classificados conforme tipologia e material, que serviram como critérios para organização na reserva técnica. Nesse contexto, a organização dos mobiliários foi realizada segundo critério numérico, em ordem crescente, e os objetos foram dispostos em diversos grupos, no caso das coleções de matriz religiosa, concentram-se principalmente nas categorias: imaginárias, pinturas, móveis, objetos de rituais litúrgicos, objetos devocionais, indumentárias, etc.

No que se refere à concepção da exposição Rainha do Céu, Mãe dos Homens: Aparecida do Brasil, observamos que foi adotada uma leitura mais poética que narrativa, diferenciando-se, assim, de outras exposições tradicionais de arte sacra. A musealização da arte sacra, é aqui entendida no sentido restrito da arte concebida para a liturgia e o culto divino.

Nessa exposição, Nossa Senhora é tida como figura central e busca referenciar seu papel para a fé cristã, seja em sua dimensão humana, seja no sentido teológico. Acreditamos que o conjunto de elementos analisados é suficiente para o público compreender a proposta dos curadores, que colocaram Maria como figura central, valorizando o patrimônio religioso e a devoção a Nossa Senhora Aparecida, assim como a participação do público, que se identifica, principalmente, com o núcleo central da exposição, onde estão os ex-votos, objetos representativos da devoção do fiel.

$\mathrm{Na}$ exposição O Museu e suas Histórias, verificamos os núcleos que exibem objetos representativos das diversas coleções do Museu, organizados por tipologia, contextualizando as relações do homem com o sagrado, suas formas de expressão, sua vida cotidiana e doméstica, assim como no universo do trabalho e sua relação com o meio ambiente.

Na sequência dessa exposição, onde recentemente foi inaugurada a Coleção Santa Gertrudes de Imagens Paulistas do século XVII, observamos a predominância de imagens da Virgem Maria, em diversas de suas invocações. Com isso, notamos certa fixação no arquétipo feminino e de busca incessante pela figura maternal. 
Acreditamos que a exposição Coleção Santa Gertrudes de Imagens Paulistas do século XVII veio engrandecer e se somar às demais coleções do Museu Nossa Senhora Aparecida, especialmente por valorizar a coleção de imagens religiosas, dando ênfase ao sagrado nas exposições museológicas.

Em relação ao Circuito de Visitação à Cúpula, que foi criado com o intuito de rememorar a grande celebração do Tricentenário do encontro da Imagem de Nossa Senhora Aparecida, em 2017, observamos que o grande ápice deste circuito é a própria cúpula central da Basílica, que pode ser admirada com uma distância de poucos metros, adornada pelas obras com temáticas religiosas e simbologias concebidas pelo artista Cláudio Pastro, que renovou a arte sacra de um dos maiores santuários católicos do mundo, também contempladas nas exposições do Museu, que compõem o Circuito de Visitação à Cúpula.

De maneira geral, ao refletir sobre a musealização de objetos sagrados ou devocionais, é necessário compreender que é muito ampla a problemática da diversidade de documentos. Entendemos que é preciso pensar o museu como uma instituição com prática científica, como um laboratório para estudo do objetodocumento, considerando que o papel do cientista é buscar compreender o objeto como documento, abstraindo todas as informações possíveis. Todavia, é evidente que o discurso científico para ser válido precisa incluir a diversidade de documentos e culturas, para haver diálogo e criação de um senso crítico.

A partir dessa análise, a abrangência social do documento é vista como a ponta de um iceberg, ou seja, o objeto precisa ser estudado mais profundamente, com o intuito de estabilizar o documento, como uma fonte de informação pública. Desta forma, ao considerar que os documentos armazenam informações, é preciso analisar também quais são os discursos gerados, pois há diferentes perspectivas que produzem discursos e resultados diferentes, a partir de um mesmo ponto de análise.

Nesse sentido, compreendemos que a pesquisa sobre o objeto-documento auxilia no entendimento de como os grupos classificam o mundo a sua volta, considerando a trajetória social dos objetos, pois essa circulação anterior à inserção dos objetos no museu pode assumir relações diversas.

Por fim, essa reflexão em torno da Museologia e o Sagrado, a partir da perspectiva do Museu Nossa Senhora Aparecida, foi apenas o início de uma pesquisa que se faz necessária para tornar o discurso palpável, com validação 
científica, por isso é importante sempre retomar as questões como: de onde veio o objeto? Quais são as relações anteriores? Onde será exposto? Qual a relação com os demais objetos expostos? Há diálogo entre outros acervos? Quais as percepções do público? Quais são as redes e práticas por trás deste objeto (deste documento)? Partindo-se da premissa de que quando se faz ciência também se faz cultura e estamos reproduzindo práticas.

Em suma, nas reflexões sobre a musealização de objetos ligados ao culto católico e à devoção, observamos que tais documentos fazem parte da cultura material, sendo possível analisar, também, as pessoas que estão envolvidas com a produção dos discursos nos museus, assim como a forma em que a sociedade se relaciona com essa materialidade. Por isso, a classificação, a conservação e a exposição desses documentos são importantes para compreensão do mundo a nossa volta.

Enfim, se faz necessário o desenvolvimento de novas pesquisas sobre os acervos e coleções do Museu Nossa Senhora Aparecida, o que permite o estudo da cultura material e de práticas sociais. Com isso, o Museu pode contribuir com a produção, difusão e socialização do conhecimento dos temas que ele aborda, com o intuito de atender as diversas demandas, em especial, contribuindo com a evangelização e propagação da devoção a Nossa Senhora Aparecida. 


\section{Referências $^{66}$}

\section{- Entrevistas}

BRAGA, Guido Machado. Entrevista concedida ao Victor Hugo Barros e à Erica Andreza Coelho. Aparecida, 20 set. 2017, 33 min 08 s. Som, Formato MP3.

CUNHA, Zenilda Cristina da. Entrevista concedida à Erica Andreza Coelho. Aparecida, 10 jan. 2018, $1 \mathrm{~h} 33$ min 17 s. Som, Formato M4A.

NICIOLI, Darci José (Arcebispo de Diamantina). Entrevista concedida à Erica Andreza Coelho. Aparecida, 19 abr. 2018, 6 min 14 s. Som, Formato M4A.

PASIN, Tereza Galvão. Entrevista concedida à Erica Andreza Coelho. Aparecida, 27 dez. 2017, 42 min 05 s. Som, Formato M4A.

PEIXE, Giselle; BIGARELI, Silvia. Entrevista concedida à Erica Andreza Coelho. Aparecida, 17 jan. 2018, 29 min 20 s. Som, Formato M4A.

RIBEIRO, Zilda Augusta. Depoimento concedido à Giselle Peixe e Silvia Bigareli. Aparecida, 2003. 60 min $58 \mathrm{~s}$. Som, Cor, Formato vídeo 8mm, com reprodução em DVD.

SILVEIRA, Victor Hugo Lapenta da (Padre Redentorista). Entrevista concedida à Erica Andreza Coelho. Aparecida, 9 ago. 2018, 29 min 03 s. Som, Formato M4A.

\section{- Fontes Documentais}

BARBOSA, Leila. [Memorando o 496/84] 21 dez. 1984, Guaratinguetá [para] CAMARGO, C.B.R. Guaratinguetá. 1f. Formulário para preenchimento do questionário EC-5 - Museus, para a Secretaria de Planejamento da Presidência da República, Fundação Instituto Brasileiro de Geografia e Estatística - IBGE.

BLOISE, Ana Silvia. Proposta de Trabalho: Museu Nossa Senhora Aparecida. 2002. Fonte: Museu Nossa Senhora Aparecida.

CAMARGO, C.B.R.; CAMARGO, V. [Carta] 16 set. 1967, Aparecida [para] ROSA, J.F., Aparecida. 1f. Apresentação de propostas para o problema de instalação de um Museu de Cera ao lado do Museu Nossa Senhora Aparecida.

CAMARGO, C.B.R. [Carta] 28 nov. 1980, Aparecida [para] GALVÃO. Aparecida. $1 f$. Doação dos móveis do antigo museu da Cúria Metropolitana de São Paulo para o Museu Nossa Senhora Aparecida.

CAMARGO, C.B.R. 17 set. 1978, Aparecida [para] MORO, F.C.A. Aparecida. $2 f$. Preenchimento de formulários para o Cadastro de Museus ao Comitê Brasileiro do ICOM, Rio de Janeiro.

${ }^{66}$ De acordo com a Associação Brasileira de Normas Técnicas (ABNT NBR 6023). 
CAMARGO, C.B.R. Manuscrito de Conceição Borges Ribeiro Camargo para divulgação do novo Museu, [s.d.]. Fonte: Museu Nossa Senhora Aparecida.

CAMARGO, C.B.R. Manuscrito de Conceição Borges Ribeiro Camargo. "História dos Ciclos Socioeconômicos", 1992. Fonte: Museu Nossa Senhora Aparecida.

CAMARGO, C.B.R. Manuscrito de Conceição Borges Ribeiro Camargo, fev., 1972. "Relação de Imagens de Nossa Senhora Aparecida retiradas da "Sala dos Milagres", da Galeria do Hotel Recreio, e enviadas ao Museu Nossa Senhora Aparecida, para incorporação ao acervo". Fonte: Museu Nossa Senhora Aparecida.

CAMARGO, C.B.R. Manuscrito de Conceição Borges Ribeiro Camargo, [s.d]. "Material que veio do Museu "Nossa Senhora Aparecida" da Galeria do Hotel Recreio, nos dias 20 e 21 de dezembro de 1971 - para o $3^{\circ}$ andar da Tôrre da Nova Basílica". Fonte: Museu Nossa Senhora Aparecida.

CAMARGO, C.B.R. Manuscrito de Conceição Borges Ribeiro Camargo, [s.d]. Rascunho para preenchimento do "Quadro 3 - quesito 8" do formulário EC-5 Museus". Fonte: Museu Nossa Senhora Aparecida.

CAMARGO, C.B.R. Manuscrito de Conceição Borges Ribeiro Camargo, [s.d]. Rascunho para o pronunciamento de 20 anos do Museu. Fonte: Museu Nossa Senhora Aparecida.

COELHO, E.A; RODRIGUIES, G.T. Relatório de cédulas catalogadas, 2010, (documento eletrônico). Fonte: Museu Nossa Senhora Aparecida.

COELHO, E.A; RODRIGUIES, G.T. Relatório de cédulas excedentes, 2010, (documento eletrônico). Fonte: Museu Nossa Senhora Aparecida.

COELHO, E.A; RODRIGUIES, G.T. Relatório de moedas excedentes, 2010, (documento eletrônico). Fonte: Museu Nossa Senhora Aparecida.

COELHO, E.A; RODRIGUIES, G.T.; OLIVEIRA, M.H. Relatório Geral de Numismática, 2009, (documento eletrônico). Fonte: Museu Nossa Senhora Aparecida.

CONTRATO de doação e outros encargos que entre si fazem Vicente Camargo e sua esposa Conceição Borges Ribeiro Camargo com a Sociedade Santuário Nacional de Nossa Senhora Aparecida. Fonte: Museu Nossa Senhora Aparecida.

CONTRATO particular de doação, 12 de outubro de 2012, tendo como doadoras: Rita Maria de Vasconcelos Motta e Maria José de Vasconcelos Motta; e, do outro lado, como donatário, o Santuário Nacional de Nossa Senhora da Conceição Aparecida. Fonte: Museu Nossa Senhora Aparecida.

CONVITE de Inauguração do Museu dos Ciclos Socioeconômicos do Vale do Paraíba, 1975. Fonte: Museu Nossa Senhora Aparecida. 
CURY, Marília Xavier. Roteiro de observação para visita a museus e exposições. Desenvolvido e disponibilizado pela Profa. Dra. Marília Xavier Cury, utilizado na disciplina: MEA 16 - Exposições Antropológicas - 1o semestre de 2018, (documento eletrônico), Museu de Arqueologia e Etnologia da USP.

CURRÍCULO. Transcrição de manuscrito pertencente ao arquivo pessoal de Conceição Borges Ribeiro Camargo, armazenado na Biblioteca Municipal de Aparecida/SP. Transcrição realizada por Michel Henrique de Oliveira, em 14/10/2007, (documento eletrônico). Fonte: Museu Nossa Senhora Aparecida.

DIÉGUES JUNIOR, Manuel. [Circular no04] 10 maio 1977, Rio de Janeiro. [para] CAMARGO, C.B.R. Levantamento das condições físicas, administrativas, técnicas e financeiras dos museus brasileiros - Departamento de Assuntos Culturais.

PASIN, Tereza Galvão. Conceição Borges, das entranhas da terra ao canto à Senhora Aparecida. Discurso proferido no evento de comemoração dos 60 anos do Museu. 2016. (Texto digitado). Fonte: Museu Nossa Senhora Aparecida.

PEIXE. Giselle; BIGARELI, Silvia. Domus Aurea: "A Sabedoria fez para si uma casa...". 2012. Fonte: Museu Nossa Senhora Aparecida.

PEIXE, Giselle; BIGARELI, Silvia. Museu do Santuário Nacional de Nossa Senhora da Conceição Aparecida: Proposta museológica institucional, proposta expositiva, proposta de ação educativa. 2004. Fonte: Museu Nossa Senhora Aparecida.

PEIXE, Giselle; BIGARELI, Silvia. Projeto Museográfico - Exposição de longa duração: Rainha do Céu, Mãe dos Homens: Aparecida do Brasil. 2004. Fonte: Museu Nossa Senhora Aparecida.

PEIXE, Giselle; BIGARELI, Silvia. Projeto Museográfico - Circuito de Visitação à Cúpula. 2017. Fonte: Museu Nossa Senhora Aparecida.

PEIXE, Giselle; BIGARELI, Silvia. Salvaguarda de acervo do Museu Nossa Senhora Aparecida - Instalação de Reserva Técnica. 2006. Fonte: Museu Nossa Senhora Aparecida.

RAMOS, Claudinéli Moreira. Relatório Final Prestação de Serviços Especializados. Fundação Patrimônio Histórico da Energia de São Paulo, 2003. Fonte: Museu Nossa Senhora Aparecida.

\section{- Fontes Impressas}

AS IRMÃS CANISIANAS nas Oficinas Gráficas de Aparecida. Almanaque de Nossa Senhora Aparecida - Ecos Marianos. Aparecida: Editora Santuário, 1957.

CAMARGO, Conceição B. R. Assumar e os 7 altares. Separa Ecos Marianos. Aparecida: Editora Santuário, 1967. 
CAMARGO, Conceição B. R. Cronistas, pintores e viajantes na capela de Nossa Senhora Aparecida séculos XVIII e XIX. Separata Ecos Marianos. Aparecida: Editora Santuário, 1985.

CAMARGO, Conceição B. R. Da Arqueologia de Aparecida. Almanaque de Nossa Senhora Aparecida - Ecos Marianos. Aparecida: Editora Santuário, 1958.

CAMARGO, Conceição B. R. Euclides da Cunha em Aparecida. Separata Ecos Marianos. Aparecida: Editora Santuário, 1965.

CAMARGO, Conceição B. R. Romaria em carro-de-boi. Separata Ecos Marianos. Aparecida: Editora Santuário, 1988.

CAMARGO, Conceição B. R.; CAMARGO, V. A Passagem da Princesa Isabel em Aparecida. Separata Ecos Marianos. Aparecida: Editora Santuário, 1964.

CAMARGO, Conceição B. R.; CAMARGO, V. Arqueologia no Vale do Paraíba Escavações Arqueológicas em Aparecida. Cadernos Culturais do Vale do Paraíba, Centro Educacional Objetivo, 1990.

CAMARGO, Conceição B. R.; CAMARGO, V. Arqueologia no Vale do Paraíba Escavações em Aparecida. X Simpósio do Vale do Paraíba. Roseira, 19 a 21 de julho de 1990.

CAMARGO, Conceição B. R.; CAMARGO, V. Os escravos de Nossa Senhora Aparecida. Separata Ecos Marianos. Aparecida: Editora Santuário, 1989.

MUSEU "Nossa Senhora Aparecida". Almanaque de Nossa Senhora Aparecida Ecos Marianos. Aparecida: Editora Santuário, 1957.

NOVA BASÍLICA a sua torre monumental. Almanaque de Nossa Senhora Aparecida - Ecos Marianos. Aparecida: Editora Santuário, 1967.

OFICINAS Gráficas do Santuário. Almanaque de Nossa Senhora Aparecida Ecos Marianos. Aparecida: Editora Santuário, 1938.

PAIXÃO, Manoel José. Museu conta um pouco da história da cidade. Almanaque de Nossa Senhora Aparecida - Ecos Marianos. Aparecida: Editora Santuário, 1998.

RIBEIRO, Zilda Augusta. O museu Nossa Senhora Aparecida e a exposição comemorativa de 2005. Almanaque de Nossa Senhora Aparecida - Ecos Marianos. Aparecida: Editora Santuário, 2006.

SALA dos Milagres. Almanaque de Nossa Senhora Aparecida - Ecos Marianos. Aparecida: Editora Santuário, 1927.

- Artigos de Jornal 
BOAS, A. V. Centro Cultural vai ocupar prédio da Rede Ferroviária. Valeparaibano. São José dos Campos, 02 nov. 1994, [recorte].

CAMARGO, C.B.R. Agradecimento. Aparecida, 30 jan. 1993, n 603. [recorte]

CORRÊA, Rita. Historiadora deixa saudades e vários trabalhos marcantes. Jornal Valeparaibano, São José dos Campos, 28 jan. 1996.

ESTAÇÃO pode virar museu. Jornal da Arquidiocese. Aparecida, 30 jul. 1994. INAUGURAÇÃO do Museu da Basílica. Oficial do Legislativo. Guaratinguetá, 24 nov. 1967, ano 1, no 25, p. 3

INAUGURADO Museu dos "Ciclos Sócio-Econômicos do Vale do Paraíba". Santuário de Aparecida. Aparecida, 05 out. 1975, nํ3728, p.1.

INAUGURADO o Museu Nossa Senhora Aparecida. A Gazeta. São Paulo, 25 set. 1956, p.25.

MUSEU ganha acervo da II Guerra Mundial. O Aparecida. Aparecida, 08 maio 1993. [recorte].

MUSEU N. S. Aparecida. O Estado de São Paulo. São Paulo, 05 set. 1976, p.35.

MUSEU N. Sra. Aparecida. Santuário de Aparecida. Aparecida, 09 nov. 1958, ano $58, n^{\circ} 52$, p. 1 .

MUSEU "Nossa Senhora Aparecida" completou 20 anos. Santuário de Aparecida. Aparecida, 12 set. 1976, ano 76, nํ⒊774, p.8.

SANTUÁRIO DE APARECIDA. Aparecida, 08 dez. 1957, ano 58, nำ 5, p.8.

SANTUÁRIO Nacional tem GED na engenharia, jurídico e no centro de documentação. Cases Brasil. Jornal do GED, maio/jun. 2004, ano 10, ํำ63, p.3.

\section{- Periódicos}

CAPPELLI, Vittorio. Rosalbino Santoro. Da Fuscaldo a Rio de Janeiro passando per San Paolo del Brasile e Taubaté - Un pintore itinerante. II Quotidiano della Domenica. p.43-45, 12 gennaio 2014c.

CAPPELLI, Vittorio. Rosalbino Santoro in Brasile: Un «pittore itinerante» a Rio de Janeiro, San Paolo e Taubaté. Rivista Calabrese di Storia del ‘900, № 2 (número monográfico), p.47-60, 2014b.

CAPPELLI, Vittorio. Rosalbino Santoro: Paesaggi e fazendas nei suoi dipinti. Itaca. Periodico Trimestrale, Anno VII, № 25, Giugno, 2014a.

COMPROMISSO com a segurança e bem-estar dos devotos. Santuário em Ação. Revista de Aparecida, julho 2008. 
REVISTA do Instituto Histórico e Geográfico de São Paulo. Vol. 65. São Paulo: IHGSP, 1968.

REVISTA do Instituto Histórico e Geográfico de São Paulo. Vol. 67. São Paulo: IHGSP, 1970.

REVISTA do Instituto Histórico e Geográfico de São Paulo. Vol. 72. São Paulo: IHGSP, 1974.

- Bibliografia

A12. Santuário em números. Disponível em: < https://www.a12.com/santuario/imprensa/releases/santuario-de-aparecida-acolhemais-de-12-6-milhoes-de-peregrinos-em-2018>. Acesso em: 02 jan. 2019.

A12. Santuário inaugura exposição "Coleção Santa Gertrudes de Imagens Paulistas do Século XVII". $<$ http://www.a12.com/santuario/imprensa/releases/santuario-inaugura-exposicaocolecao-santa-gertrudes-de-imagens-paulistas-do-seculo-xvii>. Acesso em 25 mar. 2018.

A12. XI Congresso Mariológico. Disponível em: <http://www.a12.com/academia/congressos/xi-congresso-mariologico-1>. Acesso em: 10 fev. 2018.

ABDALLA, Antonio Carlos Suster (org.). Mestres santeiros paulistas do século XVII na coleção Santa Gertrudes. (Catálogo da Exposição). São Paulo: Cult Arte e Comunicação, 2016.

ANDRADE, Mário de. A arte religiosa no Brasil. Texto crítico de Claudéte Kronbauer. São Paulo: Experimento; Giordano, 1993.

BARBOSA, Benedicto Lourenço. Nossas origens - Três séculos de História de Aparecida/SP: do povoamento a Capela (1645-1745). Aparecida: Edição do autor, 2007.

BARBUY, Heloisa Maria Silveira. A Cidade-Exposição: comércio e cosmopolitismo em São Paulo, 1860-1914 (estudo de história urbana e cultura material). Tese (Doutorado em História Urbana e Cultura Material). Faculdade de Arquitetura e Urbanismo, USP, 2001.

BARBUY, Heloisa Maria Silveira. A Exposição Universal de 1889: visão e representação na sociedade industrial. Dissertação (Mestrado em História). Faculdade de Filosofia, Letras e Ciências Humanas, USP, 1995.

BARBUY, Heloisa Maria Silveira. Documentação museológica e pesquisa em museus. p.33-43. In: MAST Colloquia. Documentação em Museus. Vol.10. Museu de Astronomia e Ciências Afins - Organizadores Marcus Granato, Claudia Penha dos Santos e Maria Lucia N. M. Loureiro. Rio de Janeiro: MAST, 2008. 
BRIET, Suzanne. Qu'est-ce que la documentation? Paris/França, Éditions Documentaires Industrielles et Técniques, 1951.

BRUNO, M.C.O.; COUTINHO, M. I. L.; ARAÚJO, M. M. (org.). Waldisa Rússio Camargo Guarnieri: textos e contextos de uma trajetória profissional. São Paulo: Pinacoteca do Estado, Secretaria de Estado da Cultura, Comitê Brasileiro do Conselho Internacional de Museus, 2010.

BRUSTOLONI, Júlio. A Senhora da Conceição Aparecida - História da Imagem, da Capela, das Romarias. Aparecida: Editora Santuário, 1982.

BRUSTOLONI, Júlio. História de Nossa Senhora da Conceição Aparecida - A Imagem, o Santuário e as Romarias. $10^{\underline{a}}$ ed. rev. e ampli. Aparecida: Editora Santuário, 1998.

BUCKLAND, Michael. Information as thing. Journal of the American Society form Information Science, v. 42, № 5, ABI/INFOMR Global, 1991, p.351-360.

BUCKLAND, Michael. What is a "Document"? Journal of the American Society form Information Science, v. 48, no 9, 1997, p.804-809.

CAPURRO, Rita. Reinterpreting a sacred place. When a church becomes a museum from an ecclesiastical point of view. In: Museology and the Sacred - Materials for a discussion. Editor François Mairesse. ICOFOM 41st Annual Symposium, Tehran (Iran), 15-19 October 2018.

CARRILHO, M. J. Fazendas de café oitocentistas no Vale do Paraíba. Anais do Museu Paulista. São Paulo. N. Sér. v.14. n.1. p. 59-80. jan.- jun. 2006. Disponível em: http://www.scielo.br/pdf/anaismp/v14n1/03.pdf. Acesso em: 05 fev. 2019.

CARPIO, Manuel Julio Vera del. A musealização da arte sacra: uma proposta museológica para o museu da Fundação Pierre Chalita. 2000. 63 f. Monografia (Especialização em Museologia). Museu de Arqueologia e Etnologia - MAE, Universidade de São Paulo, 2000.

CETINA, Karin K. How the sciences make knowledge. London/Cambridge: Harvard University Press, 1999.

COELHO, E. A. A relação entre museu e escola. 2009. 61 f. Relatório Final (Licenciatura em História). UNISAL, Centro Universitário Salesiano de São Paulo, 2009.

COELHO, E. A. Museu Nossa Senhora Aparecida: 60 anos de cultura e devoção. 2017, 62f. Monografia (Especialização em Gestão Cultural). SENAC, 2017.

COELHO, E. A. Santuário Nacional de Aparecida: um estudo sobre a musealização do espaço sagrado na perspectiva do Museu Nossa Senhora Aparecida. 2018. 124 f. Relatório de qualificação de mestrado (Mestrado em Museologia). USP, Universidade de São Paulo, 2018. 
COELHO, E. A; GONÇALVES, C. H; LIMA, J. H.; PEREIRA, E. W.; SOUZA, T. M. Tour: Uma Solução tecnológica para o Museu Nossa Senhora Aparecida. 2016. 65 f. Relatório Técnico-científico - 5o Semestre (Curso Superior de Tecnologia em Gestão da Tecnologia da Informação). FATEC, Faculdade de Tecnologia de Guaratinguetá, 2016.

COELHO, E. A; GONÇALVES, C. H; LIMA, J. H.; OLIVEIRA, A. C. M.; PEREIRA, E. W.; SOUZA, T. M. Tour System: solução tecnológica para instituições culturais. 2016. 199 f. Relatório Técnico-científico - 6o Semestre (Curso Superior de Tecnologia em Gestão da Tecnologia da Informação). FATEC, Faculdade de Tecnologia de Guaratinguetá, 2016.

CURY, Marília Xavier. Exposição: concepção, montagem e avaliação. São Paulo: Annablume, 2005.

CURY, Marília Xavier. La museología y lo sagrado - La resacralización del museo. In: Museology and the Sacred - Materials for a discussion. Editor François Mairesse. ICOFOM 41st Annual Symposium, Tehran (Iran), 15-19 October 2018.

CURY, Marília Xavier. Lições indígenas para a descolonização dos museus: processos comunicacionais em discussão. Cadernos CIMEAC. Uberaba, MG. v.7. n.1, p.184-211, 2017.

DESVALÉES, André; MAIRESSE, François. Conceitos-chave de Museologia. Tradução e comentários: Bruno Brulon Soares e Marília Xavier Cury. São Paulo: Armand Colin, 2013.

DEVIDE, A. C. P. História Ambiental do Vale do Paraíba. Revisão de literatura para qualificação ao nível de Doutorado no Curso de Pós-Graduação em Fitotecnia UFRRJ, 2013. Disponível em:

<http://orgprints.org/24815/1/HISTORIA_AMBIENTAL_VALE_DO_PARAIBA.pdf.> Acesso em: 05 fev. 2019.

DIAS, C. K. B.; SILVA, S. C.; CAMPOS, C. E. C. (orgs). Experiências religiosas no mundo antigo. $1^{\underline{a}}$ ed. Vol.1. Curitiba: Editora Prismas, 2017.

ELIADE, Mircea. Imagens e símbolos: ensaios sobre o simbolismo mágicoreligioso. Prefácio Georges Dumézil. Tradução Sonia Cristina Tamer. São Paulo: Martins Fontes, 1991.

ELIADE, Mircea. O sagrado e o profano: A essência das religiões. Tradução Rogério Fernandes. São Paulo: Martins Fontes, 1992.

FERREZ, H. D.; BIANCHINI, M. H. Thesaurus para acervos museológicos. Rio de Janeiro: Fundação Nacional Pró-Memória; Museu Histórico Nacional, 1987.

POULOT, Dominique. Museu e museologia. Tradução Guilherme João de Freitas Teixeira. Belo Horizonte: Autêntica Editora, 2013. 
GODOY, Adriano Santos. The Sacred Rooms at the Basilica of Aparecida. In: Museology and the Sacred - Materials for a discussion. Editor François Mairesse. ICOFOM 41st Annual Symposium, Tehran (Iran), 15-19 October 2018.

GONÇALVES, José Reginaldo dos Santos. Os museus e a representação do Brasil. Revista do IPHAN, número 31, 2005.

HALL, Stuart. A identidade cultural na pós-modernidade. Tradução Tomaz Tadeu da Silvia e Guacira Lopes Louro. 5르. ed. Rio de Janeiro: DP\&A, 2001.

LEILÃODEARTEBRASILEIRA. Disponível em: $<$ http://www.leilaodeartebrasileira.com.br/peca. asp?|D=110800\&ctd=89\&tot=\&tipo=2 0\&artista=>. Acesso em: 18 nov. 2018.

LIMA, L.S. Bandeirismo Paulista: o avanço na colonização e exploração do interior do Brasil (Taubaté, 1645 a 1720). Dissertação (Mestrado em História), Faculdade de Filosofia, Letras e Ciências Humanas, Universidade de São Paulo, 2011.

MAIRESSE, François. Museology and the Sacred - Materials for a discussion. Editor François Mairesse. ICOFOM 41st Annual Symposium, Tehran (Iran), 15-19 October 2018.

MARANDA, Lynn. Museology and the Sacred. In: Museology and the Sacred Materials for a discussion. Editor François Mairesse. ICOFOM 41st Annual Symposium, Tehran (Iran), 15-19 October 2018.

MARCONDES, R. L. A arte de acumular na gestação da economia cafeeira: formas de enriquecimento no Vale do Paraíba Paulista durante o século XIX. Tese (Doutorado em Economia). Faculdade de Economia, Administração e Contabilidade, Universidade de São Paulo, 1998.

MARQUESE, R. B. Diáspora africana, escravidão e a paisagem da cafeicultura no Vale do Paraíba oitocentista. Almanack Braziliense, $n^{\circ} 07$, maio, 2008. Disponível em: http://www.revistas.usp.br/alb/article/view/11686/13457. Acesso em: 05 fev. 2019.

MEIHY, José Carlos Sebe Bom. Manual de História Oral. $5^{\text {a }}$ ed. revista e ampliada. São Paulo: Loyola, 2005.

MENESES, Ulpiano T. Bezerra de. A exposição museológica e o conhecimento histórico. In: FIGUEIREDO, B. G.; VIDAL, D. G. (orgs.). Museus: dos gabinetes de curiosidades à museologia moderna. Belo Horizonte: Argvmentvm; Brasília: CNPq, 2005.

MENESES, Ulpiano Toledo Bezerra de. A pesquisa no Museu como produção de conhecimento original. Anais do IV Seminário sobre Museus-Casas. Pesquisa e Documentação. Rio de Janeiro: Fundação Casa de Rui Barbosa, 2002. 
MENESES, Ulpiano Toledo Bezerra de. A problemática da identidade cultural nos museus: de objetivo (de ação) a objeto (de conhecimento). Anais do Museu Paulista, Nova Série, número 01, 1993.

MENESES, Ulpiano Toledo Bezerra de. Educação e museus: sedução, riscos e ilusões. Ciências \& Letras, Porto Alegre, número 27, 2000.

MISAN, Simona. Os museus históricos e pedagógicos do estado de São Paulo. Anais do Museu Paulista. São Paulo. N. Sér. v.16. n.2. p. 175-204. jul.- dez 2008.

MURGUIA, Eduardo. Documento e instituição: produção, diversidade e verdade. In: FREITAS, Lídia S.; MARCONDES, Carlos H.; RODRIGUES, Ana Célia (Orgs.). Documento: gênese e contextos de uso. Vol. 1. Niteróis/RJ, EdUFF, 2010, p.123140.

MUSEUARTESACRA. Exposição - Mestres Santeiros Paulistas do Século XVII na Coleção Santa Gertrudes. Disponível em: $<$ http://www.museuartesacra.org.br/pt/exposicoes/show/mestres-santeiros-paulistasdo-seculo-xvii-na-colecao-santa-gertrudes>. Acesso em 25 mar. 2018.

NORMAS de Inventário. Coleção do Instituto Português de Museus. Portugal: DGPC. Disponível em: $<$ http://www.matriznet.dgpc.pt/matriznet/NormasInventario.aspx>. Acesso em: 11 jun. 2018.

OBJETS religieux, méthode d'analyse et vocabulaire. Canadá, França: Éditions de la Réunion des musées nationaux, 1994.

PEIXE, Giselle; BIGARELI, Silvia. Museu Nossa Senhora Aparecida. Aparecida: Editora Santuário, 2016.

PERRIN, J. Thesaurus des objets religieux du culte catholique. Edition trilingue français, anglais, italien. França: Editions du Patrimoine, 1999.

PINTO, Ágda Araújo Sardinha. O Discurso identitário nos museus de Rio Branco, Acre: Uma análise de narrativas expositivas. 116f. Dissertação (Mestrado em Museologia). USP, Universidade de São Paulo, 2014.

POULOT, Dominique. Museu e museologia; tradução Guilherme João de Freitas Teixeira. Belo Horizonte: Autêntica Editora, 2013.

ROCCA, S. V.; GUEDES, N. C.; ROQUE, M. I.; GUERREIRO, D. Thesaurus: Vocabulário de objetos do culto católico. Lisboa: Universidade Católica Portuguesa; Fundação da Casa de Bragança, 2004.

ROQUE, Maria Isabel Rocha. Comunicação no museu. In: BENCHERIT, Sarah Fassa; BEZERRA, Rafael Zamorano; MAGALHÃES, Aline Montenegro (Org.). Museus e comunicação: exposição como objeto de estudo. Rio de Janeiro: Museu Histórico Nacional, 2010. 
ROQUE, Maria Isabel. O sagrado no museu. Lisboa: Universidade Católica Editora, 2011.

SOUZA, Bianca Gonçalves de. Museu e Memória no Vale do Paraíba. In: REIS, Fábio José Garcia dos (org.). Vale do Paraíba: pessoas, instituições e movimentos: contribuições relevantes nos séculos XIX e XX. Campinas: Editora Alínea, 2008.

VARINE, Hugues de. Museus e desenvolvimento social - um balanço crítico. In: Museus como agentes de mudança social e desenvolvimento: propostas e reflexões museológicas. BRUNO, M. C. O.; NEVES, K. R. F. (coord.). São Cristóvão: Museu de Arqueologia de Xingó, 2008.

VARINE, Hugues de. As raízes do futuro: o patrimônio a serviço do desenvolvimento local. Tradução Maria de Lourdes Parreiras Horta. Porto Alegre: Medianiz, 2012. 


\section{Apêndices}

\section{APÊNDICE A - Elementos que compõem as exposições}

O Quadro 26, relaciona os elementos que compõem a exposição Rainha do Céu, Mãe dos Homens: Aparecida do Brasil.

Quadro 26: Elementos que compõem a exposição

\begin{tabular}{|c|c|c|c|}
\hline $\begin{array}{l}\text { Núcleo } \\
\text { temático }\end{array}$ & $\begin{array}{c}\text { Vitrine/ } \\
\text { Recursos } \\
\text { expográficos }\end{array}$ & $\begin{array}{l}\text { Textos e } \\
\text { imagens } \\
\text { utilizadas }\end{array}$ & Objetos expostos \\
\hline \multirow[t]{3}{*}{$\begin{array}{l}\text { Projeto de } \\
\text { salvação de } \\
\text { Deus }\end{array}$} & $\begin{array}{l}\text { Totem } \\
\text { Painel } 1 \\
\text { Painel } 2 \\
\text { Painel } 3 \\
\text { Painel } 4\end{array}$ & $\begin{array}{l}\text { Texto de } \\
\text { introdução } \\
\text { Letras de } \\
\text { música }\end{array}$ & 3283-Divino \\
\hline & $\begin{array}{l}\text { M1 } \\
\text { Painel } 5\end{array}$ & $\begin{array}{l}\text { Citação } \\
\text { bíblica }\end{array}$ & 0140/01-Crucifíxo \\
\hline & M2 & & 0588-Oratório \\
\hline Maria terrena & M3 & $\begin{array}{l}\text { Textos } \\
\text { canônicos } \\
\text { e } \\
\text { apócrifos } \\
\text { Citação } \\
\text { bíblica }\end{array}$ & $\begin{array}{l}\text { 0023-Sant 'Ana, 0043-Nossa Senhora da Piedade, } \\
\text { 0072-Crucif́xo, 0099-Bom Jesus, 0278/1A-Nossa } \\
\text { Senhora do Rosário, 0278/1B-Menino Jesus, } \\
\text { 0280-Nossa Senhora com menino, 0326- } \\
\text { Resplendor, 0327-Resplendor, 0483-Oratório, } \\
\text { 0510-Bom Jesus, 0566/01-Nossa Senhora das } \\
\text { Dores, 0568-São Joaquim, 0569/1A-São José com } \\
\text { menino, 0569/1B-Menino Jesus, 0569/02- } \\
\text { Resplendor, 0569/03-Resplendor, 0571/01- } \\
\text { Sant'Ana, 0571/03-Resplendor, 0576-Cristo no } \\
\text { calvário, 0577-Nossa Senhora do Ó, 0805-Santo }\end{array}$ \\
\hline $\begin{array}{l}\text { Dogmas } \\
\text { Marianos }\end{array}$ & Painel 6 & $\begin{array}{l}\text { Dogmas } \\
\text { Marianos }\end{array}$ & - \\
\hline $\begin{array}{l}\text { Maria dos mil } \\
\text { nomes }\end{array}$ & M5 & & $\begin{array}{l}\text { 0039-Nossa Senhora da Conceição, 0041-Nossa } \\
\text { Senhora da Conceição, 0044-Nossa Senhora da } \\
\text { Conceição, 0225-Coroa, 0233-Coroa, 0279-Nossa } \\
\text { Senhora da Conceição, 0281/01-Nossa Senhora } \\
\text { do Rosário, 0281/02-Coroa, 0281/03-Terço, 0488- } \\
\text { Nossa Senhora da Anunciação, 0490-Nossa } \\
\text { Senhora da Conceição, 0493-Nossa Senhora com } \\
\text { menino, 0498-Nossa Senhora das Graças, 0500- } \\
\text { Nossa Senhora da Conceição, 0503-Nossa } \\
\text { Senhora da Conceição, 0566/02-Resplendor, } \\
\text { 0567-Nossa Senhora da Conceição, 0582-Nossa } \\
\text { Senhora dos Anjos, 0591-Nossa Senhora da } \\
\text { Penha, 2433-Coroa }\end{array}$ \\
\hline $\begin{array}{l}\text { Devoção N.S. } \\
\text { Conceição }\end{array}$ & M6 & & 0254-Coroa, 0589-Nossa Senhora da Conceição \\
\hline
\end{tabular}




\begin{tabular}{|c|c|c|c|}
\hline $\begin{array}{l}\text { Núcleo } \\
\text { temático }\end{array}$ & $\begin{array}{c}\text { Vitrine/ } \\
\text { Recursos } \\
\text { expográficos }\end{array}$ & $\begin{array}{l}\text { Textos e } \\
\text { imagens } \\
\text { utilizadas }\end{array}$ & Objetos expostos \\
\hline \multirow[t]{3}{*}{$\begin{array}{l}\text { Devoção N.S. } \\
\text { Aparecida }\end{array}$} & $\begin{array}{l}\text { Painel } 7 \\
\text { Totem } \\
\text { Painel } 8 \\
\text { Painel } 9\end{array}$ & Fotos & - \\
\hline & M7 & & 0270-Manto, 3275-Coroa, 3276-Fac-símile \\
\hline & $\begin{array}{l}\text { M10 } \\
\text { Painel } 10 \\
\text { Painel } 11 \\
\text { Painel } 12 \\
\text { Painel } 13\end{array}$ & $\begin{array}{l}\text { Textos e } \\
\text { ilustrações } \\
\text { dos } \\
\text { milagres }\end{array}$ & ASN - 40-Pedra, ASN - 41-Corrente \\
\hline $\begin{array}{l}\text { Representações } \\
\text { de N.S. } \\
\text { Aparecida }\end{array}$ & M12 & & $\begin{array}{l}\text { 0036-Nossa Senhora Aparecida, 0368-Nossa } \\
\text { Senhora Aparecida, 0370-Nossa Senhora } \\
\text { Aparecida, 0374-Nossa Senhora Aparecida, 0375- } \\
\text { Nossa Senhora Aparecida, 0377-Nossa Senhora } \\
\text { Aparecida, 0413/01-Nossa Senhora Aparecida, } \\
\text { 0413/02-Manto, 0413/03-Coroa, 0487-Nossa } \\
\text { Senhora da Conceição, 0788-Nossa Senhora } \\
\text { Aparecida, 0794-Nossa Senhora Aparecida, 0798- } \\
\text { Nossa Senhora Aparecida, 0839-Nossa Senhora } \\
\text { Aparecida, 0865-Nossa Senhora Aparecida, 1065- } \\
\text { Nossa Senhora Aparecida, 1075-Nossa Senhora } \\
\text { Aparecida, 2345-Nossa Senhora Aparecida, 2349- } \\
\text { Nossa Senhora Aparecida, 2350-Nossa Senhora } \\
\text { Aparecida, 2352-Nossa Senhora Aparecida, 2353- } \\
\text { Nossa Senhora Aparecida }\end{array}$ \\
\hline \multirow[t]{4}{*}{$\begin{array}{l}\text { Devoção do fiel } \\
\text { (Ex-votos) }\end{array}$} & $\begin{array}{l}\text { M11 } \\
\text { Painel } 14\end{array}$ & Fotos & $\begin{array}{l}\text { 0857-Par de mãos, 0858-Escultura religiosa, 0862- } \\
\text { Par de baquetas, 0863-Homem com carroça, } \\
\text { 2359-Barco (miniatura), 2367-Boneca de pano, } \\
\text { 2377-Cabeça, 2381-Coração, 2386-Figura } \\
\text { masculina, 2387-Tronco feminino, 2390-Cabeça, } \\
\text { 2391-Cabeça, 2393-Cabeça }\end{array}$ \\
\hline & $\begin{array}{l}\text { M11 } \\
\text { Painel } 15\end{array}$ & $\begin{array}{l}\text { Fotos } \\
\text { Textos }\end{array}$ & $\begin{array}{l}\text { 0843-Pés, 0844-Mosaico olho, 0845-Escultura } \\
\text { religiosa - NSA, 0860-Cabeça de cera, 0861- } \\
\text { Braço de cera, 0871-Corrente, 2362-Mãe com } \\
\text { filho, 2370-Casa, 2392-Cabeça }\end{array}$ \\
\hline & $\begin{array}{l}\text { M11 } \\
\text { Painel } 16\end{array}$ & Foto & $\begin{array}{l}\text { 0842-Tijolo, 0846-Mão, 0847-Mão, 0856-Saco de } \\
\text { areia, 0859-Garrafa, 2351-Nossa Senhora } \\
\text { Aparecida, 2366-Cavaquinho, 2378-Cabeça, 2388- } \\
\text { Casa, 2395-Tijolo (miniatura) }\end{array}$ \\
\hline & $\begin{array}{l}\text { M11 } \\
\text { Painel } 17\end{array}$ & Foto & $\begin{array}{l}\text { 0260-Coroa, 0864-Cabeça, 2360-Quepe, 2369- } \\
\text { Tiara, 2373-Coração, 2380-Coração }\end{array}$ \\
\hline
\end{tabular}




\begin{tabular}{|c|c|c|c|}
\hline $\begin{array}{l}\text { Núcleo } \\
\text { temático }\end{array}$ & $\begin{array}{c}\text { Vitrine/ } \\
\text { Recursos } \\
\text { expográficos }\end{array}$ & $\begin{array}{l}\text { Textos e } \\
\text { imagens } \\
\text { utilizadas }\end{array}$ & Objetos expostos \\
\hline & $\begin{array}{l}\text { M11 } \\
\text { Painel } 18\end{array}$ & $\begin{array}{l}\text { Textos } \\
\text { (pedidos } \\
\text { dos } \\
\text { devotos) }\end{array}$ & $\begin{array}{l}\text { 2361-Carro (miniatura), 2364-Divisa, 2365- } \\
\text { Insígnia, 2368-Colher de pedreiro, 2372-Coração, } \\
\text { 2376-Perna, 2379-Rim, 2382-Veia, 2383-Seio, } \\
\text { 2385-Olhos }\end{array}$ \\
\hline \multirow[t]{3}{*}{$\begin{array}{l}\text { Coroação de } \\
\text { N.S. Aparecida }\end{array}$} & M18 & & $\begin{array}{l}\text { 0266-Almofada, 3277-Coroa, 3278-Coroa, 3279- } \\
\text { Coroa, 3280-Coroa, 3281-Coroa }\end{array}$ \\
\hline & $\begin{array}{l}\text { Totem } \\
\text { Painel } 19\end{array}$ & $\begin{array}{l}\text { Fotos } \\
\text { Textos }\end{array}$ & 0004-Pintura, 0585-Pintura \\
\hline & M16 & & $\begin{array}{l}\text { 0998-Prato (souvenir), 1064/01-Prato parede, } \\
\text { 1064/03-Bule (miniatura), 1064/04-Pires, 1064/05- } \\
\text { Paliteiro, 1064/06-Botom, 1064/07-Chaveiro, } \\
\text { 1071/01-Taça, 1071/02-Taça, 1071/03-Caneca, } \\
\text { 1072/01-Copo, 1072/02-Copo, 1072/03-Copo, } \\
\text { 1077/01-Vaso, 1077/02-Vaso, 1182-Tinteiro, 2396- } \\
\text { Taça, 2397-Taça }\end{array}$ \\
\hline $\begin{array}{l}\text { Cidade/ } \\
\text { Santuário }\end{array}$ & $\begin{array}{l}\text { Totem } \\
\text { Painel } 20 \\
\text { Painel } 21\end{array}$ & $\begin{array}{l}\text { Fotos } \\
\text { Textos }\end{array}$ & - \\
\hline $\begin{array}{l}\text { Maria como } \\
\text { Casa de Ouro }\end{array}$ & $\begin{array}{l}\text { M21 } \\
\text { Painel } 22 \\
\text { Painel } 23 \\
\text { Painel } 24\end{array}$ & $\begin{array}{l}\text { Textos } \\
\text { poéticos e } \\
\text { cânticos }\end{array}$ & $\begin{array}{l}\text { ASN - 0001-Âmbula, ASN - 0002/01-Cálice, ASN - } \\
\text { 0002/02-Patena, ASN - 0003-Ostensório, ASN - } \\
\text { 0004-Âmbula, ASN - 0005-Cálice, ASN - 0037- } \\
\text { Coroa, ASN - 0203-Cálice, ASN - 0038-Rosa de } \\
\text { ouro, ASN - 0039-Rosa de ouro, ASN - 0302-Rosa } \\
\text { de ouro }\end{array}$ \\
\hline
\end{tabular}

Fonte: COELHO (2019).

O Quadro 27, relaciona os elementos que compõem a exposição O Museu e suas Histórias.

Quadro 27: Elementos que compõem a exposição

\begin{tabular}{|c|c|c|c|}
\hline $\begin{array}{l}\text { Núcleo } \\
\text { temático }\end{array}$ & $\begin{array}{c}\text { Vitrine / } \\
\text { Recursos } \\
\text { expográficos }\end{array}$ & $\begin{array}{c}\text { Textos e } \\
\text { imagens } \\
\text { utilizadas }\end{array}$ & Objetos expostos \\
\hline \multirow[t]{2}{*}{$\begin{array}{l}\text { O Museu e } \\
\text { suas } \\
\text { Histórias }\end{array}$} & $\begin{array}{l}\text { N1 } \\
\text { Painel } 1\end{array}$ & $\begin{array}{l}\text { Texto de } \\
\text { apresentação } \\
\text { Fotos }\end{array}$ & ARQ - $02-002-$ Vasilha \\
\hline & $\begin{array}{l}\text { N2 } \\
\text { Painel } 2\end{array}$ & $\begin{array}{l}\text { Texto de } \\
\text { abertura da } \\
\text { exposição }\end{array}$ & $\begin{array}{l}\text { 0184-Borduna, 0198-Borduna, 0601-Santa Luzia, } \\
\text { 0971/04-Jarra, 0979/3A-Urinol, 0979/3B-Tampa, } \\
\text { 0994-Prato, 1179-Prato decorativo, 1440-Guampa, } \\
\text { 1461/01-Estribo, 1461/02-Estribo, 1476-Panela de } \\
\text { ferro, 1618-Roca, 1629/01-Capacete, 1638/03- } \\
\text { Flâmula: MMDC, 1670-Cantil, 1683-Gargalheira, } \\
\text { 1685-Cinto de castidade, 1718-Algema, 1776- }\end{array}$ \\
\hline
\end{tabular}




\begin{tabular}{|c|c|c|c|}
\hline $\begin{array}{l}\text { Núcleo } \\
\text { temático }\end{array}$ & $\begin{array}{c}\text { Vitrine / } \\
\text { Recursos } \\
\text { expográficos }\end{array}$ & $\begin{array}{c}\text { Textos e } \\
\text { imagens } \\
\text { utilizadas }\end{array}$ & Objetos expostos \\
\hline & & & $\begin{array}{l}\text { Pente adorno, 1952/01-Relógio, 2212-Tinteiro, } \\
\text { 2324-Carregador de munição, 2333-Máquina de } \\
\text { costura, 2474-Garrucha, 2480-Bacamarte, 2671- } \\
\text { Luneta, 2856-Boneco: Trajes orientais, 2865- } \\
\text { Boneca: Trajes espanhóis, 2868-Boneca: Figura } \\
\text { feminina, 2887-Bandeja de moedas, 2496-Punhal } \\
\text { com bainha, 1845-Luminária }\end{array}$ \\
\hline \multirow{7}{*}{$\begin{array}{l}\text { Homem e o } \\
\text { Sagrado }\end{array}$} & N3 & & 0592-Quadro: São Antônio \\
\hline & N4 & & 0593-Quadro: Santo Bernardino \\
\hline & $\begin{array}{l}\text { E1 } \\
\text { Painel } 3\end{array}$ & $\begin{array}{l}\text { Texto } \\
\text { Homem e o } \\
\text { Sagrado }\end{array}$ & $\begin{array}{l}\text { 0730/01-Castiçal, 0730/02-Castiçal, 3233-Oratório, } \\
\text { ASN-0292-Menino Jesus de Praga }\end{array}$ \\
\hline & E2 & $\begin{array}{l}\text { Texto culto } \\
\text { privado } \\
\text { (na vitrine) }\end{array}$ & $\begin{array}{l}\text { 0033-Coroa ,0048-Santo Antônio, 0049-São } \\
\text { Manuel, 0051-São Cosme e Damião, 0052-São } \\
\text { Francisco de Assis, 0053-Santa Rita, 0106-Santo } \\
\text { Antônio, 0118-São Francisco, 0128-São José de } \\
\text { Botas, 0148-Santa Rita, 0504-Nossa Senhora do } \\
\text { Rosário, 0530-Sant'Ana Mestra, 0552-São } \\
\text { Sebastião, 0559-São Pedro, 0573/1A-São Lázaro, } \\
\text { 0573/1B-Cachorro, 0573/02-Resplendor, 0575/01- } \\
\text { Nossa Senhora da Piedade, 0575/02-Resplendor, } \\
\text { 0595/01-Sant'ana Mestra, 0685-Resplendor, 0792- } \\
\text { Nossa Senhora Aparecida, 0804-São José, 11387- } \\
\text { Nossa Senhora da Visitação }\end{array}$ \\
\hline & E2-B & $\begin{array}{l}\text { Texto } \\
\text { (na vitrine) }\end{array}$ & Anjo, Madona, Pietá \\
\hline & N5 & $\begin{array}{l}\text { Texto culto } \\
\text { coletivo } \\
\text { (na vitrine) }\end{array}$ & $\begin{array}{l}\text { 0026-Crucifixo, 0028-Resplendor, 0584-Bom Jesus, } \\
\text { 0586-São Francisco de Paula, 0587-São Gonçalo, } \\
\text { 0595/02-Resplendor, 0680-Resplendor, 0681- } \\
\text { Resplendor, 0683-Resplendor, 0684-Resplendor, } \\
\text { 0686-Resplendor }\end{array}$ \\
\hline & N6 & $\begin{array}{l}\text { Texto } \\
\text { paulistinhas } \\
\text { (na vitrine) }\end{array}$ & $\begin{array}{l}\text { 0025-Nossa Senhora do Ó, 0091-Divino, 0092- } \\
\text { Divino, 0093-Divino, 0094-Divino, 0096-Divino, } \\
\text { 0097-Divino, 0098-Divino, 0100-Divino, 0101- } \\
\text { Oratório com Divino, 0113-Santo com menino, } \\
\text { 0114-Santo com menino, 0115-Oratório, 0117- } \\
\text { Divino, 0126-São José com menino, 0480- } \\
\text { Sant'Ana, 0481-Santa Luzia, 0482-São José de } \\
\text { Botas, 0485-Oratório com divino, 0492-Santa } \\
\text { Gertrudes, 0495-Nossa Senhora da Piedade, 0496- } \\
\text { Santa Gertrudes, 0506-São Gonçalo, 0508-Bom } \\
\text { Jesus, 0511-São Miguel, 0514-Bom Jesus, 0516- } \\
\text { São Sebastião, 0517-Nossa Senhora com menino, } \\
\text { 0518-São Francisco, 0519-Nossa Senhora da } \\
\text { Piedade, 0528-Santa Bárbara, 0529-Santa Luzia, } \\
\text { 0532-São Pedro, 0535-São João, 0536-São José, } \\
\text { 0544-Santa Mártir, 0546-São Bento, 0549-São }\end{array}$ \\
\hline
\end{tabular}




\begin{tabular}{|c|c|c|c|}
\hline $\begin{array}{l}\text { Núcleo } \\
\text { temático }\end{array}$ & $\begin{array}{c}\text { Vitrine / } \\
\text { Recursos } \\
\text { expográficos }\end{array}$ & $\begin{array}{c}\text { Textos e } \\
\text { imagens } \\
\text { utilizadas }\end{array}$ & Objetos expostos \\
\hline & & & $\begin{array}{l}\text { José de Botas, 0550-São Pedro, 0553-São Miguel, } \\
\text { 0554-São Sebastião, 0555-São José de Botas, } \\
\text { 0556-S ão José de Botas, 0558-São José, 0560- } \\
\text { Escultura: Bispo Sentado, 0697-Divino, 0762- } \\
\text { Nossa Senhora da Conceição }\end{array}$ \\
\hline & $\begin{array}{l}\text { N7 } \\
\text { Painel } 4\end{array}$ & Texto Liturgia & $\begin{array}{l}\text { 0969/01-Ostensório, 0969/02-Naveta, 0969/03- } \\
\text { Turíbulo, 0969/04-Caldeira, 0969/05-Cálice, } \\
\text { 0969/06-Patena, 0969/7A-Âmbula, 0969/7B-Tampa } \\
\text { da Âmbula, 0969/08-Crucifixo, 0969/09-Lâmpada } \\
\text { Votiva, 0969/10A-Bandeja, 0969/10B-Galheta, } \\
\text { 0969/10C-Galheta, 2542/01-Casula (João Paulo II), } \\
\text { 3217- Cadeira de braços, 3285- Cadeira de braços, } \\
\text { 3287/A-Âmbula, 3287/B-Tampa de Âmbula, } \\
\text { 3288/01-Cálice, 3288/02-Patena, 3289/1A-Galheta, } \\
\text { 3289/1B-Tampa da Galheta, 3289/2A-Galheta, } \\
\text { 3289/2B-Tampa da Galheta, 3289/03-Bandeja, } \\
\text { 11133/01-Crucifixo, 11133/02-Cálice, 11133/3A- } \\
\text { Cálice, 11133/3B-Patena, 11133/4A-Âmbula, } \\
\text { 11133/4B-Tampa, 11133/5A-Jarra, 11133/5B- } \\
\text { Bacia, 11133/6A-Galheta, 11133/6B-Tampa, } \\
\text { 11133/6C-Galheta, 11133/6D-Tampa, 11133/6E- } \\
\text { Bandeja, 11134-Missal, 11136-Cadeira de braços, } \\
\text { 11137/01-Casula, 11137/3A-Mitra, 11137/04- } \\
\text { Sanguíneo, 11137/05-Pala, 11137/06-Corporal, } \\
\text { 11145/01-Edital filatélico, 11145/02-Envelope com } \\
\text { selo e carimbo, 11145/03-Selo (quadra) - JMJ Rio } \\
\text { 2013 - Visita do Papa Francisco ao Brasil, } \\
\text { 11145/04-Selo (par) - JMJ Rio 2013 - Visita do } \\
\text { Papa Francisco ao Brasil, 11145/05-Selo (par) - } \\
\text { JMJ Rio 2013, 11145/06-Estojo, ASN - 0279/01- } \\
\text { Patena, ASN - 0279/02-Cálice, ASN - 0279/3A- } \\
\text { Âmbula, ASN - 0279/3B-Tampa, ASN - 0279/4A- } \\
\text { Jarra, ASN - 0279/4B-Bacia, ASN - 0279/5A- } \\
\text { Galheta, ASN-0279/5B-Tampa, ASN - 0279/6A- } \\
\text { Galheta, ASN - 0279/6B-Tampa, ASN - 0279/07- } \\
\text { Bandeja, ASN - 0279/8A-Vaso, ASN - 0279/8B- } \\
\text { Vaso, ASN - 0279/09-Castiçal, ASN - 0279/10- } \\
\text { Sinete }\end{array}$ \\
\hline \multirow[t]{2}{*}{$\begin{array}{l}\text { Homem e } \\
\text { Expressão }\end{array}$} & $\begin{array}{l}\text { E3 } \\
\text { Painel } 5\end{array}$ & $\begin{array}{l}\text { Texto } \\
\text { Homem e } \\
\text { Expressão }\end{array}$ & $\begin{array}{l}\text { 0081-Crucifixo, 0230-Coroa, 0234-Coroa, 0251- } \\
\text { Coroa, 0261/A -Coroa, 0274-Livro de Oração, } \\
\text { 0275-Livro de Oração, 0283-Livro de Oração, 0284- } \\
\text { Livro de Oração, 0285-Livro de Oração, 0289- } \\
\text { Terço, 0300-Medalha comemorativa, 0307- } \\
\text { Pingente, 0308-Crucifixo, 0322-Pingente: Crucifixo, } \\
\text { 0323-Cruz, 0328-Medalha comemorativa, 0329-Ex- } \\
\text { voto (Rosa), 0330-Ex-voto (Rosa), 0332-Ex-voto } \\
\text { (Rosa), 0334-Ex-voto (Rosa), 1598-Coração, 2428- } \\
\text { Coroa, 2749-Pingente comemorativa, 3258- } \\
\text { Estampa }\end{array}$ \\
\hline & E4 & & $\begin{array}{l}\text { 0211-Gravura: N.S. Aparecida, 0369-Oratório, } \\
\text { 0524-Crucifixo, 0600-Padre Cícero, 0739-Santinho }\end{array}$ \\
\hline
\end{tabular}




\begin{tabular}{|c|c|c|c|}
\hline $\begin{array}{l}\text { Núcleo } \\
\text { temático }\end{array}$ & $\begin{array}{c}\text { Vitrine / } \\
\text { Recursos } \\
\text { expográficos }\end{array}$ & $\begin{array}{l}\text { Textos e } \\
\text { imagens } \\
\text { utilizadas }\end{array}$ & Objetos expostos \\
\hline & & & $\begin{array}{l}\text { relíquia, 0786-Nossa S. Aparecida, 1074-Taça, } \\
\text { 1189-Garrafa com areia, 2635/A-Pingente: Cruz, } \\
\text { 3011-Prato, 3050-Vaso, 3241-Nicho com imagem, } \\
\text { 11126/1A-Baú, 11126/1B-Tampa, 11126/02-Figura } \\
\text { de presépio: Menino Jesus, 11126/03-Figura de } \\
\text { presépio: Maria, 11126/04-Figura de presépio: } \\
\text { José, 11126/05-Figura de presépio: Anjo, } \\
\text { 11126/06-Figura de presépio: Rei Mago } \\
\text { (ajoelhado), 11126/07-Figura de presépio: Rei } \\
\text { Mago (com pequeno bastão), 11126/08-Figura de } \\
\text { presépio: Rei Mago (com objeto circular), } \\
\text { 11126/09-Figura de presépio: Pastor, 11126/10- } \\
\text { Figura de presépio: Ovelha, 11126/11-Figura de } \\
\text { presépio: Ovelha, 11126/12-Figura de presépio: } \\
\text { Galo, 11126/13-Figura de presépio: Burro, } \\
\text { 11126/14-Figura de presépio: Vaca, 1126/15- } \\
\text { Figura de presépio: Camelo, 11126/16-Figura de } \\
\text { presépio: Camelo }\end{array}$ \\
\hline & E5 & & $\begin{array}{l}\text { 0340-Chave comemorativa, 0419-Ex-voto: Quadro, } \\
\text { 0539-São João Batista e São Joaquim, 0693- } \\
\text { Bandeja, 1382-Ex-voto: Garrafa, 2622-Chave } \\
\text { comemorativa, 2625-Chave comemorativa, 11050- } \\
\text { Ex voto: Estandarte, } 11052 \text {-Ex voto: Casa, 11053- } \\
\text { Ex voto: Carro, 11054-Ex voto: Taça, } 11055-E x \\
\text { voto: Boneco, 11056-Ex voto: Busto feminino, } \\
\text { 11058-Ex voto: Cabeça, 11059-Ex voto: Mão, } \\
\text { 11060-Ex voto: Mão }\end{array}$ \\
\hline & E6 & & $\begin{array}{l}\text { 1194-Boneca: rendeira, 1198-Confessionário, } \\
\text { 1200-Estatueta: Lenhador, 1201-Estatueta: } \\
\text { rendeira, 1202-Estatueta: passadeira, 1206- } \\
\text { Trabalhadores, 1224/01-Estatueta: Músico, } \\
\text { 1224/02-Estatueta: Músico, 1224/03-Estatueta: } \\
\text { Músico, 1224/04-Estatueta: Músico, 1224/05- } \\
\text { Estatueta: Músico, 1224/06-Estatueta: Músico, } \\
\text { 1224/07-Estatueta: Músico, 1224/08-Estatueta: } \\
\text { Músico, 1224/09-Estatueta: Músico, 1224/10- } \\
\text { Estatueta: Músico, 1224/11-Estatueta: Músico, } \\
\text { 1224/12-Estatueta: Músico, 1225-Reisado, 1226- } \\
\text { Casamento, 1272/03-Estatueta: Pavão, 1272/04- } \\
\text { Estatueta: Pavão, 1272/05-Estatueta: Pavão, } \\
\text { 1273/01-Estatueta: Pavão, 1273/02-Estatueta: } \\
\text { Pavão, 1273/04-Estatueta: Pavão, 1290-Estatueta: } \\
\text { Pavão, 1293-Presépio, 1436-Carro de boi } \\
\text { (miniatura), 1620/02-Estatueta: Mulher ajoelhada }\end{array}$ \\
\hline & E7 & & $\begin{array}{l}\text { 1406/A -Clarineta, 1411-Cítara, 1412/A-Bandolim, } \\
\text { 1413/A-Violino, 1413/B-Arco, 1416-Cavaquinho, } \\
\text { 1419-Tambor }\end{array}$ \\
\hline & E8 & & $\begin{array}{l}\text { 0417-Caneta Tinteiro, 0909/A-Máquina Fotográfica, } \\
\text { 1623-Rádio, 1624-Máquina fotográfica, 1809-Peso } \\
\text { para papel, 1832-Máquina fotográfica, 1835- }\end{array}$ \\
\hline
\end{tabular}




\begin{tabular}{|c|c|c|c|}
\hline $\begin{array}{l}\text { Núcleo } \\
\text { temático }\end{array}$ & $\begin{array}{c}\text { Vitrine / } \\
\text { Recursos } \\
\text { expográficos }\end{array}$ & $\begin{array}{c}\text { Textos e } \\
\text { imagens } \\
\text { utilizadas }\end{array}$ & Objetos expostos \\
\hline & & & $\begin{array}{l}\text { Máquina fotográfica, 1850-Caneta pena, 1889- } \\
\text { Filmadora, 2206-Tinteiro, 2216/1A-Caneta, } \\
\text { 2216/1B-Tampa, 2219-Caixa bico de pena, 2221- } \\
\text { Caixa bico de pena, 2225-Caixa bico de pena, } \\
\text { 2233-Telefone de mesa, 2237-Máquina de } \\
\text { escrever, 2531-Tinteiro }\end{array}$ \\
\hline \multirow[t]{2}{*}{$\begin{array}{l}\text { Homem e o } \\
\text { Cotidiano }\end{array}$} & $\begin{array}{l}\text { N8 } \\
\text { Painel } 6\end{array}$ & $\begin{array}{l}\text { Texto } \\
\text { Homem e o } \\
\text { Cotidiano } \\
\text { Texto } \\
\text { (na vitrine) }\end{array}$ & $\begin{array}{l}\text { 0079-Pente adorno, 0840-Porta Níquel, 0872- } \\
\text { Paliteiro, 0935/02-Leiteira, 0935/05-Leiteira, } \\
\text { 0935/06-Leiteira, 0936/01-Porta amanteigado, } \\
\text { 0936/03-Leiteira, 0936/04-Bule, 0936/05-Bule, } \\
\text { 0937/06-Colher de sopa, 0937/35-Garfo de } \\
\text { sobremesa, 0937/54-Descanso, 0937/65-Faca de } \\
\text { mesa, 0988/01-Jarra, 1001/01-Xícara, 1001/06- } \\
\text { Pires, 1001/11-Leiteira, 1001/12-Açucareiro e } \\
\text { tampa, 1006/A-Sopeira, 1006/B-Tampa, 1007- } \\
\text { Travessa, 1010/04-Xícara, 1010/05-Pires, 1010/06- } \\
\text { Xícara, 1010/07-Pires, 1010/11-Mantegueira, } \\
\text { 1010/12-Açucareiro, 1010/14-Bule, 1023/01-Xícara, } \\
\text { 1023/02-Pires, 1023/05-Xícara, 1023/06-Pires, } \\
\text { 1061-Prato decorativo, 1089-Vaso, 1137-Vaso, } \\
\text { 1422/01-Caçamba, 1422/02-Caçamba, 1434/02- } \\
\text { Cincerro, 1442-Berrante, 1472/01-Tacho, 1472/02- } \\
\text { Tacho, 1474-Ferro de passar, 1475-Moedor de } \\
\text { café, 1477-Panela de ferro, 1479/A-Almofariz, } \\
\text { 1479/B-Socador, 1491/A-Chaleira, 1491/B-Tampa } \\
\text { da Chaleira, 1493/A-Chaleira, 1493/B-Tampa da } \\
\text { Chaleira, 1498-Chocolateira, 1511/01-Estribo, } \\
\text { 1511/02-Estribo., 1512/01-Estribo, 1512/02-Estribo, } \\
\text { 1712/02-Cachimbo, 1749/01-Abotoadura, 1749/02- } \\
\text { Abotoadura, 1753-Isqueiro, 1758/A-Aparelho de } \\
\text { barbear, 1758/B-Lâmina, 1758/C-Estojo para } \\
\text { lâmina, 1758/D-Estojo do conjunto, 1764/A- } \\
\text { Recipiente, 1764/B-Pincel, 1764/C-Suporte, 1765- } \\
\text { Óculos, 1767-Bolsa, 1782/01-Grampo de cabelo, } \\
\text { 1782/02-Grampo de cabelo, 1784-Pente adorno, } \\
\text { 1795-Pente adorno, 1861-Relógio de bolso, } \\
\text { 1947/01-Luva (direita), 1947/02-Luva (esquerda), } \\
\text { 1988-Relógio de bolso, 2002-Relógio de bolso, } \\
\text { 2023-Relógio de bolso, 2049-Relógio de bolso, } \\
\text { 2112-Tacho, 2128-Relógio de pulso, 2166-Relógio } \\
\text { de pulso, 2330-Máquina de costura, 2346/2A- } \\
\text { Xícara, 2346/2B-Píres, 2346/3A-Xícara, 2346/3B- } \\
\text { Píres, 2405-Castiçal, 2416-Relógio de parede, } \\
\text { 2517-Bolsa, 2630-Ferro de passar, 2632-Ferro de } \\
\text { passar, 2696-Candeeiro, 3035/A-Sopeira, 3035/B- } \\
\text { Tampa da Sopeira, 3356-Cortador de cabelo, } \\
\text { 11098-Travessa }\end{array}$ \\
\hline & N9 & $\begin{array}{l}\text { Texto } \\
\text { (na vitrine) }\end{array}$ & $\begin{array}{l}\text { 6580-Cédula: } 500 \text { réis (Minerva), 6581-Cédula: } 1 \\
\text { mil réis (Palácio), 6585-Cédula: } 1 \text { mil réis (David } \\
\text { Campista), 6587-Cédula: } 2 \text { mil réis (quadro } \\
\text { saudades), 6594-Cédula: } 5 \text { mil réis (Barão do Rio }\end{array}$ \\
\hline
\end{tabular}




\begin{tabular}{|c|c|c|c|}
\hline $\begin{array}{l}\text { Núcleo } \\
\text { temático }\end{array}$ & $\begin{array}{c}\text { Vitrine / } \\
\text { Recursos } \\
\text { expográficos }\end{array}$ & $\begin{array}{c}\text { Textos e } \\
\text { imagens } \\
\text { utilizadas }\end{array}$ & Objetos expostos \\
\hline & & & 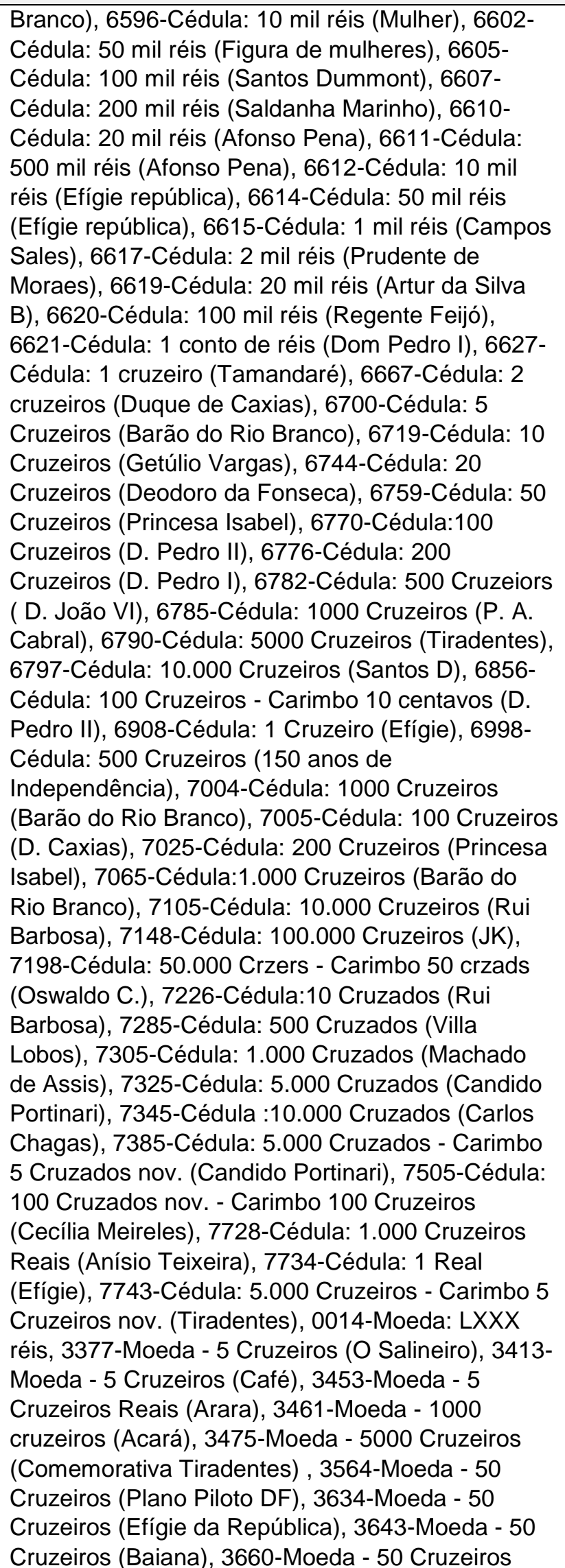 \\
\hline
\end{tabular}




\begin{tabular}{|c|c|c|c|}
\hline $\begin{array}{l}\text { Núcleo } \\
\text { temático }\end{array}$ & $\begin{array}{c}\text { Vitrine / } \\
\text { Recursos } \\
\text { expográficos }\end{array}$ & $\begin{array}{c}\text { Textos e } \\
\text { imagens } \\
\text { utilizadas }\end{array}$ & Objetos expostos \\
\hline & & & 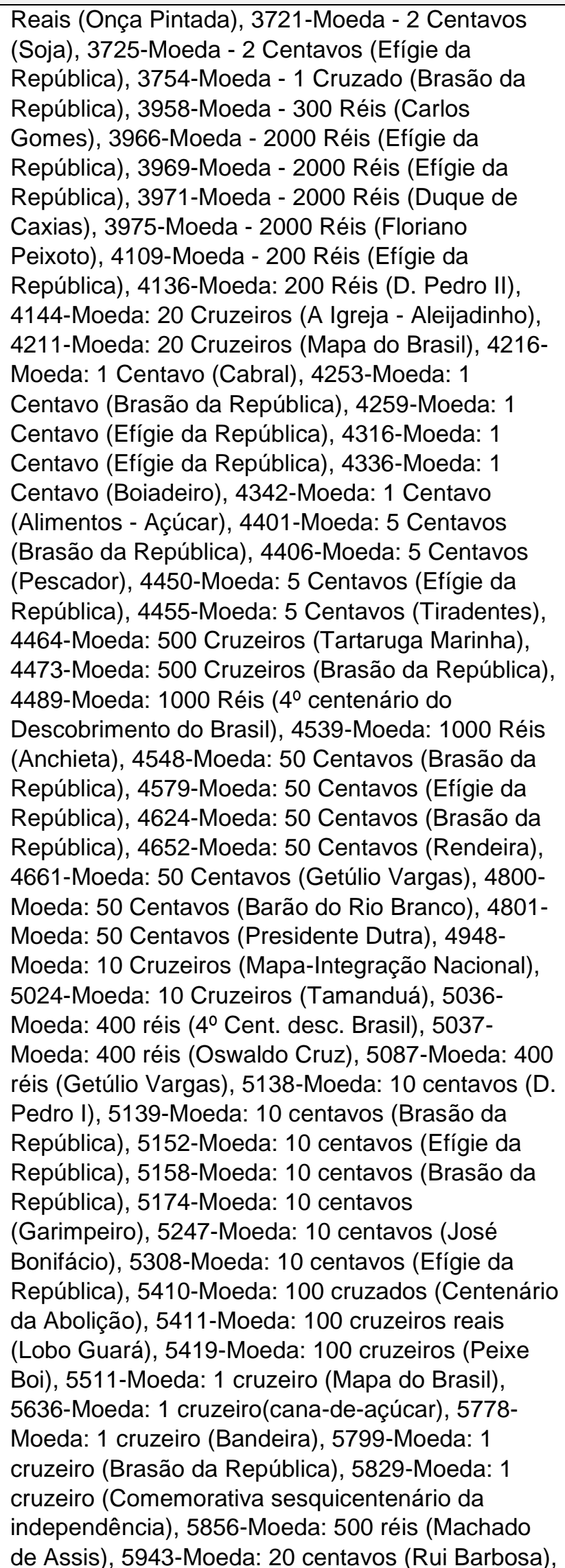 \\
\hline
\end{tabular}




\begin{tabular}{|c|c|c|c|}
\hline $\begin{array}{l}\text { Núcleo } \\
\text { temático }\end{array}$ & $\begin{array}{c}\text { Vitrine / } \\
\text { Recursos } \\
\text { expográficos }\end{array}$ & $\begin{array}{l}\text { Textos e } \\
\text { imagens } \\
\text { utilizadas }\end{array}$ & Objetos expostos \\
\hline & & & 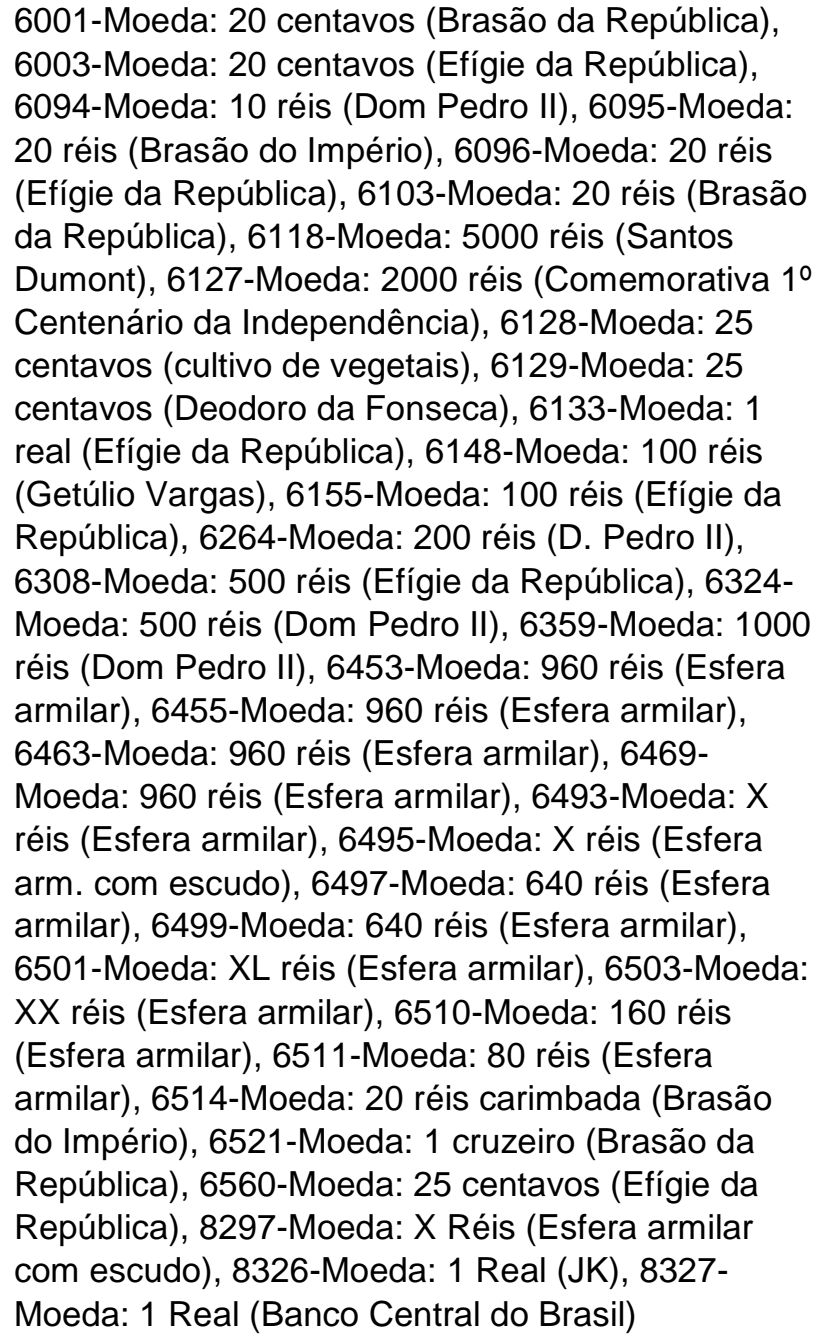 \\
\hline \multirow[t]{2}{*}{$\begin{array}{l}\text { Homem e o } \\
\text { Ambiente }\end{array}$} & $\begin{array}{l}\text { N10 } \\
\text { Painel } 7\end{array}$ & $\begin{array}{l}\text { Texto } \\
\text { Homem e o } \\
\text { Ambiente }\end{array}$ & $\begin{array}{l}\text { 0641- Pedra ametista, 1518-Estrela do mar, 1521- } \\
\text { Tartaruga, 2854-Concha, 2855-Concha, 3228/A- } \\
\text { Dente de marfim, 11061-Mineral, 11062-Mineral, } \\
\text { 11064-Mineral, 11065-Mineral, 11066-Mineral, } \\
\text { 11067-Mineral, 11068-Mineral, 11069-Mineral, } \\
\text { 11070-Mineral, 11071-Mineral, 11072-Mineral, } \\
\text { 11073-Mineral, 11074-Mineral, 11075-Mineral, } \\
\text { 11076-Mineral, 11077-Mineral, 11078-Mineral, } \\
\text { 11079-Mineral, 11080-Mineral, 11081-Mineral, } \\
\text { 11082-Mineral, 11083-Mineral, 11084-Mineral, } \\
\text { 11085/A-Fóssil, 11085/B-Fóssil, 11086-Fóssil, } \\
\text { 11087-Fóssil, 11090-Fóssil, 11091-Fóssil }\end{array}$ \\
\hline & Expositor Piso & & 642-Couro da cobra \\
\hline
\end{tabular}

Fonte: COELHO (2019). 
O Quadro 28, relaciona os elementos que compõem a exposição Coleção Santa Gertrudes de Imagens Paulistas do século XVII.

Quadro 28: Elementos que compõem a exposição

\begin{tabular}{|c|c|c|c|}
\hline $\begin{array}{l}\text { Núcleo } \\
\text { temático }\end{array}$ & $\begin{array}{c}\text { Vitrines / } \\
\text { Recursos } \\
\text { expográficos }\end{array}$ & $\begin{array}{l}\text { Fotos e } \\
\text { Textos } \\
\text { utilizados }\end{array}$ & Objetos expostos \\
\hline Apresentação & Painel 1 & $\begin{array}{l}\text { Texto de } \\
\text { apresentação }\end{array}$ & \\
\hline \multirow[t]{4}{*}{$\begin{array}{l}\text { Frei Agostinho } \\
\text { de Jesus }\end{array}$} & $\begin{array}{l}\text { E1 } \\
\text { Painel } 2 \\
\text { Totem } \\
\text { Painel } 3\end{array}$ & $\begin{array}{l}\text { Texto de } \\
\text { curadoria } \\
\text { Texto } \\
\text { Foto }\end{array}$ & $\begin{array}{l}\text { A3-Nossa Senhora da Conceição, 12040-Imagem } \\
\text { Fac-símile, 12041/01-Palma, 12041/01-Palma }\end{array}$ \\
\hline & E2 & $\begin{array}{l}\text { Texto } \\
\text { (na vitrine) }\end{array}$ & $\begin{array}{l}\text { A2-Nossa Senhora do Rosário, A4-Nossa } \\
\text { Senhora do Rosário, A5-Nossa Senhora dos } \\
\text { Prazeres, A6-São João Evangelista, A8-Nossa } \\
\text { Senhora da Conceição, A9-Nossa Senhora da } \\
\text { Conceição, A10-Nossa Senhora do Rosário, A11- } \\
\text { Nossa Senhora do Rosário, A13-Nossa Senhora } \\
\text { dos Prazeres }\end{array}$ \\
\hline & E3 & $\begin{array}{l}\text { Texto } \\
\text { (na vitrine) }\end{array}$ & $\begin{array}{l}\text { A1-Nossa Senhora do Rosário, A7-Pietá, A12- } \\
\text { Nossa Senhora (Invocação não identificada) }\end{array}$ \\
\hline & Painel 4 & Texto & - \\
\hline $\begin{array}{l}\text { Mestre de } \\
\text { Angra }\end{array}$ & E4 & $\begin{array}{l}\text { Texto } \\
\text { (na vitrine) }\end{array}$ & $\begin{array}{l}\text { D1-Cristo (Fragmento), D2-Cristo da Pedra Fria, } \\
\text { D3-Cristo da Pedra Fria, D4-Busto-Relicário de } \\
\text { Santa Engrácia }\end{array}$ \\
\hline $\begin{array}{l}\text { Mestre do } \\
\text { "Cabelinho } \\
\text { Xadrez" }\end{array}$ & E5 & $\begin{array}{l}\text { Texto } \\
\text { (na vitrine) }\end{array}$ & $\begin{array}{l}\text { C1-Nossa Senhora do Rosário, C2-Nossa } \\
\text { Senhora do Rosário, C3-Nossa Senhora dos } \\
\text { Prazeres, C4-Nossa Senhora da Conceição, C5- } \\
\text { Nossa Senhora da Conceição, C6-Sant'Ana } \\
\text { Mestra, C7-Nossa Senhora do Rosário, C8-Nossa } \\
\text { Senhora da Conceição, C9-Pietá, C10-Nossa } \\
\text { Senhora do Rosário }\end{array}$ \\
\hline \multirow[t]{2}{*}{$\begin{array}{l}\text { Mestre de } \\
\text { Sorocaba }\end{array}$} & E6 & $\begin{array}{l}\text { Texto } \\
\text { (na vitrine) }\end{array}$ & $\begin{array}{l}\text { B1-Santo Antônio, B2-Nossa Senhora dos } \\
\text { Prazeres, B3-Nossa Senhora da Conceição, B4- } \\
\text { Nossa Senhora dos Prazeres, B5-Nossa Senhora } \\
\text { da Conceição, B6-Santa Gertrudes, B7-Nossa } \\
\text { Senhora dos Prazeres, B8-Nossa Senhora da } \\
\text { Conceição, B9-Nossa Senhora da Conceição, } \\
\text { B10-Nossa Senhora da Conceição, B11-Nossa } \\
\text { Senhora dos Prazeres, B12-Nossa Senhora da } \\
\text { Conceição }\end{array}$ \\
\hline & Painel 5 & $\begin{array}{l}\text { Texto do } \\
\text { colecionador }\end{array}$ & - \\
\hline $\begin{array}{l}\text { Mestre de } \\
\text { Pirapora do } \\
\text { Bom Jesus e }\end{array}$ & E7 & $\begin{array}{l}\text { Texto } \\
\text { (na vitrine) }\end{array}$ & $\begin{array}{l}\text { E1-Nossa Senhora da Conceição, E2-Nossa } \\
\text { Senhora da Conceição, F1-Nossa Senhora da } \\
\text { Conceição, F2-Nossa Senhora da Conceição, F3- }\end{array}$ \\
\hline
\end{tabular}




\begin{tabular}{|c|c|c|c|}
\hline $\begin{array}{l}\text { Núcleo } \\
\text { temático }\end{array}$ & $\begin{array}{c}\text { Vitrines / } \\
\text { Recursos } \\
\text { expográficos }\end{array}$ & $\begin{array}{c}\text { Fotos e } \\
\text { Textos } \\
\text { utilizados }\end{array}$ & Objetos expostos \\
\hline $\begin{array}{l}\text { Mestre do } \\
\text { "Bolo de } \\
\text { Noiva" }\end{array}$ & & & Sant'Ana Mestra \\
\hline $\begin{array}{l}\text { Artistas sem } \\
\text { características } \\
\text { comuns que } \\
\text { não sejam as } \\
\text { de narração }\end{array}$ & E8 & $\begin{array}{l}\text { Texto } \\
\text { (na vitrine) }\end{array}$ & $\begin{array}{l}\text { G1-Nossa Senhora dos Prazeres, G2-Nossa } \\
\text { Senhora da Conceição, G3-Sant'Ana Mestra, G4- } \\
\text { Santa Luzia, G5-Sant'Ana Mestra, G6-Nossa } \\
\text { Senhora da Conceição, G7-Nossa Senhora dos } \\
\text { Prazeres, G8-Santa Bárbara, G9-Nossa Senhora } \\
\text { da Conceição, G10-Nossa Senhora da Conceição }\end{array}$ \\
\hline
\end{tabular}

Fonte: COELHO (2019).

O Quadro 29, relaciona os elementos que compõem o Circuito de Visitação à Cúpula.

Quadro 29: Elementos que compõem a exposição.

\begin{tabular}{|c|c|c|c|}
\hline $\begin{array}{l}\text { Núcleo } \\
\text { temático }\end{array}$ & $\begin{array}{c}\text { Vitrine / } \\
\text { Recursos } \\
\text { expográficos }\end{array}$ & $\begin{array}{l}\text { Textos e } \\
\text { Imagens } \\
\text { utilizadas }\end{array}$ & Objetos expostos \\
\hline $\begin{array}{l}\text { Módulo: } \\
\text { Construção } \\
\text { da Basílica } \\
\text { Nova }\end{array}$ & Painel 1 & $\begin{array}{l}\text { Texto de } \\
\text { Apresentação } \\
\text { Basílica Nacional: } \\
\text { a Construção de } \\
\text { um Sonho }\end{array}$ & \\
\hline \multirow[t]{4}{*}{ Núcleo 1} & $\begin{array}{l}\text { Vitrine } 1 \\
\text { Painel } 2\end{array}$ & $\begin{array}{l}\text { Texto } \\
\text { Do humilde } \\
\text { oratório } \\
\text { ao templo } \\
\text { novecentista }\end{array}$ & $\begin{array}{l}\text { 0340-Fechadura (Basílica Velha), 0341/A- } \\
\text { Chave, 0341/B-Chave, 0343-Azulejo de } \\
\text { Revestimento, 0345-Azulejo de } \\
\text { Revestimento, 0346-Azulejo de } \\
\text { Revestimento, 0347-Azulejo de } \\
\text { Revestimento, 0348-Azulejo de } \\
\text { Revestimento, 0354-Piso (Basílica Velha), } \\
\text { 0360-Tijolo (Basílica Velha), 284/01-Florão. }\end{array}$ \\
\hline & $\begin{array}{l}\text { Vitrine } 2 \\
\text { Painel } 3\end{array}$ & $\begin{array}{l}\text { Texto } \\
\text { A escolha do } \\
\text { terreno para a } \\
\text { Nova Basílica }\end{array}$ & $\begin{array}{l}\text { 12044/02-Tigela Almofariz, 12044/1E-Tigela } \\
\text { Almofariz, 12044/1F-Tigela Almofariz, } \\
\text { 12044/04-Pistilo, 12044/7D-Peneira } \\
\text { Granulométrica, 12044/7G-Peneira } \\
\text { Granulométrica, 12044/8C-Cápsula de } \\
\text { Alumínio, 12044/8H-Cápsula de } \\
\text { Alumínio,12044/9N-Cápsula de Alumínio, } \\
\text { 12044/9P-Cápsula de Alumínio. }\end{array}$ \\
\hline & $\begin{array}{l}\text { Vitrine } 3 \\
\text { Painel } 4\end{array}$ & $\begin{array}{l}\text { Texto } \\
\text { Lançando as } \\
\text { bases }\end{array}$ & $\begin{array}{l}\text { 12044/12D-Estojo com Ampolas, 12044/13A- } \\
\text { Estojo com Pesos, 12044/16A-Aparelho } \\
\text { Casagrande, 12044/16C-Cinzel Curvo, } \\
\text { 12044/16B-Calibrador de altura de queda de } \\
\text { concha, 12044/16D-Cinzel Chato, } \\
\text { 12044/21A-Balança. }\end{array}$ \\
\hline & $\begin{array}{l}\text { Vitrine } 4 \\
\text { Painel } 5\end{array}$ & $\begin{array}{l}\text { Texto } \\
\text { A construção do } \\
\text { maior templo }\end{array}$ & $\begin{array}{l}\text { 0358-Fragmentos da Cruz da Torre, 0368- } \\
\text { Ex-voto Basílica Nova (maquete), 0351/01- } \\
\text { Tijolo de construção (Basílica Nova), } \\
\text { 0351/02-Tijolo de construção (Basílica }\end{array}$ \\
\hline
\end{tabular}




\begin{tabular}{|c|c|c|c|}
\hline $\begin{array}{l}\text { Núcleo } \\
\text { temático }\end{array}$ & $\begin{array}{c}\text { Vitrine / } \\
\text { Recursos } \\
\text { expográficos }\end{array}$ & $\begin{array}{l}\text { Textos e } \\
\text { Imagens } \\
\text { utilizadas }\end{array}$ & Objetos expostos \\
\hline & & católico do Brasil & $\begin{array}{l}\text { Nova), 0351/03-Tijolo de construção } \\
\text { (Basílica Nova). }\end{array}$ \\
\hline & $\begin{array}{l}\text { Vitrine } 5 \\
\text { Televisão } 1\end{array}$ & $\begin{array}{l}\text { Vídeo sobre a } \\
\text { construção da } \\
\text { Basílica Nova }\end{array}$ & $\begin{array}{l}\text { 0371-Livros dos Devotos, 0349/01-Tijolo } \\
\text { (Campanha dos Devotos), 0349/02-Tijolo } \\
\text { (Campanha dos Devotos), 0361/4K-Guia } \\
\text { Caminho do Rosário, 0361/4H-Adesivos } \\
\text { Caminho do Rosário, 0361/4J-Adesivos } \\
\text { Caminho do Rosário, 0361/6C-Capela } \\
\text { (parcela do Manto), 0361/6B-Parcelas do } \\
\text { Manto, 0361/1A-Revista Devotos Mirins, } \\
\text { 0361/1D-Revista Devotos Mirins, 0361/1E- } \\
\text { Revista Devotos Mirins, 0361/1F-Revista } \\
\text { Devotos Mirins, 0361/2A-Revista Jovens de } \\
\text { Maria, 0361/2C-Revista Jovens de Maria, } \\
\text { 0361/3A-Revista de Aparecida, 0361/3D- } \\
\text { Revista de Aparecida, 0361/05-Calendário } \\
\text { Rezando com Maria, 0361/07-Pelúcia } \\
\text { "Tijolinho". }\end{array}$ \\
\hline \multirow[t]{5}{*}{ Núcleo 2} & $\begin{array}{l}\text { Vitrine } 6 \\
\text { Painel } 6\end{array}$ & $\begin{array}{l}\text { Texto } \\
\text { O revestimento } \\
\text { artístico }\end{array}$ & $\begin{array}{l}\text { 0359/1B-Piso, 0359/1C-Piso, 0350/01-Tijolo- } \\
\text { Basílica Nova, 0350/4A, 4B-Tijolo } \\
\text { revestimento, 0352-Telha. }\end{array}$ \\
\hline & $\begin{array}{l}\text { Vitrine } 7 \\
\text { Painel } 7\end{array}$ & $\begin{array}{l}\text { Texto } \\
\text { Nave Norte: } \\
\text { Adentrando o } \\
\text { espaço sagrado }\end{array}$ & $\begin{array}{l}\text { 0274/3B-Ornamento porta santa, 0356/06- } \\
\text { Azulejo, 0356/09-Azulejo, 0356/14-Azulejo, } \\
\text { 0356/17-Azulejo, 0356/26-Azulejo, 0356/28- } \\
\text { Azulejo. }\end{array}$ \\
\hline & $\begin{array}{l}\text { Vitrine } 8 \\
\text { Painel } 8\end{array}$ & $\begin{array}{l}\text { Texto } \\
\text { Nave Sul: O } \\
\text { Portal da Virgem }\end{array}$ & $\begin{array}{l}\text { 0283/3A-Protótipo porta santa, 0283/3B- } \\
\text { Protótipo porta santa, 0283/4A-Protótipo } \\
\text { porta santa, 0283/4B-Protótipo porta santa. }\end{array}$ \\
\hline & $\begin{array}{l}\text { Vitrine } 9 \\
\text { Painel } 9\end{array}$ & $\begin{array}{l}\text { Texto } \\
\text { A Senhora } \\
\text { Aparecida, } \\
\text { Jardim do Éden }\end{array}$ & $\begin{array}{l}\text { 0159/3E-Molde, 0159/5A-Textura, 0159/8B- } \\
\text { Textura, 0159/9A-Textura, 0159/27B- } \\
\text { Textura, 0159/42A-Textura, 0159/45A- } \\
\text { Textura, 0159/59-Textura, 0159/61-Textura, } \\
\text { 0370-Fac-símile NSA. }\end{array}$ \\
\hline & $\begin{array}{l}\text { Vitrine } 10 \\
\text { Televisão } 2\end{array}$ & $\begin{array}{l}\text { Vídeo sobre o } \\
\text { revestimento das } \\
\text { paredes }\end{array}$ & $\begin{array}{l}\text { 0356/01-Azulejo, 0356/02-Azulejo, 0356/03- } \\
\text { Azulejo, 0356/4A-Azulejo, 0356/4B-Azulejo, } \\
\text { 0356/07-Azulejo, 0356/12-Azulejo, } \\
\text { 0356/15A-Azulejo, 0356/15B-Azulejo, } \\
\text { 0356/18-Azulejo, 0356/19-Azulejo, } \\
\text { 0356/21A-Azulejo, 0356/21B-Azulejo, } \\
\text { 0356/23-Azulejo, 0356/24A-Azulejo, } \\
\text { 0356/24B-Azulejo, 0356/25-Azulejo, } \\
\text { 0356/27-Azulejo. }\end{array}$ \\
\hline \multirow[t]{2}{*}{ Núcleo 3} & $\begin{array}{l}\text { Vitrine } 11 \\
\text { Painel } 10\end{array}$ & $\begin{array}{l}\text { Texto } \\
\text { Nave Leste: } \\
\text { Fundamentos da } \\
\text { nossa Fé }\end{array}$ & $\begin{array}{l}\text { 0357/01-Vitral, 0357/02-Vitral, 0357/03-Vitral, } \\
\text { 0356/20A-Azulejo de Revestimento, } \\
\text { 0356/20B-Azulejo de Revestimento, } \\
\text { 0356/22A-Azulejo de Revestimento, } \\
\text { 0356/16-Azulejo de Revestimento. }\end{array}$ \\
\hline & $\begin{array}{l}\text { Vitrine } 12 \\
\text { Painel } 11\end{array}$ & $\begin{array}{l}\text { Texto } \\
\text { Nave Oeste: A } \\
\text { evangelização do } \\
\text { Brasil }\end{array}$ & $\begin{array}{l}\text { 0355/01-Azulejo de Revestimento, 0355/03- } \\
\text { Azulejo de Revestimento, 0355/04-Azulejo } \\
\text { de Revestimento, 0356/05-Azulejo de } \\
\text { Revestimento, 0356/08-Azulejo de } \\
\text { Revestimento, 0356/11-Azulejo de }\end{array}$ \\
\hline
\end{tabular}




\begin{tabular}{|c|c|c|c|}
\hline $\begin{array}{l}\text { Núcleo } \\
\text { temático }\end{array}$ & $\begin{array}{c}\text { Vitrine / } \\
\text { Recursos } \\
\text { expográficos }\end{array}$ & $\begin{array}{l}\text { Textos e } \\
\text { Imagens } \\
\text { utilizadas }\end{array}$ & Objetos expostos \\
\hline & & & Revestimento. \\
\hline & $\begin{array}{l}\text { Vitrine } 13 \\
\text { Painel } 12\end{array}$ & $\begin{array}{l}\text { Texto } \\
\text { As capelas } \\
\text { internas }\end{array}$ & $\begin{array}{l}\text { 0366-Ex-voto. Barco com } 3 \text { Pescadores, } \\
\text { 0367-Ex-voto. Basílica Velha (maquete). }\end{array}$ \\
\hline & $\begin{array}{l}\text { Vitrine } 14 \\
\text { Painel } 13\end{array}$ & $\begin{array}{l}\text { Texto } \\
\text { Capelas do } \\
\text { Batismo } \\
\text { e da } \\
\text { Ressurreição }\end{array}$ & $\begin{array}{l}\text { 0362-Ex-voto. Mão segurando Trolha, 0363- } \\
\text { Ex-voto. Pé, 0364/01-Ex-voto. Mão, 0364/02- } \\
\text { Ex-voto. Mão, 0365-Ex-voto. Cabeça, 12331- } \\
\text { Ex-voto. Imagem N.S. Aparecida, 12379-Ex- } \\
\text { voto. Imagem N.S. Aparecida. }\end{array}$ \\
\hline & $\begin{array}{l}\text { Vitrine } 15 \\
\text { Televisão } 3\end{array}$ & $\begin{array}{l}\text { Vídeo sobre o } \\
\text { Santuário } \\
\text { Nacional }\end{array}$ & $\begin{array}{l}\text { 0404-Placa do Carro Oficial - Cardeal Motta, } \\
\text { 0407-Placa do Carro Oficial - Cardeal Motta, } \\
\text { 0408-Medalha Comemorativa D. Penido, } \\
\text { 0455-Báculo - D Macedo, 0968-Alfinetes de } \\
\text { pálio. Cardeal Motta (3 itens), 11248-Jarro } \\
\text { Congresso Eucarístico. Brasão C. Motta, } \\
\text { 0369/01-Rosário Pe. Queiróz, 0369/02-Cinto } \\
\text { Pe. Queiróz. }\end{array}$ \\
\hline \multirow[t]{2}{*}{ Núcleo 4} & $\begin{array}{l}\text { Vitrine } 16 \\
\text { Painel } 14\end{array}$ & $\begin{array}{l}\text { Texto } \\
\text { Informações } \\
\text { gerais sobre a } \\
\text { Basílica }\end{array}$ & $\begin{array}{l}\text { 0869-Cordão peitoral, 3004/03-Cruz peitoral, } \\
\text { 3004/04-Cruz peitoral, 12180/A-Pálio, } \\
\text { 12180/B-Estojo do pálio. }\end{array}$ \\
\hline & $\begin{array}{l}\text { Vitrine } 17 \\
\text { Painel } 15\end{array}$ & $\begin{array}{l}\text { Texto } \\
\text { Fatos de } \\
\text { destaque na } \\
\text { história da Nova } \\
\text { Basílica }\end{array}$ & 12203-Lecionário, 12204-Evangeliário. \\
\hline $\begin{array}{l}\text { Módulo: } \\
\text { Cúpula } \\
\text { Central }\end{array}$ & $\begin{array}{l}\text { Três vitrines; } \\
50 \text { painéis } \\
\text { com textos e } \\
\text { imagens }\end{array}$ & $\begin{array}{l}\text { Citações bíblicas } \\
\text { sobre os arcos de } \\
\text { acesso à Cúpula } \\
\text { (Total } 7 \text { citações) }\end{array}$ & $\begin{array}{l}\text { ASN-0323-Conjunto Tésseras da Cúpula, } \\
\text { ASN-0324-Conjunto Azulejos do Baldaquino } \\
\text { (duas vitrines). }\end{array}$ \\
\hline $\begin{array}{l}\text { Módulo: } \\
300 \text { Anos }\end{array}$ & Painel 1 & $\begin{array}{l}\text { Texto de } \\
\text { Apresentação } \\
300 \text { Anos de } \\
\text { Bênçãos e de } \\
\text { Graças }\end{array}$ & \\
\hline Núcleo 1 & $\begin{array}{l}\text { Vitrine } 1 \\
\text { Painel } 2 \\
\text { Vitrine } 2 \\
\text { Vitrine } 3 \\
\text { Painel } 3 \\
\text { Vitrine } 4 \\
\text { Vitrine } 5\end{array}$ & $\begin{array}{l}\text { A imagem } \\
\text { Peregrina } \\
\text { A Coroa Jubilar }\end{array}$ & $\begin{array}{l}\text { ASN-0299/01-Manto do Jubileu-Manaus/AM, } \\
\text { ASN-0299/02-Manto do Jubileu-Boa } \\
\text { Vista/RR, ASN-0299/03-Manto do Jubileu- } \\
\text { Porto Velho/RO, ASN-0299/04-Manto do } \\
\text { Jubileu-Macapá/AP, ASN-0299/05-Manto do } \\
\text { Jubileu-Belém/PA, } \\
\text { ASN-0299/06-Manto do Jubileu-Palmas/TO, } \\
\text { ASN-0299/07-Manto do Jubileu-Rio } \\
\text { Branco/AC, ASN-0299/08-Manto do Jubileu- } \\
\text { São Luís/MA, ASN-0299/09-Manto do } \\
\text { Jubileu-Teresina/PI, } \\
\text { ASN-0299/10-Manto do Jubileu- } \\
\text { Fortaleza/CE, ASN-0299/11-Manto do }\end{array}$ \\
\hline
\end{tabular}




\begin{tabular}{|c|c|c|c|}
\hline $\begin{array}{l}\text { Núcleo } \\
\text { temático }\end{array}$ & $\begin{array}{c}\text { Vitrine / } \\
\text { Recursos } \\
\text { expográficos }\end{array}$ & $\begin{array}{l}\text { Textos e } \\
\text { Imagens } \\
\text { utilizadas }\end{array}$ & Objetos expostos \\
\hline & Painel 4 & $\begin{array}{l}\text { Carimbo } \\
\text { comemorativo }\end{array}$ & $\begin{array}{l}\text { Jubileu-Natal/RN, } \\
\text { ASN-0299/12-Manto do Jubileu-João } \\
\text { Pessoa/PB, ASN-0299/13-Manto do Jubileu- } \\
\text { Recife/PE, } \\
\text { ASN-0299/14-Manto do Jubileu-Maceió/AL, } \\
\text { ASN-0299/15-Manto do Jubileu-Aracajú/SE, } \\
\text { ASN-0299/16-Manto do Jubileu-Salvador/BA, } \\
\text { ASN-0299/17-Manto do Jubileu-Brasília/DF, } \\
\text { ASN-0299/18-Manto do Jubileu-Cuiabá/MT, } \\
\text { ASN-0299/19-Manto do Jubileu-Goiânia/GO, } \\
\text { ASN-0299/20-Manto do Jubileu-Campo } \\
\text { Grande/MS, } \\
\text { ASN-0299/21-Manto do Jubileu-Belo } \\
\text { Horizonte/MG, } \\
\text { ASN-0299/22-Manto do Jubileu - Vitória/ES, } \\
\text { ASN-0299/23-Manto do Jubileu-São } \\
\text { Paulo/SP, } \\
\text { ASN-299/24-Manto do Jubileu-Rio de } \\
\text { Janeiro/RJ, } \\
\text { ASN-0299/25-Manto do Jubileu-Curitiba/PR, } \\
\text { ASN-0299/26-Manto do Jubileu- } \\
\text { Florianópolis/SC, } \\
\text { ASN-0299/27-Manto do Jubileu-Porto } \\
\text { Alegre/RS, } \\
\text { ASN-0299/28-Manto do Jubileu-12 de } \\
\text { outubro, } \\
\text { ASN-0320/01-Coroa do Jubileu (réplica). }\end{array}$ \\
\hline Núcleo 2 & $\begin{array}{l}\text { Vitrine } 6 \\
\text { Painel } 5 \\
\text { Vitrine } 7 \\
\text { Vitrine } 8 \\
\text { Painel } 6 \\
\text { Vitrine } 9 \\
\text { Vitrine } 10 \\
\text { Painel } 7\end{array}$ & $\begin{array}{l}\text { O Campanário } \\
\text { Monumento do } \\
\text { Tricentenário } \\
\text { Memorial dos } \\
\text { Construtores }\end{array}$ & $\begin{array}{l}\text { ASN-0300/01-Terra-Manaus/AM, } \\
\text { ASN-0300/02-Terra-Boa Vista/RR, } \\
\text { ASN-0300/03-Terra-Porto Velho/RO, } \\
\text { ASN-0300/04-Terra-Macapá/AP, } \\
\text { ASN-0300/05-Terra-Belém/PA, } \\
\text { ASN-0300/06-Terra-Palmas/TO, } \\
\text { ASN-0300/07-Terra-Rio Branco/AC, } \\
\text { ASN-0300/08-Terra-São Luís/MA, } \\
\text { ASN-0300/09-Terra-Teresina/PI, } \\
\text { ASN-0300/10-Terra-Fortaleza/CE, } \\
\text { ASN-0300/11-Terra-Natal/RN, } \\
\text { ASN-0300/12-Terra-João Pessoa/PB, } \\
\text { ASN-0300/13-Terra-Recife/PE, } \\
\text { ASN-0300/14-Terra-Maceió/AL, } \\
\text { ASN-0300/15-Terra-Aracajú/SE, } \\
\text { ASN-0300/16-Terra-Salvador/BA, } \\
\text { ASN-0300/17-Terra-Brasília/DF, } \\
\text { ASN-0300/18-Terra-Cuiabá/MT, } \\
\text { ASN-0300/19-Terra-Goiânia/GO, } \\
\text { ASN-0300/20-Terra-Campo Grande/MS, } \\
\text { ASN-0300/21-Terra-Belo Horizonte/MG, } \\
\text { ASN-0300/22-Terra-Vitória/ES, } \\
\text { ASN-0300/23-Terra-São Paulo/SP, } \\
\text { ASN-0300/24-Terra-Rio de Janeiro/RJ, } \\
\text { ASN-0300/25-Terra-Curitiba/PR, } \\
\text { ASN-0300/26-Terra-Florianópolis/SC, }\end{array}$ \\
\hline
\end{tabular}




\begin{tabular}{|c|c|c|c|}
\hline $\begin{array}{l}\text { Núcleo } \\
\text { temático }\end{array}$ & $\begin{array}{c}\text { Vitrine / } \\
\text { Recursos } \\
\text { expográficos }\end{array}$ & $\begin{array}{l}\text { Textos e } \\
\text { Imagens } \\
\text { utilizadas }\end{array}$ & Objetos expostos \\
\hline & & & ASN-0300/27-Terra-Porto Alegre/RS. \\
\hline Núcleo 3 & $\begin{array}{l}\text { Vitrine } 11 \\
\text { Painel } 8 \\
\text { Vitrine } 12 \\
\text { Vitrine } 13 \\
\text { Painel } 9 \\
\text { Vitrine } 14 \\
\text { Vitrine } 15 \\
\text { Painel } 10\end{array}$ & $\begin{array}{l}\text { A Medalha } \\
\text { comemorativa do } \\
\text { Jubileu } \\
\text { Águas do Brasil } \\
\text { em Aparecida } \\
\text { Ladainha de } \\
\text { Nossa Senhora }\end{array}$ & $\begin{array}{l}\text { ASN-0301/01A-Ânfora-Rio São Mateus, } \\
\text { ASN-0301/02A-Ânfora-Rio Doce, } \\
\text { ASN-0301/04A-Ânfora-Rio Itapemirim, } \\
\text { ASN-0301/09A-Ânfora-Rio Piraí, } \\
\text { ASN-0301/10A-Ânfora-Rio Paraíba do Sul- } \\
\text { RJ, ASN-0301/12A-Ânfora-Rio Muriaé, } \\
\text { ASN-0301/15A-Ânfora-Rio Macaé, } \\
\text { ASN-0301/18A-Ânfora-Rio de Contas, } \\
\text { ASN-0301/19A-Ânfora-Rio Jaguaripe, } \\
\text { ASN-0301/20A-Ânfora-Rio São Francisco- } \\
\text { BA, } \\
\text { ASN-0301/25A-Ânfora-Rio Jequitinhonha, } \\
\text { ASN-0301/29A-Ânfora-Rio Mundaú, } \\
\text { ASN-0301/32A-Ânfora-Rio Poti, } \\
\text { ASN-0301/36A-Ânfora-Rio Capibaribe, } \\
\text { ASN-0301/37A-Ânfora-Rio Beberibe, } \\
\text { ASN-0301/39A-Ânfora-Rio Coruripe, } \\
\text { ASN-0301/41A-Ânfora-Rio Manguaba, } \\
\text { ASN-0301/44A-Ânfora-Água da praia fluvial } \\
\text { do Jacaré, } \\
\text { ASN-0301/45A-Ânfora-Rio Tapajós } \\
\text { (Santarém-PA), } \\
\text { ASN-0301/46A-Ânfora-Rio Amazonas (Costa } \\
\text { do Arapemã), } \\
\text { ASN-0301/55A-Ânfora-Rio Parnaíba, } \\
\text { ASN-0301/56A-Ânfora-Rio Uruguai, } \\
\text { ASN-0301/57A-Ânfora-Rio Paraguai, } \\
\text { ASN-0301/58A-Ânfora-Rio Araguaia, } \\
\text { ASN-0301/59A-Ânfora-Rio Tocantins, } \\
\text { ASN-0301/60A-Ânfora-Rio Paraíba do Sul - } \\
\text { SP, } \\
\text { ASN-0301/61A-Ânfora-Rio Tietê (Barra } \\
\text { Bonita - SP), } \\
\text { ASN-0301/62A-Ânfora-Rio Paranapanema, } \\
\text { ASN-0301/63A-Ânfora-Rio Grande, } \\
\text { ASN-0301/64A-Ânfora-Rio Paraná, } \\
\text { ASN-0301/65A-Ânfora-Rio lguaçu, } \\
\text { ASN-0301/66A-Ânfora-Rio Solimões, } \\
\text { ASN-0301/67A-Ânfora-Rio Tapajós } \\
\text { (Manaus/AM), } \\
\text { ASN-0301/68A-Ânfora-Rio Madeira, } \\
\text { ASN-0301/69A-Ânfora-Rio Negro, } \\
\text { ASN-0301/72A-Ânfora-Rio Amazonas, } \\
\text { ASN-0301/78A-Ânfora-Rio Xingu. }\end{array}$ \\
\hline Núcleo 4 & $\begin{array}{l}\text { Vitrine } 16 \\
\text { Vitrine } 17 \\
\text { Painel } 11\end{array}$ & $\begin{array}{l}\text { Inauguração da } \\
\text { Cúpula do } \\
\text { Baldaquino } \\
\text { Central da } \\
\text { Basílica }\end{array}$ & $\begin{array}{l}\text { 12276-A-Folha de Selos Jubileu } 300 \text { anos, } \\
\text { 12276-B-Placa com carimbo comemorativo, } \\
\text { 12277-Pasta dos Correios, } 12317-01 \text { a 03- } \\
\text { Cunhos com estojo, } 12317-04 \text { a 07- } \\
\text { Medalhas com estojo, ASN-0293-A-Mitra } \\
\text { comemorativa } 300 \text { anos, ASN-0293-B- } \\
\text { Casula comemorativa } 300 \text { anos, ASN-0293- } \\
\text { C-Estola comemorativa } 300 \text { anos, ASN- }\end{array}$ \\
\hline
\end{tabular}




\begin{tabular}{|c|c|c|c|}
\hline $\begin{array}{c}\text { Núcleo } \\
\text { temático }\end{array}$ & $\begin{array}{c}\text { Vitrine / } \\
\text { Recursos } \\
\text { expográficos }\end{array}$ & $\begin{array}{c}\text { Textos e } \\
\text { Imagens } \\
\text { utilizadas }\end{array}$ & Objetos expostos \\
\hline & & & 0293-D-Estola comemorativa 300 anos. \\
\hline
\end{tabular}

Fonte: COELHO (2019). 


\title{
Anexos
}

\section{ANEXO A - Contrato de Doação}

Figura 142: Contrato de Doação e outros encargos que entre si fazem Vicente Camargo e sua esposa Conceição Borges Ribeiro Camargo com a Sociedade Santuário Nacional de Nossa Senhora Aparecida. Inclui a Lista de inventário das peças e objetos constantes do Museu doado na data 30 de janeiro de 1967. Páginas 1 e 2.

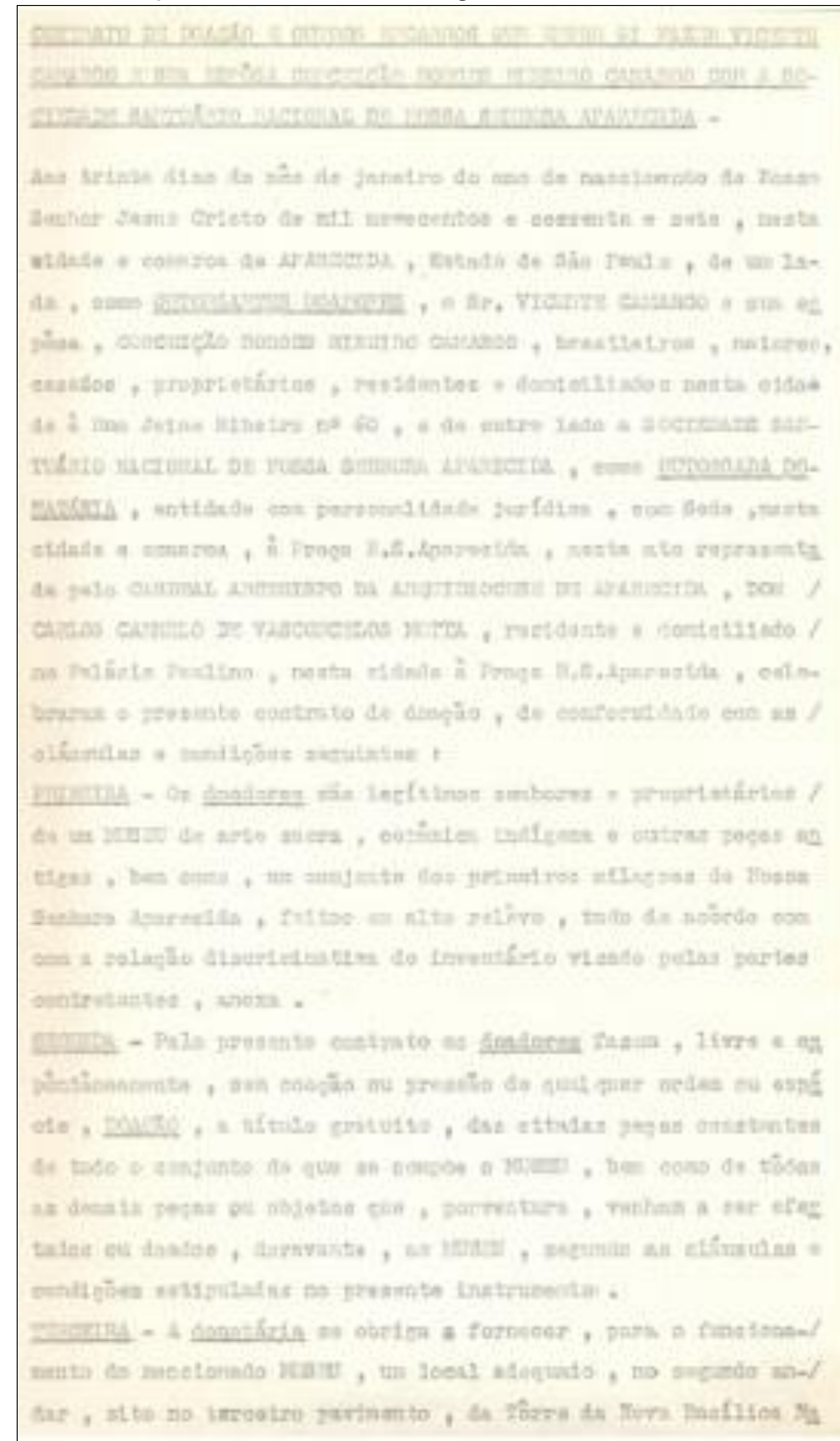

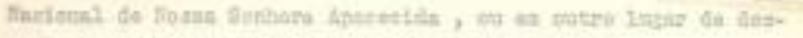

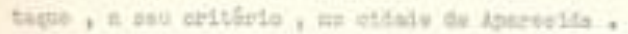

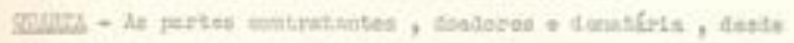

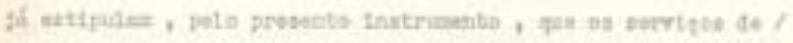

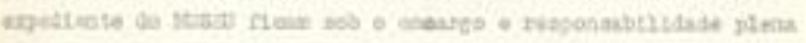

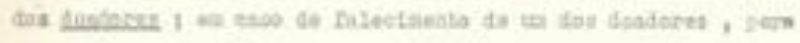

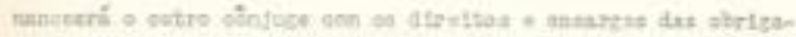

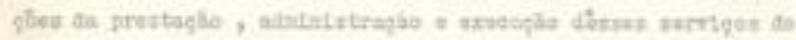

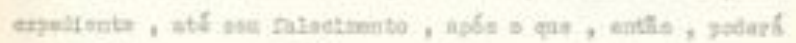

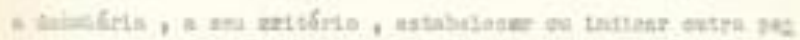

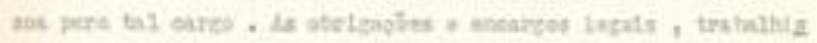

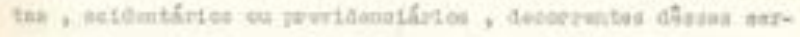

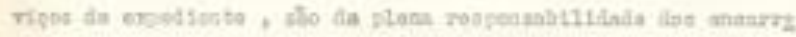

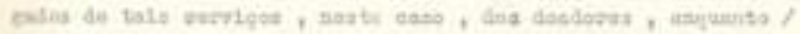

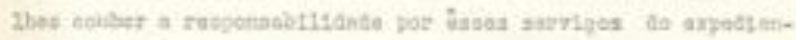
to an ingart .

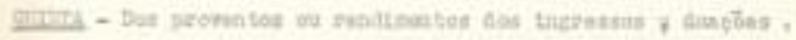

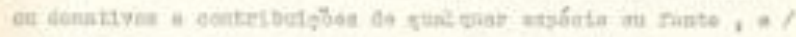

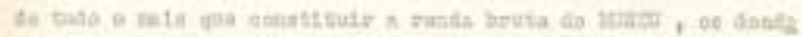

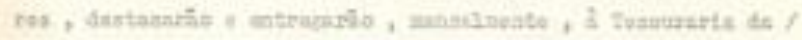

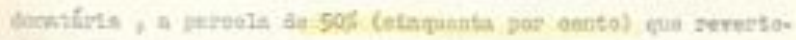

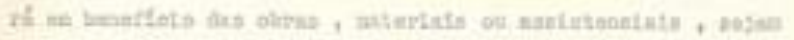

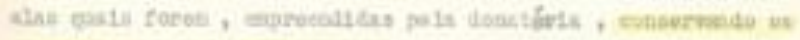

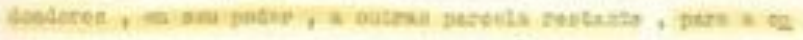

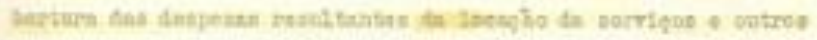

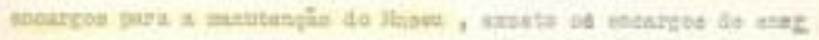

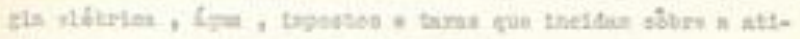

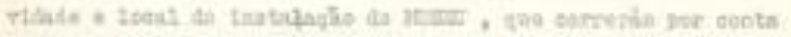
ds decathiris.

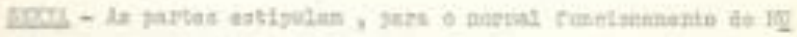

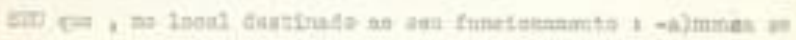

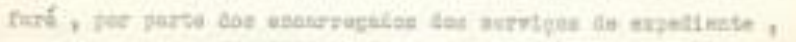

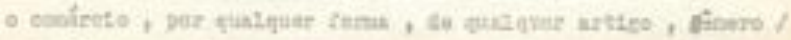

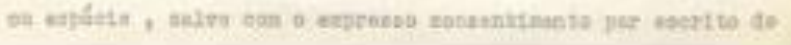

\author{
Fonte: MNSA/Santuário Nacional.
}


Figura 143: Contrato de Doação e outros encargos que entre si fazem Vicente Camargo e sua esposa Conceição Borges Ribeiro Camargo com a Sociedade Santuário Nacional de Nossa Senhora Aparecida. Inclui a Lista de inventário das peças e objetos constantes do Museu doado na data 30 de janeiro de 1967. Páginas 3 e 4.

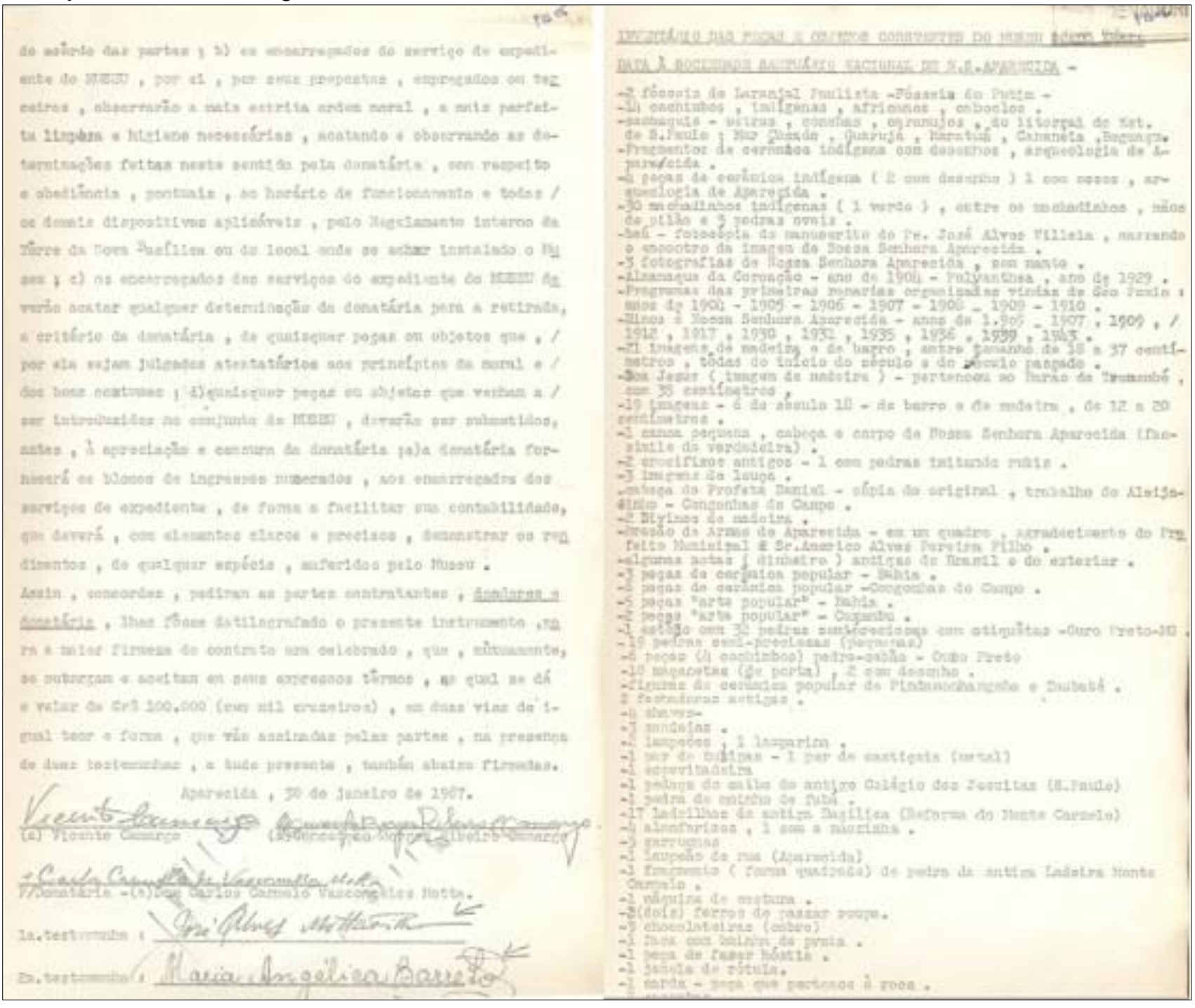

Fonte: MNSA/Santuário Nacional. 
Figura 144: Contrato de Doação e outros encargos que entre si fazem Vicente Camargo e sua esposa Conceição Borges Ribeiro Camargo com a Sociedade Santuário Nacional de Nossa Senhora Aparecida. Inclui a Lista de inventário das peças e objetos constantes do Museu doado na data 30 de janeiro de 1967. Páginas 5 e 6.

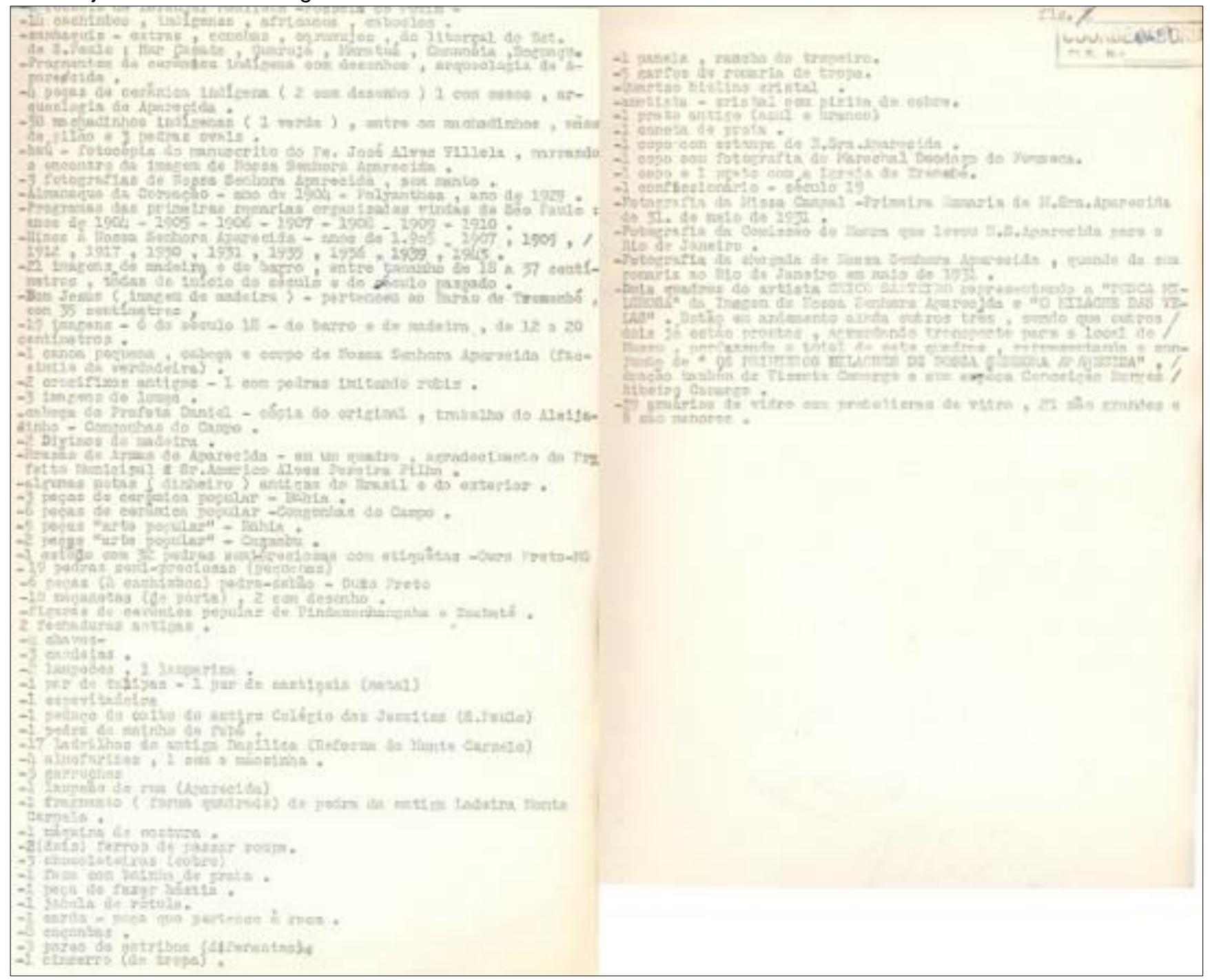

Fonte: MNSA/Santuário Nacional. 


\section{ANEXO B - Listas de entrada de objetos}

Segue a relação de entradas de objetos no Museu Nossa Senhora Aparecida, período de 2003 a 2018.

Quadro 30: Lista de entrada de objetos (2003)

\begin{tabular}{|c|c|c|c|c|}
\hline $\begin{array}{l}\text { № de } \\
\text { entrada }\end{array}$ & Descrição do Objeto & Data & Doador & $\begin{array}{l}\text { Responsável } \\
\text { Recebimento }\end{array}$ \\
\hline$E-01 / 2003$ & $\begin{array}{l}1 \text { relógio de pulso (ômega) com } \\
\text { chaveiro (avon) } 20000 \text { cruzeiros } \\
\text { reais (gaúcho) }\end{array}$ & - & Zilda Rosa Godoy & Heloisa Reis \\
\hline$E-02 / 2003$ & $\begin{array}{c}\text { Bilhete da 1aㅡ rifa - Construção da } \\
\text { Nova Basílica } 1955\end{array}$ & - & $\begin{array}{c}\text { Luiz Caiuby de } \mathrm{O} . \\
\text { Martins }\end{array}$ & Zilda Ribeiro \\
\hline E-03/2003 & 3 relógios de pulso & - & Maria Soares da Silva & - \\
\hline E-04/2003 & Rádio Incomar & - & Luis Guerra & Heloisa Reis \\
\hline$E-05 / 2003$ & Notas e moedas antigas & - & Lydia Pereira Berti & - \\
\hline$E-06 / 2003$ & $\begin{array}{c}\text { Notas: } 1000 \text { liras (Paraguai), } 1 \\
\text { dólar e } 1 \text { real }\end{array}$ & - & $\begin{array}{l}\text { Jane Crey Guedes da } \\
\text { Silva }\end{array}$ & - \\
\hline$E-07 / 2003$ & Medalha de prata (+- 60 anos) & - & Marly Belini Sebastião & - \\
\hline E-08/2003 & Pedra azul $(1 \mathrm{~kg})$ & - & Maria da Graça Silva & - \\
\hline E-09/2003 & Garrucha de 1925 & - & João Moreira & - \\
\hline$E-10 / 2003$ & $\begin{array}{l}\text { Pedras: Crisolitos, Andalusidas } \\
\text { (furtacores) }\end{array}$ & - & João Roberto Horselan & - \\
\hline$E-11 / 2003$ & $\begin{array}{c}\text { Notas: } 10 \text { e } 20 \text { cruzeiros (Princesa } \\
\text { Isabel) }\end{array}$ & - & Pedro Fermino Silva & - \\
\hline$E-12 / 2003$ & $\begin{array}{c}\text { Relógio de pulso (roscof); pulseira } \\
\text { com pedras; Ferrinho de brasa } \\
\text { pequenol e um despertador } \\
\text { (Europa) }\end{array}$ & - & $\begin{array}{l}\text { Maria Aparecida de } \\
\text { Jesus Gil }\end{array}$ & - \\
\hline$E-13 / 2003$ & $\begin{array}{c}\text { Medalha Santos Dumont (1906- } \\
1956)\end{array}$ & - & $\begin{array}{l}\text { Maria Aparecida de } \\
\text { Souza }\end{array}$ & - \\
\hline$E-14 / 2003$ & Manto bordado & - & Nice S. Bauhora & - \\
\hline$E-15 / 2003$ & Cédulas e moedas & 2003 & Família desconhecida & Zilda Ribeiro \\
\hline E-16/2003 & $\begin{array}{l}4 \text { moedas: pesos (chile) e } 10 \\
\text { (África do Sul) }\end{array}$ & $11 / 01 / 2003$ & Juliana Tuvra Marchant & Tânia \\
\hline$E-17 / 2003$ & 1 nota: 20 pesos (México) & $18 / 01 / 2003$ & $\begin{array}{c}\text { Marcos Paulo Lima de } \\
\text { Paula }\end{array}$ & Tânia \\
\hline$E-18 / 2003$ & $\begin{array}{l}\text { Corrente de prata e um relógio de } \\
\text { bolso }\end{array}$ & 19/01/2003 & $\begin{array}{l}\text { Maria Conceição } \\
\text { Moreira Cantador }\end{array}$ & Zilda Ribeiro \\
\hline E-19/2003 & Pedra carvão mineral & $26 / 01 / 2003$ & $\begin{array}{c}\text { Pedro Delfim de } \\
\text { Oliveira }\end{array}$ & Zilda Ribeiro \\
\hline$E-20 / 2003$ & $\begin{array}{c}\text { Anel cartie } 3 \text { em } 1 \text { (ouro branco, } \\
\text { vermelho e amarelo) }\end{array}$ & $26 / 01 / 2003$ & Analice dos Santos & $\begin{array}{c}\text { Michel H. } \\
\text { Oliveira } \\
\end{array}$ \\
\hline$E-21 / 2003$ & $\begin{array}{c}\text { Moeda de } 500 \text { pesos chilenos } \\
(2002)\end{array}$ & $02 / 02 / 2003$ & $\begin{array}{c}\text { Betsabe Olivia Lagos } \\
\text { Alcaide }\end{array}$ & Michel \\
\hline$E-22 / 2003$ & 1 nota de 5 dólares australianos & $11 / 02 / 2003$ & $\begin{array}{c}\text { Wilson Ribeiro dos } \\
\text { Santos }\end{array}$ & Heloisa Reis \\
\hline$E-23 / 2003$ & Relógio de bolso roskoff & $16 / 02 / 2003$ & $\begin{array}{c}\text { Benedita Darlo } \\
\text { Nascimento }\end{array}$ & Heloisa Reis \\
\hline$E-24 / 2003$ & Moeda 50 francos - Guiné Bissau & $26 / 02 / 2003$ & $\begin{array}{l}\text { Ir. Laurita Alves de } \\
\text { Oliveira }\end{array}$ & - \\
\hline$E-25 / 2003$ & $\begin{array}{c}10 \text { peças em madeira - } \\
\text { artesanato, decorativa, utilitárias }\end{array}$ & $01 / 03 / 2003$ & $\begin{array}{l}\text { Maria Montibelbr } \\
\text { Cadorm }\end{array}$ & Zilda Ribeiro \\
\hline$E-26 / 2003$ & $\begin{array}{c}\text { Nota de } 5 \text { dólares liberianos (serie } \\
\text { AA 797.5786) }\end{array}$ & $26 / 03 / 2003$ & Ir. Lourdes H. Bonapaz & - \\
\hline
\end{tabular}




\begin{tabular}{|c|c|c|c|c|}
\hline $\begin{array}{l}\text { № de } \\
\text { entrada }\end{array}$ & Descrição do Objeto & Data & Doador & \begin{tabular}{|l|} 
Responsável \\
Recebimento \\
\end{tabular} \\
\hline E-27/2003 & $\begin{array}{c}1 \text { bíblia ilustrada (Sampley } \\
\text { Public), sino do vaticano-torre } \\
\text { Eiffel, terço (ouro), } 2 \text { anéis pedra } \\
\text { branca e azul, colar de pérolas, } 1 \\
\text { par de brincos de brilhantes, } 1 \text { par } \\
\text { de brinco de ouro branco e uma } \\
\text { gargantilha de esmeralda com } \\
\text { broche e bracelete. }\end{array}$ & $13 / 03 / 2003$ & Maria Helena Mendes & Zilda Ribeiro \\
\hline$E-28 / 2003$ & Nota: 10 zehn deutsche mark & $16 / 03 / 2003$ & Samuel V. Nunes & $\begin{array}{l}\text { Michel H. } \\
\text { Oliveira }\end{array}$ \\
\hline$E-29 / 2003$ & 2 notas: 5 e 20 cruzeiros (1920) & $16 / 03 / 2003$ & $\begin{array}{l}\text { Angeval Antônio de } \\
\text { Souza }\end{array}$ & Tânia \\
\hline$E-30 / 2003$ & $\begin{array}{l}\text { Moeda: } 50 \text { Anhapa (lugoslávia) e } \\
1 \text { japonesa }\end{array}$ & $17 / 03 / 2003$ & Maicon Máximo Maciel & Heloisa Reis \\
\hline$E-31 / 2003$ & Cédula 50 reais (em circulação) & $21 / 03 / 2003$ & $\begin{array}{l}\text { José Magnus } \\
\text { Schwanch }\end{array}$ & Guido Braga \\
\hline$E-32 / 2003$ & Cédula 10 reais (em circulação) & $21 / 03 / 2003$ & Levi Pereira Ramos & Guido Braga \\
\hline$E-33 / 2003$ & Aliança de ouro & 23/03/2003 & $\begin{array}{l}\text { Tereza Woicibi } \\
\text { Nogueira }\end{array}$ & Guido Braga \\
\hline$E-34 / 2003$ & $\begin{array}{r}\text { Cédulas: } \\
\mathrm{cr}\end{array}$ & $29 / 03 / 2003$ & João Thomen & Guido Braga \\
\hline$E-35 / 2003$ & is (em circulação) & $05 / 04 / 2003$ & Valdinei Costa Batista & Guido Braga \\
\hline$E-36 / 2003$ & $\begin{array}{r}\text { Relóg } \\
\text { (Citizen - fa }\end{array}$ & 06/04/2003 & $\begin{array}{c}\text { Cecílio Floriano F. } \\
\text { Barros }\end{array}$ & Heloisa Reis \\
\hline E-37/2003 & Série de centav & $09 / 04 / 2003$ & Silvio $\mathrm{G}$ & - \\
\hline E-38/2003 & $\begin{aligned} \text { Cédula: } 1 \text { peseta (sér } \\
\text { - de 19/11/1 }\end{aligned}$ & $26 / 04 / 2003$ & $\begin{array}{l}\text { Sebastião Silvério de } \\
\text { Meira }\end{array}$ & Guido Braga \\
\hline$E-39 / 2003$ & Cédula: 50 ienes - Japão & $26 / 04 / 2003$ & $\begin{array}{l}\text { Francisco Augusto } \\
\text { Ferreira Gelamo }\end{array}$ & Guido Braga \\
\hline$E-40 / 2003$ & $\begin{array}{l}\text { Selo comemorativo: Bicentenário } \\
\text { da Fundação de Ouro fino }\end{array}$ & $24 / 05 / 2003$ & $\begin{array}{l}\text { Antônio Algnaldo } \\
\text { Guimarães }\end{array}$ & Tânia \\
\hline$E-41 / 2003$ & Rádio amador (1976) & $07 / 06 / 2003$ & Juliano Almeida Souza & Guido Braga \\
\hline$E-42 / 2003$ & Sabre de combate e um cinto & $22 / 06 / 2003$ & $\begin{array}{l}\text { Antônio Gil Bernardes } \\
\text { Nascimento }\end{array}$ & Michel \\
\hline$E-43 / 2003$ & 1 moeda 10 cent (África do Sul) & $01 / 07 / 2003$ & Maurício Luis Satun & Heloísa Reis \\
\hline$E-44 / 2003$ & $\begin{array}{c}1 \text { cédula: } 100 \text { reais (em } \\
\text { circulação) }\end{array}$ & $12 / 07 / 2003$ & Lucas Ferrão Silva & Guido Braga \\
\hline E-45/2003 & 1 cédula argentina & $12 / 07 / 2003$ & $\begin{array}{l}\text { Almir Ferreira dos } \\
\text { Santos }\end{array}$ & 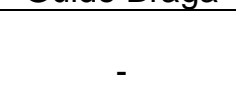 \\
\hline$E-46 / 2003$ & $\begin{array}{c}5 \text { moedas do chile: } 2 \text { moedas } 1 \\
\text { peso de } 1998,100 \text { pesos de } \\
1997,100 \text { pesos de } 2001,50 \text { pesos } \\
\text { de } 1995 \text { e } 10 \text { centavos (brasil) } \\
1998\end{array}$ & $12 / 07 / 2003$ & Guilherme Gorozalez & $\begin{array}{l}\text { Michel H. } \\
\text { Oliveira }\end{array}$ \\
\hline$E-47 / 2003$ & $\begin{array}{l}\text { Relógio de pulso com visor azul } \\
\text { (nelima); relógio (cyma) visor } \\
\text { branco e ponteiros dourado }\end{array}$ & $13 / 07 / 2003$ & $\begin{array}{l}\text { Henrique Indiano } \\
\quad \text { Ferreira }\end{array}$ & $\begin{array}{l}\text { Michel H. } \\
\text { Oliveira }\end{array}$ \\
\hline E-48/2003 & Cédulas italianas: 5 e 100 liras & $6 / 07 / 2003$ & Elizabetta Mandato & Guido Braga \\
\hline$E-49 / 2003$ & & $21 / 07 / 2003$ & Eduardo Wisniwski & - \\
\hline$E-50 / 2003$ & & $26 / 07 / 2003$ & José Maria Pires & Guido Braga \\
\hline$E-51 / 2003$ & $\begin{array}{c}\text { Medalha de bronze 10 centenário } \\
\text { Farroupilha 1835-1935 (efígie } \\
\text { Bento Gonçalves) }\end{array}$ & 28/07/2003 & $\begin{array}{l}\text { Maria Inácia Santos } \\
\text { Silva }\end{array}$ & Heloísa Reis \\
\hline E-52/2003 & $\begin{array}{l}\text { Nota: } 20 \text { markos (alemão) efígie } \\
\text { Annette von Droste Hulshoff }\end{array}$ & $30 / 07 / 2003$ & Antônio Alves Ferreira & Heloísa Reis \\
\hline E-53/2003 & Despertador & $17 / 08 / 2003$ & Benedita Custódia da & Heloísa Reis \\
\hline
\end{tabular}




\begin{tabular}{|c|c|c|c|c|}
\hline $\begin{array}{c}\text { № de } \\
\text { entrada }\end{array}$ & Descrição do Objeto & Data & Doador & $\begin{array}{l}\text { Responsável } \\
\text { Recebimento }\end{array}$ \\
\hline & & & Silva & \\
\hline$E-54 / 2003$ & 1 cédula de 100 mil cruzeiros & $23 / 08 / 2003$ & Silvério Alexandre & Guido Braga \\
\hline \multirow{2}{*}{$E-55 / 2003$} & $\begin{array}{c}\text { Chapéu de boiadeiro e relógio de } \\
\text { algibeira }\end{array}$ & $23 / 08 / 2003$ & $\begin{array}{c}\text { Ana Rosa da Mota } \\
\text { Bérgamo }\end{array}$ & Guido Braga \\
\hline & Estribo feminino & $23 / 08 / 2003$ & José Benedito Calixto & Guido Braga \\
\hline E-56/2003 & 2000 réis & $30 / 08 / 2003$ & Francisco Moraes & Heloísa Reis \\
\hline E-57/2003 & Aliança - terço de ouro & 07/09/2003 & $\begin{array}{l}\text { Maria Teresa dos } \\
\text { Santos }\end{array}$ & Guido Braga \\
\hline$E-58 / 2003$ & 1 cédula de mil cruzeiros & 07/09/2003 & Everton Soares & Guido Braga \\
\hline$E-59 / 2003$ & 20 moedas & 07/09/2003 & $\begin{array}{l}\text { Adilson de Castro dos } \\
\text { Santos }\end{array}$ & Guido Braga \\
\hline$E-60 / 2003$ & Moeda da Bélgica & 08/07/2003 & Angela Bemalé & Heloísa Reis \\
\hline E-61/2003 & Relógio de bolso com corrente & 08/09/2003 & Genésio Miguel Lima & Heloísa Reis \\
\hline$E-62 / 2003$ & $\begin{array}{c}\text { Moedas Antigas nacionais e } \\
\text { estrangeiras }\end{array}$ & $13 / 09 / 2003$ & $\begin{array}{l}\text { Alfredo Francisco José } \\
\text { Soja }\end{array}$ & Guido Braga \\
\hline$E-63 / 2003$ & Bule de porcelana & $15 / 09 / 2003$ & $\begin{array}{c}\text { Alcides Ribeiro dos } \\
\text { Santos }\end{array}$ & $\begin{array}{c}\text { Márcia } \\
\text { Mendes } \\
\end{array}$ \\
\hline$E-64 / 2003$ & $\begin{array}{c}1 \text { cédula de } 5 \text { cruzeiros - } \\
3^{\mathrm{a}} \text { estampa série } 108\end{array}$ & $17 / 09 / 2003$ & $\begin{array}{c}\text { Zélia Maria dos Santos } \\
\text { Delana }\end{array}$ & Guido Braga \\
\hline$E-65 / 2003$ & $\begin{array}{l}1 \text { moeda de } 10 \text { centavos } \\
\text { (Holanda) }\end{array}$ & $18 / 09 / 2003$ & Danilo Ribeiro & $\begin{array}{l}\text { Márcia } \\
\text { Mendes }\end{array}$ \\
\hline$E-66 / 2003$ & Ponta de flecha indígena & $20 / 09 / 2003$ & Carlos José de Almeida & $\begin{array}{l}\text { Márcia } \\
\text { Mendes }\end{array}$ \\
\hline E-67/2003 & Máquina fotográfica & $21 / 09 / 2003$ & Ana da Luz de Ávila & Heloísa Reis \\
\hline$E-68 / 2003$ & Canivete com cabo & $27 / 09 / 2003$ & $\begin{array}{c}\text { José Gonçalves da } \\
\text { Silva }\end{array}$ & César Maia \\
\hline E-69/2003 & 2000 yen (Japão) & $29 / 09 / 2003$ & Shizuko I. Nakayama & Heloísa Reis \\
\hline$E-70 / 2003$ & Notas e moedas antigas & $11 / 10 / 2003$ & João Condé & $\begin{array}{c}\text { Márcia } \\
\text { Mendes } \\
\end{array}$ \\
\hline$E-71 / 2003$ & Moeda (portuguesa) & $18 / 10 / 2003$ & $\begin{array}{l}\text { Adarílo Graciano } \\
\text { Pimentel Junna }\end{array}$ & 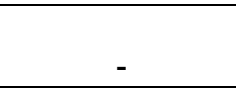 \\
\hline$E-72 / 2003$ & Relógio ultramar 15 rubis & $18 / 010 / 2003$ & Denise Aparecida Tiori & $\begin{array}{l}\text { Michel } \mathrm{H} . \\
\text { Oliveira }\end{array}$ \\
\hline$E-73 / 2003$ & 10 moedas antigas & $25 / 10 / 2003$ & $\begin{array}{l}\text { Pedro Cabral de } \\
\text { Oliveira }\end{array}$ & Guido Braga \\
\hline$E-74 / 2003$ & Relógio de algibeira (Condor) & $25 / 10 / 2003$ & $\begin{array}{c}\text { Gustavo Alves de } \\
\text { Moura }\end{array}$ & Guido Braga \\
\hline E-75/2003 & Candeia (suporte) & $25 / 10 / 2003$ & Gualter Braulino & Elvis \\
\hline E-76/2003 & $\begin{array}{c}18 \text { moedas de } 100 \text { réis } \\
\text { (emoldurada) }\end{array}$ & $26 / 10 / 2003$ & Elias Ribeiro Nunes & Guido Braga \\
\hline$E-77 / 2003$ & Xícara e pires & $29 / 10 / 2003$ & Tomé Antônio Vitor & $\begin{array}{c}\text { Marcia } \\
\text { Mendes } \\
\end{array}$ \\
\hline E-78/2003 & Paliteiro de ferro & $15 / 11 / 2003$ & José Augusto Carlos & Heloisa Reis \\
\hline E-79/2003 & $\begin{array}{c}\text { Moedas antigas nacionais e } \\
\text { estrangeiras em carteira feminina }\end{array}$ & $17 / 11 / 2003$ & Lilian Maria Bernucci & Heloisa Reis \\
\hline E-80/2003 & 2 Moedas suíça/chile (valor x) & $20 / 11 / 2003$ & $\begin{array}{c}\text { Genivaldo Alves N. } \\
\text { Filho }\end{array}$ & - \\
\hline E-81/2003 & $\begin{array}{l}\text { Moeda prata comemorativa vinda } \\
\text { do papa em julho } 1980\end{array}$ & $23 / 112003$ & $\begin{array}{c}\text { Cláudio Tadeu de } \\
\text { Souza } \\
\end{array}$ & Guido Braga \\
\hline E-82/2003 & Punhal de prata com bainha & $29 / 11 / 2003$ & José Speranza & Heloisa Reis \\
\hline E-83/2003 & $\begin{array}{c}\text { Cédulas: } 1 / 4 \text { de dólar, } 1 \text { moeda } \\
\text { china (provavelmente) }\end{array}$ & $04 / 12 / 2003$ & $\begin{array}{c}\text { Josué Ferreira de } \\
\text { Azevedo }\end{array}$ & Douglas \\
\hline$E-84 / 2003$ & 1 moeda 5 yens & $18 / 12 / 2003$ & $\begin{array}{l}\text { Gliane Guedes } \\
\text { Sakagute }\end{array}$ & Heloisa Reis \\
\hline E-85/2003 & Cédulas brasileiras & $21 / 12 / 2003$ & Tiago da Silva & Guido Braga \\
\hline
\end{tabular}




\begin{tabular}{|c|c|c|c|c|}
\hline $\begin{array}{c}\text { No de } \\
\text { entrada }\end{array}$ & Descrição do Objeto & Data & Doador & $\begin{array}{c}\text { Responsável } \\
\text { Recebimento }\end{array}$ \\
\hline E-86/2003 & $\begin{array}{c}\text { Álbuns, fitas de congregações, } \\
\text { canecos, imagens simples, freio } \\
\text { para cavalo, moedas, objetos } \\
\text { sacros simples }\end{array}$ & $21 / 12 / 2003$ & Zilda Strefezza & Guido Braga \\
\hline E-87/2003 & Cédula de 1 dólar & $23 / 12 / 2003$ & $\begin{array}{c}\text { Lindomar Veras de } \\
\text { Oliveira }\end{array}$ & Guido Braga \\
\hline E-88/2003 & $\begin{array}{c}1 \text { cédula coreana (período 1501- } \\
1570)\end{array}$ & $30 / 12 / 2003$ & Orlando Félix da Hora & Guido Braga \\
\hline E-89/2003 & $\begin{array}{c}\text { 1 prato, 1 quadro, 2 toalhas } \\
\text { bordadas,1 pano }\end{array}$ & $24 / 10 / 2003$ & Sem termo & - \\
\hline
\end{tabular}

Fonte: MNSA/Santuário Nacional.

Quadro 31: Lista de entrada de objetos (2004)

\begin{tabular}{|c|c|c|c|c|}
\hline $\begin{array}{c}\text { № de } \\
\text { entrada }\end{array}$ & Descrição do Objeto & Data & Doador & $\begin{array}{l}\text { Responsável } \\
\text { Recebimento }\end{array}$ \\
\hline E-01/2004 & Notas e moedas & $06 / 01 / 2004$ & Alexandre Sabino & Elvis \\
\hline E-02/2004 & $\begin{array}{c}\text { Moeda } 100 \text { colunes de Costa } \\
\text { Rica }\end{array}$ & $18 / 01 / 2004$ & $\begin{array}{c}\text { Rafael Pereira } \\
\text { Camargo }\end{array}$ & Guido Braga \\
\hline E-03/2004 & $\begin{array}{c}\text { Fotos, bandeira da associação } \\
\text { F.E.B., informativo }\end{array}$ & $22 / 01 / 2004$ & Antônio Cruchaki & Guido Braga \\
\hline E-04/2004 & Notas e moedas brasileiras & $24 / 01 / 2004$ & $\begin{array}{l}\text { Maria Helena dos } \\
\text { Santos Ferreira }\end{array}$ & Guido Braga \\
\hline E-05/2004 & $\begin{array}{c}\text { Cédulas brasileira e moeda: } \\
\text { Grécia e Itália }\end{array}$ & $25 / 01 / 2004$ & $\begin{array}{c}\text { Cleusa Maria Jardim } \\
\text { Rodrigues }\end{array}$ & Guido Braga \\
\hline E-06/2004 & $\begin{array}{c}3 \text { moedas: } 5 \text { cents, } 10 \text { cents e } \\
1 \text { dólar }\end{array}$ & $31 / 01 / 2004$ & Matthew McDonald & Guido Braga \\
\hline E-07/2004 & Mil réis & $01 / 02 / 2004$ & $\begin{array}{l}\text { Alfredo Batista de } \\
\text { Carvalho }\end{array}$ & Guido Braga \\
\hline E-08/2004 & $\begin{array}{c}36 \text { cédulas brasileiras e } 1 \text { real } \\
\text { atual }\end{array}$ & $12 / 02 / 2004$ & Pedro Alves & Heloisa Reis \\
\hline E-09/2004 & 1 cédula da África do Sul & $15 / 02 / 2004$ & lara Aquino da Silva & - \\
\hline E-10/2004 & Escultura face de cristo & $16 / 02 / 2004$ & $\begin{array}{l}\text { Dom Aloísio } \\
\text { Lorscheider }\end{array}$ & Heloisa Reis \\
\hline$E-11 / 2004$ & Moeda chinesa & $06 / 03 / 2004$ & Maurício Esquibelle & Tânia \\
\hline$E-12 / 2004$ & Relógio de pulso & $08 / 03 / 2004$ & $\begin{array}{l}\text { Vicente Paula } \\
\text { Rodrigues }\end{array}$ & Heloisa Reis \\
\hline$E-13 / 2004$ & $\begin{array}{c}2 \text { pedras ametistas em estado } \\
\text { bruto }\end{array}$ & $13 / 03 / 2004$ & Tarcísio Míssilo & Marcia Mendes \\
\hline$E-14 / 2004$ & Pedra ametista do Sul & $13 / 03 / 2004$ & Sônia Idarci Batista & Tânia \\
\hline$E-15 / 2004$ & Tinteiro em porcelana & $14 / 03 / 2004$ & Inácio Luis da Silva & Heloisa Reis \\
\hline$E-16 / 2004$ & Moeda 100 Forint da Hungria & $14 / 03 / 2004$ & Daniel Rogério Fonai & Heloisa Reis \\
\hline E-17/2004 & $\begin{array}{l}\text { Imagem Nossa Senhora } \\
\text { Aparecida }\end{array}$ & $18 / 03 / 2004$ & $\begin{array}{l}\text { Edson Antonio de } \\
\text { Andrade }\end{array}$ & Heloisa Reis \\
\hline E-18/2004 & 1 moeda de 1000 réis & $10 / 04 / 2004$ & José Carlos junior & - \\
\hline$E-19 / 2004$ & $\begin{array}{c}\text { Moedas antigas e cédula de } 1 \\
\text { à } 100 \text { cruzeiros }\end{array}$ & $10 / 04 / 2004$ & Carloto Maquez & Guido Braga \\
\hline E-20/2004 & 1 pedra machadinha & $10 / 04 / 2004$ & Roque Carraca & Guido Braga \\
\hline$E-21 / 2004$ & Cédula 10 rand & $11 / 04 / 2004$ & Yang & Heloisa Reis \\
\hline E-22/2004 & Candeia - séc. XIX & $19 / 04 / 2004$ & $\begin{array}{l}\text { Dária Conceição } \\
\text { Guimarães }\end{array}$ & Heloisa Reis \\
\hline$E-23 / 2004$ & $\begin{array}{c}2 \text { patacas, } 5 \text { moedas: } 100 \text { réis } \\
\text { (1934),100 réis (1901), } 400 \text { réis } \\
\text { (1901) e } 1 \text { tesoura }\end{array}$ & $21 / 04 / 2004$ & $\begin{array}{c}\text { Elita Maria dos Sonhos } \\
\text { Souza }\end{array}$ & Heloisa Reis \\
\hline$E-24 / 2004$ & Manual do cristão devoto & $23 / 04 / 2004$ & Pe. Antônio Dezidério & Heloisa Reis \\
\hline
\end{tabular}




\begin{tabular}{|c|c|c|c|c|}
\hline $\begin{array}{c}\text { № de } \\
\text { entrada }\end{array}$ & Descrição do Objeto & Data & Doador & $\begin{array}{l}\text { Responsável } \\
\text { Recebimento }\end{array}$ \\
\hline & & & Frabetti Vieira & \\
\hline E-25/2004 & 1 relógio, 1 pedra indígena & $24 / 04 / 2004$ & $\begin{array}{c}\text { Antônio Custódio de } \\
\text { Faria } \\
\end{array}$ & Marcos \\
\hline$E-26 / 2004$ & $\begin{array}{l}\text { Quadro comemorativo - } 25 \\
\text { anos da coroação N.S. }\end{array}$ & $15 / 05 / 2004$ & $\begin{array}{c}\text { Maria Regina Buori } \\
\text { Safariz }\end{array}$ & Guido Braga \\
\hline$E-27 / 2004$ & $\begin{array}{c}22 \text { bonecas artesanais, } 2 \\
\text { bonecos }\end{array}$ & $17 / 05 / 2004$ & $\begin{array}{l}\text { Amélia de Oliveira } \\
\text { Carvalho }\end{array}$ & Guido Braga \\
\hline E-28/2004 & $\begin{array}{c}\text { Relógio de pulso orient - } \\
\text { funcionando }\end{array}$ & 20/05/2004 & João Paiva Rodrigues & Guido Braga \\
\hline E-29/2004 & $\begin{array}{l}\text { Pacote de moedas e } 3 \text { cédulas } \\
\text { (cruzado e cruzeiro) }\end{array}$ & $23 / 05 / 2004$ & $\begin{array}{l}\text { Cassimiro Augusto } \\
\text { Pedro }\end{array}$ & Guido Braga \\
\hline$E-30 / 2004$ & Sem informações & $25 / 05 / 2004$ & Juderson Vale Monai & Heloisa Reis \\
\hline$E-31 / 2004$ & $\begin{array}{c}2 \text { relógios de algibeira - marca } \\
\text { Oris e Roamer e } 1 \text { de pulso } \\
\text { (mickey) }\end{array}$ & $29 / 05 / 2004$ & José Mendes & Guido Braga \\
\hline E-32/2004 & Lampião de querosene & 06/06/2004 & $\begin{array}{c}\text { Joselita Arcanjo de } \\
\text { Souza }\end{array}$ & Guido Braga \\
\hline E-33/2004 & $\begin{array}{l}7 \text { relógios de pulso: Mirea, } \\
\text { Orient, June, Sigand (marcas } \\
\text { na sequência dos no de } \\
\text { inventário) }\end{array}$ & 06/06/2004 & $\begin{array}{l}\text { Maria Aparecida } \\
\text { Grande de Paula }\end{array}$ & Heloisa Reis \\
\hline E-34/2004 & Xícara de porcelana & $12 / 06 / 2004$ & $\begin{array}{c}\text { Maria de Lurdes Valter } \\
\text { dos Santos }\end{array}$ & Guido Braga \\
\hline E-35/2004 & 5 Kronnas & $13 / 06 / 2004$ & Tomas Petrik & Heloisa Reis \\
\hline E-36/2004 & Relógio de algibeira & $13 / 06 / 2004$ & Denis Carlos Gomes & Guido Braga \\
\hline E-37/2004 & Moeda 1 dólar 1776 - 1976 & $13 / 06 / 2004$ & $\begin{array}{c}\text { Celan Fontanezzes } \\
\text { Garcis }\end{array}$ & Heloisa Reis \\
\hline E-38/2004 & $\begin{array}{c}1 \text { luminária, par de } \\
\text { castanholas, pilão pequeno } \\
\text { com mão, álbum discográfico }\end{array}$ & $29 / 06 / 2004$ & Dalva Luiza Mattos & Guido Braga \\
\hline E-39/2004 & $\begin{array}{c}1 \text { par de esporas e } 1 \text { foto da } \\
\text { romaria de Pirapora }\end{array}$ & $18 / 07 / 2004$ & Joaquim Moreira Simão & Guido Braga \\
\hline E-40/2004 & Selos comemorativos & $18 / 07 / 2004$ & Adilson Andrade & Guido Braga \\
\hline E-41/2004 & Máquina fotográfica & $18 / 07 / 2004$ & $\begin{array}{c}\text { Maria José Tavares } \\
\text { Oliveira }\end{array}$ & Heloisa Reis \\
\hline E-42/2004 & Relógio de pulso & $18 / 07 / 2004$ & Maria das Dores Rocha & Heloisa Reis \\
\hline$E-43 / 2004$ & $\begin{array}{l}1 \text { lasca de cristal branco, } 1 \\
\text { lasca de cristal com diamante }\end{array}$ & $22 / 07 / 2004$ & Antônio Geraldo Vieira & Guido Braga \\
\hline E-44/2004 & $\begin{array}{c}\text { Trabalho sobre a cidade de } \\
\text { Aparecida }\end{array}$ & $28 / 07 / 2004$ & Manuel Alves Rocha & 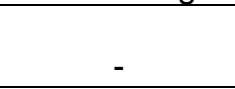 \\
\hline E-45/2004 & 2 moedas de ouro & $28 / 07 / 2004$ & $\begin{array}{l}\text { Maria Aparecida } \\
\text { Milagres }\end{array}$ & Guido Braga \\
\hline E-46/2004 & $\begin{array}{c}\text { Vitrola (Victor Lalburg Machine } \\
\text { - VV IX 554298) }\end{array}$ & $28 / 07 / 2004$ & Waldirene (do Bazar) & Guido Braga \\
\hline E-47/2004 & $\begin{array}{c}\text { Relógio de móvel (Noma } \\
\text { 30/05/92 e 18/06/85) }\end{array}$ & $28 / 07 / 2004$ & $\begin{array}{l}\text { Júlio Oliveira (do } \\
\text { transporte) }\end{array}$ & Guido Braga \\
\hline E-48/2004 & $\begin{array}{c}\text { Máquina de timbrar - símbolo } \\
\text { Basílica, gonfalone e } \\
\text { tintinabulo }\end{array}$ & 28/07/2004 & $\begin{array}{l}\text { Pe. Luís Cláudio (do } \\
\text { batizado) }\end{array}$ & Guido Braga \\
\hline E-49/2004 & Relógio & $30 / 07 / 2004$ & Roberto Licheri & Guido Braga \\
\hline E-50/2004 & $\begin{array}{c}2 \text { cópias da carta de aviso de } \\
\text { Santo Frei Manoel }\end{array}$ & $21 / 07 / 2004$ & José Bastista da Silva & Guido Braga \\
\hline$E-51 / 2004$ & $\begin{array}{c}4 \text { cédulas: } 5,10,50,100 \\
\text { kwanzas e } 1 \text { moeda: } 1 \text { kwanza }\end{array}$ & 05/08/2004 & $\begin{array}{l}\text { Filomena Maria da } \\
\text { Conceição Belo }\end{array}$ & Guido Braga \\
\hline E-52/2004 & $\begin{array}{l}1 \text { livreto, } 1 \text { segundo catecismo, } \\
\text { máquina fotográfica, moedas }\end{array}$ & 06/08/2004 & $\begin{array}{l}\text { Ir. Terezinha Gervársio } \\
\text { (Lar NSA) }\end{array}$ & Guido Braga \\
\hline
\end{tabular}




\begin{tabular}{|c|c|c|c|c|}
\hline $\begin{array}{c}\text { № de } \\
\text { entrada }\end{array}$ & Descrição do Objeto & Data & Doador & $\begin{array}{l}\text { Responsável } \\
\text { Recebimento }\end{array}$ \\
\hline & nacionais e estrangeiras & & & \\
\hline$E-53 / 2004$ & 3 castiçais dourados & 07/08/2004 & $\begin{array}{c}\text { Encaminhado pelo Pe. } \\
\text { Darci }\end{array}$ & Guido Braga \\
\hline$E-54 / 2004$ & $\begin{array}{c}\text { Relógio de pulso feminino } \\
\text { (Royce) } \\
\text { com corrente elástica }\end{array}$ & 07/08/2004 & Vanilda Marins da Silva & Guido Braga \\
\hline$E-55 / 2004$ & $\begin{array}{c}1 \text { relógio de parede, } 2 \\
\text { despertadores, } 4 \text { de pulso }\end{array}$ & $14 / 08 / 2004$ & $\begin{array}{c}\text { Dinorá Aparecida } \\
\text { Faiorato }\end{array}$ & 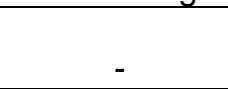 \\
\hline$E-56 / 2004$ & $\begin{array}{c}\text { Cédula } 100 \text { australes } \\
\text { (argentina) }\end{array}$ & $21 / 08 / 2004$ & Marcelo Rodrigues & Guido Braga \\
\hline$E-57 / 2004$ & Moeda 200 réis -1898 & $21 / 08 / 2004$ & Milton Carlos & Guido Braga \\
\hline$E-58 / 2004$ & $\begin{array}{l}\text { Estojo com moedas do } \\
\text { sesquicentenário da } \\
\text { independência }\end{array}$ & $23 / 08 / 2004$ & Aristeu e Lucyla Stecca & Guido Braga \\
\hline E-59/2004 & $\begin{array}{c}2 \text { copos de vidro azul com } \\
\text { suporte prata }\end{array}$ & 02/09/2004 & Ellza Rossi Frate & Guido Braga \\
\hline$E-60 / 2004$ & 1 pedra (ferramenta indígena) & $04 / 09 / 2004$ & Francisco Amaral & Guido Braga \\
\hline E-61/2004 & $\begin{array}{c}1 \text { Nota da Venezuela, } 1 \text { moeda } \\
\text { da Argentina }\end{array}$ & 07/09/2004 & $\begin{array}{c}\text { Nilson Rodrigues } \\
\text { Avelar }\end{array}$ & Guido Braga \\
\hline E-62/2004 & Cédula de 5 cruzeiros & 25/09/2004 & Caio Pronge Polizel & - \\
\hline E-63/2004 & 10 pesos Uruguai & $26 / 09 / 2004$ & $\begin{array}{c}\text { Reginaldo da Silva } \\
\text { Marcolino }\end{array}$ & Guido Braga \\
\hline$E-64 / 2004$ & $\begin{array}{c}1 \text { pedra ametista e } 1 \text { pedra } \\
\text { esmeralda }\end{array}$ & $10 / 10 / 2004$ & $\begin{array}{c}\text { Luiz Carlos Santos } \\
\text { Souza }\end{array}$ & Tânia \\
\hline E-65/2004 & Notas e moedas & 10/10/2004 & $\begin{array}{c}\text { Geraldo José Machado } \\
\text { e Geraldo Martins }\end{array}$ & Heloisa Reis \\
\hline E-66/2004 & 1 moeda fifty pence & $10 / 10 / 2004$ & Waldenir Felix Ribeiro & Heloisa Reis \\
\hline E-67/2004 & Concha batismal & $19 / 10 / 2004$ & José Martins Barbosa & Heloisa Reis \\
\hline E-68/2004 & Terço & $28 / 10 / 2004$ & Dorlei da Cunha & Heloisa Reis \\
\hline E-69/2004 & $\begin{array}{c}4 \text { quadros - ( } 3 \text { com o cardeal e } \\
1 \text { com estampa NSA) }\end{array}$ & $01 / 11 / 2004$ & $\begin{array}{l}\text { Dom Aloísio } \\
\text { Lorscheider }\end{array}$ & Cesar Maia \\
\hline$E-70 / 2004$ & Moeda 25 centavos de Cuba & 07/11/2004 & $\begin{array}{l}\text { José Lopes de } \\
\text { Carvalho }\end{array}$ & Heloisa Reis \\
\hline E-71/2004 & Cédula de 10 dólares & $10 / 11 / 2004$ & $\begin{array}{l}\text { Vanda Franco } \\
\text { Alacantara } \\
\end{array}$ & Heloisa Reis \\
\hline$E-72 / 2004$ & $\begin{array}{l}\text { Relógio de algibeira com } \\
\text { corrente de bronze (roskoff } \\
\text { patent) }\end{array}$ & $13 / 11 / 2004$ & Délio Giacomello & Guido Braga \\
\hline E-73/2004 & $\begin{array}{l}\text { Relógio de pulso com pulseira } \\
\text { (orient) }\end{array}$ & $14 / 11 / 2004$ & Valter Tadeu Leandro & Guido Braga \\
\hline$E-74 / 2004$ & $\begin{array}{l}\text { Relógio de pulso - mostrador } \\
\text { dourado (Hermes) }\end{array}$ & $14 / 11 / 2004$ & $\begin{array}{l}\text { João Evangelista A. } \\
\text { dos Santos }\end{array}$ & Heloisa Reis \\
\hline E-75/2004 & Pedra cristal & $15 / 11 / 2004$ & $\begin{array}{c}\text { Eva Ferreira de } \\
\text { Vasconcelos }\end{array}$ & 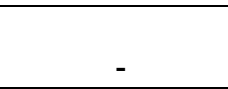 \\
\hline E-76/2004 & $\begin{array}{c}1 \text { recibo de assinatura dos } \\
\text { Ecos Marianos - } 1935\end{array}$ & $15 / 11 / 2004$ & $\begin{array}{c}\text { Eunice Correa Vieira } \\
\text { Públio } \\
\end{array}$ & Guido Braga \\
\hline E-77/2004 & $\begin{array}{l}\text { Relógio de pulso com corrente, } \\
\text { funcionando (seiko) }\end{array}$ & $19 / 11 / 2004$ & $\begin{array}{l}\text { Hilda Ana de Oliveira e } \\
\text { Silva }\end{array}$ & Guido Braga \\
\hline$E-78 / 2004$ & $\begin{array}{c}2 \text { moedas: } 500 \text { réis } 1936 \text { e } \\
\text { uma } 1922\end{array}$ & 05/12/2004 & $\begin{array}{c}\text { Domingos Pires de } \\
\text { Moraes Neto }\end{array}$ & Guido Braga \\
\hline E-79/2004 & 1 corrente, 1 medalha & 05/12/2004 & $\begin{array}{l}\text { Maria de Fatima da } \\
\text { Silva Barbosa }\end{array}$ & Guido Braga \\
\hline$E-80 / 2004$ & 1 moeda uruguaiana -1976 & $18 / 12 / 2004$ & $\begin{array}{l}\text { Marcelo Benedito } \\
\text { Medeiros }\end{array}$ & Tânia \\
\hline$E-81 / 2004$ & Moeda 2000 réis & $18 / 12 / 2004$ & Oswaldino Amario & Guido Braga \\
\hline
\end{tabular}




\begin{tabular}{|c|c|c|c|c|}
\hline $\begin{array}{c}\text { № de } \\
\text { entrada }\end{array}$ & Descrição do Objeto & Data & Doador & $\begin{array}{c}\text { Responsável } \\
\text { Recebimento }\end{array}$ \\
\hline E-82/2004 & Máquina de moer carne & $19 / 12 / 2004$ & Cleuza Cunha Severino & Guido Braga \\
\hline E-83/2004 & Moedas brasileiras & $21 / 12 / 2004$ & Maria Benedita Quisto & Heloisa Reis \\
\hline E-84/2004 & 1 moeda 20 francos belga & $28 / 11 / 2004$ & $\begin{array}{c}\text { Valdinei Gonçalves de } \\
\text { Oliveira }\end{array}$ & Guido Braga \\
\hline E-85/2004 & $\begin{array}{c}\text { Colete oficial de Treino } \\
\text { (Futebol de Araxá) }\end{array}$ & $29 / 05 / 2004$ & Fábio Rodrigues & Guido Braga \\
\hline E-86/2004 & Sacola com partituras musicais & $29 / 06 / 2004$ & Dalva Luiza Mattos & Guido Braga \\
\hline
\end{tabular}

Fonte: MNSA/Santuário Nacional.

Quadro 32: Lista de entrada de objetos (2005)

\begin{tabular}{|c|c|c|c|c|}
\hline $\begin{array}{c}\text { № de } \\
\text { entrada }\end{array}$ & Descrição do Objeto & Data & Doador & $\begin{array}{l}\text { Responsável } \\
\text { Recebimento }\end{array}$ \\
\hline E-01/2005 & 01 moeda de 5000 réis & - & Dona Maria & Guido Braga \\
\hline E-02/2005 & $\begin{array}{c}1 \text { prato decorado NSA com } \\
\text { arabescos dourado }\end{array}$ & $14 / 01 / 2005$ & Terezinha (artesanato) & Guido Braga \\
\hline$E-03 / 2005$ & 89 cédulas de vários países & $20 / 01 / 2005$ & $\begin{array}{c}\text { Encaminhado pelo Pe. } \\
\text { Darci }\end{array}$ & Cesar Maia \\
\hline E-04/2005 & Terço de prata e madrepérola & $20 / 01 / 2005$ & Pe. Darci Nicioli & Guido Braga \\
\hline E-05/2005 & 01 cédula de 500 cruzados & $22 / 01 / 2005$ & $\begin{array}{c}\text { Edina Graça de } \\
\text { Carvalho }\end{array}$ & Guido Braga \\
\hline$E-06 / 2005$ & Balança de pesar ouro & $22 / 01 / 2005$ & Piedade Barbosa Irineu & Guido Braga \\
\hline E-07/2005 & Garrafa com carro de boi & 22/01/2005 & Sebastião Luis Serpa & Guido Braga \\
\hline$E-08 / 2005$ & 01 cédula de 50 cruzados & $23 / 01 / 2005$ & $\begin{array}{c}\text { Epaminondas Barbosa } \\
\text { da Costa Filho }\end{array}$ & Guido Braga \\
\hline$E-09 / 2005$ & $\begin{array}{l}2 \text { moedas: uma de } 5 \text { e outra de } \\
100 \text { pesos chilenos }\end{array}$ & $30 / 01 / 2005$ & $\begin{array}{c}\text { Annette Franscoise de } \\
\text { Vasquez Hernandez }\end{array}$ & Guido Braga \\
\hline$E-10 / 2005$ & $\begin{array}{c}\text { Medalha de prata - Papa João } \\
\text { Paulo II / Santuário }\end{array}$ & $30 / 01 / 2005$ & Ivo de Souza & Guido Braga \\
\hline$E-11 / 2005$ & $\begin{array}{c}1 \text { relógio (F.Bachschmid Patent } \\
27553 \text { com corrente e inscrição } \\
\text { Aristides Castro), } 1 \\
\text { relog.Tissot (Omega - fechado } \\
\text { com corrente) e } 1 \text { cx verde } \\
\text { com moedas e } 1 \text { medalha } \\
\text { N.S.A }\end{array}$ & $31 / 01 / 2005$ & $\begin{array}{l}\text { Encaminhado pelo Pe. } \\
\text { Darci }\end{array}$ & Guido Braga \\
\hline$E-12 / 2005$ & $\begin{array}{c}\text { Cofre verde alemão (№ } \\
65427 / 42)\end{array}$ & $17 / 02 / 2005$ & Pe. Darci Nicioli & Guido Braga \\
\hline$E-13 / 2005$ & Pedra ametista & $18 / 02 / 2005$ & $\begin{array}{c}\text { Magno Alves dos } \\
\text { Santos } \\
\end{array}$ & Guido Braga \\
\hline$E-14 / 2005$ & 02 cédulas de 10 euros & - & Manuel Gonçalves Dias & Elvis \\
\hline$E-15 / 2005$ & $\begin{array}{l}05 \text { livros de oração (O divino, } \\
\text { Livro da missa, O alívio da } \\
\text { alma cristã, Cânticos sacros e } \\
\text { Manuela di Pietá) }\end{array}$ & 19/02/2005 & Joana Bobig & Guido Braga \\
\hline E-16/2005 & $\begin{array}{c}01 \text { moeda (denário) e } 02 \text { fotos } \\
\text { da mesma }\end{array}$ & 05/03/2005 & Augusto Budziak & Marcia Mendes \\
\hline$E-17 / 2005$ & 01 par de brincos & $05 / 03 / 2005$ & $\begin{array}{c}\text { Antônio Mario de } \\
\text { Oliveira }\end{array}$ & Marcia Mendes \\
\hline E-18/2005 & 01 par de brincos & $05 / 03 / 2005$ & $\begin{array}{l}\text { Antônio Mario de } \\
\text { Oliveira }\end{array}$ & Marcia Mendes \\
\hline E-19/2005 & 01 anel & $05 / 03 / 2005$ & $\begin{array}{c}\text { Antônio Mario de } \\
\text { Oliveira }\end{array}$ & Marcia Mendes \\
\hline E-20/2005 & 01 relógio de bolso & 05/03/2005 & $\begin{array}{c}\text { Antônio Mario de } \\
\text { Oliveira }\end{array}$ & Marcia Mendes \\
\hline E-21/2005 & 01 pedra (diamante) & $05 / 03 / 2005$ & Geraldo Alves da Silva & Marcos \\
\hline E-22/2005 & 2 cédulas de cruzeiros: 1 de & $19 / 03 / 2005$ & José Antunes da Silva & Guido Braga \\
\hline
\end{tabular}




\begin{tabular}{|c|c|c|c|c|}
\hline $\begin{array}{c}\text { № de } \\
\text { entrada }\end{array}$ & Descrição do Objeto & Data & Doador & $\begin{array}{l}\text { Responsável } \\
\text { Recebimento }\end{array}$ \\
\hline & 10.000 e 1 de 5.000 & & & \\
\hline$E-23 / 2005$ & 1 cédula de 1000 liras & $20 / 03 / 2005$ & $\begin{array}{l}\text { Mario Sebastião Leite } \\
\text { Ferreia }\end{array}$ & Guido Braga \\
\hline E-24/2005 & Paramentos Litúrgicos & $22 / 03 / 2005$ & Maria Aparecida Freitas & Zilda Ribeiro \\
\hline E-25/2005 & $\begin{array}{l}02 \text { cédulas: } 2 \text { pesos argentinos } \\
\text { e } 26 \text { cédulas do Brasil }\end{array}$ & $25 / 03 / 2005$ & Celso Mazzoli & Marcos \\
\hline E-26/2005 & 01 garrucha e 01 punhal & 03/04/2005 & $\begin{array}{l}\text { Maria Hermelinda } \\
\text { Pereira Nogueira }\end{array}$ & Heloísa Reis \\
\hline E-27/2005 & $\begin{array}{l}02 \text { relógios masculinos e } 2 \\
\text { relógios femininos }\end{array}$ & $10 / 04 / 2005$ & Cilene Bartoni Rondino & Guido Braga \\
\hline E-28/2005 & 01 pingente & $15 / 04 / 2005$ & $\begin{array}{l}\text { Benta Serafim } \\
\text { Anastácio }\end{array}$ & Guido Braga \\
\hline E-29/2005 & 04 cédulas chinesas & $16 / 04 / 2005$ & Maria José Oliveira Flor & Marcos \\
\hline E-30/2005 & $\begin{array}{c}1 \text { rosa de prata (composta } 1 \\
\text { caule, } 3 \text { folhagens e um botão } \\
\text { aberto) }\end{array}$ & $17 / 04 / 2005$ & Cremilda Moreira & - \\
\hline E-31/2005 & $\begin{array}{l}01 \text { anel feminino e } 01 \text { anel de } \\
\text { formatura }\end{array}$ & $22 / 04 / 2005$ & Laura Faria Pohhmam & Marcos \\
\hline E-32/2005 & $\begin{array}{l}01 \text { imagem N.S.A e } 01 \\
\text { medalha c/ corrente }\end{array}$ & 04/05/2005 & $\begin{array}{l}\text { Daymay de Gouveia } \\
\text { Lopez }\end{array}$ & Guido Braga \\
\hline E-33/2005 & 01 relógio de pulso & $14 / 05 / 2005$ & $\begin{array}{l}\text { Maria do Carmo } \\
\text { Casarini }\end{array}$ & Guido Braga \\
\hline E-34/2005 & $\begin{array}{c}50 \text { cruzados, } 10 \text { cruzeiros e } 01 \\
\text { cruzeiro (Cédulas) }\end{array}$ & $15 / 05 / 2005$ & $\begin{array}{l}\text { Joaquim Claudinê } \\
\text { Aparecido Pires }\end{array}$ & Guido Braga \\
\hline E-35/2005 & $\begin{array}{l}02 \text { relógios de pulso Doesnt } \\
\text { (masc.) - Condor (femin.) }\end{array}$ & $18 / 05 / 2005$ & $\begin{array}{l}\text { Genésio Miguel de } \\
\text { Lima }\end{array}$ & Camila \\
\hline E-36/2005 & 01 relógio de bolso (roskoff) & $24 / 05 / 2005$ & Miguel Novaki & Tânia \\
\hline E-37/2005 & Cédulas nacionais & $28 / 05 / 2005$ & Marcos Cardoso Vieira & César Maia \\
\hline E-38/2005 & Cédulas brasileiras & $23 / 05 / 2005$ & Marcos Cardoso Vieira & Guido Braga \\
\hline E-39/2005 & $\begin{array}{l}01 \text { Máquina de costura e } 01 \\
\text { óculos }\end{array}$ & $28 / 05 / 2005$ & Leonidas da Cruz & Guido Braga \\
\hline$E-40 / 2005$ & $\begin{array}{l}02 \text { relógios de pulso (Citizen - } \\
\text { pulseira frisos dourado) e um } \\
\text { Seiko prateado automático }\end{array}$ & 01/06/2005 & $\begin{array}{c}\text { Joselito Arcanjo de } \\
\text { Souza }\end{array}$ & Heloísa Reis \\
\hline E-41/2005 & 01 tacho e 03 caçambas & $01 / 06 / 2005$ & $\begin{array}{l}\text { Elias Airton de } \\
\text { Carvalho }\end{array}$ & Cesar Maia \\
\hline E-42/2005 & 01 cédula (1 Guarani) Paraguai & $12 / 06 / 2005$ & Marcelo de Novais & Guido Braga \\
\hline E-43/2005 & 01 Relógio de parede & $12 / 06 / 2005$ & $\begin{array}{l}\text { José Lunardeli de } \\
\text { Carvalho }\end{array}$ & Guido Braga \\
\hline E-44/2005 & $\begin{array}{l}\text { Amianto com } 07 \text { folhetos } \\
\text { explicativos }\end{array}$ & 29/06/2005 & $\begin{array}{c}\text { Denis Antonio de } \\
\text { Oliveira }\end{array}$ & Douglas \\
\hline E-45/2005 & $\begin{array}{c}01 \text { relógio de bolso com } \\
\text { corrente }\end{array}$ & $26 / 06 / 2005$ & Pedro de Souza & Guido Braga \\
\hline$E-46 / 2005$ & 01 máquina de costura (Singer) & $10 / 07 / 2005$ & Ana de Jesus Arranjo & - \\
\hline$E-47 / 2005$ & 01 Pedra cristal e 02 ametistas & $17 / 07 / 2005$ & Volmir Giotti & Marcos \\
\hline E-48/2005 & $\begin{array}{c}01 \text { xícara com pires e } 1 \text { prato } \\
\text { de bolo }\end{array}$ & 22/07/2005 & $\begin{array}{c}\text { Alderisa de Castro } \\
\text { Maciel }\end{array}$ & Guido Braga \\
\hline E-49/2005 & 01 relicário & $25 / 07 / 2005$ & Amaro Bizerra & Elvis \\
\hline E-50/2005 & $\begin{array}{l}1 \text { moeda australiana: } 1 \text { penny e } \\
1 \text { de } 1 \text { dólar }\end{array}$ & $07 / 08 / 2005$ & $\begin{array}{l}\text { Maria de Jesus } \\
\text { Sardinha }\end{array}$ & Marcos \\
\hline E-51/2005 & Quartzo de cristal branco & $04 / 09 / 2005$ & Ana Conceição Canalli & Guido Braga \\
\hline E-52/2005 & $\begin{array}{l}01 \text { anel de ouro com pedra } \\
\text { água marinha }\end{array}$ & $10 / 09 / 2005$ & $\begin{array}{l}\text { Djanira Fernandes da } \\
\text { Silva }\end{array}$ & Guido Braga \\
\hline E-53/2005 & Moedas e cédulas & $17 / 09 / 2005$ & $\begin{array}{l}\text { Francisco Antonio } \\
\text { Correa Bittencourt }\end{array}$ & Guido Braga \\
\hline
\end{tabular}




\begin{tabular}{|c|c|c|c|c|}
\hline $\begin{array}{c}\text { № de } \\
\text { entrada }\end{array}$ & Descrição do Objeto & Data & Doador & $\begin{array}{l}\text { Responsável } \\
\text { Recebimento }\end{array}$ \\
\hline E-54/2005 & 01 TV 14 polegadas & $24 / 09 / 2005$ & Valter Tadeu Leandro & Elvis \\
\hline$E-55 / 2005$ & 01 moeda de 400 réis & $30 / 09 / 2005$ & $\begin{array}{c}\text { José Raimundo de } \\
\text { Faria }\end{array}$ & Tânia \\
\hline E-56/2005 & 31 cédulas nacionais & $01 / 10 / 2005$ & $\begin{array}{c}\text { Elizabete Benedita } \\
\text { Pereira }\end{array}$ & Guido Braga \\
\hline E-57/2005 & $\begin{array}{c}01 \text { cédula e } 02 \text { moedas } \\
\text { (Guatemala) }\end{array}$ & 01/10/2005 & $\begin{array}{l}\text { Evanir Machado } \\
\text { Gomes }\end{array}$ & Guido Braga \\
\hline E-58/2005 & 01 taça (âmbula) & $07 / 10 / 2005$ & Maria de Martim & Guido Braga \\
\hline E-59/2005 & Jornal datado $2 / 11 / 1940$ & 09/10/2005 & Onofra Alves Vieira & 1 \\
\hline$E-60 / 2005$ & Moedas e cédulas & 09/10/2005 & $\begin{array}{l}\text { Benedito Heleno da } \\
\text { Silva }\end{array}$ & Guido Braga \\
\hline E-61/2005 & Pedra (machadinha) & $11 / 10 / 2005$ & Alda Cesar de Souza & Cleverson \\
\hline$E-62 / 2005$ & 03 xícaras e 3 pires & $11 / 10 / 2005$ & Vicencia Maria Pereira & Cleverson \\
\hline$E-63 / 2005$ & 01 terço de umbanda & $12 / 10 / 2005$ & $\begin{array}{c}\text { Maria Lúcia Soares } \\
\text { Oliveira }\end{array}$ & Cleverson \\
\hline$E-64 / 2005$ & $\begin{array}{c}\text { Cédulas estrangeiras (Japão, } \\
\text { Rússia, Polônia..) }\end{array}$ & $29 / 10 / 2005$ & $\begin{array}{l}\text { Agnaldo Machado dos } \\
\text { Santos }\end{array}$ & Guido Braga \\
\hline$E-65 / 2005$ & 01 relógio de bolso (Ômega) & $30 / 10 / 2005$ & Pedro Batista de Mello & Marcos \\
\hline E-66/2005 & Cédulas: $1,10,50,200$ cruzeiros & $02 / 11 / 2005$ & $\begin{array}{c}\text { Aparecida Cândida } \\
\text { Moreira }\end{array}$ & Guido Braga \\
\hline E-67/2005 & 01 pedra fóssil & $12 / 11 / 2005$ & $\begin{array}{l}\text { Silvano José dos } \\
\text { Santos }\end{array}$ & Marcos \\
\hline$E-68 / 2005$ & 01 cédula (Qatar) & $15 / 11 / 2005$ & Ricardo Gaspar Ribeiro & Guido Braga \\
\hline E-69/2005 & 01 tijelinha de louça & $18 / 11 / 2005$ & $\begin{array}{c}\text { Francisca Maria de } \\
\text { Queiroz }\end{array}$ & Guido Braga \\
\hline E-70/2005 & Xícaras e pires de café (6) & $18 / 11 / 2005$ & $\begin{array}{c}\text { Noeme Nascimento } \\
\text { Novaes }\end{array}$ & Guido Braga \\
\hline E-71/2005 & 01 nível de marceneiro & $19 / 11 / 2005$ & $\begin{array}{l}\text { Gonçalo Vicente da } \\
\text { Silva }\end{array}$ & Guido Braga \\
\hline $\mathrm{E}-72 / 2005$ & 01 pingente (dente de tubarão) & 03/12/2005 & João Vaz dos Santos & Guido Braga \\
\hline E-73/2005 & Talheres de prata & 04/12/2005 & $\begin{array}{c}\text { Eliana Aparecida Muller } \\
\text { da Silva }\end{array}$ & Tânia \\
\hline E-74/2005 & Missal & $07 / 12 / 2005$ & $\begin{array}{c}\text { Marco Antonio Santos } \\
\text { Queiroz }\end{array}$ & - \\
\hline$E-75 / 2005$ & 05 xícaras e 03 pires (vidro) & $11 / 12 / 2005$ & $\begin{array}{c}\text { Therezinha Theodoro } \\
\text { de Oliveira }\end{array}$ & Tânia \\
\hline E-76/2005 & Medalhas (vinda do Papa) & $15 / 11 / 2005$ & $\begin{array}{l}\text { Ana Dalva Ventura } \\
\text { Pereira }\end{array}$ & Elvis \\
\hline E-77/2005 & $\begin{array}{c}01 \text { relógio de bolso } \\
\text { (independência) }\end{array}$ & $18 / 12 / 2005$ & Gentil Monteiro da Silva & Tânia \\
\hline
\end{tabular}

Fonte: MNSA/Santuário Nacional.

Quadro 33: Lista de entrada de objetos (2006)

\begin{tabular}{|c|c|c|c|c|}
\hline $\begin{array}{c}\text { No de } \\
\text { entrada }\end{array}$ & Descrição do Objeto & Data & Doador & $\begin{array}{c}\text { Responsável } \\
\text { Recebimento }\end{array}$ \\
\hline E-01/2006 & 01 aliança & 2006 & $\begin{array}{c}\text { Conceição Luiza do } \\
\text { Couto }\end{array}$ & Marcia Mendes \\
\hline E-02/2006 & $\begin{array}{c}1 \text { estojo com caneta, sinete e } \\
\text { porta lápis }\end{array}$ & - & Sem doador & César Maia \\
\hline E-03/2006 & 01 pingente (crucifixo) & $01 / 01 / 2006$ & $\begin{array}{c}\text { Alessandro Pires } \\
\text { Soares }\end{array}$ & Guido Braga \\
\hline E-04/2006 & $\begin{array}{c}11 \text { estampas sacras (Escultura } \\
\text { Sacra do Brasil Colonial) }\end{array}$ & $07 / 01 / 2006$ & $\begin{array}{c}\text { Onofre da Cunha e } \\
\text { Siva }\end{array}$ & Guido Braga \\
\hline E-05/2006 & $\begin{array}{c}\text { 01 relógio de algibeira com } \\
\text { corrente (Gandar) }\end{array}$ & $21 / 01 / 2006$ & $\begin{array}{c}\text { Sebastião Domingos do } \\
\text { Nascimento }\end{array}$ & Guido Braga \\
\hline E-06/2006 & 01 anel & $30 / 01 / 2006$ & Maria Siqueira da Silva & Marcos \\
\hline
\end{tabular}




\begin{tabular}{|c|c|c|c|c|}
\hline $\begin{array}{c}\text { № de } \\
\text { entrada }\end{array}$ & Descrição do Objeto & Data & Doador & $\begin{array}{l}\text { Responsável } \\
\text { Recebimento }\end{array}$ \\
\hline E-07/2006 & $\begin{array}{c}02 \text { anéis (iguais - prata e } \\
\text { pedras) }\end{array}$ & $02 / 02 / 2006$ & $\begin{array}{l}\text { Ivani Montovani } \\
\text { Ferreira }\end{array}$ & Guido Braga \\
\hline E-08/2006 & 01 anel (pedra branca) & $20 / 02 / 2006$ & Maria Soares da Silva & Heloísa Reis \\
\hline E-09/2006 & 01 relógio & $18 / 03 / 2006$ & $\begin{array}{c}\text { Cleide Maria Ganzella } \\
\text { Lopes }\end{array}$ & Cleverson \\
\hline$E-10 / 2006$ & 1 aliança & $26 / 03 / 2006$ & Marcio Silveira Dias & Marcos \\
\hline$E-11 / 2006$ & 01 sanfoninha de 2 baixos & $01 / 04 / 2006$ & $\begin{array}{c}\text { Ataide Eustáquio } \\
\text { Ferreira }\end{array}$ & - \\
\hline E-12/2006 & Escultura - 3 pescadores & $05 / 04 / 2006$ & $\begin{array}{l}\text { Américo Eduardo da } \\
\text { Costa }\end{array}$ & Guido Braga \\
\hline$E-13 / 2006$ & $\begin{array}{l}\text { Quadra (selos) - } 75 \text { anos da } \\
\text { Coroa da imagem de NSA }\end{array}$ & $10 / 04 / 2006$ & $\begin{array}{c}\text { Michel Henrique de } \\
\text { Oliveira }\end{array}$ & Marcia Mendes \\
\hline E-14/2006 & $\begin{array}{c}\text { Envelope } 1^{\circ} \text { dia - } 75 \text { anos da } \\
\text { Coroa da imagem de NSA }\end{array}$ & $10 / 04 / 2006$ & $\begin{array}{c}\text { Michel Henrique de } \\
\text { Oliveira }\end{array}$ & Marcia Mendes \\
\hline E-15/2006 & 1 medalha da coroação 1904 & $11 / 04 / 2006$ & $\begin{array}{l}\text { Maria Aparecida } \\
\text { Benedeti Mendes }\end{array}$ & Guido Braga \\
\hline E-16/2006 & 01 lampião (preto e vidro) & $15 / 04 / 2006$ & Mauro Pereira da Silva & Guido Braga \\
\hline E-17/2006 & Corrente (ouro 18k) & $16 / 04 / 2006$ & $\begin{array}{c}\text { Sirlene Aparecida } \\
\text { Bento }\end{array}$ & Heloísa Reis \\
\hline E-18/2006 & 1 carregador de cartucho & $22 / 04 / 2006$ & Pedro Uzelotto & Guido Braga \\
\hline E-19/2006 & 1 guizo de cascavel & $26 / 04 / 2006$ & Edson Luis da Silva & Cesar Maia \\
\hline E-20/2006 & $\begin{array}{l}2 \text { véus umeral, } 2 \text { dalmáticas e } \\
1 \text { véu de cálice }\end{array}$ & $26 / 04 / 2006$ & Cúria Metropolitana & Cesar Maia \\
\hline$E-21 / 2006$ & 3 figuras de presépio & $26 / 04 / 2006$ & Guido Machado Braga & Cesar Maia \\
\hline E-22/2006 & Aliança de compromisso (18k) & $30 / 04 / 2006$ & $\begin{array}{l}\text { Celita da Paixão } \\
\text { Teixeira }\end{array}$ & Heloísa Reis \\
\hline$E-23 / 2006$ & $\begin{array}{c}\text { Anel masculino com pedra } \\
\text { vermelha }\end{array}$ & $30 / 04 / 2006$ & Angelo Neri & Heloísa Reis \\
\hline E-24/2006 & 1 pedra (xisto grafitoso) & $09 / 05 / 2006$ & André Cláudio da Silva & Eduardo \\
\hline E-25/2006 & $\begin{array}{c}\text { Talheres de alpaca (incompleto } \\
-4 \text { colheres e } 6 \text { garfos) }\end{array}$ & $14 / 05 / 2006$ & $\begin{array}{c}\text { Eliana Aparecida Muller } \\
\text { da Silva }\end{array}$ & Cleverson \\
\hline E-26/2006 & 1 caixa com bijuterias & $15 / 05 / 2006$ & $\begin{array}{l}\text { Cecília Francisca dos } \\
\text { Santos }\end{array}$ & Guido Braga \\
\hline E-27/2006 & Corrente de ouro com pingente & $15 / 05 / 2006$ & $\begin{array}{l}\text { Maria Regina de } \\
\text { Campos }\end{array}$ & Guido Braga \\
\hline E-28/2006 & $\begin{array}{c}\text { Jogo de café - metal e } \\
\text { esmaltado vermelho flores } \\
\text { pintadas }\end{array}$ & $20 / 05 / 2006$ & $\begin{array}{c}\text { Maria Regina Buosi } \\
\text { Safaríz }\end{array}$ & Guido Braga \\
\hline E-29/2006 & $\begin{array}{c}1 \text { pulseira dourada com pedras } \\
\text { brancas }\end{array}$ & $22 / 05 / 2006$ & Adriane G. Araldi & Marcos \\
\hline E-30/2006 & $\begin{array}{c}2 \text { relógios despertadores e } 1 \\
\text { seringa c/ estojo }\end{array}$ & $11 / 06 / 2006$ & $\begin{array}{l}\text { Madalena Ap. da } \\
\text { Cunha Ramalho }\end{array}$ & Guido Braga \\
\hline$E-31 / 2006$ & 4 bíblias antigas & $15 / 06 / 2006$ & $\begin{array}{l}\text { José Agostino de } \\
\text { Araújo }\end{array}$ & Guido Braga \\
\hline E-32/2006 & 1 relógio de bolso & $17 / 06 / 2006$ & $\begin{array}{c}\text { Luiz Antonio } \\
\text { Chicanoski }\end{array}$ & Guido Braga \\
\hline E-33/2006 & $\begin{array}{c}1 \text { cristal de rocha com suporte } \\
\text { em madeira }\end{array}$ & 09/07/2006 & João dos Santos Rocha & Guido Braga \\
\hline E-34/2006 & $\begin{array}{c}\text { Catálogos de moedas e } \\
\text { cédulas do Brasil }\end{array}$ & $19 / 07 / 2006$ & $\begin{array}{c}\text { Tulio Augusto Toscano } \\
\text { de Mattos }\end{array}$ & Guido Braga \\
\hline E-35/2006 & Cédulas brasileiras & $19 / 07 / 2006$ & $\begin{array}{c}\text { Tulio Augusto Toscano } \\
\text { de Mattos }\end{array}$ & Guido Braga \\
\hline$E-36 / 2006$ & Quartzo rosa lapidado & $23 / 07 / 2006$ & $\begin{array}{l}\text { Ruy Fernandes } \\
\text { Brandão }\end{array}$ & Guido Braga \\
\hline
\end{tabular}




\begin{tabular}{|c|c|c|c|c|}
\hline $\begin{array}{c}\text { № de } \\
\text { entrada }\end{array}$ & Descrição do Objeto & Data & Doador & $\begin{array}{l}\text { Responsável } \\
\text { Recebimento }\end{array}$ \\
\hline E-37/2006 & $\begin{array}{l}1 \text { relógio masc (orient), } 1 \\
\text { relógio fem. e } 1 \text { par de } \\
\text { abotoaduras }\end{array}$ & 23/07/2006 & Lourdes Correa Toniolo & Guido Braga \\
\hline E-38/2006 & 1 cédula de 200 yens (Japão) & $25 / 07 / 2006$ & $\begin{array}{c}\text { José Claudio Custódio } \\
\text { Meossi }\end{array}$ & Eduardo \\
\hline E-39/2006 & $\begin{array}{c}1 \text { quadro da Revolução de } \\
1932\end{array}$ & $25 / 08 / 2006$ & $\begin{array}{c}\text { Maria de Lourdes } \\
\text { Botelho }\end{array}$ & Guido Braga \\
\hline E-40/2006 & 1 anel de platina com diamante & $25 / 08 / 2006$ & $\begin{array}{l}\text { Maria José Dias } \\
\text { Nascimento }\end{array}$ & - \\
\hline E-41/2006 & 1 N. S. Aparecida de bronze & $26 / 08 / 2006$ & $\begin{array}{c}\text { Ana Maria Chagas } \\
\text { Basílio }\end{array}$ & César Maia \\
\hline E-42/2006 & 1 par de aliança de prata & $27 / 08 / 2006$ & Solimar Depóli Ferreira & Marcos \\
\hline$E-43 / 2006$ & Álbum com 12 discos & 02/09/2006 & Valter Tadeu Leandro & Guido Braga \\
\hline E-44/2006 & Corrente com pingente $\mathrm{Z}$ & $02 / 09 / 2006$ & Jose Carlos Pimenta & Guido Braga \\
\hline E-45/2006 & 1 relógio de mesa (Dimep) & 07/09/2006 & $\begin{array}{c}\text { Dejanira Marques } \\
\text { Moura }\end{array}$ & Heloísa Reis \\
\hline E-46/2006 & 1 relógio de mesa & 22/09/2006 & $\begin{array}{l}\text { Maria Aparecida } \\
\text { Pereira }\end{array}$ & Marcos \\
\hline E-47/2006 & 1 corrente com medalha & $24 / 09 / 2006$ & $\begin{array}{c}\text { Lázara Aparecida } \\
\text { Biano }\end{array}$ & Marcos \\
\hline E-48/2006 & 1 pulseira de ouro & $30 / 09 / 2006$ & $\begin{array}{c}\text { Maria Terezinha } \\
\text { Monteiro Coimbra }\end{array}$ & Marcos \\
\hline E-49/2006 & 1 rádio & $30 / 09 / 2006$ & $\begin{array}{c}\text { Alessandro Aparecido } \\
\text { de Oliveira }\end{array}$ & - \\
\hline E-50/2006 & $\begin{array}{c}\text { Xícara de porcelana (2 peças) } \\
\text { japonesa }\end{array}$ & $07 / 10 / 2006$ & $\begin{array}{c}\text { Maria Aparecida de } \\
\text { Lima Vieira }\end{array}$ & Guido Braga \\
\hline E-51/2006 & 1 anel de ouro & $08 / 10 / 2006$ & $\begin{array}{l}\text { Ilza Apparecida de } \\
\text { Barros Lima }\end{array}$ & Marcos \\
\hline$E-52 / 2006$ & 1 relógio de algibeira & $14 / 10 / 2006$ & Carlos Elias Mazon & Guido Braga \\
\hline E-53/2006 & 1 relógio de pulso (Citzen) & $15 / 10 / 2006$ & $\begin{array}{c}\text { Doralice Silva de } \\
\text { Araújo }\end{array}$ & Marcos \\
\hline E-54/2006 & 1 anel com pedras & $15 / 10 / 2006$ & Paula Regina de Souza & Dany Christian \\
\hline E-55/2006 & $\begin{array}{l}\text { Moedas correntes (+- } 365 \text { - } \\
\text { variadas) }\end{array}$ & $22 / 10 / 2006$ & $\begin{array}{c}\text { Maria do Patrocínio } \\
\text { Souza }\end{array}$ & Guido Braga \\
\hline E-56/2006 & 1 cordão de ouro com medalha & $24 / 10 / 2006$ & $\begin{array}{l}\text { Ermelinda Scanavachi } \\
\text { Lonchi }\end{array}$ & Marcos \\
\hline E-57/2006 & 1 miniatura de avião & $30 / 10 / 2006$ & $\begin{array}{c}\text { Maria das Graças } \\
\text { Gomes Canedo }\end{array}$ & Samuel \\
\hline E-58/2006 & $\begin{array}{c}2 \text { moedas de } 2000 \text { réis e } 1 \\
\text { moeda de } 1 \text { dólar }\end{array}$ & $30 / 10 / 2006$ & Desconhecida & César Maia \\
\hline E-59/2006 & Moedas do Império & $31 / 10 / 2006$ & Desconhecida & César Maia \\
\hline E-60/2006 & Cédulas brasileiras & $31 / 10 / 2006$ & Edilson Monteiro & César Maia \\
\hline E-61/2006 & Cédula japonesa - 10 yin & $31 / 10 / 2006$ & Desconhecida & César Maia \\
\hline$E-62 / 2006$ & Cédula de 1 boliviano & $31 / 10 / 2006$ & Desconhecida & César Maia \\
\hline E-63/2006 & Coroa artesanal & $31 / 10 / 2006$ & Desconhecida & César Maia \\
\hline E-64/2006 & $\begin{array}{c}\text { Moedas nacionais } \\
(100,200,4000 \text { réis e } 1 \text { e } 2 \\
\text { cruzeiros) }\end{array}$ & $31 / 10 / 2006$ & Desconhecida & César Maia \\
\hline$E-65 / 2006$ & Cédulas Nacionais & $31 / 10 / 2006$ & Desconhecida & César Maia \\
\hline E-66/2006 & $\begin{array}{l}1 \text { Medalha comemorativa do } \\
\text { encontro da imagem ( } 250 \\
\text { anos) }\end{array}$ & $31 / 10 / 2006$ & $\begin{array}{c}\text { Encaminado pelo Pe. } \\
\text { Darci }\end{array}$ & César Maia \\
\hline$E-67 / 2006$ & $\begin{array}{c}1 \text { medalha comemorativa de } \\
\text { São Paulo }\end{array}$ & $31 / 10 / 2006$ & Desconhecida & - \\
\hline
\end{tabular}




\begin{tabular}{|c|c|c|c|c|}
\hline $\begin{array}{c}\text { No de } \\
\text { entrada }\end{array}$ & Descrição do Objeto & Data & Doador & $\begin{array}{c}\text { Responsável } \\
\text { Recebimento }\end{array}$ \\
\hline E-68/2006 & $\begin{array}{c}\text { 1 bolsa de tecido (com pintas } \\
\text { vermelhas) com moedas }\end{array}$ & $31 / 10 / 2006$ & Desconhecida & César Maia \\
\hline E-69/2006 & 1 pulseira dourada & $31 / 10 / 2006$ & Desconhecida & César Maia \\
\hline E-70/2006 & 1 garrucha & $31 / 10 / 2006$ & Desconhecida & César Maia \\
\hline E-71/2006 & 1 faca de seringueiro & $31 / 10 / 2006$ & Sem doador & César Maia \\
\hline E-72/2006 & $\begin{array}{c}1 \text { casula e 1 estola (Papa João } \\
\text { Paulo II) }\end{array}$ & $31 / 10 / 2006$ & $\begin{array}{c}\text { Pe. Mauro José } \\
\text { Matiazzi }\end{array}$ & César Maia \\
\hline E-73/2006 & 1 relógio de bolso MONDAINE & $10 / 11 / 2006$ & Ignêz Penteado Pastro & Eduardo \\
\hline E-74/2006 & $\begin{array}{c}\text { 1 bíblia (1977) - Edições } \\
\text { Paulinas - Popular }\end{array}$ & $11 / 11 / 2006$ & $\begin{array}{c}\text { Durvalina de Moraes } \\
\text { Azevedo }\end{array}$ & Guido Braga \\
\hline E-75/2006 & $\begin{array}{c}1 \text { bandeja em metal branco } \\
\text { 1 conjunto galheteiro }\end{array}$ & $17 / 11 / 2006$ & $\begin{array}{c}\text { Noeme Nascimento } \\
\text { Novaes }\end{array}$ & $\begin{array}{c}\text { Michel H. } \\
\text { Oliveira }\end{array}$ \\
\hline E-76/2006 & $17 / 11 / 2006$ & $\begin{array}{c}\text { Noeme Nascimento } \\
\text { Novaes }\end{array}$ & $\begin{array}{c}\text { Michel H. } \\
\text { Oliveira }\end{array}$ \\
\hline E-77/2006 & 1 relógio de pulso feminino & $19 / 11 / 2006$ & Thereza Fuzaro & Heloísa Reis \\
\hline E-78/2006 & $\begin{array}{c}\text { 1 cédula de 20 pesos e 1 } \\
\text { cédula de 100 colones }\end{array}$ & $20 / 10 / 2006$ & $\begin{array}{c}\text { Encaminhado pelo Pe. } \\
\text { Cesar Moreira }\end{array}$ & César Maia \\
\hline E-79/2006 & 1 maçarico & $10 / 12 / 2006$ & Erlaine Braga Siqueira & Eduardo \\
\hline E-80/2006 & $\begin{array}{c}\text { Réplica em miniatura da casa } \\
\text { de Santos Dumont }\end{array}$ & $16 / 12 / 2006$ & José Aparecido & Conceição \\
\hline E-81/2006 & $\begin{array}{c}\text { Moedas, cédulas e 1 pedra } \\
\text { branca }\end{array}$ & $18 / 12 / 2006$ & $\begin{array}{c}\text { Odete Bechara (Sem } \\
\text { termo) }\end{array}$ & - \\
\hline
\end{tabular}

Fonte: MNSA/Santuário Nacional.

Quadro 34: Lista de entrada de objetos (2007)

\begin{tabular}{|c|c|c|c|c|}
\hline $\begin{array}{c}\text { № de } \\
\text { entrada }\end{array}$ & Descrição do Objeto & Data & Doador & $\begin{array}{l}\text { Responsável } \\
\text { Recebimento }\end{array}$ \\
\hline$E-01 / 2007$ & Castiçal & 28/01/2007 & Marise Giebiluka & Michel \\
\hline E-02/2007 & 02 Medalhas João Paulo II & 29/01/2007 & Pe. Darci Nicioli & Michel \\
\hline$E-03 / 2007$ & $\begin{array}{c}\text { Selo Comemorativo João Paulo } \\
\text { II }\end{array}$ & $09 / 04 / 2007$ & $\begin{array}{c}\text { Pe. José Luiz Majella } \\
\text { Delgado }\end{array}$ & Erica \\
\hline E-04/2007 & $\begin{array}{c}\text { Selo Comemorativo João Paulo } \\
\text { II }\end{array}$ & $09 / 04 / 2007$ & $\begin{array}{c}\text { Pe. José Luiz Majella } \\
\text { Delgado }\end{array}$ & Erica \\
\hline E-05/2007 & $\begin{array}{c}\text { Selo Comemorativo João Paulo } \\
\text { II }\end{array}$ & $09 / 04 / 2007$ & $\begin{array}{l}\text { Pe. José Luiz Majella } \\
\text { Delgado }\end{array}$ & Erica \\
\hline E-06/2007 & Ecos Marianos - 1950 & $30 / 04 / 2007$ & José Felício Frederico & Erica \\
\hline E-07/2007 & 5 Fotocópias Bento XVI & $21 / 05 / 2007$ & $\begin{array}{c}\text { Pe. José Luiz Majella } \\
\text { Delgado }\end{array}$ & Erica \\
\hline E-08/2007 & 2 Medalhas Bento XVI & $21 / 05 / 2007$ & $\begin{array}{c}\text { Pe. José Luiz Majella } \\
\text { Delgado }\end{array}$ & Erica \\
\hline E-09/2007 & $\begin{array}{c}\text { Medalha Comemorativa Bento } \\
\text { XVI }\end{array}$ & $25 / 05 / 2007$ & $\begin{array}{c}\text { Pe. Hélcio Vicente } \\
\text { Testa }\end{array}$ & Erica \\
\hline$E-10 / 2007$ & $\begin{array}{c}\text { Medalha Comemorativa Bento } \\
\text { XVI }\end{array}$ & $25 / 05 / 2007$ & $\begin{array}{c}\text { Pe. Hélcio Vicente } \\
\text { Testa }\end{array}$ & Erica \\
\hline$E-11 / 2007$ & $\begin{array}{c}\text { Medalha Comemorativa Bento } \\
\text { XVI }\end{array}$ & $25 / 05 / 2007$ & $\begin{array}{l}\text { Pe. Hélcio Vicente } \\
\text { Testa }\end{array}$ & Erica \\
\hline$E-12 / 2007$ & Carda de Fiar lã & $23 / 06 / 2007$ & $\begin{array}{c}\text { Antônia Geralda } \\
\text { Barboza } \\
\end{array}$ & Marcos \\
\hline$E-13 / 2007$ & Terço & $06 / 08 / 2007$ & $\begin{array}{l}\text { Entregue por Pe. Hélcio } \\
\text { Vicente Testa }\end{array}$ & Erica \\
\hline E-14/2007 & Terço & $06 / 08 / 2007$ & $\begin{array}{l}\text { Entregue por Pe. Hélcio } \\
\text { Vicente Testa }\end{array}$ & Erica \\
\hline E-15/2007 & Bíblia llustrada & $19 / 08 / 2007$ & $\begin{array}{c}\text { Verônica Aparecida } \\
\text { Gonçalves }\end{array}$ & Marcos \\
\hline
\end{tabular}




\begin{tabular}{|c|c|c|c|c|}
\hline $\begin{array}{c}\text { No de } \\
\text { entrada }\end{array}$ & Descrição do Objeto & Data & Doador & $\begin{array}{c}\text { Responsável } \\
\text { Recebimento }\end{array}$ \\
\hline E-16/2007 & $\begin{array}{c}\text { Pingente de ouro com zirconia } \\
\text { (Recibo № 2055) }\end{array}$ & $14 / 09 / 2007$ & $\begin{array}{c}\text { Regina Célia Acialde } \\
\text { Nogueira da Silva }\end{array}$ & Dellal \\
\hline E-17/2007 & Par de brincos (ouro e pedras) & $10 / 03 / 2007$ & João José Freire & Marcos \\
\hline
\end{tabular}

Fonte: MNSA/Santuário Nacional.

Quadro 35: Lista de entrada de objetos (2008)

\begin{tabular}{|c|c|c|c|c|}
\hline $\begin{array}{l}\text { № de } \\
\text { entrada }\end{array}$ & Descrição do Objeto & Data & Doador & $\begin{array}{l}\text { Responsável } \\
\text { Recebimento }\end{array}$ \\
\hline$E-01 / 2008$ & Dinheiro antigo & $01 / 01 / 2008$ & Renato Rodrigues & Samuel \\
\hline E-02/2008 & Mitra & 02/01/2008 & $\begin{array}{l}\text { Pe. Rodrigo José } \\
\text { Arnoso }\end{array}$ & Erica Coelho \\
\hline$E-03 / 2008$ & $\begin{array}{c}\text { Cruz Peitoral (dourada, com } \\
\text { ametista e marfim) }\end{array}$ & 02/01/2008 & $\begin{array}{l}\text { Pe. Rodrigo José } \\
\text { Arnoso }\end{array}$ & Erica Coelho \\
\hline$E-04 / 2008$ & Cruz Peitoral (dourada) & $02 / 01 / 2008$ & $\begin{array}{l}\text { Pe. Rodrigo José } \\
\text { Arnoso }\end{array}$ & Erica Coelho \\
\hline E-05/2008 & Solidéu (vermelho) & 02/01/2008 & $\begin{array}{l}\text { Pe. Rodrigo José } \\
\text { Arnoso }\end{array}$ & Erica Coelho \\
\hline E-06/2008 & Mitra & $02 / 01 / 2008$ & $\begin{array}{c}\text { Pe. Rodrigo José } \\
\text { Arnoso }\end{array}$ & Erica Coelho \\
\hline E-07/2008 & Sem identificação & $10 / 01 / 2008$ & Alexandre Lino Ribeiro & Marcos \\
\hline E-08/2008 & Medalha (NSA / Basílica) & $15 / 01 / 2008$ & $\begin{array}{c}\text { Eduardo Marcondes } \\
\text { Machado }\end{array}$ & Erica Coelho \\
\hline E-09/2008 & $\begin{array}{c}\text { Medalha (1ํㅡㄹ Congresso da } \\
\text { Padroeira) }\end{array}$ & $15 / 01 / 2008$ & $\begin{array}{c}\text { Eduardo Marcondes } \\
\text { Machado }\end{array}$ & Erica Coelho \\
\hline$E-10 / 2008$ & $\begin{array}{c}\text { Medalha (Pingente Lembrança } \\
\text { da Coroação de NSA.) }\end{array}$ & $23 / 01 / 2008$ & Vinícius dos Reis Silva & Sara \\
\hline$E-11 / 2008$ & 29 moedas diversas (antigas) & $25 / 01 / 2008$ & Sem doador & Lívia (pastoral) \\
\hline E-12/2008 & Nossa Senhora Aparecida & $29 / 03 / 2008$ & $\begin{array}{c}\text { Antonieta Alves de } \\
\text { Oliveira }\end{array}$ & Dellal \\
\hline$E-13 / 2008$ & Vestes corais (Batina e murça) & $16 / 04 / 2008$ & $\begin{array}{c}\text { Pe. Rodrigo José } \\
\text { Arnoso }\end{array}$ & Erica Coelho \\
\hline E-14/2008 & (1) & $16 / 04 / 2008$ & $\begin{array}{l}\text { Pe. Rodrigo José } \\
\text { Arnoso }\end{array}$ & Erica Coelho \\
\hline E-15/2008 & Solidéu & $16 / 04 / 2008$ & $\begin{array}{l}\text { Pe. Rodrigo José } \\
\text { Arnoso }\end{array}$ & Erica Coelho \\
\hline$E-16 / 2008$ & Mitra & $16 / 04 / 2008$ & $\begin{array}{l}\text { Pe. Rodrigo José } \\
\text { Arnoso }\end{array}$ & Erica Coelho \\
\hline$E-17 / 2008$ & Barrete & $16 / 04 / 2008$ & $\begin{array}{c}\text { Pe. Rodrigo José } \\
\text { Arnoso }\end{array}$ & Erica Coelho \\
\hline$E-18 / 2008$ & $\begin{array}{c}\text { Medalha (Jubileu áureo } \\
\text { sacerdotal) }\end{array}$ & $14 / 05 / 2008$ & $\begin{array}{l}\text { Pe. Hélcio Vicente } \\
\text { Testa }\end{array}$ & Erica Coelho \\
\hline$E-19 / 2008$ & $\begin{array}{c}\text { Medalha (Inauguração do } \\
\text { Parque Industrial de Santa } \\
\text { Cruz) }\end{array}$ & $14 / 05 / 2008$ & $\begin{array}{c}\text { Pe. Hélcio Vicente } \\
\text { Testa } \\
\end{array}$ & Erica Coelho \\
\hline$E-20 / 2008$ & Imagem NSA - em metal & 08/06/2008 & $\begin{array}{c}\text { Carolina Fernandes da } \\
\text { Silva Rocha }\end{array}$ & Conceição \\
\hline$E-21 / 2008$ & Livro de missa e fita mariana & $14 / 06 / 2008$ & Valdemar Bordignon & $\begin{array}{l}\text { Daniela } \\
\text { Ferreira }\end{array}$ \\
\hline$E-22 / 2008$ & Relógio de bolso & $14 / 06 / 2008$ & Valdemar Bordignon & $\begin{array}{l}\text { Daniela } \\
\text { Ferreira } \\
\end{array}$ \\
\hline$E-23 / 2008$ & Bíblia - ano 1816 & $12 / 07 / 2008$ & $\begin{array}{c}\text { Domingas Giaconelli } \\
\text { Langner }\end{array}$ & Samuel \\
\hline$E-24 / 2008$ & Manto de NSA & $06 / 08 / 2008$ & $\begin{array}{l}\text { Maria Wilmar T. } \\
\text { Trevisan }\end{array}$ & Samuel \\
\hline$E-25 / 2008$ & $\begin{array}{l}\text { Livro - D. Pedro Maria de } \\
\text { Lacerda }\end{array}$ & $24 / 08 / 2008$ & D. Beda Andrade Silva & Samuel \\
\hline
\end{tabular}




\begin{tabular}{|c|c|c|c|c|}
\hline $\begin{array}{c}\text { № de } \\
\text { entrada }\end{array}$ & Descrição do Objeto & Data & Doador & $\begin{array}{l}\text { Responsável } \\
\text { Recebimento }\end{array}$ \\
\hline$E-26 / 2008$ & $\begin{array}{l}\text { Nossa Senhora Aparecida } \\
\text { (pedra sabão) }\end{array}$ & $27 / 09 / 2008$ & $\begin{array}{l}\text { Willian Aparecido } \\
\text { Cândido }\end{array}$ & $\begin{array}{c}\text { Michel } \\
\text { Henrique }\end{array}$ \\
\hline$E-27 / 2008$ & Santa Rita (pedra sabão) & $27 / 09 / 2008$ & $\begin{array}{l}\text { Willian Aparecido } \\
\text { Cândido }\end{array}$ & $\begin{array}{l}\text { Michel } \\
\text { Henrique }\end{array}$ \\
\hline E-28/2008 & Pingente (relicário) & $25 / 10 / 2008$ & Margarida Paulina Leite & Daniela \\
\hline$E-29 / 2008$ & Medalhão & $10 / 11 / 2008$ & $\begin{array}{c}\text { Benedita de Andrade } \\
\text { Martins }\end{array}$ & $\begin{array}{l}\text { Michel } \\
\text { Henrique }\end{array}$ \\
\hline$E-30 / 2008$ & $\begin{array}{l}\text { Par de brincos/ dois anéis/ } \\
\text { uma aliança/ uma corrente }\end{array}$ & $24 / 11 / 2008$ & Carmen de Oliveira & $\begin{array}{c}\text { Michel } \\
\text { Henrique }\end{array}$ \\
\hline$E-31 / 2008$ & $\begin{array}{l}\text { Copos de licor (vidro com } \\
\text { decalque) }\end{array}$ & $12 / 12 / 2008$ & Mathilde Ranieri Laso & $\begin{array}{l}\text { Michel } \\
\text { Henrique }\end{array}$ \\
\hline$E-32 / 2008$ & Bíblia Sagrada & $14 / 12 / 2008$ & $\begin{array}{c}\text { Rosália Pereira de } \\
\text { Matos }\end{array}$ & Samuel \\
\hline E-33/2008 & Estola & $19 / 12 / 2008$ & $\begin{array}{c}\text { Pe. Luis Carlos de } \\
\text { Oliveira }\end{array}$ & Erica Coelho \\
\hline E-34/2008 & Quartzo & - & Sem doador & Erica Coelho \\
\hline
\end{tabular}

Fonte: MNSA/Santuário Nacional.

Quadro 36: Lista de entrada de objetos (2009)

\begin{tabular}{|c|c|c|c|c|}
\hline $\begin{array}{l}\text { № de } \\
\text { entrada }\end{array}$ & Descrição do Objeto & Data & Doador & $\begin{array}{l}\text { Responsável } \\
\text { Recebimento }\end{array}$ \\
\hline$E-01 / 2009$ & Carta & $04 / 01 / 2009$ & Adalton de Souza Lima & Dany Christian \\
\hline E-02/2009 & Relicário com fragmento NSA & $08 / 01 / 2009$ & $\begin{array}{l}\text { Pe. Matiazzi entregue } \\
\text { por Pe. Luiz Carlos }\end{array}$ & Erica Coelho \\
\hline E-03/2009 & $\begin{array}{l}\text { Divino espírito santo - } \\
\text { entalhado em madeira } \\
\end{array}$ & $18 / 01 / 2009$ & $\begin{array}{c}\text { Maria José Alves de } \\
\text { Freitas } \\
\end{array}$ & $\begin{array}{l}\text { Deciara } \\
\text { Caroline } \\
\end{array}$ \\
\hline E-04/2009 & Medalha - Papa Bento XVI & $09 / 02 / 2009$ & $\begin{array}{l}\text { Encaminhado pela } \\
\text { Silene }\end{array}$ & Erica Coelho \\
\hline E-05/2009 & Couro de Jaguatirica & $19 / 02 / 2009$ & $\begin{array}{c}\text { Pe. Rubem Leme } \\
\text { Galvão }\end{array}$ & Erica Coelho \\
\hline E-06/2009 & Couro de Sucuri & $19 / 02 / 2009$ & $\begin{array}{l}\text { Pe. Rubem Leme } \\
\text { Galvão }\end{array}$ & Erica Coelho \\
\hline E-07/2009 & Relógio de Pulso feminino & $04 / 04 / 2009$ & Avelina Rosa Ferreira & Conceição \\
\hline E-08/2009 & Escama & $20 / 04 / 2009$ & $\begin{array}{c}\text { Pe. Rubem Leme } \\
\text { Galvão }\end{array}$ & Michel \\
\hline E-09/2009 & Osso da língua do pirarucu & $20 / 04 / 2009$ & $\begin{array}{l}\text { Pe. Rubem Leme } \\
\text { Galvão }\end{array}$ & Michel \\
\hline$E-10 / 2009$ & Forje de couro & $21 / 04 / 2009$ & Vital Lopes Marinho & Valter \\
\hline$E-11 / 2009$ & Celular e estojo & 09/05/2009 & Ivo de Souza & Michel \\
\hline$E-12 / 2009$ & $\begin{array}{l}\text { Nossa Senhora Aparecida } \\
\text { (biscuit) }\end{array}$ & $28 / 05 / 2009$ & Patrícia Brazilus & Erica Coelho \\
\hline$E-13 / 2009$ & Nossa Senhora do Pantanal & $28 / 05 / 2009$ & Dom Fré & Erica Coelho \\
\hline$E-14 / 2009$ & Banco miniatura, livreto e terço & $30 / 05 / 2009$ & $\begin{array}{c}\text { Joanito Arcanjo de } \\
\text { Souza }\end{array}$ & Conceição \\
\hline$E-15 / 2009$ & Crucifixo & jun/09 & $\begin{array}{c}\text { Encaminhado pelo Pe. } \\
\text { Darci }\end{array}$ & Gabriela \\
\hline$E-16 / 2009$ & $\begin{array}{c}\text { Imagem de Nossa Senhora } \\
\text { Aparecida }\end{array}$ & $04 / 06 / 2009$ & $\begin{array}{c}\text { Iracema Grassi } \\
\text { Discinini }\end{array}$ & - \\
\hline$E-17 / 2009$ & Câmera (filmadora) & $26 / 06 / 2009$ & Sem doador & Erica Coelho \\
\hline$E-18 / 2009$ & Livro (sobre Maria) & $17 / 07 / 2009$ & $\begin{array}{c}\text { Luzia Francisca } \\
\text { Susana }\end{array}$ & Conceição \\
\hline$E-19 / 2009$ & Moeda & $22 / 08 / 2009$ & Emecir Peres & $\begin{array}{l}\text { Deciara } \\
\text { Caroline }\end{array}$ \\
\hline$E-20 / 2009$ & Moedas & $30 / 08 / 2009$ & $\begin{array}{c}\text { Ana Maria de } \\
\text { Mendonça }\end{array}$ & Valter \\
\hline
\end{tabular}




\begin{tabular}{|c|c|c|c|c|}
\hline $\begin{array}{c}\text { No de } \\
\text { entrada }\end{array}$ & Descrição do Objeto & Data & Doador & $\begin{array}{c}\text { Responsável } \\
\text { Recebimento }\end{array}$ \\
\hline E-21/2009 & $\begin{array}{c}\text { Imagem de Nossa Senhora } \\
\text { Aparecida }\end{array}$ & $07 / 10 / 2009$ & Yolanda Pepe & Daniela \\
\hline E-22/2009 & Casco de tracajá (tartaruga) & $07 / 10 / 2009$ & $\begin{array}{c}\text { Pe. Rubem Leme } \\
\text { Galvão }\end{array}$ & Erica Coelho \\
\hline E-23/2009 & Manual e fita da congregação & $21 / 10 / 2009$ & Mirtis Ferreira Inacio & Daniela \\
\hline E-24/2009 & Tela e impresso & $25 / 10 / 2009$ & Giovanni D'Andrea & Daniela \\
\hline E-25/2009 & Balança & $01 / 11 / 2009$ & $\begin{array}{c}\text { Antônio Miguel Olisses } \\
\text { de Alencar }\end{array}$ & $\begin{array}{c}\text { Deciara } \\
\text { Caroline }\end{array}$ \\
\hline E-26/2009 & Serra & $02 / 11 / 2009$ & João Camillo de Souza & $\begin{array}{c}\text { Deciara } \\
\text { Caroline }\end{array}$ \\
\hline E-27/2009 & Oratório (?) & $08 / 11 / 2009$ & $\begin{array}{c}\text { Antônio Ferreira das } \\
\text { Neves }\end{array}$ & $\begin{array}{c}\text { Deciara } \\
\text { Caroline }\end{array}$ \\
\hline E-28/2009 & Lampião & $14 / 11 / 2009$ & Luiz Antônio Dias & Valter \\
\hline E-29/2009 & Oração (papel) & $21 / 11 / 2009$ & $\begin{array}{c}\text { Edson Marques } \\
\text { Oliveira }\end{array}$ & $\begin{array}{c}\text { Deciara } \\
\text { Caroline }\end{array}$ \\
\hline E-30/2009 & Pedra indígena & $20 / 12 / 2009$ & Izalino Inacio Paixão & Rodrigo \\
\hline E-31/2009 & Cartilha - Doutrina cristã & Nov./09 & João Avelino da Silva & Dany Christian \\
\hline
\end{tabular}

Fonte: MNSA/Santuário Nacional.

Quadro 37: Lista de entrada de objetos (2010)

\begin{tabular}{|c|c|c|c|c|}
\hline $\begin{array}{l}\text { № de } \\
\text { entrada }\end{array}$ & Descrição do Objeto & Data & Doador & $\begin{array}{l}\text { Responsável } \\
\text { Recebimento }\end{array}$ \\
\hline$E-01 / 2010$ & Nossa Senhora Aparecida & - & Maria Angélica Bastos & Ana Flávia \\
\hline$E-02 / 2010$ & Medalha Papa Paulo VI & $27 / 03 / 2010$ & $\begin{array}{c}\text { Uyraja Lucas Mota } \\
\text { Diniz }\end{array}$ & Daniela \\
\hline$E-03 / 2010$ & Fechadura & $11 / 04 / 2010$ & $\begin{array}{l}\text { Francisco José de } \\
\text { Souza Pinto }\end{array}$ & Rodrigo \\
\hline E-04/2010 & Nossa Senhora da Conceição & 09/05/2010 & $\begin{array}{l}\text { Terezinha Gomes Silva } \\
\text { Dias }\end{array}$ & $\begin{array}{l}\text { Deciara } \\
\text { Caroline }\end{array}$ \\
\hline E-05/2010 & Faca de prata & 09/05/2010 & José Maria Pires & $\begin{array}{l}\text { Deciara } \\
\text { Caroline }\end{array}$ \\
\hline E-06/2010 & Rádio & $21 / 05 / 2010$ & $\begin{array}{l}\text { Manoel Silvestre da } \\
\text { Silva }\end{array}$ & $\begin{array}{l}\text { Deciara } \\
\text { Caroline }\end{array}$ \\
\hline E-07/2010 & Relógio de bolso & $13 / 06 / 2010$ & $\begin{array}{l}\text { Sonia Maria Irineu } \\
\text { Barbosa }\end{array}$ & Daniela \\
\hline E-08/2010 & $\begin{array}{c}\text { Nossa Senhora Aparecida - } \\
\text { metal }\end{array}$ & $21 / 07 / 2010$ & Edna Romão Amate & $\begin{array}{l}\text { Deciara } \\
\text { Caroline }\end{array}$ \\
\hline E-09/2010 & Máquina de costura & $31 / 07 / 2010$ & Aleci Ferreira Jales & $\begin{array}{l}\text { Deciara } \\
\text { Caroline }\end{array}$ \\
\hline$E-10 / 2010$ & Relógio de bolso & 05/09/2010 & $\begin{array}{l}\text { Paulo Araújo da } \\
\text { Trindade }\end{array}$ & Paula \\
\hline$E-11 / 2010$ & Pingente (moeda 500 réis) & $05 / 11 / 2010$ & $\begin{array}{c}\text { Antônia Aparecida } \\
\text { Nogueira de Oliveira }\end{array}$ & $\begin{array}{l}\text { Deciara } \\
\text { Caroline }\end{array}$ \\
\hline
\end{tabular}

Fonte: MNSA/Santuário Nacional.

Quadro 38: Lista de entrada de objetos (2011)

\begin{tabular}{|c|c|c|c|c|}
\hline $\begin{array}{c}\text { NNo de } \\
\text { entrada }\end{array}$ & Descrição do Objeto & Data & Doador & $\begin{array}{c}\text { Responsável } \\
\text { Recebimento }\end{array}$ \\
\hline E-01/2011 & $\begin{array}{c}\text { Notas e Moedas } \\
\text { (Comemorativas) }\end{array}$ & $22 / 01 / 11$ & $\begin{array}{c}\text { Marco Aurélio Lins de } \\
\text { Carvalho }\end{array}$ & Deciara \\
\hline E-02/2011 & Livro de poesias & $23 / 01 / 11$ & $\begin{array}{c}\text { Genivalda Zeferina de } \\
\text { Souza }\end{array}$ & Deciara \\
\hline E-03/2011 & $\begin{array}{c}\text { Quadro de N.S.A com orações } \\
\text { e milagres }\end{array}$ & $23 / 07 / 11$ & $\begin{array}{c}\text { Oswaldo Moreira } \\
\text { Antunes }\end{array}$ & Zenilda \\
\hline E-04/2011 & 3 moedas nacionais (antigas) & $05 / 08 / 11$ & $\begin{array}{c}\text { Amauri José Borgo } \\
\text { Neves }\end{array}$ & Patriza \\
\hline
\end{tabular}




\begin{tabular}{|c|c|c|c|c|}
\hline $\begin{array}{c}\text { № de } \\
\text { entrada }\end{array}$ & Descrição do Objeto & Data & Doador & $\begin{array}{l}\text { Responsável } \\
\text { Recebimento }\end{array}$ \\
\hline E-05/2011 & Relógio de parede & $08 / 10 / 11$ & Izidoro Pinotti & Patriza \\
\hline E-06/2011 & Numismática nacional & $27 / 11 / 11$ & $\begin{array}{c}\text { Natalina Soares de } \\
\text { Chaves }\end{array}$ & Zenilda \\
\hline$E-07 / 2011$ & Estojo (vacina (?)) & $18 / 12 / 2011$ & Respúcio & Paula \\
\hline E-08/2011 & 3 rádios & $25 / 12 / 2011$ & $\begin{array}{c}\text { Albertino Serafim } \\
\text { Pinheiro }\end{array}$ & Deciara \\
\hline E-09/2011 & 4 relógios de pulso & $25 / 12 / 2011$ & $\begin{array}{c}\text { Albertino Serafim } \\
\text { Pinheiro }\end{array}$ & Deciara \\
\hline$E-10 / 2011$ & 2 Santinhos relíquia & $19 / 12 / 2011$ & Pe. Darci & Zenilda \\
\hline E-11/2011 & $\begin{array}{l}1 \text { Medalha prata; } 1 \text { moeda } \\
\text { ouro; conjunto com } 1 \text { medalha } \\
\text { prata e oito moedas de euro } \\
\text { (vaticano) }\end{array}$ & 19/12/2011 & Pe. Darci & Zenilda \\
\hline
\end{tabular}

Fonte: MNSA/Santuário Nacional.

Quadro 39: Lista de entrada de objetos (2012)

\begin{tabular}{|c|c|c|c|c|}
\hline $\begin{array}{c}\text { № de } \\
\text { entrada }\end{array}$ & Descrição do Objeto & Data & Doador & $\begin{array}{l}\text { Responsável } \\
\text { Recebimento }\end{array}$ \\
\hline$E-01 / 2012$ & Cédulas e moedas & $21 / 01 / 2012$ & $\begin{array}{c}\text { Benedita Teodora S. da } \\
\text { Mata }\end{array}$ & Mariana Galvão \\
\hline$E-02 / 2012$ & Oração - impressa & 05/02/2012 & Lázara Franco Romero & Zenilda \\
\hline$E-03 / 2012$ & $\begin{array}{c}\text { Cristaleira (1 caneca, } 2 \\
\text { cristaleiras, } 3 \text { minigarrafas) }\end{array}$ & 08/02/2012 & Mary de Paula & Michel \\
\hline$E-04 / 2012$ & Tronco petrificado & 08/03/2012 & Pe. Galvão & Michel \\
\hline E-05/2012 & Livro: Recordações de 32 & 29/05/2012 & $\begin{array}{l}\text { José Renato dos } \\
\text { Santos Escobar }\end{array}$ & Paula \\
\hline E-06/2012 & Máquina de costura & $30 / 06 / 2012$ & Agnaldo Fonseca Silva & Mariana Galvão \\
\hline$E-07 / 2012$ & Santinho Relíquia & $15 / 10 / 2012$ & $\begin{array}{c}\text { Encaminhado pelo Pe. } \\
\text { Darci }\end{array}$ & Jonathas \\
\hline E-08/2012 & Pedra Basalto & $15 / 10 / 2012$ & $\begin{array}{c}\text { Encaminhado pelo Pe. } \\
\text { Darci }\end{array}$ & Michel \\
\hline$E-09 / 2012$ & Pintura em metal & $15 / 10 / 2012$ & Pe. Darci & Michel \\
\hline$E-10 / 2012$ & Jornal & $31 / 10 / 2012$ & $\begin{array}{l}\text { Paulo Roberto } \\
\text { Saggiorato }\end{array}$ & Gabriela \\
\hline$E-11 / 2012$ & Fragmento de algema (?) & $10 / 11 / 2012$ & Armando Cesar Saliemi & Mariana Galvão \\
\hline$E-12 / 2012$ & Pedra & $11 / 11 / 2012$ & $\begin{array}{l}\text { Maria Ribeiro dos } \\
\text { Santos }\end{array}$ & Mariana Galvão \\
\hline E-13/2012 & Suporte para lubrificante (?) & $14 / 11 / 2012$ & $\begin{array}{l}\text { Esmeralda de Freitas } \\
\text { Arantes }\end{array}$ & Gabriela \\
\hline$E-14 / 2012$ & Máquina de calcular & $16 / 11 / 2012$ & Luis Gulherme Valle & Roseli \\
\hline$E-15 / 2012$ & 02 Medalhas comemorativas & 20/12/2012 & Pe. Darci & Jonatas \\
\hline$E-16 / 2012$ & $\begin{array}{l}02 \text { Papiros e conjunto filatélico } \\
\text { (edital, quadra e } 2 \text { cartões com } \\
\text { selo e carimbo de } 1^{\circ} \text { dia de } \\
\text { circulação, com estojo) }\end{array}$ & $28 / 12 / 2012$ & Pe. Darci & Michel \\
\hline
\end{tabular}

Fonte: MNSA/Santuário Nacional.

Quadro 40: Lista de entrada de objetos (2013)

\begin{tabular}{|c|c|c|c|c|}
\hline $\begin{array}{c}\text { № de } \\
\text { entrada }\end{array}$ & Descrição do Objeto & Data & Doador & $\begin{array}{c}\text { Responsável } \\
\text { Recebimento }\end{array}$ \\
\hline E-01/2013 & Menino Jesus sobre pedestal & $08 / 01 / 2013$ & Paula Torres & Erica Coelho \\
\hline E-02/2013 & $\begin{array}{c}\text { Medalha - Cathédrale Notre- } \\
\text { Dame de Paris }\end{array}$ & $09 / 01 / 2013$ & $\begin{array}{c}\text { Lívia Carolina Seraphin } \\
\text { de Moraes }\end{array}$ & Jonatas Veloso \\
\hline E-03/2013 & $\begin{array}{c}\text { 2 Gravadores de áudio - } \\
\text { UHER / 4000 Report - L }\end{array}$ & $21 / 02 / 2013$ & Daniel Francisco Roma & $\begin{array}{c}\text { Paula Maria } \\
\text { Vettori }\end{array}$ \\
\hline
\end{tabular}




\begin{tabular}{|c|c|c|c|c|}
\hline $\begin{array}{c}\text { № de } \\
\text { entrada }\end{array}$ & Descrição do Objeto & Data & Doador & $\begin{array}{l}\text { Responsável } \\
\text { Recebimento }\end{array}$ \\
\hline E-04/2013 & $\begin{array}{c}\text { Maquete - Santuário Nacional } \\
\text { de Aparecida }\end{array}$ & $23 / 02 / 2013$ & $\begin{array}{l}\text { Adriana Aparecida do } \\
\text { Prado Cruz }\end{array}$ & $\begin{array}{l}\text { Paula Maria } \\
\text { Vettori }\end{array}$ \\
\hline$E-05 / 2013$ & Cédula: 200 cruzeiros & $24 / 02 / 2013$ & João Batista de Souza & $\begin{array}{c}\text { Paula Maria } \\
\text { Vettori }\end{array}$ \\
\hline E-06/2013 & Cédula: 5 cruzeiros & $03 / 03 / 2013$ & $\begin{array}{l}\text { Leonardo Henrique } \\
\text { Garcia Magri }\end{array}$ & $\begin{array}{l}\text { Camila } \\
\text { Carvalho } \\
\text { Queiroz }\end{array}$ \\
\hline$E-07 / 2013$ & Cédulas nacionais (Total 7) & $05 / 03 / 2013$ & Enes Passaretti & $\begin{array}{l}\text { Mariana da } \\
\text { Silva Santos }\end{array}$ \\
\hline$E-08 / 2013$ & $\begin{array}{c}\text { Nossa Senhora Aparecida } \\
\text { (metal) }\end{array}$ & $10 / 03 / 2013$ & $\begin{array}{c}\text { Marilda Aparecida } \\
\text { Appel }\end{array}$ & $\begin{array}{c}\text { Paula Maria } \\
\text { Vettori }\end{array}$ \\
\hline E-09/2013 & $\begin{array}{c}\text { Imagens Sacras diversas e } \\
\text { máquina fotográfica }\end{array}$ & $18 / 03 / 2013$ & Eva Alves Amorim & $\begin{array}{l}\text { Michel } \\
\text { Henrique de } \\
\text { Oliveira }\end{array}$ \\
\hline$E-10 / 2013$ & Cortador de cabelo (manual) & $23 / 03 / 2013$ & Angelo Neri & $\begin{array}{l}\text { Charlene } \\
\text { Karonline }\end{array}$ \\
\hline$E-11 / 2013$ & Cédula: 10 cruzeiros & $23 / 03 / 2013$ & Francisco José da Mata & $\begin{array}{l}\text { Natalia R. } \\
\text { Santos } \\
\text { Reguine }\end{array}$ \\
\hline$E-12 / 2013$ & Artesanato - Camarão & $29 / 04 / 2013$ & Desconhecido & $\begin{array}{l}\text { Michel } \\
\text { Henrique de } \\
\text { Oliveira }\end{array}$ \\
\hline$E-13 / 2013$ & $\begin{array}{l}2 \text { Presépios, } 1 \text { selo chumbo, } 1 \\
\text { selo Papa Bento XVI }\end{array}$ & $10 / 04 / 2013$ & Dom Darci José Nicioli & $\begin{array}{l}\text { Michel } \\
\text { Henrique de } \\
\text { Oliveira }\end{array}$ \\
\hline$E-14 / 2013$ & $\begin{array}{c}6 \text { Relógios de bolso, } 1 \\
\text { medalha, } 1 \text { isqueiro e } 4 \\
\text { moedas }\end{array}$ & 03/05/2013 & Pe. Luiz Cláudio & $\begin{array}{l}\text { Michel } \\
\text { Henrique de } \\
\text { Oliveira }\end{array}$ \\
\hline$E-15 / 2013$ & Pintura: Jogo de xadrez & $17 / 05 / 2013$ & Dom Darci José Nicioli & $\begin{array}{l}\text { Michel } \\
\text { Henrique de } \\
\text { Oliveira }\end{array}$ \\
\hline$E-16 / 2013$ & $\begin{array}{l}4 \text { cabaças (com tamanhos } \\
\text { diferentes) }\end{array}$ & $19 / 05 / 2013$ & Luiz Guedes de Moura & $\begin{array}{l}\text { Mariana da } \\
\text { Silva Santos }\end{array}$ \\
\hline$E-17 / 2013$ & $\begin{array}{c}\text { Pintura: Transladação de } \\
\text { Jesus }\end{array}$ & $24 / 04 / 2013$ & $\begin{array}{c}\text { Sobrinhos de Levy Dias } \\
\text { de Carvalho }\end{array}$ & Pe. Valdivino \\
\hline$E-18 / 2013$ & Livro: Ecos Marianos & 01/06/2013 & Antônio de Paula Silva & $\begin{array}{l}\text { Marcela de F. } \\
\text { O. Silva }\end{array}$ \\
\hline$E-19 / 2013$ & $\begin{array}{l}\text { Escultura: Santa Rita de } \\
\text { Cássia }\end{array}$ & $14 / 08 / 2013$ & $\begin{array}{c}\text { Roberto Pereira } \\
\text { Tavares }\end{array}$ & $\begin{array}{l}\text { Carolina Araújo } \\
\text { Tomé }\end{array}$ \\
\hline E-20/2013 & Cédula: 20 cruzeiros & $19 / 08 / 2013$ & $\begin{array}{c}\text { João Maria Ribeiro da } \\
\text { Cruz }\end{array}$ & $\begin{array}{c}\text { Natalia R. } \\
\text { Santos } \\
\text { Reguine }\end{array}$ \\
\hline$E-21 / 2013$ & Moeda (ficha?) - Havai & 07/09/2013 & $\begin{array}{l}\text { José Antônio da } \\
\text { Fonseca }\end{array}$ & $\begin{array}{l}\text { Solange C. dos } \\
\text { Santos P. Pinto }\end{array}$ \\
\hline$E-22 / 2013$ & Faqueiro - 51 peças & 23/09/2013 & Pe. Luiz Cláudio & $\begin{array}{c}\text { Michel } \\
\text { Henrique de } \\
\text { Oliveira } \\
\end{array}$ \\
\hline E-23/2013 & Relógios de bolso & 23/09/2013 & Pe. Luiz Cláudio & $\begin{array}{c}\text { Michel } \\
\text { Henrique de } \\
\text { Oliveira } \\
\end{array}$ \\
\hline E-24/2013 & $\begin{array}{l}\text { Bolsa, Bomba, Descanso } \\
\text { talher, abridor de carta }\end{array}$ & 23/09/2013 & Pe. Luiz Cláudio & $\begin{array}{l}\text { Michel } \\
\text { Henrique de } \\
\text { Oliveira }\end{array}$ \\
\hline E-25/2013 & 3 Coroas & $23 / 09 / 2013$ & Pe. Luiz Cláudio & $\begin{array}{c}\text { Michel } \\
\text { Henrique de } \\
\text { Oliveira } \\
\end{array}$ \\
\hline E-26/2013 & 2 Tecas e 2 Caixas de hóstia & 23/09/2013 & Pe. Luiz Cláudio & Michel \\
\hline
\end{tabular}




\begin{tabular}{|c|c|c|c|c|}
\hline $\begin{array}{l}\text { № de } \\
\text { entrada }\end{array}$ & Descrição do Objeto & Data & Doador & $\begin{array}{l}\text { Responsável } \\
\text { Recebimento }\end{array}$ \\
\hline & & & & $\begin{array}{l}\text { Henrique de } \\
\text { Oliveira }\end{array}$ \\
\hline E-27/2013 & $\begin{array}{c}\text { Sopeira de louça com tampa e } \\
\text { bandeja }\end{array}$ & $11 / 10 / 2013$ & $\begin{array}{l}\text { Efigênia Tomas } \\
\text { Guimarães }\end{array}$ & $\begin{array}{l}\text { Charlene } \\
\text { Karonline }\end{array}$ \\
\hline$E-28 / 2013$ & $\begin{array}{l}\text { Moedas: Quarter Dólar } \\
\text { (Carolina do Norte) + } 5 \\
\text { Cruzeiros }\end{array}$ & $12 / 10 / 2013$ & $\begin{array}{l}\text { Wagner da Cruz } \\
\text { Gomes }\end{array}$ & $\begin{array}{l}\text { Solange C. dos } \\
\text { Santos P. Pinto }\end{array}$ \\
\hline E-29/2013 & $\begin{array}{l}\text { Nossa Senhora Aparecida } \\
\text { (madeira policromada) }\end{array}$ & $18 / 10 / 2013$ & $\begin{array}{l}\text { Eunice Aparecida } \\
\text { Marqui Domingues }\end{array}$ & $\begin{array}{c}\text { Ana Carolina } \\
\text { Teixeira Neves }\end{array}$ \\
\hline$E-30 / 2013$ & Cédulas nacionais (Total 3) & $26 / 10 / 2013$ & Vanterir Lara & $\begin{array}{l}\text { Solange C. dos } \\
\text { Santos P. Pinto }\end{array}$ \\
\hline E-31/2013 & Cédula: 50.000 cruzeiros & $27 / 10 / 2013$ & $\begin{array}{c}\text { Sebastião Antunes da } \\
\text { Silva }\end{array}$ & $\begin{array}{c}\text { Natalia R. } \\
\text { Santos } \\
\text { Reguine } \\
\end{array}$ \\
\hline E-32/2013 & Cédulas nacionais (Total 10 ) & $01 / 11 / 2013$ & Joel Souza Oliveira & $\begin{array}{c}\text { Ana Carolina } \\
\text { Teixeira Neves }\end{array}$ \\
\hline E-33/2013 & Cédula: 1000 cruzeiros & $10 / 11 / 2013$ & $\begin{array}{c}\text { Silvanildo Fernandes } \\
\text { Barbosa }\end{array}$ & $\begin{array}{c}\text { Natalia R. } \\
\text { Santos } \\
\text { Reguine } \\
\end{array}$ \\
\hline E-34/2013 & Pedra & $10 / 11 / 2013$ & Damião Machado & $\begin{array}{l}\text { Natalia R. } \\
\text { Santos } \\
\text { Reguine }\end{array}$ \\
\hline E-35/2013 & $\begin{array}{c}\text { Relicário (Relíquia de São } \\
\text { Lourenço) }\end{array}$ & $11 / 11 / 2013$ & Lourenço Gaioto & $\begin{array}{l}\text { Pe. Alberto } \\
\text { Pasquoto }\end{array}$ \\
\hline E-36/2013 & Lembrança da Rosa de Ouro & $12 / 11 / 2013$ & Rosa Helena & $\begin{array}{c}\text { Michel } \\
\text { Henrique de } \\
\text { Oliveira }\end{array}$ \\
\hline$E-37 / 2013$ & Ecos Marianos - 1952 & $14 / 11 / 2013$ & Carolina Sotero Bim & $\begin{array}{l}\text { Solange C. dos } \\
\text { Santos P. Pinto }\end{array}$ \\
\hline E-38/2013 & Cédulas nacionais (Total 7) & $15 / 11 / 2013$ & Miguel & $\begin{array}{l}\text { Natalia R. } \\
\text { Santos } \\
\text { Reguine }\end{array}$ \\
\hline E-39/2013 & Cédula: 500.000 cruzeiros & $15 / 11 / 2013$ & Argemiro Leite & $\begin{array}{l}\text { Natalia R. } \\
\text { Santos } \\
\text { Reguine }\end{array}$ \\
\hline$E-40 / 2013$ & Caixa com diversos objetos & $16 / 11 / 2013$ & $\begin{array}{c}\text { Maria de Fátima Couto } \\
\text { Faria }\end{array}$ & $\begin{array}{l}\text { Charlene } \\
\text { Karoline }\end{array}$ \\
\hline$E-41 / 2013$ & 5 Fichas de telefone & $30 / 11 / 2013$ & Luis Antônio & $\begin{array}{c}\text { Natalia R. } \\
\text { Santos } \\
\text { Reguine }\end{array}$ \\
\hline$E-42 / 2013$ & Cédula: 50.000 cruzeiros & $01 / 12 / 2013$ & $\begin{array}{c}\text { Edivail Donizete } \\
\text { Peratelli }\end{array}$ & $\begin{array}{l}\text { Solange C. dos } \\
\text { Santos P. Pinto }\end{array}$ \\
\hline$E-43 / 2013$ & $\begin{array}{l}\text { Rocha (meteorito segundo o } \\
\text { doador) }\end{array}$ & $02 / 12 / 2013$ & José Soares Filho & $\begin{array}{c}\text { Ana Carolina } \\
\text { Teixeira Neves }\end{array}$ \\
\hline$E-44 / 2013$ & Telégrafo & $02 / 12 / 2013$ & $\begin{array}{l}\text { Francisco José Labbate } \\
\text { Neto }\end{array}$ & $\begin{array}{l}\text { Camila } \\
\text { Carvalho } \\
\text { Queiroz }\end{array}$ \\
\hline E-45/2013 & $\begin{array}{c}\text { Imagem de Nossa Senhora } \\
\text { Aparecida }\end{array}$ & 21/12/2013 & Maurício Rodrigo Cadei & $\begin{array}{l}\text { Marcela de F. } \\
\text { O. Silva }\end{array}$ \\
\hline$E-46 / 2013$ & $\begin{array}{l}\text { Máquina de escrever portátil } \\
\text { (Remiton) }\end{array}$ & $22 / 12 / 2013$ & Laurindo Muraro & $\begin{array}{l}\text { Ana Paula dos } \\
\text { Santos Leite }\end{array}$ \\
\hline E-47/2013 & Projetor & 22/12/2013 & Laurindo Muraro & $\begin{array}{l}\text { Ana Paula dos } \\
\text { Santos Leite }\end{array}$ \\
\hline$E-48 / 2013$ & Máquina de calcular & 22/12/2013 & Laurindo Muraro & $\begin{array}{l}\text { Ana Paula dos } \\
\text { Santos Leite }\end{array}$ \\
\hline E-49/2013 & $\begin{array}{l}\text { Santinho relíquia (parcela do } \\
\text { manto) }\end{array}$ & $27 / 12 / 2013$ & 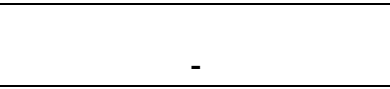 & $\begin{array}{c}\text { Michel } \\
\text { Henrique de }\end{array}$ \\
\hline
\end{tabular}




\begin{tabular}{|c|c|c|c|c|}
\hline $\begin{array}{c}\text { No de } \\
\text { entrada }\end{array}$ & Descrição do Objeto & Data & Doador & $\begin{array}{c}\text { Responsável } \\
\text { Recebimento } \\
\text { Oliveira }\end{array}$ \\
\hline E-50/2013 & $\begin{array}{c}1 \text { cédula, } 6 \text { moedas e } 1 \\
\text { medalha }\end{array}$ & $27 / 12 / 2013$ & - & $\begin{array}{c}\text { Michel } \\
\text { Henrique de } \\
\text { Oliveira }\end{array}$ \\
\hline E-51/2013 & Cédula: 100 cruzados & $31 / 12 / 2012$ & Celso Odinir Gomes & $\begin{array}{c}\text { Ana Carolina } \\
\text { Teixeira Neves }\end{array}$ \\
\hline E-52/2013 & Cédula: 200 cruzeiros & $31 / 12 / 2012$ & Leonidio Ipolito da Silva & $\begin{array}{c}\text { Ana Carolina } \\
\text { Teixeira Neves }\end{array}$ \\
\hline
\end{tabular}

Fonte: MNSA/Santuário Nacional.

Quadro 41: Lista de entrada de objetos (2014)

\begin{tabular}{|c|c|c|c|c|}
\hline $\begin{array}{l}\text { № de } \\
\text { entrada }\end{array}$ & Descrição do Objeto & Data & Doador & $\begin{array}{l}\text { Responsável } \\
\text { Recebimento }\end{array}$ \\
\hline E-01/2014 & $\begin{array}{l}\text { Lâmpada de carbureto; relógio } \\
\text { de bolso; máquina de costura e } \\
\text { manipulador de telégrafo }\end{array}$ & $10 / 01 / 2014$ & Benedito Antônio Lopes & $\begin{array}{l}\text { Solange C. dos } \\
\text { Santos P. Pinto }\end{array}$ \\
\hline$E-02 / 2014$ & $\begin{array}{c}\text { Medalha comemorativa, com } \\
\text { estojo. }\end{array}$ & $20 / 01 / 2014$ & Pe. Domingos Sávio & Jonatas Veloso \\
\hline E-03/2014 & Moeda: 400 réis & $27 / 01 / 2014$ & $\begin{array}{l}\text { Anderson José } \\
\text { Petkowicz }\end{array}$ & $\begin{array}{l}\text { Solange C. dos } \\
\text { Santos P. Pinto }\end{array}$ \\
\hline E-04/2014 & $\begin{array}{c}\text { Cédulas nacionais diversas (total } \\
27 \text { ) }\end{array}$ & $30 / 01 / 2014$ & $\begin{array}{l}\text { Benedita Lemes } \\
\text { Gouvea dos Santos }\end{array}$ & $\begin{array}{l}\text { Charlene } \\
\text { Karonline }\end{array}$ \\
\hline E-05/2014 & $\begin{array}{c}\text { Carteira com cédulas e moedas } \\
\text { diversas }\end{array}$ & 08/02/2014 & $\begin{array}{l}\text { Fatima Aparecida de } \\
\text { Carvalho }\end{array}$ & $\begin{array}{l}\text { Ana Carolina } \\
\text { Teixeira Neves }\end{array}$ \\
\hline E-06/2014 & $\begin{array}{l}\text { Missal e Livro - Devoto de Santa } \\
\text { Terezinha do Menino Jesus }\end{array}$ & $21 / 02 / 2014$ & D. Darci José Nicioli & $\begin{array}{l}\text { Natalia R. } \\
\text { Santos } \\
\text { Reguine }\end{array}$ \\
\hline E-07/2014 & $\begin{array}{c}\text { Cédulas e moedas (diversos), } 1 \\
\text { anel }\end{array}$ & $02 / 03 / 2014$ & $\begin{array}{c}\text { Geraldo de Assis } \\
\text { Ribeiro }\end{array}$ & Renan \\
\hline E-08/2014 & Cédula: 20 cruzeiros & 08/03/2014 & Arveli José Gonçalves & $\begin{array}{c}\text { Ana Carolina } \\
\text { Teixeira Neves }\end{array}$ \\
\hline E-09/2014 & Cédula: 50 cruzeiros & $23 / 03 / 2014$ & $\begin{array}{l}\text { Daniel Machado da } \\
\text { Silva }\end{array}$ & $\begin{array}{c}\text { Ana Carolina } \\
\text { Teixeira Neves }\end{array}$ \\
\hline$E-10 / 2014$ & $\begin{array}{c}\text { Medalha: Nossa Senhora } \\
\text { Aparecida e Papa João Paulo II } \\
(1980)\end{array}$ & $30 / 03 / 2014$ & João Batista Albertini & $\begin{array}{l}\text { Natalia R. } \\
\text { Santos } \\
\text { Reguine }\end{array}$ \\
\hline$E-11 / 2014$ & Apoio de ferro para engraxar & 05/04/2014 & $\begin{array}{l}\text { Maria Aparecida de } \\
\text { Jesus Gril }\end{array}$ & Renan \\
\hline$E-12 / 2014$ & $\begin{array}{l}3 \text { cédulas nacionais ( } 2 \text { de } 200 \\
\text { cruzeiros e } 1 \text { de } 5 \text { cruzeiros) }\end{array}$ & $13 / 04 / 2014$ & $\begin{array}{l}\text { Maria Edileuza dos } \\
\text { Santos Lilis }\end{array}$ & Renan \\
\hline$E-13 / 2014$ & Cédula: 10.000 cruzeiros & $16 / 04 / 2014$ & $\begin{array}{l}\text { Luiz Felipe Rodrigues } \\
\text { Almeida }\end{array}$ & $\begin{array}{l}\text { Marcela de F. } \\
\text { O. Silva }\end{array}$ \\
\hline$E-14 / 2014$ & $\begin{array}{l}\text { Cédulas e moedas nacionais } \\
\text { (11 cédulas e } 12 \text { moedas) }\end{array}$ & $19 / 04 / 2014$ & Cleiton Pinto Machado & $\begin{array}{l}\text { Charlene } \\
\text { Karonline }\end{array}$ \\
\hline$E-15 / 2014$ & 1 Estribo & $19 / 04 / 2014$ & Cleiton Pinto Machado & $\begin{array}{l}\text { Charlene } \\
\text { Karonline }\end{array}$ \\
\hline$E-16 / 2014$ & Cédula: 5.000 cruzeiros & $20 / 04 / 2014$ & Jackson Raul Alves & $\begin{array}{l}\text { Solange C. dos } \\
\text { Santos P. Pinto }\end{array}$ \\
\hline$E-17 / 2014$ & Relógio de parede & $02 / 05 / 2014$ & Jean da Silva Lopes & $\begin{array}{l}\text { Solange C. dos } \\
\text { Santos P. Pinto }\end{array}$ \\
\hline E-18/2014 & Manual do devoto & $11 / 05 / 2014$ & Célio de Souza cardoso & Renan \\
\hline E-19/2014 & Moedas nacionais (total 9) & $15 / 05 / 2014$ & Leonor Garcia Veiga & $\begin{array}{l}\text { Solange C. dos } \\
\text { Santos P. Pinto }\end{array}$ \\
\hline E-20/2014 & $\begin{array}{c}\text { Escultura religiosa: } \\
\text { Nossa Senhora Aparecida }\end{array}$ & $07 / 05 / 2014$ & Nelson Francisco Silva & Pe. Valdivino \\
\hline
\end{tabular}




\begin{tabular}{|c|c|c|c|c|}
\hline $\begin{array}{c}\text { № de } \\
\text { entrada }\end{array}$ & Descrição do Objeto & Data & Doador & $\begin{array}{l}\text { Responsável } \\
\text { Recebimento }\end{array}$ \\
\hline$E-21 / 2014$ & Caixa com 12 peças & $14 / 05 / 2014$ & $\begin{array}{c}\text { Ulysséa Silvares } \\
\text { Verificar informações } \\
\text { no Serviço Social }\end{array}$ & $\begin{array}{l}\text { Michel } \\
\text { Henrique de } \\
\text { Oliveira }\end{array}$ \\
\hline$E-22 / 2014$ & $\begin{array}{c}\text { Cédulas e moedas (nacionais e } \\
\text { internacionais) }\end{array}$ & $21 / 05 / 2014$ & $\begin{array}{l}\text { Pedro Luiz Vidigal } \\
\text { Delmaschio }\end{array}$ & $\begin{array}{c}\text { Ana Carolina } \\
\text { Teixeira Neves }\end{array}$ \\
\hline$E-23 / 2014$ & Cédula: 10 cruzados & 23/05/2014 & $\begin{array}{l}\text { Osvaldecir Adriano } \\
\text { Pereira }\end{array}$ & $\begin{array}{l}\text { Solange C. dos } \\
\text { Santos P. Pinto }\end{array}$ \\
\hline$E-24 / 2014$ & Cédula: 100.000 cruzeiros & $29 / 05 / 2014$ & Osmar Luiz Pinto & $\begin{array}{l}\text { Marcela de F. } \\
\text { O. Silva }\end{array}$ \\
\hline$E-25 / 2014$ & Cédulas e moedas (nacionais) & 01/06/2014 & $\begin{array}{c}\text { Aparecida Rodrigues } \\
\text { Pereira }\end{array}$ & Renan \\
\hline E-26/2014 & $\begin{array}{l}2 \text { máquinas fotográficas } \\
\text { (Kodak e Yashica) }\end{array}$ & 07/06/2014 & José Pereira & $\begin{array}{l}\text { Luziane } \\
\text { Aparecida } \\
\text { Ribeiro }\end{array}$ \\
\hline$E-27 / 2014$ & Moeda: 1 centavo (1969) & $15 / 06 / 2014$ & $\begin{array}{c}\text { Nilton Cavalheiro } \\
\text { Quirino }\end{array}$ & $\begin{array}{l}\text { Natalia R. } \\
\text { Santos } \\
\text { Reguine }\end{array}$ \\
\hline$E-28 / 2014$ & Cédula: 10 cruzeiros & $21 / 06 / 2014$ & $\begin{array}{l}\text { Paulo Cesar Martins } \\
\text { Dias }\end{array}$ & $\begin{array}{l}\text { Marcela de F. } \\
\text { O. Silva }\end{array}$ \\
\hline E-29/2014 & Menino com globo & $25 / 06 / 2014$ & $\begin{array}{l}\text { Marlene da paixão dos } \\
\text { Santos }\end{array}$ & $\begin{array}{c}\text { Luziane } \\
\text { Aparecida } \\
\text { Ribeiro }\end{array}$ \\
\hline E-30/2014 & Cédula: 100.000 cruzeiros & 07/07/2014 & $\begin{array}{c}\text { Gelsomar Sampaio de } \\
\text { Oliveira }\end{array}$ & $\begin{array}{l}\text { Natalia R. } \\
\text { Santos } \\
\text { Reguine }\end{array}$ \\
\hline$E-31 / 2014$ & $\begin{array}{l}\text { Conjunto de moedas, em } \\
\text { acrílico; Medalha comemorativa - } \\
\text { João Paulo II e João XXIII; } \\
\text { Medalha Casa da Moeda, em } \\
\text { acrílico; Medalha - Visita do } \\
\text { Papa Francisco ao Brasil; Placa - } \\
\text { Moedeiro do século XVII }\end{array}$ & $11 / 07 / 2014$ & $\begin{array}{c}\text { Pe. Domingos Sávio da } \\
\text { Silva }\end{array}$ & $\begin{array}{l}\text { Ana Carolina } \\
\text { Teixeira Neves }\end{array}$ \\
\hline E-32/2014 & $\begin{array}{l}\text { Cédulas diversas ( } 26 \text { nacionais } \\
\text { diversas e duas do Paraguai) }\end{array}$ & $14 / 07 / 2014$ & $\begin{array}{l}\text { Joaquim Pires dos } \\
\text { Santos }\end{array}$ & $\begin{array}{l}\text { Charlene } \\
\text { Karonline }\end{array}$ \\
\hline$E-33 / 2014$ & Moeda: 50 centavos & $18 / 07 / 2014$ & Luiz Cardoso Martins & $\begin{array}{c}\text { Natalia R. } \\
\text { Santos } \\
\text { Reguine }\end{array}$ \\
\hline$E-34 / 2014$ & Escultura religiosa: Santa Luzia & $22 / 08 / 2014$ & $\begin{array}{l}\text { Camila Maria Silva } \\
\text { Leite Romano }\end{array}$ & $\begin{array}{l}\text { Solange C. dos } \\
\text { Santos P. Pinto }\end{array}$ \\
\hline$E-35 / 2014$ & Cédulas diversas (total 79) & $24 / 08 / 2014$ & $\begin{array}{c}\text { Torcato Carlos José } \\
\text { Rodrigues }\end{array}$ & $\begin{array}{l}\text { Marcela de F. } \\
\text { O. Silva }\end{array}$ \\
\hline$E-36 / 2014$ & $\begin{array}{c}\text { Manual de Nossa Senhora } \\
\text { Aparecida }\end{array}$ & $25 / 08 / 2014$ & $\begin{array}{l}\text { Pe. José Oscar } \\
\text { Brandão }\end{array}$ & $\begin{array}{c}\text { Natalia R. } \\
\text { Santos } \\
\text { Reguine }\end{array}$ \\
\hline E-37/2014 & Cédula: 1000 cruzeiros & $27 / 08 / 2014$ & Isaias dos Santos & $\begin{array}{l}\text { Luziane } \\
\text { Aparecida } \\
\text { Ribeiro }\end{array}$ \\
\hline$E-38 / 2014$ & Cédulas diversas & $31 / 08 / 2014$ & $\begin{array}{c}\text { Roseli Barbosa } \\
\text { Barcelos }\end{array}$ & $\begin{array}{l}\text { Marcela de F. } \\
\text { O. Silva }\end{array}$ \\
\hline E-39/2014 & Moeda: 50 cruzados & 05/09/2014 & $\begin{array}{l}\text { Mases Maria da Costa } \\
\text { Campos }\end{array}$ & Larissa Ribeiro \\
\hline$E-40 / 2014$ & Cédulas diversas (total 17) & $13 / 09 / 2014$ & Nercy José Maciel & Larissa Ribeiro \\
\hline$E-41 / 2014$ & Máquina de costura & $13 / 09 / 2014$ & Bernadeth Dias Baglie & Larissa Ribeiro \\
\hline$E-42 / 2014$ & $\begin{array}{l}2 \text { Cédulas: } 1 \text { cruzeiro e } 100 \\
\text { cruzados }\end{array}$ & $21 / 09 / 2014$ & $\begin{array}{l}\text { Geraldo de Assis } \\
\text { Ribeiro }\end{array}$ & $\begin{array}{l}\text { Natalia R. } \\
\text { Santos } \\
\text { Reguine }\end{array}$ \\
\hline
\end{tabular}




\begin{tabular}{|c|c|c|c|c|}
\hline $\begin{array}{l}\text { № de } \\
\text { entrada }\end{array}$ & Descrição do Objeto & Data & Doador & $\begin{array}{l}\text { Responsável } \\
\text { Recebimento }\end{array}$ \\
\hline$E-43 / 2014$ & 3 Moedas: 1 real & 24/09/2014 & $\begin{array}{c}\text { Debora Fernanda Melo } \\
\text { de Abreu }\end{array}$ & Larissa Ribeiro \\
\hline$E-44 / 2014$ & 2 Moedas: 1000 réis & 26/09/2014 & $\begin{array}{c}\text { Deusdete Nazaré } \\
\text { Batista Ferreira }\end{array}$ & Tamires Castro \\
\hline$E-45 / 2014$ & Cédula: 100.000 cruzeiros & $28 / 09 / 2014$ & $\begin{array}{l}\text { Adriano Ananias } \\
\text { Andrade Helvecio }\end{array}$ & $\begin{array}{l}\text { Ana Paula dos } \\
\text { Santos Leite }\end{array}$ \\
\hline$E-46 / 2014$ & $\begin{array}{c}\text { Conjunto - Bule, Leiteira e } \\
\text { Açucareiro }+1 \text { São Francisco (de } \\
\text { resina) }\end{array}$ & $30 / 09 / 2014$ & Francisca Soares & $\begin{array}{l}\text { Charlene } \\
\text { Karonline }\end{array}$ \\
\hline E-47/2014 & $\begin{array}{l}\text { Imagem: Nossa Senhora do } \\
\text { Rócio }\end{array}$ & $12 / 10 / 2014$ & $\begin{array}{l}\text { Adriana do Rosil } \\
\text { Silveira }\end{array}$ & Tamires Castro \\
\hline E-48/2014 & Manto de imagem e coroa & 20/10/2014 & $\begin{array}{l}\text { Antônio de Padua } \\
\text { Maranhão Barbosa }\end{array}$ & Larissa Ribeiro \\
\hline E-49/2014 & $\begin{array}{l}\text { Medalha Santo Antônio / } \\
\text { Relicário da Lingua Benta } \\
\end{array}$ & $17 / 10 / 2014$ & $\begin{array}{l}\text { Aparecida Denadai } \\
\text { Mariana }\end{array}$ & Jonatas Veloso \\
\hline E-50/2014 & $\begin{array}{c}\text { Caneca de vidro azul (souvenir } \\
\text { de Aparecida) }\end{array}$ & 29/10/2014 & Dinah Pereira Cardoso & Tamires Castro \\
\hline$E-51 / 2014$ & Raiz de cedro envernizada & $30 / 10 / 2014$ & Mário Alvarenga & $\begin{array}{l}\text { Juliana Maria } \\
\text { S. Pereira }\end{array}$ \\
\hline$E-52 / 2014$ & Calculadora Addometer USA & $31 / 10 / 2014$ & $\begin{array}{c}\text { José Eliezer Bornia } \\
\text { Moreira }\end{array}$ & $\begin{array}{c}\text { Heliane } \\
\text { Caroline Correa } \\
\text { Lima }\end{array}$ \\
\hline$E-53 / 2014$ & $\begin{array}{l}\text { Medalha Beata Assunta } \\
\text { Marchetti / Souvenir } \\
\text { comemorativo do lançamento da } \\
\text { medalha }\end{array}$ & $11 / 11 / 2014$ & $\begin{array}{l}\text { Pe. Domingos Sávio da } \\
\text { Silva }\end{array}$ & $\begin{array}{l}\text { Juliana Maria } \\
\text { S. Pereira }\end{array}$ \\
\hline E-54/2014 & Moeda: 960 réis & 20/11/2014 & $\begin{array}{l}\text { Maria da Conceição } \\
\text { Pinto Magalhães } \\
\end{array}$ & Tamires Castro \\
\hline E-55/2014 & Prato + 59 moedas diversas & $22 / 11 / 2014$ & Augusta Maria da Silva & $\begin{array}{l}\text { Juliana Maria } \\
\text { S. Pereira }\end{array}$ \\
\hline E-56/2014 & 5 moedas & $22 / 11 / 2014$ & $\begin{array}{l}\text { Antônio Luciano de } \\
\text { Matos }\end{array}$ & $\begin{array}{l}\text { Natalia R. } \\
\text { Santos } \\
\text { Reguine }\end{array}$ \\
\hline E-57/2014 & Pilão com mão de pilão & $22 / 11 / 2014$ & $\begin{array}{c}\text { Jovenila dos Santos } \\
\text { Guimarães }\end{array}$ & $\begin{array}{l}\text { Juliana Maria } \\
\text { S. Pereira }\end{array}$ \\
\hline E-58/2014 & Cincerro e Máquina fotográfica & $28 / 11 / 2014$ & $\begin{array}{c}\text { Agostinha Maria de } \\
\text { Jesus }\end{array}$ & Tamires Castro \\
\hline E-59/2014 & Cordão com três medalhas & $30 / 11 / 2014$ & $\begin{array}{c}\text { Frei Washington Luiz } \\
\text { Barbosa }\end{array}$ & $\begin{array}{l}\text { Ana Paula dos } \\
\text { Santos Leite }\end{array}$ \\
\hline E-60/2014 & Cédulas (total 25) & $30 / 11 / 2014$ & $\begin{array}{l}\text { Maria Teixeira de } \\
\text { Santana }\end{array}$ & Larissa Ribeiro \\
\hline E-61/2014 & 04 fotos & 04/12/2014 & $\begin{array}{l}\text { Marcelina Aparecida } \\
\text { Aranda de Melo }\end{array}$ & Larissa Ribeiro \\
\hline E - 62/2014 & Turíbulo & $10 / 12 / 2014$ & $\begin{array}{c}\text { Marlene de Souza } \\
\text { Albernaz }\end{array}$ & Larissa Ribeiro \\
\hline$E-63 / 2014$ & 2 Cédulas: 500 cruzados & $21 / 12 / 2014$ & Francisco Capelario & $\begin{array}{c}\text { Charlene } \\
\text { Karonline } \\
\end{array}$ \\
\hline
\end{tabular}

Fonte: MNSA/Santuário Nacional.

Quadro 42: Lista de entrada de objetos (2015)

\begin{tabular}{|c|c|c|c|c|}
\hline $\begin{array}{c}\text { No de } \\
\text { entrada }\end{array}$ & Descrição do Objeto & Data & Doador & $\begin{array}{c}\text { Responsável } \\
\text { Recebimento }\end{array}$ \\
\hline E - 01/2015 & Cédula: 500.000 cruzeiros & $06 / 01 / 2015$ & Osmar dos Santos & Tamires Castro \\
\hline E - 02/2015 & Cédula: 2 cruzeiros & $16 / 01 / 2015$ & Antônio Braga & Flávia Oliveira \\
\hline E - 03/2015 & $\begin{array}{c}\text { 02 Máquinas fotográficas } \\
\text { (Kodak e VIVITAR) }\end{array}$ & $17 / 01 / 2015$ & Adelina Ana Patrocínio & Juliana Pereira \\
\hline E - 04/2015 & Cédulas & $19 / 01 / 2015$ & Paulo José Pereira & Juliana Pereira \\
\hline
\end{tabular}




\begin{tabular}{|c|c|c|c|c|}
\hline $\begin{array}{c}\text { № de } \\
\text { entrada }\end{array}$ & Descrição do Objeto & Data & Doador & $\begin{array}{l}\text { Responsável } \\
\text { Recebimento }\end{array}$ \\
\hline E - 05/2015 & Cédulas & 29/01/2015 & $\begin{array}{l}\text { José Rodrigues de } \\
\text { Souza }\end{array}$ & Juliana Pereira \\
\hline$E-06 / 2015$ & Cédulas & 29/01/2015 & $\begin{array}{c}\text { Fabrício Ayres de } \\
\text { Almeida }\end{array}$ & Charlene K. \\
\hline E - 07/2015 & Par de caçamba e uma espora & 07/02/2015 & $\begin{array}{c}\text { Maria Aparecida } \\
\text { Pinheiro dos Santos }\end{array}$ & $\begin{array}{l}\text { Natalia R. } \\
\text { Santos } \\
\text { Reguine }\end{array}$ \\
\hline E - 08/2015 & Cédulas e moedas & 09/03/2015 & $\begin{array}{c}\text { Ademilson Amaro de } \\
\text { Lima }\end{array}$ & $\begin{array}{c}\text { Heliane } \\
\text { Caroline C. } \\
\text { Lima }\end{array}$ \\
\hline$E-09 / 2015$ & Máquina Fotográfica & $19 / 03 / 2015$ & José Orlando & Juliana Pereira \\
\hline$E-10 / 2015$ & Cédulas e moedas & $25 / 03 / 2015$ & $\begin{array}{l}\text { Maria Edileuza dos } \\
\text { Santos Lelis }\end{array}$ & Larissa Ribeiro \\
\hline$E-11 / 2015$ & Pintura: Sagrada Face & $27 / 03 / 2015$ & Cláudio Pastro & Erica Coelho \\
\hline$E-12 / 2015$ & Cédula: 5.000 cruzeiros & $02 / 04 / 2015$ & Oldemar José Freitas & Juliana Pereira \\
\hline$E-13 / 2015$ & Mineral & $06 / 04 / 2015$ & $\begin{array}{c}\text { Laura Marcelino de } \\
\text { Souza }\end{array}$ & Charlene K. \\
\hline$E-14 / 2015$ & $\begin{array}{c}\text { Fotografia (Conceição Borges no } \\
\text { Hotel Recreio - 1963) }\end{array}$ & $11 / 04 / 2015$ & $\begin{array}{c}\text { Helenita Rodrigues } \\
\text { Borges }\end{array}$ & Flávia Oliveira \\
\hline$E-15 / 2015$ & $\begin{array}{c}\text { Livro das horas da Virgem } \\
\text { Nossa Senhora }\end{array}$ & $17 / 04 / 2015$ & Roberto Vilela Filho & $\begin{array}{l}\text { Natália R. } \\
\text { Santos }\end{array}$ \\
\hline$E-16 / 2015$ & $\begin{array}{l}\text { Cédula: } 500 \text { cruzeiros } \\
\text { (carimbada) }\end{array}$ & $25 / 04 / 2015$ & Abel Antônio da Costa & $\begin{array}{c}\text { Heliane } \\
\text { Caroline C. } \\
\text { Lima }\end{array}$ \\
\hline$E-17 / 2015$ & Rádio gravador & $10 / 05 / 2015$ & $\begin{array}{c}\text { Francisco Claudino } \\
\text { Santana Filho }\end{array}$ & Larissa Ribeiro \\
\hline E - 18/2015 & Vaso (Coimbra) & 22/05/2015 & $\begin{array}{c}\text { Pe. João Batista de } \\
\text { Almeida }\end{array}$ & Jonatas Veloso \\
\hline$E-19 / 2015$ & Relógio de bolso com corrente & $25 / 05 / 2015$ & $\begin{array}{l}\text { Helena Leite dos } \\
\text { Santos }\end{array}$ & $\begin{array}{c}\text { Heliane } \\
\text { Caroline C. } \\
\text { Lima }\end{array}$ \\
\hline E - 20/2015 & $\begin{array}{l}\text { Pedras (retirada das ruínas do } \\
\text { Palácio de Herodes) }\end{array}$ & $26 / 05 / 2015$ & Divino Barros & $\begin{array}{l}\text { Marcela de F. } \\
\text { O. Silva }\end{array}$ \\
\hline$E-21 / 2015$ & $\begin{array}{c}1 \text { mata borrão, } 1 \text { caneta pena, } 1 \\
\text { tinteiro }\end{array}$ & 29/05/2015 & Nadir Silveira & $\begin{array}{l}\text { Marcela de F. } \\
\text { O. Silva }\end{array}$ \\
\hline$E-22 / 2015$ & Relógio de parede (Cuco) & $10 / 06 / 2015$ & Zilma Piccini Quintas & $\begin{array}{l}\text { Natália R. } \\
\text { Santos }\end{array}$ \\
\hline$E-23 / 2015$ & Nossa Senhora da Conceição & $15 / 06 / 2015$ & Rita de Cássia & Tamires Castro \\
\hline E - 24/2015 & 08 Cédulas de 01 Real & $21 / 06 / 2015$ & Nadir Aparecida & $\begin{array}{l}\text { Marcela de F. } \\
\text { O. Silva }\end{array}$ \\
\hline$E-25 / 2015$ & Bíblia Sagrada & $27 / 06 / 2015$ & $\begin{array}{l}\text { Doadora: Nilza Maria } \\
\text { da Silva } \\
\text { Entregue por: Edvaldo } \\
\text { Vitor Alvino }\end{array}$ & $\begin{array}{l}\text { Natália R. } \\
\text { Santos }\end{array}$ \\
\hline$E-26 / 2015$ & Par de Estribos & 04/07/2015 & $\begin{array}{c}\text { Carlos Ferreira de } \\
\text { Araujo }\end{array}$ & $\begin{array}{l}\text { Paulo Henrique } \\
\text { da Silva }\end{array}$ \\
\hline$E-27 / 2015$ & Cuia de Purungo e Prata & $13 / 07 / 2015$ & $\begin{array}{l}\text { Manoel Antonio Ribas } \\
\text { Coelho }\end{array}$ & $\begin{array}{c}\text { Heliane } \\
\text { Caroline C. } \\
\text { Lima }\end{array}$ \\
\hline$E-28 / 2015$ & Relógio - Pulso e bolso & $13 / 07 / 2015$ & $\begin{array}{l}\text { Manoel Antonio Ribas } \\
\text { Coelho }\end{array}$ & $\begin{array}{c}\text { Heliane } \\
\text { Caroline C. } \\
\text { Lima }\end{array}$ \\
\hline$E-29 / 2015$ & Relógio de bolso com corrente & $12 / 07 / 2015$ & $\begin{array}{c}\text { Alice Rodrigues dos } \\
\text { Santos }\end{array}$ & $\begin{array}{c}\text { Paulo Henrique } \\
\text { da Silva }\end{array}$ \\
\hline$E-30 / 2015$ & Pedaço de madeira & $15 / 07 / 2015$ & Jocineia Pedroni Gava & Juliana Pereira \\
\hline
\end{tabular}




\begin{tabular}{|c|c|c|c|c|}
\hline $\begin{array}{c}\text { № de } \\
\text { entrada }\end{array}$ & Descrição do Objeto & Data & Doador & $\begin{array}{l}\text { Responsável } \\
\text { Recebimento }\end{array}$ \\
\hline$E-31 / 2015$ & 02 Cédulas & $15 / 07 / 2015$ & José de Freitas Filho & $\begin{array}{l}\text { Marcela de F. } \\
\text { O. Silva }\end{array}$ \\
\hline$E-32 / 2015$ & Relógio de Pulso & $21 / 07 / 2015$ & $\begin{array}{c}\text { Maria das Graças } \\
\text { Araujo }\end{array}$ & $\begin{array}{c}\text { Paulo Henrique } \\
\text { da Silva }\end{array}$ \\
\hline$E-33 / 2015$ & 02 Navalhas & $23 / 07 / 2015$ & João Tadeu Bueno & $\begin{array}{l}\text { Natália R. } \\
\text { Santos }\end{array}$ \\
\hline$E-34 / 2015$ & $\begin{array}{c}02 \text { anjinhos e } 3 \text { ímãs de } \\
\text { geladeira }\end{array}$ & $26 / 07 / 2015$ & Marcos Ricardo Souza & Tamires Castro \\
\hline$E-35 / 2015$ & Uma Pedra & $01 / 08 / 2015$ & $\begin{array}{l}\text { Pedro Francisco } \\
\text { Freisleben }\end{array}$ & $\begin{array}{l}\text { Natália R. } \\
\text { Santos }\end{array}$ \\
\hline$E-36 / 2015$ & Uma Pedra & $02 / 08 / 2015$ & Alisson Fabricio Krupek & $\begin{array}{l}\text { Natália R. } \\
\text { Santos }\end{array}$ \\
\hline$E-37 / 2015$ & Debulhador de milho & $31 / 07 / 2015$ & Antonio Carlos Silva & Larissa Ribeiro \\
\hline$E-38 / 2015$ & Faqueiro & $13 / 08 / 2015$ & $\begin{array}{l}\text { Luiz Alfredo S. } \\
\text { Lourenço }\end{array}$ & $\begin{array}{l}\text { Irmã Maria das } \\
\text { Dores }\end{array}$ \\
\hline E - 39/2015 & $\begin{array}{c}\text { Cédulas estrangeiras (215) e } \\
\text { nacionais }(56)\end{array}$ & $10 / 09 / 2015$ & $\begin{array}{c}\text { Maria Auxiliadora } \\
\text { Resende Pinto (Dora) }\end{array}$ & Erica Coelho \\
\hline E - 40/2015 & $\begin{array}{c}2 \text { relógios de pulso } \\
\text { (1 Orient, } 1 \text { Mondaine) }\end{array}$ & 22/09/2015 & $\begin{array}{l}\text { Anna Aparecida de } \\
\text { Moraes Ferraz }\end{array}$ & Larissa Ribeiro \\
\hline E - 41/2015 & $\begin{array}{c}\text { Medalha Comemorativa: XXXVI } \\
\text { Congresso Eucarístico } \\
\text { Internacional }\end{array}$ & $07 / 10 / 2015$ & D. Darci Nicioli & Larissa Ribeiro \\
\hline$E-42 / 2015$ & Travessa & $11 / 10 / 2015$ & $\begin{array}{l}\text { Hélia Laura Dutra } \\
\text { Lopes }\end{array}$ & $\begin{array}{l}\text { Marcela de F. } \\
\text { O. Silva }\end{array}$ \\
\hline$E-43 / 2015$ & Mão de pilão (lítico) & $05 / 11 / 2015$ & José Adauto da Silva & Rogério Borges \\
\hline E - 44/2015 & $\begin{array}{c}\text { Medalha: IV Congresso } \\
\text { Eucarístico Nacional - } 1942\end{array}$ & $17 / 11 / 2015$ & Dom Darci Nicioli & Erica Coelho \\
\hline$E-45 / 2015$ & Lata de "Guaraná Skol" & $19 / 11 / 2015$ & Arquiteta Sueli (Lótus) & Erica Coelho \\
\hline E - 46/2015 & 3 Cédulas Nacionais & $03 / 12 / 2015$ & $\begin{array}{c}\text { Cristino das Virgens } \\
\text { Dourado }\end{array}$ & Rogério Borges \\
\hline E - 47/2015 & Folheto de oração & $03 / 12 / 2015$ & $\begin{array}{l}\text { Antonio Silveira Gomes } \\
\text { Filho }\end{array}$ & Rogério Borges \\
\hline E - 48/2015 & Harpa & 28/12/2015 & $\begin{array}{c}\text { Francisco Carlos de } \\
\text { Lima }\end{array}$ & Juliana Pereira \\
\hline$E-49 / 2015$ & Medalha: 1 milhão de Fusca & $29 / 12 / 2015$ & João da Silva Nunes & Juliana Pereira \\
\hline
\end{tabular}

Fonte: MNSA/Santuário Nacional.

Quadro 43: Lista de entrada de objetos (2016)

\begin{tabular}{|c|c|c|c|c|}
\hline $\begin{array}{c}\text { No de } \\
\text { entrada }\end{array}$ & Descrição do Objeto & Data & Doador & $\begin{array}{c}\text { Responsável } \\
\text { Recebimento }\end{array}$ \\
\hline E - 01/2016 & Cédulas nacionais (Total 5) & $04 / 01 / 2016$ & Vigand Schiestl & Estefani Kelly \\
\hline E - 02/2016 & Medalha NSA e Basílica & $16 / 01 / 2016$ & Audo Rogério Sávio & Tamiris Castro \\
\hline E - 03/2016 & $\begin{array}{c}\text { Conjunto: Bule, Chaleira, } \\
\text { Leiteira, Açucareiro e Bandeja }\end{array}$ & $17 / 01 / 2016$ & $\begin{array}{c}\text { Sebastião Ribeiro da } \\
\text { Silva }\end{array}$ & Larissa Ribeiro \\
\hline E - 04/2016 & $\begin{array}{c}\text { Espingarda, Garrucha e } \\
\text { munições }\end{array}$ & $18 / 01 / 2016$ & $\begin{array}{c}\text { Aparecida Conceição } \\
\text { Pavanelli }\end{array}$ & Natália Santos \\
\hline E - 05/2016 & Moeda: 1000 réis & $10 / 02 / 2016$ & Celso Ambrósio & $\begin{array}{c}\text { Rafaela } \\
\text { Oliveira }\end{array}$ \\
\hline E - 06/2016 & Livro de oração & $14 / 02 / 2016$ & Antônio Luiz Temoteo & Natália Santos \\
\hline E - 07/2016 & Cédulas nacionais (Total 12) & $14 / 02 / 2016$ & João Batista Rodrigues & Tamiris Castro \\
\hline E - 08/2016 & Carteira de couro sintético & $21 / 02 / 2016$ & Huran de Lima & $\begin{array}{c}\text { Rafaela } \\
\text { Oliveira }\end{array}$ \\
\hline E - 09/2016 & Terço de madeira & $23 / 02 / 2016$ & $\begin{array}{c}\text { Aparecida das Graças } \\
\text { de Almeida Loyola }\end{array}$ & Natália Santos \\
\hline E - 10/2016 & Cédulas estrangeiras (49) & $29 / 01 / 2016$ & Maria Auxiliadora & Erica Coelho \\
\hline
\end{tabular}




\begin{tabular}{|c|c|c|c|c|}
\hline $\begin{array}{c}\text { № de } \\
\text { entrada }\end{array}$ & Descrição do Objeto & Data & Doador & $\begin{array}{l}\text { Responsável } \\
\text { Recebimento }\end{array}$ \\
\hline & e nacionais (2) & & Resende Pinto (Dora) & \\
\hline E - 11/2016 & Cédula: 1000 cruzeiros & $27 / 02 / 2016$ & $\begin{array}{l}\text { Edileusa Santana } \\
\text { Rodrigues }\end{array}$ & Natália Santos \\
\hline$E-12 / 2016$ & Máquina de costura & $28 / 02 / 2016$ & Ari Lopes Pinheiro & Paulo \\
\hline E - 13/2016 & Álbum de fotografia (miniatura) & $17 / 03 / 2016$ & $\begin{array}{c}\text { Vera Lúcia Silveira } \\
\text { Favero }\end{array}$ & Juliana Pereira \\
\hline E - 14/2016 & Cédula: 10.000 cruzeiros & $19 / 03 / 2016$ & $\begin{array}{l}\text { Moacir Aparecido dos } \\
\text { Santos }\end{array}$ & $\begin{array}{l}\text { Heliane } \\
\text { Caroline }\end{array}$ \\
\hline E - 15/2016 & Cédula: 5.000 cruzeiros & $25 / 03 / 2016$ & Vicente Zanella & Lucas Marcelo \\
\hline E - 16/2016 & Casula antiga & $31 / 03 / 2016$ & $\begin{array}{c}\text { Pe. José Inácio de } \\
\text { Medeiro }\end{array}$ & Erica Coelho \\
\hline E - 17/2016 & Moedas Nacionais (Total 3) & $14 / 04 / 2016$ & Clauberto Dutra & Natália Santos \\
\hline E - 18/2016 & 1 Moeda de 500 Cruzeiros & $31 / 05 / 2016$ & $\begin{array}{l}\text { Maria de Lourdes } \\
\text { Fernandes }\end{array}$ & Larissa Ribeiro \\
\hline E - 19/2016 & Bujíta ou Muínga & $31 / 05 / 2016$ & Mariana Peres Silva & Lucas Marcelo \\
\hline E - 20/2016 & Vaso de cerâmica & $12 / 06 / 2016$ & Vitória Pereira & $\begin{array}{c}\text { Rafaela } \\
\text { Oliveira } \\
\end{array}$ \\
\hline$E-21 / 2016$ & $\begin{array}{c}\text { Medalhas comemorativas e } \\
\text { moedas }\end{array}$ & 20/06/2016 & Gilberto Pinto Teixeira & Juliana Pereira \\
\hline E - 22/2016 & Balança e Ferro de passar roupa & 04/07/2016 & $\begin{array}{l}\text { Alice Rodrigues dos } \\
\text { Santos }\end{array}$ & Maria Fernanda \\
\hline$E-23 / 2016$ & $\begin{array}{c}\text { Medalhas comemorativas Papa } \\
\text { João Paulo II }\end{array}$ & $15 / 07 / 2016$ & Dom Darci José & Cesar \\
\hline E - 24/2016 & Cédula de 200 Cruzeiros & $19 / 07 / 2016$ & $\begin{array}{l}\text { Amarildo Queiroz da } \\
\text { Silva }\end{array}$ & Maria Fernanda \\
\hline E - 25/2016 & Moeda de 10 Centavos - 1995 & $19 / 07 / 2016$ & $\begin{array}{c}\text { Sergio Felipe da } \\
\text { Silveira Rezende } \\
\text { Villasanti }\end{array}$ & Maria Fernanda \\
\hline$E-26 / 2016$ & 16 cédulas diversas & $19 / 07 / 2016$ & José de Freitas Filho & Maria Fernanda \\
\hline E - 27/2016 & Cédula de 10.000 Cruzeiros & $19 / 07 / 2016$ & $\begin{array}{c}\text { Rosangela Avelina do } \\
\text { Rego }\end{array}$ & $\begin{array}{l}\text { Rafaela } \\
\text { Oliveira } \\
\end{array}$ \\
\hline E - 28/2016 & Goiaca & $17 / 07 / 2016$ & Joaquim Diocezio Silva & Juliana Pereira \\
\hline E - 29/2016 & Medalha do Menino Jesus & 23/07/2016 & $\begin{array}{l}\text { Murilo Henrique de } \\
\text { Castro Mendes }\end{array}$ & Juliana Pereira \\
\hline$E-30 / 2016$ & $\begin{array}{c}\text { Medalha em Honra a Virgem } \\
\text { Imaculado Conceição Aparecida } \\
\text { e Pasta }\end{array}$ & $19 / 07 / 2016$ & $\begin{array}{c}\text { Carmen Novoa Silva } \\
\text { (Associação Amigos da } \\
\text { Catedral) } \\
\end{array}$ & Paulo \\
\hline$E-31 / 2016$ & $\begin{array}{c}\text { Âmbula e dois Cálices de } \\
\text { Madeira }\end{array}$ & $27 / 07 / 2016$ & Vilma de Siqueira Melo & $\begin{array}{l}\text { Heliane } \\
\text { Caroline }\end{array}$ \\
\hline$E-32 / 2016$ & Relógio de pulso & 01/08/2016 & Antôniio Furman & Natália Santos \\
\hline$E-33 / 2016$ & Máquina fotográfica & $22 / 08 / 2016$ & $\begin{array}{l}\text { Benedita de Barros } \\
\text { Ribeiro }\end{array}$ & Lucas Marcelo \\
\hline E - 34/2016 & $\begin{array}{l}\text { Cédula Nacionais Cruzeiros } \\
\text { (Total 4) }\end{array}$ & $22 / 08 / 2016$ & $\begin{array}{l}\text { Reginaldo A. de } \\
\text { Medeiros }\end{array}$ & Lucas Marcelo \\
\hline$E-35 / 2016$ & Candelabro & $26 / 08 / 2016$ & Vaniely Costa Moreira & Maria Fernanda \\
\hline$E-36 / 2016$ & Bloco de notas Cardeal Motta & 05/09/2016 & $\begin{array}{c}\text { Pe. Júnior } \\
\text { Doador desconhecido }\end{array}$ & Juliana Pereira \\
\hline E - 37/2016 & $\begin{array}{c}\text { Lembrança do Congresso } \\
\text { Eucarístico Internacional do Rio } \\
\text { de Janeiro }\end{array}$ & $11 / 07 / 2016$ & José Jorge Marinho & Jonatas Veloso \\
\hline E - 38/2016 & $\begin{array}{c}\text { Cédula: } 2.000 \text { bolívares e } \\
\text { Cédula: } 1 \text { real }\end{array}$ & $11 / 09 / 2016$ & Geovane Teodoro Neto & Natália Santos \\
\hline E - 39/2016 & Cédula: 1 cruzeiro e 2 cruzeiros & 23/09/2016 & $\begin{array}{c}\text { Gerson dos Santos } \\
\text { Ribeiro }\end{array}$ & $\begin{array}{l}\text { Heliane } \\
\text { Caroline }\end{array}$ \\
\hline
\end{tabular}




\begin{tabular}{|c|c|c|c|c|}
\hline $\begin{array}{l}\text { № de } \\
\text { entrada }\end{array}$ & Descrição do Objeto & Data & Doador & $\begin{array}{l}\text { Responsável } \\
\text { Recebimento }\end{array}$ \\
\hline E - 40/2016 & 67 cédulas antigas & $25 / 09 / 2016$ & Nestor Mendes Freitas & Tamiris Castro \\
\hline E - 41/2016 & $\begin{array}{l}\text { Oratório de parede com } \\
\text { recipiente para água benta e } \\
\text { Santo Antônio }\end{array}$ & 30/09/2016 & José Francisco Coluço & $\begin{array}{l}\text { Heliane } \\
\text { Caroline }\end{array}$ \\
\hline E - 42/2016 & $\begin{array}{c}\text { Moeda: } 10 \text { cruzado e Cédula: } \\
500.000 \text { cruzeiros }\end{array}$ & 05/10/2016 & $\begin{array}{l}\text { Rosareia de Fática } \\
\text { Mendes Martins }\end{array}$ & $\begin{array}{l}\text { Heliane } \\
\text { Caroline }\end{array}$ \\
\hline$E-43 / 2016$ & Relógio (ouro) & $08 / 10 / 2016$ & Luiz Antônio Rigo & Natália Santos \\
\hline E - 44/2016 & $\begin{array}{c}\text { Medalha com estojo (SZT. } \\
\text { ISTVÁN) }\end{array}$ & $21 / 10 / 2016$ & $\begin{array}{l}\text { Gustavo Jalifi / } \\
\text { Entregue por Pe. } \\
\text { Eduardo Ribeiro }\end{array}$ & Lucas Marcelo \\
\hline$E-45 / 2016$ & Grampeador & $24 / 10 / 2016$ & José Canova & Rogério Borges \\
\hline E - 46/2016 & $\begin{array}{c}\text { Álbum de moedas } \\
\text { comemorativas - Olimpíada } 2012 \\
\text { a } 2016\end{array}$ & $28 / 10 / 2016$ & $\begin{array}{l}\text { Helenilsa Maria da } \\
\text { Silva }\end{array}$ & Rogério Borges \\
\hline$E-47 / 2016$ & Moeda: 400 réis & $11 / 11 / 2016$ & Antonio de Faria & Tamiris Castro \\
\hline E - 48/2016 & Uma imagem de São Benedito & 19/11/2016 & $\begin{array}{c}\text { Marlene Liopoldo dos } \\
\text { Santos }\end{array}$ & Maria Fernanda \\
\hline E - 49/2016 & Medalha comemorativa 300 anos & $24 / 11 / 2016$ & $\begin{array}{c}\text { Marina Agostinho } \\
\text { Salvati }\end{array}$ & $\begin{array}{l}\text { Rafaela } \\
\text { Oliveira }\end{array}$ \\
\hline E - 50/2016 & $\begin{array}{l}10 \text { Moedas de um centavo de } \\
\text { dólar e uma nota de um dólar }\end{array}$ & $28 / 11 / 2016$ & $\begin{array}{c}\text { Juliano Barusso } \\
\text { Berleze }\end{array}$ & Rogério Borges \\
\hline E - 51/2016 & 3 Relógios de pulso & 06/12/2016 & $\begin{array}{c}\text { Nilde Maria de Fatima } \\
\text { Frois }\end{array}$ & Natália Santos \\
\hline E - 52/2016 & Réplica do Campanário & 09/12/2016 & Alderísio Trevisan & Gabriel Soares \\
\hline E - 53/2016 & Máquina Fotográfica - Kapsa & $11 / 12 / 2016$ & $\begin{array}{c}\text { Maria Alice Pereira } \\
\text { Batista } \\
\end{array}$ & Rogério Borges \\
\hline E - 54/2016 & Disco de Vinil & $16 / 12 / 2016$ & José Francisco Coluço & $\begin{array}{l}\text { Heliane } \\
\text { Caroline }\end{array}$ \\
\hline E - 55/2016 & $\begin{array}{c}\text { Folha de Selos (Jubileu } 300 \\
\text { anos) + Placa com Carimbo } \\
\text { Comemorativo }\end{array}$ & $12 / 12 / 2016$ & Solange Parron & Jonatas Veloso \\
\hline E - 56/2016 & Folha de cheque - 1772 & $27 / 12 / 2016$ & $\begin{array}{c}\text { José Aparecido de } \\
\text { Oliveira }\end{array}$ & Juliana Pereira \\
\hline
\end{tabular}

Fonte: MNSA/Santuário Nacional.

Quadro 44: Lista de entrada de objetos (2017)

\begin{tabular}{|c|c|c|c|c|}
\hline $\begin{array}{l}\text { № de } \\
\text { entrada }\end{array}$ & Descrição do Objeto & Data & Doador & $\begin{array}{l}\text { Responsável } \\
\text { Recebimento }\end{array}$ \\
\hline E - 01/2017 & $\begin{array}{l}\text { Placas de homenagens, } \\
\text { diplomas e condecorações }\end{array}$ & 03/01/2017 & $\begin{array}{l}\text { D. Raymundo } \\
\text { Damasceno Assis }\end{array}$ & Erica Coelho \\
\hline E - 02/2017 & $\begin{array}{c}\text { Pasta dos Correios com selo e } \\
\text { carimbo - Jubileu } 300 \text { anos de } \\
\text { devoção }\end{array}$ & 05/01/2017 & $\begin{array}{l}\text { Pe. João Batista } \\
\text { C.Ss.R }\end{array}$ & Erica Coelho \\
\hline E - 03/2017 & $\begin{array}{l}\text { Relicário com relíquia de osso - } \\
\text { Beato Giuseppe Toniolo }\end{array}$ & 05/01/2017 & $\begin{array}{l}\text { Pe. João Batista } \\
\text { C.Ss.R }\end{array}$ & Erica Coelho \\
\hline E - 04/2017 & $\begin{array}{c}\text { Livro do } 1^{\circ} \text { centenário do } \\
\text { Município de Santa Aldélia/SP }\end{array}$ & 08/01/2017 & $\begin{array}{c}\text { Valtecir Aparecido } \\
\text { Faria }\end{array}$ & Gabriel Santos \\
\hline E - 05/2017 & $\begin{array}{c}\text { Moeda: } 1 \text { real (olimpíadas 2016) } \\
\text { - Total: } 17 \text { unidades }\end{array}$ & 09/01/2017 & $\begin{array}{c}\text { Irisvania de Souza } \\
\text { Paschoal }\end{array}$ & Maria Fernanda \\
\hline E - 06/2017 & $\begin{array}{l}\text { Livro: Standard Catalog of World } \\
\text { Coins - } 1980 \text { edition }\end{array}$ & $15 / 02 / 2017$ & $\begin{array}{c}\text { Sandra Brecheret } \\
\text { Pellegrini }\end{array}$ & Erica Coelho \\
\hline E - 07/2017 & $\begin{array}{l}\text { Cunhos descaracterizados e } \\
\text { Medalhas Comemorativas dos } \\
300 \text { anos }\end{array}$ & 20/02/2017 & $\begin{array}{l}\text { Casa da Moeda do } \\
\text { Brasil / Entregue por } \\
\text { Pe. João Batista }\end{array}$ & Jonatas Veloso \\
\hline E - 08/2017 & $\begin{array}{c}\text { Escultura: Menino Jesus de } \\
\text { Praga }\end{array}$ & $15 / 03 / 2017$ & Pe. Eduardo Ribeiro & Juliana Pereira \\
\hline
\end{tabular}




\begin{tabular}{|c|c|c|c|c|}
\hline $\begin{array}{c}\text { № de } \\
\text { entrada }\end{array}$ & Descrição do Objeto & Data & Doador & $\begin{array}{l}\text { Responsável } \\
\text { Recebimento }\end{array}$ \\
\hline E - 09/2017 & Condecorações & $21 / 03 / 2017$ & $\begin{array}{c}\text { D. Raymundo } \\
\text { Damasceno Assis }\end{array}$ & Erica Coelho \\
\hline E - 10/2017 & Bolsa feminina de metal & 08/04/2017 & $\begin{array}{l}\text { Stella Maria Jorge } \\
\text { Bastianetto }\end{array}$ & Maria Fernanda \\
\hline E - 11/2017 & $\begin{array}{l}\text { Escultura: Nossa Senhora } \\
\text { Aparecida (Gesso) }\end{array}$ & 08/04/2017 & Silvina Marins da Silva & $\begin{array}{l}\text { Heliane } \\
\text { Caroline }\end{array}$ \\
\hline E - 12/2017 & Moeda: 10 pesos uruguayos & $20 / 04 / 2017$ & $\begin{array}{c}\text { José Cláudio de Vargas } \\
\text { Teixeiras }\end{array}$ & Juliana Pereira \\
\hline E - 13/2017 & Cédula: 200 cruzeiros & 23/04/2017 & $\begin{array}{c}\text { Raimundo Alves de } \\
\text { Moraes }\end{array}$ & Rogério Borges \\
\hline E - 14/2017 & $\begin{array}{l}\text { Escultura: Nossa Senhora } \\
\text { Aparecida (Porcelana) }\end{array}$ & $25 / 04 / 2017$ & $\begin{array}{c}\text { Dom José Ubiratan } \\
\text { Lopes }\end{array}$ & Natália Santos \\
\hline E - 15/2017 & $\begin{array}{c}\text { Banner História da Princesa } \\
\text { Isabel }\end{array}$ & 28/04/2017 & João Paulino Barbosa & Lucas Marcelo \\
\hline E - 16/2017 & Relógio de Pulso & 30/04/2017 & $\begin{array}{c}\text { Francisco Cassimiro de } \\
\text { Oliveira }\end{array}$ & Rogério Borges \\
\hline E - 17/2017 & $\begin{array}{c}\text { Placas de Homenagens, } \\
\text { documento Santa Casa de } \\
\text { Aparecida }\end{array}$ & $03 / 05 / 2017$ & $\begin{array}{c}\text { D. Raymundo } \\
\text { Damasceno Assis }\end{array}$ & $\begin{array}{c}\text { Paulo } \\
\text { Bustamante }\end{array}$ \\
\hline$E-18 / 2017$ & Escultura: NSA (nó de pinho) & 06/05/2017 & Celso Antônio Malinasi & Lucas Marcelo \\
\hline E - 19/2017 & $\begin{array}{l}\text { Quadro: Padroeira do Brasil } \\
\text { (plantas naturais prensadas) }\end{array}$ & 08/05/2017 & Miriam Tatsumi & Pe. Rodrigo \\
\hline E - 20/2017 & Uma Bíblia & $30 / 05 / 2017$ & $\begin{array}{c}\text { Anilda Hildegard } \\
\text { Brodainski }\end{array}$ & $\begin{array}{l}\text { Layla De La } \\
\quad \text { Cruz }\end{array}$ \\
\hline$E-21 / 2017$ & Uma cédula de 10 Cruzeiros & $30 / 05 / 2017$ & Néze Gomes da Silva & Tamires \\
\hline$E-22 / 2017$ & Uma cédula de 2 Cruzeiros & $30 / 05 / 2017$ & Jeferson Luis Zarebelni & - \\
\hline E - 23/2017 & $\begin{array}{l}\text { Moeda } 2000 \text { Réis e uma Colher } \\
\text { de Incensário }\end{array}$ & $05 / 06 / 2017$ & $\begin{array}{c}\text { Ana Alvarenga Andrade } \\
\text { Lage }\end{array}$ & Rogério Borges \\
\hline E - 24/2017 & $\begin{array}{c}\text { Projetor Eumig (Mark 610-D), } \\
\text { Projetor Kodak Carousel, } 03 \\
\text { Carretéis para projetor, Máquina } \\
\text { fotográfica Yashica, } \\
02 \text { Fitas cassetes, Secretária } \\
\text { eletrônica (CCE T530), Máquina } \\
\text { de escrever portátil, Filmadora } \\
\text { Sony. }\end{array}$ & $10 / 06 / 2017$ & $\begin{array}{l}\text { Eneida Pinheiro de } \\
\text { Souza Martins }\end{array}$ & Natália Santos \\
\hline E - 25/2017 & Porta Joias em Metal & $18 / 06 / 2017$ & $\begin{array}{c}\text { Catarina Lucia Silveiro } \\
\text { de Souza }\end{array}$ & $\begin{array}{l}\text { Heliane } \\
\text { Caroline }\end{array}$ \\
\hline E - 26/2017 & Navio Escola Brasil (miniatura) & $26 / 06 / 2017$ & $\begin{array}{l}\text { Marinha do Brasil } \\
\text { (Niterói-RJ) }\end{array}$ & Tamires \\
\hline E - 27/2017 & $\begin{array}{c}\text { Minerais (40 minerais de } \\
\text { quartzos) }\end{array}$ & $11 / 07 / 2017$ & Alisson Fabrício Krupek & Rogério Borges \\
\hline$E-28 / 2017$ & Moedas (Total 41) & $22 / 07 / 2017$ & José Roberto Saugo & Rogério Borges \\
\hline E - 29/2017 & Capacete militar (tecido) & 29/07/2017 & Marcos José da Silva & $\begin{array}{l}\text { Heliane } \\
\text { Caroline }\end{array}$ \\
\hline$E-30 / 2017$ & $\begin{array}{l}\text { Imagem de Nossa Senhora } \\
\text { Aparecida (Gesso) }\end{array}$ & $11 / 08 / 2017$ & $\begin{array}{l}\text { Luciana de Fatima } \\
\text { João }\end{array}$ & Rogério Borges \\
\hline$E-31 / 2017$ & Estribo & $18 / 08 / 2017$ & $\begin{array}{l}\text { Marcos Vinicios dos } \\
\text { Santos Silva }\end{array}$ & Natália Santos \\
\hline$E-32 / 2017$ & Relógio de bolso & $19 / 08 / 2017$ & $\begin{array}{l}\text { Leandro Benedito } \\
\text { Domiciano }\end{array}$ & Rogério Borges \\
\hline$E-33 / 2017$ & Carro de boi (miniatura) & $19 / 08 / 2017$ & Lourival Junqueira & Felipe Cesaroni \\
\hline E - 34/2017 & Pintura: NS Aparecida & 19/08/2017 & $\begin{array}{l}\text { Maurício Gomes dos } \\
\text { Santos }\end{array}$ & $\begin{array}{l}\text { Heliane } \\
\text { Caroline }\end{array}$ \\
\hline E - 35/2017 & Moeda: 200 réis & $20 / 08 / 2017$ & $\begin{array}{l}\text { Alexandre Ferreira dos } \\
\text { Santos Memed }\end{array}$ & Lucas Marcelo \\
\hline
\end{tabular}




\begin{tabular}{|c|c|c|c|c|}
\hline $\begin{array}{l}\text { № de } \\
\text { entrada }\end{array}$ & Descrição do Objeto & Data & Doador & $\begin{array}{l}\text { Responsável } \\
\text { Recebimento }\end{array}$ \\
\hline E - 36/2017 & Moeda: Com sigla RG & $25 / 08 / 2017$ & Moizes Luiz da Silva & Rogério Borges \\
\hline E - 37/2017 & Moedas & 07/09/2017 & Maria dos Santos & $\begin{array}{c}\text { Layla De La } \\
\text { Cruz } \\
\end{array}$ \\
\hline$E-38 / 2017$ & Moedas e cédulas & $10 / 09 / 2017$ & $\begin{array}{l}\text { Luzia Marcia Gomes } \\
\text { Vicente }\end{array}$ & $\begin{array}{l}\text { Layla De La } \\
\text { Cruz }\end{array}$ \\
\hline E - 39/2017 & Uma Cédula 100.000 Cruzeiros & $16 / 09 / 2017$ & Tereza Fidelis Marinho & - \\
\hline E - 40/2017 & Moeda: 1.000 Réis (1927) & $16 / 09 / 2017$ & Nelci Maria da Silva & Tamires \\
\hline E - 41/2017 & Relógio de Pulso - Nelima & $28 / 09 / 2017$ & $\begin{array}{c}\text { Teodoro Roberto de } \\
\text { Andrade }\end{array}$ & Felipe Cesaroni \\
\hline$E-42 / 2017$ & 4 cartas dos anos de $1882-84-86$ & $30 / 09 / 2017$ & José Maria de Jesus & Felipe Cesaroni \\
\hline$E-43 / 2017$ & Canoa e dois remos (miniatura) & 06/10/2017 & $\begin{array}{l}\text { Gaspar Moreira da } \\
\text { Silva }\end{array}$ & Jéssica Dias \\
\hline E - 44/2017 & Moedas nacionais & $09 / 10 / 2017$ & Akihal Shimazu & $\begin{array}{c}\text { Bruno } \\
\text { Forasteiro } \\
\end{array}$ \\
\hline E - 45/2017 & Uma Cédula 1000 Cruzeiros & $13 / 10 / 2017$ & José Soares de Oliveira & Jésica \\
\hline$E-46 / 2017$ & $\begin{array}{c}\text { Moedas: Nacionais diversas (100 } \\
\text { reais) }\end{array}$ & $27 / 10 / 2017$ & José Porfílio dos Anjos & $\begin{array}{l}\text { Gabriela } \\
\text { Soares }\end{array}$ \\
\hline$E-47 / 2017$ & Câmera Fotográfica & $04 / 11 / 2017$ & $\begin{array}{l}\text { Thais Julianne de } \\
\text { Castro e Silva }\end{array}$ & Thaís Fernanda \\
\hline E - 48/2017 & 27 moedas e 1 bolsinha & $07 / 11 / 2017$ & $\begin{array}{c}\text { Izabel Cristina Silva } \\
\text { Souza }\end{array}$ & Laurielly \\
\hline E - 49/2017 & Jarra e bacia +3 CDs & 07/11/2017 & Cleuza de Oliveira Dias & Thais Fernanda \\
\hline E - 50/2017 & $\begin{array}{c}4 \text { cunhos (1 anverso, } 3 \text { reversos) } \\
+3 \text { medalhas }\end{array}$ & $22 / 08 / 2017$ & $\begin{array}{c}\begin{array}{c}\text { Pe. Valdivino Ferreira } \\
\text { Guimarães }\end{array} \\
\end{array}$ & $\begin{array}{c}\text { Paulo } \\
\text { Bustamante } \\
\end{array}$ \\
\hline E - 51/2017 & $\begin{array}{l}\text { Réplica da espada invicta do } \\
\text { Duque de Caxias e Diploma }\end{array}$ & $01 / 10 / 2017$ & $\begin{array}{c}\text { General de Brigada } \\
\text { Ricardo Augusto } \\
\text { Ferreira Costa Neves } \\
\end{array}$ & $\begin{array}{c}\text { Paulo } \\
\text { Bustamante }\end{array}$ \\
\hline E - 52/2017 & Placa Marinha do Brasil & $01 / 10 / 2017$ & $\begin{array}{l}\text { Comandante Eduardo } \\
\text { Bacellar Leal Ferreira }\end{array}$ & $\begin{array}{c}\text { Paulo } \\
\text { Bustamante }\end{array}$ \\
\hline E - 53/2017 & Medalha U N & $01 / 10 / 2017$ & $\begin{array}{c}\text { Capitão de Corveta } \\
\text { Cristiano da Costa } \\
\text { Vinagre }\end{array}$ & $\begin{array}{c}\text { Paulo } \\
\text { Bustamante }\end{array}$ \\
\hline E - 54/2017 & Escultura Bandeirante & $01 / 10 / 2017$ & $\begin{array}{c}\text { Comando Militar do } \\
\text { Sudeste (Quem } \\
\text { entregou?) }\end{array}$ & $\begin{array}{c}\text { Paulo } \\
\text { Bustamante }\end{array}$ \\
\hline E - 55/2017 & $\begin{array}{c}\text { Álbum de Moedas Olimpíadas } \\
\text { Rio } 2016 \\
\end{array}$ & $01 / 10 / 2017$ & Severino Alves Galvão & $\begin{array}{c}\text { Paulo } \\
\text { Bustamante }\end{array}$ \\
\hline E - 56/2017 & $\begin{array}{l}\text { Álbum de Fotos Benedicto } \\
\text { Calixto de Jesus Nétto }\end{array}$ & $06 / 11 / 2017$ & Museu da Tecnologia & Erica Coelho \\
\hline E - 57/2017 & Estribo & $18 / 11 / 2017$ & $\begin{array}{c}\text { Brenno Eduardo Freitas } \\
\text { Silva }\end{array}$ & Felipe Cesaroni \\
\hline E - 58/2017 & Relógio de pulso & $19 / 11 / 2017$ & $\begin{array}{c}\begin{array}{c}\text { José Paulino de } \\
\text { Oliveira }\end{array} \\
\end{array}$ & Maria Fernanda \\
\hline E - 59/2017 & Terço + Livro & $04 / 12 / 2017$ & Diva Luísa De Luca & $\begin{array}{c}\text { Jéssica } \\
\text { Rodrigues } \\
\end{array}$ \\
\hline$E-60 / 2017$ & Cédulas e moedas & $04 / 12 / 2017$ & Maria Mineiro da Silva & $\begin{array}{l}\text { Cássio da } \\
\text { Costa }\end{array}$ \\
\hline$E-61 / 2017$ & 2 Conchas & $09 / 12 / 2017$ & $\begin{array}{l}\text { Luiz Roberto Souza } \\
\text { dos Santos }\end{array}$ & $\begin{array}{c}\text { Bruno } \\
\text { Forasteiro }\end{array}$ \\
\hline$E-62 / 2017$ & Crucifixo com base & $17 / 12 / 2017$ & Maria do Carmo & Maria Fernanda \\
\hline$E-63 / 2017$ & Baú de metal & $17 / 12 / 2017$ & Maria do Carmo & Maria Fernanda \\
\hline E - 64/2017 & 2 Moedas & 20/12/2017 & Maria de Sousa Costa & Thaís Fernanda \\
\hline E - 65/2017 & $\begin{array}{c}\text { Diploma Honra ao Mérito - } \\
\text { Câmara Municipal de Aparecida }\end{array}$ & $21 / 12 / 2017$ & $\begin{array}{l}\text { Pe. João Batista } \\
\text { C.Ss.R }\end{array}$ & Taísa \\
\hline
\end{tabular}




\begin{tabular}{|c|c|c|c|c|}
\hline $\begin{array}{c}\text { No de } \\
\text { entrada }\end{array}$ & Descrição do Objeto & Data & Doador & $\begin{array}{c}\text { Responsável } \\
\text { Recebimento }\end{array}$ \\
\hline & ao Santuário & & & \\
\hline E - 66/2017 & Cédulas e Moedas antigas & $27 / 12 / 2017$ & $\begin{array}{c}\text { Maicon Robson } \\
\text { Rodrigues }\end{array}$ & Thaís Fernanda \\
\hline E - 67/2017 & $\begin{array}{c}\text { Quadro de Nossa Senhora } \\
\text { Aparecida }\end{array}$ & $28 / 12 / 2017$ & José Luiz de Souza & $\begin{array}{c}\text { Paulo } \\
\text { Bustamante }\end{array}$ \\
\hline
\end{tabular}

Fonte: MNSA/Santuário Nacional.

Quadro 45: Lista de entrada de objetos (2018)

\begin{tabular}{|c|c|c|c|c|}
\hline $\begin{array}{c}\text { № de } \\
\text { Entrada }\end{array}$ & Descrição do Objeto & Data & Doador & $\begin{array}{l}\text { Responsável } \\
\text { Recebimento }\end{array}$ \\
\hline E - 01/2018 & $\begin{array}{l}\text { Pasta dos Correios com selo } \\
\text { e carimbo Jubileu } 300 \text { anos }\end{array}$ & $24 / 01 / 2018$ & Pe. João Batista & Jonatas Veloso \\
\hline E - 02/2018 & Manto de imagem & 29/01/2018 & $\begin{array}{c}\text { José Eymard M.L. } \\
\text { Sobrinho }\end{array}$ & Eduardo \\
\hline$E-03 / 2018$ & $\begin{array}{l}\text { Medalha: Centenário } \\
\text { Victor Brecheret }\end{array}$ & 05/02/2018 & $\begin{array}{c}\text { Sandra Brecheret } \\
\text { Pellegrini }\end{array}$ & Erica Coelho \\
\hline E - 04/2018 & $\begin{array}{l}\text { Cédulas nacionais (39) } \\
+1 \text { Dolar + Moedas (21) }\end{array}$ & $10 / 02 / 2018$ & $\begin{array}{c}\text { Aparecida Silvestre } \\
\text { Rodrigues }\end{array}$ & Rogério Borges \\
\hline E - 05/2018 & Máquina Fotográfica (Kodak) & $13 / 02 / 2018$ & Nadir Aparecida Gielo & Layla Cruz \\
\hline E - 06/2018 & Moeda de 1000 Reis & $17 / 02 / 2018$ & $\begin{array}{l}\text { Lourdes Divina Luiíza } \\
\text { Machado }\end{array}$ & Jésica Santos \\
\hline E - 07/2018 & Cédula: 50.000 cruzeiros & $16 / 03 / 2018$ & Juraci da Costa Santos & Marcela Santos \\
\hline E - 08/2018 & Ferro de Passar & $25 / 03 / 2018$ & $\begin{array}{c}\text { Elizabeti Aparecida da } \\
\text { Silva Santos }\end{array}$ & Natalia Santos \\
\hline E - 09/2018 & Rosário & $24 / 03 / 2018$ & $\begin{array}{c}\text { Maria Neiva de Souza } \\
\text { Santos }\end{array}$ & Jésica Santos \\
\hline E - 10/2018 & $\begin{array}{c}\text { Tijolinho } \\
\text { (Campanha dos Devotos) }\end{array}$ & $10 / 04 / 2018$ & Dorothéa Barboza & Layla Cruz \\
\hline E - 11/2018 & Moeda de 5000 Réis & $17 / 04 / 2018$ & $\begin{array}{l}\text { Sebastião Waguiner } \\
\text { Sabino }\end{array}$ & Lucas \\
\hline E - 12/2018 & 4 Telas de Tapeçaria & 02/04/2018 & $\begin{array}{c}\text { Maria Apparecida } \\
\text { Monteiro }\end{array}$ & $\begin{array}{c}\text { Julia } \\
\text { (Comercial) }\end{array}$ \\
\hline$E-13 / 2018$ & 2 Telas de Tapeçaria & $13 / 04 / 2018$ & $\begin{array}{c}\text { Maria Apparecida } \\
\text { Monteiro }\end{array}$ & $\begin{array}{c}\text { Julia } \\
\text { (Comercial) }\end{array}$ \\
\hline E - 14/2018 & $\begin{array}{l}3 \text { Vitrais Basílica Nova } \\
1 \text { Tijolo Basílica Velha }\end{array}$ & $14 / 04 / 2018$ & Cesar Augusto Maia & Layla Cruz \\
\hline E - 15/2018 & $\begin{array}{c}3 \text { Tijolinhos } \\
\text { (Campanha dos Devotos) }\end{array}$ & $27 / 04 / 2018$ & Paulo Bustamante & Layla Cruz \\
\hline$E-16 / 2018$ & Uma cédula de cem mil cruzeiros & $08 / 05 / 2018$ & $\begin{array}{l}\text { João Gonçalves Miguel } \\
\text { Neto }\end{array}$ & Eduardo \\
\hline E - 17/2018 & 1 Tela de Tapeçaria & $16 / 05 / 2018$ & $\begin{array}{c}\text { Maria Apparecida } \\
\text { Monteiro }\end{array}$ & Thaís Fernanda \\
\hline E - 18/2018 & Cédulas: 34 cédulas & 04/08/2018 & $\begin{array}{l}\text { Orisio Furquim de } \\
\text { Camargo }\end{array}$ & Flávio Correia \\
\hline E - 19/2018 & Punhal com bainha & $19 / 08 / 2018$ & João de Souza Barroso & $\begin{array}{l}\text { Laurielly } \\
\text { Santos }\end{array}$ \\
\hline$E-20 / 2018$ & Moeda: 100 réis & $19 / 08 / 2018$ & Gilberto Quintilho & $\begin{array}{l}\text { Laurielly } \\
\text { Santos }\end{array}$ \\
\hline$E-21 / 2018$ & Crucifixo com base & $31 / 08 / 2018$ & Paulo Verdier & Erica Coelho \\
\hline$E-22 / 2018$ & $\begin{array}{l}\text { Coleção de Filatelia } \\
\text { (caixas com selos, editais, } \\
\text { revistas, álbuns, postais) }\end{array}$ & $24 / 09 / 2018$ & $\begin{array}{l}\text { Maria das Merces } \\
\text { Coelho Souza }\end{array}$ & Erica Coelho \\
\hline$E-23 / 2018$ & Cédula: 10 reais (plástico) & 23/09/2018 & $\begin{array}{l}\text { José Donato dos } \\
\text { Santos }\end{array}$ & Jésica Dias \\
\hline E - 24/2018 & 11 Cédulas variadas & 29/09/2018 & $\begin{array}{c}\text { Expedito Souza de } \\
\text { Senna } \\
\end{array}$ & Jésica Dias \\
\hline
\end{tabular}




\begin{tabular}{|c|c|c|c|c|}
\hline $\begin{array}{c}\text { № de } \\
\text { Entrada } \\
\end{array}$ & Descrição do Objeto & Data & Doador & $\begin{array}{l}\text { Responsável } \\
\text { Recebimento }\end{array}$ \\
\hline E - 25/2018 & 15 Cédulas variadas & $13 / 10 / 2018$ & $\begin{array}{c}\text { Dorivaldo de Souza } \\
\text { Custódio }\end{array}$ & $\begin{array}{c}\text { Jéssica } \\
\text { Rodrigues }\end{array}$ \\
\hline E - 26/2018 & $\begin{array}{c}\text { Medalha: Santiago de } \\
\text { Compostela }\end{array}$ & $18 / 10 / 2018$ & Pe. João Batista & Erica Coelho \\
\hline E - 27/2018 & Cédula: 500 cruzados novos & 20/10/2018 & $\begin{array}{c}\text { Pedro Gabriel Neves } \\
\text { Martins }\end{array}$ & Cássio Costa \\
\hline E - 28/2018 & Cédulas (Total 24) & $21 / 10 / 2018$ & Olivacir Custódio & João Alves \\
\hline E - 29/2018 & Moeda (refugo não identificado) & 20/10/2018 & Nelson Pereira Valente & $\begin{array}{c}\text { Jéssica } \\
\text { Rodrigues }\end{array}$ \\
\hline E - 30/2018 & $\begin{array}{r}\text { Copos souvenirs } 1 \\
1 \text { cane }\end{array}$ & $24 / 10 / 2018$ & José Geraldo Rocha & Marcela \\
\hline E - 31/2018 & $\begin{array}{c}\text { Xícara e pires } \\
\text { (Congresso Eucarístico } \\
\text { Internacional - 1955) }\end{array}$ & $15 / 11 / 2018$ & $\begin{array}{c}\text { Laurinda Cordeiro } \\
\text { Teixeira }\end{array}$ & Rogério Borges \\
\hline E - 32/2018 & Cédula: Mil cruzeiros reais & $28 / 10 / 2018$ & Altamiro José Lopes & Flávio Melo \\
\hline E - 33/2018 & Cédula: Cinquênta mil cruzeiros & $25 / 11 / 2018$ & $\begin{array}{l}\text { Antônio Gilberto } \\
\text { Ferreira da Silva }\end{array}$ & Jésica Dias \\
\hline E - 34/2018 & Câmera Fotogáfica & $25 / 11 / 2018$ & Jane Maria Francisco & \\
\hline E - 35/2018 & Cédulas diversas & $03 / 12 / 2018$ & Necy Costa da Silva & Flavio Melo \\
\hline E - 36/2018 & $\begin{array}{c}\text { Pintura: Nossa Senhora } \\
\text { Aparecida }\end{array}$ & 09/12/2018 & $\begin{array}{c}\text { Ricarte llidio Ferreira } \\
\text { Fonseca }\end{array}$ & $\begin{array}{l}\text { Natalia R. } \\
\text { Santos }\end{array}$ \\
\hline E - 37/2018 & Moedas diversas & $08 / 12 / 2018$ & $\begin{array}{c}\text { José Nunes de Souza } \\
\text { Filho }\end{array}$ & Jésica Dias \\
\hline
\end{tabular}

Fonte: MNSA/Santuário Nacional. 


\section{ANEXO C - Ficha Catalográfica}

Quadro 46: Ficha catalográfica.

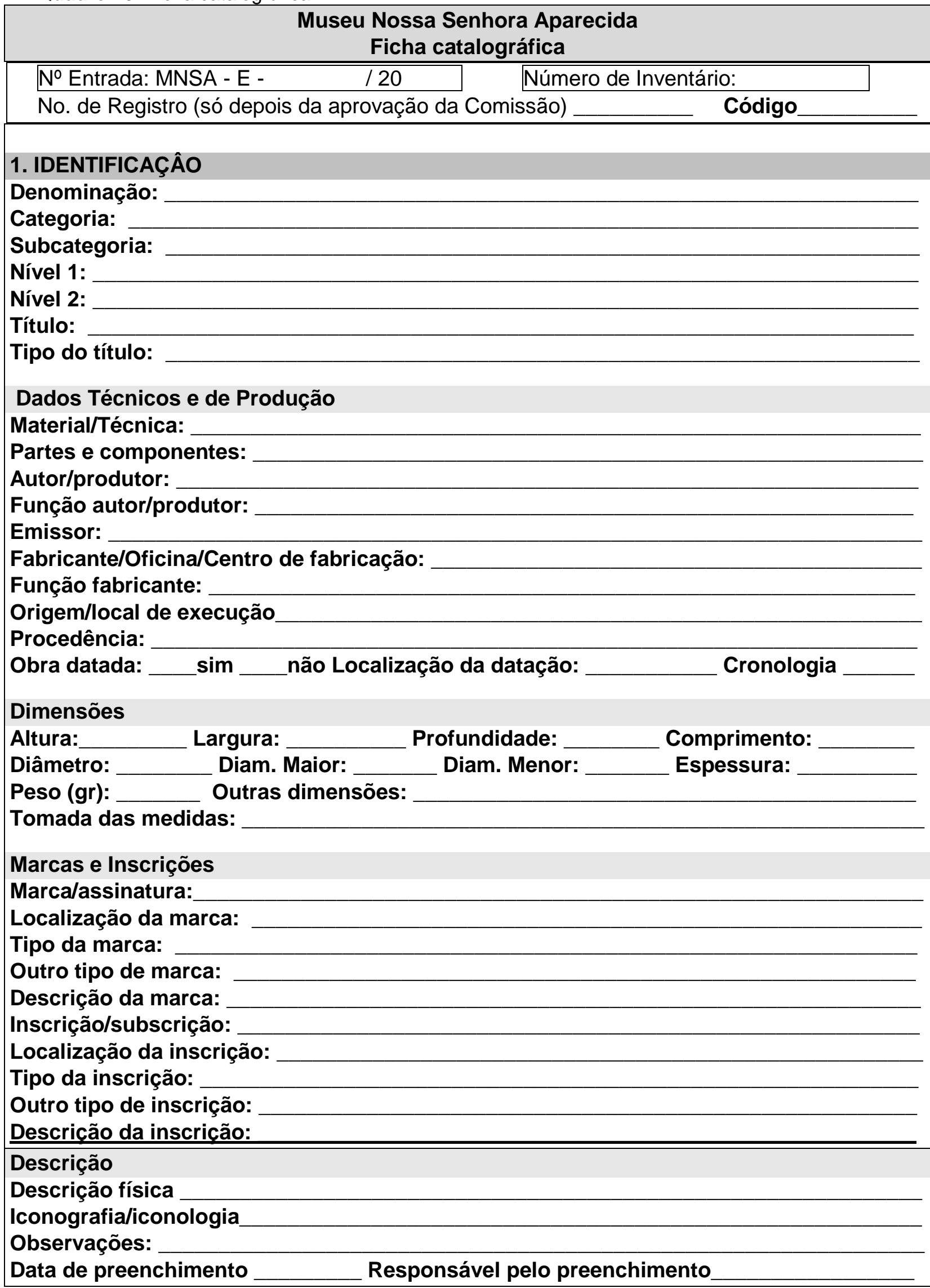




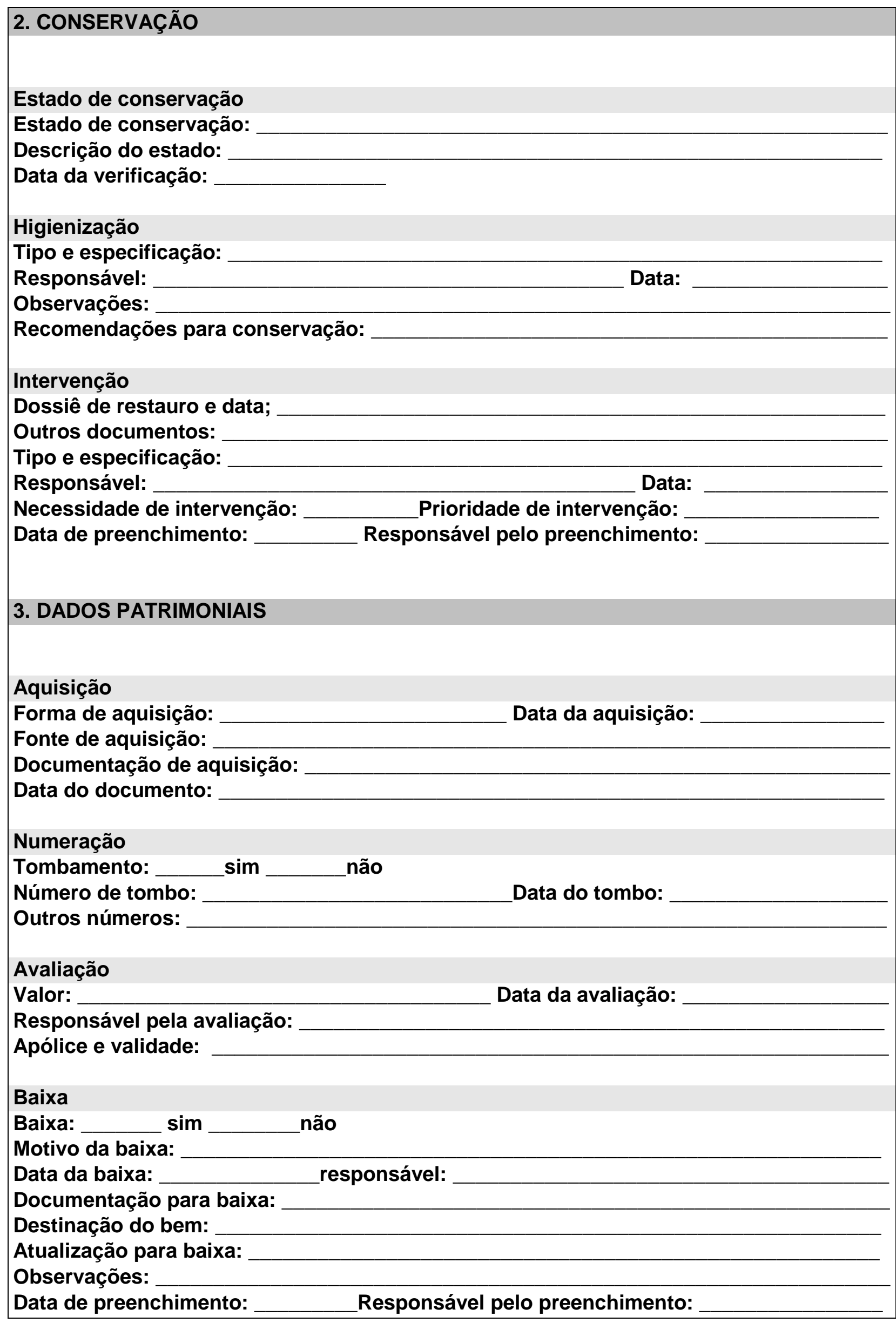




\section{HISTÓRICO E PESQUISA}

Histórico e pesquisa:

Referências bibliográficas:

Data de preenchimento: Responsável pelo preenchimento:

\section{MOVIMENTAÇÃO}

Entrada no Museu

Motivo da entrada:

Fonte da entrada:

Data de entrada:

Local de origem:

Responsável pela entrega:

Responsável pelo recebimento:

Localização Inicial

Local:

Suporte: Especificar (quando outro):

Código do suporte:

Movimentação

Finalidade:

Local de destino:

Suporte:

Código do suporte

Data da movimentação:

Responsável pela entrega:

Responsável pelo recebimento:

Observação:

Data de preenchimento: Responsável pelo preenchimento:

\section{EXPOSIÇÃO}

Título da Exposição:

Instituição e local:

Observações:

Período:

Data de preenchimento:

Responsável pelo preenchimento

Fonte: MNSA/Santuário Nacional. 


\section{ANEXO D - Termo de oferecimento de bem}

Figura 145: Termo de Oferecimento de Bem.

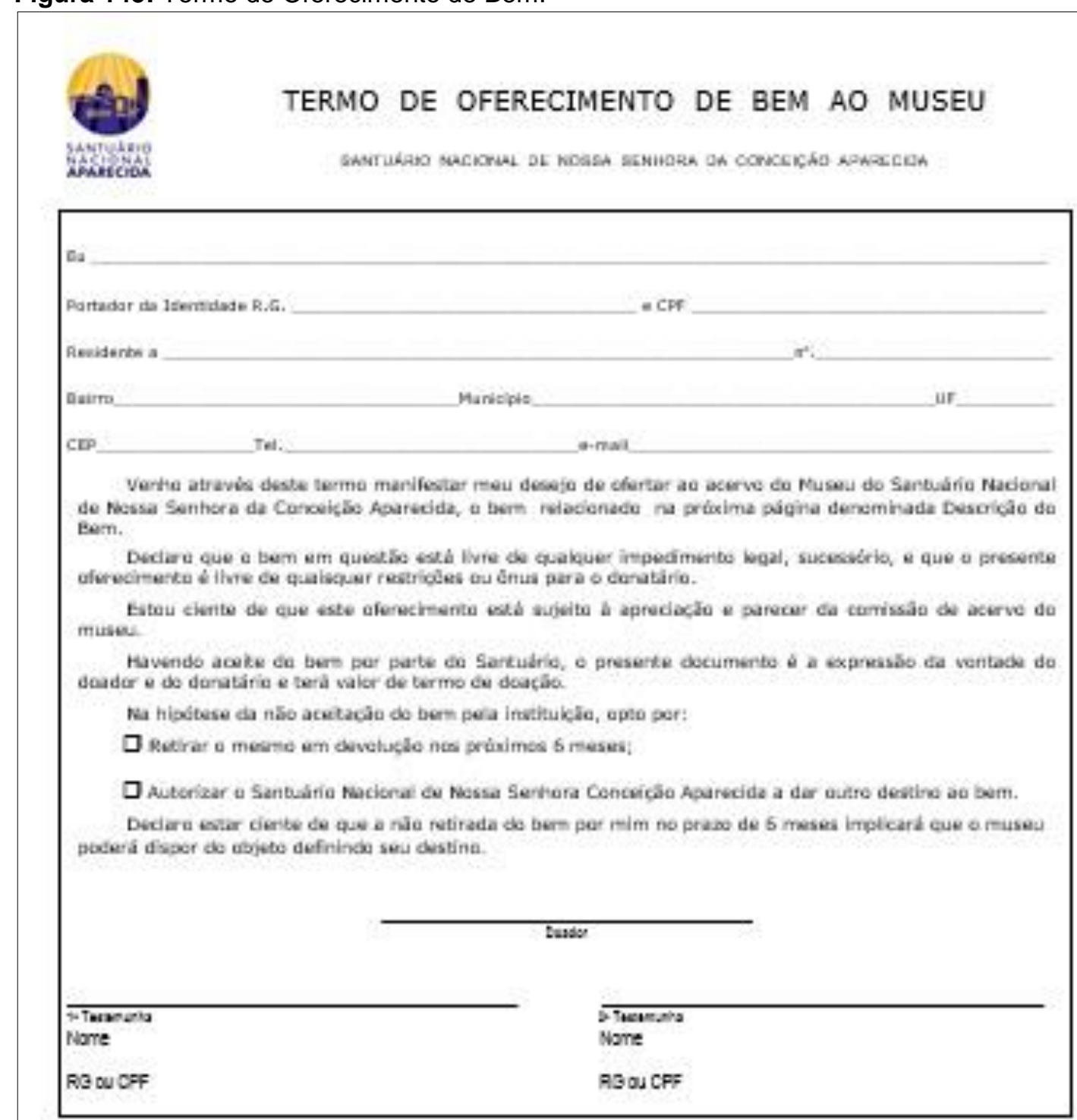

DISPCSICOCEES DO MUSEU

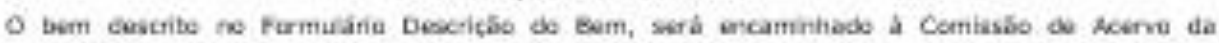

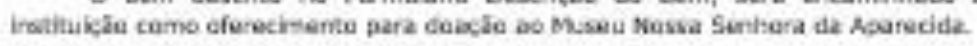

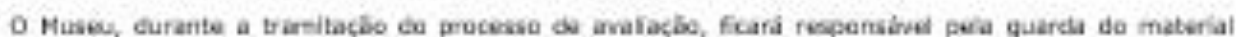

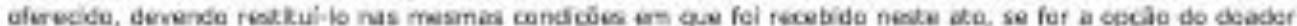
peil a develuçso.

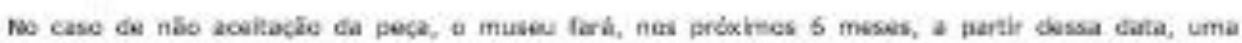

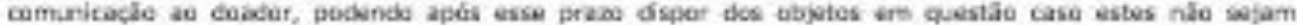
rusçaradabs.

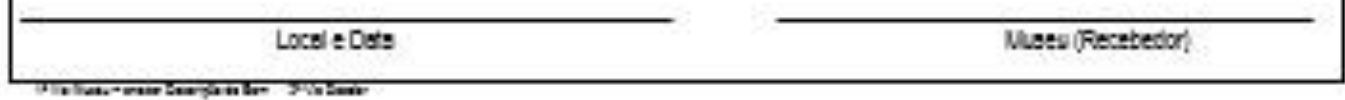

Fonte: MNSA/ Santuário Nacional 
Figura 146: Termo de Oferecimento de Bem ao Museu - Descrição do Bem.

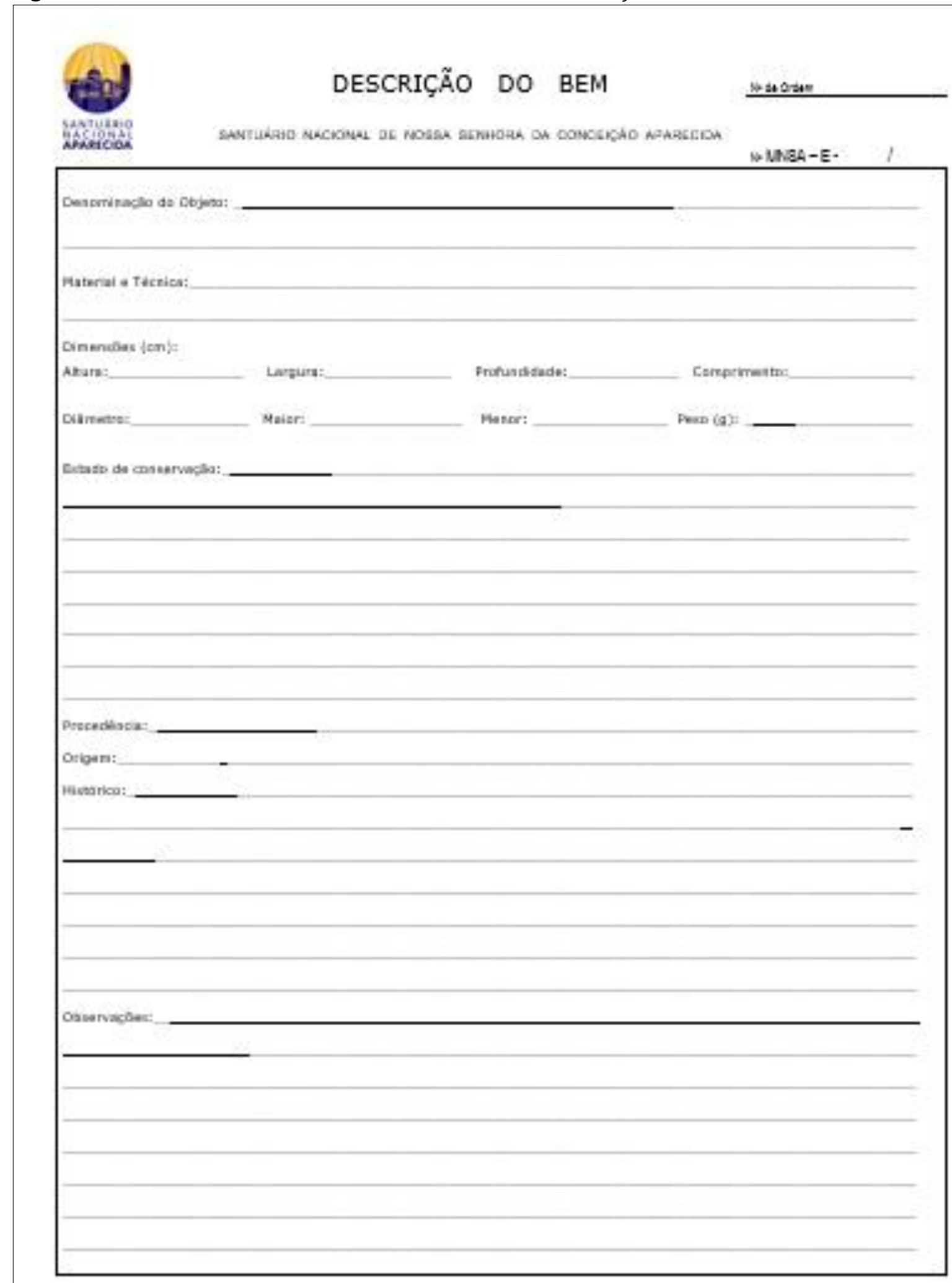

Fonte: MNSA/ Santuário Nacional 